UNIVERSIDAD

DE SALAMANCA

\title{
LA PORNOGRAFÍA INFANTIL EN LA RED. ESPECIAL REFERENCIA A LA POSESIÓN SIMPLE.
}

\author{
TESIS DOCTORAL \\ Elaborada por: \\ Ana Victoria Parra González \\ DIRIGIDA POR LAS PROFESORAS DOCTORAS: \\ María Luz Gutiérrez Francés - Nuria Matellanes Rodríguez.
}

Este trabajo fue financiado por el Programa de Becas de Alto Nivel de la Unión Europea para America Latina (ALBAN), Nº E04D034919VE.

OCTUBRE, 2011 


\section{Dedicatoria}

A Noé, José y Gabriel.

Por la fuerza y la certeza con la que persiguen los sueños. 


\section{ÍNDICE}

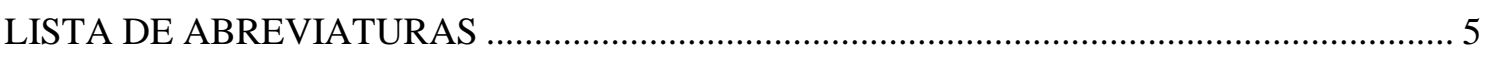

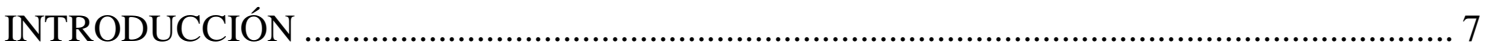

\section{CAPÍTULO I}

PORNOGRAFÍA INFANTIL. REALIDAD SOCIO/CRIMINOLÓGICA

1. EXPLOTACIÓN SEXUAL COMERCIAL INFANTIL (ESCI). EVIDENCIAS EMPÍRICAS Y ASPECTOS FENOMENOLÓGICOS.......................................................................18

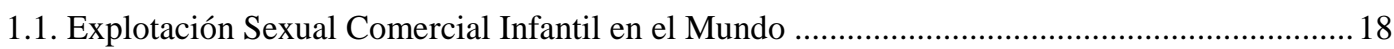

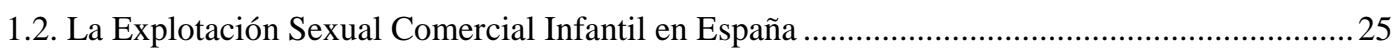

1.3. Causas y efectos de la Explotación Sexual Comercial Infantil .................................................27

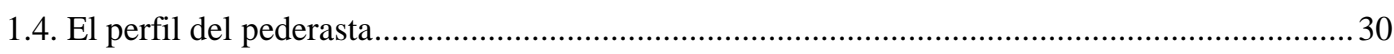

2. SOCIEDAD GLOBAL Y TECNOLOGÍAS DE INFORMACIÓN Y COMUNICACIÓN ..............................................................................................................................33

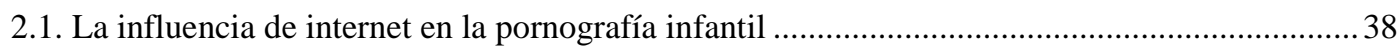

2.2. Pornografía infantil y criminalidad informática .................................................................5

3. PORNOGRAFÍA INFANTIL Y DELINCUENCIA ORGANIZADA ...........................................68

4. ALARMA SOCIAL, MEDIOS DE COMUNICACIÓN Y DELITOS SEXUALES. DE LAS EXIGENCIAS DE NEUTRALIZACIÓN DEL DELINCUENTE ....................................81

4.1. Impronta mediática y estado de alarma social ........................................................................ 82

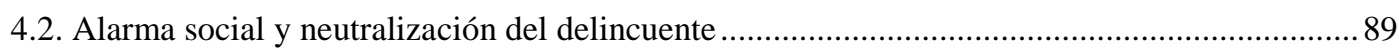

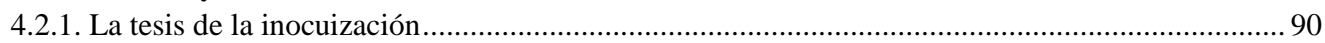

4.2.2. La tesis de la seguridad ante el riesgo................................................................................... 94

4.2.3 Medidas de neutralización del delincuente ............................................................................... 96

\section{CAPÍTULO II}

MARCO NORMATIVO INTERNACIONAL DE LA PORNOGRAFÍA INFANTIL..... 110

1. DOCUMENTOS DE REFERENCIA Y LEGISLACIÓN COMUNITARIA.....................................112

1.1. Naciones Unidas, Documentos, Convenciones Internacionales y Eventos

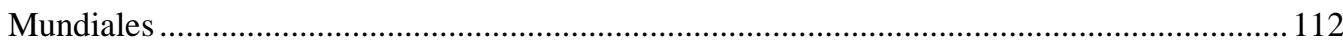

1.2. Desarrollo normativo en el espacio comunitario europeo ...................................................... 128

1.2.1. Decisión Marco 2004/68/JAI del Consejo, de 22 de diciembre de 2003, relativa a la lucha contra la explotación sexual de los niños y la pornografía infantil ..................................... 147

1.2.2. La Propuesta de Directiva del Parlamento Europeo y del Consejo Relativa a la lucha contra los sbusos sexuales, la explotación sexual de los niños y la pornografía Infantil, por la que se deroga la Decisión Marco 2004/68/JAI ........................................................... 156

1.2.2.1. Contenido de la Propuesta de Directiva .............................................................................. 157

1.2.2.2 Bloqueo del acceso a sitios de Internet que contienen pornografía infantil....................... 163

1.2.3. Toma de Postura .................................................................................................................... 164

2. CONCEPTO Y CARACTERÍSTICAS DE LA PORNOGRAFÍA INFANTIL..............................166

2.1. Características de la pornografía infantil............................................................................ 169

2.1.1 Edad en la consideración de actos de pornografía infantil.......................................................... 170

2.1.2. Representación visual .................................................................................................. 173

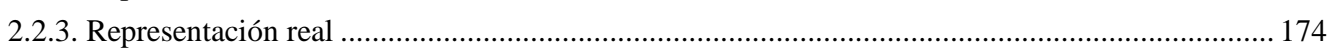

2.2.4 Conducta sexualmente explicita y erótica …................................................................... 176

3. TOMA DE POSTURA 


\section{CAPÍTULO III}

LA PORNOGRAFÍA INFANTIL EN EL CÓDIGO PENAL ESPAÑOL 184

1. INTRODUCCIÓN 185

2. CONSIDERACIONES GENERALES: LA INCORPORACIÓN DEL PRECEPTO DE PORNOGRAFÍA INFANTIL EN EL CP ESPAÑOL ............................................................186

3. LA PORNOGRAFÍA INFANTIL EN EL CÓDIGO PENAL DE 1995. 189

4. LA PORNOGRAFÍA INFANTIL EN LA REFORMA DEL CP/1999 (LO 11/1999, DE 30 DE ABRIL) SOBRE LOS DELITOS CONTRA LA LIBERTAD SEXUAL 192

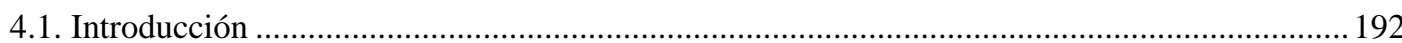

4.2. Modificaciones sustanciales en la configuración de los tipos delictivos del Artículo 189.1

4.2.1. La producción, venta, distribución, exhibición, o facilitación de material pornográfico infantil

4.2.2. Posesión de material pornográfico infantil para la producción, venta, distribución, difusión, exhibición

4.3. El Retorno de la corrupción de menores

4.4. Notas finales sobre la LO 11/1999 de 30 de abril

5. LA LEY ORGÁNICA 15/2003, DE 25 DE NOVIEMBRE, POR LA QUE MODIFICA LA LEY ORGÁNICA 10/1995, DE 23 DE NOVIEMBRE, DEL CÓDIGO PENAL

5.1. Introducción

5.2. Principales modificaciones al artículo 189.1

5.3. La Posesión simple de pornografía infantil. (Artículo 189.2) …................................................ 219

5.4. Nuevas y más agravantes. (Artículo 189.3 LO 15/2003) .........................................................222

5.5. Producción y tráfico de pornografía virtual (Artículo 189.7) .................................................229

5.6. Valoración sobre la LO 15/2003 de 25 de Noviembre ............................................................ 233

6. LEY ORGÁNICA 5/2010, DE 22 DE JUNIO, POR LA QUE SE MODIFICA LA LEY ORGÁNICA 10/1995, DE 23 DE NOVIEMBRE, DEL CÓDIGO PENAL ........................... 235

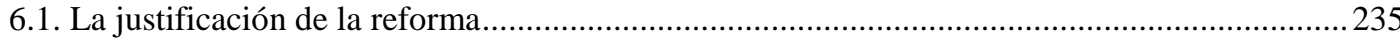

6.2. Libertad Vigilada o inocuización ................................................................................... 240

6.3. Delitos sexuales contra menores de trece años.....................................................................245

6.4. La reforma en el artículo 189 del Código Penal Español. Pornografía infantil ........................ 248 6.4.1 Modificaciones en el tipo básico del 189.1 ............................................................................. 248

6.5. Toma de postura sobre la LO 5/2010, de 22 de junio......................................................... 245

7. BIEN JURÍDICO PROTEGIDO EN LA PORNOGRAFÍA INFANTIL ...........................................260

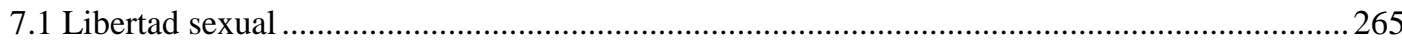

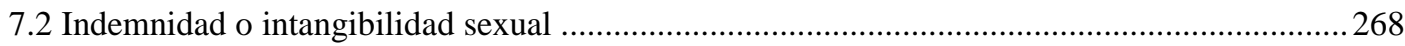

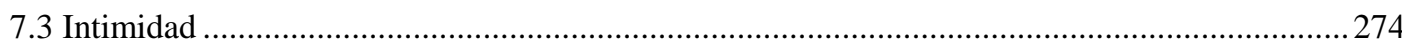

7.4 Bien jurídico protegido en el Art. 189.1 ..........................................................................2 275

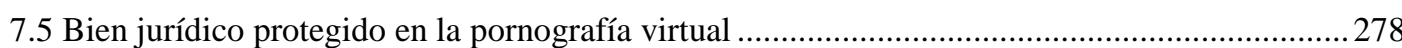

7.6 Bien jurídico protegido en el Art. 189.2 ........................................................................... 281

\section{CAPÍTULO IV}

POSESIÓN DE PORNOGRAFÍA INFANTIL ...................................................................... 286

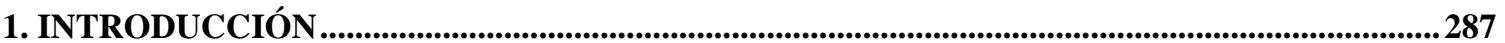


3.1 Controlar la demanda para anular la oferta y acabar con la explotación sexual Infantil

3.2. Peligro de acciones imitadoras por parte de los usuarios de pornografía infantil. vs efecto de prevención o catártico.

3.3. Empatía con las víctimas de la pornografía infantil ............................................................ 304

4. ARGUMENTOS PARA LA DESTIPIFICACIÓN DE LA POSESIÓN SIMPLE ...........................306

4.1. Vulneración de los principios de mínima intervención, ofensividad y última ratio. Afán represor y uso simbólico del Derecho Penal ........................................................306

4.2 Adelantamiento de las Barreras del Derecho Penal. Delito de peligro abstracto ...................... 309

4.3. Intromisión o invasión en la vida privada de los adultos......................................................... 312

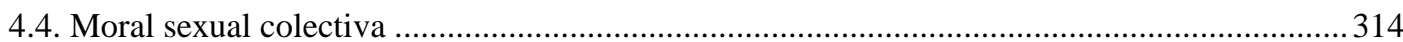

4.5. Protección de sentimientos en la posesión de pornografía infantil. ¿Legítimos o ilegítimos?

4.6. Toma de postura 324

5. ILEGITIMIDAD DE LA TIPIFICACIÓN DE LA POSESIÓN DE PORNOGRAFÍA INFANTIL

6. LA POSESIÓN COMO ACTOS ALEJADOS EN EL TIEMPO, EN EL ESPACIO Y EN LA LÍNEA DE ACCIÓN DEL EPISODIO DE ABUSO SEXUAL 329

7. FINALIDAD DE LA PENA EN LA POSESIÓN DE PORNOGRAFÍA INFANTII 332

8. ELEMENTOS EMPÍRICOS DE LA EXISTENCIA DEL DELITO DE POSESIÓN. ¿EN QUÉ INSTANTE COMIENZA O SE CONSUMA LA POSESIÓN DE PORNOGRAFÍA INFANTIL A TRAVÉS DE INTERNET?

\section{CAPÍTULO V}

ORIENTACIÓN POLÍTICO CRIMINAL EN LAS REFORMAS A LA

PORNOGRAFÍA INFANTIL

1. INTRODUCCIÓN

2. PLANTEAMIENTO: RADIOGRAFÍA DE LA TRAMA SOCIO/JURÍDICA CONTEMPORÁNEA

3. EL MODELO DE SEGURIDAD COMO RESPUESTA A LA SOCIEDAD DEL RIESGO. (MÁS SEGURIDAD, MENOS LIBERTAD)

3.1 Modernidad y globalización: El marco cultural de la sociedad del riesgo .................................350

3.2 Del Riesgo externo y el riesgo fabricado

3.3 Del riesgo postmoderno al miedo a la inseguridad. La reconstrucción del control social.

3.4 Gestión y distribución del riesgo ante individuos peligrosos

4. MEDIOS, CRIMINALIDAD Y ORDEN POLÍTICO. LA VÍCTIMA COMO ELEMENTO CENTRAL DEL DISCURSO MEDIÁTICO

4.1 Excurso introductoria 359

4.2 De la víctima real a las víctimas potenciales. las exigencias de endurecimiento del control social 
5. LA ACTUACIÓN DEL ESTADO. DEL IDEAL RESOCIALIZADOR A LA IDEOLOGÍA DE LA SEGURIDAD Y EL ANCLAJE PENAL DE LA POLÍTICA

5.1 Respuestas institucionales ante los miedos y riesgos de la sociedad posmoderna.

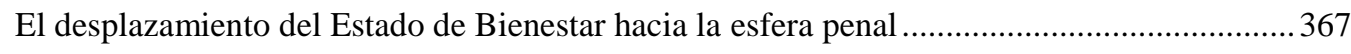

5.1.1. Del fin resocializador de la pena a los planteamientos inocuizadores ........................................ 368

5.1.2 Los delitos sexuales: entre el populismo punitivo y el protagonismo de la víctima ........................ 370

5.2. El Derecho penal del enemigo en la posesión de pornografía infantil ........................................375

5.3 La expansión del Derecho Penal: La pornografía infantil como el mejor

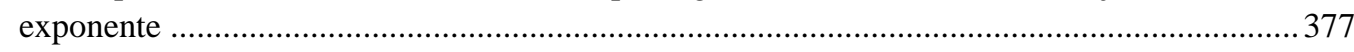

5.4 La función simbólica de la norma en la posesión de pornografía infantil ....................................379

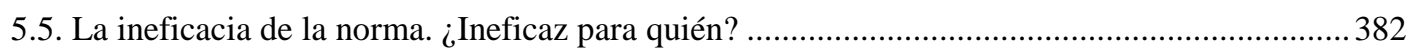

5.6. Delitos de posesión como la panacea del Derecho Penal actual. El recurso a la figura de posesión de pornografía infantil en la lucha contra los individuos "peligrosos"

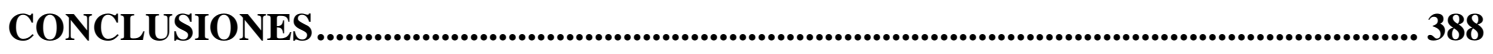

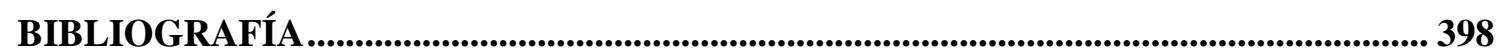


LISTA DE ABREVIATURAS

\begin{tabular}{|c|c|}
\hline AA.VV= & Autores varios \\
\hline $\mathrm{ADPCP}=$ & Anuario de Derecho Penal y Ciencias Penales \\
\hline $\mathrm{AP}=$ & Audiencia Provincial \\
\hline$A P=$ & Actualidad Penal \\
\hline $\mathrm{ARP}=$ & Aranzadi Penal \\
\hline $\operatorname{Art} .(\mathrm{s})=$ & Artículo(s) \\
\hline $\mathrm{CC}=$ & Código Civil \\
\hline $\mathrm{CE}=$ & Constitución Española de 1978 \\
\hline $\mathrm{CGPJ}=$ & Consejo General del Poder Judicial \\
\hline $\operatorname{Comp}(s)=$ & Compilador(es) \\
\hline $\operatorname{Coord}(s)=$ & Coordinador(es) \\
\hline $\mathrm{CP}=$ & Código Penal Español \\
\hline $\operatorname{Dir}(s)=$ & Director(es) \\
\hline $\mathrm{DO}=$ & Diario Oficial \\
\hline $\mathrm{Ed} .=$ & Editorial \\
\hline Edit. $(s)=$ & Editor(s) \\
\hline $\mathrm{ECPAT}=$ & Campaña contra la Explotación Sexual Infantil en los Viajes \\
\hline $\mathrm{ESCI}=$ & Explotación Sexual Comercial Infantil \\
\hline $\mathrm{FJ}=$ & Fundamento Jurídico \\
\hline $\mathrm{JAI}=$ & Justicia y Asuntos de Interior \\
\hline $\mathrm{ISP}=$ & Internet Services Provider \\
\hline $\mathrm{LAN}=$ & Red de Área Local \\
\hline $\mathrm{LL}=$ & La Ley \\
\hline $\mathrm{LO}=$ & Ley Orgánica \\
\hline $\mathrm{LOPJ}=$ & Ley Orgánica del Poder Judicial \\
\hline $\mathrm{MF}=$ & Ministerio Fiscal \\
\hline $\mathrm{N}^{\mathrm{o}} .(\mathrm{s})=$ & Número (s) \\
\hline
\end{tabular}




\begin{tabular}{|c|c|}
\hline $\mathrm{ONG}=$ & Organización no Gubernamental \\
\hline ONU $=$ & Organización de Naciones Unidas \\
\hline Pág.(s) & Página(s) \\
\hline $\mathrm{P} 2 \mathrm{P}=$ & Protocolo $\mathrm{p} 2 \mathrm{p}$ (peer to peer) \\
\hline RAPP= & Revista Aranzadi de Proceso Penal \\
\hline $\mathrm{SAP}=$ & Sentencia de la Audiencia Provincial \\
\hline $\mathrm{STC}=$ & Sentencia del Tribunal Constitucional \\
\hline $\mathrm{StGB}=$ & Código Penal Alemán \\
\hline $\mathrm{STS}=$ & Sentencia del Tribunal Supremo \\
\hline $\mathrm{TC}=$ & Tribunal Constitucional \\
\hline TEDH= & Tribunal Europeo de Derechos Humanos \\
\hline $\operatorname{trad} .=$ & traducción, traductor, traducido (a) \\
\hline $\mathrm{TS}=$ & Tribunal Supremo \\
\hline $\mathrm{TCP}=$ & Protocolo de Control de Transferencia \\
\hline $\mathrm{UE}=$ & Unión Europea \\
\hline $\mathrm{UDP}=$ & Use Datagram Protocol \\
\hline $\mathrm{UNICEF}=$ & Fondo de Naciones Unidas para la Infancia \\
\hline US Code $=$ & Código de los Estados Unidos \\
\hline Vol. $=$ & Volumen \\
\hline WI-FI= & Wireless Fidelity \\
\hline $\mathrm{WWW}=$ & World Wide Web \\
\hline
\end{tabular}




\section{INTRODUCCIÓN}

Junto a la entronización de la vida digital en el ámbito cotidiano doméstico, de trabajo o de ocio en las dos últimas décadas ha emergido la pornografía infantil. Frecuentemente nos encontramos en las ediciones impresas o digitales de los principales medios de comunicación noticias relacionadas con la tenencia y distribución de pornografía infantil en la Red, generalmente referidas a los operativos policiales llevados a cabo luego del trabajo conjunto y coordinado de cuerpos de inteligencia y seguridad de varios países que siguen la huella informática de los usuarios que visitan páginas con contenidos pedófilos. A modo de ilustración presentamos una selección de ellas, publicadas en un diario español de circulación nacional, representativas de algunas de las dimensiones del fenómeno que hemos de tratar a lo largo de este trabajo.

"Trece detenidos en cuatro operaciones contra la pornografía infantil". La Policía Nacional ha detenido a 13 personas e imputado a otras siete por distribución y tenencia de pornografía infantil en cuatro operaciones que se han desarrollado simultáneamente en distintas provincias españolas. Los agentes han realizado 17 registros en Valencia, Madrid, Tarragona, Murcia, Cáceres, Vigo, Logroño, Barcelona y Asturias, en los que se han intervenido tres ordenadores, 27 discos duros, 295 CD y DVD, una tarjeta de memoria y numerosos archivos con contenido pornográfico. La operación se inició gracias a las denuncias de varios ciudadanos que encontraron contenidos pedófilos en Internet. En algunos de los equipos examinados se detectaron programas de intercambio donde se ofrecían archivos con contenidos pedófilos, a los que se accedía a través de palabras clave de las que eran conocedoras las personas cercanas a esta actividad. Además, los implicados prestaban especial atención a cómo se llegaba a los archivos a través de Internet, con accesos para usuarios con ciertos conocimientos, lo que permitía el anonimato en las comunicaciones y el uso de programas para evitar ser hallados. (elpais.com 19-09-2011).

"Desarticulada una tupida red de pornografía infantil con miles de usuarios en todo el mundo". La operación de la policía austriaca ha desenmascarado a sospechosos en 77 países, entre ellos España. Los contenidos se alojaban en una página de Internet rusa, entre los usuarios había funcionarios, jubilados, estudiantes e incluso escolares, suman 2.360 personas sospechosas de intercambiar pornografía infantil por Internet. Sólo 23 sospechosos están en Austria. A cerca de 600 les sigue la pista el FBI estadounidense, y otros 400 han sido interrogados por las autoridades alemanas. En total hay usuarios de 77 países. (elpais.com 01-02-2007).

"Ocho detenidos en una operación internacional contra la pornografía infantil en Internet". Agentes de la Policía Nacional han detenido a ocho personas en diferentes ciudades españolas e imputado a otras 10 dentro de una operación internacional contra la distribución de pornografía infantil en Internet. La actuación policial, coordinada a través de Interpol, ha permitido la clausura de un foro que servía como punto de 
encuentro de los pedófilos en la Red. Entre los arrestados se encuentran usuarios en España de dicho foro, al que estaban conectados ciudadanos de 78 países como Estados Unidos, Rusia, Alemania y Canadá, las naciones con más conexiones. En total, se ha identificado a 3.512 personas que habían tenido contacto con esta página web. Se anunciaba como un foro de contenido legal para publicar fotos artísticas de menores, pero en realidad funcionaba como lugar de intercambio e incluso de compra-venta de archivos de pornografía infantil. La investigación policial se centró en varias fotografías distribuidas en el mencionado foro y protagonizadas por menores posando en actitud sexual y siendo sometidos a abusos. Después, los agentes localizaron a los usuarios que accedían a esa página web y se descargaban y compartían ese tipo de archivos. (elpais.com 09-08-2011)

"Dos años de cárcel para un pediatra que divulgaba porno infantil". La Audiencia Provincial de Málaga ha condenado a dos años de prisión a Rafael Diego P. M., de 50 años y pediatra de profesión, por tenencia y distribución de pornografía infantil. El facultativo no tendrá que ingresar en prisión ya que su condena ha sido suspendida durante el plazo de cinco años con la obligación de participar en un programa de educación sexual. (elpais.com 12-10-2010)

"Detenidos 10 pedófilos por posesión o distribución de pornografía infantil en la Red". La Brigada de Investigación Tecnológica del Cuerpo Nacional de Policía ha detenido a diez personas e imputado a otras dos por tenencia y distribución de material pornográfico en Internet, entre los detenidos hay un desempleado, un reponedor de mercancía, un barrendero, un jubilado, un inspector de Hacienda de 57 años, un mozo de almacén, un informático, una quiosquera, y un operario en una cadena de montaje fabril. El más destacado de los detenidos es el hombre de Alicante que grababa con cámara oculta a su cuñada utilizando para tal fin una cámara de video digital que había instalado subrepticiamente en la rejilla de ventilación del cuarto de aseo de su domicilio, donde también residía la menor. Los investigadores están rastreando si estas películas fueron distribuidas en la Red por el acusado. En esta operación, los agentes han utilizado una novedosa herramienta forense denominada Gnuwatch, desarrollada en EEUU, que cuenta con un listado de miles de archivos de contenido inequívocamente pedófilo de extrema dureza y rastrea las redes de intercambio de archivos para identificar a los usuarios que los comparten en la Red. Este software permitió a los investigadores identificar a varias personas que habían compartido y descargado estos archivos pedófilos en una de las redes peer to peer más utilizadas (la red Gnutella). Fueron incautados 38 discos duros, nueve ordenadores portátiles, una cámara de fotos, $150 \mathrm{CD}$ y DVD, ocho pendrive, seis tarjetas de memoria y diversa documentación. (elpais.com 01-03-2011)

Las noticias anteriores nos permiten exponer las manifestaciones fenomenológicas que en los últimos años ha adquirido la pornografía infantil: su alojamiento, tráfico e intercambio mediante los espacios que facilita Internet; se desdibujan las fronteras tanto para acceder a los contenidos como para la cooperación policial en la persecución de los consumidores y traficantes; se destaca la participación 
de ciber/voluntarios que alertan sobre páginas con contenidos pedófilos; reflejan también la inexistencia de un perfil definido del consumidor de pornografía infantil. Adicionalmente, el formato mediático de presentación y su frecuencia activan un estado de alarma social sobre el tema ante la facilidad de acceso a páginas de contenido pornográfico y los miedos a que cualquiera del entorno cercano pueda ser un pedófilo.

El tema de la pornografía infantil, como se aprecia, ha irrumpido con fuerza en los últimos veinte años como un asunto de relevancia pública. Varias circunstancias han contribuido a ello: desde el sentimiento de protección que universalmente embarga o concita la niñez, sentimiento que ha adquirido vigencia jurídica dentro de un orden de Derecho como lo es el orden social moderno, hasta la dinámica que ha seguido la explotación comercial sexual infantil puesta en evidencia en sus manifestaciones especialmente en su alcance global y su configuración como una de la ramificaciones de la delincuencia organizada. Pero no es solo esta la circunstancia que ha contribuido a hacer de la pornografía infantil un tema de amplio debate y actualidad. Hay otras no menos relevantes.

La más importante tal vez sea la poderosa influencia e impacto que ha ocasionado la revolución informática y de las comunicaciones, favoreciendo la irrupción de otro espacio por la que discurre buena parte de nuestras vidas: la pública en busca de información y de relación social, y la privada porque en ella construimos nuestro espacio de intercambio y guardamos la comunicación personal, videos y fotografías que vamos haciendo a la largo de nuestra biografía. Este otro espacio humano de origen reciente que algunos llaman infosfera, ambivalente como toda institución humana, al tiempo que ha potenciado nuestro espacio de relación y conocimiento, ha servido también para el aprovechamiento de la delincuencia organizada en su adecuación a la naturaleza global de nuestro tiempo. Valiéndose de ella para expandir su alcance y multiplicar sus formas delictuales liberándose y evadiendo el anclaje físico de las legislaciones nacionales que asisten con retraso a la acelerada homogenización de la realidad social. Esto es, la pornografía infantil de nuestros días es más que nunca pornografía infantil digital y ello le concede una cualidad que hace apenas algunos años no tenía. 
A ello hay que agregar el estado de alarma social en el que se vive ante los miedos y riesgos modernos que ha traído de la mano la exigencia por extremar medidas de seguridad de orden preventivas y punitivas, poniendo de relieve la emergencia de un Derecho penal que ha adelantado sus barreras desdeñando el principio de mínima intervención. Ese estado de alarma social es coadyuvado por el manejo de situaciones que rayan en el escándalo desde la exposición mediática. De manera que el estado de alarma y una realidad social construida desde los medios se suman a este cuadro en el que un delito tan susceptible de crispar sentimientos, como lo es la pornografía infantil, pasa a ser la bandera de quienes se lanzan en una cruzada moral para aleccionar sobre el ejercicio de la libertad individual en el ámbito de la intimidad sexual.

La última de las circunstancias que han hecho de la pornografía infantil un hecho de relevancia pública tiene que ver con el esfuerzo de las instituciones sociales por elevarla a esa condición y combatirla en el nuevo escenario global. En este caso son las innumerables iniciativas de las entidades supranacionales por sensibilizar a los Estados y sociedades nacionales respecto de su presencia, el nuevo contexto en el que ocurren y en las formas necesarias para afrontarlas. En este contexto internacional se trata de llegar hasta todos los territorios nacionales. Ahora bien, la regulación que ha observado la tipificación de la pornografía infantil ha seguido un curso, una dinámica, una orientación, un signo. Este curso o dinámica ha tenido una orientación que se ha desplegado desenvolviendo su razón mediante un proceso que presenta claramente su signo, especialmente en cada momento de reforma legal pero que puede ser seguido a lo largo de los lapsos de tiempo en que cortamos nuestro trabajo o apreciar en un espacio de tiempo y lugar si precediéramos a hacer una radiografía del momento socio/jurídico. En tanto que puede ser identificado, sus hitos son manifiestos y su análisis susceptible de interpretación, pasa a adquirir las cualidades de un hecho social histórico en el sentido de que es posible conocer su sentido y dirección y seguir su curso, advirtiendo su realización en el horizonte inmediato.

El discernimiento criminológico es capaz de poner al descubierto las vinculaciones y asociaciones entre los distintos momentos y situaciones socio/jurídicos para comprender el signo de su movimiento. Más aun, queremos señalar que cada paso o momento origina y determina el siguiente de manera que el conjunto del proceso se muestra como un hecho social coherente. Advertir esto, es decir que existe una 
orientación, una dirección del encadenamiento de actos socio/jurídicos que en el tiempo se han sucedido en la tipificación de la pornografía infantil, no es decir que todo está predeterminado o que viene impuesto por alguna fuerza superior. Es más bien dejar constancia de una interpretación -de nuestra interpretación- respecto de la realidad en la que las fuerzas sociales o el ideario o doctrina que prevalece actúan imponiendo intereses. Así, queremos demostrar que la orientación político criminal que desde el momento de la reforma de 1999 cuando logró reinstalar en el Código Penal Español el desacertado título de corrupción de menores, desechado apenas un lustro antes, ha configurado un orden regulatorio de la pornografía infantil que nos resulta representativo del nuevo Derecho penal que paulatinamente se viene materializando desde el ideal de la seguridad en Europa y los Estados Unidos.

Para desnudar ésta orientación nos servimos del debate surgido alrededor de la tipificación de la posesión de pornografía infantil para el autoconsumo, tipificada desde el año 2003 mediante la Ley Orgánica 15/2003 de 25 de noviembre. El principal elemento para construir un debate profundo respecto de la pertinencia de la creación de este tipo ha de centrarse sobre el bien jurídico afectado. Como tratamos de justificar de la mano de buena parte de la doctrina española, no hay razones para sancionar penalmente la posesión, a menos que el bien jurídico tutelado sea la moral sexual cosa inaceptable a la luz de un orden social de Derecho moderno en el que prive la libertad individual de las personas para su realización personal. Este debate desde la perspectiva que desarrollamos en el trabajo vuelve una vez tras otra sobre la Política Criminal que en los últimos años ha venido permeando las instituciones de control social que fundaron un enfoque centrado en el ideal de la resocialización del delincuente. O lo que es igual: en la medida que se adelantan las barreras del Derecho penal se retrae el alcance de las instituciones de control social que animaban una Política Criminal en el marco de un Estado de bienestar.

De allí una Política Criminal que de la mano del Derecho penal focaliza su atención sobre el control de los grupos peligrosos antes de la comisión de un evento delictivo y después de haber cumplido la condena. Antes, el Derecho penal era la ultima ratio de la Política Criminal. Ahora la Política Criminal se resume en el Derecho penal en sus dimensiones preventivas y ex-post. Antes, cabía el ideal de la resocialización del delincuente para lo que se disponía del marco regulatorio y administrativo de las 
instituciones de control social. Ahora el control social se sustrae a una política de inocuización del delincuente alineada con un ideal de seguridad. En ésta orientación la eficiencia en el alcance de mayores niveles de seguridad poco repara en la intromisión en el ámbito personal del ejercicio de la libertad.

En esta orientación de la Política Criminal expresada en la expansión del Derecho penal utilizado como única y primerísima herramienta de regulación, el objetivo de este trabajo gira en torno a la tipificación de la posesión para uso propio de la pornografía infantil contemplada en el artículo 189.2 del Código Penal español como el ejemplo que con mayor claridad expone el afán punitivo sobre conductas que se alejan de las prácticas mayoritarias, pero que no afectan a ningún bien jurídico.

El trabajo lo hemos dividido en cinco capítulos. El primero de ellos configura el escenario socio/jurídico en el cual nuestro problema adquiere unas cualidades de las que hasta ahora carecía. Traza los perfiles de una realidad social muy distinta de la que teníamos hace apenas unos años y en la que ha emergido como problema la explotación comercial sexual de la infancia. Revisamos algunos datos generales del problema que a pesar de su falta de rigor nos permiten asomar su carácter trasnacional. El problema es ubicado en consecuencia en una perspectiva global fuertemente impactado por el despliegue de las altas tecnologías de información y comunicación, que han alterado las dimensiones que anclaban el hecho que aquí nos interesa a los marcos físico/territoriales nacionales. Nos interesa resaltar en el mismo las formas sociales de presión sobre las instituciones del Estado, especialmente desde los medios de comunicación de la mano de la alarma social y de una moral sexual que se pretende de validez universal. En la medida que desgranamos el discurso tratamos de dejar claras dos ideas que encontramos a lo largo del trabajo, a saber, la adecuación del Derecho penal moldeada ahora por una orientación punitiva, expandiendo su ámbito de actuación, y la inscripción del fenómeno de la pornografía infantil en un nuevo contexto que le marca su impronta como lo es su irrupción como mercancía dispuesta al uso y consumo a través de la Red digital.

En el capítulo dos damos cuenta del marco normativo internacional que se ha venido configurando sobre la pornografía infantil, en particular con la influencia de los convenios y directivas comunitarias. Estas con sus méritos y limitaciones tienen en su 
haber la delimitación de un concepto de pornografía infantil alrededor del cual se ha desarrollado la respectiva doctrina española.

Los capítulos tres y cuatro están referidos al delito de pornografía infantil en el Código Penal Español. El tercero se sitúa en una perspectiva histórica reciente para revisar, a partir del seguimiento de los distintos momentos históricos en los cuales se han sucedido cambios en la ley respectiva, como ha sido el encaje normativo de la pornografía infantil en el Código Penal Español en 1995, dando cuenta de los cambios sustanciales que dejan ver la orientación político/criminal a que hacemos mención. Identificamos como ocurre una ruptura con la tendencia que progresaba desde los inicios mismos de las instituciones democráticas que se deslastraba de construcciones normativas del modo corrupción de menores, desde la reforma de 1999 hasta la última de ellas sucedida el año pasado. El objetivo fundamental es forjar un discurso que muestre cómo cada modificación legislativa que se sucede desde entonces perfila la orientación penal del tratamiento del delito de pornografía infantil que aquí identificamos y denunciamos. Destacamos el adelantamiento de los linderos del Derecho penal en el ámbito de la pornografía infantil, exhibido en el incremento de las penas, la agravación de las conductas, la expansión de su criminalización sobre conductas inocuas que no representan ni amenaza ni peligro para bien jurídico alguno y las novísimas medidas de control sobre la vida del que recupera su libertad habiendo cumplido una pena.

En este capítulo también se aborda el bien jurídico protegido en el artículo 189. Son varias las modalidades delictivas contenidas en este tipo, motivo por el cual no existe consenso en la doctrina sobre un único bien protegido. En particular hemos revisado los correspondientes a la indemnidad o intangibilidad sexual; la intimidad del menor y la libertad sexual como bienes jurídicos que pueden estar afectados en la mayoría de las figuras delictivas recogidas en el artículo 189. En atención a los objetivos de este trabajo nos centramos en el apartado primero: captación y utilización de menores de edad para la creación y tráfico de material pornográfico infantil; el apartado segundo: posesión simple; y el apartado séptimo alusivo a la pornografía virtual. 
La posesión de la pornografía infantil es diseccionada en el capítulo cuarto. Analizamos las justificaciones del legislador para tipificar (art. 189.2 del Código Penal Español) ésta conducta y resaltamos los argumentos fundamentales de las dos posiciones que gravitan sobre el asunto. Consecuentemente con las tesis centrales vertidas en todo el documento resaltamos su dimensión jurídico/criminológica para debatir sobre la existencia de razones para su tipificación y revisar las que, en cambio, aportan elementos de Derecho y de Política Criminal para su destipificación. La penalización de la posesión representa el culmen de la tendencia que en el trabajo intentamos poner en evidencia. De allí la estrategia metodológica de centrarnos en él, puesto que resume las características del avasallamiento del Derecho penal como única ratio de la Política Criminal que se ha entronizado en las instituciones normativas y de control social. Y, sin embargo, como apuntamos al inicio de ésta introducción, el proceso ya asoma sus nuevas aspiraciones reflejadas en la Propuesta de Directiva del Parlamento Europeo y del Consejo relativa a la lucha contra los abusos sexuales, la explotación sexual de los niños y la pornografía infantil que se ha presentado para sustituir a la vigente Decisión Marco 2004/68/JAI y avanzar más en la orientación que en el trabajo discernimos.

Cerramos la exposición con el capítulo quinto en el que volvemos a manera de síntesis sobre los elementos fundamentales que conforman la Política Criminal cuya orientación hemos expuesto en los capítulos anteriores, esta vez de forma especifica sobre la posesión simple. Este capítulo cierra el desarrollo expositivo desplegado a lo largo del trabajo y sintetiza los rasgos fundamentales de la Política Criminal cuya especificidad asociada al delito de pornografía infantil hemos expuesto. Se expone como la modernidad y la globalización son el marco cultural de la sociedad del riesgo, y el modelo de seguridad su correlato penal por el que se ha optado para responder a los riesgos y temores posmodernos trasmutados en miedo que en última instancia encarnan los llamados grupos peligrosos como los pederastas y ahora los pedófilos y consumidores de pornografía infantil. En el modelo penal de seguridad el Estado se limita a la gestión y distribución del riesgo ante individuos peligrosos.

El capítulo además explica cómo los medios de comunicación han incidido directamente en la tendencia represiva del Derecho otorgando un papel protagónico a las víctimas en su exigencia vindicativa. El estado abandona el ideal resocializador para 
asumir una ideología de la seguridad que reduce la dimensión social de la Política Criminal a su esfera penal. Esto abre el espacio a que se perfilen mejor los rasgos característicos del Derecho penal del enemigo como corriente teórica en el que se enmarcan las transformaciones que se suceden en el ámbito penal, especialmente materializado en el delito de posesión de pornografía infantil.

$* * * * * * *$

Aunque mi formación es de orientación sociológica y político/criminal, la justificación del tema objeto de estudio viene dado por varias razones. La referencia doctrinal y legislativa de España para Latinoamérica hace, no obstante, que no pocas normas sean trasvasadas sin contemplar las diferencias culturales, sociales y administrativas entre otras. Ello motivó el esfuerzo por hacernos del debate suscitado con ocasión de las últimas reformas penales y su discurso criminológico. Siendo que en Venezuela no está tipificada en el Código Penal la posesión de pornografía infantil pero ha suscrito convenios internacionales que instan a su tipificación- fue de nuestro interés profundizar en la discusión de la doctrina sobre la posesión simple, para aprehender criterios y argumentos sólidos, consistentes y fundados que me permita realizar un aporte de cara a los futuros debates que sobre el tema se realice.

Es por ello que decidí, acompañada del buen criterio y orientación de mis directoras, que la mejor forma de fotografiar o cartografiar la orientación político/criminal de la U.E. era a través del abordaje a un tipo penal que en el trascurso de los últimos años se hubiese modificado y ampliado. En este sentido, el artículo 189 ha sido sometido ya a tres reformas desde el Código penal de 1995. El tema me pareció además el adecuado porque refleja un formato de presentación mediática de ciertos contenidos que con el paso de los años recientes se han instaurado como emblemáticos en el imaginario social empujando el endurecimiento del Derecho penal. En la Exposición de Motivos de los últimos Proyectos de Ley y de las reformas al Código Penal, expresamente se mencionan estos casos mediáticos para justificar la necesidad de protección del menor.

Siendo investigadora del Instituto de Criminología Lolita Aniyar de Castro de la Universidad del Zulia, Instituto de amplia trayectoria en el estudio de la Criminología 
como disciplina del control social desde una perspectiva crítica, con formación universitaria en la teoría y prácticas de la intervención social (Licenciada en Trabajo Social) y después de realizar la Maestría en Ciencias Penales y Criminológicas y la Maestría en Desarrollo Social, decidí complementar mi formación con el Doctorado en Política Criminal que me permitiera el desarrollo de una investigación que profundizara el estudio del control social sobre un delito particular con las especificidades de los tiempo que corren. La Universidad de Salamanca ofrecía este programa de Doctorado.

La referencia concreta que hago a la legislación Española no es gratuita ya que obedece a la permanencia durante seis años en este país, con ocasión de cursar el Programa de Doctorado “Aportaciones de la Política Criminal a los Códigos Penales Iberoamericanos", bajo el cofinanciamiento del Programa ALBAN y la Universidad del Zulia. Esto ha permitido el acceso diario a los medios de comunicación, a las discusiones académicas realizados en la Universidad de Salamanca, a los debates de la opinión pública sobre el tema y a la disposición de la actualizada y prolija bibliografía mucha de la cual nos ha asistido en la elaboración de este trabajo.

Para finalizar quiero dejar constancia del agradecimiento a la Universidad de Salamanca, de cuyas instalaciones y servicios hice uso para producir este trabajo; a La Universidad Zulia y al Programa de Becas de Alto Nivel para América Latina de la Unión Europea (ALBAN) por su apoyo y financiamiento. Agradezco a las Directoras Profesoras Doctoras: Nuria Matellanes Rodríguez y María Luz Gutiérrez Francés por el apoyo y la ayuda constantes en la elaboración de este trabajo. Juntas han perseverado en su afán de que no decayera en el ánimo, en la exigencia y el rigor académico en el tratamiento del tema y en su exposición. Y la perseverancia, decía Octavio Paz, es promesa de resurrección. Agradezco también a los compañeros del Seminario Antón Óneca por su amistad y apoyo.

Agradezco muy especialmente a mis padres, a Noé, a José y a Gabriel por su paciencia, acompañamiento y el amor incondicional que me han ofrecido durante estos años. 
CAPÍTULO I

\section{PORNOGRAFÍA INFANTIL \\ REALIDAD SOCIO/CRIMINOLÓGICA}


El Capítulo que sigue configura el escenario en el cual nuestro problema adquiere relevancia, especificidad y alcance hasta ahora inexistentes. Dibuja los perfiles de una realidad social en la que el agregado de acontecimientos que se han sobrevenido en las dos últimas décadas (por designar un horizonte de tiempo que nos sirva de referencia) ha configurado otra distinta de la que teníamos hace apenas unos años. Muy a tono con la realidad de nuestros días, el problema es ubicado en una perspectiva global, manifestación de la primacía adquirida por la realidad virtual y su altísima potencia para trastocar las dimensiones que anclaban el hecho que aquí nos interesa a los marcos físico/territoriales nacionales. Adicionalmente, el Capítulo nos introduce en el camino de la revisión de las formas sociales contemporáneas que enmarcan el acto legislativo y de construcción de reglas de juego, de la mano de la alarma social y de una moral sexual que se pretende de validez universal, como posteriormente veremos. Esta realidad que aquí trazamos ha venido acompañada de toda una adecuación de los marcos normativos y del Derecho penal que ha estado sellada por una orientación punitiva, expandiendo su ámbito de actuación y reduciendo, al mismo tiempo, el control social del Estado a sus dominios. Revisamos el debate doctrinario suscitado con ocasión de la emergencia del hecho informático y la naturaleza de los delitos aparejados. Y el evento fundamental que caracteriza el fenómeno de la pornografía infantil, como lo es su irrupción como mercancía dispuesta al uso y consumo universal mediante su circulación en la red. Al final resumimos las ideas centrales del capítulo y dejamos expuesto el problema que se aborda a lo largo de toda la tesis en sus dimensiones criminológica y jurídica.

\section{EXPLOTACIÓN SEXUAL COMERCIAL INFANTIL (ESCI). EVIDENCIAS EMPÍRICAS Y ASPECTOS FENOMENOLÓGICOS}

\subsection{EXPlotación SEXUAl COMERCial InFANTIL EN EL MUNDO.}

Las cifras más veraces respecto de las evidencias de explotación sexual comercial infantil en el mundo están circunscritas a casos y/o estudios muy puntuales y focalizados, o bien provienen de la recopilación y el tratamiento de información sin el rigor conceptual y empírico que deberían serles propios, a veces incluso dispersos y no representativos. Ante este vacío se suelen asumir los datos y estadísticas de la UNICEF como válidos para trazar en perspectiva la magnitud y el alcance mundial del problema 
de la pornografía infantil, aunque para ello se aporten cifras en el marco más general de la denominada Explotación Sexual Comercial Infantil.

En efecto, los datos expuestos en el documento "No hay Excusas". Campaña contra la explotación sexual infantil en los viajes ${ }^{l}$, refieren que a pesar de las dificultades para obtener cifras, los últimos cálculos registrados indican que aproximadamente hasta dos millones de niños y niñas (en su mayoría niñas, pero también un número importante de varones) son víctimas todos los años de la explotación sexual comercial, un negocio al parecer de alcance global y multimillonario. Aunque no se expone de forma sistematizada, intentando una relación por continentes, para el caso de Asia el documento se hace eco de encuestas que indican la existencia entre todos los trabajadores sexuales en la subregión del Mekong de un $30 \%$ y un $35 \%$ que tienen entre 12 y 17 años de edad. Igualmente otorga validez a informes que ubican entre 40.000 y 60.000 los trabajadores sexuales infantiles en la provincia de Taiwán en China, y ubican al menos en una tercera parte los trabajadores sexuales de Camboya que son niños y niñas menores de 18 años. En el mismo Vietnam, a su vez, alrededor del $41 \%$ de los niños y niñas prostituidos forman parte de las redes de delincuencia organizada que gravita alrededor del negocio, casi todos inducidos a través de un amigo o un conocido. En Camboya, una encuesta realizada por la ONG Human Rights Vigilance entre 6.110 personas prostituidas en Phnom Penh y otras once provincias puso de manifiesto que un $31 \%$ tenían igualmente entre 12 y 17 años de edad, como ocurre también en Vietnam según vimos antes. En muchos países asiáticos, entre ellos la India, Myanmar, Nepal, Pakistán y Tailandia, la esclavitud para el pago de deudas suele ser la manera en que se involucra a las jóvenes en la prostitución. La joven debe devolver el dinero entregado a sus progenitores o a un tutor y no puede dejar de prostituirse hasta que la deuda esté totalmente saldada. Las jóvenes ganan poco dinero y los gastos como alquiler, transporte y alimentos se agregan a la deuda, con lo cual es extremadamente difícil saldarla. En un estudio realizado en el Pakistán se comprobó que, a juzgar sólo por los casos denunciados, cada día hay un caso de violación de una mujer o un menor; en promedio, al menos uno cada tres horas. Según una encuesta de la revista India Today, citada en el informe a que hacemos mención, hay en la India entre

\footnotetext{
${ }^{1}$ Ministerio de Trabajo y Asuntos Sociales. UNICEF-Comité Español, 2005. ECPAT España. Las cifras y estadísticas que se citan referidas de manera general a las manifestaciones en algunos continentes, son tomadas de este documento.
} 
400.000 y 500.000 niñas prostitutas. Asia Watch, una organización no gubernamental (ONG), ha informado sobre la venta y la trata de hasta 50.000 niñas del Nepal para llevarlas a la India como trabajadoras esclavas en prostíbulos de Bombay.

Las cifras correspondientes a África oriental y meridional hablan, citando fuentes del Ministerio de Turismo de Madagascar, que un 25\% de los trabajadores sexuales de Tulear, una zona turística de este país, son menores de 18 años. En investigaciones sobre estudiantes de escuela secundaria y de universidad en Sri Lanka se reveló que un $12 \%$ de las niñas habían sido objeto de abuso sexual en la infancia y que el número de niños varones en la misma situación - estimado en un $20 \%$ - era aún mayor. Las niñas no revelaron a los encuestadores cuál era su relación con los atacantes; los varones reconocían que con frecuencia se trataba de un miembro de la familia. Entre 1996 y 1998, niñas menores de 17 años figuraron en aproximadamente un 40\% de los casos denunciados de violación o intento de violación en Sudáfrica. De las jóvenes encuestadas en la zona meridional de Johannesburgo (Sudáfrica) un 20\% afirmaba que habían sido objeto de abuso sexual antes de cumplir 18 años. En el África occidental, según se estima, hay 35.000 niños dedicados a la industria del sexo.

En los Estados Unidos, revela el informe citado, que uno de cada cinco niños que utiliza Internet ha recibido requerimientos por parte de extraños para entablar relaciones sexuales. Igualmente se revelaba que cada año hay unos 104.000 niños y niñas víctimas de abuso sexual en ese país. A finales del año 2000, se estimaba en aproximadamente 325.000 los niños y niñas que estaban en peligro de caer en las redes de la explotación sexual comercial solamente en los Estados Unidos. Respecto de referencias cuantitativas para América Latina, puesto a conocer por el Organismo de Servicios Sociales de México, se advierte que en un estudio realizado en seis ciudades (Acapulco, Cancún, Ciudad Juárez, Guadalajara, Tapachula y Tijuana) estima en aproximadamente 4.600 los niños y niñas sexualmente explotados; se considera que hay más de 16.000 que practican la prostitución, y que es en las zonas turísticas de este país donde se concentra el mayor número de ellos. En Europa Central y Oriental la referencia que expresa el estudio hace mención de Lituania: de un 20\% a un 50\% de los trabajadores sexuales comerciales son menores de edad, con la existencia de zonas en las que hay niños y niñas menores de 11 años de edad que trabajan en prostíbulos y 
casos en los que se ha utilizado a niños y niñas de entre 10 y 12 años para realizar películas pornográficas.

Debido a que la explotación sexual comercial de los niños y las niñas está en gran medida oculta, es difícil recoger datos fidedignos al respecto. En los casos en que se han hecho estudios se utilizan diferentes definiciones de prostitución infantil y explotación sexual lo que dificulta su tratamiento metodológico. En algunos cálculos se incluyen los niños de la calle que tal vez ofrezcan relaciones sexuales si alguien lo solicita; en otros, sólo se incluyen a los niños y las niñas que trabajan en prostíbulos y salones de masaje, donde muchos se encuentran en un estado que bien puede calificarse de esclavitud. Aun cuando son incompletos y fragmentarios los datos reflejan la existencia del problema y su contexto situacional como negocio para algunos países, especialmente asociados con el llamado turismo sexual. No hay datos, sin embargo, suficientemente documentados acerca del número de niños explotados sexualmente con propósitos comerciales. Como ya se ha indicado, debido a la naturaleza clandestina de la industria internacional del sexo sólo ha sido posible efectuar cálculos estimados de orden general. No obstante, especialistas de la UNICEF estiman que cada año, aproximadamente un millón de niños ingresan en la industria del sexo. ${ }^{2}$

Poco se habla al respecto, pero los niños varones también son vulnerables a la explotación sexual comercial. Mientras las niñas suelen ser objeto de explotación en lugares organizados, clubes, prostíbulos o casas; los niños varones con frecuencia pasan el tiempo solos o en pequeños grupos y se los encuentra en calles, parques, plazas y playas. Los menores de edad prostituidos en Sri Lanka, cuya cantidad se estima entre 20.000 y 30.000, son principalmente varones. Desde Europa se suelen efectuar arreglos para que haya uno o más niños varones esperando a quien ha contratado sus servicios en el país de destino. En la República Dominicana, por ejemplo, los niños varones llamados Sanky Panky ${ }^{3}$ alternan con turistas extranjeros en las llamadas playas de Boca Chica y Sousa u otras de amplia atracción turística. Algunos de estos niños, según se

\footnotetext{
${ }^{2}$ UNICEF (2005). Hoja de datos: explotación sexual; UNICEF (2001). Aprovecharse del abuso. Una investigación sobre la explotación sexual de nuestros niños y niñas; UNICEF, Nueva York. UNICEF (2000). Children on the Edge: Protecting Children from Sexual Exploitation and Trafficking in East Asia and the Pacific. UNICEF East Asia and Pacific Regional Office, Thailand.

${ }^{3}$ Sanky Panky: con este nombre se asocia a los jóvenes y niños que visitan las zonas turísticas para ofrecer sus servicios sexuales como forma de salir de la pobreza.
} 
conoce, establecen relaciones que duran varios años. Los niños de la playa, algunos de sólo 13 años de edad, se transforman en el compañero anual de un turista sexual durante la semana en que éste visita el país. Según se estima, en este país hay 25.000 niños trabajadores en la industria del sexo. En Haití, que comparte con la República Dominicana el territorio de la antigua isla Española, hace muchos años que la industria turística explota las relaciones sexuales entre niños varones locales y hombres adultos procedentes de los Estados Unidos y Europa.

En la ciudad de Praga está ampliamente establecida la prostitución de niños varones, en su mayoría de entre 14 y 20 años de edad pertenecientes a familias disfuncionales que se han escapado de sus hogares y aldeas para ganar dinero con facilidad. Esos niños son, en su mayoría, heterosexuales, pero son explotados principalmente por hombres extranjeros, entre los cuales figuran médicos, empresarios y políticos. Cuanto más joven es el niño, más alto es el precio. En ciudades como Alejandría, Marrakech y Túnez, en la cuenca del Mediterráneo, los explotadores, que suelen ser turistas, con frecuencia proceden del mismo país, de otros países de la región del Oriente Medio y África del Norte o de Europa. Los más codiciados - lo que se traduce en una constante que marca en buena parte el auge de la pornografía infantil, como lo veremos más adelante - suelen ser los niños más precoces.

La Oficina Federal de Investigación de Estados Unidos (Federal Bureau of Investigation) (FBI) estima que más del $50 \%$ de todos los materiales de pornografía infantil confiscados en los Estados Unidos se refieren a prácticas con niños de sexo masculino. O lo que es igual: los niños varones también son víctimas de la violencia y el abuso sexual de parte en su mayoría de hombres adultos. Veamos algunas de las particularidades de la violencia sexual cuando se trata de ellos. Insistimos en que seguimos el documento del Ministerio de Justicia a que hicimos mención al inicio de este aparte.

En África, se suele reclutar a adolescentes varones en las fuerzas armadas, no sólo para combatir sino también para prestar servicios sexuales a los soldados. Durante el conflicto en Bosnia y Herzegovina, los soldados de ambos frentes fueron obligados a cometer atrocidades sexuales recíprocas con niños reclutados con los mismos fines que en África. En los Estados Unidos, un estudio realizado en 1998 por investigadores de la 
Facultad de Medicina de la Universidad de Pennsylvania llegó a la conclusión de que el abuso sexual de los niños varones está insuficientemente reconocido y registrado; y que, además, es también insuficiente el tratamiento para atender a los traumas. Los investigadores comprobaron que entre un $8 \%$ y un $16 \%$ de la población masculina en general tenía una historia de abuso sexual y que los niños que corren mayor riesgo de abuso sexual son aquellos menores de 13 años de piel oscura, procedentes de estratos socioeconómicos bajos y que no viven con sus padres. Los atacantes tienden a ser hombres conocidos de los niños, aunque no necesariamente parientes consanguíneos. Los ataques o las incidencias de abuso sexual con frecuencia ocurren fuera del hogar, entrañan penetración y son reiterados, de manera que son extendidos en el tiempo.

Es especialmente difícil para los niños varones hablar de esos abusos. Si son cometidos por una mujer, tal vez el niño no denuncie el abuso debido a que en muchas culturas las experiencias sexuales son una manera de demostrar virilidad. En algunas culturas, el ideal masculino promueve la idea de que ningún varón se resiste jamás a tener relaciones sexuales y el niño tal vez no admita, ni siquiera ante sí mismo, que ha sido objeto de abuso. Si el abuso es cometido por un hombre, el niño puede tener temor de las sospechas de homosexualidad, tema tabú en algunas culturas.

Del mismo modo que, después del ataque, el sobreviviente tropieza con dificultades para tomar conciencia de lo que le ha sucedido, también las personas cercanas familiares o del círculo de allegados a la familia, se resisten a creerlo. Cuando un adolescente revela que ha sido objeto de abuso sexual, se lo castiga aún más cuando se duda de su "virilidad" y de su orientación sexual, de modo que con frecuencia los niños varones guardan silencio con respecto al abuso sexual sufrido. Dado que muchas sociedades esperan que los niños varones y los hombres controlen sus emociones y también a los demás y a su medio ambiente, es particularmente difícil para los niños varones revelar que han sido objeto de ataque sexual. Los varones adolescentes víctimas de hombres pueden pensar que si revelan el ataque se dudará de su virilidad y de su orientación sexual. A su vez, los varones adolescentes víctimas de abuso sexual por mujeres de más edad tal vez no consideren que el contacto sexual sea abusivo. 
Según los investigadores de la Facultad de Medicina de la Universidad de Pennsylvania $^{4}$, un retraimiento social de este tipo frente a la magnitud del ataque puede contribuir a que aparezcan problemas psicosociales a largo plazo en el hombre adulto que ha sido víctima de abuso sexual en la infancia. Los más frecuentes son trastornos psiquiátricos -desde leves hasta graves- toxicomanías y graves problemas sexuales, entre ellos los relativos a la intimidad y a la identidad sexual, adopción precoz de comportamientos de alto riesgo y la transformación del niño víctima en atacante adulto.

Ahora bien, se suele creer que el abuso sexual y la explotación sexual comercial de los niños no constituyen problemas generalizados. Las cifras verdaderas permanecen ocultas tras la deserción en el acto de denuncia. Debido al secreto, a razones de tipo cultural como las comentadas y a intensos sentimientos de vergüenza, los niños - y los adultos que tienen conocimiento de abusos - pueden verse impedidos de solicitar ayuda. Nuevamente los estudios que han procurado develar ésta realidad no cuantificada - o pobremente sistematizada - presentan hallazgos que, como ocurre con la punta del iceberg, hablan de la dimensión del hecho. Ya hemos mencionado investigaciones realizadas entre estudiantes de nivel secundario y universitario en Sri Lanka que pusieron de manifiesto que el $12 \%$ de las niñas y el $20 \%$ de los varones habían sido objeto de abuso sexual en su infancia. En Kingston/Jamaica, estudios revelaron que de 450 alumnos de entre 13 y 14 años, un 13\% había sido objeto de intentos de violación. En un estudio nacional sobre niños que habían huido de su hogar y jóvenes sin vivienda en los Estados Unidos, un $17 \%$ de los encuestados habían sido obligados a entablar relaciones sexuales no deseadas por un miembro de la familia o un residente del hogar compartido.

En los Congresos Mundiales que se han promovido para tratar la Explotación Sexual Comercial Infantil (Estocolmo, 1996; Yokohama, 2001, Río de Janeiro, 2008) ${ }^{5}$ se han impulsado iniciativas de estudios y acciones que poco a poco vienen emergiendo a la luz la enorme dimensión del problema. Del consenso entre los especialistas

\footnotetext{
${ }^{4}$ UNICEF (2005). Hoja de datos: explotación sexual; UNICEF (2001). Aprovecharse del abuso. Una investigación sobre la explotación sexual de nuestros niños y niñas; UNICEF, Nueva York. UNICEF (2000). Children on the Edge: Protecting Children from Sexual Exploitation and Trafficking in East Asia and the Pacific. UNICEF East Asia and Pacific Regional Office, Thailand.

${ }^{5}$ Revisados en detalle, especialmente por sus alcance de tipo jurídicos, en el capítulo II.
} 
asistentes (2001) han surgido cifras globales estimadas que aproximan la cifra de afectados en dos millones de niños y niñas en todo el mundo.

\subsection{LA EXPLOTACIÓN SEXUAL COMERCIAL INFANTIL EN ESPAÑA.}

Dentro del panorama internacional España no está considerada como un país en el que la explotación sexual infantil sea un asunto de envergadura. Sin embargo, el problema existe y cada vez son más las voces de alarma sobre la situación de muchos niños, niñas y adolescentes que son víctimas. Como ocurre con los datos expuestos anteriormente sobre la situación en el mundo, es difícil disponer de cifras reales. Las más fiables son las que corresponden a los Cuerpos de Seguridad, aun teniendo en cuenta que sólo reflejan la cima de una pirámide de explotación de la cual no quedan registros físicamente disponibles.

La información general que se tiene sobre los casos conocidos de explotación sexual infantil en España procede de la Base de Datos de la Secretaría de Estado de Seguridad del Ministerio del Interior. Estos datos se refieren a las denuncias efectuadas a la Policía y las investigaciones realizadas por esta institución, que dispone de recursos especializados en los asuntos que afectan a los(as) menores como son el Grupo de Menores de la Policía Judicial (GRUME) y el Equipo del Menor y la Familia (EMUME) de la Guardia Civil. Las estadísticas disponibles están referidas a las actuaciones realizadas en las distintas Comunidades Autónomas desde el año 1997 hasta el año $2004^{6}$, que guardan relación con las denuncias presentadas por presuntos delitos de coacción a la prostitución, pornografía de menores y corrupción de menores y personas con discapacidad psíquica. No hay mayor información en la relación presentada que de constancia alguna de juicio sobre los casos por estos delitos.

\subsubsection{Coacción a la prostitución.}

En el periodo 1997-2004 se registraron un total de 349 casos, de los cuales el $89 \%$ hacen referencia a mujeres y $11 \%$ a varones, lo que muestra que hasta la fecha, en España es un problema que afecta principalmente a las menores. La media de los casos

\footnotetext{
${ }^{6}$ Ministerio de Trabajo y Asuntos Sociales y Observatorio de Infancia (2006). II Plan Nacional contra la explotación sexual de la infancia y la Adolescencia 2006-2009. Madrid.
} 
registrados por año asciende a 43,6 observándose que la incidencia por año de los primeros seis años evaluados (1997-2002) se ha mantenido más o menos estable, entre 30 y 42 casos por año. Esta tendencia cambia en los dos últimos años, cuando en el año 2003 se llega a 80 casos denunciados, es decir que prácticamente se duplican los casos. En el 2004 se denuncian 60 casos que, aunque baja respecto del año anterior, sigue siendo un dato muy elevado en relación con el promedio de los seis primeros años. Esto, alega el informe, puede ser un reflejo del aumento de este tipo de problemática, debido entre otros temas al aumento de la trata de mujeres procedentes de otros países, entre las que se incluyen a mujeres menores. También, puede reflejar una mayor sensibilización ante estas situaciones efectuándose un mayor número de denuncias, así como una mayor eficacia por parte de la policía. En cualquiera de las dos hipótesis ambas apuntan hacia un alineamiento entre lo que ocurre realmente y sus registro oficiales, lo que se valora con mucho acierto. En cuanto a la edad, se observa que la mayoría de los casos registrados en 2002 y $2003(87,6 \%)$ corresponden a menores que se encuentran entre los 15 y 17 años. En el año 2004, a pesar de que la proporción sigue siendo elevada entre las menores de 15 y 17 años (70\%), similar a la de años anteriores, el 23\% de los casos correspondieron a menores de 13 años.

\subsubsection{Pornografía infantil.}

El número de menores afectados durante los ocho años del periodo analizado fueron 339, de los cuales 188 fueron mujeres (55\%) y 151 varones (45\%). Por tanto, bien puede afirmarse que en lo que respecta a la pornografía infantil, ajustado a las cifras del informe en cuestión, afecta a ambos sexos por igual. La media de víctimas recogidas en las denuncias por año asciende a 42 menores, si bien la incidencia anual ha variado considerablemente. De hecho, a partir del año 1999 prácticamente se duplica el número de casos denunciados, identificándose al Internet como una de las causas principales de este aumento al ser utilizado como medio y vehículo de distribución. Durante los años 2002, 2003 y 2004, el 57\% de los casos correspondían a menores de 13 años.

\subsubsection{Corrupción de menores y de personas con discapacidad (psíquica).}


El número de menores y personas discapacitadas afectadas durante los ocho años del periodo analizado fueron 938, de los cuales 550 fueron mujeres (58\%) y 388 varones (41\%). En cuanto al análisis por edad, se observa que hasta los 14 años el porcentaje de niñas $(47 \%)$ es un poco menor que el de niños (52\%), sin embargo desde los 15 años es un problema que afecta más a las menores (77\%). El grupo de edad más afectado es el de los niños y niñas menores de 13 años, representando el 36\% de las denuncias.

Como conclusión de ésta escueta pero fundamentada radiografía de la Explotación Sexual Comercial Infantil en España, para el período 1997 / 2004, se puede afirmar que mientras que la coacción a la prostitución a menores afecta principalmente a menores mujeres entre 15 y 17 años, la pornografía infantil afecta tanto a niños como a niñas, especialmente a menores de 13 años. En cuanto a la corrupción de menores y discapacitados psíquicos afecta por igual a ambos sexos y, aunque se da de forma significativa en todas las edades, destaca el porcentaje de casos elevados de menores de trece años de ambos sexos. Como también lo señala el informe, tales datos solo se refieren a víctimas o casos registrados como denuncias y que con toda probabilidad representan sólo una parte del fenómeno de la explotación sexual infantil en España.

Los datos presentados en el Balance 2010 sobre la evolución de la criminalidad muestran que los delitos detectados y perseguidos de Corrupción de menores en España desde el año 2000 han ido en aumento. Así en el año 2000 se registraron 76 casos; 59 en años 2001; 93 en año 2002; 112 en el año 2003; 157 en el año2004; 161 en el año en el año 2005; 201 en el año 2006; 255 en el año 2007; 270 en el año 2008; 264 en el año 2009; 301 en el año 2010. ${ }^{7}$

\subsection{Causas y EFectos de la Explotación SEXuAl CoMERCial INFANTIL.}

Ahora bien, ¿cuáles son las causas y los efectos de la Explotación Sexual Comercial Infantil? Un repaso por lo que los especialistas han identificado que la originan y las consecuencias que genera en el desarrollo infantil, puede ayudarnos a aprehender el fenómeno en sus distintas facetas de cara al objetivo central de la tesis.

\footnotetext{
${ }^{7}$ Ministerio del Interior del Gobierno de España, Balance 2010. Evolución de la Criminalidad.
} 
Aunque son múltiples las causas que se pueden citar en el caso de la explotación sexual comercial infantil, es importante destacar que cada caso - hablamos de la situación por país, incluso por regiones - de ESCI es distinto a los demás y que tiene sus causas y procesos particulares, un ejemplo de ello son las situaciones particulares que se suceden en los países donde hay conflictos armados. Pero podemos resaltar dos causas generales que se presentan en casi todos los países y/o comunidades afectados: la pobreza y la discriminación de género.

La primera podemos identificarla como una causa de tipo económico. La pobreza se cita con frecuencia como la causa predominante en la explotación sexual comercial de los niños. En muchas zonas rurales las escasas oportunidades de ganarse la vida hacen que los jóvenes y las familias se desplacen a zonas urbanas, por lo que sin educación ni oficio, la prostitución se puede considerar como la única forma de sobrevivir. La falta de medios económicos también puede llevar a un abandono escolar incluso cuando la familia se queda en su comunidad. Para un niño o una niña sin estudios es muy difícil encontrar un trabajo digno.

La otra causa común es la discriminación de género. En gran parte del mundo hay una grave discriminación de género: las niñas nacen sin las mismas posibilidades u oportunidades de vida que tienen los niños. La discriminación incluso puede formar parte de las costumbres y de las pautas culturales de ciertas comunidades, como es el caso de los matrimonios precoces (con niñas tan jóvenes como de 7 a 8 años) o de la dote - institución ancestral presente en casi todas las culturas conocidas y estudiadas en la que la familia de la joven tiene que pagar por casar a su hija que además pasa a formar parte de la familia del marido. Esto hace que el interés por la niña sea mínimo en comparación con sus hermanos varones.

Otras causas suelen ser del tipo sociocultural que, aunque de menor y diferente impacto, incluyen las dinámicas cambiantes de la familia y de la comunidad. La ruptura o disfunción familiar puede conducir, no sólo a problemas económicos, sino también a un menor interés en el bienestar de los niños. En el ámbito de las políticas sociales, por ejemplo, la práctica desaparición de los sistemas de bienestar y protección en Europa Oriental y la precariedad de la administración prestacional existente ha provocado un auge de la ESCI en casi todos estos países. ESTES y WEINER han contribuido con el 
debate sugiriendo una matriz de causas que presenta dos ejes, uno de tipo micro/situacional, que sujeta las causas a razones ancladas en el contexto territorio y cultural inmediato; y otro de tipo macro/contextual con elementos socio-económicos calificados de estructurales. Luego, ya ubicados en el contexto global, sugieren que la expansión de un mercado que demanda este tipo de servicios auspicia incentivos para la oferta; y, por último, anotan también razones de orden histórico/coyunturales asociados a condiciones de guerra y/o debacle social refiriéndose en concreto al estado de los países del este europeo y las repúblicas pertenecientes a la antigua Unión Soviética, en la que se mezclan la pobreza, el desplome de las instituciones sociales y de la misma administración y la conformación de bandas organizadas que han pasado a ocupar es espacio dejado por el deslave institucional. ${ }^{8}$

Sobre las consecuencias, prácticamente existe consenso respecto a que la explotación sexual de los niños y niñas en cualquiera de sus formas tiene graves repercusiones físicas, mentales y sociales. El niño corre un alto riesgo de contraer enfermedades de transmisión sexual (ETS) o VIH/SIDA, así como sufrir posteriormente maltrato físico. El cuerpo inmaduro de un niño es más vulnerable a las enfermedades debido a que su sistema inmunológico y su cuerpo no están totalmente desarrollados. Una niña en la pubertad cuyo órgano reproductor todavía está en desarrollo puede sufrir desgarros genitales y abrasiones producidas por la actividad sexual, lo que facilita la transmisión de las enfermedades. También son problemas comunes los embarazos prematuros, los abortos y los problemas de fertilidad. Los niños desplazados a otros países se enfrentan al aislamiento social y cultural. Pueden también sufrir arrestos y detenciones debido a su entrada ilegal en el país, ingresando así al ciclo de la ilegalidad y del desamparo oficial, verdadero caldo de cultivo de donde se alimenta la delincuencia sexual organizada. Debido a que muchos de los niños afectados por la explotación sexual tienen una educación limitada y pocos alguna habilidad de la que puedan subsistir, suelen encontrar en la delincuencia una forma para sobrevivir. ${ }^{9}$

\footnotetext{
${ }^{8}$ ESTES, R.; WEINER, N., "Explotación sexual comercial de niños en Estados Unidos" en AZAOLA E., ESTES R., La infancia como mercancía sexual: México, Canadá y Estados Unidos, México, Siglo XXI, 2003, pág. 48.
}

${ }^{9}$ AZAOLA E., ESTES R., La infancia como mercancía sexual: México, Canadá y Estados Unidos, México, Siglo XXI, 2003. 


\subsection{El PERFIL DEL PEderasta.}

Por último, cabe trazar un perfil de los pederastas, no con el propósito estigmatizador sino para identificar situaciones o escenarios típicos de actuación que contribuyan con el mejor conocimiento criminológico de la situación y permitan posteriormente establecer las diferencias entre el pedófilo y el pederasta. En principio vale afirmar, para salir del tópico o lugar común, que se trata de personas que no tienen características psico/somáticas identificables o especiales. Se parecen a la mayoría de las personas: provienen de diversas culturas, profesiones y clases sociales. Pueden tener cualquier edad, estar casados o solteros. La mayoría de los que entablan relaciones sexuales con niños son hombres, aunque también ocurre la participación de mujeres. Los especialistas diferencian, sin embargo, entre los explotadores ocasionales y los preferenciales.

Los primeros, llamados ocasionales, no presentan una verdadera preferencia sexual por los niños, pero practican el sexo con ellos por carecer de límites morales claros y por satisfacer un deseo de experimentar con compañeros sexuales jóvenes, en la mayoría de los casos adolescentes (a partir de los 12 años). Algunos, como es el caso de turistas o viajeros, también pueden desarrollar inclinaciones por vivencias de situaciones en las que el sexo con niños se presenta como algo extremadamente accesible y normal, y contribuye a desinhibir al explotador y a dejar de lado sus propias ideas sobre la edad de consentimiento y la relación entre los niños y las actividades sexuales. La explotación sexual de la infancia pasa entonces a considerarse por parte del viajero como una forma de experiencia sexual "normal" en el período de vacaciones y en determinados lugares o territorios, y puede desarrollar a la larga en él un patrón de conducta de personalidad explotadora.

Los segundos - preferenciales- muestran una predilección definida y clara por el sexo con niños, habitualmente con niños impúberes (menores de 12 años). Los estudios psicológicos muestran que este tipo de personas presentan un desorden de personalidad que les incita a buscar compañeros sexuales inmaduros y vulnerables. Los explotadores 
preferenciales constituyen una pequeña minoría dentro del grupo de agresores sexuales, pero pueden abusar potencialmente de un gran número de menores. ${ }^{10}$

Esta radiografía primaria respecto del perfil del consumidor se corresponde con el existente en España, de acuerdo con los datos del Cuerpo de Policía Nacional. Los detenidos son, en un $99 \%$ de los casos, hombres con edades comprendidas entre los 16 y los 70 años, con una variada ocupación laboral ${ }^{11}$, casados o solteros, con hijos menores o sin ellos y de todas las clases sociales, lo que no permite fijar un perfil exacto de este tipo de delincuente sexual ${ }^{12}$. Según TAMARIT SUMALLA, un dato a considerar sobre los autores de abusos sexuales en niños es que un número significativo son profesionales relacionados con la infancia, fundamentalmente educadores y en menor medida pediatras, lo cual viene a confirmar el hecho de que las tendencias pedófilas suelen venir acompañadas de una atracción hacia el mundo de los menores ${ }^{13}$.

En uno de los estudios preparados para el primer Congreso Mundial contra la ESCI (Estocolmo, 1996) se concluye que la mayoría de las personas que explotan sexualmente a niños son fundamentalmente clientes de la prostitución adulta que se convierten en explotadores infantiles al utilizar los servicios de niños; $y$, en cambio, no se trata de pederastas que usan la prostitución como medio de acceder a compañeros

\footnotetext{
${ }^{10}$ Véase, AZAOLA E.; ESTES R., La infancia como... op. cit.

${ }^{11}$ Esta dispersión en la procedencia laboral de los pederastas es apreciable en las referencias de los medios cuando aluden situaciones atendidas por el Cuerpo de policías o la misma fiscalía. En las referencias de la prensa escrita se muestra la diversidad profesional u ocupacional de las personas detenidas por su vinculación con la pornografía infantil. Véanse como ejemplos los siguientes: Prisión indefinida para el "bibliotecario" de una red de pederastia en Internet (18-08-2008). Detenido un profesor de secundaria por posesión de pornografía infantil (13/04/2007). Destituido un alto cargo de la Generalitat por tenencia de pornografía infantil (08/07/2007). Detenido un mando de la policía local de Zaragoza por posesión de pornografía infantil. También ha sido detenido un psiquiatra del Hospital Clínico (29/11/2007). Dos detenidos en Málaga y Salamanca, uno de ellos pediatra, por distribución de pornografía infantil en la red. (22/05/2008). Detenidos dos monitores de campamentos acusados de abusos sexuales y pornografía. (18/07/2007). Detenido en Paterna el gerente de un club deportivo por supuestos abusos a más de 20 menores (09/07/2008). Detenido un joven de 15 años por distribuir pornografía infantil en Internet (1012/2007). Detenido un joven de Tarragona con más de 700.000 vídeos y fotos de pornografía infantil. (17/06/2008). Detenido un profesor por abusar de una niña de 11 años (12/05/2008). Un cura retirado es acusado de 93 delitos de abuso a menores en Australia (04/09/2008). Fuente: elpaís.com

${ }^{12}$ Véase, RODRÍGUEZ MARTÍN, E., "Pornografía infantil en Internet", en Foro Internacional Infancia y Violencia, en el X aniversario del Centro Reina Sofía para el Estudio de la Violencia, Madrid, 2007, pág. 79.
}

13 TAMARIT SUMALLA, J. M., La protección Penal del Menor frente al abuso y explotación sexual, Ed. Aranzadi, Navarra, 2002, págs. 23 y ss. 
sexuales infantiles. La comprensión de por qué las personas quieren comprar sexo nos puede ayudar a entender el fenómeno del abuso sexual en un contexto comercial. Algunos clientes de la prostitución argumentan que tienen una necesidad biológica real de satisfacción sexual. Otros dicen que utilizan los servicios de prostitutas como una forma de compañerismo con colegas o amigos, o por no poder negarse a propuestas de visitas colectivas en el ambiente donde interactúan. Finalmente, otros clientes pueden comprar sexo para crearse o fortalecer un sentimiento de masculinidad asociado al poder, dominio y uso sobre otras personas. Además de los propios agresores, en la estructura de la ESCI pueden participar muchos otros actores en diferentes fases del delito: miembros de la familia, líderes locales, agentes privados comerciales y, en su fase más desarrollada como industria, redes criminales organizadas.

TREMBLAY realiza una caracterización de los pedófilos donde plantea lo siguiente: “a) Se dirigen a adolescentes que no son sus propios hijos; b) en muchos casos, su orientación sexual les impidió y les disuadió de adoptar las obligación parental; c) son atraidos por niños en vez de niñas; d) podrían ser calificados como seductores ("manipuladores") en lugar de predadores"14

Existen varias hipótesis relacionadas con estos signos recurrentes en los pedófilos que pudieran considerarse característicos, entre ellas puede mencionarse las carencias afectivas; suele mostrarse simpático al lado del niño; disfruta de una capacidad de atracción que le permite ganarse su confianza sin necesidad, por lo general, de usar la fuerza. Con los adultos, el pedófilo se siente incómodo. Procura rodearse de niños a través del trabajo y el tiempo libre. Casi todos son hombres. Otros rasgos característicos que apuntan algunos profesionales es que suelen reincidir porque no pueden frenar los impulsos y regularmente en su niñez también fueron víctimas de abusos. Esta característica al parecer, sin embargo, era más frecuente en el pasado cuando no había tratamiento. Hasta ahora no existen evidencias de la influencia de factores genéticos implicados. REDONDO y ECHEBURÚA sugieren, por un lado, que la adolescencia constituye la etapa evolutiva clave en el nacimiento de esta patología y que, por otra parte, suelen racionalizar su conducta en un esfuerzo por justificarse. "Sufren distorsiones cognitivas. Se dicen a sí mismos que a los niños les gusta que les

\footnotetext{
${ }^{14}$ TREMBLAY, P., "Interacciones sociales entre pedófilos canadienses" AZAOLA E., ESTES R., La infancia como mercancía sexual: México, Canadá y Estados Unidos, Siglo XXI, México, 2003, pág. 105.
} 
toquen, que no hay nada de malo en ello, que es otra forma de cariño", reflexiona REDONDO. "Se trata de una cómoda excusa y de un fraude, pues la relación es asimétrica ya que el niño no está en condiciones de decidir qué quiere, aunque diga que $s i "$, añade ECHEBURÚA. ${ }^{15}$

\section{SOCIEDAD GLOBAL Y TECNOLOGÍAS DE INFORMACIÓN Y COMUNICACIÓN.}

Con más o menos consenso en la comunidad académica desde la segunda mitad del siglo XX se reconoce la existencia de un nuevo estadio histórico, cuyas denominaciones -entre ellas sociedad post/industrial, segunda modernidad, posmodernidad, modernidad líquida ${ }^{16}$ advierten de los rasgos de la gran transformación que se viene sucediendo y que afecta por igual a las estructuras estatales, a las condiciones laborales, al mundo de la producción y el comercio, al Derecho y aplicación de justicia, a la subjetividad colectiva, a la producción cultural, a la esfera íntima de las relaciones amorosas y la amistad, a la vida cotidiana y a las mismas relaciones de convivencia. Paralela a ella discurre, de forma marcada especialmente en los últimos veinte años, lo que se denomina globalización - suerte de correlato de la modernidad en la esfera de las finanzas, el comercio y las comunicaciones - con cuya designación se hace referencia a la homogenización de espacio / tiempo de los circuitos de producción de bienes y servicios, de capitales y de información en prácticamente toda la esfera terrestre. Proceso, además, que se ha acelerado de manera vertiginosa desde comienzos de los años noventa del siglo pasado.

Las discusiones respecto de la designación de este nuevo estadio histórico han sido largas y con no pocos desencuentros. En el ánimo de no adentrarnos en el debate asociado a la nominación de ésta nueva realidad, adoptaremos a los fines que nos proponemos en el trabajo la convención del término globalización, en la medida que, (a)

\footnotetext{
${ }^{15}$ Véase, ¿Qué ocurre en la mente de un pedófilo?, Diario El País, www.elpais.com, consultado por última vez el 02 de Mayo de 2008.

${ }^{16}$ Tales conceptos aparecen en cursivas para advertir que detrás de ellos va toda una fundamentación teórica cuya relación sobrepasa los límites establecidos por el objetivo de este trabajo. Valgan, sin embargo, las referencias a los siguientes autores y textos, entre ellos: BAUMAN, Z., La globalización: consecuencias humanas, Ed. Fondo de Cultura Económica, México, 2003; del mismo autor, Modernidad líquida, Ed. Fondo de Cultura Económica, México, 2009; LUHMAN, N., Complejidad y modernidad, Ed. Trotta, Barcelona, 1998; BECK, U., La sociedad del riesgo, Ed. Paidós, Barcelona, 1998; HABERMAS, J., "La modernidad un proyecto inacabado", en PICO, J. (ed.), Modernidad y Posmodernidad, Ed. Alianza, Madrid,1988; LYOTARD, J. F., La condición posmoderna. Ed. Cátedra, Madrid, 1984.
} 
su aceptación consuetudinaria en espacios académicos y de opinión ha pasado la prueba del tiempo, (b) refiere inmediatamente a una realidad que viene a suceder al capitalismo conocido hasta hace apenas algunos años recientes, signado por el fordismo como modelo de producción industrial y la territorialización de la producción anclada todavía a instituciones locales en un contexto de Estados nacionales, y (c) su sola designación, incluso en el lenguaje común, ubica conceptualmente el ciclo de eventos cuyo agregado es la afirmación en el imaginario social de la conformación dinámica e indetenible de una nueva realidad con rasgos que ya no se corresponden con lo que fue la sociedad de hace apenas algunos lustros.

Más exactamente, con el término globalización se indica el proceso de creciente interdependencia económica entre el conjunto de las regiones y de países del mundo, que se traduce en el continuo aumento de transacciones internacionales de capitales, tecnologías, servicios, mercancía e informaciones. Los puntos de vista sobre las perspectivas y sobre las consecuencias de este proceso de globalización son diferentes. Algunos sostienen que sobrevendrá con ella el nacimiento de un único sistema centrado en la universalización del mercado y de la democracia liberal occidental. ${ }^{17}$ Para otros producirá una creciente diferenciación e individualización de los valores y de los comportamientos. ${ }^{18}$ Otros esbozan la hipótesis de una época de gran turbulencia internacional movida por un choque de civilizaciones. ${ }^{19} \mathrm{Y}$ hasta hay quien sostiene que se producirá el triunfo del socialismo a nivel mundial. ${ }^{20}$ En cualquier caso, nadie en su sano juicio se atreve a advertir de que se trata de una etapa pasajera y circunstancial y, antes bien, insistimos, los especialistas convienen en que con ella se inaugura un nuevo estadio de la humanidad que, a juzgar por el potencial de los medios que la impulsan, apenas comienza y cuya dinámica amenaza con romper los moldes institucionales que desde los Estados nacionales pretenden domesticarlos y gobernarlos.

\footnotetext{
${ }^{17}$ FUKUYAMA, F., El fin de la historia y el último hombre, Ed. Planeta, Barcelona, 1992, págs. 167183.

${ }^{18}$ GIDDENS, A., Las consecuencias de la modernidad. Ed. Alianza, Madrid, 1994, págs. 109-119.

${ }^{19}$ HUNTINGTON, S., El choque de civilizaciones, Ed. Paidós, Madrid, 1997, págs 212 ss.

${ }^{20}$ WALLERSTEIN, I., El futuro de la civilización capitalista, Ed. Icaria /Antrazyt, 1997, págs. 90 ss.
} 
Con mucho acierto se suele denominar sociedad de la información a este período de la modernidad marcada por la explosión de nuevas tecnologías y los avances científicos sin precedentes, a la vanguardia de las cuales están las denominadas tecnologías blandas asociadas al manejo, procesamiento, archivo y transmisión de datos e información. ${ }^{21}$ Sin extendernos, ya que se aprecia cierto consenso sobre el alcance del concepto, repasemos ligeramente algunas definiciones, siguiendo el trabajo de Oscar PICARDO Joao. ${ }^{22}$

Para Paul A. DAVID (Universidad de Stanford) y Dominique FORAY (Instituto de Investigación e Innovación de París) ${ }^{23}$, lo más esencial de la sociedad de la información y el conocimiento se resume en la aceleración sin precedentes del ritmo de creación, acumulación y depreciación del conocimiento, lo cual se plasma en la intensidad del progreso científico y tecnológico. Maryann FELDMANN ${ }^{24}$, de la Universidad John Hopkins, analizando los efectos que las Tecnologías de la Información y las Comunicaciones (TIC) derivadas de Internet han ocasionado en la sociedad, señala que Internet ha generado una verdadera revolución, no solo por anclarse dentro del sector económico de vanguardia más importante dentro del mundo de la producción, sino por sus características versátiles y sus diversas aplicaciones en otros sectores de la vida productiva y cotidiana. Los flujos de información que se deslizan desde Internet y las innovaciones derivadas de esta herramienta han modificado sustantivamente la dinámica de las sociedades en materia de comunicación, manejo y administración de información. Para $\mathrm{FRADE}^{25}$, una de las dinámicas descriptivas de esta nueva sociedad global del consumo se puede sintetizar en la "movilidad" como

\footnotetext{
${ }^{21}$ Sobre una revisión de la evolución de las denominadas tecnologías blandas hasta llegar a la revolución digital de nuestros días y su impacto cultural Véase, CASTELLS, M., La era de la información, Volumen I, La sociedad red, Ed. Alianza, Madrid, 1996.

22 PICARDO, O., El escenario actual de las Ciencias Sociales: La Sociedad del Conocimiento, Universitat Oberta de Catalunya, 2003. disponible en www.uoc.edu/dt/20318/index.html

${ }^{23}$ Ibídem, pág. 3

${ }^{24}$ Ibídem, pág. 4.

${ }^{25}$ FRADE, C., "Estructura, dimensiones, facetas y dinámicas fundamentales de la sociedad global de la información”, mimeografiado, Universitat Oberta de Catalunya, 2002.
} 
valor dominante de la sociedad global emergente y la "libertad de movimiento" como su eje estratificador fundamental. ${ }^{26}$

Más allá de estas opiniones que asoman aristas de lo que ha de entenderse por sociedad de la información, tal vez valga convenir con CASTELLS en que: “... se trata de una sociedad en la que las condiciones de generación de conocimiento y procesamiento de información han sido sustancialmente alteradas por una revolución tecnológica centrada sobre el procesamiento de información, la generación del conocimiento y las tecnologías de la información. Esto no quiere decir que la tecnología sea lo que determine; la tecnología siempre se desarrolla en relación con contextos sociales, institucionales, económicos, culturales, etc. Pero lo distintivo de lo que está pasando en los últimos diez o quince años es realmente un cambio de paradigma тиy parecido al que ocurrió cuando se constituyó la sociedad industrial (...) Se constituye un paradigma de un nuevo tipo en el que todos los procesos de la sociedad, (...) de la economía, pasan a verse afectados por la capacidad de procesar y distribuir energías de forma ubicua en el conjunto de la actividad humana, ${ }^{, 27}$.

Aunque hay quienes pretenden reducir la complejidad social al fenómeno tecnológico, no es menos cierto que la designación refleja con propiedad el estado de una realidad cuya dimensión se ha desprendido del mundo físico y tangible, creando otra autónoma, digital, con perfil propio, de características bien definidas y que hoy conocemos como realidad virtual. No significa esto que la vida se ha desmaterializado; ésta sigue anclada en estructuras institucionales, culturales y biofísicas, pero ha emergido otra del tipo virtual que avanza haciendo emerger otra dimensión de la realidad que atiende sus propios códigos.

La entronización de ésta en la vida cotidiana, su despliegue sobre la rutina diaria de la vida moderna en ámbitos públicos y privados generando una relación de

\footnotetext{
${ }^{26}$ En otra perspectiva y con ánimo más crítico, Boltanski y Chiapello han insistido en que justamente la liberación de vínculos sociales referentes que sujetaban o anclaban al individuo contemporáneo, se corresponde con las nuevas demandas en ésta nueva fase del capitalismo global para posibilitar se suceda la conexión a la realidad virtual, Véase, BOLTANSKI, L.; CHIAPELLO, E., El nuevo espíritu del capitalismo, Ed. Akal, Barcelona, 2002.

27 Véase, CASTELLS, Manuel, "La dimensión cultural de Internet”, Universitat Oberta de Catalunya, disponible en http://www.uoc.edu/culturaxxi/esp/articles/castells0502/castells0502.html, consultado por última vez el 7 de junio de 2006.
} 
dependencia asociada a su funcionalidad y versatilidad, ha marchado a una velocidad tan vertiginosa que no solo rebasa la capacidad de muchos Estados y sociedades para regularla, sino que, en su propia dinámica, amplía el alcance de sus efectos, multiplicado por la renovación permanente de medios cada vez más sofisticados, versátiles y móviles, lo que hace difícil su propia regulación, dada la alta tasa de renovación de aparatos compatibles con la tecnológica que le acompaña. Luego, no erramos cuando se afirma que el dominio y control públicos sobre estos son importantes para garantizar su aprovechamiento con sujeción al Derecho, a las buenas prácticas orientadas al bien común y a los mismos valores fundacionales de la sociedad moderna. $\mathrm{O}$ a un nuevo contrato social si este emergiera.

De manera ordinaria e indiscriminada se suelen utilizar diversos términos asociados con la revolución cibernética y digital para hacer mención a la misma realidad. Esto que resulta normal en el ámbito de la vida cotidiana y el sentido común, no es admisible en el medio científico y profesional en los que se demandan precisión del objeto a considerar y delimitación conceptual. Seguramente cuando se mencionan vocablos como: informática, cibernética, computadoras, se hace referencia al mundo de la realidad virtual que hemos mencionado anteriormente y cuyo acceso se inicia con un medio físico como lo es el ordenador. Pero, en realidad, los significados de estos no tendrían la resonancia que tienen a los fines de la ligazón entre los temas tratados en este trabajo, de no ser por su vínculo a la Internet. Ya no se trata de un reservorio de medios electrónicos físicos de generación, procesamiento y archivo de datos e información, como lo que en un principio representó la revolución informática. Ahora es la conexión con alcance mundial de una red de redes de datos e información susceptibles de acceso, visualización, renovación, transformación y transferencia en tiempo real. Y justamente ésta conjunción es la que ha alterado la cualidad de la informática y de la misma telemática para crear el universo digital del que venimos dando cuenta.

La realidad virtual a que se hace mención aquí es aquella intangible, simultánea, omniabarcante, cuasi infinita, por la que circulan cualquier cantidad de archivos de datos, textos o imágenes, información y conocimientos, asociados o no a sistemas operativos y programas de software de cualquier orden y a través de los cuales accedemos tomando decisiones o siendo receptores de decisiones que otros han tomado. 
La existencia de ordenadores físicos, servidores o sistemas particulares, sin embargo, solo representan la dimensión física de esta realidad. Es la interconexión en redes de sistemas, base de datos y programas a los que podemos acceder en tiempo real desde nuestros hogares a través de la www (siglas en inglés de World Wide Web) lo que genera el mundo virtual aludido. Ésta nueva dimensión de la realidad, hoy día tan al uso como cotidiano, ha alterado el orden social moderno y guarda en sí mismo mayor potencial de transformación del que ahora ha mostrado. A partir de su irrupción y entronización definitiva e imprescindible en nuestra vida diaria, las realidades se han complejizado aún más y ya no son lo que eran apenas una década atrás. A partir de ésta nueva realidad global y el avance vertiginoso de las tecnologías de información la pornografía infantil - y otras tantas realidades criminales - ya no es la misma que se relataba a mediados de los años noventa del siglo XX.

\subsection{LA INFLUENCIA DE INTERNET EN LA PORNOGRAFÍA INFANTIL.}

Seguidamente pasemos a considerar de manera más focalizada elementos de la realidad española asociadas a la pornografía infantil, de manera que gradualmente quede plasmado el marco real a partir del cual han de girar las proposiciones teóricas asociadas con las dimensiones criminológica y jurídica que pretendemos justificar a lo largo de este trabajo. Antes, esbozamos el marco de alcance internacional desde las relatorías de la ONU sobre el asunto, para situarnos también en la perspectiva global que caracteriza el problema. Vemos con detalle la evolución reciente de la cuestión criminal asociada a la pornografía infantil en España, de acuerdo con las estadísticas de los cuerpos de seguridad a los fines de hacernos de una visión más objetiva de la misma. La relación de la emergencia de evidencias fácticas solo procura demostrar su multiplicación en los últimos años, alcance y dimensión adquirida con el uso de las nuevas tecnologías de información.

2.1.1 Acuerdo de la ONU. Datos estadísticos y consideraciones recientes sobre el aumento de la pornografía infantil en Internet.

Según los datos aportados por NAJAT M'JID MAALA, relatora de la ONU sobre venta, prostitución y pornografía infantil, "La pornografía infantil registra un constante aumento en Internet y otras plataformas como los teléfonos móviles. Se 
calculan que unos 750 mil pedófilos en el mundo están conectados permanentemente a la red y que existen 4 millones de sitios Web con contenidos pornográficos que exponen niños" (...) Se trata de un fenómeno que ha devenido una verdadera industria del delito, que genera miles de millones de dólares y que cada vez se extiende más debido al acceso generalizado a las nuevas tecnologías. Se cree que la producción y distribución de imágenes pornográficas criminales abusando de niños podrían representar un negocio de hasta 20.000 millones de dólares por año (...) Uno de los mayores puntos débiles en la lucha contra la pornografía por Internet $u$ otras plataformas de comunicación es que todavía no está criminalizado a nivel internacional. Si hay diferentes legislaciones nacionales, entonces los pedófilos pueden burlar las leyes utilizando niños de otros países" 28

El número de imágenes de explotación sexual de niños se cuadruplicó entre 2003 y 2007. De otra parte, la relatora alertó del gran aumento del llamado "grooming", anglicismo con el que se denomina a las solicitudes de (o contactos directos con) niños por Internet, especialmente a través de las redes sociales y foros de discusión, figura ya reconocida en la legislación española (LO 5/2010 de 22 de junio, art. 183 bis). Como una muestra de la volatilidad con la que operan desde las redes sociales escenarios proclives al delito asociado con el abuso sexual en el marco de las relaciones personales, la policía británica creó el perfil de una atractiva adolescente en una red social que inmediatamente fue contactada por una treintena de pedófilos y recibió doce invitaciones para encuentros personales. Seguramente son pocos los que para evitar los riesgos que supone el mundo virtual abogarán por restringir las libertades asociadas a su naturaleza; pero algún tipo de marco regulatorio ha de imponerse sobre su dinámica y funcionamiento, puesto que a falta de regulación se impone el poder de los intereses privados. La regulación no es muestra de la voluntad autoritaria y represora del Estado o la administración como la necesidad de salvaguardar la dimensión pública de ésta nueva realidad. Además, ésta situación, en conjunto, ofrece a los niños y adolescentes un modelo de sexualidad sin otra mediación que las pulsiones e instintos, por lo que la dimensión educativa y de orientación familiar adquiere enorme vigencia e importancia.

\footnotetext{
28 Véase, Alerta la ONU. Aumenta la pornografía infantil en Internet, en http://semana.com.ve/article.php?id=7869, septiembre 17, 2009.
} 
La lucha contra la pornografía infantil requiere de medios tecnológicos importantes, de una información actualizada de los servicios que albergan los sitios pedo/pornográficos y una altísima especialización de las fuerzas de seguridad en delitos cibernéticos. Asimismo un marco institucional y de regulación internacional que favorezca y potencie la colaboración y cooperación entre los países, ya que por lo que antes se ha advertido, a falta de regulación uniforme la delincuencia organizada salta de una latitud a otra, recurriendo a la difuminación de la identidad de las personas ancladas a un territorio. Por lo demás, la relatora de la ONU que citamos, abogó por la necesidad de responsabilizar legalmente en este ámbito a los proveedores de acceso a Internet y a los servidores, así como también establecer la imputación de responsabilidades sobre las entidades financieras y bancos de manera que bloqueen el flujo de movimientos financieros de los grupos criminales de pornografía con niños y colaboren con los cuerpos de seguridad nacionales. $^{29}$

\subsubsection{España. Datos y estadísticas de los Cuerpos Policiales.}

Entre los años 2000 y 2005 los detenidos por pornografía infantil se han multiplicado por diez, pasando de 26 a 260. De acuerdo con las cifras que maneja la Brigada de Investigación Tecnológica del Cuerpo Nacional de Policía, hasta el 2003 los datos de investigaciones abiertas y de número de detenidos fueron más o menos estables. Es a partir del año 2004 cuando ocurre una ruptura en la cuantificación anual estos pasan de 20 (2003) a 167 - y en la dinámica mostrada en el período de años al que se hace mención antes ${ }^{30}$.

Los datos presentados por el Balance de la evolución de la criminalidad 2010 evidencian el gran aumento experimentado por la pornografía infantil en España. Según estas estadísticas, en el año 2000 fueron detectados y perseguidos 45 casos; en el año 2001 77; en el 2002 se registraron 87 casos ; en el 2004 se registra un aumento de casi el doble llegando a 157; el año 2005 la los delitos detectados y perseguidos se

\footnotetext{
${ }^{29}$ Idem.

${ }^{30}$ En el año 2000 hubo 164 investigaciones abiertas y sólo 26 detenciones; en el año siguiente 170 investigaciones y 29 detenidos, en el año 2002 aumentan el número de investigaciones a 205 y los detenidos se mantienen en 30; en el 2003 se producen 112 investigaciones y 20 detenidos, en el 2004 las investigaciones fueron 125 y el número de detenidos subió significativamente a 167; en el 2005 se abrieron 122 investigaciones y subió aún más el número de detenciones hasta 260. Véase, RODRÍGUEZ MARTÍN, E., Pornografía infantil en... op. cit., pág. 79.
} 
duplicaran en relación al año anterior con 327 casos investigados o perseguidos; en el 2006 fueron 392; en el 2007 continúa el aumento vertiginoso a 677; y el 2008 tiene el record de persecución con 1.131; en 2009 fueron 1.087 y en $2010862^{31}$.

Un hecho especial de resaltar en relación con la evolución en estos años del fenómeno de la pornografía infantil en Internet en España, es que ocurre un evento hasta entonces inexistente, a saber, la generación en el territorio nacional de producción de pornografía infantil a los fines de difusión y comercialización: tres casos puestos en evidencia en el año 2006 y dos en el año 2007. Hasta entonces las estadísticas y registros de los cuerpos de seguridad hablaban de un mercado de consumidores de productos de proveniencia internacional.

El incremento en las denuncias y la relación entre menos investigaciones y más detenidos suele explicarse desde los organismos de seguridad como muestra de eficacia $^{32}$. Explican que aunque los detenidos han aumentado, las investigaciones abiertas han descendido entre 2003 y 2005 (112, 125 y 122) frente a las 164 de 2000 o 205 de 2002, lo que implicaría una mayor eficacia en su acción ya que con menos investigaciones han detenido a más personas. Sin embargo, un análisis criminológico más exhaustivo consideraría otros elementos adicionales a la explicación de los organismos de seguridad. Un dato importante a tener en cuenta es que a partir del 1 de octubre del año 2004 comenzó aplicarse el art. 189.2 del Código Penal que penaliza la posesión simple, criminalizando una nueva conducta que antes era impune, por lo cual, no es de extrañar que el número de detenidos se eleve. Antes de la vigencia y aplicación de este tipo no se podía detener a ningún ciudadano que almacenara elementos o productos de pornografía infantil para su propio consumo pues estaba dentro de la legalidad.

Las intervenciones policiales se han intensificado durante los años 2007, 2008 y $2009^{33}$. Regularmente los medios reportan las operaciones realizadas por los Cuerpos de

\footnotetext{
${ }^{31}$ Ministerio del Interior del Gobierno de España, Balance 2010. Evolución de la Criminalidad.

${ }^{32}$ Desde la criminología crítica, antes bien, se presentan estas cifras como parte de las funciones de la policía como instrumento de control del Estado, orientando su actuación hacia la criminalización del mayor número de personas para justificar su existencia y eficacia.

${ }^{33}$ Ver la relación de operaciones realizadas por la Guardia Civil relacionadas con la distribución y posesión de Pornografía infantil. (Revisado el 25 de noviembre de 2009).
} 
Seguridad para desarticular redes de pornografía infantil que, según parece, suelen tener alcance internacionales. En algunos casos la noticia sobre una misma operación aparece varios días consecutivos, tornándose repetitiva y transmitiendo la sensación de que se trata de sucesos y operaciones diferentes, construyéndose una realidad delictiva de mayor magnitud a la real ${ }^{34}$.

https://www.gdt.guardiacivil.es/hrelevantes.php. Operación Punto de Encuentro: En colaboración con policías de diecinueve países se logró la completa desarticulación de una red internacional dedicada a la distribución de pornografía infantil a través de Internet. Operación Panzer: Desarrollada conjuntamente con la policía italiana, tuvo como resultado la detención de los participantes en un foro en el cual se distribuía pornografía infantil. Operación Global: Actuación policial coordinada contra la distribución e intercambio de contenidos de pornografía infantil a través de Internet. Operación Azahar: En colaboración con las policías de Argentina, Brasil, Chile, Venezuela, República Dominicana, Panamá, Méjico, EE.UU, Francia, Reino Unido, Polonia, Lituania, Letonia, Estonia, Ucrania e Israel, se logró la mayor actuación policial internacional coordinada contra la distribución de pornografía infantil a través de la red Edonkey de P2P. Los objetivos fueron identificados por el buscador "HISPALIS" diseñado específicamente para la localización de usuarios que facilitan la distribución de contenidos de pornografía infantil. Operación Santiag: primera operación dirigida por el Servicio de Criminalidad Informática de la Fiscalía General del Estado, contra la distribución de pornografía infantil en la redes Edonkey y Ares del P2P. Para la ocasión se desarrolló un nuevo buscador, NAUTILUS, que ampliaba el campo de búsqueda a más redes.

${ }^{34}$ Un resumen de los titulares que suelen acompañar la relación de los medios impresos se muestra en seguida. "Desarticulada una tupida red de pornografía infantil con miles de usuarios en todo el mundo. La operación de la policía austriaca ha desenmascarado a sospechosos en 77 países, entre ellos España".(07/02/2007) "Detenidas 25 personas en 23 provincias por distribuir pornografía infantil en Internet. En total se han realizado 59 registros domiciliarios. Dos mil cien correos electrónicos han sido analizados" (22/02/2007). "La policía detiene a 12 personas en tres operaciones contra la pornografía infantil. Los arrestados están acusados de tenencia y distribución de archivos pedófilos por Internet" (07/03/2007). "Desarticulada una red de pornografía infantil con más de medio millón de fotos y vídeos" (10/03/2007). "Primera redada por pornografía infantil en los teléfonos móviles" (08/06/2007). "Desmantelada una red. 30 días de arresto a un soldado por ver pornografía infantil durante una guardia" (09/07/2007). "La operación 'Penalty' contra la pornografía infantil, un éxito gracias a los internautas. La brigada de investigación tecnológica recibe cada año más de 7.000 denuncias de usuarios de Internet" (16/07/2007). "Treinta detenidos en España por descargarse el vídeo de un pederasta arrestado en Madrid. Otras 30 personas han sido arrestadas en otra operación de la Guardia Civil contra la pornografía infantil" (17/10/2007). "92 detenidos en 19 países por poseer porno infantil" (06/11/2007). "40 detenidos en 22 provincias por corrupción de menores y posesión de pornografía infantil, mediante operación denominada "Membrillo"' (22/11/2007). "Dos detenidos en Huelva y Valencia por almacenar miles de fotos y vídeos de pornografía infantil". (07/12/2007). "La Policía Nacional detiene a 63 personas en cinco operaciones contra la pornografía infantil entre los detenidos se encuentran desde los productores, distribuidores y consumidores del material pedófilo" (16/12/2007). "63 detenidos en cinco redadas en toda España contra la pornografía infantil". (17/12/2007). "La policía alemana lanza la mayor operación contra la pornografía infantil en la Red en la historia del país. Más de 12.000 personas están siendo investigadas por difundir o bajar de Internet fotografías y vídeos con contenidos delictivos". (24/12/2007). "Desarticulada una de las mayores redes de distribución de pornografía infantil en España". 24/01/2008. "La Guardia Civil logra desmantelar una red de pornografía infantil gracias a la colaboración ciudadana". (25/01/2008). "Un guardia civil, entre los 51 detenidos por pedofilia en la red" (26/01/2008) "La Guardia Civil cuelga fotos de pederastas para lograr su identificación" (20/02/2008). "La policía detiene a 41 personas en varias comunidades por distribuir pornografía infantil en la Red. De los arrestados, seis habían contactado a través de Internet con menores para tratar de concertar citas sexuales". (06/04/2008). "La INTERPOL difunde imágenes de un pederasta para que la ayuda ciudadana permita localizarlo" (06/05/2008). "Más de medio centenar de detenidos en un golpe policial a la pornografía" (03/06/2008). Fuente: Diario El País. 
Otro elemento a considerar en el comportamiento y la evolución de la pornografía infantil es la participación ciudadana en las denuncias constantes. Se estima que las denuncias de los internautas ya son aproximadamente unas tres mil al mes. ${ }^{35}$ Los denunciantes por lo general son internautas que se topan por sorpresa con los archivos fotografías o vídeos- o páginas con pornografía de menores ${ }^{36}$ : una madre que buscaba por Internet algún artículo para su bebé; jóvenes que intentaba bajar archivos musicales; un vigilante de seguridad que recibió en su teléfono móvil un archivo pornográfico; un hombre que baja una película de dibujos que, en realidad, contenía escenas eróticas, o técnicos informáticos que reparan ordenadores y detectan archivos sospechosos con material de pornografía con menores. ${ }^{37}$

El hecho más relevante de las notas anteriores es que deja en evidencia que la pornografía infantil, como realidad criminal - como sucede con gran parte de los delitos cuya dinámica ocurre en redes -, se ha redimensionado con el uso de las Tecnología de Información y Comunicación. Desde el momento que se produce su masificación se ha dado un repunte y aceleración sin precedentes de la producción, tráfico, difusión y tenencia de la pornografía infantil. Las potencialidades de Internet ${ }^{38}$ expresadas en el

\footnotetext{
${ }^{35}$ Véase, La pedofilia desborda a la Policía y se convierte en una "epidemia", Diario El País, www.elpais.com, 02 de julio de 2008.

${ }^{36}$ También la reseña de medios suele abundar en ésta nota. Véase, Relación de las principales noticias de casos de denuncia a la policía realizadas por internautas. "Desarticulada una red de pornografía infantil con más de medio millón de fotos y vídeos (operación Metallica)" (10 marzo de 2007). "Un internauta destapa una red de pornografía infantil" (06 mayo de 2007). "Cuarenta detenidos en 22 provincias por corrupción de menores y posesión de pornografía infantil. Operación Membrillo" (22 noviembre de 2007). "La Guardia Civil logra desmantelar una red de pornografía infantil gracias a la colaboración ciudadana 'Operación Fabiola", ( 25 de enero de 2008). "Una madre internauta de Málaga descubre una red de pedofilia. Cinco detenidos por distribuir pornografía infantil en Internet” (27/08/2008). Fuente: Diario El País, www.elpais.com
}

37 "Pescar en Internet a los aficionados a la pornografía infantil no es tarea fácil, pero es mucho más sencillo gracias a la intervención de otros internautas que, con sus denuncias, e-mails y avisos ponen a los investigadores sobre la pista de estos delincuentes”. Así lo admite Joan Mesquida, Director General de la Policía y la Guardia Civil, quien reconoce que en la detención de estos individuos "han sido también de gran ayuda las denuncias recibidas de internautas y diferentes ONG de protección al menor". La Brigada de Investigación Tecnológica (BIT) recibe más de 7.000 correos electrónicos al año en este sentido. Véase diario El País, www.elpais.com, 05 de febrero de 2007.

${ }^{38}$ Internet que antes era un medio utilizado para agilizar las comunicaciones y garantizar el secreto de las comunicaciones en el ejército norteamericano, se convierte de la noche a la mañana en una aplicación utilísima en el mundo empresarial, un campo abierto para informáticos, una expansión increíble del comercio. Luego, junto al teléfono móvil facilita la expansión del intercambio de comunicaciones experimentado en los últimos años, así como la forma de ocio y entretenimiento más utilizada; pero también pasa a ser el cauce para la difusión y desarrollo de conductas ilegales más rápido y seguro conocido hasta entonces. Véase, ROJO GARCÍA, J.C., "La realidad de la pornografía infantil en Internet”. Revista de Derecho Penal y Criminología, $2^{\mathrm{a}}$ Época, № 9, 2002, págs. 211-251. FERNÁNDEZ 
fácil acceso, el carácter gratuito, las posibilidades de intercambio desde distintos espacios del mundo globalizado, la facilidad para ocultar la identidad o mantener el anonimato; la velocidad y rapidez con la que viajan los contenidos, son ventajas bien aprovechadas por los consumidores o difusores de este tipo de material ${ }^{39}$. Estas utilidades y beneficios que ofrece la tecnología informática han acabado por consolidar las pautas y patrones de la producción y tráfico, signando la naturaleza de la pornografía infantil en los últimos años ${ }^{40}$.

Para FERNÁNDEZ TERUELO, el fenómeno Internet ha abierto una nueva vía de comunicación y relación interpersonal de extraordinaria trascendencia social y por ello fundamental para el desarrollo de todo tipo de actividades de carácter lúdico, cultural, financiero o comercial. La Pornografía Infantil está aprovechando Internet como medio para desplegarse más que cualquier otra modalidad delictiva, a juzgar por la dimensión cuantitativa alcanzada y el alcance de sus efectos cualitativos. En primer lugar, de acuerdo con los organismos encargados de su persecución constituyen más o menos la mitad de los delitos que se cometen utilizando Internet; en segundo lugar, por la importancia de los bienes jurídicos lesionados, y finalmente por tratarse de una modalidad en la que se ponen de manifiesto de un modo destacado todas esas peculiaridades que dificultarían notablemente la persecución de las conductas delictivas llevadas a cabo a través de este medio ${ }^{41}$.

Así, la pornografía infantil ha pasado a representar uno de las formas de la explotación sexual infantil que ha experimentado una mayor profusión y una redimensión en sus formas de presentación y difusión más llamativo en los últimos

TERUELO, J., La sanción penal de la distribución de pornografía infantil a través de Internet: Cuestiones claves. En revista Boletín de la Facultad de Derecho, No 20, 2002, págs. 249-277.

39 Véase, MORILlAS FERNÁNDEZ, D. L., Análisis dogmático y criminológico de los delitos de pornografía infantil, Ed. Dykinson, Madrid, 2005; ESQUINAS VALVERDE, P., "El tipo de posesión de Pornografía infantil en el Código Penal español (art. 189.2): Razones para su destipificación". en Revista de Derecho Penal y Criminología, $2^{a}$ Época, № 18, 2006, págs. 171-227.

${ }^{40}$ MORALES PRATS, F., "El Derecho Penal ante la pornografía infantil en Internet. en MORALES PRATS, F.; MORALES GARCÍA, O., (Coords.), Contenidos ilícitos y responsabilidad de los prestadores de servicio de Internet. Revista Aranzadi de Proceso Penal, № 8 Madrid, págs. 95- 118.

41 FERNÁNDEZ TERUELO, J., La Sanción penal..., op. cit, págs. 250 y ss. 
años, representativo, además, de la especial vinculación con el desarrollo de las tecnologías de la comunicación y de la información. ${ }^{42}$

La diferencia entre el antes y el después de Internet se encuentra en el acceso a este material. Mientras que cualquier persona puede acceder en cualquier lugar del mundo a material pornográfico legal de cualquier tema, por extraño e impensable que pueda ser, el acceso a material pornográfico ilegal es, precisamente por esta característica, muy restringido. Si a esto unimos la ya comentada elevación del precio de estos productos y el riesgo que supone tanto la producción como el comercio de pornografía infantil, nos encontraremos con unas conductas muy lucrativas pero muy reducidas en cuanto a su difusión. ${ }^{43}$ Ya en el marco de la Convención sobre el Cibercrimen realizada en Budapest en 2001, miembros del Consejo de Europa afirmaban que tan sólo en Estados Unidos se calcula que la pornografía infantil deja ganancias por tres billones de dólares al año. ${ }^{44}$

Sin duda, el carácter internacional de la conexión junto con el anonimato, son las características que han hecho especialmente aprovechable el uso de Internet para el intercambio y difusión de la pornografía infantil ${ }^{45}$. La facilidad con la que un usuario cualquiera con conocimientos básicos puede desde un determinado país introducir imágenes y videos con contenidos pornográficos infantiles haciendo que la información transite por el llamado "ciberespacio intermedio" y pueda ser consumida en cualquier

\footnotetext{
${ }^{42}$ CABRERA MARTÍN, M., "la pornografía infantil: nuevos retos para el Derecho Penal", en LAZARO GONZÁLEZ, I.; MAYORLA NARROS, I., (Coords.), Jornadas sobre Derecho de los menores. Ed. Universidad Pontificia Comillas. Madrid, 2003, págs. 401-417.

${ }^{43}$ ROJO GARCÍA, J. C., La realidad de la pornografía..., op. cit., págs. 213 y ss.

${ }^{44}$ Este documento puede consultarse en www.legal.coe.int/economiccrim, consultado por última vez el 18 de mayo, 2009.

${ }^{45}$ Frente a las películas y revistas de pornografía infantil producidas y comercializadas en la sombra, se pasa a un comercio rápido, seguro y oculto en la multitud de páginas web existentes; frente a la ocultación de este tipo de material, se pasa a su ofrecimiento al gran público de forma clara y manifiesta; frente al riesgo extremo de estos comportamientos, se pasa a la relativa seguridad del seguimiento de archivos relacionados u otra información a través de la red. Véase, ROJO GARCÍA, J.C., La realidad de la pornografía..., op. cit., pág. 214.
} 
punto del planeta sin la posibilidad de identificación de la fuente o el origen del material son unas condiciones idóneas para este tipo de actividad con tanto rechazo social ${ }^{46}$.

Volviendo sobre las evidencias empíricas en España, a finales del año 2009 los medios de comunicación se hicieron eco de la advertencia de una ONG en la que calificaba al país como el segundo del mundo con mayor intercambio de archivos compartidos en Internet, susceptibles de contenido pornográfico infantil en formato fotografía o vídeo $^{47}$. En efecto, la Fundación Alia $2^{48}$ en su informe semestral respecto de la evolución de la pornografía infantil en España a partir de una muestra de 9.647 archivos ha detectado que México lidera el intercambio de archivos o P2P (a través de páginas como Emule, Kazaa, Limewire, entre otras.), con un total de 2.213 materiales, seguido de España (711), Estados Unidos (607), Argentina (344) y Brasil (329).

Las detenciones por delitos telemáticos -advierte la ONG- relacionadas con la protección del menor aumentaron en un 53\% durante los últimos cuatro años y representan ya el $61 \%$ de las detenciones, según cifras de la Brigada de Investigación Tecnológica del Cuerpo Nacional de Policía. La fundación proporciona herramientas a la Policía y a la Guardia Civil para ayudar a detectar a los distribuidores de pornografía.

\footnotetext{
${ }^{46}$ MORÓN LERMA apunta que las técnicas para enmascarar la fuente de origen de los materiales pueden ser muy sofisticadas, pues al alcance del usuario mínimamente avezado se halla la utilización de los "anonymous remailers", que permiten el envío de "e-mails" sin remitente; los "remailers" suponen el uso de servidores de correo electrónico intermedios entre el remitente y el destinatario final, de modo que el remitente envía un "mail" a un servidor que, a la vez, lo reenvía al destinatario final sin que aparezcan los datos del remitente. MORÓN LERMA, E., Internet y Derecho Penal: Hacking y otras conductas ilícitas en la Red. Ed. Aranzadi, Pamplona, 1999, págs. 27 y ss.

47 “España, segundo país con más intercambio de pornografía infantil en la Red”, Diario El País, www.elpais.com, 25 de noviembre de 2009.

48 De aparente solvencia toda vez que nace contando entre sus patronos al ex-miembro del Comité Olímpico Internacional (COI) Juan Antonio SAMARANCH y al ex-baloncestista Fernando ROMAY. Suerte de ONG que hace de Observatorio respecto de la evolución del problema y la actuación de gobierno, instituciones y sociedad. Alia2 permite a todo aquel que quiera participar en la fundación crear "software" de código abierto para colaborar con el desarrollo de aplicaciones, además de publicar un informe semestral para "informar y concienciar" a la sociedad sobre los abusos a menores y la distribución de la pornografía infantil. En la misma línea, existen otras ONG como: Protegeles.com Asociación sin ánimo de lucro, cuyo objetivo es facilitar a la policía y a la Guardia Civil información que permita la detección de páginas de pornografía infantil, para perseguir a los autores de los mismos, Creada en el año 2002, se financia con subvenciones de la Comisión Europea, en el marco del Plan de acción para un Uso Seguro de Internet (SIAP). En el año 1998 nació otra ONG Acción contra la pornografía infantil, con el objetivo de luchar contra la explotación sexual de menores: pornografía infantil, prostitución infantil y turismo sexual. Todos sus miembros son voluntarios y cuenta con socios en toda España. Su plan lo basa en Prevención; búsqueda de menores desaparecidos; lucha contra la pornografía infantil en Internet; campañas de sensibilización; apoyo a organizaciones de ayuda a las niñas prostituidas.
} 
Entre ellas estarán programas diseñados como "Germá", encargado de indexar contenido ilegal para crear una base de datos que ayude a la detección; "Carolina" un filtro de control para descargas involuntarias que contengan material de pornografía infantil; "Florencio", un rastreador de redes sociales y "Danba", herramienta de control parental que pretende auxiliar desde los hogares el control de los padres sobre el acceso de menores en las redes sociales y en Internet.

\subsubsection{El antes y después de Internet en la pornografía infantil.}

A los fines de ordenar las cualidades particulares que fundamentan cuanto venimos afirmando respecto de la nueva dimensión de la Pornografía Infantil potenciada por el recurso de Internet, enumeremos y describamos ligeramente aquellas que permiten mostrar la alteración social de su dinámica. :

\section{a) Intensificación y masificación.}

Anteriormente hemos hecho mención de las cifras aportadas por el Cuerpo Nacional de Policía respecto del incremento en los delitos de pornografía infantil, a juzgar por el número de detenidos, y como estos habían repuntado desde el año 2004. A su vez, la proliferación de páginas y sitios de Internet con contenido pedófilo, admiten fuentes de la misma Policía, excede con creces la capacidad de los organismos de seguridad para detectarlos, recurriéndose al voluntariado desde la sociedad civil para ampliar el radio de control social y facilitar las investigaciones.

\section{b) De la intimidad de la casa al espacio público.}

Estas nuevas pautas de tráfico y difusión se evidencian en la sustitución que la Web ha realizado del correo postal y de la compra directa mediante la presencia física de material pornográfico de revistas o películas de cine o de video. Ya no se trata de un acto privado y aislado; ahora ocurre una conexión global con millones de usuarios con acceso instantáneo a contenidos ilimitados ${ }^{49}$. Para el año 2000 se estimaba en más de

\footnotetext{
49 Pese a la dificultad del cómputo, se estima que en el año 2005 ya existían más de cuatro millones de sitios en Internet con material de sexo con menores, los cuales recibirían más de dos mil millones de visitas anuales. Véase, FERÁNDEZ TERUELO, J., "La sanción penal en la llamada distribución de pornografía infantil a través de Internet y otras modalidades afines tras la reforma de 15/ 2003", en GUZMÁN DÁlbORA, J. L.; SERRANO, MAÍllo, A. (edits), Derecho Penal y Criminología como
} 
treinta millones las personas que se encuentran simultáneamente conectados a los servicios de Internet. ${ }^{50}$. Se ha reducido a un mínimo porcentaje la venta convencional de documentos gráficos (revistas) en formato papel o audiovisuales (dvd), sustituidos por los formatos digitales intercambiado por la Red por los propios consumidores. ${ }^{51}$

\section{c) Del tráfico al intercambio entre pedófilos.}

Las nuevas autopistas de la información también han modificado la motivación de la colocación en el mercado de material pornográfico infantil. Anteriormente era el tráfico con ánimo de lucro y ahora la tendencia es al intercambio entre pedófilos ${ }^{52}$. En efecto, señala ESQUINAS VALVERDE que los pedófilos se intercambian fotografías de menores desnudos o en actitud más o menos obscena, sin contraprestación económica adicional alguna y aprovechando la impunidad y el anonimato, e incluso fundados en la sensación de una "comunidad de intereses" y de compañerismo que brinda la existencia de grupos, "salones de conversación" y otros foros temáticos en Internet, a partir de los cuales se construyen sentidos de pertenencia a una comunidad compartida $^{53}$. Se trata del esquema de intercambio recíproco de material que, junto con el negocio también virtual de suministro periódico de imágenes a los clientes, a cambio de pagos efectuados con tarjetas de crédito, estaría dinamizando en gran medida este sector de la criminalidad ${ }^{54}$. En este sentido, MORALES PRATS advierte que el

fundamento de la Política Criminal. Estudios homenaje al profesor Alonso Serrano Gómez., Ed. Dykinson, Madrid, 2006, págs. 703-725.

${ }^{50}$ MORALES PRATS, F., "Pornografía infantil e Internet: La respuesta en el Código Penal Español", en Problemática Jurídica en torno al fenómeno de Internet. Cuadernos de Derecho Judicial, Madrid, 2000, págs. 177-205.

${ }^{51}$ ESQUINAS VALVERDE, P., El tipo de posesión..., op. cit., pág. 172.

52 Para CABRERA MARTÍN, M. La pornografía infantil puede constituir una poderosa forma de justificación de las conductas y preferencias pederastas, en la medida en que el intercambio de material de este tipo pone en contacto a personas que padecen este trastorno de la inclinación sexual, las retira del aislamiento y la marginación en la que hasta entonces habían tenido que vivir su tendencia y les hace creer que su inclinación constituye una opción sexual válida, con las consecuencias que ello puede acarrear al inhibir los frenos de cara a un posible paso al acto pederasta. CABRERA MARTÍN, M., La pornografía infantil..., op. cit., pág. 401-417.

${ }^{53}$ Comunidades estéticas llama el sociólogo Zygmunt Bauman a los grupos que se conforman alrededor de un artista o una causa particular de orden lúdico o que rompe con cierta moral pública, ajena a las antiguas causas sociales, y de amplio alcance, proliferación y vigencia en el mundo virtual. Véase, BAUMAN, Z. Vida líquida, Ed. Paidós, Barcelona, 2005, págs. 109-153.

${ }^{54}$ ESQUINAS VALVERDE, P., El tipo de posesión..., op. cit., pág. 172. 
intercambio de material entre pedófilos se ha amplificado como pauta de comportamiento, ocurriendo que los usuarios pueden ser receptores, consumidores y difusores al recibir o introducir material con contenido pornográfico infantil. Por consiguiente, puede trazarse una línea evolutiva que desplaza la elaboración y producción de la pornografía infantil de parámetros comerciales organizados a ámbitos descentralizados "amateurs" y domésticos. ${ }^{55}$ Ésta evolución, por ejemplo, no hubiera sido posible sin la masificación y abaratamiento de los aparatos de vídeo doméstico. Advierte igualmente MORALES PRATS, que no solamente la implantación de Internet sino el vídeo casero han convertido la pornografía infantil en una "sofisticada industria casera" al alcance de muchos ${ }^{56}$. Este mismo autor alerta del hecho de que estos nuevos medios propician algo más peligroso y es que existe menos riesgo de detección ya que no se requiere un tercer intermediario para desarrollar las imágenes como en la fotografía convencional, la edición de la reproducción con miras a su mejora está al alcance de cualquiera y las imágenes digitalizadas no se envejecen o pierden su calidad a través de las copias. ${ }^{57}$

En cuanto a los espacios virtuales donde se desarrolla la distribución de pornografía infantil, estos suelen ser principalmente los chats o conversaciones entre personas que permiten intercambiar textos y fotografías (especialmente los canales IRC), donde se concentra aproximadamente el $85 \%$ de estos materiales ${ }^{58}$, aunque en algunos casos la difusión se realiza en los denominados grupos de noticias (newsgroups) $^{59}$ e incluso a través de páginas web. El empleo de los denominados computer bulletin boards (tablones de anuncios de ordenador) también puede constituir otro mecanismo de intercambio de información entre pedófilos, mediante los cuales es

\footnotetext{
${ }^{55}$ MORALES PRATS, F., "Pornografía infantil e Internet:", Jornadas de Responsabilidad Civil y Penal de los Prestadores de servicios en Internet, Barcelona, 22-23 de noviembre de 2001, pág. 181.

${ }^{56}$ Ídem.

${ }^{57}$ En efecto las técnicas de producción e introducción de tal material en la Red se han multiplicado: escaneado de fotos, introducción en la Red de vídeo clips, e-mails provistos de imágenes o vídeos. Véase, MORALES PRATS, F., Pornografía infantil e..., op. cit. pág. 182.

${ }^{58}$ Agencia Efe, 8 de mayo de 2001.

${ }^{59}$ El procedimiento más habitual es el siguiente: El sujeto inserta mensajes en los grupos dejando entrever que posee este tipo de materiales. Los interesados se ponen en contacto con él a través del correo electrónico y ambos pactan la fórmula de entrega.
} 
posible mantener conversaciones y debe subrayarse que, en la mayoría de los países, no se requiere licencia ni registro para introducir los referidos tablones de anuncios.

Según TREMBLAY Pierre, Internet tiene un significado especial para los pedófilos ya que les proporciona un foro que a) permite intercambios inter/personales íntimos; b) permite llevar a cabo estos intercambios bajo condiciones seguras; y, c) posibilita intercambios que no están restringidos por barreras geográficas o $\operatorname{costos}^{60}$.

Esta última característica es importante ya que cuanto más pequeño sea el tamaño real de una minoría en un ambiente (ciudad o nación), tanto más aislada estará del alcance de control social alguno. La Red neutraliza de este modo la barrera de la distancia y aumenta la probabilidad de alcanzar una masa crítica para el desarrollo de una minoría importante. Los foros de intercambio proporcionan a los pedófilos una oportunidad de vencer su aislamiento. Conforme se convierten en parte de una comunidad, aunque sea una comunidad clandestina, pueden definir normas comunes de comportamiento y formar una cultura propia, ello permite que los pedófilos participen en el desarrollo de una subcultura y que se perciban a sí mismos como pertenecientes a una comunidad socio/virtual que arraiga sentido de pertenencia ${ }^{61}$. La implicación obvia es que un foro estable para contactos íntimos, aunque virtuales, "para los pertenecientes al grupo de individuos que normalmente se ven atrapados por un secreto incompartible, tendrá efectos duraderos en el compromiso de aquellos con su atracción y finalmente en la incidencia de las infracciones de la edad de consentimiento"62.

\subsection{PORNOGRAFÍA INFANTIL Y CRIMINALIDAD INFORMÁTICA.}

\subsubsection{Internet y Derecho Penal.}

¿Cómo se ha entendido la irrupción de ésta nueva realidad global con sus tecnologías de información y comunicación a la vanguardia en el campo del Derecho? ¿En qué medida ha alterado las categorías y principios sobre las que se funda por

\footnotetext{
${ }^{60}$ TREMBLAY, P., "Interacciones Sociales entre Pedófilos Canadienses", en La infancia como mercancía sexual, en AZAOLA, E.; ESTES, R. J., (Coords.), Ed. Siglo XXI, 2003, México, pág.124

${ }^{61}$ Idem.

${ }^{62}$ Ibídem pág. 137.
} 
ejemplo el Derecho penal? ¿Acaso no se trastorna la realidad cuando ésta muta desde la mera existencia física de un ordenador y sus componentes de hardware con fines personales de escritura, administración y base de datos, a otra en la que aquel es la puerta de acceso a un espacio virtual por donde discurre buena parte de la vida moderna, susceptible de participación e intervención desde cualquier teclado y desde cualquier lugar? ¿Y cómo se regula la legalidad de actuaciones virtuales que pueden generar daños sobre determinados bienes jurídicos? Más aun, ¿cómo opera el proceso penal sobre una realidad que rompe con la dimensión espacio / temporal conocidas? Desde los asuntos que hemos venido tratando hasta aquí, ¿cuál ha sido su comprensión en gobiernos, parlamentos y sectores académicos en tanto que medios con altísima potencia y eficacia al servicio de la criminalidad organizada? ${ }^{63}$.

Como se puede apreciar no se trata de temas que podamos despachar con laxitud. Su propia naturaleza contribuye a ello, pues no debe olvidarse que Internet es un sistema poseedor de una estructura descentralizada dispuesta para la conexión entre sí de millones de ordenadores a la vez. Esto plantea enormes beneficios, pero también diversos problemas prácticos como muy bien señala BARNES VÁZQUEZ, “...cualquier ciudadano puede convertirse en editor o en emisora de radio y televisión; o utilizar la red como sistema de correo universal, servicio telefónico, de distribuidor de prensa, como biblioteca, como lugar de encuentro (...) Estamos ante un nuevo medio de comunicación de masas de carácter interactivo. Con la llegada de los sistemas de comunicación electrónicos se han roto las fronteras y se han multiplicado las posibilidades" ${ }^{\prime 64}$. Las tradicionales formas de comunicación escrita, de voz a distancia y de encuentro físico, pueden realizarse y se encuentran potenciadas mediante la red. La única diferencia radica en que el papel o la voz son cambiados por soportes

\footnotetext{
${ }^{63}$ Sobre el tema véase: GUTIRERREZ FRANCÉS María LUZ, Fraude Informático y Estafa, Ministerio de Justicia, Madrid-España, 1991; de la misma autora: "Delincuencia Económica en el nuevo Código Penal", en ARROYO ZAPATERO, Luis; TIEDEMANN, Klaus, Estudios de Derecho Penal Económico, Ed. Universidad de castilla la Mancha, Cuenca, 1994, pág. 249-305; de la misma autora, "Notas sobre la delincuencia Informática: Atentados contra la "Información" como valor Económico de la empresa", en Ámbito Jurídico de las tecnologías de la Información en Revista Cuadernos de Derecho Judicial, 1996, págs. 183- 209; de la misma autora, "Reflexiones sobre la Ciberdelincuencia hoy (En torno a la Ley Penal en el espacio virtual)", en Revista electrónica de la Facultad de Derecho de Universidad de La Rioja $\mathrm{N}^{\circ}$ 3, 2005, pág. 69- 92.; "Problemas de aplicación de la Ley penal en el espacio virtual", en ROMEO CASABONA, C. M., Cibercrimen. Nuevos retos jurídico - penales, nuevas respuestas político criminales, Ed. Comares, Granada, 2006, pág. 43- 68.

${ }^{64}$ BARNES VÁZQUEZ, J., "La Internet y el Derecho", en Cuadernos y Estudios de Derecho judicial, 1997, pág. 9.
} 
electrónicos. La eclosión de Internet, en definitiva, es una de las principales revoluciones tecnológicas acontecidas a escala mundial. Las posibilidades comunicativas, informativas y ociosas que ofrece han permitido que entre 1996 y 2003, en solo siete años, se multiplique por treinta y tres el número de usuarios de Internet en España y, además, no para de sumar usuarios o internautas de todas las edades, sexo y grupo social $^{65}$.

En relación a la necesidad de regulación del fenómeno Internet, MATELLANES RODRÍGUEZ plantea que "Siendo el Derecho el instrumento regulador por excelencia de las relaciones sociales, resulta indispensable la incidencia de la informática en el mundo jurídico. En primer lugar, porque las nuevas técnicas han supuesto la incorporación al mundo jurídico de un nuevo ámbito de regulación (los derechos u obligaciones consecuentes a la creación, distribución y uso del hardware y del software, a las bases de datos, a la contratación de servicios informáticos o a la transferencia electrónica de datos); y también porque tales aparatos y tales técnicas han supuesto cambios revolucionarios en la manera de entender las relaciones jurídicas tradicionales. Así ha tomado carta de naturaleza entre nosotros un nuevo sector del ordenamiento jurídico, el Derecho informático, cajón de sastre apenas sistematizado al que se atribuye la ordenación de esa moderna tipología de relaciones" ${ } 66$.

Describamos brevemente algunas de las características inmanentes a la realidad virtual que inciden en la comisión de los fraudes informáticos, por la importancia que tiene para la posterior relación con el Derecho penal y las implicaciones derivadas del uso que de ellas hace la criminalidad organizada. Entre estas, tenemos: ${ }^{67}$

\footnotetext{
${ }^{65}$ Informe ANESVAD, de Parry Aftab, www.anesvad.org/nymphasex, consultado por última vez el 21 de septiembre de 2008.

${ }^{66}$ MATELLANES RODRÍGUEZ, N., "Algunas notas sobre las formas de delincuencia informática en el Código penal" en DIEGO DÍAZ-SANTOS y SÁNCHEZ LÓPEZ, V., Hacia un Derecho Penal sin fronteras, Ed. Colex, 2000, págs. 129 y ss.

${ }^{67}$ Relación general tomada de CONSENTIDO GARCÍA, G.; TEJERO, J.; TEJERO N., "Tras los pasos de la seguridad perdida. Delitos informáticos" Informática y Derecho. Revista Iberoamericana de Derecho Informático, UNED, Extremadura, España, 1998, No 23-26, Vol. II, págs. 1210 y ss.
} 
a) Tendencia hacia la concentración de la información en grandes bases de datos sobre la que interactúan multitud de usuarios una vez penetradas las medidas de control de accesos.

b) Difícil detección y prueba del delito ${ }^{68}$. Ausencia de registros visibles. No existe la posibilidad de descubrir un hecho fraudulento por simple inspección visual al estar la información grabada en forma de impulsos eléctricos.

c) Los programas y los datos pueden alterarse sin dejar rastros.

d) Fácil eliminación de pruebas, sean programas o ficheros de datos alterados, pulsando una tecla o emitiendo una instrucción de borrado.

e) Complejidad de entorno técnico. Incluso los sistemas más sencillos son de una gran complejidad en términos de capacitación técnica.

f) Dificultad y complejidad para la protección de los ficheros en soportes magnéticos.

g) Carencia de controles internos en las aplicaciones que resultan débiles ante los intentos de manipulación fraudulenta.

h) Dispersión territorial de los puntos de entrada al sistema virtual.

i) Dependencia de redes públicas de transmisión de datos. No es posible establecer medidas de control de los mensajes y programas propios desde las redes públicas.

j) A todas estas vale agregar, acaso la más importante, la relatividad del espacio y tiempo informático, que permite al delincuente investirse con atributos absolutos

\footnotetext{
${ }^{68}$ HERRERA MORENO, M., "El fraude informático en el derecho penal español”, Revista Actualidad Penal, Nº $^{\circ}$, Madrid, 2001, pág. 931.
} 
de intemporalidad y ubicuidad operando como autentica capa de invisibilidad, disponiendo el camino para la indefensión de la víctima. ${ }^{69}$

Con tales ventajas inherentes a la naturaleza de las TIC, potenciadoras de la criminalidad informática en la medida que los actos en el mundo virtual prácticamente se realizan o bien sin sujeción alguna a controles, o bien con alcances limitados y posteriores en el caso de realizarse la Internet, se ha convertido en un factor criminógeno al servicio de la delincuencia organizada al ampliar ilimitadamente su radio de actuación contra derechos, bienes e intereses jurídicos. Más exactamente, se ha convertido en un vehículo especialmente poderoso para violentar de manera especial cuatro tipos de bienes jurídicos básicos, a $\operatorname{saber}^{70}$ : la intimidad, la imagen, la dignidad y el honor de las personas; la libertad sexual; la propiedad intelectual e industrial, el mercado y los consumidores; la seguridad nacional y el orden público. En adelante trataremos de ordenar un conjunto de ideas que procuran revisar las tesis desarrolladas por autores reconocidos sobre el tema, delimitar conceptualmente el uso de los términos que se utilizan indiscriminadamente cuando se refieren a los medios tecnológicos de información y comunicación y resaltar las dificultades y retos que representa para el Derecho penal la mediación de tales tecnologías en la comisión de delitos.

Apenas la emergencia de la sociedad de la información y el mundo virtual por el que discurre fueron reconocidos comenzó el debate, especialmente para el Derecho penal, sobre si representaba un espacio con la cualidad suficiente para sumar nuevos tipos de delitos al concierto de aquellos clásicos en la doctrina. Siguiendo las tesis de GUTIÉRREZ FRANCÉS, daremos cuenta de los dos aspectos de acuerdo con los cuales ha de enfocarse el debate de las consecuencias para el Derecho penal de la realidad virtual que discurre a través de las TIC. Estos son: 1) La especificidad de la delincuencia informática, 2) Los problemas de aplicación de la ley penal en el espacio virtual $^{71}$.

\footnotetext{
${ }^{69}$ Ibídem, pág. 930.

70 PÉREZ LUÑO, A., "Internet y el Derecho" en Informática y Derecho, Revista Iberoamericana de Derecho Informático, UNED, Extremadura, España, 1998, Vol. I, № 19-22, pág. 723

${ }^{71}$ GUTIÉRREZ FRANCES, M. L., Problemas de aplicación..., op. cit., págs. 43- 68.
} 
En cualquiera de ellos, dados los rasgos transnacional y de actuación ilimitada sin sujeción inmediata a referencias espacio / temporales, su identificación, prevención y castigo se hace más difícil, incluso siendo detectadas, pueden ocurrir conflictos sobre la jurisdicción sancionadora correspondiente. De manera que Internet, lleva en sí mismo una preocupante paradoja, a saber, una eficacia global e ilimitada para atentar contra bienes y derechos, a la que se contrapone una jurisprudencia fraccionada por las fronteras nacionales para atender estos daños. Porque, aunque los asuntos jurídicos relacionados con Internet no son absolutamente nuevos - intimidad, propiedad, responsabilidad, libertad, orden público - hay que aceptar que ponen a prueba los conceptos tradicionales y exigen una adaptación de los mismos a los nuevos retos que plantea el mundo virtual de la Internet ${ }^{72}$.

\subsubsection{Criminalidad informática}

La primera reacción de los sistemas legales ante la irrupción de la realidad virtual fue delimitar, tipificar y calificar las actuaciones ilegales susceptibles de ocurrencia. A falta de mejor nombre se les designó de forma general al conjunto de ellos como delitos informáticos ${ }^{73}$. Así los denominó, por ejemplo, en sus primeros momentos, la Unión Europea cuando crea el Eurojust con ocasión de la decisión del Consejo del 28 de febrero del 2002 para reforzar la lucha contra formas graves de delincuencia, entre las que califica a la delincuencia informática. La misma Ley española 3/2003 del 14 de marzo de ese mismo año, habla de “...delitos de alta tecnología, en particular delito informático". A su vez, en el caso de Latinoamérica las legislaciones que se sucedieron a lo largo de los primeros años de este siglo para tipificar los actos ilegales ocurridos dentro de la realidad virtual aludida, o cometidos mediante el empleo de tecnologías de información - digital o electrónicas - incurrieron también en el mismo desatino, llegando en algunos países a designar a la ley respectiva con el nombre mismo de delitos informáticos. ${ }^{74}$

\footnotetext{
${ }^{72}$ CARRASCOSA LÓPEZ, Valentín: “¿Es necesaria una legislación mundial para Internet? Informática y Derecho", Revista Iberoamericana de Derecho Informático, UNED, Extremadura, España, 1998, № $27-$ 29, pág. 173.

${ }^{73}$ GUTIÉRREZ FRANCÉS, M. L., Delincuencia Económica en..., op. cit., pág. 251.

${ }^{74}$ Ley Especial contra los Delitos Informáticos. República Bolivariana de Venezuela, Asamblea Nacional, 2001.
} 
En los primeros momentos de regulación penal de la realidad aludida asistimos a una pretensión de reconocimiento de nuevos tipos de delitos fundados en el hecho informático, como si con ella emergiera una nueva categoría de delitos adicionales a los clásicos. Es posible, como acertadamente sugiere GUTIÉRREZ FRANCÉS ${ }^{75}$, que desde el lenguaje cotidiano acuñarlos bajo esta denominación contribuyera al entendimiento lógico al situar a los interlocutores sobre el tema en cuestión; pero desde la Ciencia jurídica y desde el Derecho penal, con bases históricas y doctrinal sólidas, bien fundadas y sostenidas en el tiempo, darles carta de identidad demandaría que sus efectos ocurrieran sobre un bien jurídico claramente determinado. De tal manera que la interrogante sería ¿se genera un nuevo bien jurídico con la realidad virtual?

Pese al extendido uso de la expresión "delitos informáticos”, para la doctrina española y bajo una perspectiva estrictamente jurídica, bien lo indican ORTS BERENGUER y ROIG TORRES, tal denominación no se utiliza en ninguno de los tipos previstos en el Código Penal ${ }^{76}$, reduciendo su alcance únicamente a la condición de medio comisivo a través del cual pueden lesionarse distintos bienes jurídicos tales como el patrimonio, la propiedad industrial e intelectual, la intimidad. Sin embargo, aclaran, en algunas infracciones el objeto material lo integran los propios sistemas o soportes informáticos ${ }^{77}$. Así pues, delito informático, y su correspondiente genérico delincuencia informática, para la dogmática jurídica carecen de relevancia a efectos penales en España, por lo que no existe una incriminación o tipo concreto que castigue una conducta de este tipo.

En el mejor de los casos, existe si una semántica en el Código Penal que alude al descubrimiento, modificación o revelación de secretos personales y familiares (art. 197); manipulación informática aunque vinculado a la estafa (art. 248.2); hechos relativos a la propiedad intelectual sobre obras en soporte informático (art. 270);

\footnotetext{
${ }^{75}$ GUTIÉRREZ FRANCES, M. L., “Delincuencia Económica en...” op. cit. pág. 251.

${ }^{76}$ De la misma opinión, MATA Y MARTÍN, R., Delincuencia... op. cit. pág. 21; GÓMEZ PERAL, M., "Los Delitos Informáticos en el Derecho Español", en Actas del III Congreso Iberoamericano de Informática y Derecho, Mérida, 1994, pág, 481, donde señala que la expresión "delitos informáticos" no aparece recogida en ninguna legislación por lo que no puede hablarse de auténtico delito.

77 ORTS BERENGUER, E.; ROIG TORRES, M., Delitos informáticos y delitos comunes cometidos a través de la informática. Valencia, 2001, pág. 13 y ss.
} 
descubrimiento de secretos de empresa en soporte informático (art. 278.1); uso indebido de terminales de telecomunicación (art. 256); fabricación o tenencia de programas o aparatos destinados a la falsificación (art. 400); interceptación de las telecomunicaciones y su divulgación por autoridad o funcionario público (art. 536). Para algunos, en cambio, concurren elementos suficientes para hacer valer la pertinencia del término delito informático, tanto desde una dimensión criminológica como jurídica, aunque sea para ésta última bajo unos postulados incompletos y primarios ${ }^{78}$. En cualquier caso, antes de asomar las razones sobre las que insisten a estos fines, estimamos de utilidad apreciar el tratamiento que se le ha dado en el orden internacional.

En el orden comunitario solemos encontrarnos con declaraciones de intenciones por parte de los Estados miembros de la UE, tendentes a facilitar la investigación y persecución de los delitos penales relacionados con sistemas y datos informáticos así como la creación de tipos penales. Ejemplo de ello es la Posición Común, de 27 de mayo de 1999, adoptada por el Consejo sobre la base del artículo 34 del Tratado de la Unión Europea, relativo a las negociaciones del proyecto de Convenio sobre delincuencia en el ciberespacio celebradas en el Consejo de Europa ${ }^{79}$. Los textos que desarrollan una actuación en tal sentido, a nivel internacional, provienen también desde el espacio comunitario de la Comunicación de la Comisión al Consejo y al Parlamento Europeo y, en concreto, de la Propuesta de Decisión Marco del Consejo relativa a la lucha contra la explotación sexual de los niños y la pornografía infantil ${ }^{80}$. En ésta, apunta MORILLAS FERNÁNDEZ, de forma quizás excesivamente genérica, se define - en su artículo 1 - "sistema informático" como "cualquier dispositivo o conjunto de dispositivos interconectados o relacionados, uno o más de los cuales realice, de acuerdo con un programa, un tratamiento automático de datos". ${ }^{81}$

\footnotetext{
${ }^{78}$ MORILLAS FERNÁNDEZ, D. L., Análisis dogmático y criminológico..., op. cit., pág. 100.

${ }^{79}$ Do No L 142 de 05/06/1999 págs. 0001-0002.

${ }^{80}$ Aprobada por Resolución Legislativa del Parlamento Europeo en su Acta del 12/06/2001; A50206/2001.

${ }^{81}$ MORILLAS FERNÁNDEZ, D. L., Análisis dogmático y criminológico..., op. cit., pág. 101.
} 
También proceden de los distintos documentos pertenecientes a la "Convención sobre delincuencia en la red" del Consejo de Europa, en donde abundan conceptualizaciones más precisas $^{82}$; y la Comunicación de la Comisión al Consejo, al Parlamento Europeo, al Comité Económico y Social y al Comité de las Regiones para la creación de una sociedad más segura mediante la mejora de la seguridad de las infraestructuras de información y la lucha contra los delitos informáticos (e-Europe $2002)^{83} /^{84}$.

Este último texto sí se habla en concreto de delincuencia informática entendiéndolo como "cualquier delito que de alguna manera implique el uso de las TIC (tecnología de la información)", señalando la necesidad de diferenciar entre delito informático específico y delitos tradicionales perpetrados con ayuda de la informática, una distinción esencial en el momento de dilucidar sobre la naturaleza y especificidad de los delitos informáticos. A tal efecto, distingue entre cuatro modalidades:

a) Delitos contra la intimidad. Constituyen infracciones a los derechos fundamentales relativos al respeto de la vida por la recogida, almacenamiento, modificación, revelación o difusión ilegales de datos personales;

b) Delitos relativos al contenido. Se refiere a la difusión, sobre todo por Internet, de pornografía, y en especial de pornografía infantil, de declaraciones racistas, de declaraciones revisionistas sobre el nazismo, de la información que incita a la violencia, y en general a la difusión de anti/valores ajenos a la modernidad o a la civilización occidental;

c) Delitos económicos, acceso no autorizado y sabotaje ${ }^{85}$. Están relacionados con el acceso no autorizado a sistemas informáticos (espionaje informático, difusión de

\footnotetext{
${ }^{82}$ A tal efecto Véase, "Draft Convention on Cyber-crime" Doc. 8875 de la Asamblea Parlamentaria del Consejo de Europa, de 9 de abril de 2001; "Explanatory Report of Convention on Cybercrime" del Consejo de Europa, adoptado el 8 de noviembre de 2001, ETS 185.

${ }^{83}$ Hecho en Bruselas a 26/01/2001.COM (2000) 890 final.

${ }^{84}$ Sobre estos documentos nos detenemos con más detalle en el Capítulo II.

85 Para unos, el sabotaje informático, tipificado en el artículo 264.2 del Código Penal Español es un antecesor de la posterior validez a los fines jurídicos del tipo delito informático.
} 
virus, falsificación y fraude informático) y con las nuevas formas de comisión de delitos mediante algún elemento físico o digital de un ordenador;

d) Delitos contra la propiedad intelectual. Son infracciones contra la protección jurídica de los programas (software) de ordenador y de las bases de datos, de los derechos de autor y derechos afines ${ }^{86}$.

Aunque no existe una concepción firme con miras a delimitar correctamente el concepto de delincuencia informática. Antes bien, coexisten dos corrientes o posiciones doctrinales que debaten respecto de su pertinencia ${ }^{87}$. De un lado están quienes sugieren la importancia de establecer la distinción entre computadoras usadas para cometer un delito y aquellas que son usadas como objetos sobre las que recae el mismo ${ }^{88}$, entre los cuales el más representativo dentro de la doctrina española es GONZÁLEZ RUS. Para este "En el primer caso, delitos contra el sistema informático o contra elementos de naturaleza informática, se incluyen los comportamientos en los que cualquiera de estos componentes -tanto físicos (hardware) como lógicos (software y ficheros y archivos)resulta el objeto material de ilícitos patrimoniales, bien porque son en sí objeto específico de protección (terminales de comunicación, programas de ordenador, datos, informaciones, documentos electrónicos) bien porque pueden servir de soporte a elementos protegidos de manera general, pero en los que la aparición de implicaciones informáticas puede plantear peculiaridades dignas de atención específica (secretos de empresa, obras literarias o artísticas, datos con eventual valor probatorio recogidos en ficheros informáticos, etc.). En todo caso, diferenciando entre los delitos contra elementos físicos, que no plantean realmente problemas significativos, y los que afectan a elementos lógicos, cuya naturaleza suscita concretas y muy interesantes cuestiones. En el segundo grupo se incluyen, en cambio, los delitos que se realizan por medio del

\footnotetext{
${ }^{86}$ Dictamen del Comité Económico y Social sobre la "Comunicación de la Comisión al Consejo, al Parlamento Europeo, al Comité Económico y Social y al Comité de las Regiones, eEurope 2002" (DO C 311 de 07/11/2001 pág. 0012). Citado por MORILLAS FERNÁNDEZ, D. L., Análisis dogmático y criminológico..., op. cit., pág. 101

87 Aunque MORILLAS FERNÁNDEZ, autor que aquí seguimos en este asunto, da cuenta de tres posiciones, descartamos aquella que el menciona como una posición amplia por extemporánea y poco fundada.

${ }^{88}$ En una posición homóloga, Téllez Valdés, habla de “....actitudes ilícitas en que se tiene al disponer del computador como instrumento o fin y conductas típicas antijurídicas y culpables en que se tiene a las computadoras como medio o fin”. TÉLLEZ VALDÉS, Derecho Informático, México, 1996.
} 
sistema informático o utilizando elementos de naturaleza informática, que aparecen como el instrumento utilizado para la realización del ilícito patrimonial o socioeconómico. Ello, tanto si el objeto de ataque es un elemento patrimonial cualquiera (dinero, en caso de las transferencias electrónicas de fondos o en la utilización de tarjetas de cajeros automáticos, por ejemplo) como cuando es también un sistema informático (introducción de virus, acceso ilícito a ordenadores y redes, etc.)»89

De manera que, de acuerdo con este enfoque debe diferenciarse entre (a) La informática usada para cometer un delito o como instrumento delictivo; es decir, no crear nuevas tipologías delictivas sino adaptar las existentes a los avances de la técnica. En estos casos no convendría hablar de delito informático en sí mismo sino de delito relacionado con la informática, y cuyo ejemplo más representativo suele ser la pornografía infantil a través de Internet, pues es una figura típica que ha existido a lo largo de la historia representándose en papel y que ha evolucionado hasta Internet en los últimos años. (b) La informática como objeto del delito, lo que presenta cuestiones más complejas que las anteriores pues obliga a diferenciar entre software y hardware ${ }^{90}$, con lo que al tipificar el delito informático se procura tutelar el contenido de la información del sistema informático y no el hardware en sí mismo ${ }^{91}$. La afectación ocurre sobre el software o ficheros de información o programas de aplicaciones; pero no por la

${ }^{89}$ GONZÁLEZ RUS, J. J., "Protección penal de sistemas, elementos, datos, documentos y programas informáticos", en Revista Electrónica de Ciencia Penal y Criminología, No 1, 1999, págs. 1 y ss.; del mismo autor, "Aproximación al tratamiento penal de los ilícitos patrimoniales relacionados con medios o procedimientos informáticos”, en $R F D U C M, \mathrm{~N}^{\circ} 12,1982$, págs. 116 y ss.

${ }^{90}$ En su Manual de Derecho Informático, DÁVARA RODRÍGUEZ, define: "El software es el soporte lógico de las instrucciones y órdenes (programas) que se dan a un ordenador para que realice un proceso. Puede ser de tres tipos: a) Software de base o de sistema, formado por los programas que controlan y guían las funciones del sistema (ordenador); b) Software de utilidad, formado por diversos programas de utilidad general; y c) Software de usuario o de aplicaciones (...) Por hardware o soporte físico debe entenderse todos los dispositivos y componentes físicos que realizan las tareas de entrada y salida permitiendo la comunicación entre el ordenador y el usuario. Entre los primeros cabe citar el teclado, los lectores de tarjeta, el escáner, el ratón (...); mientras los segundos quedarían conformados por monitor, impresora (...). Véase, DÁVARA RODRÍGUEZ, M. A. Manual de Derecho Informático, Ed. Thomson Aranzadi, Madrid, 1997, pág. 9.

91 JIJENA LEIVA, R., Chile, la protección penal de la intimidad y el delito informático, Santiago de Chile, 1992, pág. 110. En términos semejantes Véase, HERRERA BRAVO, R., "Reflexiones sobre la delincuencia vinculada con la tecnología digital", 2001, pág. 5, disponible en http://rodolfoherrera.galeon.com/refxdel.pdf). 
alteración física de su soporte como por el daño sobre la secuencia intrínseca del programa o fichero ${ }^{92}$.

Ajustado a ésta diferenciación, “...debería distinguirse el supuesto en que un sujeto quema la CPU de un ordenador, destruyendo con ello el soporte informático, del ataque con virus al disco duro del mismo en virtud del cual se procede al borrado de archivos; es decir, las situaciones delictuosas en las que los materiales informáticos no tienen más función que la de un simple objeto no se configuraría como delito informático". ${ }^{93}$ En este caso, la quema del ordenador no constituiría delito informático y sí lo sería, en cambio, la introducción de virus. Ejemplos similares serían también considerados delitos informáticos: los supuestos de reproducción ilícita de obras de software, de bases de datos o topografías de semiconductores, entre otros ${ }^{94}$.

Tal vez un ejemplo contribuya a apreciar mejor la manera como se resuelve desde ésta perspectiva la emergencia del universo informático para el Derecho penal. De la mano de PALAZZI ${ }^{95}$ y HERRERA BRAVO ${ }^{96}$, consideremos el caso siguiente. Se introduce un virus que perturba el funcionamiento del sistema generando un recalentamiento que quema el disco duro, la tarjeta de vídeo y el monitor; sin embargo, el daño no alcanza a alterar información alguna ni genera perturbación en los programas de funcionamiento del ordenador. Siendo así, para HERRERA BRAVO no existe delito informático puesto que el virus ha provocado la quema del hardware y no del software Bastaría, advierte, demostrar que el disco duro no ha sido dañado y la información sea susceptible de conservar mediante su traspaso a otro dispositivo o en el mismo disco duro si cabe su arreglo. Por tanto, existe afectación del hardware pero no de los datos que contiene, luego no cabría hablar de delito informático.

Distinto, señala MORILLAS FERNÁNDEZ, “.... sería el caso en que el software se viera afectado; es decir, sería el proceso normal de un virus: entra en el equipo

\footnotetext{
${ }^{92}$ MORILLAS FERNÁNDEZ, D. L., Análisis Dogmático y criminológico..., op. cit., págs. 103 y ss.

${ }^{93}$ Idem.

${ }^{94}$ Idem.

${ }^{95}$ PALAZZI, P., Delitos informáticos, Ed. AD- HOC, Buenos Aires, 2000, págs. 33-36.

${ }^{96}$ HERRERA BRAVO, R., "Reflexiones sobre la...”, op cit. pág. 5.
} 
informático y comienza a reproducirse en distintos archivos borrándolos - piénsese a tal efecto que el disco duro se halla externamente en perfecto estado pero el virus ha borrado todos sus datos. Aquí sí habría afectación del software y, por consiguiente, delito informático. Tampoco debe olvidarse, por último, la presencia de ambos hechos; estos es, primero afectación al software y posteriormente al hardware -primero se genera el borrado de archivos y luego la quema del disco-, o viceversa" ${ }^{\text {97 }}$. De manera pues que en ésta concepción la informática es a la vez objeto y medio de una acción, sería suficiente se compruebe la afectación sobre uno de los dos componentes y estaremos en presencia de un delito informático 98 /99.

Otra concepción, mayoritaria dentro de la doctrina jurídica española, es la que niega la emergencia de un nuevo tipo de delito ligado al campo de la informática. Para ello centra el foco del debate en la naturaleza del bien jurídico afectado, esto es en los fundamentos esenciales que permiten tipificar la existencia o no de un hecho susceptible de calificarlo con la entidad suficiente, a la luz de la doctrina penal, para representar un nuevo tipo de delito cuyo conjunto pudiéramos abarcar dentro de lo que denominaríamos delito informático.

Pues bien, aunque el potencial de las tecnologías de información y comunicación se dilata y no se aprecia por los momentos límites a su expansión, compartimos el criterio de GUTIÉRREZ FRANCÉS cuando sentencia que el criterio fundamental para determinar si la emergencia de la realidad digital y la revolución cibernética que le acompaña suponen una alteración profunda de la naturaleza del delito conocida lo constituye la naturaleza del bien jurídico cuya afección se pretenda evitar y, como concluye, el hecho informático carece de entidad para ello ${ }^{100}$. Admitamos efectivamente que la mediación de los mecanismos tecnológicos de información y comunicación basta repasar los ejemplos vistos - amplifiquen enormemente el poder de la comisión de delitos y que sus efectos tienen un alcance mucho mayor, justamente por la cualidad del mundo digital que ya hemos comentado en otro aparte del trabajo; pero en ningún caso

\footnotetext{
${ }^{97}$ MORILLAS FERNÁNDEZ D. L., Análisis Dogmático y criminológico..., op., cit. pág. 105.

${ }^{98}$ PALAZZI, P., Delitos informáticos, op. cit, pág. 36.

${ }^{99}$ MORILLAS FERNÁNDEZ, D. L., Análisis dogmático y criminológico..., op. cit., pág. 105.

${ }^{100}$ GUTIÉRREZ FRANCÉS, M. L., Reflexiones..., op. cit, pág. 78.
} 
alteran la naturaleza del bien jurídico afectado. Esto es, siguen siendo una mediación que facilita el delito, cuya calificación, insistimos, no depende del medio conducente a su propósito, sino del bien jurídico vulnerado y cuya naturaleza, como es obvio, no se transforma virtualmente, por muy compleja que sea la nueva realidad y amplias las dificultades para su regulación y represión. ${ }^{101}$

Estimamos de utilidad insistir en las razones para evitar ésta confusión y darle, como pretenden algunos, entidad de delito a los actos que pueden calificarse parte de la criminalidad informática, pero que sustantivamente siguen siendo delitos cuya categoría se define con sujeción a la naturaleza del bien jurídico, no obstante el reconocimiento que si ocurre en la doctrina comparada. ${ }^{102}$

Además de las justificaciones que hemos venido exponiendo en el marco del debate doctrinario, existen otras dos que se derivan de las consecuencias prácticas generadas, a saber: (a) con la aspiración de algunos de darle título de delito a la criminalidad informática, se abre el camino a la elaboración legislativa de cuerpos normativos impregnados de tipos descriptivos que se irán ampliando y diversificándose en la medida que emerjan nuevos medios o formas de comisión para los mismos delitos, dificultando enormemente su aplicación; (b) las implicaciones prácticas traducidas en dispersión de esfuerzos y recursos de las instituciones supranacionales y nacionales que, movidos desde ésta confusión, impulsan políticas de lucha contra la criminalidad organizada paralelas a la criminalidad informática, como si no se tratara de la misma que ahora, en una aldea con rasgos globales mucho más acentuados que los que advirtió MCLUHAM cuando acuñó su nombre, se asiste de las tecnologías de información y comunicación por las ventajas que proporcionan para sus propósitos. ${ }^{103}$

En todo caso vale asumir, con fines criminológicos, la expresión criminalidad informática para referirnos al agregado de problemas que gravitan alrededor de las nuevas técnicas de procesamiento de datos y a las conductas criminales asociadas, que

\footnotetext{
${ }^{101}$ Idem.

${ }^{102}$ HERRERA MORENO cita el caso de la República de Alemania, cuya reforma se funda en "...la falta de adecuación de los tipos tradicionales para abarcar las diversas formas del delito informático". HERRERA MORENO, M., El fraude informático..., op. cit., págs. 927 y ss.

${ }^{103}$ MILITELLO V., Iniciativas supranacionales en ..., op. cit. pág. 177.
} 
retan su ubicación dentro del Derecho penal vigente y los tipos penales. ${ }^{104}$ De manera que para ubicar conceptualmente tales eventos convengamos de la validez de su uso para dar cuenta de la dimensión criminológica del problema, que no jurídica toda vez que está negada por las razones expuestas su denominación. Pero abundemos un poco más en el asunto, a los fines de ampliar la fundamentación y dejar claro la orientación conceptual del trabajo en este aspecto.

Como decíamos arriba la criminalidad informática, para comenzar a denominarla de ésta forma, es un hecho especial, nuevo, que ha venido aparejado a la expansión de las tecnologías de información y comunicación y que no puede contemplar figuras delictuales antiguas adaptadas a nuevas formas comisivas; lo que denominaba PALAZZI “...como "delito relacionado con la informática”, pues se está usando la computadora como elemento delictivo o instrumento accesorio, quedando el bien jurídico protegido totalmente aislado de tal conducta. Piénsese, por ejemplo, en el caso que nos ocupa de la difusión de material pornográfico infantil por Internet, que es, alineado con la argumentación que seguimos, una modernización de conductas típicas tradicionales adaptadas a la tecnología moderna" ${ }^{105}$.

Si se observa el bien jurídico protegido - cuyo análisis se aborda en el capítulo tercero del trabajo - "... se comprueba como la conducta lesiva ya ha sido producida con anterioridad mediante la sesión fotográfica o el rodaje del vídeo en el que participa el menor, quedando la difusión por la Red como una conducta accesoria de difusión. (...) Pero, más aún, carecería de efectos prácticos el hipotético caso de considerar un tipo legal de delincuencia informática que abarque los delitos relacionados con las tecnologías de información y comunicación pues en el momento de aplicar el precepto penal correspondiente nos hallaríamos ante una dualidad de normas: la norma antigua el 189.1 del Código Penal - más el nuevo delito informático, por lo que habría que recurrir a un concurso aparente de leyes penales"106.

\footnotetext{
${ }^{104}$ GUTIÉRREZ FRANCÉS, M. L., Fraude Informático ..., op. cit., pág. 63.

${ }^{105}$ PALAZZI, P., Delitos informáticos, op. cit., pág. 35.

${ }^{106}$ MORILlAS FERNÁNDEZ, D. L., Análisis Dogmático y Criminológico... op. cit., pág. 106.
} 
Se pretende incluso que se aborde como delito informático, desde el ámbito estrictamente jurídico, a toda aquella afectación producida sobre el software de un sistema informático por persona ajena al mismo, excluyendo, con ello, los supuestos de afección del hardware. Para autores como GONZÁLEZ RUS aquí pudiera estar la génesis de este nuevo tipo penal amparado en que “...los comportamientos con eventual relevancia penal se llevarán a cabo exclusivamente mediante procedimientos informáticos, copiando, borrando, manipulando, accediendo ilícitamente al sistema, transmitiendo la información o las instrucciones que contienen los datos, los ficheros o los programas afectados"107. Es a partir de la década de los ochenta del siglo pasado cuando este tipo de actuaciones ilícitas de intromisiones en sistemas informáticos ajenos comienzan a adulterar su funcionamiento convirtiéndose en un problema de amplio alcance. Hoy día representan los supuestos de actuación más comunes: la piratería informática, la manipulación de cajeros o los abusos en los sistemas de telecomunicaciones y la difusión de virus redes informáticas ${ }^{108}$.

Pero la abundancia y recurrencia de tales actuaciones no es razón suficiente para consentir la creación de ese nuevo tipo que se encaje con el mundo digital que discurre por la red y que tantos efectos genera sobre la vida real, ya que, insistimos, no ocurre la afectación sobre un nuevo bien jurídico por el incremento cuantitativo de eventos similares como pudiera suceder con los virus informáticos, por ejemplo; antes bien, se afectan los ya conocidos mediante nuevas formas comisivas.

Decíamos, sin embargo, que a falta de otra denominación cabe su uso dentro del objeto de estudio de la criminología en tanto ciencia interdisciplinaria que tiene por objeto de estudio la conducta desviada y los mecanismos y formas de control social, al tiempo que construye críticamente un discurso del hecho delictivo que aunque alimenta guarda autonomía respecto de la ciencia penal. La criminología en tanto ciencia social, más que el delito consumado profundiza en los contextos, mecanismos o vías a través

${ }^{107}$ GONZÁleZ RUS, J J., Protección penal de..., op. cit., pág. 3.

${ }^{108}$ MORILLAS FERNÁNDEZ señala la magnitud de la intensidad de dicha manifestación delictiva los datos correspondientes a Alemania, país en el que en 1996 la policía justificó la existencia de 32.128 casos de delincuencia informática de los que 26.802 provenían de manipulaciones en cajeros automáticos; 3.588 fraudes informáticos; 933 supuestos de "Hawking" (entrada en equipos informáticos para la obtención de datos); 282 supuestos de alteración de datos y sabotaje informático; y 198 falsificaciones en bases de datos. Véase, MORILlAS FERNÁNDEZ, D. L., Análisis Dogmático y Criminológico... ., pág. 107. 
de los cuales se genera y desarrolla la conducta ilícita. Así pues cuando a lo largo de este trabajo se hace mención de la criminalidad informática ha de contemplarse “...tanto el supuesto en que la informática sea objeto del delito en los términos expuestos anteriormente y aquellos en que se utilice como vía de comisión o modernización de antiguos tipos delictivos" ${ }^{\prime 109}$.

Así visto, la pornografía infantil en Internet ha de ser considerada como una de tantas manifestaciones de la criminalidad informática en el sentido criminológico señalado, pues en su evidencia empírica se manifiesta como una actualización de antiguas formas de difusión del mencionado material ${ }^{110}$, con las peculiaridades inmanentes a la criminalidad informática de nuestros días asociadas a la complejidad de la persecución, regulación y sanción que viene no del hecho informático como de la transnacionalización del delito que potencian las tecnologías de información y comunicación.

Justo en ésta dimensión de la criminalidad informática referida a la difuminación de las fronteras nacionales mientras prevalecen legislaciones ancladas en el principio de soberanía territorial, es de donde proviene la confusión respecto de si se trata de un nuevo tipo de delitos. Que se niegue la existencia del delito informático como una nueva categoría de delito a lo que hemos denominado criminalidad informática o cibernética, no significa desdeñar el impacto que sobre el sistema penal genera la realidad virtual como espacio desde el cual opera la ciber/criminalidad. El problema no es la emergencia de un nuevo tipo de delitos como los retos que demanda la aplicación de la ley penal en el espacio virtual.

De allí la necesidad de ubicar en este contexto la conexión entre la pornografía infantil, las tecnologías de información y comunicación y la ciber/criminalidad. Carece de sentido procurar la comprensión de fenómenos globales como los que aquí se tratan desde los viejos patrones de análisis que apenas unos lustros antes servían para su acertada lectura.

\footnotetext{
${ }^{109}$ MORILLAS FERNÁNDEZ, D. L., Análisis Dogmático y Criminológico..., op. cit., pág. 111.

${ }^{110}$ Ibídem, págs. 111y ss.
} 
Aunque la pornografía infantil es un hecho antiguo, con huellas en las culturas a lo largo de la evolución de la civilización humana, el alcance que hoy día presenta en su magnitud y efectos solo podemos entenderla en su naturaleza y complejidad a partir de su imbricación con la delincuencia global y el abuso que ésta hace de las ventajas ofrecidas por la revolución cibernética y los sistemas de comunicación electrónica. ${ }^{111}$ No se trata de fenómenos independientes, de acuerdo con GUTIÉRREZ FRANCÉS, sino necesariamente vinculados en la medida que son dichos medios electrónicos de transmisión de datos y las bondades venidas del espacio digital quienes han dado los rasgos que hoy configuran una delincuencia organizada con alcance mundial. ${ }^{12}$ Más adelante, tratamos como un aparte las implicaciones político-criminales de su uso por parte de la denominada ciber/criminalidad y revisar someramente los principales instrumentos jurídicos internacionales dedicados a regular y reprimir la criminalidad informática.

Respecto de la clasificación de los delitos que caben dentro de lo que aquí se denomina criminalidad informática, todavía guarda vigencia la clasificación formulada por Ulrich SIEBER ${ }^{113}$, quien separa estos de acuerdo con las siguientes áreas:

a) Infracciones que afectan la intimidad y la vida privada. Tienden a afectar la privacidad de los datos personales disponibles principalmente en las bases de datos públicas o privadas.

b) Delitos económicos. Citemos principalmente el hacking, el espionaje informático, la piratería, el sabotaje o el fraude informático.

c) Contenidos ilegales y nocivos. Son los conocidos como delitos de contenido que circulan en Internet, en particular la de contenido discriminatorio para minorías o, tratándose de nuestro estudio, el caso de la pornografía infantil.

\footnotetext{
${ }^{111}$ GUTIÉRREZ FRANCÉS, M .L., “Las altas tecnologías...”, op. cit, pág. 191.

${ }^{112}$ Ibídem, pág. 194.

113 SIEBER, U., La delinquance informatique. Centre de Recherches Informatique et Droit des Facultés Universitaires de Namur. E. Story Scientia, Bruselas, 1990, págs. 7-38.
} 
d) Otros delitos. En el que incluye los delitos contra el Estado y los intereses políticos constitucionalmente establecidos; aquellos otros que atentan contra la integridad de las personas; el crimen organizado, como forma de comunicación o actuación; o las guerras electrónicas, principalmente en referencia a las manipulaciones militares $^{114}$.

Como conclusión de ésta parte y para ir delimitando nuestro objeto de estudio, debe considerarse a la pornografía infantil a través de Internet una manifestación de la criminalidad informática en su sentido criminológico. Sin embargo, siguiendo a GUTIÉRREZ FRANCÉS, no es posible su designación como delito informático en su acepción jurídica, ya que no se ubica dentro de los parámetros expuestos reguladores del tipo penal aplicable al efecto en tanto no es más que una modernización de antiguas formas delictivas ${ }^{115} /{ }^{116}$. De tal manera que no cabe asignarle la calificación de delito informático, designación que apreciamos equivocada para designar una nueva realidad que, sin embargo, obliga a su revisión no para crear nuevos tipos como para encajar mejor la emergencia del mundo virtual dentro de los tipos penales existentes puesto que, como hemos visto, no crea nuevos bienes jurídicos.

En el aparte siguiente avanzamos un paso más en el objeto de este primer capítulo de situar el marco criminológico que fija el problema de la pornografía infantil, estableciendo los lazos de conexión entre el delito que aquí se estudia y el tipo de organización que hace de ella un negocio de alcance global, a partir de las potencialidades que facilita la Internet y las restricciones de los marcos nacionales de aplicación de normas regulatorias.

\section{PORNOGRAFÍA INFANTIL Y DELINCUENCIA ORGANIZADA.}

Las consideraciones hechas hasta aquí alusivas al impacto que sobre el Derecho penal han causado las tecnologías de información y comunicación, así como la nueva

114 SIEBER, U., "Documentación para una aproximación al delito informático”, en MIR PUIG Delincuencia Informática, Barcelona, 1992. En su primera obra, referida en la nota anterior SIEBER no incluye la que hace alusión a los contenidos ilegales y nocivos (literal c). Estos aparecen reflejados en sus trabajos posteriores, especialmente en los destinados a cumplir con exigencias de la Comisión Europea sobre el asunto.

${ }^{115}$ GUTIÉRREZ FRANCÉS, M. L., “Las altas tecnologías...”, op. cit, pág. 194.

${ }^{116}$ MORILLAS FERnÁNDEZ, D. L., Análisis Dogmático y Criminológico... op., cit. pág. 112. 
dimensión adquirida en tanto realidad criminal por la pornografía infantil potenciada por sus usos desde la Internet, nos llevan a esbozar un planteamiento final en ésta parte para ubicar las relaciones que surgen entre la pornografía infantil y la criminalidad organizada o delincuencia organizada. En principio, y partiendo de eventos similares que desde otras realidades criminales se han trazado para dar cuenta de cómo se han transformado a partir de Internet, vamos a apreciar las características que presenta la nueva criminalidad organizada de acuerdo con el marco normativo europeo y la doctrina española y ubicar dentro de ella la realidad que nos atañe.

La relación entre la criminalidad organizada y las tecnologías de información y comunicación cada vez se aprecia y entiende con mayor claridad, sea en el desarrollo doctrinal que se va decantando pasadas las limitaciones de comprensión iniciales con ocasión de las primeras reflexiones en el ámbito jurídico sobre el advenimiento de la sociedad de la información, sea en la conciencia asumida respecto de la necesidad de entenderlos -e intervenirlos- imbricados a los fines de su confrontación mediante políticas públicas. Detengámonos en algunos de ellos para referir sus planteamientos y posteriormente detallar de manera más sistemática ésta conexión.

MILITELLO, citado anteriormente, recuerda en relación con el uso de la informática por parte de la criminalidad organizada, que el llamado ciberespacio abre los horizontes a nuevas posibilidades de comunicación entre las organizaciones criminales dedicadas a programar y ejecutar actividades ilícitas. Esta posibilidad resulta aún más atractiva debido al hecho de que se pueden efectuar comunicaciones a través de formas cifradas que garanticen la información y anulen el riesgo de que sean interceptadas por los investigadores. No es difícil predecir que esta última posibilidad tendería a incrementarse debido a la facilidad de acceso a las técnicas de cifrado y descifrado $^{117}$. Lo que es igual, siguiendo con la tesis central planteada al inicio: la dimensión actual que caracteriza a la delincuencia global le viene del uso a sus fines e intereses de la revolución informática que vivimos. ${ }^{118}$ Los recursos de variado orden propiciados por las tecnologías de información y comunicación susceptibles de uso con fines ilícitos, contribuyen a que la delincuencia que actúa como criminalidad organizada

\footnotetext{
${ }^{117}$ MILITELLO, V., “Iniciativas supranacionales en...”, op cit. pág. 183.

${ }^{118}$ GUTIÉRREZ FRANCÉS, M. L., “Las altas tecnologías...”, op. cit, pág. 211
} 
multiplique sus posibilidades delictivas, extienda su alcance y, al mismo tiempo, actúe con absoluta impunidad en la medida que recurre entre otros recursos a los lenguajes cifrados o encriptados de los sistemas informáticos

Podemos afirmar que la Ciber/delincuencia es la delincuencia moderna organizada - que ha sacado máximo rendimiento al desarrollo y expansión de las nuevas tecnologías, y que se ha hecho para sus fines del espacio virtual, un espacio poco regulado, ilimitado e incontrolado ${ }^{119}$. Esto, además, se ve potenciado por el acceso fácil, económico e inmediato a las redes de telecomunicaciones y por la irrupción del ordenador personal como bien doméstico de uso cotidiano infaltable en los hogares modernos, conectado al mundo virtual mediante la amplia gama de ofertas de medios de conexión a la Internet.

En el marco de las instituciones comunitarias la delincuencia organizada y su tipificación aparecen reguladas en la Acción Común de 21 de diciembre de 1998, adoptada por el Consejo con base en el Título VI, artículo K.3, del Tratado de la Unión Europea $(98 / 733 / \mathrm{JAI})^{120}$. Se trata de una norma breve de apenas siete artículos y cuyas motivaciones se sustraen a la necesidad de un enfoque o marco común de la delincuencia organizada y de fundar las bases de la necesaria cooperación entre los Estados miembros en la lucha contra ella. De allí que se esfuerce en delimitar una definición y de dictar orientaciones de políticas alineadas con la adecuación o compatibilidad de las normas nacionales y un marco de cooperación.

En ella se define una organización delictiva (art. 1) como “...una asociación estructurada de dos o más personas, establecida durante un cierto período de tiempo, y que actúe de manera concertada con el fin de cometer delitos sancionables con una pena privativa de libertad o una medida de seguridad privativa de libertad con un máximo de al menos cuatro años como mínimo o con una pena aún más severa, con independencia de que esos delitos constituyan un fin en sí mismos o un medio de obtener beneficios patrimoniales y, en su caso, de influir de manera indebida en el funcionamiento de la autoridad pública”.

\footnotetext{
${ }^{119}$ GUTIÉRREZ FRANCÉS, M. L., “Reflexiones sobre...”, op. cit, pág. 92

${ }^{120}$ DO L 351 de 29/12/1998 pág. 1 y 2.
} 
El artículo segundo que seguidamente transcribimos ahonda en la definición mediante la delimitación del alcance de la responsabilidad de quienes participen en este tipo de organizaciones.

\section{Artículo 2.}

1. Para facilitar la lucha contra las organizaciones delictivas, los Estados miembros se comprometerán, conforme al procedimiento contemplado en el artículo 6, a garantizar que uno o los dos comportamientos contemplados a continuación estén sujetos a sanciones penales efectivas, proporcionales y disuasorias:

a) el comportamiento de toda persona que, de forma intencional y teniendo conocimiento bien del objetivo y de la actividad delictiva general de la organización, bien de la intención de la organización de cometer los delitos en cuestión, participe activamente: i)en las actividades delictivas de la organización contempladas en el artículo 1, aun cuando esta persona no participe en la ejecución propiamente dicha de los delitos de que se trate y, sin perjuicio de los principios generales del Derecho Penal del Estado miembro, incluso cuando no tenga lugar dicha ejecución; ii) en las demás actividades de la organización teniendo, además, conocimiento de que su participación contribuye a la ejecución de las actividades delictivas de la organización contempladas en el artículo 1;

b) el comportamiento de toda persona consistente en concertarse con una o varias personas para llevar a cabo una actividad que, en caso de materializarse, equivalga a la comisión de los delitos contemplados en el artículo 1, aunque dicha persona no participe en la ejecución propiamente dicha de la actividad.

2. Independientemente de si han elegido tipificar penalmente el comportamiento contemplado en la letra a) o el de la letra b) del apartado 1, los Estados miembros se prestarán la mayor asistencia mutua posible en lo que se refiere a las infracciones contempladas en el presente 
artículo y a las infracciones contempladas en el apartado 4 del artículo 3 del Convenio relativo a la extradición entre los Estados miembros de la Unión Europea, celebrado por el Consejo el 27 de septiembre de 1996.

Poco más se dice en el cuerpo de la norma de relevancia al interés nuestro, salvo el mandato de coordinación policial y judicial mencionado en el artículo cuarto cuando se tratare de delitos transnacionales. Como no podía ser de otra manera la definición que se puede extraer de los dos primeros artículos apenas despertaba aceptación en la doctrina. Desde la teoría criminológica, aunque sin consenso al respecto, hay resistencia a convenirse sobre su definición (ambigua) y uso (escasa utilidad práctica). Autores como GARRIDO, STANGELAND O REDONDO la definen como “...un tipo de actividad criminal que implica la existencia de grupos con una reglas de actuación, con un propósito definido (que puede ser político en el caso del terrorismo o económico en las mafias) y que tiende a transmitir sus normas y pautas a los nuevos allegados a la organización" "121. En el análisis doctrinal que siguen posteriormente los autores se detienen fundamentalmente en dar cuenta de aquello que se conoce en la opinión pública como sindicatos del crimen que, en el marco de la globalización y las posibilidades que otorga Internet, más allá de los estereotipos clásicos conocidos de Italia y Estados Unidos representativos de la mafia organizada del siglo XX, en no pocos casos sobrepasan el poder de muchos Estados nacionales convirtiéndose en una amenaza para el orden internacional. HERRERO HERRERO a su vez señala dos concepciones de delincuencia organizada. En primer lugar, y de manera muy general la contempla como “...la actividad delictiva, metódicamente planificada y ejecutada, generalmente por individuos que viven del crimen”. En un sentido más restringido sería aquélla que “...se realiza a través de un grupo o asociación criminal revestidos de las siguientes características: carácter estructurado, permanente, autorrenovable, jerarquizado, destinados a lucrarse con bienes y servicios ilegales o a efectuar hecho antijurídicos con intención sociopolítica, valedores de la disciplina y la coacción con relación a sus miembros y de toda clase de medios frente a terceros con el fin de alcanzar sus objetivos"122.

\footnotetext{
${ }^{121}$ GARRIDO, V.; STANGElAND, P.; REDONDO, S., Principios de Criminología, Valencia, 2001, pág. 667.

${ }^{122}$ HERRERO HERRERO, C, Criminología, Ed. Dykinson, Madrid, 2001, págs. 534-536.
} 
En todo caso, desde la misma Criminología se establecen los siguientes rasgos o características que permiten identificar cuando se está en presencia de ella ${ }^{123}$ :

1) Realizar la actividad por medio de un grupo o asociación criminal. Ello permite la diferencia más primaria al excluir las acciones aisladas personales. No obstante, precisa BORRALLO, hay también que diferenciarla de la delincuencia de grupo o las bandas juveniles ${ }^{124}$.

2) Estructura organizativa, disciplinada y jerárquica. Cada miembro de la organización debe tener asignada una función específica o general, dentro de un organigrama más o menos diseñada, y estar sometido a unas reglas o códigos de comportamiento compartido, funcionales y de sobrevivencia. MEDINA ARIZA entiende que la organización resulta esencial en toda definición de crimen organizado. Sin embargo, organización no significa ordenación jerárquica, ni una clara delimitación de funciones y competencias en un esquema rigurosamente estructurado ${ }^{125}$. MORILLAS FERNÁNDEZ hace mención de autores italianos que objetan, sin embargo, que “...no es necesaria una organización propia con jerarquía interna y distribución específica de cometidos, ni tampoco llena de medios, siendo suficiente una unidad mínima embrionaria, rudimentaria no estructurada"126.

123 Seguimos aquí fundamentalmente a ANARTE BORRALLO, Enrique., "Conjeturas sobre la criminalidad organizada", en FERRÉ OLIVÉ, J. C.; ANARTE BORRALLO, E., Delincuencia organizada: Aspectos penales, procesales y criminológicos, Huelva, 1999, págs. 22-33; Herrero Herrero, C, Criminología, op. cit., págs. 538 y 539; MORILLAS FERNÁNDEZ, D. L., Análisis dogmático y criminológico..., op. cit.; MEDINA ARIZA, J. J., "Una introducción al estudio criminológico del crimen organizado", en ANARTE BORRALLO, E., FERRÉ OLIVÉ, J. C., Delincuencia organizada: Aspectos penales, procesales y criminológicos, Huelva, 1999, págs. 111-114.

${ }^{124}$ Para ANARTE BORRALLO, algunas de las diferencias son: en la delincuencia organizada es el cliente quien determina primaria y fundamentalmente el delito, a diferencia de las bandas que suelen actuar por una suerte de identidad grupal; en su extensión grupal las bandas suelen ser de acceso reducido aunque asequible; las bandas tienen una vida más breve que las organizaciones; la estructura, jerarquía, cohesión y estabilidad organizativas, suelen tener un ámbito local, mientras que la internacionalización es hoy una de las notas características de los grupos criminales organizados. ANARTE BORRALLO, E., Conjeturas..., op. cit., págs. 21 y ss.

${ }^{125}$ MEDINA ARIZA, J. J., "Una introducción al estudio criminológico del crimen organizado", en Ferré Olivé, Juan C.; ANARTE BORRALLO, E., Delincuencia..., op. cit., pág. 113.

126 Gargani, A., "L'adeguatezza della struttura organizzativa", en De Francesco, G., La criminalitá organizzata ti'a esperienze normative e prospettive di collaborazione intemazionale, Torino, 2001, pág. 57. De la misma opinión, Ardizzone, "Associazione per delinquere e criminalitá organizzata", en Militello, V., Paoli, L. y Amold, J., // crimine organizzata come fenómeno transnazionale, Friburgo- 
3) Carácter permanente y autorrenovable. Esto es, debe tener vocación de permanencia y estabilidad en el tiempo, por lo que habría de excluir aquellas asociaciones o grupos de carácter transitorio ${ }^{127}$.

4) Internacionalidad y movilidad. Rasgo que se ha potenciado con la globalización y el uso de las TIC a sus fines. BLANCO CORDERO, ZUÑIGA RODRÍGUEZ y GUTIÉRREZ FRANCÉS, entre otros, destacan esto como una consecuencia indeseada de la globalización. En particular BLANCO CORDERO apunta las ventajas que ofrece la globalización económica en la medida que (a) posibilita el acceso a mercados de bienes ilícitos muy lucrativos; (b) se incrustan en espacios territoriales de fragilidad institucional en diferentes sociedades, principalmente aquellas que se hallan en la llamada fase de desarrollo y las democracias emergentes; (c) lo que permite cierta seguridad frente a la persecución penal, sea por la carencia de legislación en esta materia, o porque amparados en el principio de soberanía territorial se limita la cooperación judicial internacional; (d) hacen uso del sistema financiero global que, con la eliminación de controles, hace cada vez más difícil el rastreo de los mismos; (e) recurren a paraísos fiscales en los que es posible ocultar e invertir los fondos de origen delictivo con el propósito de blanquearlos para preparar su retomo a la economía legal ${ }^{128}$.

5) Objetivos. La obtención o afán de lucro económico es el objetivo primordial y fundamental. Ello le otorga una orientación empresarial y capitalista en el sentido de Schumpeter, cuyo radio de acción termina siempre asociándose a fines sociopolíticos. "La expansión de los mercados ilegales a nivel mundial ha influido profundamente en la estructura de las organizaciones criminales, de modo que estas ahora (...) trabajan según criterios económicos, esto es, con una planificación de sus actividades orientadas

Milán, 2000, pág. 193. Citado por MORILLAS FERNÁNDEZ, D. L., Análisis dogmático y criminológico..., op. cit., pág. 116.

${ }^{127}$ El Código Penal Español de 1995 contempla la figura de la organización o asociación criminal de carácter transitorio en diversos tipos penales, verbigracia el tráfico de drogas o el nuevo artículo 189.3 e) establecido en la Ley Orgánica 5/2010, de 22 de junio, referente a la pornografía infantil.

${ }^{128}$ BLANCO CORDERO, I., "Principales instrumentos internacionales (de Naciones Unidas y la Unión Europea) relativos al crimen organizado: la definición de la participación en una organización criminal y los problemas de aplicación de la Ley Penal en el espacio", en Criminalidad organizada, Reunión Preparatoria de la sección nacional Española preparatoria del XVI Congreso de la AIDP en Budapest, Universidad de Castilla-La Mancha, 1999, págs. 22 y ss. 
por la demanda de bienes y servicios ilegales, con división del trabajo y con la finalidad de obtener ganancias"129

En los orígenes de este tipo de criminalidad, como se sigue de las grandes transformaciones en el mundo de las comunicaciones y del comercio mundiales que hemos apuntados en los apartes anteriores, está la nueva trama globalizada de la realidad de nuestro días. Para BLANCO CORDERO viene originada por los grandes procesos y cambios contemporáneos. Entre ellos, la “...globalización de la economía es el factor más importante que ha influido en el desarrollo y expansión de la criminalidad a nivel mundial. Las grandes organizaciones criminales tienen una gran habilidad para aprovechar las ventajas que ofrece el nuevo espacio mundial, con la creación de zonas libre de comercio en algunas regiones del mundo, en las que se produce una permeabilización económica de las fronteras nacionales y se reducen los controles. La habilidad para utilizar las condiciones y recursos que ofrece el nuevo espacio mundial explica la extraordinaria expansión de las grandes organizaciones criminales"130/131.

Hay, sin embargo, amplio consenso en la doctrina de los peligros que representa la asunción generalizada de la doctrina de la seguridad anglosajona que homologa terrorismo con delincuencia organizada. Esto, además de confundir conceptualmente la identificación de una y otra, simplifica la complejidad adquirida por la delincuencia organizada para reducir su lucha a la actuación policial y judicial contra los actos y organización del llamado terrorismo integrista o fundamentalista. Buena parte de la responsabilidad de los miedos colectivos han sido agravados hasta el paroxismo por ésta doctrina de la seguridad mundial que se ha extendido como mancha de aceite sobre los Estados nacionales desde el desgraciado ataque a las Torres Gemelas en Nueva York en septiembre de 2001.

\footnotetext{
${ }^{129}$ Ibídem, pág. 21.

${ }^{130}$ Ibídem, págs. 19 y ss.

131 Hay, sin embargo, amplio consenso en la doctrina de los peligros que representa la asunción generalizada de la doctrina de la seguridad anglosajona que homologa terrorismo con delincuencia organizada lo que además de confundir conceptualmente la identificación de una y otra, simplifica la complejidad adquirida por la delincuencia organizada para reducir su lucha a la actuación policial y judicial contra los actos y organización del llamado terrorismo integrista o fundamentalista.
} 
Bajo estos parámetros, la alternativa más eficaz en la lucha contra la delincuencia organizada parece debe descansar sobre dos actuaciones complementarias: la creación de leyes penales que asiente un marco regulatorio de derecho y la actuación cooperativa de los Estados en la persecución de tales estructuras organizativas mediante el intercambio de información, creación de organismos policiales conjuntos tanto para coordinar actividades como para actuar contra el crimen, entre otros, tal como apuntaba la dirección de la Acción Común del 21 de diciembre de 1998 que citamos antes.

Desde el punto de vista jurídico, no obstante el marco común europeo que traza la norma revisada, existen tantas definiciones y diferencias como leyes nacionales, sobre las que no vamos a entrar en su revisión, dado que no es el objeto central de este trabajo.

Ahora bien, las características que hoy día presenta la pornografía infantil ajustada a lo que en el marco jurídico y criminológico hemos descrito como la delincuencia organizada, permiten ubicarla y conceptuarla dentro de ella. La eclosión de Internet y las nuevas tecnologías han permitido que este tipo de delincuencia ocurra fundamentalmente a través de esta vía. Si se considera que las principales fuentes de difusión de la pornografía infantil -el intercambio de videos, fotos e iconografías relacionadas a través del correo electrónico por parte de los propios consumidores, o en los últimos dos o tres años mediante la trasferencia instantánea que ocurre a través de las redes sociales- lo hacen a sus anchas desde la red digital a través de Internet, no es descabellado afirmar que su producción y distribución se encuentra en gran medida en manos de una delincuencia organizada que, siguiendo a MORILLAS FERNÁNDEZ, tiene las siguientes características:

a) Realiza su actividad a través de redes asociativas, agrupadas o no en formas de empresas, generalmente encubiertas. Advierte MORILLAS FERNÁNDEZ que no obstante la dificultad para hallar a las personas responsables de la creación, mantenimiento y actualización de las páginas, “...tales acciones lleva aparejada lo innecesario de encubrir tales actos, siendo bastante frecuente, para la localización de las mismas, el único requisito de introducir en cualquier buscador de Internet alguna palabra relacionada con el material pornográfico deseado -las más comunes son “teens" (adolescentes), “nude teen" (adolescente desnudo), el término "lolitas" o 
algún personaje de dibujos animados de moda seguido con las siglas $X X X$ (...)- e inmediatamente el ordenador mostrará una serie de resultados en los que, una vez pinchado sobre la página deseada, ésta se redirigirá a otra en la que se halle el contenido ilícito" ${ }^{\prime 32}$. Como se entenderá, la tarea de identificar el origen de la página web de donde emana o bien la fuente principal de envío de material pornográfico es una tarea ardua y compleja por la especialización que demanda la pericia de quien investiga.

b) Aunque el trabajo de indagación, acopio y manejo suele ser sencillo y no demanda más que la interrelación entre el ordenador y quien procede a través de él, lo más común es la integración de un equipo de personas cada una de las cuales ostenta algunas funciones atribuidas -captación de niños, filmación de imágenes, fotografiado, publicidad, edición- y supervisadas por un organizador o responsable. En cualquier caso, generalmente se asume que existe una relación directa entre la calidad del producto en la web y la organización que lo genera: a menor número de miembros de la organización se corresponde trabajo más artesanal; a mayor número mayor calidad del producto $^{133}$.

c) Operan de forma permanente, hecho que viene dado por la actualización de la página. A veces, sea porque han sido descubiertos, o bien como pauta de actuación para evitar lo sean, cambian regularmente de dirección o de servidor esquivando así el seguimiento.

d) Internacionalidad. Lo que antes era una limitación al tener que disponer físicamente de material y cruzar fronteras, hoy ha pasado a ser un atributo que lo potencia como nunca, por todas las bondades, alcance y gratuidad que facilita Internet ${ }^{134}$.

e) Su objetivo es meramente económico. A estos efectos y para no dejar rastro suelen usarse los mecanismos comerciales y financieros de productos legales.

\footnotetext{
${ }^{132}$ MORILLAS FERNÁNDEZ, D. L., Análisis dogmático y criminológico...op. cit., págs. 119 y ss.

${ }^{133}$ Idem.

${ }^{134}$ Idem.
} 
Es preciso apuntar aquí que el legislador español con la intención de combatir la delincuencia organizada alrededor de la pornografía infantil agrava (art. 189.3e) la pena en grado cuando el culpable perteneciera a una organización o asociación, incluso de carácter transitorio, que se dedicare a la realización de actividades relacionadas a la producción, venta, distribución, difusión o exhibición de pornografía infantil. Obsérvese que se trata con énfasis a la organización criminal que trafica con la pornografía infantil, por lo que atinadamente el legislador identifica la dimensión organizativa asociada al delito tipificado. La redacción es la siguiente:

"Se impondrá la pena superior en grado cuando el culpable perteneciere a una organización o asociación, incluso de carácter transitorio, que se dedicare a la realización de actividades".

Para MORILLAS FERNÁNDEZ “....por su propia génesis, la aplicación de este parágrafo circunscrito a la delincuencia organizada procedente, principalmente, de grandes publicaciones en papel como puede ser el caso, por ejemplo, de revistas; vídeos relativos a productoras de este tipo de material; y difusión de imágenes de Internet"135. Para BOLDOVA PASAMAR se trata del mismo tipo agravado que figura en el delito de prostitución de menores en el art. 187.3, cuyo fundamento reside en el mayor desvalor de la acción y concretamente en la mayor peligrosidad de la conducta que deriva de que el culpable realice sus actividades delictivas al amparo de la criminalidad organizada $^{136}$. En la misma línea se posiciona MUÑOZ CONDE al plantear que está plenamente justificado haber introducido este agravante ya que en la prostitución y utilización para espectáculos pornográficos de menores o incapaces es uno de los ámbitos donde suele presentarse el fenómeno de la delincuencia organizada, con ramificaciones que van más allá de las fronteras nacionales ${ }^{137}$. En relación al concepto de Asociación para este autor coincide con el de asociación ilícita del art. 515, es decir debe tratarse de un conjunto de tres o más personas organizadas, aunque sea de forma transitoria, para llevar a cabo estos delitos. El concepto de organización aunque

\footnotetext{
${ }^{135}$ MORILLAS FERNÁNDEZ, D. L., Análisis dogmático y criminológico..., op. cit., pág. 136.

136 BOLDOVA PASAMAR, M.,: “Art. 189...” en AA.VV, Comentarios al Código Penal, Parte Especial, tomo II. Ed. Tirant lo Blanch, Valencia, 2002, pág. 524.

${ }^{137}$ MUÑOZ CONDE, F., Derecho Penal, Parte Especial, Tirant lo Blanch, Valencia, 2002, pág 241.
} 
impreciso, por razones de seguridad debe interpretarse como equivalente al de $\operatorname{asociación~}^{138}$.

Para tener una idea de la dimensión alcanzada por la delincuencia que opera estas redes de tráfico, producción, difusión y venta de pornografía infantil, baste citar las actuaciones policiales de renombre de las que comúnmente se hacen eco los medios impresos de comunicación que, además, ponen en evidencia la necesidad de la cooperación internacional para luchar contra ella: "Desarticulada una tupida red de pornografía infantil con miles de usuarios en todo el mundo. La operación de la policía austriaca ha desenmascarado a sospechosos en 77 países, entre ellos España"139 " "Con el nombre de "Operación Koala" una operación coordinada por Europol y Eurojust desmantela una red mundial de pornografía con 92 detenido en 19 países por poseer porno infantil ${ }^{140}$; “63 detenidos en cinco redadas en toda España contra la pornografía infantil. Cinco operaciones (Operación Malkone), (Lolita E-10yo), (Operación Nokian), (operación Naruto)" ${ }^{\natural 141}$.

Queda claro, para cerrar, que la criminalidad informática no es un problema exclusivo de los países con desarrollo económico y tecnológico; se trata de un fenómeno globalizado que carece de fronteras espaciales-territoriales cuyas más graves expresiones ocurren en el espacio virtual. Por tal motivo se requiere de respuestas de carácter supranacional que trascienda la $\mathrm{UE}^{142}$ y al primer mundo para frenar y reprimir

\footnotetext{
${ }^{138}$ Idem.

${ }^{139}$ El País del 7 de febrero de 2007.

${ }^{140}$ El País, de 6 de noviembre de 2007.

${ }^{141}$ El país, 17 de diciembre de 2007.

142 Es conveniente referir el itinerario a partir del cual se han tejido las diferentes iniciativas internacionales en materia de delincuencia informática, que han terminado configurando un marco normativo que empuja hacia escenarios más vinculantes en términos de legislación común, voluntad política de aplicación y cooperación en su administración judicial. Entre ellas tenemos, 1) Entre las actuaciones iniciales deben resaltarse las reuniones de expertos que originaron documentos o acuerdos que precedieron a los convenios posteriores como (a) Recomendaciones de la comisión de expertos de la OCDE, firmada en Paris en 1986. (b) Recomendaciones de la AIDP tras el encuentro sobre computer crimen en Wurzburg 1993. Existía la idea errónea de que los instrumentos clásicos de los principios de eficacia de ley penal en el espacio, con la legislación interna ya adaptada, eran adecuados para resolver problemas de posible impunidad. 2) Iniciativas en materia de cooperación internacional en la Unión Europea. (a) Convenio relativo a la asistencia judicial en materia penal de 29 de mayo de 2000. (b) La Decisión Marco del Consejo de 13 de junio de 2002, relativa a la orden Europea de detención y entrega. En este instrumento jurídico nace la versión informática del delito de terrorismo. (c) Decisión del Consejo
} 
dicha criminalidad. Esta situación exige una conjunción de las diferentes legislaciones penales y una flexibilización de los mecanismos de cooperación internacional. A partir de la segunda mitad de los años ochenta y, sin dudas, desde la década de los noventa se pone de relieve la necesidad de algún tipo de cooperación entre los Estados para atender a los alcances de una delincuencia informática globalizada. No obstante, la lucha contra la delincuencia a nivel internacional se ve reducida a convenios bilaterales o multilaterales entre los Estados y cuya efectividad depende de la voluntad política y de los arreglos institucionales para recogerlo en las legislaciones internas.

En los últimos años son muchas las iniciativas acordadas en la comunidad internacional para atender la dimensión global adquirida por la delincuencia organizada. No pocas de ellas repetitivas, redundantes, yuxtapuestas, sobre crimen organizado, terrorismo internacional y legitimación de capitales, especialmente. Sin embargo, las diferencias culturales, sociales y políticas dificultan la creación de iniciativas de cooperación a nivel mundial en la represión penal, amén de las dificultades que afronta la comunidad internacional con el principio ius ponendi como expresión de la soberanía territorial de los Estados, lo que relega el ámbito de validez espacial de la ley penal a un papel secundario.

de 28 de febrero de 2002 por la que se crea EUROJUST para reforzar la lucha contra formas de delincuencia más graves.

Con estos instrumentos jurídicos se apostaba por superar en el ámbito de la UE, al menos en teoría, las dificultades para poner en marcha la cooperación para las formas más graves de delincuencia. Respecto de las (3) Medidas específicas orientadas a la lucha contra el cibercrimen en el ámbito de la Unión Europea, vale enumerar: (a) Plan de acción contra la criminalidad organizada. Parlamento Europeo, resolución de 28 de octubre de 1997. (b) Consejo de la Unión Europea del 18 de diciembre de 1997 que daba cuenta de la necesidad de combatir el "uso de las altas tecnologías con fines delictivos" y de que éstas sean utilizadas eficazmente contra la criminalidad. (c) Consejo de Tampere, Finlandia, 16 de octubre de 1999 (una versión nueva del tratado de Ámsterdam) Libertad, seguridad y justicia en reunión de 28 de febrero de 2003. Se acordó la necesidad urgente de aproximar las legislaciones internas a los Estados miembros con el fin de evitar lagunas legislativas, al mismo tiempo se fijan criterios para establecer la competencia jurisdiccional en casos de ciber/delitos de carácter trasnacional. (d) Consejo Europeo (CE) 1999/364/JAI de 27 de mayo de 1999, adoptada por el Consejo sobre la base del artículo 34 del Tratado de la Unión Europea, relativa a las negociaciones del proyecto de convenio sobre ciber/crimen del Consejo de Europa. En su mayoría resultan acuerdos de orden declarativas o "llamadas de atención" respecto de la necesidad de facilitar la cooperación internacional ante las modernas formas de delincuencia. (e) Reglamento interno de la Eurojust relativas al tratamiento y a la protección de datos personales, aprobado por el Consejo el 24 de febrero de 2005/C 68/OI). (f) La Decisión No 854/2005/CE del Parlamento Europeo y del Consejo, de 2 de mayo de 2005, relativa al interés de fomentar un uso más seguro de Internet y las nuevas tecnologías en línea. (g) Parlamento Europeo y del Consejo del 10 de marzo de 2004, Reglamento (CE) No 460/2004. Se crea la Agencia Europea de Seguridad de las Redes y de la Información. 
Desde la Unión Europea recientemente se han producido avances con la eliminación de los mecanismos de extradición dentro de países miembros. Con el propósito de lograr la cooperación judicial, policial y legislativa, se implantó la Decisión Marco del 17 de julio de 2000 para hacer efectivo el "Espacio Judicial Único" para la represión de un importante número de delitos en los que se incluyen delitos de altas tecnologías específicamente aquellos que aquí encerramos dentro de los criminológicamente llamamos delincuencia informática. El mayor logro ha sido la sensibilización en todas las instancias nacionales internas, a quienes compete directamente el ejercicio de ius ponendi (policía, jueces, juristas, legisladores) sobre los riesgos de las TIC.

\section{ALARMA SOCIAL, MEDIOS DE COMUNICACIÓN Y DELITOS SEXUALES. DE LAS EXIGENCIAS DE NEUTRALIZACIÓN DEL DELINCUENTE.}

Un último asunto nos pareció de relevancia adjuntar en este primer capítulo, para cerrar la conformación del marco sobre el que plasmar posteriormente el foco del asunto y que contiene las tesis centrales de orden criminológico y jurídico sobre el delito de pornografía infantil. Este quiere dar cuenta de la atmósfera social y mediática sobre la cual se viene legislando a golpe de escándalo para tomar prestada una denominación dada por un medio impreso de comunicación ${ }^{143}$. La justificación para hacer mención a ésta atmósfera viene dada porque enlaza posteriormente con la denuncia que se hace en este trabajo, sobre la emergencia de la ideología de la seguridad que deja su impronta sobre la Política Criminal y hace su encaje en el cuerpo de normas penales que le envisten de legitimidad jurídica. Los miedos sociales expuestos al amparo de la lógica que imponen los medios de comunicación dan fuerza a la extensión de ésta ideología de la seguridad sobre las actuaciones de las instituciones políticas de administración,

\footnotetext{
${ }^{143}$ Dos casos emblemáticos y muy reseñados en la prensa nacional conocidos como: "el violador de la Vall d' Hebron" que tras cumplir 16 años de condena (la Audiencia Provincial de Barcelona le había condenado a 311 años), salió de la cárcel en el 2007; "el violador del ensanche", con un amplio prontuario delictivo en materia de agresión sexual a menores (cinco agresiones sexuales, y cuatro intentos de agresión sexual frustrados) también salió de la cárcel en el 2007 después de cumplir 16 años de condena. Estos dos casos dispararon las alarmas mediáticas sobre los riesgos de dejar en libertad a delincuentes sexuales y se plantearon debates que demandaban medidas de inocuización del delincuente tales como cadena perpetua, el registro de pederasta, castración química entre otras. Véase, MATELLANES RRODRÍGUEZ, N., "Penas, Rehabilitación y Delincuentes sexuales" en SANZ MULAS, N., Dos décadas de reformas penales, Ed. Comares, Granada, 2008, pág. 81.
} 
legislación y de justicia, como intentamos demostrar en las tesis desarrolladas en este aparte.

En este acápite realizamos un breve análisis de los temas debatidos alrededor de la pornografía infantil a partir de la referencia de las informaciones recogidas en los medios de comunicación. Hacemos especial énfasis en el manejo que se hace de contenidos concretos que alimentan la alarma social como son el perfil de los agresores sexuales de menores, el manejo de las reiteradas informaciones sobre los operativos realizados por los Cuerpos policiales para la investigación y detención de dichos agresores, y la solicitud persistente -desde la identificación que se hace del receptor con la víctima- del endurecimiento de penas y medidas. Vale aclarar que con ello se pretende construir el marco sobre el cual descansa una de las premisas de orden criminológicas que aborda este trabajo, a saber, la influencia de los medios de comunicación en la configuración de la alarma social alrededor de la pornografía infantil, lo que genera sesgos en una opinión pública que demanda mayor seguridad con penas cada vez más duras. ${ }^{144}$

\subsection{IMPRONTA MEDIÁTICA Y ESTADO DE ALARMA SOCIAL.}

Las demandas sociales de seguridad han legitimado el endurecimiento del Derecho penal consolidándose la ideología de la seguridad ciudadana frente al modelo garantista democrático $^{145}$. Existe una interrelación en forma de espiral entre la ciudadanía y el poder político: mientras que desde la ciudadanía se tiene cada vez mayor aceptación social frente a las medidas de seguridad propuestas por el poder político,

\footnotetext{
${ }^{144}$ En este aparte la fuente utilizada para revisión son justamente las noticias diarias de la prensa. considerando la importante influencia que los medios tienen en el público en la conformación de la alarma social. Las noticias reseñadas en este trabajo forman parte de un registro propio del seguimiento a las informaciones relacionadas a la pornografía infantil aparecidas en el Diario El País durante los años 2006, 2007, 2008, 2009 y 2010.

${ }^{145}$ La producción científica penal de los últimos tiempos la ideología de la seguridad ciudadana y el populismo punitivo aparece como uno de los temas más discutidos. A modo de referencia Véase. DIEZ RIPOLLES, J., "El nuevo modelo penal de la seguridad ciudadana", Jueces para la democracia, $\mathrm{N}^{\circ} 49$, 2004, pág. 25 y ss; MUÑOZ CONDE, F., El nuevo derecho penal autoritario, en Estudios penales recuerdo del Profesor Ruiz Antón, Valencia, 2004, pág 803 y ss; CANCIO MELIA, M., Derecho penal del enemigo y delitos de terrorismo. Algunas consideraciones sobre la regulación de las infracciones en materia de terrorismo en el Código Penal español después de la LO 7/2000, Jueces para la democracia, $\mathrm{N}^{\circ}$ 44, 2002, pág 21; ACALE SÁNCHEZ, M., "Código Penal de la democracia al Código de la seguridad", en Serta in memoriam Alexandro Baratta, Universidad de Salamanca, 2003; SÁEZ VALCÁRCEL, R., La inseguridad, lema de campaña electoral. Jueces para la democracia”, No 45, 2002.
} 
éste, a su vez, transmite el mensaje de que está dando respuestas a las exigencia y preocupaciones de la sociedad. ${ }^{146}$

¿Hasta dónde puede llegar el temor creado por la alarma social? ¿Expresan y representan los mass media los intereses de la ciudadanía? ¿Son los medios de comunicación un interlocutor válido entre la ciudadanía y el poder político? ¿Pueden estos actuar de hecho en la intermediación y entre unos y otros asumiéndose dueños de la última palabra? ¿Cuáles son los efectos de las propuestas que en el marco de la opinión pública, escenario por excelencia del debate en las sociedades modernas, se formulan como respuestas a situaciones de alarma social? ¿Hasta dónde las instituciones del Estado pueden saciar el deseo de castigo y vigilantismo sociales, ante eventos de escándalo público asociados con una moral sexual que se pretende universal sin violar los derechos fundamentales y garantías constitucionales? ¿Se pierden el ejercicio de la ciudadanía y los derechos inherentes a la condición humana, cuando se contraviene la ley y el delincuente pasa a ser un elemento de peligrosidad social para el que hay que adelantar las barreras del Derecho penal?

Uno de los signos característicos de la sociedad de nuestros días es su impronta esencialmente mediática, de allí que sean los medios y no las instituciones públicas quienes la dotan de estructura interna ${ }^{147}$. Esto es una realidad casi planetaria. La globalización es al mismo tiempo una mundialización cultural mediática escultora de imaginarios colectivos de pertenencia a una cultura global en la que nos reconocemos e identificamos. La representación mediática se convierte en un nuevo proyecto de vertebración social $^{148}$. A través de los medios se hacen y reconstruyen nuevas formas de relación social. Éste es el caso de la vinculación que ocurre entre el binomio que han conformado los medios de comunicación y la inseguridad personal. Ésta relación viene caracterizada a lo largo de estos últimos años por el manejo y la manipulación que los medios hacen de la violencia delictiva. Los episodios de ésta violencia, especialmente si

\footnotetext{
${ }^{146}$ GARCÍA ARÁN, M., "Delincuencia, inseguridad y pena en el discurso mediático, en Problemas actuales del Derecho Penal y de la Criminología". Estudios penales en memoria de la Profesora María del Mar Díaz Pita, MUÑOZ CONDE (Dir), Tirant lo Blanch, Valencia 2008, págs. 85- 113.

${ }^{147}$ CASTELLS, M., La era de la información, Ed. Siglo XXI, Barcelona, España, 2000.

${ }^{148}$ BISBAL, M., "Medios, ciudadanía y esfera pública en la Venezuela de hoy", Revista SIC Ed. Centro Gumilla, Caracas, $\mathbf{N}^{\circ}$ 622, 2004. págs. 52-54
} 
estos son transmitidos en tiempo real, pasan de ser un tema de fuerte impacto social a producto de alto consumo, mediado por un discurso construido desde la lógica ideológica y comercial que mueve la comunicación de masas. ${ }^{149}$

Los estudios actuales cuestionan el punto de vista tradicional de los medios de comunicación que los considera como meros trasmisores de mensajes y que, consecuentemente, conciben las noticias como un espejo de la realidad. Los medios no se limitan a describir pasivamente ni a registrar los sucesos noticiables del mundo, sino que los (re)construyen activamente, amparándose fundamentalmente en muchos tipos de discursos de fuente ${ }^{150}$. Establecen cuáles temas son importantes en el propósito de cautivar el interés del público y cuáles temas han de ignorarse. De esta manera, por exceso o por defecto, la realidad se desvirtúa, se deforma, hasta perder su esencia y convertirse en otra realidad construida y mediatizada por los flujos informativos. Solo parece real lo que se legitima mediáticamente; el resto de la realidad no lo es. ${ }^{151}$

Tal vez el problema debe plantearse, como lo establece David GARLAND ${ }^{152}$, en las coordenadas de una "cultura del control" a partir de la cual el Estado crea la necesidad a través de la alarma para expandir las medidas de control y dominación, atendiendo a demandas sociales asumidas como legítimas. Esta dimensión criminológica de la realidad social de nuestros días que pone de manifiesto la lógica del Estado para expandir sus mecanismos de control social, será tratada más adelante. Nos interesa describir elementos empíricos de cómo ocurre el tratamiento en la comunidad política y en los medios de comunicación del tema que pretendemos analizar en su perspectiva criminológica y jurídica, la pornografía infantil en Internet.

Diariamente los titulares de los medios de comunicación dan cuenta de las operaciones que realiza la Policía para desarticular redes y grupos de distribuidores y consumidores de pornografía infantil en España y el mundo mediante la cooperación

\footnotetext{
${ }^{149}$ PARRA GONZÁLEZ, A.V.; DOMÍNGUEZ, M., "Los Medios de comunicación desde la perspectiva del delincuente”, en revista OPCIÓN, Maracaibo, 2004, año 20, № 44, pág. 36.

${ }^{150}$ Ibídem, pág. 30.

${ }^{151}$ Ibídem, pág. 32.

${ }^{152}$ GARLAND, D., La cultura del control. Crimen y orden en la sociedad contemporánea. Ed. Gedisa, Barcelona. 2005.
} 
entre los organismos de seguridad. Un ejemplo de la presencia diaria de estas informaciones y el tratamiento alarmista desde la opinión pública, es la gran agitación que provocó una convocatoria a celebrar el "día del orgullo pedófilo", a la que convocaba una página por Internet. En seguida diversas instituciones y ONGs se movilizaron en contra del llamado International Love Boy Day ${ }^{153}$, literalmente en castellano, día internacional del amor al niño. Después de la alarma causada en la opinión pública, un informe elaborado por la Guardia Civil para la Fiscalía señalaba que la pedofilia no es delito, a diferencia de la pederastia; por otra parte, que la página en cuestión había convocado para un día del año 2006, o lo que es igual, la alarma era cuando menos extemporánea. Pero la convocatoria actúa sobre un estado de expectación y sensibilidad social que prende enseguida en alarma aunque, como se dio cuenta posteriormente, se trataba cuando menos de un evento infundado.

Una sola intervención u operación policial puede generar noticias varios días seguidos. La investigación llevada a cabo por SOTO NAVARRO, evidencia las pautas sobre las cuales ocurre el tratamiento de las noticias relativas a la delincuencia en los medios impresos: más del $70 \%$ de las mismas en las páginas de sección reservadas para información que alude al genérico de España. Es muy significativo que el segundo lugar donde se localizan sea la primera página, lo que indica el propósito de conducir la atención del lector a estas noticias. Y un dato curioso: en las páginas de la sección Sociedad encontramos noticias de sucesos que en buena parte están relacionados con delitos contra la libertad sexual, sobre todo si la víctima es un menor. Sin embargo, no resulta fácil una explicación, pues, quizá estos sucesos despiertan en la opinión pública una sensibilidad distinta, no tan próxima a la alarma social como a la protección del mundo de la infancia. ${ }^{154}$

La preocupación por el delito repercute de modo directo en las actitudes punitivas, de modo que, a mayor preocupación, mayores exigencias de amplitud e intensidad de la intervención penal. Las variables demográficas que parecen influir más

\footnotetext{
${ }^{153}$ Véase "Movilización contra el 'Día del orgullo pedófilo"” (23 de junio de 2008); "La Guardia Civil no encuentra delito en la web que convocó el "día del orgullo pedófilo"” (25 junio de 2008); "La convocatoria para el "día del orgullo pedófilo" era para 2006 (25 de junio de 2008); "La Fiscalía pide la investigación del día del orgullo pedófilo" (26 de junio de 2008). Fuente: Diario El País.

${ }^{154}$ SOTO NAVARRO, S., "La influencia de los medios en la percepción social de la delincuencia", en Revista Electrónica de Ciencia Penal y Criminología, № 07-09, 2005, pág. 10.
} 
en las actitudes punitivas son la edad, la formación y especialmente la tendencia política. ${ }^{155}$

El miedo al delito, fundado o no, puede tener graves consecuencias hasta el punto de que se ha llegado a considerar un problema tanto o más grave que la propia delincuencia. A nivel individual, provoca cambios de conducta en el intento de no sufrir un delito que afecta al estilo y calidad de vida del ciudadano. A nivel colectivo, las repercusiones pueden ser muy destructivas para la vida comunitaria en tanto que se reduce la interacción social, se abandonan los espacios públicos o se rompe el control social informal. ${ }^{156}$

Es notorio cómo a partir de casos específicos y particulares han aumentado las informaciones en los diarios españoles respecto del fenómeno de la pederastia ${ }^{157}$. El caso "Mariluz" ha sido tomado como el expediente público y mediático para la cruzada contra los pederastas durante todo el año $2008^{158}$. Este caso, que mantuvo conmovida a la opinión pública del país desde enero de ese año, se refiere a una niña -Mariluz- de 5 años que el 13 de enero de 2008 desapareció, siendo encontrado su cuerpo el día 7 de marzo de ese mismo año en las rías de Huelva. Fue asesinada, presuntamente, por Santiago Del Valle, pederasta reincidente, quién estaba en libertad a pesar de que sobre él recaía una condena desde noviembre de 2002 por el Juzgado de lo Penal número 1 de Sevilla, a dos años y nueve meses de prisión por un delito continuado de abusos sexuales a su hija menor. Una sentencia de la Audiencia de Sevilla confirmó en diciembre de 2005 ésta sentencia, aunque la ejecutoria de la misma estuvo paralizada durante más de dos años y dos meses. Además cuenta con otra condena de dos años de

\footnotetext{
${ }^{155}$ Ibídem, pág. 4.

${ }^{156}$ Ibídem, pág. 5.

${ }^{157}$ Aquí seguimos su tratamiento a partir del Diario El País por ser el de mayor circulación nacional. Pero, obviamente, su cobertura es general y abarca medios impresos, radiofónicos, televisivos y digitales. En ocasiones haremos referencias a otros diarios como La Vanguardia y El Mundo para destacar el manejo de la misma información en diferentes diarios.

158 También ha servido este caso para llevar a la palestra la discusión sobre la eficacia de la administración de Justicia. El supuesto asesino debía estar en prisión por condenas anteriores no ejecutadas. La responsabilidad del Juez Tirado se estableció en falta leve y 3000 euros de multas y la sanción de la secretaria judicial en falta grave y 2 años de suspensión de su sueldo y actividad laboral, la diferencia en las sanciones ha generado disputas gremiales conllevando a paralizaciones y protestas por parte de los secretarios judiciales alegando desproporción en las sanciones. Al juez Tirado le sancionó su gremio; a la secretaría el Ministerio de Justicia.
} 
cárcel que dictó el Juzgado penal 4 de Sevilla, en diciembre de 2004, por agredir sexualmente a otra menor. ${ }^{159}$ Desde que la niña desapareció, la familia Cortés se movilizó activamente siendo atendida por el Consejo General del Poder Judicial, por el presidente del Gobierno, José Luis Rodríguez Zapatero, por el líder de la oposición, y organizado una campaña de recolección de firmas en apoyo a una iniciativa popular de legislación para demandar el endurecimiento de las penas para los pederastas, la publicación de una lista con sus identidades y la imposición de la cadena perpetua en ciertos casos de delitos sexuales. ${ }^{160}$

Según SOTO NAVARRO, los delitos que tienen una mayor cobertura informativa son los homicidio/asesinato, lesiones, delitos contra la libertad sexual, robo y desórdenes públicos. Los delitos contra la libertad sexual noticiables son principalmente los que implican violencia, la pornografía infantil y los abusos sexuales de menores. ${ }^{161}$ Además de los típicos criterios de selección de los hechos noticiosos (novedad, actualidad, cercanía, conflicto), en el periodismo sensacionalista se explotan las categorías "interés humano" -eufemismo con el que se denomina a las escenas de dramatismo y dolor que promueven la comunicación en directo de los receptores- e "impacto", estas últimas las que aluden el estímulo de fuertes reacciones emocionales.

El periodismo sensacionalista se distingue por la presentación de relatos sobre personas, conductas o sucesos que suponen transgresiones de la ley, de la moral aceptada y de las normas sociales que se presumen conforman las virtudes públicas. Este tipo de prensa se nutre de asuntos próximos a la colectividad, utiliza una serie de recursos lingüísticos y discursivos que contribuyen a falsear los hechos e hiperbolizar la realidad, y busca convertir al lector o receptor en un testigo imaginario de los sucesos narrados. ${ }^{162}$ Para SOTO NAVARRO, los medios publican los datos oficiales -

\footnotetext{
${ }^{159}$ Véase "La Audiencia de Sevilla tardó 31 meses en redactar la sentencia de Del Valle" (02/04/08); "El Consejo se inclina por imponer una multa leve al juez del "caso Mariluz" (24/06/2008). Diario el País, www.elpais.com

${ }^{160}$ Véase "Miles de personas se manifiestan por la niña de Huelva" (17/01/2008). "El padre de Mariluz proseguirá su campaña en Arrigorriaga" (03/0772008). "La familia de Mariluz se siente "estafada, utilizada e indignada" (25/06/2008). "Miles de personas se manifiestan por la niña de Huelva" (17/01/2008). "La manifestación más triste” (22/0672008), Diario El país, www.elpais.com

${ }^{161}$ SOTO NAVARRO, S., La influencia..., op. cit. pág. 12.

${ }^{162}$ PARRA GONZÁLEZ, A. V.; DOMÍNGUEZ, M., Los Medios de comunicación... op. cit., pág. 33.
} 
facilitados por el gobierno- sobre la delincuencia en España con un inevitable sesgo para convertirla en material noticiable, reconstruyendo una distorsión mediática de la realidad delictiva ${ }^{163}$.

Al hilo del caso emblemático "Mariluz", ampliamente reseñado y expuesto en todos los medios de comunicación, se ha abierto un debate sobre la eficiencia del sistema de justicia en España, ${ }^{164}$ desplegándose respuestas de todo orden asociadas con exigencias sociales de medidas que debe tomar el gobierno, creando un espacio de discusión de opiniones académicas y de especialistas sobre los menores como víctimas y las características y el perfil de sus agresores, especialmente el pederasta.

El tema de la pornografía infantil también ha estado presente cotidianamente en los medios a través de las declaraciones de los Cuerpos policiales informando de las operaciones realizadas para desarticular redes de tráfico y difusión de material. La batería de medidas punitivas que constantemente se propusieron y debatieron en los medios, cada cual más dura, era indicativa de la orientación que posteriormente sería asumida, con ocasión del momento definitivo en el que se pactaron los acuerdos que dieron lugar a la reforma penal. Describimos algunas de ellas, de acuerdo con las reseñas de medios, solo a los fines de configurar la perspectiva o dimensión fenomenológica que nos interesa de la pornografía infantil. Más adelante tendremos la oportunidad de revisarlos en su conformación normativa en la LO 5/2010 de 22 de junio. Lo que nos interesa en este momento es dar cuenta de ellas como parte de la atmósfera social construida y desde la cual se alimentó la reforma definitiva.

\footnotetext{
${ }^{163}$ Véase SOTO NAVARRO, S., La influencia..., op. cit., pág. 42.

164 Véase "El CGPJ reformará sus sistema de inspección tras el “caso Mariluz”" (01/04/2008).” El presidente del Tribunal andaluz pide una reforma judicial tras el "caso Mariluz" (17/04/2008). "El Poder Judicial debe dar explicaciones sobre el caso Mariluz" (31/03/2008). "Justicia expedienta a la secretaria judicial del "caso Mariluz" por incumplir sus funciones" (16/04/2008). "El informe sobre el caso Mariluz justifica el error judicial por la saturación del juzgado” (04/09/2008). "Bermejo asegura que "el caso Mariluz no volverá a producirse" (21/05/2008). "El padre de Mariluz exige la expulsión del juez Tirado por ser "responsable” del caso" (08/07/2008). "El CGPJ multa con 1500 euros al juez. Tirado" (10/09/2008). "El padre de Mariluz exige la expulsión del juez Tirado y convoca una manifestación" (26/06/2008). "Cortes: debe ser retirado de la carrera judicial" (03/09/2008). "El consejo se inclina por poner una multa leve al juez del caso "Mariluz" ((01/07/2008). "El fiscal urge al poder judicial para que sancione a Tirado” (06/08/2008), Diario El País, www.elpais.com
} 


\subsection{ALARMA SOCIAL Y NEUTRALIZACIÓN DEL DELINCUENTE.}

Entre las medidas que se reclamaron desde la opinión pública y que fueron contempladas en documentos de trabajo en procura de formular el proyecto de ley que se llevó a consideración de las Cortes, se encontraban un conjunto de medidas que sancionaban duramente a los agresores sexuales de menores de edad. Entre ellos: la creación de un registro público de pederastas, la vigilancia mediante dispositivos GPS $^{165}$, la aplicación de inhibidores hormonales o -también llamada- castración química, la libertad vigilada mediante condiciones especiales para evitar reincidencia y el cumplimiento efectivo de las condenas.

A pesar que buena parte de los actores beligerantes en el debate mediático abiertamente rechazaron siempre la cadena perpetua, casi todos se mostraban de acuerdo con el endurecimiento de las sanciones y penas. La Ley Orgánica 5/2010 de 22 de junio por la que se modifica el Código Penal, recoge en ella toda la exigencia que se blandió desde ciertos sectores para endurecer las penas a los pederastas, establece la imposición de medidas a los pederastas tras haber cumplido su condena ${ }^{166}$, en procura de que los condenados no recuperen su "libertad total" de movimientos mientras no haya "confirmación y garantía total" de su rehabilitación (cursivas añadidas). Esta iniciativa permitiría a los jueces aprobar medidas de control como el seguimiento electrónico, la obligación de asistir a tratamientos médicos externos o de someterse a un control médico posterior, o prohibir su aproximación a centros donde haya menores mientras no existiera la confirmación de que el condenado estuviera totalmente rehabilitado.

Antes de pasar a dar cuenta de estas medidas de forma específica, es conveniente hacer mención de los factores o elementos que alimentan la tendencia político criminal que está detrás de todas ellas. Ésta tendencia viene revestida de una función ideológica

\footnotetext{
165 GPS, Siglas en inglés Global Position System, es un Sistema Global de Navegación por Satélite (GNSS) que permite determinar en todo el mundo la posición de un objeto, una persona, un vehículo o una nave, con una precisión de escaso margen de error.

${ }^{166}$ Véase "Justicia quiere imponer medidas de control a los pederastas tras cumplir condena. El País, 04 de agosto de 2008. La reforma, de acuerdo con el ministro de justicia Mariano Fernández Bermejo, prevé el cumplimiento efectivo de las condenas. Bermejo apuesta por un endurecimiento de las condenas contra pederastas.” El País, 04 de septiembre de 2008, www.elpais.com
} 
que atiza el ideal neoliberal de la seguridad en lugar del discurso resocializador propio del Estado de Bienestar. Al mismo tiempo instaura unas concepciones de riesgo y seguridad de la población solo posible de realizar mediante la neutralización del delincuente.

\subsubsection{LA TESIS DE LA INOCUIZACIÓN.}

Para empezar por este último, bien podemos afirmar que las medidas anteriores muestran un retorno de la inocuización del delincuente, propio del Positivismo Criminológico. Dicha tendencia está en sintonía con la ideología general de la Política Criminal de los años noventa, expresada mediante un modelo legislativo que renuncia a la orientación anterior de tipo terapéutico y con fines de resocialización del delincuente. Contrario a esto, le da acogida y brinda cauces a la línea que aquí denunciamos punitiva y neutralizadora del delincuente ${ }^{167}$.

En efecto, bien puede afirmarse de acuerdo con SILVA SÁNCHEZ -cuya orientación impregna este aparte- que el fracaso de la función resocializadora ${ }^{168}$ aunada al miedo ante el riesgo y las exigencias de seguridad por parte de un amplio sector de la sociedad conforman la base ideológica de la inocuización o neutralización del delincuente $^{169}$. En relación con el abandono del ideal resocializador, MATELLANES RODRÍGUEZ plantea que la realidad empuja "hacia el retorno de la mera inocuización, o aseguramiento del delincuente sexual, sobre el que se desea un ingreso prolongado, lo más prolongado posible en la prisión. En este ámbito un terreno perdido por el pensamiento resocializador que ha ido siendo conquistado por los defensores de la inocuización: si "nada da resultado", si el tratamiento resocializador no garantiza la no reincidencia, entonces (este parece ser el razonamiento imperante) todos los condenados son incorregibles: limitémonos entonces a inocuizar al delincuente, a separarlo de la sociedad pues al menos el tiempo en el que esté en prisión no podrá delinquir.

\footnotetext{
${ }^{167}$ SILVA SÁNCHEZ, J. M., "El retorno de la inocuización. El caso de las reacciones jurídico-penales frente a los delincuentes sexuales violentos". En ARROYO ZAPATERO, L.; BERDUGO GÓMEZ DE LA TORRE, I., (Dirs.), Homenaje al Dr. Mariano Barbero Santos in memoriam, Ed. Universidad de Castilla -La Mancha, Ed., Universidad de Salamanca, Cuenca 2001. pág. 703.

${ }^{168}$ El desencanto de la resocialización del delincuente no solo es ideológico. Tiene mucho que ver también con la voluntad política de reducir gastos e inversiones en tratamientos penitenciarios por parte del Estado. Política jalonada por el ideal neoliberal de recortes del gasto social y los arreglos presupuestarios para el déficit cero como principio de la política fiscal.
}

${ }^{169}$ SILVA SÁNCHEZ, J. M., El retorno de la inocuización.., op. cit., pág. 701. 
Destinemos los medios económicos, no a mejorar los programas de tratamiento, sino a construir más y mayores prisiones. Y llenémosla" ${ }^{\text {170 }}$

La estructura del nuevo modelo penal de consecuencias jurídicas para delincuentes sexuales violentos, implica la ejecución de medidas con duración indeterminadas posterior y adicional a la pena ${ }^{171}$. No es que haya una sustitución de la pena por la imposición de una medida de seguridad. Es que, adicional a la pena, hay medidas de aseguramiento social contra la reincidencia del delincuente, que vienen azuzadas por los criterios de peligrosidad social que significaría su libertad incondicional cumplida la pena. De manera que se trata de una medida posterior y adicional a la pena. Suerte de sub/sistema penal dual para los delincuentes sexuales: penas más medidas de vigilancia, tratamiento y control una vez agotadas las primeras. La reforma penal en España ha seguido, incluso calcado, el guión que han seguido las reformas penales en los últimos años en los países de tradición anglosajona. Desde que la doctrina española advirtió el giro dado en aquellos países, el recorrido o itinerario transcurrido en la legislación nacional no se ha apartado en lo fundamental del libreto.

En los Estados Unidos, esta tendencia ha quedado de manifiesto en lo legislativo con las llamadas leyes de "three strikes" y en lo doctrinal con la difusión de las teorías de la inocuización selectiva (selective incapacitation) ${ }^{172}$. Las principales medidas

\footnotetext{
${ }^{170}$ MATELLANES RODRÍGUEZ, N., Penas, Rehabilitación y... op. cit., págs. 106 y ss.

${ }^{171}$ Se inicia en 1990 en el Estado de Washington con la "Sexually Violent Predators Act"

172 "En las últimas décadas ha cobrado mucho auge la inocuización de determinados grupos de delincuentes a través de dos fenómenos: (1) el legislativo, con la proliferación de las leyes de "Three Strikes" en Estados Unidos que incorpora el principio de "three strikes and you're out" [recoge una máxima del lenguaje del beisbol, primer deporte norteamericano, que literalmente traduce: luego de tres oportunidades en la oportunidad de bateo desaprovechadas estás fuera (out) de juego (observación nuestra)] y (2) el doctrinal, esto es, la difusión de las teorías de la inocuización selectiva (selective incapacitation). La premisa mayor de la teoría de la inocuización selectiva es que resulta posible individualizar a un número relativamente pequeño de delincuentes (high risk offenders), respecto de los cuales cabe determinar que han sido responsables de la mayor parte de hechos delictivos y predecir que lo seguirán siendo. De modo que la inocuización de los mismos -esto es, su retención en prisión el máximo tiempo posible- conseguiría una radical reducción del número de hechos delictivos y, con ello, importantes beneficios al menor coste. Expresado en términos contables: recluir 2 años a cinco delincuentes cuya tasa predecible de delincuencia es de 4 delitos por año, "ahorra" a la sociedad 40 delitos y le cuesta 10 años de prisión. En cambio, si esos mismos diez años de prisión se emplean en recluir 5 años a dos delincuentes cuya tasa predecible de delincuencia es de 20 delitos por año, el "ahorro social" es de 200 delitos; y así sucesivamente. Con ello, la "selective incapacitation" muestra significativas ventajas económicas frente a la indiscriminada, o ciega, "general incapacitation". Evidentemente, la teoría de la inocuización selectiva plantea -como, en general, las tesis inocuizadorasproblemas de fundamentación empírica, por un lado, y de legitimación axiológica (proporcionalidad), por el otro.”. SILVA SÁNCHEZ, J. M., El retorno de la inocuización..., op. cit., nota de pie pág. 700 y 703.
} 
utilizadas para la neutralización del delincuente y que explican claramente el sistema dualista son: i) las medidas de supervisión y control posteriores al cumplimiento de la pena; ii) la aplicación durante el período de ejecución de la pena privativa de libertad de tratamientos hormonales; y, iii) los deberes de registro de ex/delincuentes sexuales. Algunas de las medidas que se enmarcan dentro de estas tres líneas pueden ser vitalicias en ciertos Estados norteamericanos. Aunque en principio son opcionales, estas medidas $\mathrm{y}$ tratamientos pueden llegar a ser obligatorios en caso de reincidencia ${ }^{173}$.

Apunta SILVA SÁNCHEZ que puede establecerse una diferencia entre la orientación contemporánea a la inocuización de la que tuvo lugar en Estados Unidos a comienzos de este siglo. En primer lugar, la diferencia del grupo de sujetos sobre los que se proyecta la pretensión inocuizadora. En su día éstos habían sido básicamente delincuentes habituales contra la propiedad; ahora, en cambio, se trata de delincuentes sexuales violentos. Adicionalmente, en segundo lugar, el método de abordaje de la cuestión de la peligrosidad también ha cambiado. La base ideológica del recurso a tales métodos a principios de siglo se justificaba desde perspectivas del Estado Social; mientras que ahora se trata de un enfoque neoliberal ${ }^{174}$.

En tercer lugar, el método para predecir la peligrosidad y determinar el grupo de delincuentes que han de ser inocuizados también ha cambiado. Los métodos predictivos basados en el análisis psicológico individual de responsabilidad o peligrosidad han sido sustituidos por otros de naturaleza actuarial. El delito pasa a ser abordado con las mismas técnicas probabilísticas y cuantitativas que, en el ámbito de los seguros, se utilizan para la gestión de riesgos: identificar los grupos potenciales de siniestros, sus probabilidades de ocurrencia y reparto del coste de aseguramiento sobre la población. Se recurre, pues, al método estadístico para construir programas sobre la base de algunas variables e indicadores. Ajustados a ciertos parámetros y condiciones de acuerdo con la información disponible para una población, sector o grupo social, se construyen y determinan indicadores cuya cuantificación es el punto de partida para emitir pronósticos de peligrosidad sobre grupos o clases de sujetos. Ya no hay estudios sobre la personalidad del individuo, ni sobre las condiciones materiales de vida de

\footnotetext{
${ }^{173}$ Véase SILVA SÁNCHEZ, J. M., El retorno de la inocuización..., op. cit. pág. 704.

${ }^{174}$ Ibídem, pág. 700.
} 
donde emergen los delincuentes. Tampoco, menos aún, cuestionamientos sobre la corresponsabilidad de las instituciones sociales respecto del acto desviado que lesiona un bien jurídico. Lo que hay son probabilidades de ocurrencia de delitos, apelación a métodos preventivos para reducir ésta ocurrencia, y focalización de los grupos de peligrosidad sobre quienes recaen un conjunto de medidas que deben mitigar cuando no eliminar su potencial peligroso o delictivo contra la sociedad. Sobre esta noción, en la que se basa la llamada en los Estados Unidos, "New Penology", existe ya una muy extensa bibliografía ${ }^{175}$.

El conjunto de medidas resulta enormemente revelador de los extremos a los que puede llegar la supuesta lógica de la "seguridad colectiva", a la hora de restringir derechos individuales y estigmatizar al sujeto. ${ }^{176}$ En efecto, la cuestión vista desde la perspectiva de los derechos individuales es si el delincuente que ha cumplido su condena no tiene el derecho a la privacidad sobre los hechos que dieron lugar a la misma. Expresado de otro modo, cabe poner en cuestionamiento si acaso al Estado le asiste el derecho de establecerlos; suponiendo que lo tiene, si podría declarar ilimitado el período de vigencia de los antecedentes penales y, por último, si puede hacerlos de dominio público.

Europa no escapa de la gran influencia que tiene Norteamérica en todo el mundo. Como referencia puede mencionarse la legislación vigente en Alemania desde 1998 en materia de reacciones a los delincuentes sexuales. Su leit motiv es, como en el caso norteamericano, la maximización de la idea de seguridad; aunque, a diferencia de lo que sucede en aquel país, por lo pronto no se abandona la dimensión resocializadora del tratamiento. ${ }^{177}$

En relación a las reacciones pre/delictuales SILVA SÁNCHEZ, considera que: “...la absolutización de la seguridad como objeto político-criminal conduce a la reconstrucción de un derecho de la peligrosidad"178. (cursivas añadidas) Expresado de

\footnotetext{
${ }^{175}$ Ibídem, pág. 701.

${ }^{176}$ Ibídem, pág. 705.

${ }^{177}$ Ibídem, pág. 706.

${ }^{178}$ SILVA SÁNCHEZ, J.M., "El retorno de la inocuización. El caso de las reacciones jurídico-penales frente a los delincuentes sexuales violentos". En ARROYO ZAPATERO, L.; BERDUGO GOMÉZ DE
} 
otro modo: se vuelve a replantear el recurso a medios de aseguramiento cognitivo, junto a la pena como mecanismo de aseguramiento contrafáctico de la vigencia de la norma ante grupos que resumen el ideal de peligrosidad social. Así, nos vamos adentrando en este proceso de adelantamiento de los linderos del Derecho penal en un estado del debate en el que la cuestión girará en torno a si debe o no esperarse a la producción de un hecho lesivo para proceder a arbitrar una reacción, cuando resulta que existen las bases para formular un juicio de peligrosidad.

¿Puede el principio de peligrosidad legitimar realmente una intervención restrictiva de derechos sobre el sujeto activo? Si así fuere, ¿hasta qué punto puede hacerlo? Para SILVA SÁNCHEZ, lo importante sobre el nuevo Derecho de la peligrosidad es advertir y valorar el hecho de que el mismo se concibe como Derecho de estricta seguridad frente al futuro (puramente preventivo) y no de respuestas frente al pasado. En cambio, menos relevancia asigna a la cuestión relativa a la etiqueta de las reacciones cognitivas que se establezcan: civiles, penales o administrativas. Esta cuestión de la etiqueta de reacción, sin embargo, ha enzarzado a la doctrina española en los últimos años, y acabó influyendo sobre el código de $1995^{179}$. En el caso de los inimputables, el principio de peligrosidad evidentemente sí legitima la restricción de derechos.

\subsubsection{La tesis de la seguridad ante el riesgo.}

Pareciera que se ha legitimado la idea de que la sociedad ya no comparte la tesis de que la "culpabilidad por el hecho", ha de definir la frontera absoluta de distribución de riesgos entre individuo y sociedad. En el Estado Social prevalecía la idea de que, cumplida la condena ajustada a la culpabilidad, la sociedad asumía los riesgos de un delito futuro cometido por el sujeto imputable. Es decir, se daba por cumplido el contrato social con el penado quedando para este el futuro abierto a su realización sin estigmatización que cercenara sus posibilidades. Por el contrario, en el nuevo Derecho penal parece que se admite la idea de que la constatación de una seria peligrosidad subsistente tras el cumplimiento de la condena debería dar lugar a medidas de

LA TORRE, I., (Dir.), Homenaje al Dr. Mariano Barbero Santos in memoriam, Ed. de la universidad de Castilla -La Mancha, Ed. Universidad de Salamanca, Cuenca 2001. pág. 708.

${ }^{179}$ Idem. 
protección social o alguna fórmula de aseguramiento cognitivo adicional ${ }^{180}$. De manera que se penaliza de cara a la peligrosidad y no sobre los actos o hechos cumplidos. Se atiende al potencial de delincuencia latente en un individuo y no a las lesiones de bienes jurídicos efectivamente ocurridos. Se adecúa el Derecho penal a las exigencias sociales de seguridad de cara al futuro y no al itinerario real pasado y presente del delincuente.

Frente a este hecho es conveniente señalar que las reformas penales no deben ser presididas por criterios de "oportunismo", producida, como en el caso alemán o el norteamericano, bajo el impacto emocional de un caso (o una serie de casos) de consecuencias ciertamente dramáticas ${ }^{181}$. No obstante, es el mismo guión que orienta los cambios en la legislación penal en España en la que se activan los resortes institucionales ante el escándalo o la alarma mediática.

En España, algunas de las medidas exigidas mencionadas y que ya forman parte del marco normativo no requerían ningún cambio legal para ser implementadas. Bastaría con que los órganos jurisdiccionales aprovecharan la libertad condicional para "condicionar" de verdad y exigir el cumplimiento de una serie de reglas de conducta, controlada por el personal adecuado para ello. Hubiere sido suficiente el aprovechamiento de la habilitación legal del Art. 90.2 del CP (“podrán”) para imponer, al decretar la libertad condicional, una o varias de las reglas del Art. 105 del $\mathrm{CP}^{182}$. Otras medidas, en cambio, si requerían efectivamente de una reforma penal como las de control de la vida en libertad tras el licenciamiento definitivo del penado, o las pretendidas medidas de seguridad para sujetos calificados de habituales o peligrosos, desde luego no sujetas a un principio absoluto de proporcionalidad con el hecho cometido, que las anula antes de empezar, tampoco absolutamente indeterminadas, ni, menos aún, condicionadas a la -discutible- reversión del pronóstico de peligrosidad.

Por el contrario, habría de tratarse de medidas regidas por un criterio de proporcionalidad que determine el momento en que el riesgo de reincidencia pasa a ser asumido por el conjunto de la sociedad, como parece razonable que tenga lugar en el

\footnotetext{
${ }^{180}$ Véase, SILVA SÁNCHEZ, J. M., El retorno de la inocuización..., op. cit., Pág. 709.

${ }^{181}$ Idem.

${ }^{182}$ Idem.
} 
marco de un Estado Social de Derecho que disponga una distribución equilibrada de cargas entre individuo y sociedad. ${ }^{183}$

El criterio rector de cualquier reforma debería apuntar hacia la búsqueda de criterios valorativos de distribución razonable entre el individuo y la sociedad de la carga de la inseguridad. Una reforma penal anidada en la concepción que subyace en esta tesis, descartaría cualquier concepción radical de la inoculación, así como una distribución desequilibrada de cargas en perjuicio del penado. Pues, como señalan con razón Schall/ Schreibauer, si la sociedad quiere mantenerse dentro de un Derecho penal respetuoso con la individualidad y los derechos fundamentales de la persona debe también estar dispuesta a asumir parte de los riesgos para la seguridad de la colectividad. Incluso, respetuoso con el delincuente a quien le asigna el derecho, el espacio social, el marco normativo y los recursos administrativos y de todo orden para la resocialización y reinserción social ${ }^{184}$. No obstante, el despliegue de medidas que justificaron la reforma correspondiente fue adquiriendo legitimidad siendo ampliamente divulgadas en los medios de comunicación.

\subsubsection{Medidas de neutralización del delincuente.}

Así, por ejemplo, antes de que el Ministro de Interiores lo planteara abiertamente, ya existía consenso en la comunidad política de España para que una reforma legislativa vinculada a la pornografía infantil, incluyera el registro público de pederastas dentro del marco de endurecimiento de penas para los delitos sexuales como una de las formas de evitar la reincidencia ${ }^{185}$. Desde el Poder Judicial, también voceros representativos apostaban por la creación de un registro central de condenados por delitos contra la libertad sexual, similar al que ya existe para los delitos de violencia de género $^{186}$. Hasta entonces no existían en España medidas de inocuización de

\footnotetext{
${ }^{183}$ Véase SILVA SÁNCHEZ, J. M., El retorno de la inocuización..., op. cit., pág. 709.

${ }^{184}$ Ibídem, pág. 710.

${ }^{185}$ Véase "El Gobierno no descarta la creación de un registro público de pederastas", El País, 30 de marzo de 2008. El anuncio que también hicieran en su momento el líder del partido principal de la oposición Mariano Rajoy y un portavoz del partido nacionalista CIU, sobre los registros de pederastas, fue aprobado finalmente por el parlamento el día 04 de agosto de 2008. El Congreso aprueba un registro de pederastas para evitar otro caso "Mariluz” El País, 30 de junio de 2008.

${ }^{186}$ Véase. Declaración de Enrique López como portavoz del Poder judicial. El país, 30 de marzo de 2008.
} 
delincuentes sexuales imputables y peligrosos para después del cumplimiento de la pena.

La divulgación de datos personales asociado a listas negras viene a calmar un deseo de neutralización del delincuente, al que se considera incorregible y se pretende segregar definitivamente de la sociedad. El registro sólo sirve para satisfacer un interés puramente vindicativo de la sociedad, pues no tiene incidencia directa en la inhibición de los delitos sexuales. Las listas, además de favorecer la estigmatización y dificultar la resocialización $^{187}$, son una pena especialmente aflictiva que llega a ser infamante ${ }^{188}$. Poner en disposición de la sociedad registros públicos donde poder hurgar en datos, informaciones y detalles acerca del pasado de los ciudadanos, deja en manos de los particulares procesar el alcance y significado de la biografía de cada uno, lo que unido al alarmismo inherente a la lógica de la seguridad lleva necesariamente a la estigmatización y exclusión permanente de la vida social de quienes ya han cumplido condena. Toda una invitación a las llamadas "reacciones informales", que están muy lejos del pretendido ideal de seguridad. No reparamos en considerar que la publicación de registros de delincuentes es un exceso punitivo que afecta a principios constitucionales y fundacionales del Derecho penal como el derecho a la intimidad.

Tampoco parece que el Estado de Derecho disponga de una vía transitable para lograr mayor seguridad recurriendo a medidas de control centrada en estrategias de intervención psíquica y/o corporal. La administración de ciertos medicamentos para el tratamiento de determinados trastornos sexuales -el empleo del término "castración" como usualmente se hace puede implicar el riesgo de impedir un análisis racionalpuede ser útil en algunos casos como complemento a una terapia psíquica convencional. Sin embargo, sus posibilidades de legitimación como medida alternativa a la privación de libertad dependen en gran parte de, por lo menos, tres extremos. Por un lado, del uso cuidadosamente focalizado para aquellas situaciones en las que se conoce con certeza su

187 GÓMEZ NAVAJAS, J., “Lista de delincuentes: ¿pena de “escarnio público”?”, en MORILLAS CUEVA, L., (Coord.), Estudios Penales sobre violencia doméstica, Ed. Derecho Reunidas, S. A., Madrid, 2002, págs. 493- 508.

188 GARCÍA ARÁN, M., "Delincuencia, inseguridad y pena en el discurso mediático", en MUÑOZ CONDE, F., (Dir.), Problemas actuales del Derecho Penal y de la Criminología. Estudios penales en memoria de la Profesora María del Mar Díaz Pita, Ed. Tirant lo Blanch, Valencia, 2008, págs. 85-113. 
eficacia. Por otro lado, de los efectos secundarios sobre los cuales los resultados que se conocen hoy resultan alarmantes. Finalmente, del carácter voluntario o forzoso de su administración. Esta última consideración pone sobre el tapete la necesidad de una discusión racional en el marco del Derecho, sobre las posibilidades y límites de las terapias forzosas. En cualquier caso, no parece procedente considerar que la administración de medicamentos para atender situaciones de trastornos como los que aquí se aluden, puedan alcanzar sus objetivos sin la predisposición y colaboración del sujeto y la asistencia psiquiátrica correspondientes ${ }^{189}$.

En la reforma 5/2010 de 22 de junio del Código Penal, tanto la libertad vigilada posterior a la pena como el sometimiento a terapia en tanto medidas de seguridad tampoco vinculan a la situación de peligrosidad del sujeto -sino siempre a la reincidencia- lo que las hace totalmente innecesarias cuando aquella no exista y quizás insuficientes cuando exista. La terapia parece recibir aquí un carácter forzoso, lo que implica una quiebra con el principio de voluntariedad del tratamiento en sujetos imputables que han inspirado siempre la legislación penitenciaria española. ${ }^{190}$

La propuesta de uso de GPS para ubicar a los pederastas "no rehabilitados" después de cumplir sus condenas, ya ha sido puesta en práctica en España desde el año 2005. Ocho españoles condenados por violación y en libertad, habiendo cumplido sus penas, fueron los primeros a quienes se aplicó este sistema de control por vía satélite que permite conocer en tiempo real la ubicación físico / territorial del portador. Desde entonces estos dispositivos GPS no han dejado de utilizarse como mecanismos de control social, aunque su uso se limita a casos excepcionales en los que se estima que ese control puede minimizar los riesgos de reincidencia de un recluso durante los $\operatorname{permisos}^{191}$.

Desde el año 2000, también se utilizan en España otros dispositivos menos sofisticados y con más años de aplicación para controlar, a distancia, la ubicación de

\footnotetext{
${ }^{189}$ ROBLES PLANAS, R., "Sexual Predatour estrategias y límites del Derecho Penal de la Peligrosidad", en Revista para el análisis del Derecho. INDRET 4/2007, Barcelona, octubre 2007, pág. 17.

${ }^{190}$ Ibídem, págs. 17 y ss.

191 Según afirma Elena Puerta subdirectora adjunta de Medio Abierto de la Dirección General de Instituciones Penitenciarias. La Vanguardia, Barcelona, 22 de mayo de 2008.
} 
internos. Son los casos de las pulseras o tobilleras telemáticas que utilizan reclusos que están en tercer grado de régimen penitenciario con permiso diario para salir a trabajar. Este sistema, que permite a los presos no pernoctar en el centro penitenciario, se activa cuando el interno entra en su lugar de residencia, al emitir la pulsera una señal que recoge un receptor conectado a la línea telefónica ${ }^{192}$. TAMARIT SUMALLA, es partidario de aprovechar los avances de las nuevas tecnologías en este tipo de controles; sin embargo, conviene en que para usarlos con personas que ya han salido de la cárcel tras cumplir sus condenas habría que reformar el Código Penal. Esta medida, ya recogida por la ley reformada y que se aplicaría sin el consentimiento del afectado, debería establecerse ya en la sentencia para ser empleada en el momento de la excarcelación cuando existiera un alto riesgo de reincidencia ${ }^{193}$.

En relación con la medida de los inhibidores hormonales debemos advertir que, en la complacencia del estamento político de empuñar las medidas punitivas que afirmen la ideología de la seguridad como respuestas que apacigüen los miedos y temores sociales, ha sido bandera política de muchos, entre ellos del actual presidente de Francia, Nicolás Sarkozy ${ }^{194}$. Más exactamente, sugería la creación de un hospital especial para pedófilos y el fin de las reducciones de pena para los delincuentes sexuales a cambio del uso de inhibidores hormonales para aquellos pederastas que así lo consintieran ${ }^{195} /{ }^{196}$.

\footnotetext{
${ }^{192}$ Desde el año 2000 más de cuatro mil presos las han llevado. Hasta el 20 de mayo de 2008 eran controlados por este sistema un total de 1.711 presos en España. En el caso de Cataluña, esta medida se empezó a aplicar también en el año 2000, y actualmente duermen en sus lugares de residencia, controlados con estas pulseras, 76 internos. El País, 22 de mayo de 2008.

${ }^{193}$ Véase Vigilados con GPS al salir de la cárcel, La Vanguardia, 22 de mayo de 2008. Los terroristas y delincuentes sexuales serán vigilados durante 20 años al ser excarcelados. El País, 10 de septiembre de 2008.

194 Véase Sarkozy propone un hospital especial y la castración química para luchar contra los pederastas, El hospital especial se pondría en funcionamiento en 2009 en Lyon. El fin de las reducciones de pena, los delincuentes solo saldrán de prisión una vez hayan cumplido sus condenas y después de pasar una evaluación de peligrosidad que efectuaría un equipo médico. Los que presenten riesgos para la sociedad serían enviados al hospital. Quienes opten por ser curados podrán tener permisos llevando un brazalete electrónico y siguiendo un tratamiento hormonal. El País, 20 de agosto de 2007.

195 El proyecto legislativo francés es la respuesta de las autoridades frente al lamentable suceso de Roubaix, donde un niño de cinco años estuvo secuestrado varias horas sufriendo abusos sexuales por un pederasta reincidente (que posteriormente confesó haber cometido cuarenta delitos similares), caso que ha conmocionado a la sociedad francesa.
} 
La aplicación de inhibidores hormonales consiste en un tratamiento terapéutico temporal y completamente reversible mediante el cual se inyecta al varón una hormona sintética femenina, la Depo-Provera, nombre comercial del principio Acetato de Medroxyprogesterona, (DMPA), que produce un efecto anti/andrógeno y reduce el nivel de testosterona para inhibir su deseo sexual durante aproximadamente seis meses. La DMPA puede producir efectos secundarios graves, tales como diabetes, depresión, disnea, trombosis, flebitis, hipertensión, disminución y pérdida de vello facial y corporal, así como redistribución de grasa en el cuerpo, entre otros. En general, puede decirse que reporta un desarrollo de las características femeninas en el varón sometida a ella, factores por lo que su aplicación es muy contestada tanto por sociedades médicas como por organizaciones de derechos humanos. También se han utilizado como medicación, análogos del GNRH ${ }^{197}$ y el Acetato de Ciproterona, otro anti/andrógeno ${ }^{198}$

La DMPA, en principio diseñada para el tratamiento del cáncer de próstata avanzado, utiliza sustancias que bloquean la producción de testosterona. Los efectos directos causados sobre la persona se traducen en una disminución de la intensidad y frecuencia de los pensamientos eróticos (impulsos sexuales), la inhibición de la irrigación de sangre al pene -lo que no permite la erección- y el impedimento de la

\footnotetext{
${ }^{196}$ Esta propuesta ha sido recogida en España por una reunión de expertos en Cataluña que ha planteado se aplique la libertad vigilada y un tratamiento hormonal consentido para reducir el deseo sexual en los casos graves de violadores que hayan cumplido la totalidad de su condena y que, al quedar libres, presenten un alto riesgo de reincidencia. Dicho comité de expertos en concreto ha propuesto la reforma del Código Penal para añadir la "libertad vigilada" durante tres o cinco años, como instrumento de control posterior a la excarcelación, y la "supresión hormonal reversible", una especie de inhibidor farmacológico aplicado con el consentimiento del violador para reducirle el deseo sexual una vez quede en libertad. La que para entonces era Consejera de Justicia en Cataluña, Montserrat Tura, confirmaba que las comisiones de tratamiento de los centros penitenciarios catalanes ya estudiaban los perfiles de los presos que podrían someterse a la castración voluntaria para evitar la reincidencia en delitos sexuales.
}

${ }^{197}$ La hormona liberadora de gonadotropina (GNRH, LHRH o LHRF) es una hormona liberada por el hipotálamo cuyo centro de acción es la hipófisis. La gonadotropina posee su centro de acción en las gónadas masculina y femenina. Los niveles de la hormona liberadora de gonadotropina (GNRH) están regulados por mecanismos de retroalimentación gracias a los andrógenos y estrógenos liberados por las gónadas, que actúan en el hipotálamo. El Acetato de Ciproterona es un derivado de la Progesterona al que se le conocen propiedades anti/androgénicas. Es el anti/andrógeno más empleado en Europa. Posee efecto antagonista del receptor y también actúa como anti/gonadotrópico merced a su efecto pro-gestacional. También presenta actividad progestagénica. Véase, ROBERT, W., Tratado de Endocrinología. Ed. Salvat, Barcelona, 1981.

${ }^{198}$ GUDÍN RODRÍGUEZ-MAGARIÑOS, F., "La castración química para pedófilos: un problema ético y penológico", Actualidad Jurídica, ARANZADI, 8 de noviembre de 2007, pág. 4, Disponible en tu actualidad jurídica en la Red. www.aranzadi.es 
obtención del orgasmo a través de la eyaculación. Para asegurar su efectividad, las indicaciones médicas ordenan la repetición de la dosis cada seis meses.

En definitiva, consiste en administrar un tratamiento hormonal dirigido a inhibir la libido; pero dicha medicación tiene unas secuelas temporales aunque, en principio, completamente reversibles. Se cuestiona la fundamentación ética de su aplicación puesto que vierte un principio activo hormonal de naturaleza femenina en la fisiología masculina. Y, obviamente, es contrario a la naturaleza masculina la segregación de hormonas femeninas; su tratamiento de choque, además, comporta numerosas secuelas físicas y psíquicas difíciles de evaluar. La condición humana posee unos atributos inmanentes a su naturaleza (masculina y femenina); intentar alterarlos unilateralmente arrastra consigo un grave menoscabo de la dignidad del individuo sometido a esos cambios.

El uso de inhibidores hormonales para delincuentes sexuales forma parte de las legislaciones de Australia, Alemania, Suecia, Suiza, Canadá, Dinamarca, ocho Estados de EEUU y está en revisión en algunos países de Latinoamérica como Colombia, Chile, México, El Salvador y Argentina. En Alemania comenzó a utilizarse desde 1969 y en Suecia desde $1993^{199}$. En julio de 2007 el gobierno Británico anunciaba que pondría a disposición de pederastas y otros delincuentes sexuales el procedimiento de la aplicación de inhibidores hormonales, programa voluntario que incluirá la administración de medicamentos para suprimir la libido del individuo. En Francia, ya en noviembre de 2004 se había puesto en marcha un programa piloto para violadores y pederastas encarcelados. Como en la mayoría de los países europeos, el número de delitos sexuales en Francia se ha incrementado de manera alarmante en los últimos años. Los condenados en este país por estos delitos representaban el $5 \%$ del total hace

\footnotetext{
${ }^{199}$ En los EEUU, fue en California donde se utilizó por primera vez en 1996 como requisito obligatorio impuesto sobre algunos pederastas para poder tener acceso a la libertad condicional. En 1997 Florida/EEUU aprobó la ley correspondiente contra delincuentes sexuales reincidentes que quieren acceder a la libertad condicional. Sin embargo, en ese estado es el juez quien determina la duración del tratamiento que puede llegar a ser de por vida. Si el condenado deja de utilizar el tratamiento sin autorización judicial no sólo habrá violado su estado condicional de libertad, sino que se le imputaría nuevamente habiendo cometido un nuevo delito
} 
tres lustros. Hoy se sitúa en torno al $22 \%$, de los que un tercio se perpetraron por violaciones a menores. $^{200}$

Ello corrobora los planteamientos formulados a lo largo del trabajo respecto de la mutación sufrida por la realidad social con la irrupción de la red virtual como espacio de comunicación, consumo e intercambio y los ajustes del marco normativo para regular el hecho, lamentablemente estrechando su control social mediante el ensanchamiento de las barreras del Derecho penal y sesgando mediante la pena privativa de libertad cualquier desviación. En la sociedad polaca en medio de la conmoción - otra vez en el marco de un estado de alarma social- tras conocerse el caso del hombre que secuestró y violó a su hija durante seis años en una localidad hacia el este del país el Gobierno ha entregado un proyecto de ley para imponer el uso de inhibidores hormonales a los pederastas reincidentes. Como suele ocurrir, lo medios se hicieron eco de estudios de opinión en los que una amplia mayoría (79\%) se manifestaba de acuerdo con ello ${ }^{201}$.

La irrigación de medidas de este tipo, dirigidas a la regulación de la pulsión sexual de quienes han sido penados por algún comportamiento tipificado, ha venido construyendo un paisaje de legislaciones nacionales, fundamentalmente europeos y anglosajones, proclives a su reconocimiento y legitimación social. En su adecuación normativa la reinserción del penado sencillamente no tiene acogida. Si como parece, en cambio, su objetivo es atenuar los miedos sociales ante estados de peligrosidad que se le atribuyen, el proceso de inocuización apenas comienza y bastará otro episodio para continuar avanzando en la senda de la penalización de todo acto que escandalice la moral sexual con la que se enjuicia. Pero hagamos unos comentarios adicionales para cerrar este punto sobre el uso de los inhibidores hormonales.

En primer lugar, la raíz del problema no radica en el aparato genital sino en el cerebro. Si se quiere anular la tendencia sexual, en principio, habría que considerar que la inclinación sexual se encuentra en la zona erógena del cerebro, en los centros donde se construyen los estados conscientes e inconscientes del placer. En este sentido, este castigo o inocuización corporal reduce los impulsos sexuales, pero no tanto los instintos

\footnotetext{
${ }^{200}$ GUDÍN RODRÍGUEZ-MAGARIÑOS, F., La Castración química ..., op. cit., pág. 4

${ }^{201}$ Véase, “Polonia quiere castrar a todos los pederastas”, El País, 26 de septiembre de 2008.
} 
violentos. Tampoco borra de la memoria la dimensión del hecho vivido o por vivir asociado a las experiencias sexuales. De allí que su reducción de la cuestión sexual al hecho fisiológico tiene un efecto francamente limitado sobre el mundo del delincuente sexual.

En segundo lugar, y como consecuencia de lo anterior, se ha advertido que la falta de excitación sexual no es una barrera infranqueable a la agresión sexual. Esto lo demostraron estudios en Suecia que evidenciaban que con el tratamiento al individuo le será muy difícil excitarse; sin embargo, ello no le inhibe de ser capaz de tener relaciones sexuales. Si el individuo objeto de un tratamiento como alguno de los que hemos referido antes, desea superar los efectos de estos medicamentos, lo podrá conseguir si es capaz de imaginar una fantasía sexual intensa o recurrir a pornografía extrema. Esto es, procuran llevar al extremo las circunstancias de excitación para romper el efecto inhibidor del tratamiento. Ocurre entonces que se han presentado casos de sujetos, descargando mayor virulencia en el ataque sobre el menor. Por tanto, los resultados no son inmunes a la reincidencia, antes bien propician la emergencia de un estado de sobre/excitación que ha terminado en mayor ensañamiento y sadismo con sus siguientes víctimas. Como bien ha afirmado Nikolaus Heim, este tratamiento debe utilizarse como último recurso ya que genera en la persona un alto grado de frustración ${ }^{202}$. Por más que se rebajen los niveles hormonales, si no existe correspondencia entre el tratamiento fisiológico y el psicosocial del que debe venir acompañado, el estado de frustración puede empujarle al uso de mayor violencia y humillación de las eventuales víctimas. Pero la disponibilidad de recursos para atender a las condiciones materiales y objetivas en las cuales ocurren actos sexuales tipificados no está bien vista por la ideología de la seguridad $^{203}$.

Los anti/hormonales resultan a todas luces limitados para atender el complejo de causas psicológicas, educativas, culturales y aflictivas que dan origen a las desviaciones sexuales, según Bernard CORDIER. El uso de los inhibidores hormonales -cuya denominación como castración química, insistimos, sesga el debate- no logra borrar el

\footnotetext{
${ }^{202}$ Ibídem, pág. 5

203 Ídem.
} 
imaginario y las representaciones del criminal sexual ${ }^{204}$. Si la aceptación no es verdaderamente voluntaria y no viene acompañada de una asistencia psicológica y social paralela, su eficacia resulta seriamente cuestionada. Por ello, CORDIER compara este tipo de tratamiento con sus homólogos contra el alcoholismo o el tabaquismo, inseparables también de un seguimiento psicológico y de acompañamiento familiar. "Es gracias a la voluntad individual acompañada de un tratamiento la que marca la diferencia. Tal como sucede a un alcohólico, el impulso para un violador o un pedófilo no desaparece nunca, el desafío es aprender a controlarse y a vivir con ello",205

Además de ser ineficaz si no reúne estas condiciones, aplicarla sin el consentimiento del afectado como pena imperativa y no alternativa comportaría, según nuestro criterio, de manifiesta inconstitucionalidad por vulnerar directamente el derecho a la integridad física consagrado en el art. 15 C.E. Por lo tanto, no basta con la libre aceptación circunstancial del afectado; su instauración precisaría, según el criterio prácticamente unánime de los expertos, combinar el tratamiento biológico (farmacológico y hormonal) con la asistencia de terapias y métodos antidepresivos, y la adecuación de una atmósfera social de acogida de reconocimiento y apoyo.

En definitiva, esta contravención del principio neminem laedere corporal presenta enormes dificultades de acomodación al marco jurídico constitucional, porque comporta una modificación traumática y artificial de la personalidad, que excede mucho más allá del sufrimiento de la pena de cárcel amparada en el art. 25.1 de la C.E ${ }^{206}$. Si se opta por esta medida corporal, deberá hacerse absolutamente de forma voluntaria con un cúmulo de garantías convenientemente reflejadas en un marco jurídico y para casos muy especiales y concretos. Por lo demás, la vigilancia electrónica de aplicación progresiva en España puede representar una alternativa si lo que se procura es mantener el control sobre el penado una vez puesto en libertad y evitar la ocurrencia de situaciones objetivas proclives a la reincidencia

\footnotetext{
${ }^{204}$ GUDÍN RODRÍGUEZ-MAGARIÑOS, F., La Castración química ..., op. cit., pág. 5 ${ }^{205}$ Idem.

${ }^{206}$ Ibídem, pág. 6
} 
La última de las medidas que aquí recogemos en línea con las anteriores orientadas por la peligrosidad que viene colonizando las reformas penales que se suceden, una tras otra, delineando cada vez mejor su nuevo ideario, es la creación de una base de datos de $\mathrm{ADN}$ de las personas. Veamos los pasos que al respecto se han dado en Inglaterra. Desde el año 2004 la policía británica tiene la facultad legal de tomar muestras genéticas a los detenidos mayores de 10 años, a partir de las cuales se ha creado una base de datos de ADN con registros de medio millón de jóvenes de entre 10 y 18 años $^{207}$. No obstante que el Reino Unido cuenta con la mayor base de datos de ADN de Europa con 4,5 millones de muestras genéticas, el director forense de Scotland Yard considera que no son suficientes, por lo que ha propuesto crear bases de datos que procesen el ADN de niños potencialmente peligrosos, los menores de cinco años con una conducta que dibuje el perfil del futuro delincuente serían los candidatos a ingresar en este registro ${ }^{208}$. Para argumentar esta propuesta, sus autores se basan en estudios realizados por el Instituto Británico de Investigación de Políticas Públicas, que ha sugerido que los programas de prevención de conductas criminales deberían aplicarse en edades muy tempranas porque los típicos agresores comienzan a actuar entre los $10 \mathrm{y}$ los 12 años. Entre las razones que presentan estarían la del ahorro de grandes sumas de dinero ya que los crímenes violentos cuestan a Reino Unido cerca de 17 billones de euros al año. Como no puede ser de otra forma y sin menoscabo de la justificada necesidad de ahorro del gasto público, planea sobre la propuesta el cuestionamiento del gasto social en políticas sociales que han de atender el sustrato sociocultural de la delincuencia. Prevalece el criterio actuarial que ya mencionamos y el foco biológico para vacunar a la delincuencia y neutralizar la peligrosidad de ciertos grupos de los que hay que cuidar a la sociedad.

\footnotetext{
${ }^{207}$ Véase "Registros de ADN para niños potencialmente peligrosos", El País, 16 de marzo de 2008. El reportaje toma las declaraciones de Gary Pugh, director forense de Scotland Yard.

${ }^{208}$ Contra esta propuesta han respondido organizaciones defensoras de derechos civiles cuyos portavoces han criticado abiertamente la propuesta del director forense de Scotland Yard: "Los ciudadanos británicos respetan a la policía y están abiertos a excéntricos debates, pero jugar con la inocencia de nuestros menores es ir demasiado lejos", protesta CHAKRABARTI, directora de Liberty ONG. Así mismo Chris DAVIS, de la Asociación de Directores de Escuelas Primarias, ha apuntado que la creación de bases de datos para criminales en potencia supone "un paso hacia un Estado policial" y un grave peligro puesto que significa "condenar a niños por algo que todavía no han hecho". Para Davis, la función de los profesores no es identificar a los "niños potencialmente peligrosos" sino educarlos". El País, 16 de marzo de 2008.
} 
Con los argumentos anteriores el Reino Unido ha creado el banco de perfiles genéticos considerado el mayor del mundo. Contiene hasta diciembre de 2007 los datos de 303.393 menores, de los que exactamente 39.095 corresponden a niños o adolescentes de entre 10 y 17 años que no han sido ni "condenados ni amonestados", ni tienen cargo alguno pendiente ${ }^{209}$. Entre los perfiles genéticos existentes hay 680 niños de 10 años y 49 menores de esa edad.

Según se observa, prevalecen o retoñan los criterios peligrositas que recuerdan los estudios de LOMBROSO sobre el hombre delincuente, impregnado de criterios somáticos y, ahora, biológicos, sin ninguna consideración a los factores estructurales, sociales, de origen externo, que investigaciones posteriores dentro del campo de la criminología como la teoría de la desviación, el interaccionismo simbólico y la Criminología Critica han puesto en evidencia al demostrar la relatividad del delito en el tiempo y el espacio, con lo cual determinar predisposiciones genéticas resulta absurdo. A la luz de tales referencias para el Reino Unido y las pretensiones expuestas antes para el caso de España, ya no sólo se archiva en una base de datos a los menores infractores, sino también a los "potencialmente peligrosos".

En este contexto adquiere relevancia recordar que la Escuela Positivista biológica o psicológica no desconocía la influencia de los factores ambientales pero, posiblemente, su diferencia con las primeras escuelas sociológicas era que éstas entendían que en un contexto social criminógeno cualquier persona podía delinquir, en tanto que la primera entendía que estos factores sociales sólo propician la realización de actos delictivos en personas que además presentan una degeneración de su organismo físico o psíquico" ${ }^{210}$. (subrayado añadido)

Como se aprecia, pareciera que la cultura del control cada vez reduce más su dimensión social y expande su ratio penal encajando mejor dentro de un Estado policial

\footnotetext{
${ }^{209}$ Véase "Reino Unido almacena datos genéticos de 40.000 menores inocentes", El País, 17 de agosto de 2008. "Reino Unido pierde los datos personales de miles de delincuentes", El País, 22 agosto de 2008.

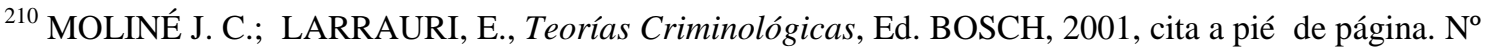
9.
} 
que de un Estado de Bienestar. A pasos agigantados se va imponiendo con medidas fundadas en teorías peligrosistas de la criminalidad y legitimándose sobre la base de la renovación de viejas y primarias ideas respecto de las predisposiciones subjetivas del delincuente, abandonando la concepción garantista del Estado Democrático de Derecho.

Este conjunto de medidas extremas de orden punitivo permanentemente copan espacios públicos de debate, regularmente movidos por eventos ocasionales de alta sensibilidad social y cuyo tratamiento mediático suele inducir climas de vindicación social que terminan por avalar su implementación.

Aunque el agregado cuantitativo de noticias es una variable influyente, se ha podido comprobar que el contenido de las mismas puede serlo aún más, de tal manera que algunos de los índices más altos de preocupación o miedo al delito se alcanzan en meses que no se caracterizan por un mayor volumen de noticias, pero sí, por ejemplo, por recoger sucesos especialmente cruentos. Ya hemos comentado antes que no son pocos los estudios que han demostrado que los medios de comunicación construyen una visión deformada de la realidad delictiva de un país. Pueden, por ejemplo, iniciar la cobertura de una supuesta ola de delitos, con independencia de los índices que aportan los datos oficiales, e igualmente ponerle fin. Esta construcción social de una realidad delictiva produce, sin embargo, consecuencias muy reales: aumento de efectivos policiales, reformas legislativas o costes políticos elevados, como la posible pérdida de unas elecciones si los ciudadanos creen, con base o sin ella, que un Gobierno no puede controlar la delincuencia ${ }^{211}$.

Volviendo a la idea inicial de este aparte sobre la alarma social, los medios de comunicación y los delitos sexuales, vale señalar que la expansión del control por parte del Estado consolidando el modelo de seguridad en desmedro de las garantías y libertades de los ciudadanos, parece contar con el consenso de amplias capas de la población, que asume como prioritaria la necesidad de protección ante un sentimiento colectivo de inseguridad, propiciada por la alarma social a partir del manejo al que recurren frecuentemente los medios de comunicación - al respecto, el caso "Mariluz" resulta emblemático- orientando la dirección de un debate que se reduce a las medidas punitivas como respuesta a la demanda social de seguridad.

${ }^{211}$ SOTO NAVARRO, S., La influencia de los..., op. cit., pág. 3. 
Hasta aquí hemos puesto de relieve a grandes rasgos el lienzo en el que hemos de encajar nuestro problema. Lo hemos hecho con aire crítico en procura, no ya de describir lo que apreciamos, como de tratar de descomponerlo y aislar aquellos elementos que vienen a caracterizar la realidad por la que discurre la pornografía infantil y los delitos asociados y el debate social, público y doctrinario que le ha acompañado. No es casual la exposición, obviamente, porque nos interesa bordar el discurso en el que se encaja al análisis jurídico/criminológico que a partir de ahora iremos desplegando. Resumamos entonces los dicho hasta aquí y dejemos planteado el problema.

Sintetizando, las ideas centrales que hemos expuesto a lo largo de este capítulo se resumen en las siguientes. En primer lugar que la explotación sexual comercial infantil cada vez es más reconocida y su categorización, aunque todavía imprecisa en cuanto al alcance y magnitud que ha adquirido de manera que permitan su cuantificación empírica, ha permitido ir apreciando su naturaleza, especificidades y la evolución reciente desde su emergencia como hecho criminológico en los últimos años. En segundo lugar, el reconocimiento de los efectos que han tenido las Tecnologías de Información y Comunicación (TIC) en la construcción de la sociedad global de nuestros días y la manera como ha potenciado la distribución, el consumo e intercambio de pornografía infantil a través de la red. La pornografía infantil a partir de Internet ha adquirido otra dimensión asignándole el rasgo más característico que presenta en estos momentos.

No obstante ello - en tercer lugar- la irrupción de Internet no justifica la creación de nuevos tipos dentro del Derecho penal. Si bien es cierto que cabe hablar de delincuencia informática en el argot criminológico, no es admisible la construcción delitos informáticos puesto que no se adecúa a la opinión mayoritaria dentro de la doctrina penal respecto de que la existencia de Internet no trae consigo la emergencia de un nuevo bien jurídico. Lo que sí es reconocible es que la globalización, con las TIC a la vanguardia, han trastocado los límites físico/territoriales de los Estados nación que aún rigen el combate contra la criminalidad organizada que no repara en aprovechar las bondades y recursos disponibles mediante la red para incrementar la eficacia de sus actuaciones, entre las que están las redes de comercio de pornografía infantil. 
Por último, que ante el estado de alarma social que gobierna una sociedad de miedos ante los riesgos modernos, no pocas veces manipulados desde los medios de comunicación, se ha impuesto una orientación de Política Criminal punitiva que adelanta las barreras del Derecho penal pretendiendo la neutralización del delincuente mediante medidas de tipo preventivas posterior al cumplimiento de la condena, seriamente cuestionadas por lo que traducen para el orden de libertades y garantías hasta ahora conocidas.

Nuestro problema, cuyo tratamiento nos ocupa los próximos capítulos, está anclado y delimitado por el hecho criminológico de la pornografía infantil. Aunque ya en este primer capítulo hemos asentado ciertas aristas de tipo fenomenológicos, su revisión en el marco de las normas legales que han tratado de regirla nos obliga a revisar el ordenamiento jurídico internacional, la legislación española y el debate doctrinal de la reforma sucedida recientemente. En ellos tratamos de rescatar siempre la dimensión criminológica que acompaña la orientación general de la reforma en este caso y del encaje final que la tendencia que aquí señalamos ha tejido para el delito de posesión tipificado en el artículo 189.2 del Código Penal. 


\section{CAPITULO II}

MARCO NORMATIVO INTERNACIONAL DE LA PORNOGRAFÍA INFANTIL 
La materialización de un marco de atributos de ciudadanía a la infancia o a la niñez es un fenómeno inherente a la modernidad ${ }^{212}$. Más aún, y sin menoscabo de los avances en el orden social especialmente en los ámbitos educativo y sanitario que se observan desde finales del siglo XVIII en Europa y Estados Unidos especialmente, en términos explícitamente jurídicos es un evento de la modernidad reciente, cuyos efectos y alcances se han institucionalizado adquiriendo acelerada vigencia desde la última década del siglo pasado.

Desde la Declaración de los Derechos del Niño (Ginebra 1920) hasta los días que corren un agregado de Declaraciones y Resoluciones de alcance universal han conformado un marco de derechos inmanentes a la infancia que han sido encajados en su mayoría dentro del orden normativo de buena parte de los países. Pero es a partir de la Convención de los Derechos del Niño a finales de los años ochenta (1989) ${ }^{213}$ del siglo veinte cuando comienza el despliegue normativo de principios y derechos establecidos, dándose inicio a la expansión de todo un orden jurídico asociado que en lo que nos interesa vinculado con la pornografía infantil es solo a mediados de la década de los noventa cuando pasa a ser un tema de relevancia en la opinión pública y empiece a ser tratado con profundidad. De forma, pues, que se trata de un tema cuya producción doctrinal, dimensión socio / criminológica y aplicación de políticas es relativamente novísimo en el tiempo aunque de amplia resonancia pública.

En lo que sigue, procuramos una relación cronológica sustantiva de los hitos internacionales y, particularmente, en el espacio comunitario, que han ido construyendo el tronco común sobre el que hoy día están fundados y reconocidos los derechos universales de la infancia, con especial énfasis en el avance gradual de las formas normativas que abrieron camino al tratamiento jurídico de la pornografía infantil. Posteriormente se disecciona el progresivo avance hacia una definición de lo que se entiende por pornografía infantil y, siempre a la luz de los instrumentos normativos

\footnotetext{
${ }^{212}$ Fue a partir de la adopción de medidas y políticas que acordaron países y organismos a nivel internacional que la explotación sexual comercial de niñas y niños es etiquetado y delimitado como un fenómeno con un perfil propio, diferenciada de la prostitución adulta. Respecto de la conformación de la infancia como un espacio de vida institucionalizado en el orden social moderno. Véase, ARIÈS, P., $E l$ niño y la vida familiar en el Antiguo Régimen. Ed. Taurus, Madrid, 1988; CHODOROW N., El ejercicio de la maternidad. Ed. Gedisa, Barcelona, 1988; SEGALENE M., Antropología histórica de la Familia, Ed. Taurus, Madrid, 2000.
}

${ }^{213}$ Resolución 44/25 de la Asamblea General de Naciones Unidas, 20 de noviembre de 1989. 
internacionales referidos en la primera sección de ésta parte, describir las características que la conforman.

\section{DOCUMENTOS DE REFERENCIA Y LEGISLACIÓN COMUNITARIA.}

\subsection{NACIONES UNIDAS, DOCUMENTOS, CONVENCIONES INTERNACIONALES Y EVENTOS MUNDIALES.}

Con base en el aparte de la Declaración Universal de los Derechos Humanos del 10 de diciembre de 1948, que hace mención a la infancia en su artículo 25.2, la Asamblea General de Naciones Unidas actualiza el 20 de noviembre de 1959 la Declaración de Derechos del Niño de Ginebra y constituye lo que desde entonces se conoce como "Declaración de los Derechos del Niño de 1959"214 y que bien puede considerarse el primer instrumento relevante de Naciones Unidas en materia de protección de los derechos de la infancia, en la medida que ha servido de base para la adopción de posteriores instrumentos internacionales ${ }^{215}$. La Declaración amplía los principios de desarrollo, atención, formación y educación consagrados en el documento de Ginebra de 1924 e introduce los de protección, tratamiento y unidad familiar ${ }^{216}$. Asienta el principio de que el niño, por su falta de madurez física y mental, necesita protección y cuidados especiales, incluso la debida protección legal previa y posterior al nacimiento. MARCOS MARTÍN ${ }^{217}$ ve en el artículo 9 de la Declaración el primer antecedente de la protección de los niños contra los abusos sexuales en general, cuyo texto señala que “...en ningún caso se le dedicará ni se le permitirá que se dedique a ocupación o empleo alguno que pueda perjudicar su salud o educación o impedir su desarrollo físico, mental o moral."

Pasarán unos treinta años hasta que en 1989 se establezca la Convención de Derechos del Niño que, al tiempo que recopila lo que en la materia se había venido

\footnotetext{
${ }^{214}$ Resolución 1386 (XIV) de la Asamblea General de Naciones Unidas de 20 de noviembre de 1959.

${ }^{215}$ MARCOS MARTÍN, T., "Pornografía infantil en Internet: Los derechos del niño y su protección internacional" en VILLAGRASA ALCAIDE, C.; RAVETLLAT BALLESTÉ (Coords.), Ed. Ariel S.A, Barcelona, 2006, pág. 323

${ }^{216}$ MORILLAS FERNÁNDEZ, D.L., Análisis dogmático y criminológico..., op. cit. pág. 31.

${ }^{217}$ MARCOS MARTíN, T., Pornografía infantil en ..., op. cit. pág. 323
} 
consagrando en documentos generales previos $^{218}$, pasa a ser el primer documento cuyo objeto de derechos, libertades y protecciones lo constituyen exclusivamente los menores de $\operatorname{edad}^{219}$. Se trata del Convenio Internacional más importante en la materia, haciéndose, además, de una amplia aceptación por parte de los $\operatorname{Estados}^{220}$. Esta Convención precisa el límite del alcance del objeto de su articulado al definir como sujeto de su aplicación a "todo ser humano menor de dieciocho años de edad salvo que, en virtud de la ley que le sea aplicable, haya alcanzado antes la mayoría de edad,221. Entre las disposiciones sustantivas fundamentales prevé el derecho a un nombre - lo que otorga cualidad de ciudadanía - a una nacionalidad, a la educación, al más alto nivel de salud posible y, en lo que concierne al tema objeto de nuestro estudio, se recoge, dentro del conjunto de medidas de protección especial, el proteger a los niños de la explotación económica, protegerlos del uso de narcóticos, de la explotación sexual ${ }^{222}$, del rapto y del tráfico $^{223}$.

\footnotetext{
${ }^{218}$ Ya en los primeros años de la década de los setenta va surgiendo en Naciones Unidas la idea de la necesidad de una convención específica sobre los derechos de los niños, debido a la conciencia de que los tratados internacionales sobre Derechos Humanos no recogían una protección específica dedicada a las especiales necesidades de la infancia. Véase, MARCOS MARTÍN, T., Pornografía infantil en..., op. cit., pág. 321.

${ }^{219}$ Vale citar, no obstante, como antecedente algo lejano en el tiempo pero en el marco de un instrumento de amplio calado, que en el Pacto Internacional de Derechos Civiles y Políticos (16 de diciembre de 1966) ya comienzan a reconocerse expresamente derechos básicos específicos de la infancia frente a otros que resultaban de carácter general. El artículo 24 del citado Texto introduce los principios de no discriminación, inscripción y nacionalidad. "1. Todo niño tiene derecho, sin discriminación alguna por motivos de raza, color, sexo, idioma, religión, origen nacional o social, posición económica o nacimiento, a las medidas de protección que su condición de menor requiere, tanto por parte de su familia como de la sociedad y del Estado.2. Todo niño será inscrito inmediatamente después de su nacimiento y deberá tener un nombre. 3. Todo niño tiene derecho a adquirir una nacionalidad".
}

\footnotetext{
${ }^{220}$ Ha sido ratificada por 191 Estados, faltando entre otros Somalia y Estados Unidos.

${ }^{221}$ Artículo 1 de la Convención.
}

${ }^{222}$ Un importante antecedente dentro del espacio comunitario europeo que, aunque en la Recomendación 1044 (1986) del Consejo de Europa comienza a vislumbrarse una preocupación de los Estados miembros por adoptar medidas concretas en relación a determinadas figuras delictivas, no será hasta la Recomendación 1065 (1987) del Consejo de Europa, sobre tráfico de niños y otras formas de explotación infantil, cuando se observe semejante inquietud en referencia a diversas conductas típicas relacionadas con menores hablándose expresamente de la prostitución, de la pornografía o de la adopción ilegal, entre otras, y la necesidad que tienen los Estados de perseguir estas manifestaciones ilícitas. Véase, MORILLAS FERNÁNDEZ, D. L., Análisis dogmático y criminológico..., op. cit., pág. 32

${ }^{223}$ En particular los artículos 32, 33 y, en especial, el artículo 34 de la Convención:

Art. 32: 1. Los Estados Partes reconocen el derecho del niño a estar protegido contra la explotación económica y contra el desempeño de cualquier trabajo que pueda ser peligroso o entorpecer su educación, o que sea nocivo para su salud o para su desarrollo físico, mental, espiritual, moral o social. 2. Los 
Sin duda, a partir de esta Convención se establecieron los límites de los marcos normativos nacionales, dado que los documentos internacionales o leyes nacionales que le han sobrevenido han evitado contravenir lo consagrado en ella y, por otra parte, se ha procurado su desarrollo mediante instrumentos que amplían su alcance y avanzan en su materialización. En el año 2000 Naciones Unidas acuerda dos documentos de especial relevancia para el desarrollo actual del panorama legislativo, cultural y social en el ámbito de la venta de niños, la prostitución y la pornografía infantil. El primer Documento se concretó el 8 de febrero de 2000 cuando el Comité Especial encargado de elaborar una convención contra la delincuencia organizada transnacional formaliza la "Nota de la Oficina del Alto comisionado de las Naciones Unidas para los Derechos Humanos, el Fondo de las Naciones Unidas para la Infancia y la Organización Internacional para las Migraciones sobre los Proyectos de protocolo relativos al tráfico de migrantes y la trata de personas ${ }^{, 224}$ en el se definen los términos de trata de personas y trata de niños, en esta última categoría se incluye la producción de pornografía $^{225}$.

El segundo Documento se concreta con la aprobación de los Protocolos Facultativos de la Convención sobre los Derechos del Niño relativos a la participación

\footnotetext{
Estados Partes adoptarán medidas legislativas, administrativas, sociales y educacionales para garantizar la aplicación del presente artículo. Con ese propósito y teniendo en cuenta las disposiciones pertinentes de otros instrumentos internacionales, los Estados Partes, en particular: a) Fijarán una edad o edades mínimas para trabajar; b) Dispondrán la reglamentación apropiada de los horarios y condiciones de trabajo; c) Estipularán las penalidades u otras sanciones apropiadas para asegurar la aplicación efectiva del presente artículo.

Art. 33: Los Estados Partes adoptarán todas las medidas apropiadas, incluidas medidas legislativas, administrativas, sociales y educacionales, para proteger a los niños contra el uso ilícito de los estupefacientes y sustancias psicotrópicas enumeradas en los tratados internacionales pertinentes, y para impedir que se utilice a los niños en la producción y tráfico ilícito de esas sustancias.

Art. 34: Los Estados Partes se comprometen a proteger al niño contra todas las formas de explotación y abuso sexuales. Con este fin, los Estados Partes tomarán, en particular, todas las medidas de carácter nacional, bilateral y multilateral que sean necesarias para impedir: a) La incitación o la coacción para que un niño se dedique a cualquier actividad sexual ilegal; b) La explotación del niño en la prostitución u otras prácticas sexuales ilegales; c) La explotación del niño en espectáculos o materiales pornográficos.

${ }^{224}$ A/AC. $254 / 27$.

${ }^{225}$ Por trata de niños entiende el Documento de Naciones Unidas la "abducción, el transporte, el traslado, el cobijamiento o la recepción de un niño o el ofrecimiento de pago u otros beneficios para lograr el consentimiento de una persona a cuyo cargo esté un niño para los fines señalados en el párrafo 2 supra, así como con el objeto de utilizar, adquirir u ofrecer a un niño para la explotación sexual, incluida la producción de pornografía, o para que preste servicios pornográficos".
} 
de niños en conflictos armados y a la venta de niños, la prostitución infantil y la utilización de niños en pornografía ${ }^{226}$.

Desde aquella Convención de 1989 hasta la adopción del Protocolo Facultativo en el año (2000), se había generado a nivel mundial todo un movimiento regulador destinado a la persecución de los abusos y otras conductas de contenido sexual que tienen como sujeto pasivo a los menores de edad y que ha terminado consagrándose en diferentes instrumentos internacionales ${ }^{227}$ y germinando modificaciones legislativas internas de muchos países. Estos instrumentos internacionales en materia de protección de derechos del niño con carácter general, junto con los resultados de los Congresos Internacionales, desembocan en el instrumento internacional específico en la materia objeto de estudio, que se adopta en desarrollo, como anunciamos, de la Convención para los Derechos del niño. Se trata del Protocolo Facultativo sobre los derechos del niño relativo a la venta de niños, prostitución y la utilización de niños en la pornografía ${ }^{228}$.

El Protocolo Facultativo recoge en su artículo 2 un glosario de términos que contribuye a la delimitación de su ámbito de aplicación. Las definiciones contenidas en el artículo son las siguientes: a) venta de niños: "Todo acto o transacción en virtud del cual un niño es transferido por una persona o grupo de personas a otra a cambio de remuneración o de cualquier otra retribución". b) prostitución infantil "la utilización de un niño en actividades sexuales a cambio de remuneración o cualquier otra retribución”, c) pornografía infantil "toda representación, por cualquier medio, de un niño dedicado a actividades sexuales explícitas, reales o simuladas, o toda representación de las partes genitales de un niño con fines primordialmente sexuales”. d) Por representación se entienden fotografías, negativos, diapositivas, revistas, libros, dibujos, películas, cintas de vídeo y discos de computadora o archivos. La inclusión de estas definiciones en el Protocolo Facultativo contribuyó a cubrir importantes lagunas detectadas por la doctrina y que representaban un obstáculo a nivel internacional para la regulación de estas conductas.

\footnotetext{
${ }^{226}$ Asamblea General de Naciones Unidas, A/54/L.84.

${ }^{227}$ Que, por su parte, han servido de base para la adopción de dicho Protocolo.

${ }^{228}$ Ratificado en el momento actual por 67 Estados.
} 
En este documento se comprenden, interrelacionadas, la prostitución y la pornografía, asumiendo que en la mayoría de los casos esto se desarrolla conjuntamente, tejiendo una misma cadena de explotación. La producción, distribución, importación, exportación, oferta, venta, o posesión de pornografía infantil quedaron establecidas en el artículo 3, párrafo tercero, apartado primero de la letra c. En el mismo artículo se contempla la tentativa y la complicidad para cualquiera de estas conductas; los delitos se castigarán con penas adecuadas a su gravedad $\mathrm{y}$, finalmente, contempla la responsabilidad penal, civil o administrativa de las personas jurídicas.

Entre las disposiciones del Protocolo Facultativo destacan las relativas a la extradición, hecho que da cuenta de la asunción del carácter trasnacional del delito y de la realidad global que lo enmarca. Así pues, todos los delitos relacionados con la explotación infantil se considerarán incluidos entre aquéllos que dan lugar a extradición en todo tratado de extradición celebrado entre los Estados Partes en el Protocolo; además, se incluirán también como delitos que dan lugar a extradición en los tratados que celebren entre sí en el futuro. Más aún, en los artículos 4 al 6 se establece una norma de mayor cobertura, que consiste en que el Estado Parte que subordine la extradición a la existencia de un tratado, si recibe de otro Estado parte con el que no tiene Tratado al respecto una solicitud de extradición, podrá invocar dicho protocolo como base jurídica para la extradición respecto de esos delitos ${ }^{229}$.

En el artículo 8 se contempla la defensa de los intereses del menor a lo largo de los procesos penales, considerado la vulnerabilidad de los niños víctimas. Se destaca la necesidad de adaptar los procedimientos de forma que se reconozca sus necesidades especiales, incluidas las necesidades especiales para declarar como testigo. Consideramos sobre el asunto que el reconocimiento de las necesidades especiales de los niños es de gran utilidad y relevancia para brindar una verdadera protección a los niños víctimas. Atendiendo a esta consideración esencial queda establecida la protección en los derechos siguientes: la información a los niños víctimas acerca de sus derechos, de su papel, el alcance, las fechas y la resolución de la causa; la autorización de la presentación, consideración de opiniones, necesidades y preocupaciones de los niños víctimas en que se vean afectados sus intereses personales, de un manera

\footnotetext{
${ }^{229}$ MARCOS MARTíN, T., Pornografía infantil en..., op. cit., pág. 326.
} 
compatible con la legislación nacional. El contenido de este artículo representa uno de los más fuertes compromisos entre los Estados Partes en el Protocolo.

Como medidas concretas de prevención se exhorta a los Estados Partes a que adopten medidas: a) para incautar y confiscar los bienes materiales, activos y otros medios utilizados para cometer o facilitar la comisión de estos delitos; b) para incautar y confiscar las utilidades obtenidas de esos delitos; c) para cerrar, temporal o definitivamente los locales utilizados para cometer estos delitos (artículo 7). En relación a la protección de las víctimas el Protocolo recoge una serie de medidas tales como: la protección de la identidad y la intimidad de los niños víctimas y adoptar medidas de conformidad con la legislación nacional para evitar la divulgación de información que pueda conducir a la identificación de las víctimas; velar por la seguridad de los niños víctimas, así como la de sus familias y los testigos a su favor, frente a intimidaciones y represalias; el acceso sin demoras a los procedimientos y resoluciones para obtener, sin discriminación de las personas legalmente responsables, reparación por los daños sufridos; y garantizar que el hecho de haber dudas acerca de la edad real de la víctima no impida la iniciación de las investigaciones penales, incluidas las investigaciones encaminadas a determinar la edad de la victima. (artículos 8 y siguientes); asimismo y no de poca importancia, el fortalecimiento del principio de cooperación internacional para la persecución de estas manifestaciones delictivas (artículo 10).

Es nuestro criterio que la mayor aportación de este Protocolo respecto de los instrumentos internacionales anteriores tiene que ver con dos cosas. En primer lugar con la definición de términos legales (venta de niños, trata, pornografía infantil entre otras) que facilitan la regulación internacional de las conductas; y en segundo lugar con la protección y atención de las víctimas y su entorno y las medidas concretas en relación con ellas.

En tales disposiciones es notoria la influencia de acuerdos en eventos de carácter mundial como los Congresos de Estocolmo (1996) y el de Yokohama (2001) que han pasado a formar parte de la doctrina sobre la materia. De hecho buena parte de la legislación europea suele mencionar en la exposición de motivos el primero de ellos como el evento fundacional de la legislación relacionada. El primer Congreso Mundial contra la Explotación Sexual Comercial de los Niños se realizó en Estocolmo, Suecia, 
atrayendo la representación de 122 países. En la Declaración del Programa de Acción de este Congreso se reitera su compromiso en favor de los derechos del niño y hace un llamamiento a todos los Estados en cooperación con las organizaciones nacionales e internacionales y la sociedad civil para: proteger a los niños frente a la explotación y los abusos sexuales y promover la recuperación física y psicológica y la reintegración social de las víctimas infantiles; otorgar una alta prioridad a la acción contra la explotación sexual comercial de los niños y asignar los recursos adecuados para este fin; así mismo, insiste en una cooperación más sólida entre los Estados y todos los sectores sociales para prevenir la participación de los niños en el comercio sexual y reforzar el papel de la familia en la protección de los niños; difundir el carácter delictivo de la explotación sexual comercial de los niños, así como otras formas de explotación sexual, y condenar y castigar a todos los delincuentes implicados, ya sean locales o extranjeros, a la vez que se garantiza que las víctimas infantiles de estas prácticas quedan exoneradas de toda culpa $^{230}$.

El Congreso Mundial de Estocolmo también insta a los Estados a aplicar la legislación, las políticas y los programas para proteger a los niños frente a la explotación sexual comercial y reforzar la comunicación y cooperación entre las autoridades encargadas de la aplicación de la ley. Así mismo, promover la adopción, implementación y difusión de leyes, políticas y programas con el apoyo de los mecanismos pertinentes a nivel local, nacional y regional contra la explotación sexual comercial de los niños; desarrollar e implementar planes y programas integrales que incluyan las diferencias de género, para prevenir la explotación sexual comercial de los niños, y proteger y asistir a las víctimas infantiles con el fin de facilitar su recuperación y reintegración dentro de la sociedad; crear un clima adecuado mediante la educación, la movilización social y las actividades de desarrollo para garantizar que los progenitores y otras personas legalmente responsables puedan cumplir sus derechos, obligaciones y responsabilidades para proteger a los niños frente a la explotación sexual y comercial; movilizar a los políticos y otros aliados relevantes, las comunidades nacionales e internacionales, comprendidas las organizaciones intergubernamentales y no gubernamentales, para ayudar a los países en la eliminación de la explotación sexual

${ }^{230}$ Declaración de la reunión realizada en Estocolmo con motivo del Congreso Mundial contra Explotación Sexual Comercial de los Niños Estocolmo, 24 de agosto de 1996. 
comercial de los niños; y resaltar el papel de la participación popular, comprendida la de los propios niños, en la prevención y eliminación de la explotación sexual comercial de los niños. En definitiva, el Congreso de Estocolmo concluye en que la explotación sexual comercial de los niños constituye una forma de coerción y violencia contra los niños, que puede implicar el trabajo forzoso y formas contemporáneas de esclavitud ${ }^{231} / 232$. Su realización, espíritu de consenso y de sensibilidad ante el problema, tiene el enorme mérito de haber posicionado el debate en la órbita de los grandes temas mundiales que demandan un estado de cooperación, dada la dimensión transnacional de la delincuencia organizada que trafica con ella. Sus conclusiones han pasado a inspirar cuando no a conformar buena parte de las legislaciones nacionales que vierten sus contenidos en el marco normativo correspondiente.

El éxito del Congreso de Estocolmo está fundado en el compromiso de los Estados para combatir la explotación sexual infantil a través de la adecuación normativa de las legislaciones respectivas y el principio de cooperación internacional para reducir su ámbito de aplicabilidad ${ }^{233}$. Exactamente se establece el deber de los Estados de desarrollar o reforzar y aplicar medidas legales nacionales para establecer la responsabilidad criminal de los proveedores de servicios, clientes e intermediarios en la prostitución, tráfico y pornografía infantil, comprendida la posesión de material pornográfico infantil, y otras actividades sexuales ilegales. Por otra parte, se instituyó el compromiso que para el año 2000 pueda disponerse de bases de datos sobre los niños vulnerables a la explotación sexual comercial, atendiendo a las variables de edad, género, etnia, status indígena, circunstancias estas que influyen en la explotación sexual

231 Declaración de la reunión realizada en Estocolmo con motivo del Congreso Mundial contra Explotación Sexual Comercial de los Niños, Estocolmo, 24 de agosto de 1996.

${ }^{232}$ Un objetivo importante a destacar en cuanto a la protección de niños se refiere es la conformación de redes de cooperación contra la explotación sexual infantil. Así en el I Congreso Mundial de Estocolmo se establece: "identificar y estimular el establecimiento de redes nacionales e internacionales y coaliciones entre miembros de la sociedad civil para proteger a los niños frente a la explotación sexual comercial; fomentar la acción y la interacción entre comunidades, familias, organizaciones no gubernamentales, el sector de negocios, comprendidas las agencias turísticas, la Organización Mundial del Turismo, empresarios y sindicatos, la industria electrónica e informática, los medios de comunicación, las asociaciones profesionales, y los proveedores de servicios para vigilar e informar sobre los casos presuntamente delictivos a las autoridades, y adoptar códigos éticos voluntarios de conducta; y h) crear refugios seguros para los niños que escapan a la explotación sexual comercial, y proteger a quienes prestan ayuda a las víctimas infantiles de la explotación sexual frente a la intimidación y el acoso".

${ }^{233}$ Véase, MORILLAS FERNÁNDEZ, D. L., “Análisis dogmático y criminológico..., op. cit., pág. 34 
comercial, igualmente un perfil sobre sus explotadores, y respeto a la confidencialidad de las víctimas infantiles especialmente en lo relativo a la exposición pública ${ }^{234}$

Cinco años más tarde, en 2001, tiene lugar el II Congreso Mundial contra la explotación sexual comercial de los niños, que se celebra en Yokohama ${ }^{235}$. En este segundo Congreso se subraya la necesidad de proteger los derechos del niño contra la explotación sexual comercial bajo sus formas de prostitución infantil, pornografía infantil y tráfico de niños para fines sexuales. Puntualmente se compromete a "tomar las medidas necesarias para enfrentar aspectos negativos de las nuevas tecnologías, en particular la pornografía infantil en Internet, reconociendo al mismo tiempo el potencial que tienen las nuevas tecnologías como instrumento de protección contra la explotación sexual comercial de niños debido a su capacidad de difusión, de intercambio de información y de conexión con otros organismos interesados"236. Para ello se proponen estrategias y planes de acción a nivel nacional e internacional, creación de nuevas leyes que criminalicen este tipo de explotación, incluyendo cláusulas con efecto extraterritorial. En relación a la atención a los niños víctimas se compromete a la implementación de servicios especiales tales como líneas de ayuda telefónica, refugios y prácticas judiciales y administrativas destinadas a prevenir la violación de sus derechos y proveer remedios efectivos. Por último, declara la exigencia a los Estados para que "la explotación sexual de niños no puede ser tolerada y prometer poner todos los medios necesarios para erradicarla" 237 .

No obstante la voluntad de erradicación de la explotación sexual infantil, los esfuerzos de sensibilización de la comunidad internacional y la emergencia progresiva de legislaciones nacionales que definen un marco normativo para el combate de estos

\footnotetext{
${ }^{234}$ Declaración de la reunión realizada en Estocolmo con motivo del Congreso Mundial contra Explotación Sexual Comercial de los Niños Estocolmo, 24 de agosto de 1996.

235 Este Congreso fue convocado por UNICEF, el Gobierno Japonés y ECPAT. Asistieron aproximadamente unos tres mil representantes de 138 países que suscribieron nuevos compromisos. Aunque, fue adoptado por consenso, varias delegaciones decidieron agregarle Notas Explanatorias. Así lo hicieron la Unión Europea, los Estados Unidos, la India, Irán y el grupo de Estados Árabes y Africanos. Aunque estas adiciones desarrollan ciertos puntos de vista peculiares a países o regiones, todos ellos endorsan el Compromiso de Yokohama.

${ }^{236}$ Véase, Compromiso Global de Yokohama 2001.

${ }^{237}$ Véase, Compromiso Global de Yokohama 2001.
} 
delitos, los estudios realizados durante los años transcurridos entre un Congreso y otro pusieron de relieve que especialmente los niños del tercer mundo continuaban siendo sacrificados para la explotación comercial. Igualmente que ningún Estado estaba libre de explotación infantil, que ninguna sociedad es inmune y que ningún niño está totalmente protegido contra este tipo de prácticas. Se detecta también que la demanda de los usuarios de pornografía infantil va en aumento y que se trata de un fenómeno cuya dinámica avanzaba a pasos agigantados hacia un estado de complejidad que las medidas esporádicas no pueden resolver.

Por otra parte se identificó acertadamente que la irrupción del SIDA como endemia generalizada había empujado hacia el aprovechamiento sexual de menores, razón por la que se explica que un mayor número de niños, cada vez de más corta edad, eran víctimas de la prostitución infantil. Los pedófilos creen que cuanto menor sea el niño, menor será el riesgo de infectarse con el VIH. Obviamente se trata de una percepción errónea que las organizaciones internacionales han tratado de rebatir. En todo caso la mayor trascendencia de los resultados de estos Congresos se resumen en la creación de foros globales que han hecho concienciar a diferentes sectores en el plano internacional y haber promovido la adopción de medidas a nivel nacional ${ }^{238} / 239$.

Siete años más tarde (2008) se reunieron 137 países para celebrar en Río de Janeiro, Brasil, el III Congreso Mundial sobre la explotación de niños, niñas y adolescentes. En este Congreso se firma la Declaración de Río de Janeiro y el Plan de Acción para prevenir y detener la explotación sexual de niños y adolescentes. La Declaración de Río plantea la criminalización de las imágenes virtuales de pornografía infantil, difundiendo tal categoría en un sentido muy amplio. Además, se plantea la necesidad de responsabilizar a todos los actores que están directamente involucrados con los servicios de Internet (proveedores de servicios, compañías de telefonía móvil, Cyber cafés) en la adopción de medidas de protección a los menores de edad. Se aboga por modificar la terminología legal, sustituyendo el término de pornografía infantil por el de imágenes de abusos a menores. En resumen, la Declaración de Río en las formas

\footnotetext{
${ }^{238}$ MARCOS MARTín, T., Pornografía infantil en..., op. cit., pág. 322

239 El Congreso de Yokohama tuvo una gran influencia en Latinoamérica donde se elaboró un diagnóstico coordinado y publicado por el Instituto Interamericano del niño, con sede en Montevideo, (IIN 2000) que contiene un análisis de la situación con diez países de la región, con el apoyo de UNICEF.
} 
de explotación sexual y sus nuevos escenarios en un apartado dedicado a las imágenes de pornografía infantil o abuso infantil, exhorta a los Estados y las sociedades correspondientes a que:

a) "se criminalicen la producción, distribución, recepción y posesión intencional de pornografía infantil, incluyendo imágenes virtuales y la representación de niños, niñas y adolescentes con fines de explotación sexual, así como el consumo, acceso y visualización intencional de dichos materiales. Cuando no haya habido contacto físico con el niño, la responsabilidad legal debe extenderse a entidades como corporaciones y compañías por su responsabilidad o participación en la producción y/o difusión de dichos materiales.

b) se realicen acciones específicas para prevenir y detener la pornografía infantil y la utilización de Internet y las nuevas tecnologías para la preparación de niños para abuso virtual o físico y para la producción y difusión de pornografía infantil y otros materiales. La identificación de la víctima, el apoyo y la atención por parte de personal especializado deben ser una prioridad.

c) se lleven a cabo campañas educativas y de concientización que se concentren en los niños, padres, maestros, organizaciones juveniles y otras que trabajan con y para los niños, con el fin de mejorar su compresión de los riesgos del uso de Internet, teléfonos celulares y otras tecnologías nuevas con fines de explotación sexual, incluyendo brindar información a los niños sobre cómo protegerse, conseguir ayuda y denunciar instancias de pornografía infantil y de explotación sexual en línea.

d) se tomen las medidas legislativas necesarias para requerir que los proveedores del servicio de Internet, las empresas de telefonía móvil, los motores de búsqueda y otros actores pertinentes denuncien y retiren los sitios web de pornografía infantil y las imágenes de abuso sexual infantil, además de desarrollar indicadores para monitorear los resultados y mejorar los esfuerzos.

e) se urjan a los proveedores de Internet, las empresas de telefonía móvil, los cibercafés y otros actores pertinentes a que desarrollen e implementen Códigos de Conducta voluntarios y otros mecanismos de responsabilidad 
social corporativa junto con el desarrollo de herramientas legales para permitir la adopción de medidas de protección de los niños en sus empresas.

f) se exhorten a las instituciones financieras a que tomen medidas para rastrear y detener el flujo de transacciones financieras realizadas a través de sus servicios que faciliten el acceso a la pornografía infantil.

g) se confeccionen una lista común de sitios web, con el auspicio de Interpol, que contengan imágenes de abuso sexual, basándose en estándares uniformes, cuyo acceso será bloqueado; la lista deberá ser actualizada continuamente, compartida a nivel internacional y utilizada por el proveedor para bloquear el acceso.

h) se realicen investigaciones y desarrollen, en el sector privado, tecnologías sólidas para identificar imágenes tomadas con dispositivos electrónicos digitales y poder rastrearlas y retirarlas para contribuir a la identificación de los perpetradores.

i) Se promuevan la asociación entre el sector privado y el público para mejorar la investigación y desarrollo de tecnologías sólidas para investigar y rastrear a las víctimas con el fin de detener de inmediato su explotación y brindarles todo el apoyo necesario para su total recuperación.

j) se logren que se pueda acceder a las tecnologías con facilidad, que sean económicas y que padres y otros cuidadores las encuentren sencillas de utilizar, además de asistir en el uso de filtros para bloquear las imágenes de niños que sean dañinas o inapropiadas" 240 .

Vale destacar el hecho de que si en los dos Congresos anteriores las advertencias respecto del poder de las tecnologías de información ya eran relevantes por la dinámica que generan sobre la creación, producción, tráfico y consumo de iconografías asociadas a la pornografía infantil, en este la naturaleza digital adquirida por las manifestaciones de pornografía infantil ya están instaladas en el corazón de las instituciones internacionales que observan su desarrollo.

Aunque con menos realce que los dos Congresos Mundiales mencionados anteriormente, conviene mencionar por su ocurrencia y participación de Estados y

${ }^{240}$ III Congreso Mundial sobre la explotación de niños, niñas y adolescentes. Declaración de Río de Janeiro y Plan de Acción para prevenir y detener la explotación sexual de niños y adolescentes (2008). 
voceros de la comunidad europea, el Encuentro Internacional de Expertos celebrado en Lyón en mayo de $1998^{241}$, y la Conferencia Internacional de Lucha contra la Pornografía Infantil en Internet celebrada en Viena en 1999. En la Conferencia de Viena se proclamó la tolerancia cero y la penalización en todo el mundo de la producción, distribución, trasmisión, importación, posesión intencional y propaganda de pornografía infantil, señalando la necesidad de una colaboración y asociación más estrechas entre los gobiernos y el sector de Internet.

En el Encuentro de Lyón se efectuaron las siguientes recomendaciones a) la necesidad de adopción en la legislación de los ordenamientos nacionales de medidas legislativas que incriminen la producción, distribución, comunicación, importación, exportación y posesión de pornografía infantil, incluida la pseudo/pornografía, a través de Internet; b) la armonización internacional en cuanto al límite de edad en la conceptualización de los menores y en cuanto a la definición de pornografía infantil; c) el incremento de la cooperación policial y judicial, tanto en cuestiones relativas a la aplicación de la ley penal como con relación a la asistencia técnica; d) la promoción del desarrollo de programas similares a los antivirus, que permitan filtrar o bloquear la pornografía infantil en Internet (PSI), mediante una base de datos central actualizada regularmente con impresiones de imágenes de pornografía infantil ${ }^{242}$.

En una reunión promovida por la UNESCO en París (1999) con la participación de cuarenta países, aproximadamente trecientos especialistas se abocaron a analizar los retos que plantea y las formas de combatir el uso creciente de Internet para la pedofilia y la pornografía infantil. Allí se informó del incremento en el número de niños que son ubicados por este medio con el propósito de ser abusados sexualmente y de los millones de fotografías de niños que circulan y se difunden a través de él. Se señaló que tan sólo en Japón se habían contabilizado más de 1300 sitios de pornografía con imágenes de

\footnotetext{
${ }^{241}$ Este Encuentro contó con la asistencia de 19 países e importantes Organizaciones No Gubernamentales.

${ }^{242}$ MARCOS MARTÍN, T., “Pornografía infantil en...”, op. cit, pág. 331.
} 
menores disponibles. Se emitió una declaración y se acordaron diversas medidas para hacer frente al problema ${ }^{243}$.

Desde la perspectiva exclusivamente infantil, en el marco del vigésimo séptimo período extraordinario de sesiones de la Asamblea General, Naciones Unidas elabora el Informe del Comité Especial Plenario ${ }^{244}$. Se aprueba el Documento "Un mundo apropiado para los niños" en el que se reitera la necesidad de proteger a los niños, entendiendo por éstos a todos los seres humanos menores de dieciocho años, de todas las formas de explotación sexual, incluida la pedofilia, la trata de personas y los secuestros. Naciones Unidas reconoce como elementos clave a los fines de su eficacia: la promulgación de leyes, la facilitación y asignación de recursos financieros y su supervisión. En relación a la pornografía infantil se compromete entre otras a:

a) tomar medidas con carácter de urgencia, a nivel nacional e internacional, para erradicar la venta de niños y de sus órganos, impedir que se les haga objeto de explotación y abusos sexuales, incluida su utilización con fines pornográficos, de prostitución y pedofilia, y luchar contra los mercados existentes en esa esfera;

b) crear conciencia de la ilegalidad y las consecuencias nocivas de la explotación y el abuso sexuales, incluso por conducto de la Internet;

c) tomar las medidas para tipificar como delito y sancionar efectivamente, de conformidad con todos los instrumentos internacionales pertinentes y aplicables, la prostitución infantil, la pedofilia, la pornografía infantil, el turismo sexual con participación de niños, la trata, la venta de niños y de sus órganos y la utilización de niños en trabajo forzoso y cualquier otra forma de explotación, al tiempo que se vela por que, en el tratamiento por el sistema de justicia penal de los niños que son víctimas, la consideración primordial sea el interés supremo del niño.

d) para combatir la utilización ilícita de las tecnologías de la información, incluida la Internet, a los fines de la venta de niños, la prostitución infantil, la

\footnotetext{
243 ESTES R. J.; AZAOLA E., (Coords.), La infancia como mercancía sexual. Ed. Siglo veintiuno, México D.F., 2003, pág. 23.

244 Asamblea General, vigésimo séptimo período extraordinario de sesiones, Suplemento No. 3(A/S27/19/Rev.1). Naciones Unidas. Nueva York 2002.
} 
pornografía infantil, el turismo sexual con participación de niños, la pedofilia y otras formas de violencia contra los niños y los adolescentes se tomaran las medidas que impliquen la cooperación entre los gobiernos, las organizaciones intergubernamentales, el sector privado y las organizaciones no gubernamentales.

Llama la atención la utilización los usos asignados al término "pedofilia" en este Documento. En efecto se propone perseguir y tipificar la pedofilia como conductas análogas o similares a las de pornografía infantil o prostitución. Hasta ahora la tipificación de esta tendencia sexual es rechazada por la mayoría de la doctrina, pues el pedófilo o paidófilo no realiza ninguna conducta que ponga en peligro bien jurídico alguno. Las autoridades de la lengua española reconocen como paidofilia la "Atracción erótica o sexual que una persona adulta siente hacia niños o adolescentes". Obviamente la ambigüedad en los usos de términos no ayuda a la delimitación del problema; antes bien, extiende sobre ellos el mismo tratamiento estigmatizando uno y otro y legitimando la punibilidad generalizada. En ese sentido, cabe advertir de las limitaciones de los documentos y congresos internacionales, puesto que en cuanto se refiere a la doctrina española las diferencias entre pedofilia o paidofilia y la pederastia están fuera de dudas, como también lo está que la primera no constituye delito alguno.

En cualquier caso, el documento "Un mundo apropiado para los niños" que comentamos abunda en la misma línea de los instrumentos anteriores de las Naciones Unidas teniendo en cuenta el interés superior del niño. Se propone recabar el apoyo del sector privado, incluido el sector del turismo, y de los medios de comunicación para llevar a cabo una campaña contra la explotación sexual y la trata de niños; determinar y combatir las causas subyacentes y los factores fundamentales, incluidos los factores externos, que llevan a la explotación sexual y la trata de niños. Aplicar estrategias de prevención contra la explotación sexual y la trata de niños; garantizar la seguridad y la protección de las víctimas de la trata de niños y de la explotación sexual y prestarles asistencia y servicios para facilitar su rehabilitación y reintegración social; y brindarle una protección especial a los niños más vulnerables como los indígenas que pertenecen a minorías que se encuentran en una inferioridad desproporcionada debido a todo tipo de discriminación, incluida la discriminación racial. 
En la misma dirección del documento anterior, la Resolución de la Comisión de Derechos Humanos ${ }^{245}$ de las Naciones Unidas (2002), destaca la necesidad de luchar contra todas las formas de violencia sexual y trata de personas, e insta a los Gobiernos a que tipifiquen como delito tales conductas y alienten a quienes prestan servicios de Internet para que adopten o hagan más estrictas las medidas de autorregulación que promuevan una utilización más responsable de estos servicios.

Aunque no proviene emanado de la misma fuente, no puede dejar de mencionarse el texto que acuerda la Organización Internacional del Trabajo (OIT), El Convenio sobre la prohibición de las peores formas de trabajo infantil y la acción inmediata para su eliminación ${ }^{246}$, que se convierte en un referente en las sucesivas manifestaciones de las distintas instituciones nacionales, regionales e internacionales. Aporta una conceptualización necesaria en la definición de menor ${ }^{247}$ y un reconocimiento claro de las peores formas de trabajo infantil entre las cuales identifica -en su artículo tercero- las siguientes:

(a) Todas las formas de esclavitud o las prácticas análogas a la esclavitud, como la venta y el tráfico de niños, la servidumbre por deudas y la condición de siervo, y el trabajo forzoso u obligatorio, incluido el reclutamiento forzoso u obligatorio de niños para utilizarlos en conflictos armados.

(b) La utilización, el reclutamiento o la oferta de niños para la prostitución, la producción de pornografía o actuaciones pornográficas (...).

(c) La utilización, el reclutamiento o la oferta de niños para la realización de actividades ilícitas, en particular la producción y el tráfico de estupefacientes, tal y como se definen en los tratados internacionales pertinentes.

(d) El trabajo que, por su naturaleza o por las condiciones en que se lleve a cabo, es probable que dañe la salud, la seguridad o la moralidad de los niños.

\footnotetext{
${ }^{245}$ Resolución de la Comisión de Derechos Humanos 2002/51. Naciones Unidas.

${ }^{246}$ Conferencia Internacional del Trabajo, Convenio no 182, Ginebra, junio de 1999.

${ }^{247}$ A tal efecto, el artículo 2 identifica "niño" con toda persona menor de dieciocho años.
} 
El hecho de que los organismos internacionales como la OIT y Naciones Unidas reconozcan expresamente que la pornografía infantil es "una de las peores formas de trabajo infantil”, muestra la inmensa preocupación que existe a nivel internacional sobre este fenómeno delictivo que se ha redimensionado con la eclosión de las altas tecnologías de información y comunicación. Al ser objeto de los pronunciamientos y denuncias, así como de las recomendaciones de prácticas y políticas de parte de estas entidades ha significado que en cuanto es el Derecho internacional el problema de la pornografía infantil ha llegado a un máximo de sensibilización de los organismos internacionales. Sin embargo, para el caso de la OIT tal reconocimiento y pronunciamientos lleva implícito el compromiso de los Estados firmantes a prohibir y eliminar tales prácticas. Como ya se advierte, a diferencia de otros documentos que representaban solo una declaración de intenciones de los países firmantes de los acuerdos, este Convenio sobre la prohibición de las peores formas de trabajo infantil y la acción inmediata para su eliminación se convirtió en un referente internacional muy presente en las sucesivas resoluciones, tratados e informes relacionados con menores. Por lo demás, enmarca el problema dentro del mundo del trabajo lo que abre una óptica más amplia y plural para considerarlo desde la perspectiva socio / criminológica especialmente para encuadrar su tratamiento en la situación de extrema pobreza de muchos países.

\subsection{DeSARrollo Normativo EN El ESPACIO COMUNitARIO EUROPEO.}

En el interregno de los documentos principales que hemos visto hasta aquí, estableciendo como hitos la Convención de los Derechos del Niño de 1989 y el establecimiento de los Protocolos Facultativos que lo desarrollan relativos a la participación de niños en conflictos armados y a la venta de niños, la prostitución infantil y la utilización de niños en pornografía, del año 2000, se generó en Europa todo un compendio de resoluciones, acuerdos, comunicaciones, recomendaciones y otros que, en el marco de las competencias de las instituciones comunitarias, abonaron el terreno para los avances que se han alcanzado en materia internacional. Este aparte pretende dar cuenta de ello, no solo con fines de apreciar su significado en la construcción de un cuerpo doctrinario y de políticas que luego influyeron en el concierto internacional, también lo hacemos como marco propiamente dicho del 
desarrollo legislativo y doctrinario que en la materia se ha consagrado en el Derecho español que será objeto de un tratamiento especial en el capítulo tercero de este trabajo.

Un apunte importante de realizar antes de iniciar la revisión de cada documento en detalle, es que la actividad de producción y aprobación de instrumentos referidos a la pornografía infantil ha sido profuso y abundante en la Unión Europea. El avance de las TIC y la aparición de nuevas formas de difusión han hecho que se trasponga un Documento tras otro en forma de Resolución, Comunicación, Dictamen, Documento, Recomendación, etc. Adicionalmente hay que señalar que la mayoría de esos documentos no tienen una vinculación jurídica directa, lo que, sin embargo, no menoscaba su importancia en el farragoso proceso de formación de normas de la Unión Europea y en su traducción con el paso de los años en documentos que alimentan la doctrina. Este aparte solo pretende a grandes rasgos precisar aquellos que podemos tratar como hitos referenciales para la doctrina y su influencia en los marcos normativos comunitarios. Para ello nos servimos de la investigación minuciosa y sistemática realizada por la doctrina española en especial MORILLAS FERNÁNDEZ ${ }^{248}$ 249. $^{249}$.

\footnotetext{
${ }^{248}$ Véase, MORILLAS FERNÁNDEZ, D. L., Análisis dogmático y criminológico..., op. cit., pag. 34.

249 Refiere MORILLAS FERNÁNDEZ, la recurrencia de este cuerpo de ideas en toda la producción declarativa o normativa de las instituciones comunitarias. Obsérvese, sin embargo, en la larga cita de este autor la marcada y reiterada incidencia desde mediados de los años noventa cuando irrumpe de manera generalizada Internet en la vida social. "Idea plasmada en la Resolución del Parlamento Europeo de 19 de septiembre de 1996, sobre los menores víctimas de violencia (DO C 320 p. 0190) donde se sugiere la creación de unidades especializadas en asuntos de delincuencia sexual que afecten a niños y la necesaria cooperación interestatal como única vía para desmantelar las redes organizadas; Resolución de la Asamblea Parlamentaria del Consejo de Europa 1099 (1996), de 25 de septiembre de 1996, sobre explotación sexual de menores; Resolución 51/77 de 20 de febrero de 1997 de la Asamblea General de Naciones Unidas, sobre derechos del niño, en relación a la cooperación que debe existir entre autoridades e instituciones competentes encargadas de hacer cumplir la ley a fin de desmantelar las redes nacionales, regionales e internacionales de trata de niños; Resolución sobre la Comunicación de la Comisión relativa a los contenidos ilícitos y nocivos en Internet, de 24 de abril de 1997 (DO C 150 de 19/05/1997 p. 0038) en consonancia con la formación de funcionarios de policía para la detección y represión de los delitos vinculados a los medios telemáticos y la colaboración entre policías en los casos de pornografía infantil detectados en las redes informáticas; Resolución del Parlamento Europeo de 6 de noviembre de 1997 sobre la Comunicación de la Comisión sobre la lucha contra el turismo sexual que afecta a niños y el Memorándum relativo a la contribución de la Unión Europea a la intensificación de la lucha contra los abusos y la explotación sexual de que son víctimas los niños (DO C 358 de 24/11/1997 p. 0037), sobre el papel principal que debe ejercer la Europol en la lucha contra la explotación sexual de los niños; Protocolos facultativos de la Convención sobre los Derechos del Niño relativos a la participación de niños en conflictos armados y a la venta de niños, la prostitución infantil y la utilización de niños en pornografía. Asamblea General de Naciones Unidas (A/54/L.84), artículo 10 sobre la cooperación internacional entre Estados; la Propuesta de Decisión Marco del Consejo relativa a la lucha contra la explotación sexual de los niños y la pornografía infantil (2001/2025 (CNS)) incluida como Anexo en la Comunicación de la Comisión al Consejo y al Parlamento Europeo sobre lucha contra la trata de seres humanos y lucha contra la explotación sexual de los niños y la pornografía infantil, (2001/0025 (CNS)),
} 
Prueba de cuanto afirmamos en el párrafo anterior, alineado con lo que nos interesa, es la Recomendación (91) 11 del Comité de Ministros del Consejo de Europa de 1996, que habla de figuras delictivas concretas como la pornografía infantil, la prostitución y el tráfico de niños y adultos. Respecto de la pornografía infantil, advierte la Recomendación que se cita, recogiendo el legado de las conclusiones fundamentales del Congreso de Estocolmo, que es necesaria "la adopción de medidas tendentes a castigar la producción y distribución, estudiar si cabe lícitamente tipificar la posesión, buscar la cooperación entre Estados para perseguir tales actos e introducir nuevas medidas de control social como por ejemplo una especialización de diversos sectores en esta materia" 250 .

La Asamblea Parlamentaria del Consejo de Europa toma la iniciativa de pronunciar la Resolución 1099 (1996), apenas un mes después del Congreso de

aprobada por Resolución Legislativa del Parlamento Europeo en su Acta de 12/ 06/2001 (A5-0206/2001), texto en DO C 062 de 27/02/2001 p. 0327-0330, sobre cooperación policial y judicial en materia penal; Moción presentada a la Asamblea Parlamentaria del Consejo de Europa sobre la "protección de los menores contra la pornografía infantil en Internet" el 7 de mayo de 2001 (Documento 9093) sobre la colaboración policial en la lucha contra la pornografía infantil; Comunicación de la Comisión al Consejo, al Parlamento Europeo, al Comité Económico y Social y al Comité de las Regiones para la Creación de una sociedad de la información más segura mediante la mejora de la seguridad de las infraestructuras de información y la lucha contra los delitos informáticos, eEurope 2002, hecho en Bruselas el 26 de enero de 2001 (COM (2000) 890 final), en relación a medidas no legislativas como la especialización de unidades o cooperación entre Estados; en el mismo sentido Dictamen del Comité Económico y Social sobre la "Comunicación de la Comisión al Consejo, al Parlamento Europeo, al Comité Económico y Social y al Comité de las Regiones, eEurope 2002" (DOC 311 de 07/11/2001 p. 0012-0019); Recomendación (2001) 16 del Comité de Ministros del Consejo de Europa, adoptada el 31 de octubre de 2001, Título VIII referente a la cooperación internacional; Dictamen del Comité de las Regiones sobre la "Comunicación de la Comisión al Consejo y al Parlamento Europeo -Lucha contra la trata de seres humanos y lucha contra la explotación sexual de los niños y la pornografía infantil", la "Propuesta de Decisión marco del Consejo relativa a la lucha contra la trata de seres humanos" y la "Propuesta de Decisión marco del Consejo relativa a la lucha contra la explotación sexual de los niños y la pornografía infantil" (DO C 357 de 14/12/2001 p. 0041- 0043), referente a la armonización del Derecho penal y mejora de la cooperación en materia policial; la Resolución del Consejo relativa a la aportación de la sociedad civil en la búsqueda de niños desaparecidos y explotados sexualmente (DO C 283 de 09/10/2001 p, 0001-0002), referente a la cooperación de los Estados miembros en la localización de niños desaparecidos y explotados sexualmente; Informe del Comité Especial Plenario del vigésimo séptimo período extraordinario de sesiones de la Asamblea General de Naciones Unidas (A/S-27/19/Rev. 1) con el propósito de fomentar una mayor cooperación entre los gobiernos, las organizaciones intergubernamentales, el sector privado y las organizaciones no gubernamentales para combatir la utilización ilícita de las tecnologías de la información, incluida Internet; Recomendación 1583 (2002) del Consejo de Europa sobre prevención de los delitos contra menores, en donde se invita a los Estados miembros a que coordinen sus esfuerzos para combatir la pornografía infantil y la explotación sexual de menores; Decisión Marco 2004/68/JAI del Consejo, de 22 de diciembre de 2003, relativa a la lucha contra la explotación sexual de los niños y la pornografía infantil (DO L 13 de 20/01/2004 pág. 44-48)" MORILLAS FERNÁNDEZ, D. L., Análisis dogmático y criminológico..., op. cit., págs. 33 y ss.

${ }^{250}$ Véase, MORILLAS FERNÁNDEZ, D. L., Análisis dogmático y criminológico..., op. cit., págs. 32 y ss. 
Estocolmo, por lo que bien puede calificársele de pionera en el encaje legal de las normas, principios y conclusiones derivadas del Congreso de Estocolmo y asentadas en los documentos de Naciones Unidas antes revisadas. En el artículo 4 de ésta Resolución se insiste en la Recomendación un mil sesenta y cinco del año 1987 sobre tráfico de niños y otras formas de explotación infantil, en la que insta a los Estados miembros a la promulgación de leyes y regulaciones estrictas para combatir la pornografía infantil, y armonizar las legislaciones de los Estados miembros relevantes, y exhorta a estos a combatir la pornografía infantil en todas sus formas (publicaciones, videos, Internet). En su artículo 12 la Asamblea insta a los Estados miembros a que refuercen las medidas punitivas a nivel nacional y la legislación sobre la prostitución infantil sin demora. Se subraya especialmente la necesidad de:

i." incluir en su legislación penal el principio de la persecución extraterritorial y la condena por delitos;

ii. prever una limitación legal lo suficientemente largo para el enjuiciamiento de los delitos contra menores de edad (por lo menos veinte años, y un límite de tiempo para iniciar un procedimiento que se extiende por lo menos cinco años más allá de la mayoría de edad);

iii. para crear los siguientes nuevos delitos, castigados con penas de disuasión:

a. la posesión de material pornográfico, como videos, documentos o fotografías a los niños;

b. la fabricación, transporte y distribución de material pornográfico que muestra los menores de edad;

c. la radiodifusión y la grabación de imágenes pornográficas de menores de edad;

iv. para promulgar la legislación establece que todos los delitos sexuales con niños deberían ser clasificados como delitos graves, delitos que en ningún caso se incluirán en la categoría de delitos menos graves;

v. armonizar, en la medida de lo posible en toda Europa, el tratamiento de delincuentes sexuales, en particular en relación con la liberación condicional, tratamiento psicológico y el control social; 
vi. para incorporar en su legislación el principio de que un menor de 15 años no puede dar su consentimiento o su a tener relaciones sexuales con un adulto;

vii. permitir que las asociaciones de protección del niño y las organizaciones no gubernamentales (ONG) que actúan como querellantes en los casos de abuso sexual de niños.

Desde un primer momento las iniciativas venidas del ámbito europeo estuvieron marcadas por dos hechos: la acertada concepción de una pornografía infantil redimensionada por el potencial ilimitado de Internet y la voluntad de concebir y aplicar políticas de intervención, sea mediante la regulación ordenadora del Derecho, sea a través de iniciativas administrativas de todo orden que permitiera un análisis más profundo del tema. De allí que se expandiera un campo de actuación constitutivo de múltiples medidas, políticas o programas comunes, de vigencia temporal en procura de estudiar, desde una perspectiva multidisciplinar, la emergencia y evolución de diversas tipologías delictivas concretas a través de conferencias, estudios, proyectos de investigación, entre otros con financiamiento europeo ${ }^{251}$. Estos proyectos tienen su origen en la Acción Común de 29 de noviembre de 1996 adoptada por el Consejo de Europa sobre la base del Artículo K.3 del Tratado de la Unión Europea ${ }^{252}$, por el que se establece durante el periodo 1996-2000 un programa de fomento de iniciativas coordinadas relativas a la lucha contra la trata de seres humanos y la explotación sexual de los niños, a las desapariciones de menores y a la utilización de los medios de telecomunicación para la trata de seres humanos y la explotación sexual de niños"253.

\footnotetext{
251 "Entre ellas cabe mencionar STOP, programa de apoyo y financiamiento de la Conferencia Internacional sobre la lucha contra la pornografía infantil en Internet, celebrada en Viena en 1999 y el proyecto COPINE, estudio que se analizó el comportamiento de los consumidores de pornografía infantil, y la creación de una base de datos operativa sobre pornografía infantil que utiliza sistemas automáticos de indización y búsqueda; STOP II, (continuación del primero) programa de fomento, intercambios, formación y cooperación destinado a los responsables de la acción contra la trata de seres humanos y la explotación sexual de niños; DAPHNE programa para los años 2000-2003 de acción preventiva de la Comunidad Europea para luchar contra la violencia ejercida sobre los niños, adolescentes y las mujeres, y que surge como complemento del STOP II, entre otros ha financiado un proyecto para la identificación de víctimas de la pornografía infantil y ha organizado multitud de seminarios”. MORILLAS FERNÁNDEZ, D. L., Análisis dogmático y criminológico..., op. cit., pág. 36, nota a pie $\mathbf{N}^{\circ} 21$.

${ }^{252}$ DO L 322 de 12/12/1996 págs. 0007-0010.

${ }^{253}$ Véase, MORILLAS FERNÁNDEZ, D. L., Análisis dogmático y criminológico..., op. cit., pág. 36.
} 
En diciembre de 1996, una Resolución del Parlamento Europeo sobre medidas de protección de menores en la Unión Europea ${ }^{254}$ solicita al Consejo la adopción de propuestas encaminadas a prevenir y luchar contra la difusión de mensajes de carácter pedófilo por Internet. El Consejo, actuando en consecuencia y mediante Resolución sobre contenidos ilícitos y nocivos en Internet ${ }^{255}$ de 17 de febrero de 1997, promueve: a) Fomentar y facilitar sistemas de autorregulación, que incluyan instancias representativas de los suministradores y usuarios de los servicios de Internet, códigos de conducta eficaces $y$, eventualmente, mecanismos de información de emergencia accesibles al público ${ }^{256}$; b) Fomentar el suministro a los usuarios de mecanismos de filtro y alentar la creación de sistemas de evaluación, por ejemplo, debería promoverse la norma PICS por sus siglas en inglés (Plataforma de Selección de Contenidos de Internet) establecida por el consorcio internacional World-Wide-Web con ayuda comunitaria $^{257}$.

Con la Resolución sobre la Comunicación de la Comisión relativa a los contenidos ilícitos y nocivos en Internet, de 24 de abril de $1997^{258}$, de importancia por el uso de filtros y la prohibición en el acceso a diversas páginas que puede sufrir el usuario, queda abierto el debate respecto de la censura de la libertad de expresión en Internet. La Resolución confirma el derecho fundamental a la libertad de expresión que toda persona posee y reconoce la libre circulación de la información en Internet como una manifestación que le es inmanente; no obstante, entiende que la pornografía infantil es un delito grave porque constituye un documento visual o escrito de abusos reales contra éstos, por lo que la coexistencia de ambos generaría un conflicto de intereses a

\footnotetext{
${ }^{254}$ DO C 020 de 20/01/1997 pág. 0170.

${ }^{255}$ DO C 070 de 06/03/1997 pág. 0001-0002.

${ }^{256}$ En este sentido como un precedente relacionado, la Recomendación del Consejo de la Unión Europea de 24 de septiembre de 1998, relativa al desarrollo de la competitividad de la industria europea de servicios audiovisuales y de información mediante la promoción de marcos nacionales para ello, ordena que dicha competitividad vaya alineada con un nivel de protección comparable y efectivo de los menores y de la dignidad humana (DO L 270 de 07/10/1998 p. 0048-0055), en lo referente a códigos de conducta, información a los usuarios y posibilidad de crear señales de advertencia sonoras o visuales, marcado descriptivo o clasificación del contenido y sistemas de comprobación de la edad de los usuarios.
}

\footnotetext{
${ }^{257}$ Véase, MORILLAS FERNÁNDEZ, D. L., Análisis dogmático y criminológico..., op. cit., pág. 37.

${ }^{258}$ DO C 150 de 19/05/1997 pág.0038.
} 
resolver en beneficio del interés del débil jurídico, esto es, el menor ${ }^{259}$. De allí que concluya instruyendo a la Comisión a que elabore un etiquetado de calidad europeo aplicable a los suministradores de servicios de Internet y a que apoye una armonización a nivel internacional de un etiquetado de esas características con vistas a garantizar que los suministradores no colaboren con personas que transmiten informaciones ilícitas o nocivas.

El etiquetado que se sugiere obligaría a los suministradores de servicios de Internet a controlar y mantener la calidad de la información recogida en su sistema, pues la red no es un ente aséptico y, antes bien, puede utilizarse como herramienta para la distribución de material nocivo de temática sexual cuando las personas que aparecen son víctimas de la explotación sexual y de la degradación de su integridad y dignidad personal, estando las legislaciones nacionales limitadas para reducir los efectos nocivos de esta industria mundial, de ahí la necesidad de adoptar políticas de cooperación y colaboración entre países. Establece igualmente una propuesta de sumo interés en el alcance de la imputación de responsables al prever la posible responsabilidad de los suministradores de información en Internet pues se les reconoce la obligación de identificar al emisor; extiende hacia los padres la utilización de sistemas de control a través de las nuevas técnicas de filtrado e iniciativas de autorregulación, el establecimiento de sistemas europeos de codificación que hagan posible el control del proceso. Finalmente insta al establecimiento de dispositivos de denuncia de fácil, sencillo y gratuito uso ${ }^{260}$.

Anteriormente, la Acción Común de 24 de febrero de 1997 adoptada por el Consejo con fundamento en el artículo K.3 del Tratado de la Unión Europea, relativo a la lucha contra la trata de seres humanos y la explotación sexual de niños ${ }^{261}$ daba un paso más hacia la conceptualización de diversas formas delictuales procediendo a la

\footnotetext{
${ }^{259}$ De conformidad con este planteamiento, la Recomendación del Consejo de la Unión Europea de 24 de septiembre de 1998, señalada antes, estima necesario considerar por separado las cuestiones relativas a los contenidos ilícitos que atentan contra la dignidad humana y las cuestiones relativas a los contenidos legales que pueden ser nocivos para los menores y afectar a su desarrollo físico, mental o moral; pues estas dos problemáticas pueden requerir planteamientos y soluciones distintas. Véase, MORILLAS FERNÁNDEZ, D. L., Análisis dogmático y criminológico..., op. cit., pág. 38, pie de pág. 28.

${ }^{260}$ Véase, MORILLAS FERNÁNDEZ, D. L., Análisis dogmático y criminológico..., op. cit., pág. 38.

${ }^{261}$ DO L 063 de 04/03/1997 p. 0002-0006.
} 
definición de trata y explotación sexual de niños y adultos; a la enumeración de una serie de medidas que deben adoptarse a escala nacional (revisión de legislaciones, incriminación de personas jurídicas, confiscación y cierre de establecimientos; normas especiales sobre la competencia para entrar a conocer una determinada causa; la adecuada protección de testigos, la asistencia a las víctimas y sus familias); y al reconocimiento del principio de cooperación entre Estados y compromiso y actuación consecutiva.

Este texto, a pesar de sus aportes, ha terminado siendo demeritado ${ }^{262}$, por considerarla insuficiente en lo que se refiere a la territorialidad del delito, dejando en manos de los Estados miembros la recurrencia al principio de punibilidad en el país de comisión del delito, siendo que se había venido consolidando el principio de protección a los niños con independencia de su nacionalidad y lugar de residencia, y a la luz de la doctrina de la Unión Europea no son menos dignos de protección aquellos a quienes sus propios países les denieguen la protección. Tales documentos concluyen en la necesaria revisión de la mencionada Acción Común de 1997, con la finalidad de blindar la garantía de que no haya refugio seguro para aquellas personas sospechosas de haber explotado sexualmente a niños en un país distinto al de su origen ${ }^{263}$.

Gradualmente comienzan a ser reconocidos de manera expresa los efectos del Internet sobre la pornografía infantil y el contenido de los Documentos comunitarios cada vez con más énfasis abunda en las recomendaciones a los Estados miembros para atender el problema en el marco de su medio masivo y eficaz de propagación como lo es Internet. La Resolución del Parlamento Europeo de 6 de noviembre de 1997 sobre la Comunicación de la Comisión sobre la lucha contra el turismo sexual que afecta a niños y el Memorándum relativo a la contribución de la Unión Europea a la intensificación de

\footnotetext{
${ }^{262}$ Las criticas fueron realizadas entre otras, por la Resolución del Parlamento Europeo sobre la Comunicación de la Comisión al Consejo, al Parlamento Europeo, al Comité Económico y Social y al Comité de las Regiones sobre la aplicación de las medidas de lucha contra el turismo sexual que afecta a los niños(DO C 378 de 29/12/2000 p. 0080-0087); por la Comunicación de la Comisión al Consejo y al Parlamento Europeo sobre "lucha contra la trata de seres humanos y lucha contra la explotación sexual de los niños y la pornografía infantil", de 22 de diciembre de $2000^{262}$; o el Proyecto de Informe sobra la Comunicación de la Comisión, al Consejo, al Parlamento Europeo, al Comité Económico y Social y al Comité de las Regiones, sobre la aplicación de las medidas de lucha contra el turismo sexual que afecta a niño (COM (2000) 854 final). Véase, MORILLAS FERNÁNDEZ, D. L., Análisis dogmático y criminológico..., op. cit., pág. 43.
}

${ }^{263}$ Véase, MORILLAS FERNÁNDEZ, D. L., Análisis dogmático y criminológico..., op. cit., pág. 39. 
la lucha contra los abusos y la explotación sexual de que son víctimas los niños ${ }^{264}$ profundiza en las directrices ya expuestas en la Resolución 1099 (1996), pues reconoce expresamente que se usa cada vez más Internet como medio para difundir pornografía infantil $^{265}$. Los Estados miembros, dice la Resolución, deben armonizar el marco conceptual de sus correspondientes legislaciones penales e introducir en sus respectivos Códigos Penales tipos que contemplen los actos de pederastia, el turismo sexual que afecta a los niños, la pornografía infantil o la omisión a la justicia de los actos o indicios graves de pederastia o malos tratos a menores. En concreto se insta a los Estados a que incluyan en su legislación penal la tipificación y condena de las siguientes conductas: (a) La utilización de menores de edad con fines o en espectáculos exhibicionistas o pornográficos, tanto públicos como privados, o para elaborar cualquier clase de material pornográfico. (b) La producción, venta, distribución, exhibición o facilitación de la producción, de la venta, de la difusión, de la exhibición por cualquier medio o de la tenencia de material pornográfico en cuya elaboración hayan sido utilizados menores de edad. (c) Los asistentes a los espectáculos previstos en el apartado anterior.

\section{El Anexo I del Dictamen del Comité Económico y Social sobre Explotación} infantil y turismo sexual ${ }^{266}$ de 1998, introduce el primer intento serio y real de homologar políticas comunes entre los Estados miembros, el establecer pautas comunes de definición respecto de términos como niño, explotación infantil, negligencia y malos tratos, abandono o turismo sexual infantil ${ }^{267}$. Meses después, la Decisión $\mathrm{N}^{\mathrm{o}}$ 276/1999/CE del Parlamento Europeo y del Consejo de 25 de enero de $1999^{268}$ conviene la implementación de un plan plurianual de acción comunitaria para propiciar una mayor seguridad en la utilización de Internet mediante la lucha contra los contenidos ilícitos y nocivos en las redes mundiales ${ }^{269}$ : Ésta última hace énfasis en la necesidad de

\footnotetext{
${ }^{264}$ DO C 358 de 24/11/1997 p. 0037.

${ }^{265}$ Véase, MORILLAS FERNÁNDEZ, D. L., Análisis dogmático y criminológico..., op. cit., pág. 40.

${ }^{266}$ DO C 284 de 14/09/1998 pág. 0092.

${ }^{267}$ El segundo capítulo de ésta parte se detiene en las aristas del problema conceptual justamente a la luz de los documentos e instrumentos citados en ésta primera parte, por lo que remitimos el debate conceptual para esa sección.

${ }^{268}$ DO L 033 de 06/02/1999 p. 0001-0011.

269 De hecho, MORILLAS FERNÁNDEZ, y otros autores llaman la atención respecto de que la designación última de la decisión, luego de pasar por varias alternativas de designación, termina en el
} 
crear un entorno de utilización de Internet más seguro que no menoscabe el derecho a la libre expresión. En particular encierra las posibles acciones ilícitas mediante Internet los casos de los delitos contra menores, del tráfico de seres humanos o de la difusión de ideas racistas o xenófobas. Con ésta orientación se aprueba un Plan de acción se con vigencia de cuatro años (1999 / 2002) ${ }^{270}$, estableciendo como objetivos prioritarios el fomento de la autorregulación del sector, el filtrado y los mecanismos de supervisión de los contenidos $^{271}$, especialmente los relativos a pornografía infantil o aquellos que inciten al odio por motivos de raza, sexo y religión. En procura de poner a disposición de los ciudadanos mecanismos de denuncia se insta a la creación de líneas directas que permitan a los usuarios notificar los contenidos ilícitos arriba identificados.

La Propuesta de Decisión del Parlamento Europeo y del Consejo por la que se modifica la Decisión No 276/1999/CE que comentamos amplía el ámbito de influencia de la norma al espectro de medios más allá de Internet, a las nuevas tecnologías en línea, incluidos los contenidos de telefonía móvil, banda ancha, juegos en línea, transferencia de archivos de igual a igual y todas las formas de comunicación en tiempo real, incluidos las salas de charla electrónica y los mensajes inmediatos ${ }^{272}$. Doce años después de la sanción de la Decisión citada buena parte del tráfico o intercambio de iconografía virtual de pornografía infantil ocurre mediante las redes sociales que vienen sustituyendo otros espacios de comunicación virtual como el chat o el correo.

Casi inmediatamente a la aprobación del Protocolo Facultativo de la Convención sobre los Derechos del Niño de Naciones Unidas en febrero de 2000, el 29 de mayo de

mismo nombre justificándose mediante la relación que asocia seguridad en Internet con la ausencia de contenidos ilícitos y/o nocivos. Así en la Propuesta de Decisión del Parlamento Europeo y del Consejo por la que se modifica la Decisión $n^{\circ}$ 276/1999/CE por la que se aprueba un plan plurianual de acción comunitaria para propiciar una mayor seguridad en la utilización de Internet mediante la lucha contra los contenidos ilícitos y nocivos en las redes mundiales, hecha en Bruselas el 22 de marzo de 2002, se propone, entre otras modificaciones, enunciar el referido texto como sigue "Decisión N 276/1999/CE del Parlamento Europeo y del Consejo de 25 de enero de 1999 por la que se aprueba un plan plurianual de acción comunitaria para propiciar una mayor seguridad en la utilización de Internet y las nuevas tecnologías en línea mediante la lucha contra los contenidos ilícitos y nocivos (eSafe)". Véase, MORILLAS FERNÁNDEZ, D. L., Análisis dogmático y criminológico..., op. cit., pág. 41.

${ }^{270}$ Más adelante se terminaría extendiendo su vigencia mediante prórrogas sucesivas hasta 2004 y 2006 respectivamente.

${ }^{271}$ De igual forma recogidas como las tres líneas principales de actuación en la referida Propuesta de Decisión del Parlamento Europeo y del Consejo por la que se modifica la Decisión N 276/1999/CE.

${ }^{272}$ Véase, MORILLAS FERNÁNDEZ, D. L., Análisis dogmático y criminológico..., op. cit., pág. 41. 
2000 se aprueba la Decisión del Consejo de la Unión Europea relativa a la lucha contra la pornografía infantil $(2000 / 375 / \mathrm{JAI})^{273}$ con el propósito de prevenir y combatir el abuso sexual de los niños y, en particular, la producción, el tratamiento, la posesión y la difusión de material pornográfico infantil a través de Internet ${ }^{274}$. Para lograr tales objetivos se emiten varias medidas de control social formales e informales. Entre ellas se mencionan:

a) Las medidas de control social informales giran sobre dos ejes. Uno de ellos demanda la colaboración de todos los internautas con las autoridades policiales comunicando sus sospechas sobre la difusión de material pornográfico en la red, para lo que se proponen las llamadas líneas directas. El segundo eje exige la cooperación de los proveedores de Internet retirando de la circulación el material de pornografía infantil del que tengan conocimiento, conservando datos de tráfico referentes a estas páginas con el propósito de perseguir penalmente a sus autores, creando sistemas propios de control destinados a combatir la producción, el tratamiento, la posesión y la difusión del referido material, y estableciendo filtros de control, de forma conjunta con los Estados miembros, como técnica de prevención.

b) Dentro del campo del control social formal, destaca el impulso definitivo a la creación de unidades especializadas dentro del ámbito policial con los conocimientos específicos, atributos particulares y los recursos materiales necesarios para tratar con celeridad las denuncias o informaciones sobre supuestos casos de producción, tratamiento, difusión y posesión de pornografía infantil, debiendo informar en la medida de lo posible a Europol y actuando con sujeción al principio de cooperación entre Estados con el propósito de facilitar la investigación y persecución eficaz de estos hechos delictivos ${ }^{275}$.

\footnotetext{
${ }^{273}$ DO L 138 de 9/6/2000 págs. 0001 -0004.

${ }^{274}$ Es importante distinguir entre dos documentos presentados en el año 2000 por el Consejo de la Unión Europea, el primero de ellos es esta Decisión del Consejo de 29 de mayo de 2000 orientada únicamente a aspectos esenciales para la coordinación de medios de lucha no legislativos contra la pornografía infantil; el otro es la Propuesta de Decisión Marco del Consejo relativa a la lucha contra la explotación sexual de los niños y la pornografía infantil, hecha en Bruselas el 22/12/2000, centrada exclusivamente en aspectos legislativos sobre esta materia.

${ }^{275}$ Véase, MORILLAS FERNÁNDEZ, D. L., Análisis dogmático y criminológico..., op. cit., pág. 44 y ss.
} 
La Resolución del Parlamento Europeo sobre la Comunicación de la Comisión al Consejo, al Parlamento Europeo, al Comité Económico y Social y al Comité de las Regiones sobre la aplicación de las medidas de lucha contra el turismo sexual que afecta a los niños (A5-0052/2000) ${ }^{276}$ destaca por el reflejo sólido, descarnado y real que realiza de la pornografía infantil. Reconoce el alcance limitado de los tratados y documentos comunitarios que al permanecer dentro del campo de lo conceptual y lo declarativo en forma de principios no desarrollan políticas concretas susceptibles de aplicación ${ }^{277}$. Luego pasa a señalar enfáticamente que la única posibilidad de actuación eficaz de las instituciones europeas en procura de propiciar cambios en la realidad diagnosticada alusiva en este caso al turismo sexual que afecta a los niños, es la realización y apoyo de determinados proyectos concretos. Para MORILLAS FERNÁNDEZ, la Resolución acierta respecto de los principales defectos caracterizadores de las políticas comunitarias llevadas a cabo hasta el momento, pues, o bien se procede a delimitar conceptualmente algún término, a indicar la existencia del problema o, regularmente como conclusión, a apuntar la necesidad de adoptar políticas comunes. Del mismo modo reconoce, dentro de un planteamiento pesimista, que “...la imposibilidad de controlar Internet favorece la comisión de tales crímenes, ya que a través de esa red se puede difundir gratuitamente material de pornografía infantil ${ }^{, 278}$; la ratificación en la concepción de menor a toda persona que no haya cumplido los dieciocho años y la necesidad de

\footnotetext{
${ }^{276}$ DO C 378 de 29/12/2000 pág. 80-87.

${ }^{277}$ Entre otras, deben reseñarse necesariamente la Resolución del Parlamento Europeo de 12 de diciembre de 1996, la Resolución del Parlamento Europeo de 6 de noviembre de 1997 sobre la Comunicación de la Comisión sobre la lucha contra el turismo sexual que afecta a niños y el Memorando relativo a la contribución de la Unión Europea a la intensificación de la lucha contra los abusos y la explotación sexual de que son víctimas los niños, la Decisión del Consejo de la Unión Europea relativa a la lucha contra la pornografía infantil aprobada el 29 de mayo de 2000 (2000/375/JAI) (...). Varios autores coinciden en este juicio, entre otros, MORILLAS FERNÁNDEZ, D. L., Análisis dogmático y criminológico..., op. cit.; MARCOS MARTÍN, T., Pornografía infantil en..., op. cit., págs. 317-334.

${ }^{278}$ Ha resultado polémica la calificación de “...imposibilidad de controlar Internet..." a que hace mención la Resolución. En efecto, posteriormente el Dictamen del Comité de las Regiones sobre la "Comunicación de la Comisión al Consejo y al Parlamento Europeo -Lucha contra la trata de seres humanos y lucha contra la explotación sexual de los niños y la pornografía infantil", la "Propuesta de Decisión marco del Consejo relativa a la lucha contra la trata de seres humanos" y la "Propuesta de Decisión marco del Consejo relativa a la lucha contra la explotación sexual de los niños y la pornografía infantil" (DO C 357 de 14/12/2001 p. 0041-0043) sustituyen el adjetivo "imposible" por el de "dificil" al referirse a la necesaria regulación de Internet.
} 
establecer una legislación común que prohíba explícitamente la utilización de Internet para propagar mensajes de esa naturaleza ${ }^{279}$.

En diciembre del año 2000 se presentan al Consejo y al Parlamento de la Unión Europea la Comunicación de la Comisión sobre lucha contra la trata de seres humanos y lucha contra la explotación sexual de los niños y la pornografía infantil ${ }^{280}$, en la que se recoge una Propuesta de Decisión Marco del Consejo relativa a la lucha contra la trata de seres humanos ${ }^{281}$ y otra relativa a la lucha contra la explotación sexual de los niños y la pornografía infantil ${ }^{282}$.

La Comunicación surge con la intención de establecer una serie de normas comunes relativas a los elementos constitutivos del Derecho penal en materia de trata de seres humanos y explotación sexual de niños, con especial referencia a la pornografía infantil en Internet. No obstante, amplía el haz de alternativas de formas de actuación sobre el asunto para incluir una gama de medidas de control social que van desde la rigurosa salvaguarda legal de todos los individuos hasta pautas preventivas pasando por medidas para garantizar la adecuada protección y asistencia a las víctimas y abordar toda la cadena entera tanto de la trata como de la explotación. La Comunicación tiene sus méritos: identifica el acentuado carácter virtual de la pornografía infantil, orienta su tratamiento penal considerando toda la cadena y sugiere el necesario control social del delito como mecanismo de participación e la sociedad en un asunto que difícilmente pueda ser abordado solo desde el Estado. Lamentablemente la adecuación normativa y de políticas ha restringido el control social a la esfera penal ensanchando su ratio y olvidado el conjunto de medidas que ya sugerían los documentos comunitarios -en perfecta comunión con las políticas de bienestar europeas de amplio arraigo- y que han sido barridos posteriormente al amparo de la ideología de la seguridad.

\footnotetext{
${ }^{279}$ Véase, MORILLAS FERNÁNDEZ, D. L., Análisis dogmático y criminológico..., op. cit., págs. 45 y SS.

${ }^{280} \mathrm{COM}$ (2000) 854 final.

${ }^{281} 2001 / 0024$ (CNS).

${ }^{282} 2001 / 0025$ (CNS).
} 
La Propuesta de Decisión Marco del Consejo, relativa a la lucha contra la explotación sexual de los niños y la pornografía infantil ${ }^{283}$, es una pequeña "Ley especial sobre explotación sexual a los niños y pornografía infantil" que concretó su aprobación de forma definitiva el 22 de diciembre de 2003 como Decisión Marco 2004/68/JAI del Consejo, relativa a la lucha contra la explotación sexual de los niños y la pornografía infantil ${ }^{284}$. En el espacio de tiempo entre la Propuesta y la Decisión definitiva fueron muchos los documentos oficiales sobre posibles modificaciones o enmiendas al texto provisional propuesto como la Resolución Legislativa del Parlamento Europeo aprobada en su Acta del 12/06/2001 (A5-0206/2001) ${ }^{285}$.

En enero de 2001 se presenta la Comunicación de la Comisión al Consejo, al Parlamento Europeo, al Comité Económico y Social y al Comité de las Regiones para la Creación de una sociedad de la información más segura mediante la mejora de la seguridad de las infraestructuras de información y la lucha contra los delitos

${ }^{283}$ El Parlamento Europeo formula enmiendas al referido Texto, siendo finalmente aprobado en la Decisión Marco 2004/68/JAI del Consejo, de 22 de diciembre de 2003, relativa a la lucha contra la explotación sexual de los niños y la pornografía infantil (DO L 13 de 20.1.2004 pág. 44-48).

${ }^{284}$ DO L 13 de 20/01/2004 pág. 44-48.

${ }^{285}$ Entre el amplio articulado sugerido por el Parlamento Europeo destacan las siguientes Enmiendas: $L a$ Enmienda 42 del Parlamento Europeo define "conducta sexualmente explícita" como: "i) todo material audiovisual, textual o escrito, con independencia de su naturaleza, como por ejemplo fotografías, fotomontajes, películas, cintas de vídeo, películas cinematográficas y datos informáticos elaborados, elaborado en soporte electrónico, mecánico o de cualquier otro tipo que: - represente a niños participando o presenciando actos explícitamente sexuales, o - trate principalmente de la exposición de los genitales o de la región púbica de niños para fines sexuales; ii) cualquier material audiovisual, textual o escrito cuyo objeto sea: - fomentar, incitar o instigar a actos pedófilos, - facilitar o proporcionar información sobre niños utilizada para fines de explotación sexual". Esta compleja terminología no fue acotada finalmente en la referida Decisión Marco 2004/68/ JAI del Consejo, de 22 de diciembre de 2003, sino que se optó, como en la mayoría del articulado, por respetar el texto inicial formulado por el Consejo. La Enmienda 7 habla de "producción o procesamiento de pornografía infantil" en vez de producción. La Enmienda 8 sustituye la terminología "distribución, difusión o transmisión" por "importación, exportación, compra, venta y distribución de material de pornografía infantil". La Enmienda 9 amplía la letra d) del artículo tercero de la Propuesta de Decisión Marco al tipificar las siguientes conductas: d) distribución, difusión o transmisión de pornografía infantil, o d bis) incitación o facilitación de los actos anteriores, d ter) adquisición o posesión de pornografía infantil, que sólo será punible si es consciente y la posesión se prolonga de manera deliberada. La adquisición o posesión de pornografía infantil con el fin de entregarlo a las autoridades responsables de hacer cumplir la ley no constituirá delito". Las Enmiendas 15, 18, 37 y 21 amplían en los tipos agravados la edad del menor hasta los dieciséis años. Las Enmiendas 16, 19, 37 y 21 eliminan la circunstancia de la agravante de productividad económica introduciendo la Enmienda 17 los supuestos que "impliquen a un niño con discapacidad física o psíquica". La Enmienda 23 incluye como causa para que un Tribunal entre a conocer del hecho el caso de que el autor "resida de forma temporal o permanente en el territorio del Estado miembro de que se trate". La Enmienda 24 amplía el supuesto a los casos en que el beneficiario sea también una persona física (DO C 53, de 28/02/2002, pág. 108-112). La gran mayoría de las iniciativas referidas por el Parlamento fueron finalmente excluidas del texto definitivo radicando el núcleo base del articulado definitivo de la Decisión Marco en la referida Propuesta. 
informáticos ${ }^{286}$. Este texto en parte se funda en el acuerdo para mejorar la seguridad de las infraestructuras de la información en todos los órdenes susceptibles de avance, e informa de la magnitud alcanzada por las nuevas comunicaciones. Su principal aporte al tratamiento internacional a la pornografía infantil radica en su reconocimiento expreso como manifestación de una ciber/criminalidad, diversos apuntes de Derecho procesal relativas principalmente a la obtención de pruebas y su valor- y una serie de propuestas legislativas -aproximación de políticas en materia de pornografía infantil en consonancia con la Decisión Marco del Consejo- y no legislativas - exhortos a la cooperación y colaboración entre diversos entes- ${ }^{287}$.

Posteriormente, el 31 de enero de 2001 la Comisión, de conformidad con el artículo 262 del Tratado constitutivo de la Comunidad Europea, decidió consultar al Comité Económico y Social sobre la mencionada comunicación, produciéndose el Dictamen del Comité Económico y Social sobre la "Comunicación de la Comisión al Consejo, al Parlamento Europeo, al Comité Económico y Social y al Comité de las Regiones, eEurope 2002,288 en el que se reafirman los aspectos reseñados anteriormente relacionados con la pornografía infantil. Por otra parte, asoma la necesidad de abordar conceptualmente la categoría delitos informáticos de manera que pueda precisarse si se está en presencia de un nuevo delito o antes bien los usos y aprovechamientos ilícitos de Internet potencian la realización o comisión de los tradicionales más fáciles de cometer ahora gracias al uso de ordenadores y redes informáticas. No abundamos respecto de este debate puesto que ya lo revisamos con ocasión del marco criminológico que esbozamos en el capítulo primero. Ya concluíamos entonces de la inexistencia de un tal delito informático puesto que la irrupción de la Internet tan reconocida por el Derecho no ha traído consigo la emergencia de un nuevo bien jurídico. En todo caso y solo a los efectos criminológicos tenía validez el uso del compuesto criminalidad o delincuencia informática para dar cuenta general del hecho delictivo que rodea su aprovechamiento.

En mayo de 2001 se eleva una iniciativa de acuerdo a la Asamblea Parlamentaria del Consejo de Europa sobre la "protección de los menores contra la pornografía infantil

\footnotetext{
${ }^{286} \mathrm{COM}(2000) 890$ final.

${ }^{287}$ Véase, MORILLAS FERNÁNDEZ, D. L., Análisis dogmático y criminológico..., op. cit., pág. 50.

${ }^{288}$ DO C 311 de 07/11/2001 págs. 0012-0019.
} 
en Internet" ${ }^{289}$ en la que se recomienda a los Estados miembros la adopción de las siguientes medidas:

a) prevenir y combatir la producción, proceso, posesión y distribución de pornografía infantil, según la legislación vigente;

b) adoptar las medidas necesarias para alentar a los usuarios de Internet a que denuncien los casos en que hallen material pornográfico infantil en la red;

c) coordinar las fuerzas de seguridad de los distintos países para intensificar el intercambio de información en la lucha contra la pornografía infantil.

Deben mencionarse tres documentos que han realizado una gran compilación y aportación en cuanto a medias de armonización del Derecho penal, mejora de la cooperación en materia policial, tipificación de la difusión y posesión de pornografía infantil, y el establecimiento del límite de edad en los dieciocho años. Nos referimos: al Dictamen del Comité de las Regiones sobre la Comunicación de la Comisión al Consejo y al Parlamento Europeo "Lucha contra la trata de seres humanos y lucha contra la explotación sexual de los niños y la pornografia infantil"; a la "Propuesta de Decisión Marco del Consejo relativa a la lucha contra la trata de seres humanos"; y a la "Propuesta de Decisión Marco del Consejo relativa a la lucha contra la explotación sexual de los niños y la pornografía infantil" ${ }^{290}$ adoptada los días 13 y 14 de junio de $2001^{291}$.

La Resolución del Consejo relativa a la aportación de la sociedad civil en la búsqueda de niños desaparecidos y explotados sexualmente ${ }^{292}$ en diciembre de 2001, muestra la decisión firme de parte de los Estados miembros de adoptar las medidas necesarias para la localización de niños desaparecidos o explotados sexualmente; y la de persecución de estos delitos, hace referencia explícita a la pornografía infantil como

\footnotetext{
${ }^{289}$ Moción no discutida en la Asamblea para una Resolución presentada por Mrs. Pozza Tasca y otros el 7 de mayo de 2001 en el Consejo de Europa (Documento 9093).

${ }^{290}$ DO C 357 de 14/12/2001 p. 0041-0043.

${ }^{291}$ Véase, MORILLAS FERNÁNDEZ, D. L., Análisis dogmático y criminológico..., op. cit., pág. 51.

${ }^{292}$ DO C 283 de 09/10/2001 págs. 0001-0002.
} 
forma de explotación sexual ${ }^{293}$. Antes, en octubre del mismo año, el Comité de Ministros del Consejo de Europa adopta la Recomendación (2001) 16, en la que se propone la lucha contra cualquier manifestación de abuso sexual, violencia o explotación infantil; implantar medidas policiales o de cualquier otra naturaleza, de protección del menor frente a la explotación sexual; velar por la cooperación de los Estados miembros en la lucha contra la explotación sexual; y eliminar la pornografía infantil, la prostitución infantil y el tráfico de niños. Para lo cual deben adoptarse medidas de todo tipo desde educacionales, informativas, de prevención, identificación, asistencia, legislativas, investigadoras, hasta aquellas que consoliden mecanismos de cooperación internacional ${ }^{294} /^{295}$.

Es interesante la evolución en la definición de los términos o vocablos que procede a hacer esta Recomendación. Por "menor" entiende toda persona que no haya alcanzado los dieciocho años; incluye la pornografía infantil como manifestación expresa de la explotación sexual y la define como todo material que muestre bien a un menor desarrollando una conducta sexual explícita, bien a una persona que aparentemente sea un menor desarrollando una conducta sexual explícita o bien represente imágenes realistas de un menor desarrollando una conducta sexual explícita. Hace un esfuerzo por delimitar el alcance del delito de pornografía infantil sustrayéndolo a la realización de alguna de las siguientes conductas:

a) producción de pornografía infantil para su distribución;

b) ofrecimiento o fabricación de pornografía infantil;

c) distribución o transmisión de pornografía infantil;

d) procurar u obtener pornografía infantil para sí mismo o para otros;

e) posesión de pornografía infantil.

Termina la Recomendación por sugerir sanciones penales dependiendo de la gravedad del delito cometido; tipificar la mera posesión de material pornográfico de menores o su simulación; e ilustrar mediante campañas de información de los

\footnotetext{
${ }^{293}$ Véase, MORILLAS FERNÁNDEZ, D. L., Análisis dogmático y criminológico..., op. cit., pág. 50.

${ }^{294}$ Ibídem, pag. 52.

${ }^{295}$ La descripción de las mismas se halla en la mencionada Recomendación (2001) 16 págs. 3-6 y 8-10.
} 
mecanismos o recursos ciudadanos dispuestos en los procedimientos legales y otras formas de asistencia a las víctimas ${ }^{296}$.

En noviembre de 2001 se sanciona en el seno del Consejo de Europa ${ }^{297}$ el Convenio sobre Ciber/criminalidad de Budapest que en su título III contempla las infracciones relativas a contenidos en el ámbito de la criminalidad informática, y específicamente en su artículo 9 se indica qué actos deben tipificarse bajo la denominación de "pornografía infantil en la red". A saber:

a) La producción de pornografía infantil con la intención de difundirla a través de un sistema informático;

b) El ofrecimiento o la puesta a disposición de la pornografía infantil a través de un sistema informático;

c) La difusión o la trasmisión de pornografía infantil a través de un sistema informático;

d) El hecho de procurarse o de procurar a otro pornografía a través de un sistema informático

e) La posesión de pornografía infantil en un sistema informático o en un medio que posibilite el almacenamiento de datos informáticos ${ }^{298}$.

Este Convenio hace referencia expresa a lo que se entiende por pornografía infantil en su artículo 9.2, definiéndola como cualquier material que represente de

\footnotetext{
${ }^{296}$ Véase, MORILLAS FERNÁNDEZ, D. L., Análisis dogmático y criminológico..., op. cit., pág. 53.

${ }^{297}$ Solicitada por el Consejo de Ministros. Su borrador puede hallarse en el Documento 8875 de 9 de abril de 2001 y su Informe explicativo fue adoptado por el Comité de Ministros del Consejo de Europa en su 109 sesión celebrada el 8 de noviembre de 2001.

${ }^{298}$ El contenido de cada una de estas conductas típicas aparece expresamente definido en el "Informe Preparatorio de la Convención sobre delincuencia en la red" del Consejo de Europa, adoptado el 8 de noviembre de 2001 (ETS $n^{\circ}$ 185). Se realizan, entre otras, especificaciones del siguiente tenor; a) Por ofrecer debe entenderse tratar que otras personas obtengan pornografía infantil a través de un sistema informático, ya sea directamente o a través de la descarga de archivos on-line de una página web o a partir de hipervínculos establecidos en el mencionado sitio. b) Distribución o transmisión. Distribución es la diseminación de material pornográfico mientras el envío en sí de un equipo informático a otro sería transmisión. c) El término "procurar para sí mismo o para terceros material pornográfico" abarca la obtención activa de pornografía infantil mediante simple actividades como la descarga de archivos. d) La posesión de pornografía infantil tanto en disquete como en CD-Rom quedaría encuadrado dentro de la mencionada conducta típica. Véase, MORILLAS FERNÁNDEZ, D. L., Análisis dogmático y criminológico..., op. cit.
} 
manera visual a un menor adoptando un comportamiento sexualmente explícito. Define a la pornografía técnica como aquella que se proyecta sobre una persona que aparece en la imagen como si fuera menor adoptando comportamientos sexuales de manera explícita. La pseudo/pornografía es entendida como imágenes realistas que representan a un menor en los referidos comportamientos sexuales. Por último, entiende menor como toda persona que no ha alcanzado los 18 años de edad, no obstante reconoce la competencia de las legislaciones nacionales para reducirla hasta los dieciséis como límite máximo. MORALES PRATS es muy critico con éste Convenio Internacional de Budapest por considerar que se trata de una suerte de cruzada incriminatoria en todo lo relativo a la pornografía infantil ${ }^{299}$.

Obsérvese cómo permanece latente en el devenir de tales documentos una preocupación por integrar criterios tendentes a la tipificación de las conductas tradicionales como producción, ofrecimiento, utilización, distribución, facilitación y posesión, con la especificidad contemporánea que les viene de su aprovechamiento de las tecnologías de información y comunicación. Hay un esfuerzo como vimos en la nota anterior por diferenciar clases de pornografía infantil (pseudo, técnica) extendiendo su definición hacia creaciones que bien pueden ubicarse en el campo de la ficción.

En los documentos anteriores que hemos repasado no queda claro qué debe entenderse por conducta sexual explicita ${ }^{300}$. En este sentido, es más específico el "Informe Preparatorio de la Convención sobre delincuencia en la red" del Consejo de Europa $^{301}$ al indicar expresamente cualquier imagen real o ficticia que incluya contacto sexual (incluyendo el genital-genital, oral-genital, anal-genital u oral-anal) entre menores, o entre un adulto y un menor, del mismo u opuesto sexo; brutalidad;

\footnotetext{
${ }^{299}$ MORALES PRATS, F., "Los ilícitos en la Red (II): Pornografía infantil y cibercriminalidad" en ROMEO CASABONA, C. M. (Coord.), El cibercrimen. Nuevos retos jurídicos-penales, nuevas respuestas político-criminales, Ed. Comares, Granada, 2006, pág. 280.

${ }^{300}$ Entre otros, Recomendación (2001) 16 del Comité de Ministros del Consejo de Europa, adoptada el 31 de octubre de 2001 .

${ }^{301} \mathrm{ETS} \mathrm{N}^{\circ} 185$.
} 
masturbación; el desarrollo de conductas sádicas o masoquistas; la exhibición lasciva de los genitales o el área púbica de un menor ${ }^{302}$. (cursivas añadidas)

Otro documento importante de destacar es la Recomendación 1583 (2002) del Consejo de Europa ${ }^{303}$. Diferencia dos tipologías delictuales: a) delitos crueles cometidos por los padres, tutores o guardas; y b) delitos sexuales, muchos de los cuales suelen ser cometidos por personas que presentan alguna alteración en su conducta sexual. La Asamblea del Consejo de Europa recomienda al Consejo de Ministros la adopción de medidas formales e informales e invita a los Estados miembros a que adopten las medidas necesarias de protección al menor de cualquier tipo de violencia y explotación y coordinen sus esfuerzos para combatir la pornografía infantil ${ }^{304}$.

\subsubsection{DECISIÓN MARCO 2004/68/JAI DEL CONSEJO, DE 22 DE DICIEMBRE DE 2003, RELATIVA A LA LUCHA CONTRA LA EXPLOTACIÓN SEXUAL DE LOS NIÑOS Y LA PORNOGRAFÍA INFANTIL.}

La Propuesta de Decisión Marco relativa a la lucha contra la explotación sexual de los niños y la pornografía infantil queda aprobada en virtud de la Decisión Marco 2004/68/JAI del Consejo, de 22 de diciembre de 2003, relativa a la lucha contra la explotación sexual de los niños y la pornografía infantil ${ }^{305}$. Para MORILLAS se trata "de un compendio de normas reales, proporcionales y que eliminan la práctica totalidad de problemas jurídicos concediendo a las legislaciones nacionales de una flexibilización, conforme a sus propias leyes internas, necesaria para la correcta legislación de una materia tan ardua como la aquí presentada (...) un texto paradigmático en la evolución normativa del asunto que tiene la bondad de respetar, en mayor o menor medida, la autonomía legislativa de los Estados integrantes y al mismo

\footnotetext{
${ }^{302}$ En los mismos términos se manifiesta la legislación estadounidense (sección 2256 del US Code) a la hora de delimitar el contenido de la acepción "conducta sexual explícita", como se tratará en el aparte siguiente. Véase, MORILLAS FERNÁNDEZ, D. L., Análisis dogmático y criminológico..., op. cit., pág. 54 , pie de pág. $\mathrm{N}^{\circ} 74$.

${ }^{303}$ Texto adoptado por el Comité en nombre de la Asamblea el 18 de noviembre de 2002.

${ }^{304}$ Véase, MORILLAS FERNÁNDEZ, D. L., Análisis dogmático y criminológico..., op. cit., pág. 57.

${ }^{305}$ DO L 13 de 20.1.2004 págs. 44-48.
} 
tiempo delinear unas coordenadas que favorezcan el trazad común de normas, políticas y actuaciones" 306 .

Por la notable influencia que la Decisión Marco 2004/68/JAI del Consejo, de 22 de diciembre de 2003 ha tenido en la legislación española -recogida en las últimas reformas realizadas al artículo 189 de Código Penal- consideramos necesario revisar detenidamente los trece artículos que lo conforman en los que se abordan diversas demandas en materia de pornografía infantil y explotación sexual de niños.

Artículo 1. Definiciones.

En este artículo se define los términos como: niño -toda persona menor de dieciocho años-; pornografía infantil "cualquier material pornográfico que describa o represente de manera visual: i) a un niño real practicando o participando en una conducta sexualmente explícita, incluida la exhibición lasciva de los genitales o la zona púbica de un niño, o ii) a una persona real que parezca ser un niño practicando o participando en la conducta mencionada en el inciso i), o iii) imágenes realistas de un niño inexistente practicando o participando en la conducta mencionada en el inciso i). Este artículo también define sistema informático como cualquier dispositivo o conjunto de dispositivo interconectados o relacionados, uno o más de los cuales realice de acuerdo con un programa, un tratamiento automático de datos y persona jurídica como : cualquier entoldad que con arreglo la ley aplicable tenga esa consideración, con excepción de los Estados o demás organismos públicos e el ejercicio de la autoridad estatal, y de las organizaciones internacionales públicas. (subrayados añadidos)

Artículo 2. Infracciones relacionadas con la explotación sexual de los niños.

En este artículo se insta a los Estados miembros a adoptar las medidas necesarias para garantizar la punibilidad de las conductas intencionales siguientes:

\footnotetext{
${ }^{306}$ Véase, MORILLAS FERNÁNDEZ, D. L., Análisis dogmático y criminológico..., op. cit., págs. 558 y ss.
} 
a) coaccionar a un niño para que se prostituya o participe en espectáculos pornográficos, o lucrarse con ello o explotar de cualquier otra manera a un niño para tales fines;

b) captar a un niño para que se prostituya o participe en espectáculos pornográficos;

c) practicar con un niño actividades sexuales recurriendo a alguno de los medios siguientes:

i) hacer uso de la coacción, la fuerza o la amenaza,

ii) ofrecer al niño dinero $\mathrm{u}$ otras formas de remuneración o de atenciones a cambio de que se preste a practicar actividades sexuales,

iii) abusar de una posición reconocida de confianza, autoridad o influencia sobre el niño.

\section{Artículo 3. Infracciones relacionadas con la pornografía.}

Los Estados miembros castigarán la producción, distribución, difusión, transmisión, ofrecimiento o suministro y la adquisición o posesión de pornografía infantil -independientemente que sea por medio de un sistema informático o no-. En su apartado segundo establece que se podrá excluir la responsabilidad penal en los casos siguientes:

a) en el inciso ii) de la letra b) del artículo 1, a la persona que se hace pasar por un niño tuviera al menos dieciocho años en el momento de la representación;

b) contemplada en los incisos i) y ii) del citado precepto, en los supuestos de producción y posesión, se produzcan y posean imágenes de niños que hayan alcanzado la edad del consentimiento sexual, con el consentimiento de los mismos y exclusivamente para su uso privado, Aún en los casos que se demuestre que ha habido consentimiento, este no se considerará válido si se ha obtenido valiéndose por ejemplo, de una mayor 
edad, madurez, posición, status, experiencia o relación de dependencia de la víctima con el autor.

c) contempladas en el inciso iii), de la letra b) del artículo 1) cuando haya quedado acreditado que el productor produce el material pornográfico y está en posesión del mismo, estrictamente para su uso privado, siempre que para esta producción no se haya utilizado el material pornográfico al que se refieren los incisos i) y ii) y que el acto no entrañe ningún riesgo de difusión del material.

De acuerdo con este artículo, quedan excluidos los supuestos de la tipificación de la denominada pornografía técnica, la producción y posesión de material pornográfico infantil cuando los menores hayan alcanzado la edad mínima para consentir sexualmente y, en los casos de pseudo/pornografía ${ }^{307}$, posea con carácter privado la iconografía siempre y cuando su origen no radique en los supuestos contemplados en las dos referencias anteriores.

\section{Artículo 4. Inducción, complicidad y tentativa.}

Los Estados miembros adoptaran las medidas necesarias para garantizar la punibilidad de la inducción y la complicidad, y establece la tentativa a los supuestos de participación de un menor en un espectáculo pornográfico y la producción, distribución, difusión o transmisión de pornografía infantil.

\section{Artículo 5. Sanciones y circunstancias agravantes.}

Establece la pena privativa de libertad con una duración máxima de al menos entre uno y tres años, para las infracciones contempladas en los artículos 2, 3, y 4. En las circunstancias agravantes, el límite máximo de la consecuencia jurídica de la norma no podrá presentar una duración inferior a cinco años ni superior a diez y deberá apreciar los siguientes aspectos en materia de pornografía infantil:

\footnotetext{
${ }^{307}$ La pseudo/pornografía, en palabras de MORALES PRATS Y GARCÍA ALBERO, consiste en insertar "fotogramas o imágenes de menores reales en escenas pornográficas (animadas o no) en la que no han intervenido realmente" MORALES PRATS, F.; GARCÍA ALBERO, R., Artículo 189..., op. cit., pág. 982.
} 
a) coaccionar a un niño para que se prostituya, participe en un espectáculo pornográfico o haga uso de la coacción, la fuerza o la amenaza para practicar con un niño actividades sexuales;

b) lucrarse con el estado de prostitución o la participación del menor en un espectáculo pornográfico o explotarlo para tales fines o bien su captación para semejantes iniciativas siempre y cuando se aprecie alguna de las siguientes situaciones:

i) que la víctima sea un niño que no haya alcanzado la edad del consentimiento sexual según el Derecho nacional,

ii) que el autor haya puesto en peligro de forma deliberada o por imprudencia temeraria la vida del menor,

iii) que la infracción se haya cometido empleando violencia grave contra el infante o causándole un daño grave,

iv) que el hecho se hubiera cometido en el marco de una organización delictiva según la definición de la Acción Común 98/733/JAI cualquiera que sea el grado de la sanción contemplada en dicha Acción Común $^{308}$.

c) se establece la consecuencia accesoria de inhabilitación temporal o permanente para el ejercicio de actividades profesionales que supongan el cuidado de niños cuando se haya cometido alguna de las infracciones reseñadas en los artículos 2, 3 y 4;

\footnotetext{
308 La referida Acción Común 98/733/JAI define organización delictiva como "una asociación estructurada de dos o más personas, establecida durante un cierto período de tiempo, y que actúe de manera concertada con el fin de cometer delitos sancionables con una pena privativa de libertad o una medida de seguridad privativa de libertad con un máximo de al menos cuatro años como mínimo o con una pena aún más severa, con independencia de que esos delitos constituyan un fin en sí mismos o un medio de obtener beneficios patrimoniales $y$, en su caso, de influir de manera indebida en el funcionamiento de la autoridad pública». De igual forma, con el propósito de facilitar la lucha contra esta tipología delictiva, el artículo 2 amplía la responsabilidad de aquellos sujetos que participen de su actividad en los siguientes términos: «a) el comportamiento de toda persona que, de forma intencional y teniendo conocimiento bien del objetivo y de la actividad delictiva general de la organización, bien de la intención de la organización de cometer los delitos en cuestión, participe activamente: - en las actividades delictivas de la organización contempladas en el artículo I, aún cuando esta persona no participe en la ejecución propiamente dicha de los delitos de que se trate $\mathrm{y}$, sin perjuicio de los principios generales del Derecho penal del Estado miembro, incluso cuando no tenga lugar dicha ejecución, - en las demás actividades de la organización, teniendo, además, conocimiento de que su participación contribuye a la ejecución de las actividades delictivas de la organización contempladas en el artículo I; b) el comportamiento de toda persona consistente en concertarse con una o varias personas para llevar a cabo una actividad que, en caso de materializarse, equivalga a la comisión de los delitos contemplados en el artículo 1, aunque dicha persona no participe en la ejecución propiamente dicha de la actividad".
} 
d) Los Estados miembros podrán incorporar cualquier otro tipo de sanción o medida, independientemente de su naturaleza, en los supuestos de imágenes realistas de un niño inexistente practicando o participando en la conducta mencionada en el inciso $i$.

\section{Artículo 6. Responsabilidad de las personas jurídicas.}

Se establece la responsabilidad penal y civil de las personas jurídicas. Esta responsabilidad es complementaria de la de la persona física. La persona jurídica será responsable si la infracción es cometida en su provecho por cualquier sujeto, actuando a título individual o como parte de un órgano de la persona jurídica que ocupe una posición de mando otorgada en virtud de:

a) un poder de representación de dicha persona jurídica, o

b) una autoridad para adoptar decisiones en nombre de dicha persona jurídica, o

c) un mandato para ejercer el control en el seno del referido ente.

El punto segundo de este artículo hace referencia a que los Estados miembros adoptarán las medidas necesarias para garantizar que una persona jurídica pueda ser considerada responsable cuando la falta de vigilancia o control por parte de una de las personas a que se refiere el apartado 1 haya hecho posible que cometa alguna de las infracciones contempladas en los artículos 2, 3 y 4, en provecho de la entidad, o una persona sometida a la autoridad de esta última.

El punto tercero establece que la responsabilidad de las personas jurídicas se entenderá sin perjuicio de las penales ejercidas particularmente contra las personas físicas que sean autores, inductoras o cómplices.

Artículo 7. Sanciones contra las personas jurídicas.

Las sanciones de las personas jurídicas serán "efectivas, proporcionadas y disuasorias", pudiendo incluir multas de carácter penal o administrativo, así como otras tales como:

a) la exclusión del disfrute de ventajas o ayudas públicas; 
b) inhabilitación temporal o permanente para el ejercicio de actividades comerciales;

c) sometimiento a vigilancia judicial;

d) medida judicial de liquidación; o

e) cierre temporal o definitivo de los establecimientos utilizados en la comisión de la infracción.

Artículo 8. Competencia y enjuiciamiento.

Para evitar que el delito quede impune por conflicto de competencia, se establecen conflictos de atribución. Un Estado tendrá poder de jurisdicción cuando:

a) la infracción se haya cometido, total o parcialmente, en su territorio,

b) el autor de la infracción sea uno de sus nacionales;

c) la infracción haya sido cometida en provecho de un apersona jurídica establecida en su territorio

En el artículo se señalan los principios de territorialidad, nacionalidad, lugar de establecimiento de la persona jurídica, reconociéndose expresamente la posibilidad de extradición de los nacionales.

Artículo 9. Protección y asistencia a las víctimas.

En este artículo se establece que:

a) Las investigaciones o enjuiciamiento de las infracciones contempladas en esta Decisión Marco no estén sujetas a la denuncia o acusación de la víctima cuando rija el principio de territorialidad;

b) Las víctimas de las infracciones contempladas en el artículo 2, relacionadas con la explotación sexual de los niños, deben tener la consideración de especialmente vulnerables de conformidad con lo establecido en los artículos 2.2, 8.4 y 14.1 de la 
Decisión marco 2001/220/JAI del Consejo, de 15 de marzo de 2001, relativa al estatuto de la víctima;

c) Cada Estado miembro tomará todas las medidas posibles para garantizar una adecuada asistencia a la familia de la víctima. De igual forma, aplicará el artículo 4 de la anterior Decisión marco en aquellos supuestos en que sea apropiado y posible ${ }^{309}$.

\section{Artículo 12. Aplicación.}

Los Estados miembros fijaron la fecha de 20 de enero de 2006 como límite para que se tomarán las medidas necesarias para dar cumplimiento a la Decisión. Asimismo, las decisiones adoptadas por los países deberían se comunicadas a la Secretaría General del Consejo y a la Comisión.

La citada Decisión Marco traza una perspectiva de importancia mayor en materia normativa y de políticas que no dudamos en calificarlo de hito en la construcción de un orden internacional, más allá del espacio comunitario, que persiga y sancione la pornografía infantil en la dimensión que ha obtenido en el mundo digital que cotidianamente representa la realidad que vivimos.

\footnotetext{
${ }^{309}$ Artículo 4 de la Decisión Marco 2001/220/JAI del Consejo, de 15 de marzo de 2001, establece que: "Los Estados miembros garantizarán que la víctima tenga acceso, en particular desde el primer contacto, con las autoridades policiales, por los medios que consideren adecuados $\mathrm{y}$, cuando sea posible, en lenguas de comprensión general, a la información pertinente para la protección de sus intereses. Dicha información incluirá, como mínimo: a) el tipo de servicios u organizaciones a los que puede dirigirse para obtener apoyo; b) el tipo de apoyo que puede recibir; c) el lugar y el modo en que puede presentar una denuncia; d) las actuaciones subsiguientes a la denuncia y su papel respecto de aquéllas; e) el modo y las condiciones en que podrá obtener protección; f) la medida y las condiciones en que puede acceder a: i) asesoramiento jurídico, o ii) asistencia jurídica gratuita, o iii) cualquier otro tipo de asesoramiento, siempre que, en los casos contemplados en los incisos i) y ii), la víctima tenga derecho a ello; g) los requisitos para tener derecho a una indemnización; h) si reside en otro Estado, los mecanismos especiales de defensa de sus derechos que puede utilizar. 2. Los Estados miembros garantizarán que la víctima que lo solicite sea informada: a) del curso dado a su denuncia; b) de los elementos pertinentes que le permitan, en caso de enjuiciamiento, seguir el desarrollo del proceso penal relativo al inculpado por los hechos que la afectan, salvo en casos excepcionales en que el correcto desarrollo de la causa pueda verse afectado; c) de la sentencia del tribunal. 3. Los Estados miembros adoptarán las medidas necesarias para garantizar, al menos en el caso de que pueda existir un riesgo para la víctima, que en el momento de la puesta en libertad de la persona inculpada o condenada por la infracción, se pueda decidir, en caso necesario, informar de ello a la víctima. 4. En la medida en que un Estado miembro transmita por iniciativa propia la información a que se refieren los apartados 2 y 3 , deberá garantizar a la víctima el derecho a optar por no recibir dicha información, salvo en el caso en que su envío sea obligatorio en el marco del proceso penal de que se trate".
} 
Otro documento importante especifico para la protección de niños, niñas y adolescentes en el ámbito de la Unión Europea es La Convención del Consejo de Europa para la protección de los niños contra la explotación y abuso sexual de 25 de octubre de 2007 (Convenio de Lanzarote) ${ }^{310}$. Tiene como finalidad la prevención y persecución de la explotación sexual y el abuso sexual infantil. En el artículo 20 referido a la pornografía infantil propone la tipificación de la producción, la oferta o puesta a disposición, la difusión o transmisión, la adquisición para sí o para otro, la posesión, el acceso a pornografía infantil, con conocimiento de causa y por medio de las tecnologías de la información y la comunicación. Define la pornografía infantil como "todo material que represente de forma visual a un niño manteniendo una conducta sexualmente explícita, real o simulada, o toda representación de los órganos sexuales de un niño con fines principalmente sexuales".

Sin embargo, el apartado tercero del artículo 20 deja a potestad de cada uno de los Estados Miembros el derecho de no tipificar, en todo o en parte, a la producción y a la posesión de material pornográfico en los casos que: a) consista exclusivamente en representaciones simuladas o imágenes realistas de un niño no existente; b) en el que participen niños que hayan alcanzado la edad de consentimiento sexual, cuando dichas imágenes hayan sido producidas por ellos y estén en su poder, con su consentimiento y únicamente para su uso particular. Igualmente se deja a criterio de los Estados Miembros el derecho de no aplicar, en todo o en parte, el apartado referido al acceso a pornografía infantil, con conocimiento de causa y por medio de las tecnologías de la información y la comunicación

En relación con la participación de niños en espectáculos pornográficos, el artículo 21 establece que se tipificaran como delitos las siguientes conductas intencionales:

a. "Reclutar a un niño para que participe en espectáculos pornográficos o favorecer la participación de un niño en dichos espectáculos;

$b$. obligar a un niño a participar en espectáculos pornográficos o beneficiarse de un niño o explotarlo de otro modo para tales fines;

c. asistir, con conocimiento de causa, a espectáculos pornográficos en los que participen niños."

\footnotetext{
${ }^{310}$ Ratificado por España en el BOE Núm. 274 de 12 de Noviembre de 2010.
} 
Los Estados podrán reservarse el derecho de limitar la tipificación de la asistencia a espectáculos pornográficos en los que participen niños a los casos en que los niños hayan sido reclutados u obligados según lo dispuesto en los literales a o b del apartado 1 .

\subsubsection{La Propuesta de Directiva del Parlamento Europeo y Del CONSEJO Relativa a la luCHA CONTRA los Abusos SeXuales, la EXPlotación SEXUAl de loS NiÑOS Y La PORNOGRAFÍA INFANTIL, POR LA QUE SE DEROGA LA DECISIÓN MARCO 2004/68/JAI}

Vale recordar que la justificación aportada tanto en el Anteproyecto de la Ley como en el Preámbulo de la LO 5/2010 de 22 de junio, establece la necesidad de la armonización jurídica con los instrumentos de la Unión Europea. En materia de delitos sexuales contra menores, específicamente se refiere a la Decisión Marco 2004/68/JAI del Consejo, de 22 de diciembre de 2003 relativa a la lucha contra la explotación sexual de los niños y la pornografía infantil. Ahora bien, antes de la aprobación de la Ley Orgánica que analizamos -en fecha 29 de marzo de 2010- el Parlamento Europeo y el Consejo ya han presentado una nueva Propuesta de Directiva por la que se deroga la Decisión Marco 2004/68/JAI que España acaba de recoger en su legislación. La observación obvia es que, o bien el ritmo de las instituciones españolas es muy parsimonioso en el proceso de ajustar su legislación a la Comunitaria, o bien que aquella anda acelerada, puesto que la asimetría de los tiempos institucionales en ambos provoca los desajustes que apreciamos.

La explicación que consideramos más sensata es que -como venimos apuntando a lo largo de ésta tesis- las últimas reformas de la legislación Española y Europea en materia de delitos sexuales contra menores y en particular sobre la pornografía infantil obedece a una orientación político criminal de utilización del Derecho penal como única vía para resolver los conflictos. Es por ello que se derogan Instrumentos con pocos periodos de vigencia y aceleren y ensanchen la misma tendencia de criminalización de nuevas conductas y aumento de las penas para los tipos que ya existen. En este sentido 
la Propuesta de Directiva del Parlamento y el Consejo anuncia nuevas reformas penales para España que aún no ha empezado a aplicar la anterior ${ }^{311}$.

\subsubsection{Contenido de la Propuesta de Directiva}

La Exposición de Motivos la Propuesta de Directiva Marco del Parlamento Europeo y el Consejo (PDPCUE), hace alusión a que la Decisión Marco 2004/68/JAI “presenta una serie de deficiencias. Esta Decisión sólo aproxima las legislaciones para un número reducido de delitos, no trata las nuevas formas de abusos y explotación que utilizan la tecnología informática, no suprime los obstáculos a la persecución de los delitos fuera del territorio nacional, no cubre todas las necesidades específicas de las victimas infantiles, y no contiene medidas adecuadas para prevenir los delitos"312.

La propuesta de directiva (PDPCUE) que derogaría la Decisión marco 2004/68/JAI, se propone en materia de Derecho penal positivo lo siguiente ${ }^{313}$ :

1. Tipificar el turismo sexual que afecta a niños, y la explotación y los abusos sexuales graves que no estén actualmente regulados en la legislación de la UE.

2. Modificar la definición de pornografía infantil para aproximarla al Convenio del Consejo de Europa y al Protocolo facultativo de la Convención sobre los Derechos del Niño. Se tienen especialmente en cuenta los delitos contra los niños que se encuentran en una situación particularmente vulnerable.

3. Aumentar el nivel de las sanciones penales "para hacerlas proporcionadas, efectivas y disuasorias. A fin de determinar el nivel de gravedad e imponer sanciones proporcionadas se considerarán los diferentes factores que pueden intervenir en los

\footnotetext{
${ }^{311}$ La nueva LO 5/2010 de 22 de junio ya contiene muchas de las conductas tipificas en esta Propuesta de Directiva como el child grooming.

${ }^{312}$ Véase, Propuesta de Directiva del Parlamento Europeo y del Consejo. Relativa a la lucha contra los abusos sexuales, la explotación sexual de los niños y la pornografía infantil, por la que se deroga la Decisión Marco 2004/68/JAI.

${ }^{313}$ Véase, Propuesta de Directiva del Parlamento Europeo y del Consejo. Relativa a la lucha contra los abusos sexuales, la explotación sexual de los niños y la pornografía infantil, por la que se deroga la Decisión Marco 2004/68/JAI.
} 
diferentes tipos de delitos como el daño infligido a la víctima, el nivel de culpabilidad del autor del delito y el grado de riesgo para la sociedad."

4. Se agrupan los delitos básicos de acuerdo a su gravedad. Como un acierto consideramos la diferenciación de los delitos básicos en cinco grupos diferentes según su nivel de gravedad, a los que les corresponderán diferentes niveles de sanciones. Así, se determina que:

a) Las actividades que implican contacto sexual son más graves que las que no lo hacen;

b) la existencia de explotación aumenta la gravedad del delito; la coerción, la fuerza o las amenazas son más graves que el abuso de una posición de poder por parte del autor del delito o de debilidad de la víctima, que a su vez es más grave que el libre consentimiento de la víctima.

c) La prostitución, que implica actividades sexuales y dinero, es más grave que los espectáculos pornográficos, que pueden incluirlos o no;

d) la captación para la prostitución o actividad similar es más grave que la mera provocación, ya que implica la utilización de los niños como mercancías.

e) En cuanto a la pornografía infantil, la producción, que suele implicar la captación y el contacto sexual con el niño, es más grave que los delitos de distribución o de ofrecimiento, que a su vez son más graves que la posesión o el acceso.

5. Se tipifican los espectáculos pornográficos en línea. "En materia de delitos en el contexto de las Tecnologías de la Información (TI) se tipificarán las nuevas formas de explotación y abusos sexuales que utilicen las TI. Esto incluye los espectáculos pornográficos en línea, o la obtención de acceso con conocimiento de causa a la pornografía infantil, a fin de incluir aquellos casos en los que la visión de pornografía infantil a partir de sitios de Internet sin descargar ni almacenar imágenes no equivale a la "posesión" ni a la "adquisición" de pornografía infantil". 
6. También se incorpora el nuevo delito de seducción de niños con fines sexuales (Child grooming), que sigue fielmente la formulación acordada en el Convenio del Consejo de Europa en materia de prevención de delitos.

7. Habitualidad y reincidencia. Se introducen modificaciones con la expectativa de que que contribuirán a prevenir los delitos de abuso y explotación sexual de la infancia a través de una serie de medidas centradas en antiguos delincuentes y destinadas a prevenir la reincidencia y limitar el acceso a la pornografía infantil en Internet.

8. Restricción del acceso a la Red. Se pretende reducir la circulación de pornografía infantil, dificultando la utilización de la Web accesible al público. Esto no sustituye a la acción de retirar contenidos en origen o de enjuiciar a los autores de delitos.

En la Exposición de Motivos de la PDPCUE se plantea la necesidad de un mayor nivel de protección, puesto que se incluyen elementos que no se recogen en el Convenio del Consejo de Europa ${ }^{314}$, "tales como garantizar la aplicación en el conjunto de la UE de la prohibición de actividades con niños que se impone a los delincuentes, el bloqueo del acceso a la pornografía infantil en Internet, la tipificación del delito de coacción a un niño para que mantenga relaciones sexuales con terceros, los abusos sexuales de niños en espectáculos pornográficos en línea, y la cláusula de no aplicación de sanciones a los niños víctimas. La propuesta va más allá de las obligaciones que impone el Convenio del Consejo de Europa sobre el nivel de las sanciones, el asesoramiento jurídico gratuito a los niños víctimas y la represión de actividades de difusión de los abusos y del turismo sexual que afecta a niños."315

En relación con las consecuencias jurídicas establecidas en el artículo 4 de la Propuesta de Directiva del Parlamento y el Consejo de la UE de marzo de 2010, para los delitos relacionados con la explotación sexual, se presentan las conductas

\footnotetext{
314 Convenio CETS $\mathrm{N}^{\circ} 201$ del Consejo de Europa, sobre la protección de la infancia contra la explotación y el abuso sexual.

${ }^{315}$ Véase, Propuesta de Directiva del Parlamento Europeo y del Consejo. Relativa a la lucha contra los abusos sexuales, la explotación sexual de los niños y la pornografía infantil, por la que se deroga la Decisión Marco 2004/68/JAI. pág. 10
} 
especificadas en cada uno de los tipos con penas de acuerdo al criterio de gravedad en los delitos de: espectáculos pornográficos, pornografía infantil y Prostitución infantil. (Ver Tabla No2).

\section{TABLA No 2}

Delitos relacionados con la explotación sexual. Artículo 4 de la propuesta de directiva del Parlamento y el Consejo de la UE. Marzo, 2010

\begin{tabular}{|c|c|c|c|}
\hline Provocar & $\begin{array}{c}\text { Espectáculos } \\
\text { Pornográficos }\end{array}$ & $\begin{array}{c}\text { Pornografía } \\
\text { Infantil }\end{array}$ & $\begin{array}{c}\text { Prostitución } \\
\text { Infantil }\end{array}$ \\
\hline Asistir & 2 años & 5 años & \\
\hline Captar & 2 Años & & \\
\hline Lucrarse & 5 años & 8 años & 5 años \\
\hline Participar & 8 años & & 5 años \\
\hline Coaccionar & & & 10 años \\
\hline
\end{tabular}

La primera observación que podemos hacer es la diferencia que se establece en la cuantía de la pena entre las conductas de los espectáculos pornográficos donde se utilicen niños y la pornografía infantil, diferencia que no se hace en la legislación española como se verá más adelante. El artículo 189 del CP Español se coloca en el mismo tipo y con los mismos margen de pena para ambas modalidades, "el que captare o utilizare a menores de edad o a incapaces con fines o en espectáculos exhibicionistas o pornográficos tanto públicos como privados, o para elaborar cualquier clase de material pornográfico cualquiera sea su soporte, o financiare cualquiera de estas actividades o se lucrare con ellas". 
Es decir, en España tienen igual respuesta jurídica la exhibición pornográfica en directo, donde se está produciendo la utilización del niño al momento de forma directa y lesionando el bien jurídico (libertad e indemnidad sexual) en el acto, que al que facilita, difunde, exhibe o intercambia un material pornográfico elaborado no se sabe cuando (y que en todo caso, afectaría el bien jurídico de la intimidad e imagen del menor). Aunque el abuso sexual a un menor siempre será reprochable, pareciera de mayor gravedad la utilización de un niño en un espectáculo en directo u en línea que el intercambio de un material en el que fue utilizado un niño en un episodio alejado en el tiempo.

El criterio que se utiliza en la Propuesta de Directiva (PDPCUE) es a la inversa, se castiga con mayor pena la pornografía infantil que el espectáculo pornográfico; así, por ejemplo, provocar que un niño participe en espectáculos pornográficos tiene una pena privativa de libertad de dos años y esa misma conducta en la pornografía infantil es decir que quede grabada la imagen, sonido- tiene una pena de cinco años. Esto es compatible con el criterio compartido por parte de la doctrina ${ }^{316}$ que considera que el bien jurídico protegido en la pornografía infantil es la intimidad y propia imagen del niño. En este sentido, se considera que cuando queda registrado y puede seguir reproduciéndose o viéndose por mayor cantidad de personas y cada vez que el material es visto se lesiona nuevamente el bien jurídico. El objeto de protección aquí es el material pornográfico y no el niño. El criterio seguido en nuestro trabajo es absolutamente contrario a este que se esgrime. Creemos con el criterio mayoritario de la doctrina que cuando el abuso es alejado en el tiempo no se afecta o lesiona el bien jurídico.

GÓMEZ TOMILLO, es del criterio que la utilización de menores o incapaces en espectáculos exhibicionistas o pornográficos o su utilización para elaborar material de este tipo, merece un reproche penal superior, ya que el acto de grabar o exhibir el hecho sexual con fines de lucro cuando menos afecta a la intimidad del menor o incapaz ${ }^{317}$.

\footnotetext{
316 GIMBERNAT ORDEIG, E., presentación del libro: La Teoría del Bien Jurídico ¿Fundamento de legitimación del Derecho Penal o juego de abalorios dogmáticos?, en ROLAND, Hefendehl, (edit.), Ed., Marcial Pons, Madrid, 2007, págs. 11y ss.

317 GÓMEZ TOMILLO, M. "Derecho penal Sexual y reforma legal. Análisis desde una perspectiva político criminal”, en Revista Electrónica de Ciencia Penal y Criminología, RECPC 07-04-2005, pág. 3.
} 
En todos los delitos agrupados en el artículo 4 de la Propuesta de Directiva se penaliza la inducción y complicidad. La tentativa está prevista en: provocar, captar, lucrarse y coaccionar en espectáculos pornográficos con niños; así mismo, también se contempla en provocar, captar, y coaccionar para la elaboración de pornografía infantil; y en la prostitución infantil esta prevista en la acciones de lucrarse, participar y coaccionar.

El artículo 5 de la PDPCUE recoge todas las conductas relacionadas con la pornografía infantil ${ }^{318}$. Es conveniente apuntar que todos sus tipos están recogidos en el artículo 189 del CP español, a excepción de la obtención o acceso a material con pornografía infantil a sabiendas. Hasta ahora en España el mero acceso a materiales de pornografías infantil sin almacenar una copia en algún dispositivo informático no está tipificado. Como hemos explicado anteriormente, para la ocurrencia del tipo es necesario poseer, es decir tener guardado para su disposición en cualquier momento.

De la misma forma como hemos manifestado nuestro desacuerdo con criminalizar conducta como la posesión para el propio consumo de pornografía infantil que no lesionan ningún bien jurídico, más aún expresamos el rechazo a que se penalice una conducta como el simple visionado de alguna imagen o representación pornográfica. A quien se debe penalizar es a los proveedores de servicios que permiten que estos contenidos circulen por la red. (Ver Tabla $\mathrm{N}^{\mathrm{o}} 3$ )

En relación al delito del Grooming, en la PDPCUE (art. 6) está penalizado con dos años de pena privativa de libertad. En el CP español la pena va de uno (1) a tres (3) años o multa de 12 a 24 meses. El artículo 7 de la PDPCUE castiga la apología de los delitos de explotación sexual de menores cuando se penaliza la difusión de materiales que hagan publicidad.

\footnotetext{
${ }^{318}$ En la definición de pornografía infantil la PDPCUE equipara la pornografía real con la simulada. El art. 2 b) define la pornografía infantil de la siguiente forma: "i) cualquier material que describa o represente de manera visual a un niño participando en una conducta sexualmente explícita real o simulada; o ii) cualquier descripción o representación de los órganos sexuales de un niño con fines eminentemente sexuales; o iii) cualquier material que describa o represente a una persona que parezca ser un niño participando en una conducta sexualmente explícita real o simulada o cualquier descripción o representación de los órganos sexuales de una persona que parezca ser un niño, con fines eminentemente sexuales; o iv) imágenes realistas de un niño participando en una conducta sexualmente explícita o imágenes realistas de los órganos sexuales de un niño, con independencia de la existencia real de dicho niño, con fines eminentemente sexuales".
} 
En todas las conductas del artículo 5, delitos relacionados con la pornografía infantil, se penalizan la inducción y complicidad. La tentativa esta prevista en la posesión, el acceso, el ofrecimiento y la producción de pornografía infantil. La Tabla $\mathrm{N}^{\mathrm{o}} 3$ recoge una comparación de las penas en la PDPCUE y las vigentes para estos delitos en el Código Penal Español.

\section{TABLA No 3}

Cuadro comparativo de las conductas relacionadas a la pornografía infantil sancionadas en la Propuesta de Directiva del Parlamento y del Consejo de la UE en relación a la Legislación Española

\begin{tabular}{|c|c|c|}
\hline & $\begin{array}{c}\text { Propuesta de Directiva del } \\
\text { Parlamento y del Consejo } \\
\text { de la UE }\end{array}$ & Código Penal Español \\
\hline Posesión Adquisición & 1 año & $\begin{array}{c}3 \text { meses a } 1 \text { año o multa } \\
\text { de } 6 \text { meses a } 2 \text { años }\end{array}$ \\
\hline $\begin{array}{c}\text { Acceso u obtención a } \\
\text { pornografía infantil }\end{array}$ & 1 año & 1 a 5 años \\
\hline Distribución & 2 años & 1 a 5 años \\
\hline Ofrecimiento & 2 años & 1 a 5 años \\
\hline Producción & 5 años & \\
\hline
\end{tabular}

\subsubsection{Bloqueo del Acceso a Sitios de Internet que Contienen Pornografía Infantil}

En relación a la circulación por la Red de material con pornografía infantil, la propuesta se plantea reducir la circulación del material de abusos contra la infancia dificultando la carga de tales contenidos en la red de acceso público ${ }^{319}$. A través de la

\footnotetext{
${ }^{319}$ En el artículo 21 de la PDPCUE, se establece que "los Estados miembros adoptarán las medidas necesarias para lograr bloquear el acceso de los usuarios de Internet en su territorio a páginas de Internet que contengan o difundan pornografía infantil. El bloqueo del acceso se someterá a las debidas garantías, en particular el bloqueo se limitará a lo necesario, los usuarios estarán informados del motivo del bloqueo y los proveedores de contenidos estarán informados, en la medida de lo posible, de la posibilidad de recurrirlo. Sin perjuicio de lo dispuesto en el apartado anterior, los Estados miembros adoptarán las medidas necesarias para retirar las páginas de Internet que contengan o difundan pornografía infantil”.
} 
cooperación con los terceros países y las organizaciones internacionales, la UE creará mecanismos para bloquear el acceso desde el territorio de la Unión a las páginas de Internet identificadas que contengan o difundan este tipo de contenido. La propuesta ordena "facilitar a las autoridades judiciales o policiales competentes la adopción de la orden de bloqueo o apoyar y animar a los proveedores de servicios de Internet a desarrollar con carácter voluntario códigos de conducta y directrices para bloquear el acceso a esas páginas de Internet (...) Tales acciones deben respetar los derechos de los usuarios finales, adoptar los procedimientos judiciales y legales existentes y cumplir el Convenio Europeo de Derechos Humanos y la Carta de los Derechos Fundamentales de la Unión Europea" ${ }^{320}$ Para llevar a cabo esta tarea la UE cuenta con Safer Internet Programme, programa con una red de líneas directas que almacena información y garantizar la cobertura y el intercambio de informes sobre los principales tipos de contenidos ilegales en línea ${ }^{321}$.

\subsubsection{Toma de postura}

La armonización de la legislación en el ámbito de la Unión Europea es un aspecto positivo que impide el desarrollo de los paraísos legislativos. Si además, ésta unificación en el ámbito jurídico promueve la cooperación judicial y policial entre los países miembros sus objetivos resultan inobjetables y no se puede si no apoyar su realización y reconocer sus avances.

Ahora bien, algunas tendencias legales son reprochables por la dudosa lesividad de la conducta que se exige. El mejor ejemplo lo encontramos en la pornografía infantil donde el afán punitivo se ha expresado en la penalización de la posesión de este tipo de material, y ahora se pretende ir más lejos con el afán punitivo al castigar el simple

\footnotetext{
${ }^{320}$ Véase, Propuesta de Directiva del Parlamento Europeo y del Consejo. Relativa a la lucha contra los abusos sexuales, la explotación sexual de los niños y la pornografía infantil, por la que se deroga la Decisión Marco 2004/68/JAI. pág. 14.

${ }^{321}$ Según la PDPCUE el Safer Internet Programme, fue "creado para fomentar un uso más seguro de Internet y las nuevas tecnologías en línea, especialmente en lo que respecta a la infancia, así como para luchar contra los contenidos ilegales. Contribuye a prevenir los abusos sexuales contra los niños a través de una serie de medidas como la capacitación y protección de los menores, la concienciación y la educación, la autorregulación y los instrumentos de seguridad."
} 
visionado por Internet de algún material con esa clase de contenidos ${ }^{322}$. Esta como todas las anteriores propuestas muy probablemente serán aceptadas y recogidas en las siguientes reformas al CP español.

No se entiende por qué la tendencia político criminal que anima la nueva propuesta de Directiva arremete contra el consumidor de estos contenidos y no contra los proveedores de servicio que permiten que los materiales circulen por la Red. El documento analizado (PDPCUE) no se muestra proporcionado cuando se trata de sancionar a los proveedores de servicio. Al respecto solo se insta a "apoyar y animar a los proveedores de servicios de Internet a desarrollar con carácter voluntario códigos de conducta y directrices para bloquear el acceso a esas páginas de Internet” ${ }^{, 323}$. (Cursivas nuestras)

Con lo que sí estamos de acuerdo es con el conjunto de medidas como el bloqueo de contenidos o la restricción de acceso a Internet de materiales con pornografía de menores; o el asesoramiento jurídico gratuito a los niños víctimas. O el diseño e implementación de programas de capacitación y protección de los menores frente a las Tecnologías de Información. Y en general con todo el conjunto de medidas que tiendan a reforzar el control social de la sociedad sobre el delito de la pornografía infantil, antes que su defección ante la expansión de las barreras del Derecho penal que empujado por la doctrina de la seguridad lastra la dimensión social del hecho fijando conductas delictivas de las que hay que proteger a la sociedad.

Todo apunta, pues, al agotamiento de las previsiones y protocolos comunitarios para que ocurra en breve plazo la sanción de la nueva Directiva. El visto bueno en fecha reciente fue del Dictamen del Comité Económico y Social Europeo sobre la "Propuesta de Directiva del Parlamento Europeo y del Consejo relativa a la lucha contra los abusos sexuales, la explotación sexual de los niños y la pornografía infantil, por la que se

\footnotetext{
${ }^{322} \mathrm{El}$ apartado 3 del artículo 5 de la (PDPCUE) establece que "la obtención a sabiendas de acceso a la pornografía por medio de las tecnologías de la información y la comunicación se castigará con penas privativas de libertad de una duración máxima de al menos un año".

${ }^{323}$ Véase, Propuesta de Directiva del Parlamento Europeo y del Consejo. Relativa a la lucha contra los abusos sexuales, la explotación sexual de los niños y la pornografía infantil, por la que se deroga la Decisión Marco 2004/68/JAI. pág. 14 (PDPCUE).
} 
deroga la Decisión marco 2004/68/JAI, así lo confirma"324. El Dictamen concluye que el Consejo Económico y Social Europeo (CESE) "condena firmemente todo abuso y explotación sexual de los niños y elogia a la Comisión por reforzar el compromiso de Europa en la lucha contra los abusos a menores sustituyendo la Decisión marco 2004/68/JAI por una nueva directiva, más objetiva. Nunca se debe subestimar la gravedad de los delitos, la magnitud del daño que causan y el nivel de riesgo y vulnerabilidad de los niños de todo el mundo. La protección de los menores a todos los niveles debe ser una prioridad y es preciso ofrecer la máxima asistencia tanto a las víctimas como a los delincuentes para facilitar su recuperación, a fin de promover la futura protección social” ${ }^{325}$. Dejamos para el final del capítulo las principales conclusiones de este aparte para resumirlas en un solo espacio y pasamos a abordar la definición de la Pornografía infantil ajustado a los hitos fundamentales que en la normativa comunitaria e internacional hemos repasado y el criterio de la doctrina española.

\section{CONCEPTO Y CARACTERÍSTICAS DE LA PORNOGRAFÍA INFANTIL.}

Habiendo revisado la evolución histórica de la regulación de normas internacionales y comunitarias que han legislado sobre el tema en estudio, vamos a referirnos en este segundo acápite del segundo Capítulo al concepto de pornografía Infantil y sus rasgos característicos de acuerdo con la doctrina internacional, pero revisando además la discusión y los aportes hechos desde la doctrina española.

La definición de pornografía infantil es compleja, depende de múltiples factores de tipo cultural, de creencias de tipo moral, de pautas de comportamiento sexual, así

\footnotetext{
${ }^{324}$ El Dictamen del Comité Económico y Social Europeo, es publicado en el Diario Oficial de la Unión Europea en fecha (15.2.2011). El 22 de julio de 2010, de conformidad con el artículo 304 del Tratado de Funcionamiento de la Unión Europea (TFUE), el Consejo y el Parlamento Europeo decidieron consultar al Comité Económico y Social Europeo sobre la "Propuesta de Directiva del Parlamento Europeo y del Consejo relativa a la lucha contra los abusos sexuales, la explotación sexual de los niños y la pornografía infantil, por la que se deroga la Decisión marco 2004/68/JAI" COM(2010) 94 final - 2010/0064 (COD). La Sección Especializada de Empleo, Asuntos Sociales y Ciudadanía, encargada de preparar los trabajos en este asunto, aprobó su Dictamen el 2 de septiembre de 2010. Ponente: Madi SHARMA. En su 465 o Pleno de los días 15 y 16 de septiembre de 2010 (sesión del 15 de septiembre), el Comité Económico y Social Europeo ha aprobado por 110 votos a favor y 7 abstenciones el presente Dictamen. (2011/C 48/24) [COM(2010) 94 final — 2010/0064 (COD)]
}

${ }^{325}$ [COM(2010) 94 final — 2010/0064 (COD)]; (2011/C 48/24). 
como de las ideas religiosas imperantes en cada comunidad. Lógicamente, estas fluctuaciones conceptuales tienen un reflejo en los conceptos legales utilizados por los ordenamientos de cada país ${ }^{326} / 327$. Usualmente se ha considerado a la pornografía infantil una manifestación de otras conductas delictivas, entre ellas la explotación sexual infantil $^{328}$ y la trata de seres humanos ${ }^{329}$. Estas figuras trazaron las formas primarias de encajar jurídicamente la pornografía infantil, sin embargo, la redimensión que ha tomado este delito a partir del desarrollo de las altas tecnologías de información y comunicación ha llevado a los organismos internacionales, a científicos y académicos a abocarse a construir definiciones con espacio y peso específico de la pornografía infantil.

En la perspectiva de las Naciones Unidas, la pornografía infantil fue definida como "toda representación, por cualquier medio, de un niño dedicado a actividades sexuales explícitas, reales o simuladas, o toda representación de las partes genitales de un niño con fines primordialmente sexuales ${ }^{330}$. En el ámbito del Consejo de la Unión Europea, amplia ésta concepción incluyendo en su definición la posibilidad de pornografía virtual, la pseudo/pornografía y la pornografía técnica, cuando contempla la

\footnotetext{
${ }^{326}$ MORALES PRATS, F., "Pornografía Infantil e Internet: La respuesta en el Código Penal español”, en Problemática Jurídica en torno a fenómenos de Internet, Escuela Judicial Consejo General del Poder Judicial. MARTÍN -CASALLO LOPÉZ (Dir), Madrid, 2000 págs. 178 y ss.

${ }^{327}$ El diccionario de la Real Academia Española define pornografía como "obra literaria o artística de carácter obsceno, es decir, torpe, ofensivo al pudor".

${ }^{328}$ En la Decisión Marco 2004/68/JAI en su artículo 2 considera la explotación sexual infantil cuando se pretende: “(a) coaccionar a un niño para que se prostituya o participe en espectáculos pornográficos, o lucrarse con ello o explotar de cualquier otra manera a un niño para tales fines; (b) captar a un niño para que se prostituya o participe en espectáculos pornográficos;(c) practicar con un niño actividades sexuales recurriendo a alguno de los medios siguientes: i) hacer uso de la coacción, la fuerza o la amenaza, ii) ofrecer al niño dinero u otras formas de remuneración o de atenciones a cambio de que se preste a practicar actividades sexuales, iii) abusar de una posición reconocida de confianza, autoridad o influencia sobre el niño.
}

${ }^{329}$ La Asamblea General de Naciones Unidas define la trata de seres humanos como "la abducción, el transporte, el traslado, el cobijamiento o la recepción de un niño o el ofrecimiento de pago u otros beneficios para lograr el consentimiento de una persona a cuyo cargo esté un niño para los fines señalados en el párrafo 2 supra, así como con el objeto de utilizar, adquirir u ofrecer a un niño para la explotación sexual, incluida la producción de pornografía, o para que preste servicios pornográficos". Véase, Nota de la Oficina del Alto comisionado de las Naciones Unidas para los Derechos Humanos, el Fondo de las Naciones Unidas para la Infancia y la Organización Internacional para las Migraciones sobre los proyectos de protocolo relativos al tráfico de migrantes y la trata de personas (A/ AC.254/27).

${ }^{330}$ Anexo II de los Protocolos facultativos de la Convención sobre los Derechos del Niño relativos a la participación de niños en los conflictos armados y a la venta de niños, la prostitución infantil y la utilización de niños en la pornografía, de 16 de mayo de 2000 (A/54/L.84). 
representación visual de “(...) una persona real que parezca ser un niño practicando o participando en la conducta mencionada en el inciso i) o imágenes realistas de un niño inexistente practicando o participando en la conducta mencionada en el inciso i)". ${ }^{331}{ }^{332}$ Se puede concluir, por tanto, que desde las instancias internacionales citadas se ampara un concepto de pornografía infantil que incluye los siguientes tres elementos: representación, de un niño - real, aparente o simulado -, en conductas sexualmente explícitas - reales o simuladas $-{ }^{333}$. Obsérvese que en esta definición abarca la hipótesis de la pornografía simulada, técnica y la pseudo/pornografía.

Por su parte El Convenio de Lanzarote (2007) en su artículo 20.2 establece que por pornografía infantil se entenderá todo material que represente de forma visual a un niño manteniendo una conducta sexualmente explicita, real o simulada, o toda representación de los órganos sexuales de un niño con fines principalmente sexuales ${ }^{334}$. Pero ahondemos en el alcance y comprensión de cada uno de estos elementos que la doctrina internacional da por constitutivos del delito que aquí nos interesa.

En lo que respecta a la representación, hay que decir que si bien el Protocolo Facultativo de la Convención señala que aquélla puede ser por cualquier medio, en el seno del Consejo de Europa y de la Unión Europea se especifica que la representación ha de ser visual ${ }^{335}$. La representación visual se entiende que englobaría las cintas de video y las películas no reveladas, así como los datos almacenados en discos de

\footnotetext{
${ }^{331}$ Decisión Marco 2004/68/JAI del Consejo, de 22 de diciembre de 2003, relativa a la lucha contra la explotación sexual de los niños y la pornografía infantil (DO L 13 de 20/01/2004 pág. 45).

${ }^{332}$ En la Recomendación (2001) 16 del Comité de Ministros del Consejo de Europa de 31 de octubre de 2001. Se definía la pornografía infantil en los mismos términos, "todo material que muestre bien a un menor desarrollando una conducta sexual explícita, bien a una persona que aparentemente sea un menor desarrollando una conducta sexual explícita o bien represente imágenes realistas de un menor desarrollando una conducta sexual explícita"
}

333 CABRERA MARTÍN, M., "La pornografía infantil: Nuevos retos para el Derecho Penal" en Jornadas sobre Derecho de los menores, LAZARO GONZÁLEZ, I; MAYORAL NARROS, I. (Coords.) Ed. Universidad Pontificia Comillas, Madrid, págs. $402-405$.

334 Convenio del Consejo de Europa para la protección de los niños contra la explotación y el abuso sexual, hecho en Lanzarote el 25 de octubre de 2007. Ratificado por el BOE 274, del 12 de noviembre de 2010.

335 Así, Véase, Rec (2001) 16 del Consejo de Europa, Convención sobre Cibercrimen y Propuesta de decisión marco sobre explotación sexual infantil. 
ordenador o por medios electrónicos que puedan convertirse en imágenes visuales ${ }^{336}$. Se aprecia una tendencia internacional a extender el concepto de pornografía infantil con objeto de insertar dentro de él contenidos de determinadas actividades y representaciones que, si bien desde un punto de vista estricto no constituyen pornografía infantil, se encuentran muy cercanas a ésta y pueden llegar a producir los mismos efectos.

Así, se incluyen dentro de la noción de pornografía infantil tipos de contenidos con representaciones de un niño real implicado en actividades sexuales; representaciones en las que la imagen del niño se ha insertado en un contexto sexual mediante un montaje; imágenes pornográficas que representan a un adulto simulando ser un niño; representaciones en las que la imagen del niño se ha obtenido a través de la alteración, por medios técnicos, de la imagen de personas adultas; e imágenes de niños en actividades sexuales, generadas a través de ordenador o de otros medios técnicos ${ }^{337}$.

De acuerdo con lo visto hasta aquí y de manera unánime en la doctrina internacional la pornografía infantil puede ser entendida como "toda representación visual y real de un menor desarrollando actividades sexuales explícitas”338

\subsection{Características de la Pornografía Infantil.}

Una vez revisados los documentos internacionales encontramos que aunque no existe un concepto unánime y con consenso a nivel mundial sobre la pornografía infantil, hay características que están presentes en las definiciones presentadas que pueden ser sistematizadas de la forma siguiente: a) La edad de las personas que

\footnotetext{
${ }^{336}$ Véase, Exposición de motivos de la Propuesta de Decisión Marco sobre explotación sexual infantil e Informe explicativo de la Convención sobre Cibercrimen, adoptado el 8 de noviembre de 2001. La exigencia de que la representación sea visual plantea un problema acerca de la consideración respecto del material de carácter sonoro, razón por la cual parecería más conveniente asumir la posición del protocolo, más amplia, y aceptar cualquier tipo de medio o soporte.
}

337 Véase, Informe explicativo de la Convención sobre Cibercrimen y Exposición de motivos de la Propuesta de decisión marco sobre explotación sexual infantil.

${ }^{338}$ Véase, MORILLAS FENÁNDEZ, D. L., Análisis dogmático y criminológico..., op. cit., pág. 67; BOLDOVA PASAMAR, M. Á., en DIEZ RIPOLLÉS, J.; ROMEO CASABONA, C. "Comentarios al Código Penal, Parte Especial", Vol. II, Valencia, 2004, pág. 531; GARCÍA VALDÉS, C., "Acerca del Delito de Pornografía Infantil”, en OCTAVIO DE TOLEDO Y UBIETO, E.; GURDIEL SIERA, M.; CORTES BECHIARELLI, E., Estudios penales en recuerdo del profesor Ruiz Antón, Ed. Tirant lo Blanch, Valencia, 2004, págs. $411-414$. 
participan; b) Representación visual; c) Representación real y d) Conducta sexualmente explicita y erótica. Antes de pasar a considerar lo relativo a si se trata de una representación real o virtual, o si la conducta sexual debe ser explicita, pasamos a considerar lo que consideramos la característica esencial como lo es la referida a la edad.

\subsubsection{Edad en la consideración de actos de pornografía infantil}

Constituye el elemento a partir del cual los organismos e instrumentos internacionales y las legislaciones internas diferencian entre la pornografía y la pornografía infantil. Más aun, es aceptado como criterio socio/criminológico para establecer el límite entre la pornografía infantil y la pornografía común (cuyo consumo no es ilegal) quedaría fijado en los dieciocho años. Como veíamos en la mayoría de los instrumentos internacionales revisados anteriormente, se referían a menor como todo ser humano que no haya alcanzado los 18 años de edad; sin embargo en las legislaciones internas esa edad varía dependiendo de aspectos culturales, sociales y político criminales. En consecuencia, desde el punto de vista jurídico y entre los mismos países miembros de la Comunidad Europea, no puede sostenerse una edad determinada para considerar la pornografía infantil pues la misma dependerá de las disposiciones legales vigentes. El asunto se torna más espinoso si se amplía el radio a países de otros continentes, marcados por otras culturas, variables demográficas y costumbres, que definen la edad a partir de la cual se considera adulto.

Esta diferencia en el establecimiento de la edad conlleva al problema principal y más común en torno a la definición de pornografía infantil. Esto es: ¿a partir de qué edad la filmación o grabación de tales imágenes dejan de ser actos de pornografía infantil? Una de las situaciones puntuales a resolver tiene que ver cuando se fija los 18 años de edad como límite de edad de la persona que aparece en el material pornográfico, pero la edad no coincide con el consentimiento sexual, por ejemplo los 13 años, como es en la legislación española para este último ${ }^{339}$. Como explicamos anteriormente existe consenso en los documentos y la doctrina internacionales sobre la edad límite

\footnotetext{
${ }^{339}$ En el Derecho comparado hay muchas diferencia en cuanto la edad contemplada en cada legislación en materia de pornografía infantil. Así en Alemania son los 14 años, en Australia 16; Austria 14; Bélgica 16; Dinamarca 15; Finlandia 15; Francia 15; Greca 18; Islandia 18; Irlanda 17; Italia 18; Luxemburgo 18; Holanda 18; Portugal 18; España 18; Suecia 18; Reino Unido 16; Estados Unidos 18 años.
} 
contemplada en materia de pornografía infantil, esto es, los 18 años. Sin embargo, la Convención de Cibercrimen realizada en Budapest ${ }^{340}$, celebrada el 23 de noviembre de 2001 en el seno del Consejo de Europa, en su artículo 9.3, establece la posibilidad de reducir hasta los dieciséis años la edad límite en la consideración de actos de pornografía infantil.

Esta política de armonización europea debería contribuir a asentar la doctrina al respecto en los ordenamientos jurídicos de los Estados Miembros sobre todo en cuestiones tan relevantes como la pornografía infantil siendo, como hemos anotado antes, las asimetrías legales un recurso aprovechado por la delincuencia organizada o la ciber/criminalidad para escurrir la vigilancia y la regulación.

Naciones Unidas aborda el problema de cuando no está determinada la edad del menor o se presentan dudas al respecto. En este sentido, establece en el artículo 8.2 del Protocolo Facultativo de la Convención sobre Derechos del Niño relativo a la venta de niños, la prostitución infantil y la utilización de niños en la pornografía ${ }^{341}$ que "el hecho de haber dudas acerca de la edad real de la víctima no impida la iniciación de las investigaciones penales, incluidas las investigaciones encaminadas a determinar la edad de la víctima". Así, el desconocimiento de la edad del sujeto pasivo debe entenderse en positivo en relación a la adopción de las medidas necesarias para detener la distribución o circulación del referido material ${ }^{342}$.

\footnotetext{
${ }^{340}$ Solicitada por el Consejo de Ministros. Su borrador puede hallarse en el Documento 8875 de 9 de abril de 2001 mientras su Informe explicativo fue adoptado por el Comité de Ministros del Consejo de Europa en su sesión 109 celebrada el 8 de noviembre de 2001.

${ }^{341} \mathrm{~A} / 54 / 1.84$, de 16 de mayo de 2000.

${ }^{342}$ Advierte MORILLAS FERNÁNDEZ como una alternativa de solución a cuando ocurra un evento similar es la contemplada en la legislación estadounidense la cual, en la sección 2257 del US Code, establece la obligatoriedad de llevar a cabo un registro de todos los sujetos intervinientes en cualquier tipo de producción donde se representen imágenes que contengan hechos sexuales explícitos. Sección 2257. "Registro obligatorio. (a) El que produzca cualquier libro, revista, periódico, película, cinta de vídeo o cualquier otro material que contenga una o más imágenes visuales realizadas después del 1 de noviembre de 1990 en donde se desarrollen conductas sexuales explícitas; y sea producido de forma íntegra o parcialmente con materiales enviados por correo o transportados interestatalmente o destinado al comercio internacional, o simplemente enviados o transportados o su tentativa; deberá crear y mantener unos archivos identificativos de forma individual donde se contemplen los datos referentes a todos los sujetos que aparezcan en la referida imagen". Véase, MORILLAS FERNÁNDEZ, D. L., Análisis dogmático y criminológico ...", op. cit., págs. 74 y ss.
} 
La jurisprudencia española también se pronuncia sobre los 18 años como la edad abarcada en el delito de pornografía infantil. Así la SSTS no 803/2010 de 30 de septiembre sentencia que "las conductas descritas en el art. 189 tienen en común que el sujeto pasivo es un menor de 18 años (o incapaz) y que su consentimiento es no válido al existir una presunción legal en el sentido de que no concurren condiciones de libertad para el ejercicio de la sexualidad por parte de estos, cuando dicho ejercicio implica su utilización por terceras personas con fines pornográficos o exhibicionistas, lo que implica que un sector doctrinal considera, en cuanto a cual sea el bien jurídico protegido, que no es tanto la indemnidad sexual de la personalidad del menor, como su dignidad como menor o su derecho a la propia imagen, lo que justifica esa irrelevancia del consentimiento de los menores de 18 años que deciden intervenir en la elaboración del material pornográfico, incluso sin mediar abuso de superioridad o engaño, cuando ese consentimiento, por el contrario, si sería válido para la práctica de relaciones sexuales cuando no mediasen tales circunstancias". En la misma línea se pronuncia la SSTS n ${ }^{\circ} 796 / 2007$, de 1 de octubre.

Una de las dificultades que se presenta a menudo tiene que ver con la determinación de la edad de la persona que participa en la imagen o video cuando no está identificada y por tanto se desconoce la edad real de la misma. En esta situación se puede recurrir a especialistas que aplican la escala de Tanner para identificar las fases de desarrollo en niños en la fase de pubertad, desde los 13 a los 18 años. No obstante, la jurisprudencia española revela que en la mayoría de los casos basta que el juez a través de la observación directa del material determine que se trata o no de un menor de edad y si la edad es menor de 13 años (que reúne la condición de agravante). Así la STS nº 292/2008, de 28 de mayo (Pte.: Ramos Gancedo, Diego) declara que "en lo referente a la prueba de localización e identificación de los menores para determinar su edad exacta, es claro que se trata de una diligencia prácticamente imposible de realización y que, además, el dato en cuestión ha podido ser establecido en la sentencia por propias fotografías que no dejan lugar a dudas". Igualmente se pronuncia la STS n $739 / 2008$, de 12 de noviembre (Pte.: Sánchez Melgar, Julián) cuando señala que "es suficiente con examinar tales fotografías para percatarnos, por los rasgos infantiles de la mayoría de 
los que allí aparecen, que en la elaboración de este material pornográfico fueron utilizados personas menores de trece años" ${ }^{343}$.

Siempre que existan dudas sobre la determinación de la edad de las personas que participan en el material pornográfico deberá resolverse a favor del reo. La SAP Alicante, sec. $1^{\text {a }} n^{\text {o }} 58 / 2006$, de 30 de enero señala que "no pudiéndose establecer con absoluta certeza que en efecto se trate de niños, es decir menores de 18 años, refiriéndose el informe pericial (...) en todo momento a "posibles" menores (...) procede la absolución del procesado por este segundo delito"

\subsubsection{Representación visual}

En la difusión de pornografía infantil se hace referencia a todos los documentos susceptibles de ser representados tales como: fotografías, video o DVD, telefonía móvil. Casi todos los supuestos de pornografía infantil en la actualidad son a través de Internet. Este medio se ha convertido en el principal vehículo de difusión de imágenes fotografías, videos- con esta iconografía. Resulta idóneo puesto que su adquisición es rápida, más o menos anónimo, el procedimiento es sencillo y no existe distancia geográfica puesto que todo está al alcance de un clic. Los métodos más usados son la utilización de chats, donde los pedófilos dialogan entre sí y acuerdan intercambiarse a través del correo electrónico el referido material, la compra directa de este elemento por medio de alguna página web o la simple descarga de $\operatorname{archivos}^{344}$. La adquisición física de fotografías o video ha quedado reducida a un evento marginal. Toda la difusión como el tráfico y la distribución, y la misma comunidad de adeptos, se constituyen hoy

\footnotetext{
${ }^{343}$ A nivel de la Audiencia Provincial también existe mucha jurisprudencia donde el juez determina que no hace falta más evaluación que la observación directa para determinar la edad de las personas que participan en el material pornográfico. Véase, SAP Coruña, sec. $2^{\mathrm{a}}$, no $28 / 2009$, de 6 de julio que declara "Que algunas de las menores que aparecen en las fotografías enviadas son menores de 13 años se deduce de la constatación directa de este tribunal tras el visionado de las mismas"; SAP Barcelona, sec. $2^{\mathrm{a}}, \mathrm{n}^{\mathrm{o}}$ 188/2009, de 16 de marzo, declara que se trata de niños "lejos algunos de la pubertad lo que se evidencia no sólo de su aspecto sino claramente del desarrollo de sus órganos genitales externos, por lo que ninguna otra prueba era precisa de lo que integra un hecho notorio: que los menores utilizados lo eran efectivamente y que algunos de ellos tenían menos de trece años"; La SAP Madrid, sec. $6^{\mathrm{a}}, \mathrm{n}^{\mathrm{o}}$ 52/2010, de 3 de febrero señala que basta con examinar a las fotografías para inferir "que todos los intervinientes en las mismas son inequívocamente menores de edad, a la vista de su incipiente desarrollo de los denominados caracteres secundarios (pechos o vello pubiano)". ; La SAP Barcelona sec. $2^{\mathrm{a}}, \mathrm{n}^{\mathrm{o}} 35 / 2009$, de 26 de enero declara que "ninguna otra prueba era precisa de lo que integra un hecho notorio: que los menores utilizados tenían menos de trece años".
}

${ }^{344}$ Véase, MORILLAS FENÁNDEZ, D. L., Análisis dogmático y criminológico...”, op. cit., págs. 67 y ss. 
alrededor de la red virtual. Ahora bien, que la representación sea visual no significa que las imágenes sean de niños reales, es por ello que resulta necesario explicar la siguiente característica.

La voz del menor sin representación visual no es pornografía infantil, aun cuando el artículo 183.7 contempla la utilización de la voz del menor, se requiere de una imagen para que realice el tipo. No obstante en la doctrina existe una versión más amplia que considera que hasta una representación pictórica o escultórica realizada sobre un modelo menor de edad puede constituir material pornográfico infantil ${ }^{345}$. DE LA ROSA CORTINA, va un poco más lejos cuando plantea que "Con independencia de las dificultades que tales propuestas conllevan puede defenderse de lege ferenda la tipificación de la difusión de relatos explícitos pornográficos de sexo con menores y la tipificación de la apología de la corrupción de menores"346

\subsubsection{Representación real ${ }^{347}$}

Las imágenes plasmadas y reproducidas deben ser verdaderas. En esta categoría quedan excluidos los materiales que muestren a menores de edad irreales o virtuales creadas a través de ordenador u otras técnicas ${ }^{348}$. En la misma línea se ubica BOLDOVA PASAMAR cuando plantea que en esta categoría - la representación realse concentran las figuras de la conducta sexual explicita filmada o exhibida en la que participa de forma directa un menor de edad o incapaz. En este sentido, cuando los que participan en la representación visual no son menores reales entra en la clasificación de lo que se conoce como pornografía virtual, es decir, los protagonistas no reúnen la condición de menor e incapaz, en realidad se trata o bien de mayores de edad que

\footnotetext{
${ }^{345}$ GÓMEZ TOMILLO, Considera que la pornografía infantil puede estar conformado por "Cintas magnetofónicas, películas de video o cualquier otro formato; el mero empleo del menor o incapaz como modelo fotográfico o, incluso pictórico" GÓMEZ TOMILLO, M. "Derecho penal sexual y reforma legal" en Revista Electrónica de Ciencia Penal y Criminología RECPC, Nº7, 2005, pág.

${ }^{346}$ DE LA ROSA CORTINA, J. M., Los delitos de pornografía infantil. Aspectos penales, procesales y criminológicos, TOL2 163.840 www.tiranonline.com.

347 Para BOLDOVA PASAMAR semejante característica se configura como un elemento esencial apreciable en el sujeto plasmado en el material pornográfico. Véase, BOLDOVA PASAMAR, M. A., Artículo 189..., op. cit., pág. 531.
}

${ }^{348}$ MORILLAS FENÁNDEZ, D. L., Análisis dogmático y criminológico..., op. cit., págs. 67 y ss. 
simulan ser menores o de imágenes creadas a través de las tecnologías. A su vez, en esta categoría puede ubicarse la pornografía técnica, la artificial y la pseudo/pornografía ${ }^{349}$.

Se entiende por pornografía técnica la "protagonizada por mayores de edad que aparentan ser menores por muy diversos medios o procedimientos ("retoque" de fotografías o filmaciones consistentes en eliminación de vello púbico o facial, suavización de facciones, empleo de vestimentas de adolescentes) ${ }^{\$ 350}$. Compartimos la opinión de MORILLAS FERNÁNDEZ cuando afirma que "para este caso no cabe hablar de pornografía infantil en tanto que no reúne las características propias de esta tipología delictual ya que, entre otros elementos, adolece de bien jurídico protegido para ser considerado delito amén de las cualidades del sujeto interviniente" ${ }^{351}$.

Además de la pornografía técnica, BOLDOVA PASAMAR, menciona una pornografía infantil artificial ${ }^{352}$ para identificar los supuestos en los que se representa a los menores a través del dibujo u otra clase de animación como, por ejemplo, el Manga japonés. Para este autor, tanto la pornografía artificial como técnica son una manifestación de pseudo/pornografía conforme al criterio de la representación de pornografía infantil falsa $\mathrm{s}^{353} / 354$.

En la pseudo/pornografía ${ }^{355}$ o pornografía infantil virtual, este supuesto de la imagen que se reproduce no es de una escena con menores reales. Se trata de un

\footnotetext{
${ }^{349}$ BOLDOVA PASAMAR, M. A., Artículo 189..., op. cit., pág. 566.

${ }^{350}$ MORALES PRATS, F.; GARCÍA ALBERO, R., Artículo 189... op. cit., pág. 982.

${ }^{351}$ MORILlaS FENÁNDEZ, D. L., Análisis dogmático y criminológico..., op. cit., pág. 69.

352 BOLDOVA PASAMAR incluye esta terminología para identificar los supuestos en los que se representa a los menores a través del dibujo u otra clase de animación circunscribiéndola, junto con la pornografía técnica, a una manifestación de pseudo/pornografía conforme al criterio de la representación de pornografía infantil falsa. Véase, BOLDOVA PASAMAR, M. A., Artículo 189... op. cit., pag. 531.

${ }^{353}$ BOLDOVA PASAMAR, M. A., Artículo $189 . . .$, pág. 531

354 MORILLAS FERNÁNDEZ en la pornografía artificial se agruparía todo aquella representación pornográfica en la que participa un menor o incapaz creado íntegramente a partir de un patrón irreal, por ejemplo un dibujo animado. Véase, MORILLAS FENÁNDEZ, D. L., Análisis dogmático y criminológico..., op. cit., pág. 69.
}

${ }^{355}$ MORALES PRATS Y GARCÍA ALBERO la han identificado con fotogramas o imágenes de menores reales en escenas pornográficas, animadas o no, en la que no han intervenido realmente -bien insertando sólo el rostro, bien todo el cuerpo-. Véase, MORALES PRATS, F.; GARCÍA ALBERO, R., Artículo 189..., op. cit., pág. 982. 
montaje o creación ficticia en la que se introducen caracteres parciales identificables de menores reales como la cara, el cuerpo o la voz. En la doctrina son más comunes las referencias a esta categoría con el nombre de pornografía virtual. Así CARMONA SALGADO, la define como "la realización por agentes de montajes de naturaleza pornográfica a través de la manipulación de imágenes o sonidos de menores o incapaces"356. De igual forma, BOLDOVA PASAMAR la precisa como "aquella en la que se inserta a un menor o incapaz real (su rostro o cuerpo) mediante un montaje, lo que supone la utilización de una persona"357. Para MORILLAS FERNÁNDEZ esta categoría es una manifestación intermedia entre la pornografía técnica y la artificial en la que no puede hablarse de pornografía infantil en términos absolutos al no aparecer el sujeto pasivo íntegramente representado sino a través de elementos característicos ${ }^{358}$. A efectos de este trabajo nos referiremos a ella como pornografía virtual.

La introducción de este precepto en la LO 15/2003 de 25 de noviembre ha sido polémico y rechazado por parte de la doctrina por considerar que no se afecta al bien jurídico indemnidad sexual. Sin embargo, autores como MORILLAS FERNÁNDEZ consideran que no debe "eximirse de responsabilidad penal al creador o traficante de semejante iconografía pues, si bien no parece conveniente identificar el bien jurídico aquí protegido con la indemnidad sexual, (...) no es menos cierto que otros objetos tutelables como la intimidad, en el sentido del derecho a la propia imagen, o la dignidad pudieran verse afectados, lo cual lleva implícito un tratamiento independiente de los supuestos de pornografía infantil en términos absolutos" 359 .

\subsubsection{Conducta sexualmente explicita y erótica}

Sobre las conductas "sexualmente explícitas", en las que las imágenes infantiles han de aparecer inmersas, para CABRERA MARTÍN ${ }^{360}$ deben incluir al menos el

\footnotetext{
356 CALMONA SALGADO, C., "Delitos contra la libertad sexual II", en COBO Del ROSAL, Derecho Penal Español, Madrid, 2004, pág. 304.

${ }^{357}$ BOLDOVA PASAMAR, M. Á., Artículo 189..., op. cit., pág. 532.

${ }^{358}$ Véase, MORILLAS FENÁNDEZ, D. L., Análisis dogmático y criminológico..., op. cit., pág. 70.

${ }^{359}$ MORILLAS FENÁNDEZ, D. L., Análisis dogmático y criminológico...”, op. cit., pág. 70.

${ }^{360}$ CABRERA MARTÍN, M., La pornografía infantil..., op. cit., págs. 402 - 404.
} 
acceso carnal mediante contacto genital-genital, bucal-genital, genital-anal o bucal-anal; el bestialismo; la masturbación; la violencia sadomasoquista, y la exhibición obscena de los genitales o de la región pubiana ${ }^{361}$. Se incluyen también aquellas imágenes en las que la actividad sexual ha sido simulada. Así lo entiende el Consejo de Europa, en el "Informe Preparatorio de la Convención sobre delincuencia en la red" del citado órgano, adoptado el 8 de noviembre de $2001^{362}$.

En relación a este tema se ha planteado la interrogante de si un simple desnudo constituye una imagen pornográfica. La jurisprudencia del Tribunal Supremo así lo confirma en la STS nº 1342/2003, de 20 de octubre (Pte.: Jiménez Villarejo, José) considera que "la imagen de un desnudo - sea menor o adulto, varón o mujer- no puede ser considerada objetivamente material pornográfico, con independencia del uso que de las fotografías pueda posteriormente hacerse y que no consta cual fuese en la ocasión de autos”. En la misma línea la STS no 376/2006 de 8 de marzo RJ 2003/7509, (Ponente: Saavedra Ruiz Juan) cuando determina que la imagen de un desnudo sin más "no puede ser considerada objetivamente material pornográfico, con independencia del uso que de las fotografías pueda posteriormente hacerse". Más recientemente este criterio se reafirma en la STS nº 373/2011 de 13 de mayo RJ 2011/3871; y STS n 105/2009, de 30 de enero (Pte.: Sánchez Melgar, Julián). También coincide la STS nº 803/2010, de 30 de septiembre (Pte.: Berdugo Gómez de la Torre, Juan Ramón), que concluye que por “elaboración de cualquier clase de material pornográfico podemos entender tanto fotografías como videos, como cualquier soporte magnético que incorpore a un menor en una conducta sexual explicita, entendiendo por ésta el acceso carnal en todas sus modalidades, la masturbación, zoofilia, o las prácticas sadomasoquistas, pero no los simples desnudos”

\footnotetext{
${ }^{361}$ En el caso de los desnudos o semidesnudos - que, por sí solos, no tienen por qué tener connotaciones pornográficas - parece que lo adecuado será atender al contexto y a la finalidad que se persiga con la imagen para establecer si tiene la consideración de obscena, esto es, si está exclusiva o primordialmente dirigida a provocar la excitación sexual del que la contemple. Véase, CABRERA MARTíN, M., La pornografía infantil..., op. cit., págs. 402 - 404. En iguales términos lo hace MORILLAS FERNÁNDEZ, D. L., Análisis dogmático y criminológico...”, op. cit., pág. 66.

${ }^{362}$ Documento 8875 revisado, ETS N ${ }^{\circ} 185$.
} 
A nivel de la Audiencia provincial ${ }^{363}$ también se siguió este criterio. Así, la SAP

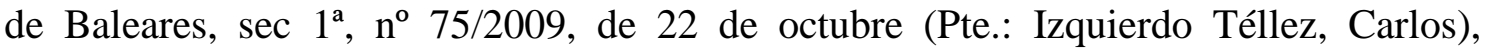
considera que unas fotografías en la que aparecen menores en la playa carecen de contenido sexual. En el mismo sentido se pronuncia La SAP de Girona, sec, $3^{\mathrm{a}}, \mathrm{n}^{\mathrm{o}}$ 422/2009, de 10 de junio, (Pte.: Ramírez Souto, Fátima), estima que "ninguna de las fotos puede calificarse de pornográfica porque no se efectúan actos de contenido sexual (...) la imagen de un desnudo -sea menor o adulto, varón o mujer- no puede ser considerada objetivamente material pornográfico con independencia del uso de las fotografías".

A nivel doctrinal podemos citar a FERNÁNDEZ TERUELO quien plantea que "con cierta frecuencia los materiales que se intercambian en la red son fotografías de menores desnudos, que sin embargo no realizan actos o gestos obscenos con connotación sexual. El precepto se refiere a material pornográfico y en principio, lo pornográfico indica (...) la realización de actos de carácter sexual. En coherencia con lo expuesto habrá que concluir que en tales supuestos no cabe sanción penal, al faltar un elemento del tipo, en concreto, la cualidad de pornográfico"364. Queda claro que una simple fotografía de un desnudo de un menor no puede ser considerada como pornografía infantil ${ }^{365}$.

Este aspecto deja abierto la delimitación entre la pornografía infantil y el erotismo, respecto del cual abundan los disensos. Inicialmente se acota el término conducta sexual explícita para diferenciar la pornografía infantil de otras manifestaciones sexuales. El asunto adquiere junto al tema de la edad perfiles determinantes en la delimitación de las conductas ilícitas a la luz del orden legal.

\footnotetext{
363 La SAP Madrid, sec, 17ª n $^{\circ}$ 238/2009, de 5 de marzo, (Pte.: Coronado Buitrago, María Jesús) concluye que "es cierto que las conversaciones transcritas en la causa que se corresponden a las mantenidas por el acusado atribuyen al intercambio unas connotaciones que sólo vendrían a confirmar el hecho ilícito si se hubiere constatado el objeto material del delito con remisión de imágenes de pornografía infantil. Nadie niega las aficiones del acusado y las respuestas ofrecidas por el mismo a la carga sugestiva del otro usuario que era el periodista que realizaba la investigación. Pero ello no convierte en pornográfico un material que no sólo descontextualizado, sino en el mismo contexto en el que fue ofrecido carece de entidad para atacar la indemnidad, seguridad y dignidad de la infancia"

${ }^{364}$ FERNÁNDEZ TERUELO, J. G., "La sanción penal de la distribución de pornografía infantil a través de Internet: Cuestiones claves". Universidad Nacional de educación a Distancia. Boletín de la facultad de Derecho, Nº 20, 2002, pág. 262.
}

${ }^{365}$ En este sentido se pronuncia la STS 10.10.2000 (RJ 2000/9151) 
Siguiendo a LANNING, la pornografía infantil comprendería la reproducción de imágenes de conductas sexuales explícitas de un menor, mientras que el erotismo abarcaría cualquier tipo de material de naturaleza sexual que incluya a menores y no desarrolle aquéllas ${ }^{366} / 367$.

La STS n 1058/2006, de 2 de noviembre (pret.: Berdugo Gómez de la Torre, Juan Ramón) expone “...es cierto que la distinción de pornografía de lo meramente erótico es, a veces, un problema complejo por cuanto depende de múltiples factores". Más reciente, la STS no 803/2010, de 30 de septiembre determina que el concepto de material pornográfico sería el resultado de la combinación de dos criterios: el contenido exclusivamente libidinoso del producto tendiente a la excitación sexual de forma grosera y la carencia de valor literario, artístico o educativo". En la misma línea la STS

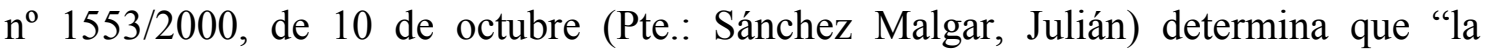
pornografía, en relación con su difusión a menores e incapaces, desborda los límites de lo ético, de lo erótico y de lo estético, con finalidad de provocación sexual, constituyendo por tanto imágenes obscenas o situaciones impúdicas, todo ello sin perjuicio de que, en esta materia (...) las normas deben ser interpretadas de acuerdo con la realidad social, como impone el art. 3.1 del Código Civil"

Siguiendo los argumentos expuestos anteriormente, no todo material sexual producido donde participen menores posee naturaleza pornográfica. Al respecto existe una clasificación de las imágenes que pueden encontrarse en cualquier reportaje de estas características: a) Indicativo. Representado por aquel material que muestra a menores vestidos, sugiriendo un interés sexual por los niños. b) Indecente. El menor aparecería

\footnotetext{
${ }^{366}$ LANNING, K., Child Molesters: A Behavioural Analysis. Washington D.C., 1992, pág. 24-26, citado por MORILLAS FERNÁNDEZ, D. L., Análisis Dogmático y Criminológico...”, op. cit, pág. 75.

${ }^{367}$ Para GARCÍA VALDÉS “el ánimo libidinoso va inscrito en el propio concepto de lo pornográfico, por lo que corresponde al aplicador del Derecho y no al legislador, concretar en cada caso si el acto es de naturaleza erótica o pornográfica, elemento normativo del tipo de carácter jurídico versus elemento normativo del tipo de carácter socio- cultural" Véase, GALCÍA VALDÉS, Carlos, "acerca del delito de pornografía infantil" en OCTAVIO DE TOLEDO Y UBIETO, E; GURDIEL SIERA, M. CORTES BECHIARELLI, E., Estudios penales en recuerdo del profesor Ruiz Antón, Ed. Tirant lo Blanch, Valencia, 2004, pág. 417.
} 
desnudo, aludiendo un interés sexual por los niños. c) Obsceno. Describiría a un infante desarrollando actos de naturaleza sexual explícita ${ }^{368}$.

Estando más o menos claras las dos últimas, es obvio que el debate se centra en las circunstancias por las cuales apreciar que el tono o carácter indicativo de una representación de un menor es erótico o pornográfico. La dinámica mediante la cual los Estados fortalecen su voluntad de perseguir cualquier manifestación ilícita en materia sexual cuando el sujeto pasivo sea un menor, apunta a que no serán pocas las representaciones en las que la duda sea aplicada alineada con dicha pretensión, en consecuencia siendo objeto de censura y sanción ${ }^{369}$.

Pero, entonces ¿qué debemos entender por erotismo infantil? Inicialmente no existen manifestaciones sobre su contenido. No obstante, dentro del Proyecto COPINE se recoge una clasificación del contenido de las colecciones del material más común utilizado por los pedófilos donde se hace expresa mención a los componentes erótico y pornográfico, los cuales vendrían representados por las siguientes conductas: “a) Todo aquel material de niños tomado clandestinamente en áreas de recreo y diversión y muestren al menor semi-desnudo o desnudo. b) El que deliberadamente muestre imágenes de niños total o parcialmente vestidos o desnudos siempre y cuando de las mismas se derive un componente sexual, entendiendo por éste cualquier manifestación externa tales como poses provocativas o incitantes (...). c) Aquéllas en las que se haga un especial énfasis a las áreas genitales del menor independientemente de que se muestren. d) Imágenes de menores desnudos o semi-desnudos destinadas a escenas nudistas cuya procedencia sea legítima"370. Este último caso es relativo pues dependerá de la naturaleza o finalidad de la iconografía, siendo necesario entonces atender a las circunstancias y el contexto en el que aparece la imagen ${ }^{371}$. Es totalmente distinto la exhibición de un menor de edad desnudo en una revista médica, que en una página web

368 TAYLOR, M.., HOLLAND, G. ;QUAYLE E., "Typology of Paedophile Picture Collections", COPINE Project, The Pólice Journal, 74, 2001, pág. 98.

${ }^{369}$ MORILLAS FENÁNDEZ, D. L., Análisis dogmático y criminológico...”, op. cit., pág. 76.

${ }^{370}$ TAYLOR, M., HOLLAND, G.; QUAYLE Ethel., Typology of Paedophile..., op. cit., pág. 101.

${ }^{371}$ El ejemplo más común o los de cualquier empresa que anuncie productos para bebés (pañales o toallitas de aseo), obviamente, el contenido de estos clips publicitarios es meramente informativo o divulgativo por lo que no pueden ser considerados como manifestaciones de pornografía infantil pese a cumplir el requisito enunciado. 
dedicada exclusivamente a un contenido pornográfico ${ }^{372}$. En este sentido, MORILLAS FERNÁNDEZ estima que deben quedar fuera del tipo todas las representaciones respaldadas por un carácter científico, cultural, informativo y divulgativo. Propone el autor que se incluya en la descripción de esta conducta la especificación "con fines sexuales" con el propósito de excluir las anteriores ${ }^{373}$.

Sin embargo, como se refería, la vocación controladora del Estado o la cultura del control social a la que hacíamos mención al inicio de este trabajo, tiende a englobar bajo la terminología pornografía infantil tanto comportamientos donde se desarrolla una conducta sexual explícita como los denominados eróticos, lo que conllevaría una errónea sobrevaloración conceptual. Claro está que mientras se mantenga la inexactitud terminológica de la acepción "exhibición lasciva de los genitales o el área púbica de un menor", caracterizadora de la pornografía, frente a la "imagen desnuda o semi-desnuda del infante" de la que se derive un comportamiento sexual susceptible de calificar de erotismo infantil, será difícil la distinción entre uno y otro, por lo que habrá que recurrir al contexto para identificar elementos calificadores al respecto ${ }^{374}$.

Queda claro que las actividades sexuales tienen que ser explicitas que no basta una fotografía de un niño desnudo sin más que el contexto o circunstancias donde se realiza son determinantes.

\section{TOMA DE POSTURA.}

En el capítulo hemos visto pues dos asuntos relacionados: la evolución normativa internacional respecto de la explotación sexual infantil que progresivamente se viene construyendo desde finales de la década de los años ochenta del siglo pasado, y de manera acelerada desde comienzos de este siglo. De ésta, además, hemos rescatado para su disección el concepto de pornografía infantil del que analizamos sus principales características.

\footnotetext{
${ }^{372}$ URIARTE VALIENTE, L. M., "delitos relativos a la pornografía infantil y corrupción de menores", Centro de estudios Jurídicos, pág. 4.

${ }^{373}$ MORILLAS FENÁNDEZ, D. L., Análisis dogmático y criminológico..., op. cit., pág. 77.

${ }^{374}$ Idem.
} 
Sobre la evolución normativa hemos de concluir que sin dudas ha significado un enorme avance principalmente por tres razones. La primera de ellas es haber formulado el problema de la pornografía infantil en un contexto global determinado por el impacto que las altas tecnologías de información y comunicación ejercen sobre ella, potenciando enormemente su alcance y favoreciendo su aprovechamiento por la delincuencia organizada. La segunda de ellas es haber trazado líneas de orientación comunes, especialmente dentro del ámbito comunitario europeo, con miras a alinear las legislaciones nacionales tras unas pautas doctrinarias comunes que contribuyeran a ordenar un espacio normativo homogéneo proclive a la identificación, combate y control del delito de pornografía infantil. Seguramente la síntesis del esfuerzo llevado a cabo lo representa el mismo concepto de pornografía infantil - "toda representación visual y real de un menor desarrollando actividades sexuales explícitas"- cuyos rasgos característicos al tiempo que es preciso en sus contornos que lo forman es flexible para encajar dentro de él aquellas definición que así convenga el legislador nacional respectivo.

La tercera es haber sensibilizado a los Estados firmantes de tantos convenios contra el delito de pornografía infantil sobre la necesaria cooperación policial, judicial y de todo orden que trascienda los marcos de la soberanía territorial, horizonte en el que hay que combatir el delito.

Sobre las limitaciones de los documentos, convenios internacionales y directivas europeas apuntamos dos críticas. De un lado su vocación punitiva, pretendiendo la regulación de la pornografía infantil a partir de la clasificación de conductas tipificadas, desdeñando la tradición de políticas de bienestar europeas que reconocen la dimensión social del problema y en ese sentido disponían de actuaciones administrativas cónsonas con un ideal político criminal: el de la resocialización del delincuente. Ciertamente en algunos documentos de los revisados aquí se dictaban pautas en el sentido de recuperar el control social de la sociedad sobre el hecho que aquí seguimos; pero, sea porque el acento estaba puesto en la dimensión penal, sea porque el acomodo en las legislaciones nacionales influenciadas por el ideal de la seguridad se ha sustraído a ésta, se ha erigido un marco normativo cuyo cerrojo penal se ha impuesto sobre toda la cadena, incluida la posesión para el autoconsumo como analizaremos seguidamente en los capítulos tercero y cuarto. De manera que si en algún aspecto las normas que sugiere u ordenan los 
documentos o Directivas Europeas analizadas ha sido seriamente rebatido por la doctrina nacional ha sido el que corresponde al delito de posesión de pornografía infantil. 


\section{CAPÍTULO III}

LA PORNOGRAFÍA INFANTIL EN EL CÓDIGO

PENAL ESPAÑOL 


\section{INTRODUCCIÓN}

En el capítulo se presenta una revisión de la evolución del delito de pornografía infantil en la legislación Española. El enfoque que aquí se sigue procura mediante el análisis progresivo de cada reforma poner en evidencia la tendencia Político Criminal que se ha seguido desde el Código Penal de 1995 hasta nuestros días. Su objetivo, en consecuencia, no es el de hacer un estudio dogmático exhaustivo o una evaluación sistemática de los tipos penales, sus elementos y categorías. Más bien forjar un discurso que dé cuenta de cómo cada modificación legislativa que se sucede desde entonces perfila la orientación penal del tratamiento del delito de pornografía infantil que aquí identificamos y denunciamos.

Así, destacamos la tendencia clara de expansión del Derecho penal en este particular ámbito -pornografía infantil-, manifestado en el incremento de las penas; agravación de las conductas; aumento desmesurado de criminalización de conductas que, en algunos casos, penaliza conductas inocuas que no representan ni amenaza ni peligro para bien jurídico alguno.

El repaso que hacemos del artículo 189 del CP nos aporta sustentos argumentativos en el desarrollo y ratificación de la hipótesis central de este trabajo: la tendencia de una Política Criminal basada en el modelo que privilegia la seguridad antes que las garantías de los ciudadanos, expresada en la expansión del Derecho penal utilizado como única y primerísima herramienta de regulación ${ }^{375}$. La tipificación de la posesión para uso propio de la pornografía infantil contemplada en el artículo 189.2 del Código Penal español es un ejemplo que con mayor claridad expone el afán punitivo sobre conductas que se alejan de las prácticas mayoritarias, pero que no afectan a ningún bien jurídico.

Es lo que en este trabajo hemos denominado el anclaje penal de la Política Criminal $^{376}$. Ciertamente, compartimos el criterio de que "El empleo del Derecho penal socialmente puede estar sometido a importantes dosis de irracionalidad en momentos de

\footnotetext{
${ }^{375}$ Véase, en el capítulo V, 4.3, La expansión del Derecho penal.

${ }^{376}$ Véase, en el capítulo V, 5, La actuación del Estado. Del ideal resocializador a la ideología de la seguridad y el anclaje penal de la política criminal.
} 
crisis social o de aumento de la criminalidad. Lo que, a su vez, tiene peligro de traducirse en políticas generalizadas de limitación de libertad (...) No debe olvidarse la tensión entre eficacia y garantía en el empleo del Derecho penal o las relaciones entre Derecho penal y Moral"377. Las tensiones a las que hace mención el autor - eficacia / garantías; Derecho / moral - parecieran decantarse en las últimos años por la ampliación de la ratio penal de la Política Criminal, invirtiendo su papel de ultima ratio; y por la realización de las pretensiones normativas de cierta moral para hacer de derecho sus juicios sobre el bien y el mal.

Revisamos, a partir del seguimiento de los distintos momentos históricos en los cuales se han sucedido cambios en la ley respectiva, como ha sido el encaje normativo de la pornografía infantil en el código penal español, dando cuenta de los cambios sustanciales significativos que dejan ver la orientación político/criminal a que hacemos mención. Nos detenemos, especialmente, en la última reforma para debatir sobre el bien jurídico protegido. Al final presentamos un resumen que nos permita cerrar el capítulo y abrir el cauce para el siguiente.

\section{CONSIDERACIONES GENERALES: LA INCORPORACIÓN DEL PRECEPTO DE PORNOGRAFÍA INFANTIL EN EL CP ESPAÑOL}

Durante cuarenta años aproximadamente -desde 1948 hasta 1989- el Título IX del libro segundo del Código Penal que recogía los delitos relacionados a la libertad sexual se denominaba "Delitos contra la Honestidad". En virtud de las críticas recibidas desde la doctrina y la jurisprudencia en relación a que los títulos debían expresar el bien jurídico de los diferentes preceptos, y la honestidad no hacía referencia a un contenido típico ni constituía objeto de protección como cualidad del sujeto pasivo ${ }^{378}$, se produjo un consenso en torno a la contemplación de la libertad sexual como bien jurídico genérico individual. Es así como en la reforma del Código Penal 3/1989 de 21 de junio, el mencionado título pasa a llamarse "Delitos contra la Libertad sexual".

\footnotetext{
377 BERdugo GÓMEZ DE LA TORRE, I. y otros, Curso de Derecho Penal. Parte general, Ed. Experiencia, Barcelona, 2004, pág. 137.

${ }^{378}$ Véase, passin, BAJO FERNANDEZ, M., Compendio de Derecho Penal, Parte Especial, Vol. II, Ed. Centro de estudios Ramón Areces, S. A., Madrid, 1998, pág. 101.
} 
En el Código Penal de 1995 la rubrica continúa agrupándose bajo el mismo nombre. Con la reforma de 1999 de 30 de abril, se modifica el nombre del Título VIII del libro II quedando como "delitos contra la libertad e indemnidad sexuales"; se cambia también el nombre al Capítulo V, que queda como "De los delitos relativos a la prostitución y la corrupción de menores". En la reforma de 25 de noviembre de 2003 se mantiene el mismo nombre tanto en el Título VIII del libro II, como en el Capítulo V.

Históricamente los delitos de contenido sexual han estado marcados por concepciones moralizantes. Desde la perspectiva político criminal en los últimos 30 años en España pueden señalarse dos etapas o momentos bien diferenciados en función de la aceptación o rechazo a la moral sexual como bien jurídico a tutelar en los delitos sexuales.

La primera de estas tendencias podemos ubicarla en las reformas penales producidas desde 1978 hasta el Código Penal de 1995, orientadas hacia la tutela de la libertad sexual y con clara disposición a deslastrarse de las nociones moralizantes en la regulación de los delitos sexuales. Esta orientación político criminal quedó plasmada en las reformas penales a través de:

a) la modificación de los delitos de estupro y rapto, la supresión del adulterio y amancebamiento, y algunas disposiciones comunes en 1978;

b) la remodelación de algunos de los delitos relativos a la prostitución y algunas de las disposiciones comunes en 1983;

c) la sustitución del delito de escándalo público por los de exhibicionismo y provocación sexual en 1988;

d) la modificación de la rúbrica "de los delitos contra la honestidad" por la de “de los delitos contra la libertad sexual". Se retocó de manera sustancial el delito de violación y los de agresiones sexuales reemplazaron a los de abusos deshonestos contemplados en la reforma de 1989;

e) se eliminó el delito de corrupción de menores en el nuevo Código Penal 1995 lo que representó la consolidación de una orientación político criminal centrada en la 
tutela de la libertad sexual ${ }^{379}$. De hecho es entonces cuando aparece por primera vez el precepto de pornografía infantil (Art. 189).

Lamentablemente, a partir de la Reforma de 1999 puede señalarse un cambio de ésta tendencia político criminal en materia de delitos sexuales, volviéndose sobre el retorno y restauración a la moral sexual delimitadora del delito. Ésta reforma significó un retroceso, pues lanzaba por la borda el esfuerzo de 20 años de trabajo legislativo orientado a la protección de la libertad sexual como bien jurídico digno de tutela en los delitos sexuales. Un breve repaso por las reformas que se suceden en el lapso de estos últimos diez años muestra claramente la involución desde la perspectiva político criminal que han experimentado los delitos sexuales en el Código Penal español.

a) en la LO 11/1999 de 30 de abril se incorpora nuevamente el polémico delito de corrupción de menores que había sido eliminado en el C P de 1995; Además, se amplían los tipos de pornografía infantil castigando la posesión para la producción, venta y distribución de este tipo de material. Las modificaciones sustanciales tienen que ver con la ampliación y/o expansión del delito de pornografía infantil. Los tres apartados en el Código Penal de 1995 pasan a cinco en la reforma de 1999, introduciendo el tráfico de material pornográfico infantil, además de la agravante cuando el culpable pertenezca a una organización criminal.

b) En la LO 15/2003 de 25 de noviembre se acentúa la propensión represiva aumentando la pena de prisión y continúa la tendencia expansiva del artículo 189 quedando conformada por ocho preceptos. Los cambios fundamentales ocurridos en el referido artículo han sido la introducción de dos nuevos delitos como son la posesión para consumo propio y la pornografía virtual, además de la previsión de circunstancias agravantes que implican un importante incremento en la pena.

c) Por último, en la Ley Orgánica 5/2010, de 22 de junio, del Código Penal, continúa el patrón de las reformas anteriores aumentando las penas y agregando nuevos tipos tales como el que captare, se lucrase u ofreciere pornografía infantil. Las penas

\footnotetext{
379 Véase, ORTS BERENGUER, E.; ALONSO RIMO, A., Delitos contra la libertad sexual. Valencia, 1995, págs. 29 y ss.
} 
para los agresores sexuales se amplifican y se introducen nuevas medidas de seguridad como la libertad vigilada posterior al cumplimiento de pena de prisión.

¿En qué contribuyen y a que razones obedecen las continuas reformas y contrarreformas en un ámbito central del Derecho penal como los delitos sexuales?

No parecieran existir fundamentaciones sustantivas. Como intentaremos demostrar éstas reformas no obedecen a "factores relacionados con la intolerancia social hacia el incremento del riesgo, a la reconsideración de ciertos intereses huérfanos de protección como dignos de tutela penal o a la proliferación de conductas delictivas en un determinado sector de la delincuencia. Obviamente, las razones son de otro signo, a menudo próximas a los postulados del Derecho penal simbólico, incluso con una indisimulada función promocional de valores morales o políticamente correctos, bien alejadas de las únicas que habrían de informar la legislación positiva: la tutela de los genuinos bienes jurídicos" ${ }^{380}$.

En las líneas que siguen repasamos más detenidamente respecto de la evolución histórica y el análisis jurídico del artículo 189 del Código Penal español.

\section{LA PORNOGRAFÍA INFANTIL EN EL CÓDIGO PENAL DE 1995}

La pornografía infantil es tipificada por primera vez en el Código Penal de 1995. Antes de esta regulación la utilización de menores de edad o incapaces con fines o en espectáculos exhibicionistas o pornográficos, podía llegar a sancionarse con algunos matices por vía de la prostitución o de la corrupción de menores. Con tres numerales el artículo 189 del CP tipifica la pornografía infantil de la siguiente forma:

\section{"1. El que utilizare a un menor de edad o a un incapaz con fines o en espectáculos exhibicionistas o pornográficos será castigado con la pena de prisión de uno a tres años.}

2. El que tuviere bajo su potestad, tutela, guarda o acogimiento a un menor de edad o incapaz y que, con noticia de la prostitución de éste, no haga lo

\footnotetext{
${ }^{380}$ SUÁREZ-MIRA RODRÍGUEZ, C., "Delitos relativos a la prostitución, corrupción de menores y pornografía infantil: una nueva revisión", en FARALDO CABANA, P., (Dir.), Política criminal y reformas penales, Ed. Tirant lo Blanch, Valencia, 2007, pág. 260.
} 
posible para impedir su continuación en tal estado, o no acudiera a la autoridad para el mismo fin si carece de medios para su custodia, incurrirá en la pena de multa de tres a diez meses.

3. El Ministerio Fiscal promoverá las acciones pertinentes con objeto de privar de la patria potestad, tutela, guarda o acogimiento familiar, a la persona que incurra en alguna de las conductas mencionadas en el párrafo anterior."

Un análisis más detallado sobre los preceptos del artículo 189 será desarrollado en el punto dedicado a la LO 11/1999, por ahora basta con destacar la ubicación sistémica y el contenido de los preceptos.

El apartado primero conformaría el tipo básico del delito de pornografía infantil. Se castiga con la pena de prisión de uno a tres años al que utilizare a un menor de edad o a un incapaz con fines o en espectáculos exhibicionista ${ }^{381}$ o pornográficos. Para que se realice el tipo no es suficiente con que el menor desarrolle tareas auxiliares en el espectáculo (por ejemplo servir bebidas a los espectadores), sino que se requiere que intervenga activamente en el propio espectáculo, que sea parte de él y su intervención tenga un contenido sexual ${ }^{382}$.

Según SUÁREZ-MIRA RODRÍGUEZ resulta redundante el vocablo de "espectáculos" pues, si se utilizan a menores e incapaces en actos exhibicionistas o pornográficos se está haciendo con tales fines. Para el autor no tiene mucho sentido el empleo alternativo de las voces "exhibicionistas o pornográficos", "pues además de generar una posible confusión con los delitos de exhibicionismo y provocación sexual, nada se gana con semejante profusión terminológica, bastando con referirse a fines "pornográficos", es decir, dirigidos a la excitación sexual de quienes contemplan al menor o incapaz utilizado",383.

\footnotetext{
381 El exhibicionismo exige la presencia de actos obscenos, que incorporen conductas de contenido lúbrico, como por ejemplo la exhibición de genitales o bien de prácticas masturbatorias. Véase, MORALES PRATS, F., El derecho penal ante..., op. cit., pág. 102.

${ }^{382}$ Véase, GÓMEZ TOMILLO, M., Derecho penal sexual..., op. cit., pág. 27.

383 SUÁREZ-MIRA RODRÍGUEZ, C., "Delitos relativos a la prostitución...”, op. cit., pág. 273.
} 
Otra impresión no menos grave la apunta GÓMEZ TOMILLO. Señala que al referirse el numeral primero a "espectáculo", "parece que exige la necesidad de contacto visual entre el que despliega la acción con contenido sexual y el espectador o espectadores. De esa manera, en principio, se cerraría el paso a la sanción penal de los supuestos en los que es un menor o incapaz quien atiende una línea telefónica erótica, salvo que se quiera forzar la letra de la ley. No obstante, dado que es suficiente con utilizar al menor con fines pornográficos, también el caso descrito sería punible" ${ }^{\text {,34 }}$.

En el segundo apartado se recoge la conducta omisiva del responsable de un menor e incapaz, que no impida la continuación en el estado de prostitución, o que no acuda a la autoridad con el mismo fin. Se castiga con la pena de multa de tres a diez meses. En el tercer precepto del artículo 189 se establece que el Ministerio Fiscal promoverá las acciones pertinentes con objeto de privar de la patria potestad, tutela a la persona que incurra en alguna de las conductas mencionadas en el párrafo anterior ${ }^{385}$.

En relación al sujeto activo, salvo en el delito omisivo del apartado dos, en el resto de las figuras delictivas contenidas en el art. 189 el sujeto activo puede ser cualquiera, incluidos otros menores o incapaces con independencia de cuál sea su responsabilidad criminal por este concepto. La conducta esta referida a un sujeto activo indiferenciado $^{386}$.

El sujeto pasivo en todas las figuras delictivas del art. 189 es el menor de 18 años o incapaz. Es importante destacar que el consentimiento no es válido, ya que en el caso de menores e incapaces existe una presunción legal irrebatible en el sentido de que nunca concurren condiciones de libertad para el ejercicio de la sexualidad por parte de estos, cuando dicho ejercicio implica su utilización por terceras personas con fines exhibicionistas o pornográficos ${ }^{387}$. En la determinación del sujeto pasivo existe una dificultad probatoria cuando los menores o incapaces no sean conocidos por el Tribunal,

\footnotetext{
${ }^{384}$ GÓMEZ TOMILLO, M., Derecho penal Sexual..., op. cit., pág. 27.

${ }^{385}$ Véase, Código Penal Español de 1995, artículo 189.

386 ORTS BERENGUER, E.; ROIG TORRES, M., Delitos informáticos y delitos comunes, cometidos a través de la informática, Ed. Tirant Lo Blanch, Valencia, 2001, pág. 130.

${ }^{387}$ Véase, RODRÍGUEZ GÓMEZ, C., “Tráfico, explotación y venta de menores", en Sanz Mulas (Coord.), El desafío de la criminalidad organizada, Ed. Comares, Granada 2006, pág. 195.
} 
puesto que la incapacidad no siempre es perceptible a simple vista, ni tampoco la minoridad en tramos fronterizos con la mayoría de edad.

\section{LA PORNOGRAFÍA INFANTIL EN LA REFORMA DEL CP/1999 (LO 11/1999, DE 30 DE ABRIL) SOBRE LOS DELITOS CONTRA LA LIBERTAD SEXUAL}

\subsection{INTRODUCCIÓN}

Una de las razones que motivó la reforma era la de sancionar penalmente los supuestos de distribución de pornografía infantil a través de Internet ${ }^{388}$, cuyo potencial en la expansión y alcance de conocimiento y la información apenas comenzaba a desplegarse, pero con ello también se ampliaban las posibilidades de la criminalidad organizada. La Exposición de Motivos de la Ley (LO 11/1999, de 30 de abril), expresa como objetivo principal de la reforma "garantizar una auténtica protección de la integridad y libertad sexuales de los menores e incapaces". Consideró el legislador que la reforma atendía a "los requerimientos de la sociedad española, alarmada por la disminución de protección jurídica que se ha producido en el ámbito de los delitos de significación sexual a partir del Código Penal de 1995" que no respondía adecuadamente, "ni en la tipificación de las conductas ni en la conminación de las penas correspondientes, a las exigencias de la Sociedad nacional e internacional" ${ }^{389}$. En este sentido, el artículo 189 se amplió pasando a tener cinco preceptos, manteniéndose los tres existentes en el Código de 1995 que, aunque con cambios significativos, se corresponden con los apartados primero, cuarto y quinto de la reforma de 1999.

Con duras críticas fue recibida desde la doctrina la vuelta de la figura de corrupción de menores que había sido eliminada en el CP de 1995. No obstante, sin lugar a dudas, la modificación más significativa y polémica del nuevo texto punitivo tiene que ver con la incriminación de conductas relativas a la producción o tráfico de

\footnotetext{
${ }^{388}$ Según MORALES PRATS, el caso que abrió el debate sobre las carencias de protección penal del menor fue el conocido asunto de los "pornonautas de Vic" de 1996. Véase, MORALES PRATS, F., "La intervención penal en la red. La represión penal del tráfico de pornografía infantil estudio particular" en ZÚÑIGA RODRÍGUEZ, L.; MÉNDEZ RODRÍGUEZ, C.; DIEGO DÍAZ- SANTOS, R., (Coords.), Derecho penal sociedad y nuevas tecnologías, Ed. Colex, Madrid, 2001, pág.123.

${ }^{389}$ Exposición de Motivos de la Ley Orgánica 11/1999, de modificación del título VIII del Código Penal.
} 
pornografía infantil $^{390}$. No olvidemos que en el Código Penal de 1995 se limitaba la punición para el que "utilizare" a un menor o a un incapaz con fines pornográficos, más no se contemplaba sanción para los que difundieran, intercambiaran o comercializaran con el material sin haber intervenido de forma directa en su elaboración o producción.

Otra de las conductas que generó una profunda discusión en la doctrina era la posesión para el tráfico o producción de este material por lo difícil que resultaba determinar cuando se posee este material pornográfico para el consumo propio y cuando es para la difusión, venta o exhibición ${ }^{391}$. Obsérvese que se trata de dos supuestos sobre los cuales el abrumador impacto y dominio del Internet sobre la circulación, tráfico y distribución de material pornográfico obligaba aceleradamente a regular su tipificación.

En relación al sujeto activo no hay cambios mayores respecto del Código Penal de 1995.

Por el contrario, en la reforma de LO 11/1999 se produjo un cambio en la redacción del sujeto pasivo, se paso del singular "un menor o un incapaz" en el Código Penal de 1995 al plural "menores e incapaces". Esta modificación aunque pareciera intrascendente tiene una connotación importante a nivel de la protección penal, dado que estimar un único delito cuando en el material estén involucrados más de un menor e incapaz, puede dar la impresión de una protección colectiva, es decir, que no se protege personalmente al concreto menor o incapaz. Por eso es conveniente valorarse tantas infracciones como menores e incapaces resulten abarcados en el material pornográfico $^{392}$.

Consideramos necesario en este aparte recoger brevemente algunas modificaciones introducidas por el legislador en la LO 11/1999 que aunque no son

\footnotetext{
${ }^{390}$ Véanse entre otros a MORALES PRATS, F.; GARCÍA ALBERO, R., "Delitos contra la libertad sexual" en QUINTERO OLIVARES, G., Comentarios a la Parte Especial del Derecho Penal, Navarra, 2002; BOLDOVA PASAMAR, M. Á, "Artículo 189..." en DÍEZ RIPOLLÉS y otros, Comentarios al Código Penal, Parte Especial, tomo II, Ed. Tirant lo Blanch, valencia, 2004; MUNOZ CONDE, F., Derecho Penal, Parte Especial, Ed., Valencia, 2002.

${ }^{391}$ Véase, MUNOZ CONDE, F., Derecho Penal, Parte Especial, Ed., Valencia, 2002, pág. 236

${ }^{392}$ Véase, BOLDOVA PASAMAR, M. Á., Artículo 189..., op. cit., págs. 529 y ss.
} 
centrales para el tema objeto de estudio en este trabajo, merecen ser mencionadas por la importancia que tienen sobre la conformación definitiva del marco punitivo.

a) Con la intención de combatir la delincuencia organizada alrededor de la pornografía infantil el legislador agrava la pena en grado cuando el culpable perteneciere a una organización o asociación, incluso de carácter transitorio, que se dedicare a la realización de actividades relacionadas a la producción, venta, distribución, difusión o exhibición de pornografía infantil. Se trata de la lucha contra las redes o grupos dedicados exclusivamente a comercializar con pornografía infantil, sobre cuyos perfiles y características apuntamos unas líneas en el capítulo primero.

b) En esta reforma el legislador contempla la posibilidad de agravar la pena en los supuestos en que el individuo ostentador de la potestad, tutela, guarda o acogimiento de un menor o incapaz tuviera conocimiento de su estado de prostitución o corrupción y no empleara los medios a su alcance para poner fin a tal situación. Desde la doctrina se ha planteado que este precepto es "de criticable factura y abierta indefinición, pues no es tarea sencilla la de averiguar qué debe entenderse por estado de prostitución o corrupción, ni parece que ésos sean los términos más apropiados para referirse a la situación vital de un menor o incapaz"393.

En este precepto se producen modificaciones importantes en relación al CP de 1995. En primer lugar, el cambio sistémico del punto 2, que pasa ahora a estar ubicado en el punto 4. Además se producen modificaciones en la redacción como el que acabamos de hacer sobre la inclusión de la referencia al "estado de prostitución o corrupción". Por último, también se incrementa la pena que pasa de multa de tres a diez meses en el CP de 1995 a la pena de multa de seis a doce meses. De acuerdo con MORILLAS FERNÁNDEZ, el bien jurídico protegido, "es la indemnidad sexual (relativa) en tanto se trata de un tipo penal en el que se sanciona la conducta omisiva llevada a cabo por el titular de la relación legal del menor a quien, entre los distintos deberes legales asignados, corresponde velar por la correcta formación del infante en el

\footnotetext{
${ }^{393}$ SUÁREZ-MIRA RODRÍGUEZ, C., Delitos relativos a la prostitución..., op. cit., pág. 279.
} 
ámbito sexual, justificándose a través de la incriminación penal la inobservancia de semejante directriz" ${ }^{394}$.

c) En el 189.5 contempla la posibilidad de que el Ministerio Fiscal promueva "las acciones pertinentes con objeto de privar de la patria potestad, tutela, guarda o acogimiento familiar, en su caso la persona que incurra en algunas de las conductas descritas en el apartado anterior". La doctrina ha calificado este precepto de redundante, ya que no se perdería nada si no coexisten otras normas en las que el Ministerio Público puede fundamentarse para promover dichas acciones ${ }^{395}$.

\subsection{MOdificaCiONES SuSTANCIALES EN LA CONFIGURACión DE LOS TiPos DeLiCTIVOS DEL ARTíCULO 189.1}

\subsubsection{Modalidades típicas en el artículo 189.1 a)}

El apartado a) del artículo 189 quedó redactado de la forma siguiente:

"Será castigado con la pena de prisión de uno a tres años:

a) El que utilizare a menores de edad o a incapaces con fines o en espectáculos exhibicionistas o pornográficos, tanto públicos como privados, o para elaborar cualquier clase de material pornográfico, o financiare cualquiera de estas actividades."

Se contemplan tres modalidades típicas diferentes en el artículo 189.1. a): la primera, referida a la utilización de menores de edad o a incapaces con fines o en espectáculos exhibicionistas o pornográficos, requiere para que se realice el tipo que el menor participe en vivo y de forma directa -no en trabajos auxiliares como portero, camarero etc.- en el espectáculo, mostrando su cuerpo desnudo o ejecutando actividades lascivas ante un grupo de personas que se deleitan en su contemplación ${ }^{396}$. Por otra parte, el tipo no exige colaboración entre el actor y la víctima -sea forzada o

\footnotetext{
${ }^{394}$ Véase, MORILLAS FERNÁNDEZ, D. L., Análisis dogmático y criminológico..., op. cit., pág. 185.

${ }^{395}$ SUÁREZ-MIRA RODRÍGUEZ, C., Delitos relativos a la prostitución..., op. cit., pág. 280.

${ }^{396}$ Véase, SUÁREZ-MIRA RODRÍGUEZ, C., Delitos relativos a la prostitución ..., op. cit., pág. 274.
} 
acordada-, basta que el sujeto pasivo aparezcan como "objeto sexual provocador", sin llevar a cabo ninguna acción sexual, pues, quien a de actuar con fines exhibicionistas o pornográficos es ante todo el sujeto activo que hace una instrumentalización sexual del menor o incapaz ${ }^{397}$.

A ésta figura delictiva que había sido contemplada en el Código penal de 1995 se añade la expresión "tanto público como privado" para dejar claro que los actos exhibicionistas no necesitan de publicidad para reunir la conducta típica ${ }^{398}$. Lo que se pretende con esta expresión es cerrar todo margen o posibilidad de interpretación, incluyendo de forma explicita toda clase de supuestos: con o sin publicidad, con o sin finalidad divulgativa, y sobre todo determinar que existe utilización sexual del menor o incapaz por parte del sujeto activo aún cuando se limite a la exclusiva contemplación. Sin embargo, para este autor, resulta innecesario agregar "tanto públicos como privados" puesto que unos y otros supuestos encajaban sin dificultad en la redacción originaria del Código Penal de $1995^{399}$. SUÁREZ-MIRA RODRÍGUEZ, afirma que "no parece que esté dato añada nada al injusto, por lo que lo correcto habría sido eliminar toda referencia al carácter del espectáculo (...) como ya he indicado anteriormente, la propia idea de espectáculo es redundante respecto de los fines" ${ }^{400}$.

En resumen conviene precisar que en ésta modalidad: i) es necesaria la participación directa del menor como objeto sexual provocador; ii) no requiere que el evento sea registrado o grabado en soportes y posteriormente ser difundidos a terceros; iii) tampoco es necesario que exista colaboración -forzada o voluntaria- entre víctima y autor; y, iv) que no se requiere de publicidad del acto, pues incluye la exclusiva contemplación por parte del autor.

b) La segunda modalidad típica establece la utilización de menores o incapaces para la elaboración de cualquier clase de material. En este tipo, "se utiliza a la víctima

\footnotetext{
${ }^{397}$ Véase, BOLDOVA PASAMAR, Miguel Á, Artículo 189..., op. cit. págs. 529 y ss.

${ }^{398}$ Véase, En este sentido, MORALES PRATS, F.; GARCÍA ALBERO, R., Delitos contra la..., op. cit., pág. 371.

${ }^{399}$ Véase, BOLDOVA PASAMAR, Miguel Á, Artículo 189..., op. cit., págs. 529 y ss.

${ }^{400}$ SUÁREZ-MIRA RODRÍGUEZ, C., Delitos relativos a la prostitución..., op. cit., págs. 273 y ss.
} 
asignándole un papel protagonista en el material elaborado, actuando sobre su propio cuerpo, sobre el de otra persona o permitiendo la manipulación del suyo y que ello sea fotografiado o filmado"

La expresión "cualquier clase" pone de manifiesto la voluntad del legislador de no dejar ningún resquicio de impunidad en los atentados contra la libertad sexual de menores e incapaces, sin embargo, colocarlo literalmente, resulta "superfluo, dado que está abarcado en la utilización con fines pornográficos"402. Quedan incluidos materiales como los reportajes fotográficos, filmaciones de vídeo $\mathrm{u}$ otro tipo de cintas pornográficas y cualquier otro tipo de material en soporte magnético, digital o papel ${ }^{403}$.

c) En este precepto se incluye además la referencia al que "financiare cualquiera de estas actividades". En ésta modalidad se sanciona a quien soportare económicamente una actividad exhibicionista o pornográfica y la intención es darle el mismo carácter tenga un destinatario particular o colectivo. La discusión doctrinal sobre este precepto se ha cifrado alrededor de dos interrogantes: Por un lado, ¿es necesaria la figura o ya era subsumibles en la cooperación necesaria del ex art. 28 del CP?. Por otro lado, y la que mayor polémica ha generado ¿el que asiste a un espectáculo público de pornografía infantil financia la actividad?

En relación a la primera interrogante existen dos posiciones opuestas en la doctrina española. Una que considera relevante haber incluido esta figura, "pues hace que encaje ahora sin dificultades en la autoría directa o coautoría de este delito la conducta del productor de pornografía o exhibicionismo infantil, esto es, quien financia mediante el pago a otras personas la elaboración de pornografía o la organización y realización de espectáculos de ese carácter" ${ }^{\natural 04}$.

La otra posición tacha de innecesaria y peligrosa porque se eleva a la categoría de autoría material, una conducta que, de otro modo, hubiera constituido una cooperación

\footnotetext{
${ }^{401}$ SUÁREZ-MIRA RODRÍGUEZ, C., Delitos relativos a la prostitución..., op. cit., pág. 274.

${ }^{402}$ BOLDOVA PASAMAR, Miguel Á, Artículo 189... op. cit., págs. 530 y ss.

${ }^{403}$ Véase, MORALES PRATS, F., El Derecho Penal ante la..., op. cit., pág. 102

${ }^{404}$ BOLDOVA PASAMAR, M. A., Artículo 189..., op. cit., págs. 533 y ss.
} 
necesaria ex-art. 28 y, en cuanto tal, una forma de participación equiparada a la autoría a efectos punitivos ${ }^{405}$.

Volvamos sobre la segunda cuestión. ¿Asistir a un espectáculo pagando es financiar la actividad exhibicionista o pornográfica?

En el trasfondo del análisis de sí el cliente de un espectáculo es o no, autor de la financiación de ésta actividad, está latente el criterio del principio económico de "no hay oferta sin demanda" ${ }^{, 406}$. La actual tendencia legislativa es incriminar la conducta del consumidor final del producto, esto es, penalizar al consumidor como último eslabón de la cadena criminal. De partida apuntamos que, como la mayor parte de la doctrina, no compartimos este criterio pues el mero cliente de un espectáculo no debe resultar incluido en tal cláusula por las implicaciones que tiene en la expansión e inflación del Derecho penal y la afectación al principio de minima intervención penal.

El primer argumento para negar la participación del cliente como financista de la actividad es el dominio del hecho. Así, el mero consumidor de un espectáculo de pornografía infantil (espectador o adquirente de estos productos), no se puede considerar autor de la financiación de la pornografía o del espectáculo infantil ya que éste no tiene el dominio del hecho ${ }^{407}$. Esta opinión no es compartida por GÓMEZ TOMILLO que considera responsable al espectador en la medida que está aportando una cantidad de dinero que permite sustentar esa clase de actividad, "quién asiste por precio coopera a la verificación del tipo del delito descrito en el art. 189.1. a), y, por consiguiente, es, cómo mínimo, cómplice, pues, no se puede negar que incrementa ex_ ante el riesgo de que la conducta principal tenga lugar" ${ }^{\text {"408. }}$.

\footnotetext{
${ }^{405}$ Véase, MORALES PRATS, F., La intervención penal..., op. cit., pág. 123

406 El criterio económico de controlar la demanda para eliminar la oferta es la justificación que ha utilizado el legislador para la criminalización de la posesión para uso propio del material de pornografía infantil. Véase, capítulo IV Posesión de pornografía infantil.

${ }^{407}$ Véase, BOLDOVA PASAMAR, M. A., Artículo $189 .$. , op. cit., pág. 533 y ss.

${ }^{408}$ GOMEZ TOMILLO, M., Derecho penal sexual..., op. cit., pág. 28.
} 
El segundo argumento sería la equiparación punitiva del mero espectador y el explotador, tendría para algunos un efecto perverso y disparatado ${ }^{409}$. Así lo expresa TAMARIT SUMALLA, cuando plantea que "no cabrá sostener que la conducta consistente en comprar pornografía infantil o asistir a espectáculos de esta clase tiene carácter típico en tanto que vía de financiación de estas actividades (atendiendo a lo previsto en el último inciso del art. 189.1 a), si no se quiere incurrir en la perversión valorativa que supondría castigar con mayor pena al mero adquirente que a quien posee el material con la finalidad de traficar posteriormente con el mismo" ${ }^{410}$.

Ahora bien, los que consideran que el cliente financia la actividad llegan aún más lejos con una interpretación más extensiva del tipo en la que se preguntan si sólo se incluye al aporte monetario del espectador o si también entra en el tipo quién proporciona o cede el lugar donde se realiza la actividad o presta algún aparato o instrumento que se utilice grabar las imágenes etc. En relación a esto GÓMEZ TOMILLO plantea que "tan sólo la contribución directamente crematística integra las exigencias típicas, lo que no es óbice para que en los supuestos descritos se pueda aplicar las reglas de la participación en el delito y, singularmente, las de la complicidad, necesaria o no" ${ }^{\prime 411}$.

En resumen las tres modalidades delictivas que se recogen en el artículo 189.1 a) son claramente reiterativas e innecesarias; porque con establecer la punición de la utilización de menores con fines exhibicionistas o pornográficos se comprenderían todas las hipótesis especificadas - tanto públicos como privados, o para elaborar cualquier clase de material pornográfico, o financiare cualquiera de estas actividadesy porque la tercera constituye una cooperación necesaria, cuyo castigo está asegurado con carácter general merced al artículo $28 \mathrm{CP}^{412}$.

\footnotetext{
${ }^{409}$ Hasta el momento de esta Reforma (LO 11/1999), en España no se había tipificado la posesión simple de pornografía infantil. Es con la Reforma LO 15/2003 que se penaliza la mera posesión de material pornográfico infantil.

${ }^{410}$ Véase, TAMARIT SUMALLA, J. M., La protección penal del menor frente al abuso y explotación sexual, Ed. Aranzadi a Thomson Company, Navarra 2ºdición, 2002, pág. 112.

${ }^{411}$ Véase, GÓMEZ TOMILLO, M., Derecho penal Sexual..., op. cit., pág. 27.

${ }^{412}$ ORTS BERENGUER, E.; ALONSO RIMO, A., La reforma de los delitos..., op. cit., pág. 50.
} 
En este sentido se ha incurrido en un ejercicio de complicación innecesaria con la intención de tipificar de un modo amplio toda actividad inadecuada de manipulación de los menores e incapaces en éste ámbito ${ }^{413}$.

\subsubsection{Modalidades típicas en el artículo 189.1.b. Producción, venta, distribución, exhibición, y facilitación de pornografía infantil}

En la LO 11/1999 de 30 de abril, se sanciona por primera vez en el Código Penal Español el tráfico o favorecimiento del tráfico de pornografía infantil, determinado en las conductas de producción, venta, distribución y exhibición de pornografía infantil. En este tipo el legislador está contemplando el uso de las altas tecnologías de información y comunicación como Internet que ha potenciado y/o caracterizado el tráfico e intercambio de pornografía infantil en los últimos años ${ }^{414}$. El precepto quedó redactado de la siguiente forma:

"el que produjere, vendiere, distribuyere, exhibiere o facilitare la producción, venta, difusión o exhibición por cualquier medio de material pornográfico en cuya elaboración hayan sido utilizados menores de edad o incapaces, aunque el material tuviere su origen en el extranjero o fuere desconocido a quien poseyera dicho material para la realización de cualquiera de estas conductas se le impondrá la pena en su mitad inferior."

Éste precepto fue objeto de un amplio debate doctrinal. El legislador avaló los criterios de quienes consideraban necesaria la inclusión del tipo arguyendo la existencia de una laguna de la ley penal, pues dejaba impune diversas conductas de sujetos integrantes en la actividad delictiva por no haber sido ellos los que obtuvieron el material pornográfico de forma directa ${ }^{415}$. Esta parte de la doctrina, exponía la falta de previsión del Código Penal para el caso en el que son distintas personas las que

\footnotetext{
${ }^{413}$ SUÁREZ-MIRA RODRÍGUEZ, C., Delitos relativos a la prostitución..., op. cit., pág. 273.

${ }^{414}$ Para Morillas Fernández, el principal logro de la Reforma de la LO 11/1999, de 30 de abril, fue la punición de la pornografía infantil a través de Internet, pues en la actualidad es el medio más utilizado para comercializar e intercambiar pornografía infantil. Véase, MORILLAS FERNÁNDEZ, D. L., Análisis dogmático y criminológico..., op. cit., págs 55 y ss.

${ }^{415}$ Véanse, Entre otros a MORALES PRATS, F., "El Derecho Penal ante la pornografía infantil en Internet" en Revista Aranzadi, No 8, 2002; FERNÁNDEZ TERUELO, J. Cibercrimen. Los delitos..., op. cit.; MORILLAS FERNÁNDEZ, D. L., Análisis dogmático y criminológico..., op. cit.
} 
difundían e intercambiaban las imágenes de pornografía infantil de las que la elaboraban $^{416}$.

Con una postura contraria, otro sector de la doctrina, estima que la tipificación de las conductas relacionadas con la difusión y/o tráfico de pornografía infantil (producción, venta, distribución, exhibición) son innecesarias ya que podían ser sancionadas antes de la reforma de 1999 (LO 11/1999), en cualquiera de las formas de autoria o participación castigadas como autoría en el art. 28 (inducción o cooperación necesaria), sin necesidad de mencionarlas expresamente ${ }^{417}$. BOLDOVA PASAMAR, aprecia que en este precepto se está penalizando lo que en principio serían actos de agotamiento del delito constituido por la utilización del menor o incapaz en la elaboración del material pornográfico ${ }^{418}$.

\subsubsection{La producción, venta, distribución, exhibición, o facilitación de material pornográfico infantil.}

En relación a la conducta típica, la aplicación de una figura delictiva del artículo 189.1, tanto de las letras a) y b), se comportan como un tipo mixto alternativo, es decir, que basta una sola de esas conductas para realizar el tipo y aunque se realicen varias de ellas es uno solo el delito cometido en relación con un mismo sujeto pasivo. Como bien advierte, BOLDOVA PASAMAR, "las acciones típicas de la letra b) no son un aliud ni un plus de las acciones típicas de la letra a), sino un ídem en fase de agotamiento"419.

En relación a la referencia expresa a la facilitación de la producción, venta, difusión o exhibición de material pornográfico, resulta superflua porque para eso están

\footnotetext{
${ }^{416} \mathrm{El}$ primer supuesto de difusión de pornografía infantil que se juzgó en España fue archivado por el juzgado de Instrucción número 24 de Barcelona. En este caso, no pudo ser aplicado el art. 189.1 CP de 1995 debido a que normalmente los archivos de imágenes de pornografía infantil son copiadas de otros servidores en la propia Red, y los que las difunden, distribuyen o venden no son los mismo que la elaboran. En el caso archivado participaron dos estudiantes de telecomunicaciones, detenidos en una operación de la Interpol en la que se detectó un servidor de Internet que ofrecía fotografías de pornografía infantil para intercambio. La policía intervino en el disco duro de uno de los ordenadores 2000 imágenes obscenas de niños entre 3 y 15 años. También se incautaron disquetes, agendas, cintas de video y fotografías de imágenes pornográficas. Véase, FERNÁNDEZ TERUELO, J., Cibercrimen. Los delitos cometidos a través de Internet, Ed. Constitutio Criminalis Carolina (CCC), 2007, pág. 56.

${ }^{417}$ Véase, MUÑOZ CONDE, Francisco, Derecho Penal, Parte Especial, Ed., Valencia, 2002, pág. 236.

${ }^{418}$ Véase, BOLDOVA PASAMAR, M. A., Artículo 189...., op. cit., pág. 536 y ss.

${ }^{419}$ BOLdOVA PASAMAR, M. A., Artículo 189.... op. cit., págs. 536 y ss.
} 
las normas de la complicidad. Ahora bien, la referencia expresa a cada una de éstas conductas de acuerdo con GÓMEZ TOMILLO "produce dos efectos: eliminar el sometimiento al principio de accesoriedad de tal conducta y asegurar que se le impondrá la pena del autor. En cualquier caso, no se entiende el por qué de esa nueva concesión al concepto unitario de autor en este marco concreto, cuando la decisión político criminal general es la de optar por un concepto restrictivo. Asimismo, la referencia a la producción de material pornográfico en el que intervengan menores es dudoso que aporte algo nuevo a la elaboración o a la financiación de material pornográfico prevista en la letra a) del artículo $189^{״ 420}$.

Siendo que el principal medio de distribución de material pornográfico es Internet, y teniendo en cuenta que la modalidad más frecuente en los últimos años es el intercambio entre pedófilos, el legislador redactó el tipo penal sin la exigencia de ánimo de lucro en la conducta del autor. Este elemento subjetivo del injusto es ajeno al tipo, puesto que muchas de las conductas de introducción de material pornográfico en Internet no vienen informadas por un ánimo o intencionalidad de tales características ${ }^{421}$. Siguiendo entonces la hipótesis de que la manifestación más frecuente del delito es a través de la red, surge una interrogante: sí los que distribuyen, venden, exhiben, facilitan e intercambian han obtenido el material pornográfico -las imágenes- a través de Internet, sí desconocen a quiénes pertenecen las imágenes y quiénes son los menores en ellas impresos. ¿Están utilizando al menor e incapaz o la “imagen” de los menores? ${ }^{422}$. En esta línea, y para expresarlo en términos más dogmáticos, ¿cual es el bien jurídico protegido, la libertad sexual o de la intimidad del menor?

Las conductas antes mencionadas atentan contra la intimidad de los menores e incapaces por utilizar su imagen y no contra su libertad sexual, dado que no utilizan a los menores directamente, los hechos de abusos están muy distanciados en el tiempo. Sí se entiende que las penas deben ser proporcionales al daño o lesividad que generan al bien jurídico, resulta incomprensible que se sancione con la misma pena conductas que no afectan con la misma intensidad al bien jurídico protegido. Es así como en los

\footnotetext{
${ }^{420}$ GÓMEZ TOMILLO, M., Derecho penal Sexual..., op. cit., pág. 30.

${ }^{421}$ Véase, MORALES PRATS, F., La intervención penal en la red..., op. cit., pág. 128.

${ }^{422}$ Véase, FERNÁNDEZ TERUELO, J., Cibercrimen. Los delitos..., op. cit., págs. 55 y ss.
} 
supuestos típicos contenidos en los apartados a) y b) del art. 189.1, existe una equiparación punitiva, "pues no parece lógico -ni proporcional- que se utilice idéntica respuesta penal frente al que recurre directamente a los menores para elaborar material pornográfico que frente al que, sin haber tenido nada que ver en la elaboración de dicho material, lo venda, distribuya, exhiba o facilite tales conductas o frente a quien únicamente los posea para esos fines. El primer supuesto ostenta una evidente mayor intensidad lesiva, por su nítida aproximación al bien jurídico, en la medida en que supone la utilización de los menores en actividades de carácter pornográfico y no simplemente de su imagen"423. De igual forma resulta disparatada la equiparación dentro del propio artículo 189.1 b) que se sancione con la misma pena la facilitación que la producción u exhibición.

Para finalizar la discusión sobre el artículo 189.1 b) hacemos referencia a la ampliación del marco de persecución de esta modalidad delictiva, cuando se añade en el precepto aunque el material tuviere su "origen en el extranjero o fuere desconocido". La jurisdicción Española podrá conocer de la creación de material de pornografía infantil realizado en el extranjero, aunque no haya llegado a exhibirse en España.

Nuevamente el legislador considera Internet como principal medio de comisión del delito, dejando bien fundado que no existen fronteras en el ciberespacio, realidad virtual donde el traslado o movimiento del material a cualquier parte del mundo es al instante. La intención de expandir la persecución del delito más allá de las fronteras españolas es hacer frente a la impunidad que reina en los países considerados "paraísos jurídicos" cuya ausencia de legislación que regule y controle estas conductas en sus territorios favorece que los contenidos pasen luego a circular en la red. Aquí entran también en juego los países productores y los consumidores de material pornográfico en los que se utilicen niños; se pretende de ésta forma no sólo abarcar la difusión o tráfico, sino llegar hasta los productores que abusan directamente de dichos menores e incapaces.

La inclusión de forma expresa del origen del material pornográfico sea en el extranjero o fuere desconocido no agrega nada ni viene a cubrir ninguna laguna de

\footnotetext{
${ }^{423}$ FERNÁNDEZ TERUELO, Javier, Cibercrimen. Los delitos... op. cit., pág. 60.
} 
punibilidad $^{424}$, dado que esto podía abarcarse con el artículo 23 de la Ley Orgánica del Poder Judicial en el precepto 4, punto d), que establece que en los delitos relativos a la prostitución y corrupción de menores e incapaces la jurisdicción española tiene la facultad para conocer de los hechos cometidos por españoles o extranjeros fuera del territorio nacional susceptibles de tipificarse, según la Ley española ${ }^{425}$. De igual forma actuará el principio de justicia universal en el supuesto de desconocimiento del origen de éste material que circule por Internet. La relevancia del principio de justicia universal (art. 23,4 LOPJ) tiene que ver con la internacionalización de la lucha contra este tipo de delincuencia, dado que se le ha otorgado carácter de reincidencia a las condenas de los tribunales extranjeros ${ }^{426}$.

\subsubsection{Posesión de material pornográfico infantil para la producción, venta, distribución, difusión, exhibición.}

No fue contemplada en la reforma de 1999 la tipificación de la mera posesión de material pornográfico infantil para su propio consumo. El tipo estuvo orientado a la distribución. En el apartado segundo de este precepto 189.1 b), se criminaliza la posesión de material pornográfico infantil para la producción, venta, distribución, difusión, exhibición ${ }^{427}$.

Compartimos la opinión de algunos autores ${ }^{428}$ que plantean que la incriminación de la posesión de material pornográfico para la distribución puede suscitar inseguridad jurídica, debido a lo problemático o difícil que es determinar cuando la posesión es para consumo propio y cuando es para facilitar el tráfico. La situación se complica más aún por las bondades de la red para el acceso a la información y las posibilidades ilimitadas

\footnotetext{
${ }^{424}$ Véase, MUÑOZ CONDE, F., Derecho Penal..., op. cit., pág. 236.

${ }^{425}$ Véase, Ley Orgánica 1/2009 de 3 de noviembre, por la que se modifica la Ley Orgánica 6/1985, de 1 de julio, del Poder Judicial.

${ }^{426}$ Véase, MUÑOZ CONDE, F., Derecho Penal..., op. cit., pág. 241.

${ }^{427}$ En el tipo no queda incluido la tenencia de la materia prima necesaria para la elaboración de pornografía como puede ser cintas vírgenes, vídeos sin contenido, ordenadores, etc. para la elaboración de, por ejemplo, films pornográficos, por mucha intención que se tenga de destinar tales medios a producciones en las que intervengan menores o incapaces. Véase, GÓMEZ TOMILLO, M., Derecho penal Sexual..., op. cit., pág. 31.

${ }^{428}$ En este sentido, Véase, MORALES PRATS, F., El Derecho Penal ante la ..., op. cit., pág. 236.
} 
de producción o difusión que se pueden alcanzar con una sola copia del material. Sin embargo, en este caso la cantidad no es un elemento que permita determinar la intencionalidad. Puede darse el caso de que alguien posea un abundante material destinado a la propia complacencia (como suele ser el comportamiento del coleccionista) y el caso contrario, en el que una persona tenga una escasa dotación de material pornográfico y dirigirla a una múltiple difusión. ${ }^{429}$

En el elemento subjetivo se encuentra buena parte de la complicación probatoria, probar el ánimo o la intención de vender, distribuir o exhibir el material pornográfico se enfrenta al problema de que no se puede acudir a los indicios objetivos de un modo similar a como se ha hecho en materia de drogas (previsto en el art. 368 de C. P), en la que la cantidad de droga incautada o la condición de drogodependiente del sujeto es útil para determinar cuando es para consumo y cuando está el ánimo de tráfico.

En el caso de pornografía infantil el criterio cuantitativo no es útil. Las cantidades que se suele acumular para el consumo pueden ser muy grandes, como sucede en el caso del coleccionista; la discreción del lugar donde puede realizarse -en el domicilio por ejemplo-; y el formato donde se guarda -en cualquier soporte informático, electrónico, telemático- contribuye a que se acumule más, pues son escasas las manifestaciones al exterior ${ }^{430}$. Es por ello que no es oportuno aplicar "convenciones interpretativas sobre posesión para el propio consumo de drogas, y conceptualmente son inaplicables criterios estándar tales como "patrones de consumo diario" o "patrones de acopio o establecimiento para propio consumo". Salvo que existan múltiples copias de un mismo material, el juicio de inferencias se torna muy dificultoso" ${ }^{\natural 31}$.

Un ejemplo de ello es que el acto mismo de coleccionar objetos de igual naturaleza es inmanente al hecho de consumir. O lo que es igual, el coleccionismo es propio de simple consumo.

\footnotetext{
${ }^{429}$ Véase, SUÁREZ-MIRA RODRÍGUEZ, C., Delitos relativos a la prostitución ..., op. cit., pág. 275.

${ }^{430}$ Véase, FERNÁNDEZ TERUELO, J., Cibercrimen. Los delitos... op. cit., págs. 75 y ss.

${ }^{431}$ MORALES PRATS, F., El Derecho Penal ante la ...,op. cit., pág. 112.
} 
Al respecto, MUÑOZ CONDE plantea que "si bien, el requisito de la finalidad salva a este precepto de castigar una conducta que realizada en el ámbito privado debe quedar al margen de la intervención del Derecho penal, no deja de ser cuestionable que se haya creado un delito de sospecha, pues siempre será difícil probar cuando la posesión del material pornográfico esta destinada a las conductas de producción, venta, difusión o exhibición citadas en el apartado b). Si la posesión es un acto integrante de las mismas carece de sentido la atenuación de la pena, y si no lo es, debe quedar impune" ${ }^{, 432}$.

FERNÁNDEZ TERUELO considera que existe una notable ampliación del radio de protección penal. Se castigan conductas preparatorias del delito principal cuando sanciona la tenencia del material pornográfico en cuya elaboración se hayan utilizado menores, siempre que se trate de una posesión finalística dirigida a la venta, distribución o exhibición del material ${ }^{433}$.

En resumen y siguiendo a los autores anteriores, puede afirmarse que este tipo resulta muy ineficaz por las dificultades para determinar cuando la posesión es para consumo propio y cuando para el tráfico. Especialmente, resulta muy complejo probar el elemento subjetivo con indicios objetivos. Los criterios cuantitativos son inútiles dado que se puede estar ante casos de coleccionismo pedófilo. Sancionar estas conductas implica un intolerable adelantamiento de las barreras del Derecho penal, ${ }^{434}$ castigando conductas preparatorias del delito principal. Amén de la desnaturalización del Derecho penal moderno que significa crear un delito de sospecha.

Es preciso apuntar que ésta dificultad no quedó zanjada con la reforma de LO 15/2003 de 25 de noviembre que sanciona ambas conductas tanto la posesión para la distribución y tráfico, como para el consumo propio. Lo que en la LO 11/1999 de 30 de

\footnotetext{
${ }^{432}$ MUÑOZ CONDE, F., Derecho Penal...op. cit., pág. 236.

${ }^{433}$ Véase, FERNÁNDEZ TERUELO, J., Cibercrimen. Los delitos... op. cit., pág. 75.

${ }^{434}$ Véase, ORTS BERENGUER, Enrique; ALONSO RIMO, Alberto, "La reforma de los delitos contra la libertad sexual" en ZÚÑIGA RODRÍGUEZ; MÉNDEZ RODRÍGUEZ; DIEGO DÍAZ- SANTOS, Derecho penal sociedad y nuevas tecnologías, Ed. Colex, Madrid, 2001, pág. 51.
} 
abril era una dificultad probatoria ahora es un problema mayor desde el punto de vista político criminal pues se sancionan conductas que no lesionan ningún bien jurídico ${ }^{435}$.

\subsection{El RETORNO DE LA CORRUPCIÓN DE MENORES.}

En el apartado 3 del mencionado artículo 189, se introduce el delito de corrupción de menores o incapaces ${ }^{436}$, que ya había sido suprimido en el código de 1995 . El regreso de este tipo penal busca dar respuesta al clima de alarma social creada alrededor de varios casos de abusos a menores en la sociedad española. Esto es encontramos sus motivaciones en una opinión pública mediatizada y no en la existencia de una necesidad real de protección de bienes jurídicos. Se criminaliza de esta forma actos que ya se encuentran castigados de algún modo en la norma penal con la creencia de que otros tipos delictivos son insuficientes para cubrir adecuadamente las lagunas o déficit de incriminación $^{437}$.

El concepto de corrupción de menores ha sido muy criticado por ser demasiado amplio y por la carga moral de su contenido. Así puede apreciarse en la definición en el Proyecto de Ley Orgánica de modificación del Título VIII del Código Penal ${ }^{438}$, como aquellos actos "encaminados a iniciar o mantener a los menores o incapaces en una vida sexual precoz o prematura, así como los actos de naturaleza sexual cuya intensidad, persistencia o continuidad pueden alterar el proceso normal de formación o desarrollo de la personalidad de aquellos" ${ }^{, 439}$. En esta definición se castiga cualquier forma de

\footnotetext{
${ }^{435}$ Véase, en este capítulo 5.3 la posesión simple de pornografía infantil. (art. 189.2 de la LO15/2003)

${ }^{436}$ La iniciativa a nivel de la jurisprudencia puede ubicarse en el contenido de la conocida STS de 16 de septiembre de 1996, a la que siguieron otras como la Proposición no de Ley presentada por el GPP el 411-1996 y la Recomendación del Defensor del Pueblo presentada el 28-11-1997. Véase, FERNÁNDEZ TERUELO, J., Cibercrimen. Los delitos... op. cit., pág. 57.

${ }^{437}$ PÉREZ CEPEDA, afirma que el retorno del delito de corrupción de menores se debió a las insatisfactorias consecuencias punitivas que se derivan de la aplicación del delito de abuso sexual cometido con abuso de autoridad. “...la jurisprudencia ofrece un concepto muy amplio de corrupción, que viene a ser como un cajón de sastre al que reconducir cualquier conducta de naturaleza sexual subsumibles en otros tipos delictivos, siempre que sea un menor el sujeto pasivo y sea difícil probar la ausencia de su consentimiento, propiciando una expansión punitiva en la praxis que llevó a sancionar contactos sexuales con menores que, en modo alguno, afectaban a bienes jurídicos merecedores de protección. Véase, PÉREZ CEPEDA, A. I., "Un ejemplo más del Derecho penal simbólico: el delito de corrupción de menores", en Revista Actualidad Penal No 22, 2001, pág. 475.

${ }^{438}$ Véase, Proyecto de Ley que posteriormente conformaría la Ley Orgánica 11/1999, de 30 de abril.

${ }^{439}$ MORILLAS FERNÁNDEZ, D. L., Análisis dogmático y criminológico..., op. cit., pág. 147.
} 
iniciar al menor en el sexo, por ejemplo a través de enseñanzas desviadas, sin necesidad de que se practiquen actos de naturaleza sexual. Así, se afirma reiteradamente en muchas sentencias ${ }^{440}$ que asientan doctrina y jurisprudencia sobre el alcance del delito, incluso antes de la reforma comentada.

DÍEZ RIPOLLÉS entiende por corrupción de menores, cualquier comportamiento que pueda fomentar en el menor actitudes sexuales que se alejan de las pautas sociales mayoritarias, es decir, de la moral sexual colectiva sin tener en cuenta si ello supone un atentado a su libertad sexual o no ${ }^{441}$. Por el contrario, BLANCO LOZANO ${ }^{442}$ evitando en el concepto todas aquellas referencias moralizantes como "vicio", "perversión" o "depravación", lo define como la ejecución de uno o varios actos de naturaleza sexual con un menor de edad, (corrompido o no), que le causen un perjuicio en su desarrollo sexual. De está forma intenta suprimir del concepto la moral sexual. Procura ésta autora el avance hacia una definición conceptual construida sobre conductas observables y no sobre juicios subjetivos venidos de una pretendida moral sexual colectiva.

El Precepto en la Reforma 11/1999 de 30 de abril quedó redactado como sigue:

"El que haga participar a un menor o incapaz en un comportamiento de naturaleza sexual que perjudique la evolución o desarrollo de la personalidad de éste, será castigado con la pena de prisión de seis meses a un año o multa de seis a doce meses".

En el tipo no es necesario ni la coacción, ni el engaño o abuso ${ }^{443}$, basta con la mera inducción al menor ${ }^{444} \mathrm{o}$ incapaz a que realice prácticas de naturaleza sexual ya

\footnotetext{
${ }^{440}$ Véase, la Sentencia del Tribunal Supremo 2936/1993, de 27 de diciembre [RJ 199319800], que contempla la corrupción de menores cuando "se avasallan las facultades anímicas, mente y voluntad, del menor, corrompiéndolo sexualmente".

${ }^{441}$ Véase, DÍEZ RIPOLLÉS, J., La protección de la libertad sexual, Barcelona, 1985, pág. 172.

${ }^{442}$ Véase, BLANCO LOZANO, C., "Delitos relativos a la prostitución: conceptos de prostitución y corrupción de menores. Perspectivas jurídico-incriminadoras ante el nuevo código penal de 1995", en $C P C, \mathrm{~N}^{\mathrm{o}} 61,1997$, pág. 127 y ss.

${ }^{443}$ El tipo esta exento de violencia, intimidación o disenso de la víctima, así como otros elementos cuya concurrencia haría surgir otras figuras como agresiones sexuales, abusos sexuales, exhibicionismo, provocación, favorecimiento de prostitución, etc. Véase, SUÁREZ-MIRA RODRÍGUEZ, C., Delitos relativos a la prostitución,..., op. cit., pág. 278 y ss.
} 
sea con quien lo incita, con un tercero o sobre si mismo -una masturbación-. La consecuencia de esas prácticas debe resultar perjudicial para la evolución o desarrollo de su personalidad. Son punibles tanto los actos de iniciación como los de mantenimiento $^{445}$, siendo irrelevante el hecho de que el sujeto pasivo sufriera con anterioridad al de corrupción algún trastorno de su personalidad sexual ${ }^{446}$. En los términos en los que aparece descrita la conducta típica no ofrecen espacio a la comisión por omisión. Habrá tantos delitos de corrupción como sujetos pasivos ${ }^{447}$.

En relación al tipo subjetivo ha de concurrir el dolo tanto directo como eventual y la tendencia de involucrar al menor de edad o incapaz en un contexto sexual perjudicial para su personalidad sexual ${ }^{448}$. La gran dificultad en este delito se presenta en constatar que el resultado producto de las prácticas sexuales ha afectado de forma negativa la evolución de la personalidad $^{449}$. Al respecto, BOLDOVA PASAMAR, plantea que no debe considerarse que cualquier práctica sexual se hace acreedora del calificativo de corruptora, sólo las prácticas sexuales de carácter desviado o aberrante, que sean susceptibles de perjudicar el desarrollo de la personalidad ${ }^{450}$. Ahora bien, si consideramos que este precepto está ubicado dentro del ámbito de los delitos sexuales, los perjuicios a que se refiere el tipo son los trastornos sexuales de la personalidad ${ }^{451}$, es

\footnotetext{
${ }^{444}$ El menor debe ser mayor de trece años, pues si no alcanza esa edad existiría un abuso sexual.

${ }^{445}$ En la sentencia STS de 21-2-1996, A. 1325 se admite el delito sin necesidad de la nota de persistencia o habitualidad.

${ }^{446}$ Véase, RODRÍGUEZ GÓMEZ, C., Tráfico, explotación y..., op. cit., págs. 202 y ss.

${ }^{447}$ Como el bien jurídico que se protege tiene identidad personal (la indemnidad sexual del menor) habrán tantos delitos como menores o incapaces sean afectados, así lo recogen las sentencias SsTS de 31-11997, A.396, y 15-3-1997, A.1729.
}

${ }^{448}$ Véase, BOLDOVA PASAMAR, M. Á., Artículo 189..., op. cit., pág. 559.

${ }^{449}$ El requisito que exige el tipo -que dicho comportamiento perjudique su evolución y desarrollo de su personalidad- es un extremo muy difícil de comprobar. Véase, ORTS BERENGUER, E.; ALONSO RIMO, A., La reforma de los delitos..., op. cit., pág 53.

${ }^{450}$ Véase, BOLDOVA PASAMAR, M. A., Artículo $189 . . .$, op. cit., págs. 551 y ss.

${ }^{451}$ La jurisprudencia anterior a la LO $11 / 1999$ se pronuncia sobre los efectos perjudiciales en la personalidad sexual del menor y no a cualquier otro aspecto de la personalidad., Véase, las sentencias (SsTS de 31 -1-1997, A. 396); (SsTS 4-2-1997, A 693); (SsTS 19-2-1997, A. 1134); (10-4-1997, A.2770); (21-3-2000, A. 2385). 
decir, no cualquier perjuicio para la personalidad del menor o incapaz sino sólo los que afectan a su personalidad sexual clasificados por la $\mathrm{OMS}^{452}$.

Sin embargo, llama la atención BOLDOVA PASAMAR, sobre la jurisprudencia que se viene aplicando el nuevo delito de corrupción (a partir de la LO 11/1999). En algunos casos ni siquiera se comprueba la concurrencia de un perjuicio, bastando una actitud genérica para producirlo ${ }^{453}$ y en otras se señala un perjuicio para la evolución o el desarrollo de la personalidad del menor, pero no en su aspecto sexual ${ }^{454}$. Esto no tiene ningún sentido considerando que los efectos perjudiciales sobre cualquier aspecto de la personalidad "no justifican la existencia de un delito sexual y han de ser objeto de la responsabilidad civil o, si fuera el caso, tratarse como un delito de lesiones, y concretamente contra la salud psíquica del menor o incapaz" ${ }^{455}$.

Cuando se habla de efectos negativos en la personalidad sexual del menor o incapaz hay que tener en cuenta el tiempo, es decir, habría que distinguir los efectos a corto, medio y largo plazo. "A pesar del art. 132.1 del CP que establece que los plazos de prescripción del delito computan a partir de la mayoría de edad de la victima (cuando los hechos se cometieren siendo esta menor de edad) quedan fuera del ámbito de protección de la norma los resultados sobrevenidos muy posteriormente y por lo tanto no se podrá imputar objetivamente el resultado acaecido a muy largo plazo a la conducta de corrupción" 456 .

De acuerdo con lo expuesto anteriormente, la corrupción de menores está presente en cualquier conducta que produzca un comportamiento de naturaleza sexual perjudicial en la evolución o desarrollo de la personalidad del menor o incapaz. En este sentido en cualquier acto de pornografía infantil hay corrupción de menores, pero no necesariamente la corrupción de menores ocurre por actos de pornografía infantil.

\footnotetext{
${ }^{452}$ Véase, BOLDOVA PASAMAR, M. A., Artículo 189..., op. cit., págs. 554 y ss.

${ }^{453}$ Véase, Las sentencias: SsAP de Valencia de 6-2-2002, A. 113061, y Murcia de 19-4-2002, 176970.

${ }^{454}$ Véase, Las sentencias: SsAP de las Palmas de 18-4-2002, A. 155407 y de Córdoba de 5-5-2003, A. 151367.

${ }^{455}$ BOLDOVA PASAMAR, M. A., Artículo $189 . .$. , op. cit., págs. 555 y ss.

${ }^{456}$ RODRÍGUEZ GÓMEZ, C., Tráfico, explotación y..., op. cit., págs. 202 y ss.
} 
Mientras en la pornografía infantil se requiere de actos de contenido sexual explícito con o ante menores de 18 años, la corrupción es más amplia y abarca conductas que impliquen un perjuicio en la evolución o el desarrollo del menor. Basta con proporcionar información o inducir al menor en el aprendizaje de prácticas que le puedan corromper ${ }^{457}$.

Las principales críticas surgidas desde la doctrina expresan que:

a) se trata de una norma mal formulada y de compleja comprobación ${ }^{458}$;

b) la indeterminación del precepto provoca inseguridad jurídica ${ }^{459}$;

c) la figura solo sirve para resguardar la moral sexual y los patrones de comportamiento mayoritarios ${ }^{460}$;

d) funciona como un cajón de sastre en el que incluir prácticamente toda la gama de conductas susceptibles de ser calificadas con arreglos a otros preceptos y siempre que tuvieran como sujeto pasivo al menor ${ }^{461}$;

e) el precepto puede ser considerado incluso como inconstitucional por infracción del principio de legalidad ${ }^{462}$;

f) que puede derivar en una intolerable "pancriminalización" de cualquier acto de connotaciones sexuales en relación con menores o incapaces ${ }^{463}$;

g) no se han respetado las exigencias dimanantes del principio de legalidad - la taxatividad brilla por su ausencia-, ni las de proporcionalidad -las conductas que pueden acabar sancionándose a través suyo deberían quedar extramuro de los lindes del Derecho penal- ${ }^{464}$;

\footnotetext{
${ }^{457}$ Véase, MORILLAS FERNÁNDEZ, D. L., Análisis dogmático y criminológico..., op. cit., pág. 148.

${ }^{458}$ Véase, ORTS BERENGUER, E.; ALONSO RIMO, A., La reforma de los delitos..., op. cit., pág. 53.

${ }^{459}$ Véase, MUÑOZ CONDE, F., Derecho Penal, ..., op. cit., pág. 239.

${ }^{460}$ Véase, DIÉZ RIPOLLÉZ, J. L., Corrupción de Menores, el país 28/11/1996.

${ }^{461}$ Véase; MORALES PRATS, F.; García Albero, R., Delitos contra la..., op. cit., pág. 365

${ }^{462}$ Véase, MUÑOZ CONDE, F., Derecho Penal..., op. cit., pág. 239

${ }^{463}$ Véase; SUÁREZ-MIRA RODRÍGUEZ, C., Delitos relativos a la prostitución..., op. cit., pág. 278.

${ }^{464}$ Véase, ORTS BERENGUER, E.; ALONSO RIMO, A., La reforma de los delitos..., op. cit. pág. 53.
} 
h) hipertrofia la protección dispensada al bien jurídico, consistente en el adecuado proceso de formación y socialización del menor o incapaz;

i) El campo de aplicación de este tipo es ínfimo, y denotativo de su superfluidad;

j) y por último, de acuerdo con MORALES PRATS y GARCÍA ALBERO, “en detrimento de toda técnica subsuntiva, las especialidades de la conductas sexuales ilícitas concerniente a menores, su diversa naturaleza e incluso gravedad, quedaban diluidas, fundidas ahora en la amalgama de los actos en todo caso corruptores."

Puede concluirse que la libertad sexual como esfera de realización individual del ejercicio inalienable de la libertad, debe ser protegida de las pretensiones normativas de la moral sexual, llámese colectiva o dominante. Como bien dice PÉREZ CEPEDA "No es función del Derecho penal la protección de intereses morales, que sólo afectan al fuero interno de la conciencia individual. El legislador debe reducir, dentro de la esfera del Derecho penal sexual, la protección del ejercicio de la libertad sexual, en la concreta esfera de la autorrealización sexual, y en ningún caso extender dicha protección a unas determinadas pautas morales en el seno de la sociedad. Por ello, no le falta razón a DÍEZ RIPOLLÉS, cuando alerta sobre la necesidad de superar en una sociedad pluralista regida por un principio de tolerancia las connotaciones moralistas que lleva implícita esta figura delictiva."465

\subsection{NOTAS FINALES SOBRE LA LO 11/1999 DE 30 DE ABRIL}

En forma resumida puede afirmarse que las principales modificaciones en el artículo 189 de La Ley Orgánica 11/1999 de 30 de Abril, de Reforma del Código Penal, tienen que ver con que se definen claramente los conceptos de pornografía y prostitución, se sancionan nuevos patrones delictuales en materia de pornografía infantil, como el empleo de Internet y añade la agravante de organización delictiva. Pero sin duda desde el punto de vista político criminal lo más infortunado tiene que ver con el regreso del delito de corrupción de menores que en palabras de Pérez Cepeda "al margen de sus trasnochadas concepciones moralizantes, de ser político-criminalmente inútil y encontrarse sociológicamente desconectado de la realidad, resulta disfuncional

${ }^{465}$ PÉREZ CEPEDA, A. I., Un ejemplo más del Derecho..., op. cit., págs. 475 y ss. 
al haber perturbado históricamente el esquema aplicativo de los delitos sexuales concernientes a menores de edad, dando lugar a complejos problemas concursales" ${ }^{\$ 66}$.

\section{LA LEY ORGÁNICA 15/2003, DE 25 DE NOVIEMBRE, POR LA QUE MODIFICA LA LEY ORGÁNICA 10/1995, DE 23 DE NOVIEMBRE, DEL CÓDIGO PENAL.}

\subsection{INTRODUCCIÓN}

En la Exposición de Motivos de la Ley se hace referencia a la necesidad de reajustar el Código Penal para abarcar las nuevas problemáticas delictivas y responder a las más apremiantes preocupaciones sociales. Amparado en la valoración social negativa del sistema penal calificado de ineficaz por ser excesivamente blando o tolerante, tiene el legislador la convicción de que la eficacia del sistema penal, entendida como la respuesta efectiva a la realidad delictual depende de su rigor o dureza $^{467}$. Así, establece en la Exposición de Motivos que "Respecto a los delitos relativos a la corrupción de menores, se ha abordado una importante reforma del delito de pornografía infantil, endureciendo las penas, mejorando la técnica en la descripción de las conductas e introduciendo tipos como la posesión para el propio uso del material pornográfico en el que se hayan utilizado menores o incapaces o los supuestos de la denominada pornografía infantil virtual ${ }^{, 468}$. (Subrayado añadido)

La ampliación de la intervención del Derecho penal y la exasperación de penalidad del legislador están de manifiesto en el art. 189 en la reforma de $2003^{469}$ expresado en: a) aumento del marco de penalidad de 1 a 4 años de prisión,-en el texto reformado contemplaba 1 a 3 años-; b) La posesión para los fines de producción, venta, distribución, exhibición ó facilitación de las anteriores conductas; pasa a ser una modalidad típica básica alternativa, dejando de constituir un tipo privilegiado, como hacía el texto de 1999; c) la posesión para uso propio de material pornográfico, en cuya

\footnotetext{
${ }^{466}$ PÉREZ CEPEDA, A. I., Un ejemplo más del Derecho..., op. cit., pág. 475.

${ }^{467}$ Véase, GARCÍA ARAN, M., "Delincuencia seguridad y pena en el discurso mediático" en MUÑOZ CONDE (Dir.), Problemas Actuales de Derecho Penal y Criminología. Estudios penales en memoria de la profesora María del Mar Díaz Pita. Tiran lo Blanch, Valencia, 2008, pág. 101.

${ }^{468}$ Exposición de Motivos de la Ley Orgánica 15/2003, de 25 de noviembre, por la que modifica La Ley Orgánica 10/1995, de 23 de noviembre, del Código Penal.

${ }^{469}$ Véase, MORALES PRATS, F.; GARCÍA ALBERO, R., Artículo 189..., op. cit., págs. 353 y ss.
} 
elaboración se hubieran utilizado menores de edad o incapaces, se incorpora como tipo privilegiado; d) se amplían los tipos agravados y las penas, con prisión de cuatro a ocho años; e) se incrimina la denominada pseudo-pornografía, donde no han sido utilizados directamente menores o incapaces, pero se emplea, su voz o imagen alterada o modificada. Además, f) junto al incremento de las penas de prisión, se posibilita la imposición de cualquiera de las consecuencias accesorias del art. $129 \mathrm{CP}$, cuando el culpable perteneciere a una sociedad, organización o asociación, incluso de carácter transitorio, que se dedicare a la realización de tales actividades.

Está reforma se ajusta a las exigencias de instrumentos normativos internacionales, sobre todo a los provenientes de la Unión Europea. En general, la tipificación penal de la explotación sexual de menores, y en especial la pornografía infantil a través de Internet, responden a los compromisos adquiridos en La Acción común adoptada por la Unión Europea de 29 de Noviembre de 1996, renovada en diciembre de 2000 .

Aunque las previsiones contenidas en el art. 9 del Convenio de Cibercriminalidad de Budapets ${ }^{470}$ estaban ya recogidas en la reforma anterior de 1999, faltaba la incriminación de la posesión para el propio consumo de pornografía infantil que ha sido contemplada en esta reforma. Sin embargo, a criterio de MORILLAS FERNÁNDEZ el texto legal que marca las pautas o directrices operantes en el artículo 189 de la reforma 15/2003 de 25 de noviembre, es la Propuesta de Decisión Marco del Consejo de Europa relativa a la lucha contra la explotación sexual de los niños y la pornografía infantil ${ }^{471}$, “todos los tipos descritos en el articulado, supuesto de hecho y consecuencia Jurídica, aparecen expresadamente recogidos en el mencionado documento internacional -a excepción de la exhibición y de las circunstancias agravantes referentes al menor de 13 años (el texto internacional lo circunscribe en diez años) y el carácter degradante o vejatorio de las mismas-"

\footnotetext{
${ }^{470}$ Véase, Convenio sobre Cibercriminalidad de 23 de noviembre de 2001, Budapest.

${ }^{471}$ Véase, Resolución Legislativa del Parlamento Europeo aprobada en su Acta del 12/06/ 2001 (A50206/2001).

${ }^{472}$ Véase, MORILLAS FERNÁNDEZ, D. L., Análisis dogmático y criminológico..., op. cit., pág. 139 y SS.
} 
En relación a la obediencia a los documentos internacionales es conveniente advertir que, si bien resulta pertinente la unificación, y coordinación de la legislación internacional en materia de la criminalidad organizada, en especial la que utiliza el ciberespacio como escenario donde desarrolla sus actividades, también es cierto que tomar las recetas y vaciarlas tal cual en las legislaciones nacionales puede conllevar a que se legisle de espaldas a la realidad social de cada país y que se tipifiquen conductas que antes que resolver crean más problemas al interior de cada nación.

Antes de iniciar el análisis de los preceptos que contiene el art. 189 de la LO15/2003 conviene señalar que parte de la doctrina considera negativa la valoración de la reforma, puesto que concluyen que el Derecho penal interviene en ámbitos en los que no resulta sencillo determinar bien jurídico afectado alguno ${ }^{473}$.

No se producen cambios en relación al sujeto pasivo y al sujeto activo contemplados en la LO 11/1999. Si acaso, conviene precisar que en el precepto 7 referido a la pornografía virtual- si se considera que la finalidad del legislador es la de evitar que el consumo de este tipo de material pueda estimular a los paidófilos a involucrar a niños reales en contexto de naturaleza sexual. El sujeto pasivo no sería el niño al que se modifico su imagen o su voz, sino el conjunto de niños vulnerables y posibles víctimas de estas conductas.

Algunos preceptos se mantienen en los mismos términos que la ley anterior con la salvedad del orden sistemático. Así, en el apartado 4 del articulo 189 referido al delito de corrupción de menores que pasa a ser el apartado cuatro en vez del tercero y lo más significativo es que se suprime la multa y se mantiene la pena de prisión de seis meses a un año. En el apartado quinto también las novedades son de cambio sistemático. Esto es, del párrafo cuarto pasa al quinto del tipo penal; y la ampliación de la consecuencia jurídica a la optatividad discrecional del Juez para imponer bien una pena de prisión de tres a seis meses o multa de seis a doce meses. Igualmente, en el párrafo sexto no presenta modificación a excepción de un cambio sistemático, del apartado quinto ahora pasa a ocupar el sexto.

$\overline{473}$ Véase, FERNÁNDEZ TERUELO, J., Cibercrimen. Los delitos..., op cit., pág. 62. 
Una de las Novedades de esta reforma tiene que ver con la inclusión del apartado octavo del art. 189 que prevé la posibilidad de imponer las medidas del art. 129 del Código Penal $^{474}$, a las personas jurídicas en función de las acciones ilícitas -relacionadas a la pornografía infantil- que realizan las personas físicas que operan para dichas organizaciones. Fundamentado en la peligrosidad objetiva de tales personas jurídicas su aplicación está orientada a prevenir la continuidad en la actividad delictiva y los efectos de la misma tal como lo establece el punto 3 del art. 129. La aplicación de estas consecuencias jurídicas son totalmente independientes de la agravación de la pena contemplada para la persona física en art. 189.3.e $)^{475}$.

De entrada conviene apuntar que aunque el precepto se supedita a los casos previstos en los apartados anteriores art. 189, su ámbito de aplicación se concreta en los apartados 1 y 7 , que hacen referencia a los delitos de pornografía infantil y de pornografía virtual de menores e incapaces donde tendría cabida la vinculación del culpable con la pertenencia a una sociedad, organización o asociación, incluso de carácter transitorio, que se dedique a la realización de tales actividades delictivas. En este sentido, quedan fuera los que propiamente no establecen delitos como el apartado 189.3 -las circunstancias agravantes-; y el 189.6 -actuación del ministerio fiscal-; tampoco tiene sentido apreciar consecuencias accesorias en el art 189.2 -posesión simple-, ni en el 189.5 -conducta omisiva de garante- ${ }^{476}$. En el apartado 4 referido a la

\footnotetext{
${ }^{474}$ El artículo 129 del Código Penal Español establece que: “1. El juez o tribunal en los supuestos previstos en este Código, y sin perjuicio de lo establecido en el artículo 31 del mismo, previa audiencia del ministerio fiscal y de los titulares o de sus representantes legales podrá imponer, motivadamente, las siguientes consecuencias: a) Clausura de la empresa, sus locales o establecimientos, con carácter temporal o definitivo. La clausura temporal no podrá exceder de cinco años; b) Disolución de la sociedad, asociación o fundación; c) Suspensión de las actividades de la sociedad, empresa, fundación o asociación por un plazo que no podrá exceder de cinco años; d) Prohibición de realizar en el futuro actividades, operaciones mercantiles o negocios de la clase de aquellos en cuyo ejercicio se haya cometido, favorecido o encubierto el delito. Esta prohibición podrá tener carácter temporal o definitivo. Si tuviere carácter temporal, el plazo de prohibición no podrá exceder de cinco años; e) la intervención de la empresa para salvaguardar los derechos de los trabajadores o de los acreedores por el tiempo necesario y sin que exceda de un plazo máximo de cinco años.

2. La Clausura temporal prevista en el subapartado a) y la suspensión señalada en el subapartado c) del apartado anterior, podrán ser acordadas por el Juez Instructor también durante la tramitación de causa.

3. Las consecuencias accesorias previstas en este artículo estarán orientadas a prevenir la continuidad a la actividad delictiva y los efectos a la misma."

${ }^{475}$ BOLDOVA PASAMAR, M. Á., Artículo 189..., op. cit., págs. 570 y ss.

${ }^{476}$ Véase, BOLDOVA PASAMAR, M. Á., Artículo 189..., op. cit., pág. 570. Este autor llama la atención sobre el problema conceptual que se presenta al designar como "medidas" a las consecuencias accesorias.
} 
corrupción de menores, es discutible que puedan aplicarse las consecuencias jurídicas del $189.8^{477}$

La peligrosidad objetiva de la persona jurídica estará determinada por la realización de la conducta contraria a la ley de uno de sus miembros en el marco de actividades delictivas. En este caso el culpable no es precisamente la persona física que realiza la acción delictiva, sino la sociedad, empresa, fundación o asociación de la que forma parte ${ }^{478}$.

En relación al pronunciamiento de la doctrina sobre la inclusión de este precepto, se apreciaba aceptación por su eficacia para impedir la comisión de nuevos delitos ${ }^{479}$. Sin embargo, en la recién aprobada Ley Orgánica 5/2010, de 22 de junio, fue suprimida ésta norma y sustituida por el nuevo artículo 189 bis, que a su vez remite al nuevo artículo 31 para la determinación de las personas jurídicas.

\subsection{Principales Modificaciones al Artículo 189.1}

En el artículo 189.1 a) se siguen incriminando las tres modalidades típicas que estaban previstas en la reforma de 1999, a saber: a) la utilización de menores e incapaces con fines o en espectáculos exhibicionistas o pornográficos, tanto público

\footnotetext{
${ }^{477}$ En relación al art. 194 del Código Penal español que contempla la disposición común aplicable a los delitos sexuales de los Capítulos IV y V, este precepto va mucho más lejos. Siguiendo a Boldova Pasamar podemos apuntar la diferencia en:

a) En el precepto estudiado (art. 189.8) se sujetan los establecimientos o locales a la existencia de una sociedad, organización o asociación criminal; en el art. 194 no necesariamente se vinculan a las agrupaciones mencionadas.

b) $\quad$ El apartado 8 del art. 189 establece que además de locales o establecimientos, se pueda imponer la clausura temporal o definitiva también a empresas, el requisito es que se dediquen a la realización de actividades de pornografía infantil, no es necesario que la empresa, sus locales o establecimientos hayan sido utilizados en la realización de dichas actividades. Donde si convergen tanto los art. 189.8 y 194 es en la limitación de la clausura temporal a cinco años, así como la posibilidad de adoptarla con carácter cautelar o durante la tramitación de la causa. Además de las anteriores consecuencias jurídicas accesorias para los delitos del art. 189 se puede aplicar otras como: la disolución o la suspensión de las actividades de la sociedad, asociación o fundación por un plazo que no deberá exceder de cinco años, y que podrá acordarse durante la tramitación de la causa; también podrá prohibirse la realización en el futuro de actividades, operaciones mercantiles o negocios de la clase de aquellos en cuyo ejercicio se haya cometido, favorecido o encubierto el delito con carácter definitivo o temporal, sin que pueda exceder de cinco años; y, finalmente, la intervención de la empresa para salvaguardar los derechos de los trabajadores o de los acreedores por el tiempo necesario y sin que pueda exceder de un plazo máximo de cinco años. Véase, BOLDOVA PASAMAR, M. Á., Artículo 189..., op. cit., págs. 569 y ss.

${ }^{478}$ BOLDOVA PASAMAR, M. Á, Artículo 189..., op. cit., págs. 569 y ss.

${ }^{479}$ SUÁREZ-MIRA RODRÍGUEZ, C., Delitos relativos a la prostitución..., op. cit., pág. 281.
} 
como privado; b) la elaboración de cualquier clase de material pornográfico donde se utilice a menores e incapaces y c) la financiación de cualquiera de las actividades $\operatorname{descritas}^{480}$.

Son dos, las principales modificaciones que pueden apuntarse. La primera es que se eleva el límite máximo de las penas de prisión aplicable al sujeto activo al pasar de tres a cuatro años. La segunda es que agrega la frase "cualquiera que sea su soporte" con la intención de abarcar todo tipo de dispositivo donde pueda insertarse el referido material vía telemático, magnéticos o en papel. Compartimos la posición de MORALES PRATS cuando plantea que está referencia es desde todo punto de vista innecesaria dada la amplitud con la que ya se venía redactando con anterioridad el artículo 189.1 a del $\mathrm{CP}^{481}$.

Ahora bien, en el art. 189.1a) no queda claro el grado de implicación del menor en el espectáculo exhibicionista o pornográfico para el que es utilizado. "Debe entenderse que la "ratio" del precepto no limita al ámbito de incriminación a los supuestos en el que el menor es parte activa de conductas o escenas de tipo obscenas. En este sentido, el precepto abarca también conductas en las que el menor se limita a presenciar la conducta obscena protagonizada por mayores de edad, por cuanto, en tales casos, el menor queda involucrado en un contexto atentatorio a su indemnidad sexual" 482 .

Otra de las nuevas referencias la encontramos en el 189.1 b) donde se agrega, "por cualquier medio". El 189.1 b) pretende abarcar las redes informáticas además de cualquier tipo de soporte, ya sea difusión gráfica, fotográfica, analógica, digital o de cualquier otra forma. En este mismo precepto hay un cambio en el 189.1 b) en la redacción en relación a la posesión destinada a la producción, venta, distribución, exhibición o facilitación de material pornográfico infantil. En la reforma de 1999 aparecía en un párrafo independiente "A quién poseyera dicho material para la realización de...", por lo que se trataba de un tipo privilegiado; ahora en la reforma del 2003 queda "o lo poseyere para estos fines" pasando a ser una modalidad típica básica

\footnotetext{
${ }^{481}$ Véase, MORALES PRATS, F.; García Albero, R., Artículo 189..., op. cit., pág. 350.

${ }^{482}$ MORALES PRATS, F.; GARCÍA ALBERO, R. Artículo 189..., op. cit., pág. 351.
} 
alternativa. Desaparece la atenuación de la pena que se recogía antes de la modificación, para el que posea material pornográfico de menores equiparando dicha conducta a las otras previstas en el mismo artículo (producción, venta, distribución exhibición, o la facilitación para los mismos fines). En este tipo habrá tantos delitos como sujetos pasivos aunque sea el mismo sujeto activo el que los cometa.

En el punto sobre la posesión finalística, las dificultades probatorias para establecer cuando la posesión es para consumo propio y cuando para el tráfico o difusión reúne una opinión desfavorable por parte de la doctrina sobre el precepto ${ }^{483}$, la actitud coleccionista del pedófilo complica los criterios para determinar la intención o ánimo acorde con la cantidad de material que posee. Ahora bien, con la reforma de LO 15/2003 se sanciona la posesión tanto para la distribución y tráfico, como para el consumo propio. En este sentido, la ausencia de prueba respecto a la finalidad de la posesión determinará, en todo caso, la aplicación subsidiaria del tipo referido a la posesión para autoconsumo contemplado en el 189.2.

\subsection{La Posesión Simple de Pornografía Infantil. (Artículo 189.2)}

Hasta la LO 15/2003, la posesión de material pornográfico para el propio consumo era atípica en la legislación española, sin embargo, ya estaba establecida en la mayor parte de las legislaciones europeas ${ }^{484}$. A partir de la mencionada reforma quedó contemplado en el artículo 189.2 redactado de la siguiente forma:

"El que para su propio uso posea material pornográfico en cuya elaboración se hubieran utilizado menores de edad o incapaces, será castigado con la pena de tres meses a un año de prisión o con multa de seis meses a dos años."

\footnotetext{
${ }^{484}$ El Código Penal Frances castiga en el art. 227-23 el hecho de detentar una imagen o representación de un menor cuando muestren un carácter pornográfico, con pena de multa y dos años de prisión; En Alemania, el § 184.b. IV del Strafgesetzbuch (Código Penal) impone hasta dos años de prisión o multa a quien lleve a cabo actos para procurarse la posesión de documentos pornográficos que reproduzcan un hecho real o con apariencia de realidad, o a quien posea dichos documentos. El Código Penal Italiano en su art. 600 cuarto, establece una pena máxima de tres años de prisión y multa para aquel que, «conscientemente se provea o disponga de material pornográfico producido por medio de la explotación sexual de menores de dieciocho años». En Holanda se castiga el tráfico de pornografía infantil en el art. 240b sec. 1 del Código Penal, que ha sido reformado en abril de 1995 para incluir la posesión. También Noruega modificó su Código Penal en 1992 para incluir la posesión. Véase, International Centre for Missing \& Exploited Children (Feb. 10, 2006).
} 
Se trata de un tipo privilegiado, que requiere la tenencia de al menos un documento, independientemente del soporte donde se encuentre en el que hayan sido utilizados un menor o incapaz real para su elaboración, desempeñando acciones de inequívoco carácter libidinoso y que esa posesión sea para el propio uso del tenedor. Para la observancia de este delito, es necesaria la tenencia física y tangible del material pornográfico, o su conservación en los archivos de un ordenador. No obstante, el simple visionado o audición de contenido pornográfico no se entendería como realización del tipo, ya que sería necesario almacenarlo en algún dispositivo y que el usuario pueda acceder a él autónomamente ${ }^{485}$.

Este tipo penal presenta graves problemas de prueba. Determinar cuando se posee un material con la finalidad de consumo propio y cuando con la finalidad divulgativa, no es tarea fácil, ya que la diferencia entre los dos delitos no reside en un aspecto objetivo, sino subjetivo, del comportamiento. Para saber si estamos en un supuesto o en otro no es suficiente la mera cantidad de material poseído, ya que bien se puede tratar de una posible existencia de un coleccionismo pedófilo sin finalidad divulgativa ${ }^{486}$. En consecuencia, atender en tales casos al criterio cuantitativo de material acumulado no resulta en absoluto decisivo ${ }^{487}$. En el 189 se castiga entonces toda clase de posesión de pornografía infantil, con la diferencia de que la pena por posesión con finalidad divulgativa (189.1 b) prisión de uno a cuatro años superior a la que corresponde a la posesión para uso personal, prisión de tres meses a un año o multa de seis meses a dos $\operatorname{años}^{488}$. MORALES PRATS y GARCÍA ALBERO, consideran que en la tipificación de la posesión "se ha optado por la opción mas inquisitiva reclamada por algunos sectores, cifrada en la represión genérica de la mera posesión, según el modelo que ofrecen algunos países de la Unión Europea. Por consiguiente, la mera y estricta posesión queda incriminada, lo que significa que en todo caso el tipo queda descargado de la prueba de

\footnotetext{
485 Véase, ORTS BERENGUER, E., "Delitos contra la indemnidad sexual" en VVAA Derecho Penal. Parte Especial, Ed. Tirant lo Blanch, Valencia2004, págs. 294 y ss.; BOLDOVA PASAMAR, Miguel Á, Artículo $189 .$. op. cit., págs. 539 y ss.

${ }^{486}$ Véase, en este capítulo, 4.2 .2 b) sobre posesión de material pornográfico infantil para la producción, venta, distribución, difusión, exhibición.

${ }^{487}$ BOLDOVA PASAMAR, Miguel Á, Artículo 189..., op. cit., págs. 539 y ss.

${ }^{488}$ Véase, BOLDOVA PASAMAR, M. Á, Artículo 189..., op. cit., pág., 539 y ss.
} 
una preordenación al tráfico en las conductas de posesión a incriminar ex art. 189.1b) apartado segundo" $489 / 490$.

El tipo cuenta con el rechazo de la mayor parte de la doctrina por razones político criminal, sobre todo por la inexistencia de bien jurídico protegido y por entender que va en contra de los principios de mínima intervención y lesividad del Derecho penal ${ }^{491}$.

A nivel legislativo la aprobación de este tipo fue muy criticada, así la enmienda $\mathrm{n}^{\mathrm{o}}$. 52 ante el Congreso de los Diputados del PNV (Partido Nacionalista Vasco) también reproducida ante el Senado- consideró que la sanción penal de esta posesión sin ánimo de difusión rebasa los limites de un Derecho penal exclusivamente protector de bienes jurídicos, por muy repugnante que sea desde el punto de vista moral, pero el Derecho penal no debe proteger concepciones morales y tal posesión no crea ningún riesgo para la libertad sexual e indemnidad del menor. En la misma línea, La enmienda $\mathrm{n}^{\mathrm{o}} .108$ del PSOE, planteó su suspensión porque la criminalización del consumidor de pornografía resulta desproporcionada con los fines perseguidos en el precepto que son fundamentalmente la protección de la libertad sexual e indemnidad del menor ${ }^{492}$.

En el capítulo IV abordaremos de forma más detallada cada uno de los argumentos por los que consideramos que debe destificarse la mera posesión para el consumo.

\footnotetext{
${ }^{489}$ MORALES PRATS, F.; GARCÍA ALBERO, R. Artículo 189..., op. cit., pág. 361

490 A modo ilustrativo hacemos referencia a los artículos que recogen la tipificación de la posesión en Códigos Penales Extranjeros. El Código Penal danés en sus art 235 castiga, inter alia, la difusión y posesión de otras reproducciones visuales de material pornográfico relativo a menores de 18 años; $E l$ Código Penal estonio castiga en los arts. 177 y 178 el uso de un menor o el uso de cualquier otra forma para manufacturar o almacenar pornografía infantil. Por su parte el Código Penal griego en el art. 348a castiga distintos delitos relativos a la pornografía infantil, incluyendo la posesión, la compra y la difusión; Código Penal de Islandia en el art 210 sanciona la posesión de fotografías, películas, o material comparable representando niños en una forma sexual u obscena; El Código Penal de Luxemburgo en el art 383 del castiga no solo la elaboración y posesión (para comerciar, distribuir o exhibir públicamente) de escritos, impresos, imágenes, fotografías, películas u otros objetos de naturaleza pornográfica sino también la comisión de delitos de pornografía infantil de cualquier modo;. Véase, International Centre for Missing \& Exploited Children (Feb. 10, 2006).
}

${ }^{491}$ Véase, RODRÍGUEZ GÓMEZ, C., Tráfico, explotación y..., op. cit. págs. 202.

492 SÁNCHEZ MELGAR, J., (Coord.) Código Penal. Comentarios y Jurisprudencia, Ed. SEPIN, $2^{\mathrm{a}}$ edición, Madrid, 2006, págs. 1118 y ss. 


\subsection{NueVas y MÁS AgravanteS. (ARTículo 189.3 LO 15/2003)}

En el apartado189.3 que recoge la figura agravatoria de la responsabilidad penal. Ocurren en él cambios importantes en relación a la LO 11/1999 de 30 de abril, tales como: se incrementa considerablemente la pena hasta ocho (8) años prisión; se agrega un listado con seis (6) circunstancias que no existían hasta ese momento a excepción del apartado e) referida a la pertenencia a una organización u asociación delictiva, y la letra f) a la condición del sujeto activo de tutor, guarda, maestro etc. En relación a estas dos circunstancia se produjo también un cambio sistémico en la LO 11/1999 se contemplaba de forma separada en los puntos 2 y 4 .

El apartado quedó redactado de la siguiente forma:

"Serán castigados con la pena de prisión de cuatro a ocho años los que realicen los actos previstos en el apartado 1 de este artículo cuando concurra alguna de las circunstancias siguientes:

a) Cuando se utilicen a niños menores de 13 años.

b) Cuando los hechos revistan un carácter particularmente degradante o vejatorio.

c) Cuando los hechos revistan especial gravedad atendiendo al valor económico del material pornográfico.

d) Cuando el material pornográfico represente a niños o a incapaces que son víctimas de violencia física o sexual.

e) Cuando el culpable perteneciere a una organización o asociación, incluso de carácter transitorio, que se dedicare a la realización de tales actividades.

f) Cuando el responsable sea ascendiente, tutor, curador, guardador, maestro o cualquier otra persona encargada, de hecho o de Derecho, del menor o incapaz."

La coexistencia de dos o más de estas circunstancias no supone un incremento de pena con arreglo a este precepto, aunque sí pueda suponerlo con la aplicación de las reglas generales de determinación de la pena ${ }^{493}$. Estas circunstancias agravantes sólo se aplican para el apartado 1, es decir, no se aplica al delito de posesión para propio uso de pornografía infantil contemplado en el 189.2 del CP.

\footnotetext{
${ }^{493}$ Véase, SUÁREZ-MIRA RODRÍGUEZ, C., Delitos relativos a la prostitución..., op. cit. pág. 277.
} 
El apartado a) referido la condición del sujeto pasivo ${ }^{494}$, indica el desvalor mayor de la acción cuando se trate de niños menores de 13 años, teniendo en cuenta la vulnerabilidad desde un punto de vista físico y psicológico, para oponerse a la conducta del sujeto activo. La apreciación de esta circunstancia agravante especial requiere del dolo del sujeto activo, en este sentido no queda abarcado el tipo cuando sobre la base del artículo 14.2 del Código Penal, los casos en los que se yerre sobre la edad del menor, por ejemplo, por su prematuro desarrollo físico ${ }^{495}$. Esta posición la comparte BOLDOVA PASAMAR, cuando plantea que el dato cronológico de la edad debe ser abarcado por el dolo — si bien sea eventual— del sujeto activo. Lo importante en este caso es que "la ley ha establecido un criterio objetivo, al margen de que deba ser comprendido por el dolo, que no permite la acreditación ni en positivo ni en negativo de los fundamentos internos de la agravación" ${ }^{496}$.

En este apartado es conveniente recoger la observación que hace GÓMEZ TOMILLO, sobre el hecho de que no haya sido contemplada su aplicación a los supuestos descritos en el artículo 187, "cuando se trata de prostitución de los mismos sujetos pasivos, si se considera que los hechos con contenido sexual pueden ser idénticos"497. Considera el autor que es inadmisible que la prostitución de un menor de trece años no merezca una sanción agravada, frente a los supuestos en los que no concurre tal circunstancia. "Otra cosa es que, insistimos, la utilización de menores o incapaces en espectáculos exhibicionistas o pornográficos o su utilización para elaborar material de esa índole, siempre por precio, merezca o necesite un reproche penal superior al de la prostitución en la que no se procede a grabar o a exhibir el hecho sexual, y ello en la medida en que, en este último caso, cuanto menos potencialmente, podría afectarse a la intimidad del menor o incapaz" ${ }^{498}$.

\footnotetext{
${ }^{494}$ Véase, este tipo agravado es similar al que se encuentra previsto en el art. 180.1.3a) para los delitos de agresiones y abusos sexuales, y, por lo tanto, el aumento de pena tiene el mismo fundamento que en esos casos. Véase BOLDOVA PASAMAR, M. Á. Artículo 189..., op. cit., pág. 540.

${ }^{495}$ Véase, GÓMEZ TOMILLO, M., Derecho penal Sexual y..., op. cit., pág. 32

${ }^{496}$ Véase, BOLDOVA PASAMAR, M. Á., Artículo 189..., op. cit., pág. 540.

${ }^{497}$ GÓMEZ TOMILLO, M., Derecho penal Sexual y..., op. cit., pág. 32

${ }^{498}$ Ibídem, pág. 3.
} 
En el literal b) se hace mención a la naturaleza de los hechos ejecutados, cuando revista un carácter particularmente degradante o vejatorio ${ }^{499}$. Este tipo agravado "está refiriendo a las conductas de la letra a) del art. 189.1, de utilización de menores o incapaces con fines exhibicionistas o pornográficos o para elaborar pornografía, incluida la financiación de estas actividades, aunque en este último caso no es el hecho de financiar, sino el hecho financiado lo que puede revestir un carácter particularmente degradante o vejatorio. Por el contrario, carece de sentido su aplicación a las conductas de la letra b) consistentes en el tráfico o posesión para el tráfico de pornografía infantil, puesto que tales hechos se sitúan ya en la fase de agotamiento del hecho de utilizar sexualmente al menor o incapaz de forma degradante o vejatoria" ${ }^{, 500}$.

Según GÓMEZ TOMILLO, “Aun cuando quizá pueda justificarse la introducción de esta circunstancia, para sancionar más gravemente hechos que el hombre medio considera especialmente graves, la misma puede generar cierta problemática social...Los medios de comunicación no suelen entender que aun cuando toda agresión sexual es degradante para su víctima, cabe la posibilidad de que algunas lo sean en un grado valorativamente superior, sin que, precisamente por tratarse de un concepto normativo, se pueda precisar, matematizar cuándo se produce ese salto cualitativo; lo que desde el punto de vista de una racional intelección de la Ley no cabe es el vaciado de contenido del tipo básico. En cualquier caso, el salto punitivo que su apreciación implica es tan grande que el legislador debería haber precisado más, descartando elementos puramente valorativos" ${ }^{, 501}$.

El contenido del apartado c) "Cuando los hechos revistan especial gravedad atendiendo al valor económico del material pornográfico", trata de un tipo cualificado soportado en que es "más grave el desvalor del resultado, pues el valor económico del material pornográfico estará en relación directa con la existencia de cantidades de notoria importancia, lo que implica que en ellos se encuentran perpetuados un número

\footnotetext{
${ }^{499}$ Según BOLDOVA PASAMAR, se trata de un tipo agravado semejante al previsto para el delito de agresión sexual en el art. 180.1-1- ${ }^{\mathrm{a}}$, la diferencia consiste en que en la agresión sexual el carácter particularmente degradante o vejatorio viene referido exclusivamente a la violencia o intimidación ejercidas, mientras que aquí dicha característica alude a los hechos. Véase, BOLDOVA PASAMAR, M. Á., “Artículo 189...”, op. cit., pág. 541.

${ }^{500}$ BOLDOVA PASAMAR, M. Á., Artículo 189..., op. cit., pág. 541.

${ }^{501}$ Véase, GÓMEZ TOMILLO, M., Derecho penal Sexual y..., op. cit., pág. 32
} 
proporcional de atentados contra la libertad o indemnidad sexuales de menores de edad o incapaces. ${ }^{, 502}$ La jurisprudencia determinará los valores económicos del objeto del delito a partir de los cuales deberá estimarse una especial gravedad ${ }^{503}$. GÓMEZ TOMILLO, es crítico de este tipo agravado afirmando que “... el carácter indeterminado de la cláusula impide matematizar cuándo procede su apreciación"

Calificada por la doctrina como la peor diseñada de todas las circunstancias agravantes por los múltiples problemas que presenta, el apartado d) queda transcrito así: cuando el material pornográfico represente a niños o a incapaces que son víctimas de violencia física o sexual. El primer problema a señalar es que de acuerdo al verbo empleado no se requiere que la violencia sea real, sino que es suficiente la representación de ésta con lo cual se puede estar ante una exaltación de la violencia, pues tiene el mismo desvalor la violencia real que la representada. El segundo problema es que la violencia debe ser ejercida por un tercero y no del propio sujeto pasivo para ser considerado "víctima",505. Una tercera observación viene dada por lo criticable que resulta que el legislador no haya concretado a lo que se refiere con la expresión "niño". Debe entenderse, sin embargo como equivalente a un menor de trece años ${ }^{506}$. El cuarto problema, tiene que ver con no perder de vista que estamos hablando de material pornográfico en el que intervienen menores con actos con contenido sexual, en este sentido se debe definir cuándo estamos en presencia de "violencia sexual" y plantear la

502 BOLDOVA PASAMAR, M. Á. Artículo 189..., op. cit., pág. 541.

${ }^{503}$ Para BOLDOVA PASAMAR, la jurisprudencia determinará los valores económicos probablemente a partir de los criterios ya empleados en los delitos en los que figuran tipos agravados de similares características, como sucede en el ámbito de las infracciones penales contra el patrimonio (arts. 235.3 para el hurto, 241.1 para el robo, 250.1.6.- para la estafa y 252 para la apropiación indebida). En éstas la jurisprudencia actual del Tribunal Supremo viene considerando la especial gravedad atendiendo al valor de los efectos sustraídos o defraudados cuando dicho valor económico supera los 12.020 euros. Véase, BOLDOVA PASAMAR, M. Á., Artículo 189..., op. cit., pág. 541.

${ }^{504}$ GÓMEZ TOMILLO, M., Derecho penal Sexual y..., op. cit., pág. 32.

${ }^{505}$ De acuerdo a esta circunstancia agravante cuando la violencia es real habrá que apreciar concurso de delitos con agresiones sexuales, lesiones, etc. Véase, BOLDOVA PASAMAR, M. Á. Artículo 189..., op. cit., pág. 542.

${ }^{506}$ Según GÓMEZ TOMILLO, es posible entender la expresión "niños" al menos de dos maneras: En primer lugar, como equivalente a menor de trece años, en consonancia con la letra a) de este mismo artículo 189.3. En segundo lugar, atendiendo al concreto desarrollo del menor, de forma que se aplicará siempre que físicamente el menor no haya traspasado el umbral de la adolescencia, con independencia de la concreta edad que posea. Pese a ello, no satisface la segunda de las opciones sugeridas, por cuanto arrojaría una enorme inseguridad jurídica". Véase, GÓMEZ TOMILLO, M. Derecho penal Sexual y..., op. cit., pág. 33. 
diferencia desde el punto de vista legal de la "violencia física"507. Ello es de suma importancia puesto que una interpretación demasiado amplia dejaría sin contenido al tipo básico. Para GÓMEZ TOMILLO, “...probablemente se deba considerar violencia sexual con menores los hechos que más gravemente atentan contra su indemnidad sexual, esto es, aquellos que, concurriendo el resto de requisitos típicos, constituirían un delito de violación: acceso carnal por vía vaginal, anal o bucal o introducción de miembros corporales u objetos por cualquiera de las dos primeras vías, a los que habría que sumar, probablemente las hipótesis de zoofilia",508.

La estructura organizada contemplada en el punto e) cuando el culpable perteneciere a una organización o asociación, incluso de carácter transitorio, que se dedicare a la realización de tales actividades, estaba ya prevista desde la LO 11/1999, y se fundamenta en el mayor desvalor de la acción y sobre todo en la mayor peligrosidad de la conducta que deriva de que el culpable realice sus actividades delictivas al amparo de la criminalidad organizada. Esta agravante es similar a la que figura en el delito de prostitución de menores en el art. $187.3^{509}$.

En este punto es conveniente exponer aunque sea de forma breve, el amplio margen de interpretación judicial a que se presta la agravante de pertenencia a una organización o asociación, incluso de carácter transitorio vinculada a la pornografía infantil. Siguiendo a RUIZ RODRÍGUEZ y GONZÁLEZ AGUDELO ${ }^{510}$, que toman como referencia dos sentencias diferentes STS 1444/2004 (Sala de lo penal, Sección 1.a) de 10 de diciembre y la STS 913/2006 de 20 de septiembre de 2006, constatan que las argumentaciones de ambas y la respuesta jurídica son en direcciones totalmente opuestas, aún cuando los supuestos de hechos son similares. Según los autores en estas

\footnotetext{
${ }^{507}$ Para BOLDOVA PASAMAR, "la violencia física es algo más que el uso del vis phisica y alude como mínimo al maltrato de obra. La violencia sexual, si ha de diferenciarse de la material, debe acotarse a la violencia que, ejercida de forma real o simulada, está íntimamente ligada a la satisfacción sexual como por ejemplo, el sadismo.” BOLDOVA PASAMAR, M. Á. Artículo 189..., op. cit., pág. 542.

${ }^{508}$ GÓMEZ TOMILLO, M. Derecho penal Sexual y..., op. cit., pág. 33

${ }^{509}$ Véase, BOLDOVA PASAMAR, M. Á. Artículo 189..., op. cit., pág. 542.

${ }^{510}$ Para más detalle sobre este tema Véase, RUIZ RODÍGUEZ, L. R., GONZÁLEZ AGUDELO, G., "El factor tecnológico en la expansión del crimen organizado. ¿Menores en riesgo?, en Puente Alba Luz María (Dir.) Criminalidad organizada, terrorismo e inmigración. Retos contemporáneos de la política criminal, Ed. Comares, $N^{\circ} 98,2008$, pág. 35 y ss.
} 
sentencias "lo más destacado no sólo son las distintas posibilidades de interpretación ofrecidas por la indeterminación de los conceptos, sino los argumentos utilizados en uno y otro caso para ampliar o restringir la aplicación de la agravante"511.

En el primer dictamen del ponente Manuel Maza Martín, STS 1444/2004 razonado en que uno de los sujetos elaboró y aportó a la página Web álbumes de fotografías, se confirma la condena de este como autor de corrupción de menores con la concurrencia de la agravante específica de "organización" ${ }^{, 512}$. La sentencia señala que cuando se cometan delitos utilizando las redes informáticas "...el propio instrumento comisivo la "Red", bastará para integrar tanto la utilización de medios idóneos para configurar la actuación coordinada propia de la organización delictiva, como para alcanzar la finalidad pretendida... la simple utilización de la red de comunicaciones informáticas supone ya el aporte del elemento de coordinación y el empleo excepcional que se proyecta hacia una mayor lesividad, imprescriptibles, aunque no del todo suficientes, para la consideración de la existencia de una organización criminal"513.

La segunda sentencia del ponente Antonio Martín Tallin, STS 913/2006, ${ }^{514}$ en una dirección totalmente opuesta a la anterior, señala que "las acciones ejecutivas imputables a una persona a la que se la adjudica la condición de miembro de una asociación pasa por un cierto dominio del hecho, caso que no concurre en el consumo y aportación de imágenes de origen desconocido a la red de pornografía infantil. Los autores de hecho como el que estamos examinando casi siempre actuarán en función de sus instintos sexuales y nunca por medio de órdenes, instrucciones o cualquier otra tarea previamente convenida" ${ }^{, 515}$. Así mismo, la sentencia cuestiona la extensión del concepto de organización delictiva a estos supuestos, pues no contribuye a proteger el bien

\footnotetext{
${ }_{511}^{511}$ RUIZ RODÍGUEZ, L. R.; GONZÁLEZ AGUDELO, G., El factor tecnológico en ..., op. cit., pág. 35. ${ }^{512}$ Idem.

${ }^{513}$ Ibídem, pág. 36.

${ }^{514}$ La sentencia cuestiona la vaguedad e imprecisiones del legislador al momento de definir la organización como conjunto de tres o más malhechores, con una mínima estructura y coordinación. Para el ponente Martín Tallin esto supone que el concepto de organización lleva implícito un pacto previo en el que se establecen los modos o formas de actuación, la estructura jerárquica, el reparto de papeles y la continúa o frecuente comunicación entre sus componentes. Véase, STS 913/2006 de 20 de septiembre de 2006.

${ }^{515}$ RUIZ RODÍGUEZ, L. R.; GONZÁLEZ AGUDELO, G., El factor tecnológico en la..., op. cit., pág. 36.
} 
jurídico tutelado, por el contrario va en contra del principio de proporcionalidad, y además se utiliza "un Derecho penal objetivo en el que la culpabilidad, más moral que jurídica, se conecta con el resultado, a través de los hilos invisibles del ordenador y discurre por el inabarcable Software de la Red"516.

La presentación de las anteriores sentencias muestran como en la medida que el legislador no precisa con claridad los tipos; no plasma de forma clara la intención político criminal, estableciendo los bienes jurídicos tutelados en cada caso, mayor será el margen de interpretación y la inseguridad jurídica. El aprovechamiento que hace la criminalidad organizada de las altas tecnologías de información y comunicación para el desarrollo de su actividad lesiva, plantean nuevos riesgos a los que se pretende responder relajando las reglas de juego -instrumentos jurídicos- para garantizar la eficacia en el control y la represión de dicha criminalidad. Sin embargo, no hay que perder de vista que "la efectividad de un sistema de libertades requiere unos presupuestos políticos, económicos, sociales y culturales que contribuyen las llamadas "garantías generales" de los derechos fundamentales, y estas son irreductibles"517.

El último de los agravante contemplado en el artículo 189.3 apartado f) cuando el responsable sea ascendiente, tutor, curador, guardador, maestro o cualquier otra persona encargada, de hecho o de Derecho, del menor o incapaz, se fundamenta en el mayor desvalor de la acción por la infracción de deberes jurídicos específicos, "la agravación trae su causa en la quiebra de la función de garantía que incumbe al autor sobre los bienes jurídicos del menor o incapaz"518. "El responsable hay que entender que puede serlo en concepto de autor o de cómplice. A éste se le impondrá, no obstante, la pena inferior en grado. Por otro lado, al haberse contenido esta circunstancia en un tipo agravado específico no se aplicará lo dispuesto en el párrafo primero del art. 192.1, donde se recoge un aumento de pena para esta clase de sujetos activos de inferior magnitud" $" 519$.

\footnotetext{
${ }^{516}$ STS 913/2006 de 20 de septiembre de 2006.

${ }^{517}$ RUIZ RODÍGUEZ, L. R.; GONZÁLEZ AGUDELO, G., El factor tecnológico en la...” op. cit., pág. 35 .

${ }^{518}$ BOLDOVA PASAMAR, M. Á. Artículo 189..., op. cit., pág. 542.

${ }^{519} \mathrm{Idem}$.
} 


\subsection{Producción y Tráfico de Pornografía Virtual (Artículo 189.7)}

En el apartado 7 del art. 189 de la LO 15/2003 de 25 de noviembre de 2003 se ha tipificado como delito el tráfico de pornografía infantil virtual ${ }^{520}$. Con la tipificación de estas conductas el legislador procura abarcar las manifestaciones que con mayor frecuencia se realizan a través de la red. Las conductas punibles relacionadas a la pornografía con menores o incapaces requerían hasta dicha reforma la utilización directa de menores e incapaces para involucrarlas en un contexto sexual ${ }^{521}$. De acuerdo con las distintas formas de utilización de menores e incapaces - directa e indirecta- que pueden producirse se distingue entre: pornografía infantil real o propiamente dicha, cuando directamente son utilizados menores o incapaces, y pornografía infantil virtual, cuando son utilizados indirectamente. Dentro de ésta categoría virtual puede diferenciarse entre pseudopornografía infantil, cuando no se utiliza menores o incapaces, pero se los representa de forma artificial mediante el dibujo, por ordenador; o técnica cuando se trata de adultos caracterizados como menores o incapaces ${ }^{522}$. Tras la citada reforma el artículo queda redactado de la siguiente forma:

"Será castigado con la pena de prisión de tres meses a un año o multa de seis meses a dos años el que produjere, vendiere, distribuyere, exhibiere o facilitare por cualquier medio material pornográfico en el que no habiendo sido utilizados directamente menores o incapaces, se emplee su voz o imagen alterada o modificada."

Como punto de partida es necesario aclarar que el objeto sobre el que recae la conducta típica es sobre el material pornográfico y no sobre el grupo de personas que se desea proteger. En este sentido, el tipo no puede equiparse a la pornografía infantil en los términos como lo ha definido el propio Código Penal español en su tipo básico 189.1, ya que no se utiliza de forma directa a los menores e incapaces. También es conveniente señalar que la calificación de virtual de este material pornográfico se deriva de que no se trata de menores de edad o incapaces reales, sino que se ha empleado la

\footnotetext{
${ }^{520}$ En la Exposición de Motivos de la ley LO 15/2003 el legislador se refiere a este precepto con la expresión pornografía virtual, y a partir de la reforma empieza a gozar de atención penal. Véase, BOLDOVA PASAMAR, M. Á. Artículo 189..., op. cit., pág. 566.

${ }^{521}$ Idem.

${ }^{522}$ Idem.
} 
voz o la imagen distorsionadas de estos. Ahora bien, el tipo no capta toda hipótesis de pornografía virtual, se excluye la pornografía técnica como objeto material de los delitos del art. 189, puesto que en estos casos no se produce una utilización, ni siquiera indirecta, de menores o incapaces reales, sino que se recurre a artificios informáticos o de otra índole -maquillaje, disfraz- para obtener el resultado. En este sentido, quedan fuera del tipo los supuestos en los que las imágenes manipuladas sean las de una persona mayor de edad ${ }^{523}$.

El tipo contiene las acciones contempladas en el apartado 189.1 b) de producir, vender, distribuir y exhibir, además se agrega la más genérica de facilitar el material pornográfico virtual, el alcance del precepto es la puesta a disposición a otras personas del material pornográfico en cuestión, resultando indiferente la cantidad de personas a las que abarque ya puede tratarse de una sola persona o de una multitud, de igual forma, no se requiere el ánimo de lucro, ya que también estaría incluido un intercambio de forma gratuita. En relación al medio a través del cual se facilita o distribuye el material, el precepto no permite excepciones y establece que la conducta de tráfico de material pornográfico infantil virtual se podrá realizar por cualquier medio. Queda excluida del tipo la posesión de dicha pornografía, tanto la que está preordenada al tráfico como la que se destina al propio uso ${ }^{524}$.

En relación al segundo supuesto, se emplee su voz o imagen alterada o modificada, compartimos la apreciación de BOLDOVA PASAMAR cuando afirma que: "hay que entender que alterada o modificada como calificativos de imagen o sonido significa en ambos casos que éstos han sido sacados de su contexto e insertados por cualquier medio en otro diferente que les representa en una escena sexual, solos o en

\footnotetext{
${ }^{523}$ Véase, GÓMEZ TOMILLO, M. Derecho penal Sexual..., op. cit., pág. 2. Considera éste autor que "en el caso de que las imágenes manipuladas sean de personas mayores de edad cabe tan sólo la posibilidad de acudir a los delitos contra la intimidad y el derecho a la propia imagen, concretamente al artículo 197.2 en relación con el apartado 3 del mismo artículo, siempre y cuando se den las circunstancias descritas, esto es, que la imagen obtenida y posteriormente manipulada proceda de una base de datos reservados protegidos por el derecho a la intimidad, como puede ser un ordenador privado. Por el contrario, permanecería impune el hecho si la imagen modificada procede de un lugar accesible a todo el mundo, lo cual no es complicado en el caso de los personajes públicos".

524 Véase, BOLDOVA PASAMAR, M. Á. Artículo 189..., op. cit., pág. 568. El autor agrega que "Únicamente la acción de producir representa un estadio previo al tráfico que la ley equipara a las conductas anteriores en la medida que estamos ante un delito que comporta un determinado ciclo de actividades".
} 
compañía de otros menores (o incapaces) o de adultos. En consecuencia, se alude en realidad a que la actuación sobre las imágenes o los sonidos de menores o incapaces en relación con el producto final ha supuesto un montaje o composición, pudiendo hablarse también de una pornografía infantil por montaje" ${ }^{, 525}$. Este precepto permite incriminar supuestos en los que participan mayores de edad en actos sexuales explícitos y se le inserta la voz real de un menor o incapaz, es lo que algunos autores reconocen como pornografía infantil simulada. Sin embargo, no quedan incriminados los supuestos de comics de pornografía infantil en los que no se utilice voces reales de menores ${ }^{526}$.

Ahora bien, la intención del legislador al tipificar la pornografía infantil simulada es la de prevenir que el consumo de estos materiales por parte de paidófilos pueda estimular en ellos acciones de abusos sexuales a menores e incapaces reales; además incriminando estas conductas se procura evitar que emerjan nuevas formas de pornografía infantil que traten de eludir la ley penal, pero provoquen los mismos efectos en sus consumidores ${ }^{527}$. En este sentido el sujeto pasivo no sería el menor en concreto al que se emplea la voz o la imagen modificada y en el producto final no es reconocible o identificable, sino el conjunto de los menores que se encuentren en determinadas situaciones de vulnerabilidad por las condiciones sociales, económicas o geográficas que los lleven a ser potenciales víctimas de este tipo de prácticas ${ }^{528}$. BOLDOVA PASAMAR considera que: "el sujeto pasivo del delito queda sobredimensionado, pues independientemente del menor o incapaz concretamente afectado por dicha pornografía en relación con sus imágenes o sonidos, quien aparece más como un perjudicado, sujeto pasivo de ese peligro abstracto es todo el colectivo de menores de edad y de incapaces." $" 529$

\footnotetext{
525 BOLDOVA PASAMAR, M. Á., Artículo 189..., op. cit., pág. 569.

${ }^{526}$ Véase, entre otros a MORALES PRATS, F.; y GARCÍA ALBERO, R., Delitos contra la..., op. cit., págs. 362 y ss.

${ }^{527}$ El Consejo General del Poder Judicial, en el informe al Anteproyecto de Ley Orgánica de reforma de la L. O. 10/1995, de 23 de noviembre, se pronuncia en contra de la inclusión de este precepto por la anticipación a la tutela penal de forma exagerada, ya que los comportamientos de la pornografía virtual no se encuentran necesariamente en una relación de causa a efecto con la efectiva puesta en peligro del bien jurídico. Véase, Boldova Pasamar, M. Á., Artículo 189..., op. cit., pág. 567.

${ }^{528}$ Véase, FERNÁNDEZ TERUELO, J., Cibercrimen. Los delitos... , op cit., pág. 63.

${ }^{529}$ BOLDOVA PASAMAR, M. Á., Artículo 189..., op. cit., pág. 567.
} 
Por otra parte puede resultar muy complejo determinar si las imágenes son auténticas o si se trata de un montaje o manipulación; "en tales hipótesis, en caso de duda, al tener el precepto que examinamos un carácter privilegiado desde el punto de vista de la pena a él vinculada, debe optarse por su aplicación, frente a los tipos diseñados para captar la producción, venta, exhibición o distribución de material pornográfico en el que intervienen menores" ${ }^{\text {"530. }}$.

Por lo menos al momento de asignar la pena el legislador ha percibido la diferencia entre utilizar directamente a menores o incapaces y utilizarlos indirectamente, así, la pena entre el tráfico de pornografía infantil real es de prisión de uno a cuatro años, pudiendo alcanzar hasta ocho años si concurre uno de los tipos agravados, y en el tráfico de pornografía infantil virtual, prisión de tres meses a un año o multa de seis meses a dos años ${ }^{531}$.

Existe antecedentes en Europa de la tipificación de esta conducta. Refiere ESQUINAS VALVERDE que, “el Strafgesetzbuch alemán reprime desde 1997 con carácter unitario la tenencia de material pornográfico "que reproduzca un suceso cercano a la realidad": es decir, precisamente no real. De esa forma, lograrían abarcarse aquellos supuestos en los que según la apariencia externa se representara un hecho real, pero sin que pudiera excluirse que se tratara de una representación ficticia, por ejemplo, generada por ordenador, o confeccionada mediante un fotomontaje, o con trozos o se estaría sancionando en este caso sería un supuesto resultado general de puesta en peligro de la indemnidad sexual de los menores a partir de un comportamiento socialmente reprobado de mera concepción de fantasías, de manera que se estaría adelantando desmesuradamente lo que ya en sí constituye una intervención estatal muy gravosa, como es la de naturaleza penal" ${ }^{\prime 532}$.

Entre críticas y aprobación la doctrina se ha manifestado creando gran polémica alrededor de la necesidad o no de este precepto. MORILLAS FERNÁNDEZ considera un acierto la punición de la pornografía infantil virtual argumentando el avance de la

\footnotetext{
${ }^{530}$ GÓMEZ TOMILLO, M., Derecho penal Sexual y..., op. cit., pág. 2.

${ }^{531}$ Véase, BOLDOVA PASAMAR, M. Á., Artículo 189..., op. cit., pág. 568.

${ }^{532}$ ESQUINAS VALVERDE, P., El tipo de..., op. cit., págs. 217 y ss.
} 
informática, lo sencillo que resulta hacer montajes con imágenes y sonidos reales y lo que esto significa para la intimidad de las personas ${ }^{533}$. El cuestionamiento que este autor hace al precepto es la ubicación sistemática, que según su criterio está totalmente fuera de lugar, pues debería de aparecer dentro de los primeros cinco números. ${ }^{534}$ Igualmente GÓMEZ TOMILLO plantea que en términos generales, y en correspondencia con los tratados internacionales, la tipificación de la pornografía infantil virtual, merece ser valorada positivamente, la única salvedad que hace es a la ubicación sistemática de la figura, más próxima a los delitos que tutelan el derecho a la intimidad o a la propia imagen $^{535}$.

\subsection{VALORACIÓN SOBRE LA LO 15/2003 DE 25 DE NOVIEMBRE}

Nos encontramos nuevamente ante las interrogantes:¿Que aportan las reformas a los tipos ya establecidos en el CP? ¿Qué significando o lectura puede hacerse desde la perspectiva político criminal?. ¿A qué responde la excesiva penalización y/o punición desmedida de conductas ausentes de daño o lesividad?. La orientación la LO 15/2003 de 25 de noviembre, la misma de las reformas anteriores al texto de 1995, responde a una lógica de la expansión del modelo político criminal de emergencia caracterizado por más penas y más agravantes, que apela al Derecho penal como prima ratio y que recurre a la creación de delitos de peligro abstracto para castigar conductas previas, muy anteriores a las que producen un daño real.

La exigencia de más represión desde los programas de opinión y asociación de víctimas entre otros, ha alimentado la tendencia al endurecimiento del sistema penal. En la exposición de Motivos de la ley en comento el legislador señala la valoración negativa que hace la sociedad sobre el mismo. La imagen de laxo y tolerante es asumida como la causa de la ineficacia para la evitación del delito, de igual forma el legislador apuesta por la severidad y dureza del sistema penal como muestra de

\footnotetext{
${ }^{533}$ Véase, MORILLAS FERNÁNDEZ, D. L., Análisis dogmático y criminologico..., op. cit., pág. 144. El autor, hace referencia a lo fácil que resulta con un escáner y un software, en poco tiempo (una hora) modificar una fotografía de una persona vestida a totalmente desnuda y publicada en una página Web visible en cualquier parte del mundo.

${ }^{534}$ Véase, MORILLAS FERNÁNDEZ, D. L., Análisis dogmático y criminologico..., op. cit., pág. 144.

${ }^{535}$ Véase, GÓMEZ TOMILLO, M., Derecho penal Sexual y..., op. cit., pág. 2
} 
eficacia $^{536}$. Esto ha sido reflejado en el delito de pornografía infantil (Art. $189 \mathrm{CP}$ ), teniendo una clara tendencia de expansión y de endurecimiento de las penas desde el Código Penal del 1995 hasta la reforma de 2003.

Ahora bien, ¿qué criterio utilizó el legislador para justificar la intervención penal en una esfera tan privada como el consumo de material pornográfico infantil?

El razonamiento utilizado por el legislador para trasladar hasta el consumidor la responsabilidad penal, establecida en el precepto 189.2 -posesión para consumo propio-, es el criterio económico de la oferta y la demanda, soportado en la idea de que la puesta en el "mercado" de materiales con contenido pornográficos de menores genera nuevas necesidades, estimulando la demanda y si aumenta la demanda del consumo de estos materiales, aumentará también la oferta y la oferta sólo puede cubrirse utilizando a menores "de carne y hueso". En definitiva, esta lógica se formula en atacar al consumidor como el último eslabón de la cadena criminal de explotación sexual de menores. Es así como con la criminalización de este comportamiento se pretende disuadir al usuario para que no adquiera estos productos, lo que incide en la producción y la quiebra del negocio. Pero como suele ocurrir con una visión ortodoxa de la Economía, estos factores (oferta-demanda) no siempre actúan de la forma esperada, el mercado no es estático y la mayor parte de las veces es impredecible y el comportamiento humano no se rige solo por el principio de elección racional. Es por ello que es menester estar atento a la evolución y desarrollo del fenómeno estudiado, nutriéndose de disciplinas como la criminología, la sociología, la estadística entre otras, que ayudan a comprender mejor la dimensión del problema y la mejor forma de dar respuesta que no siempre es jurídica.

Conforme a lo anteriormente expuesto, referimos que los estudios iniciales sobre este tema daban cuenta del volumen de capital que movilizaba la industria de la pornografía infantil, la tercera más importante después del tráfico de drogas y el tráfico de $\operatorname{armas}^{537}$.(En este supuesto puede tener cabida el criterio expuesto anteriormente).Sin

\footnotetext{
${ }^{536}$ GARCÍA ARAN, M., Delincuencia seguridad y..., op. cit., pág. 101.

537 Según declaraciones de Najat M’jid, Relatora de la ONU sobre venta, prostitución y pornografía infantil, la producción y distribución de imágenes pornográficas representa un negocio de 20.000 millones de dólares al año. Véase, Aleta la ONU. Aumenta pornografía infantil en Internet. disponible en http://www.semana.com.ve, última consulta 17 de septiembre de 2009. Informaciones más recientes son
} 
embargo, estudios más reciente muestran como el avance de la Tecnologías de la Información y Comunicación (TIC) ha potenciado las redes sociales y esto permite conglomerar a personas con los mismos intereses y preferencias sexuales como los pedófilos, que les ha permitido obtener el material sin necesidad de comprarlo, por medio del intercambio. Ahora bien, debe tenerse muy claro que lo que justifica la intervención penal en este ámbito es la explotación sexual de menores y no la satisfacción sexual con la contemplación de imágenes de menores, lo que en definitiva queda dentro de la moral sexual de cada persona. Dentro de un Derecho penal moderno encajado en el marco de un Estado de Bienestar, siempre serían más asumibles el déficit de protección de bien jurídico que los costos de una penalización ilimitada por la simple consulta de una página de pornografía infantil ${ }^{538}$.

\section{LEY ORGÁNICA 5/2010, DE 22 DE JUNIO, POR LA QUE SE MODIFICA LA LEY ORGÁNICA 10/1995, DE 23 DE NOVIEMBRE, DEL CÓDIGO PENAL}

\subsection{LA JUSTIFICACIÓN DE LA REFORMA.}

El preámbulo de la L.O 5/2010 de 22 de junio, justifica la extensión y variedad de temas que aborda la Reforma en función de las obligaciones internacionales contraídas en el ámbito de la armonización jurídica europea ${ }^{539}$; de la cambiante realidad social que determina el surgimiento de nuevas cuestiones que han de ser abordada ${ }^{540}$; de ciertas

las ofrecidas por La Oficina de Naciones Unidas Contra la Droga y el Delito (ONUDD) que cifra los beneficios del delito de pornografía infantil por Internet en 250 millones de dólares, con unas 50.000 imágenes nuevas que se publican anualmente en Internet. disponible en http://www.terra.com. última consulta 22 de agosto de 2010.

${ }^{538}$ TAMARIT SUMALLA, J. M., La protección penal del..., op. cit., págs. 110 y ss.

539 Aunque uno de loa motivos de la reforma era la armonización de la legislación con la normativa europea, el legislador español se apresuró al momento aprobar La Ley Orgánica 15/2003 de 25 de noviembre y no esperó a que se aprobara la Decisión Marco 2004/68/JAI del Consejo, de 22 de diciembre de 2003, (relativa a la lucha contra la explotación sexual de los niños y la pornografía infantil). La consecuencia obvia fue que un mes después de aprobada la LO 15/2003 era necesario una nueva reforma para incorporar lo establecido en la Decisión Marco. Véase MORILLAS FERNÁNDEZ, D. L., "Cuestiones Conflictivas en la actual regulación de los delitos de pornografía infantil”, en GARCÍA GONZÁLEZ, J. (Coord.), Ciberacoso: la tutela penal de la intimidad, la integridad y la libertad sexual en Internet, Ed. Tirant lo Blanch, Valencia, 2010, pág. 191.

${ }^{540}$ Cabe preguntarse ¿Donde se produce el debate a partir del cual se concluye la necesidad de que se penalice nuevas conductas? En los medios de comunicación a partir de casos particulares y esporádicos se realizan campañas informativas y se suceden programas que difunden tendencias, sin embargo, la opinión pública no se resume en las noticias que interesadamente reproducen los medios de comunicación. 
carencias o desviaciones evidenciadas a partir de la aplicación del C.P que es preciso corregir; y, por último, hace referencia a que las continuas y profusas modificaciones introducida al texto original de 1995 han generado efectos de distorsión o incongruencia necesitados de corrección. ${ }^{541}$

En lo que se refiere a los Instrumentos Internacionales, QUINTERO OLIVARES, plantea que "respecto de esas obligaciones derivadas de la pertenencia de España a un ámbito jurídico y político de la importancia de la Unión Europea solo puede expresarse satisfacción, sin perjuicio de que alguna formulación legal pueda ser objetada por razones técnicas. Pero si esa adecuación es la finalidad y se tiene en cuenta también que la UE recomienda la armonización de los sistemas penales en todo aquello que pueda ser preciso para la efectividad del mercado único, no se entiende por qué se ha prescindido (abandonado lo que se proponía en el proyecto de reforma de 2007) de la incriminación de la creación y uso de sociedades vacías de contenido como medio de burlar obligaciones o responsabilidades (testaferros), así como la reformulación de delitos de enorme importancia financiera -y social en estos tiempos de crisis- como es el de quiebra o concurso doloso, que en el sistema español recibe un tratamiento tan excesivamente simplista que resulta casi impracticable, amén de que con posterioridad al CP de 1995 se produjo la promulgación de la Ley Concursal con la cual lógicamente debe de coordinarse el Código Penal. A ello se suma, por mor del requisito de doble incriminación que para acceder a la extradición se exige, que esas conductas, tipificadas en otros Códigos europeos, serán aquí impunes"542

Por otra parte, vale acotar que en los Instrumentos internacionales se insta a los países a que recojan en su normativa interna las tipificaciones que ellos establecen, lo que no significa que estén obligados a ello, sobre todo cuando la doctrina mayoritaria del país señala la improcedencia de la aplicación de la norma por no ser coherente con los principios constitucionales en un Estado Social y Democrático de Derecho. El

\footnotetext{
${ }^{541}$ Ley Orgánica 5/2010, de 22 de junio, por la que se modifica la Ley Orgánica 10/1995, de 23 de noviembre, del Código Penal. Ésta Ley entrará en vigor el 23 de diciembre de 2010.

${ }^{542}$ Véase, QUINTERO OLIVARES, G., "Sobre el Anteproyecto de Ley de Reforma del Código Penal de 2009. Examen crítico de las líneas maestras de la reforma propuesta", en trabajo presentado en el XXI Congreso de Alumnos Universitarios de Derecho Penal. Universidad de Salamanca. Salamanca, 2009, págs. 2 y ss.
} 
preámbulo IV de esta Ley reconoce abiertamente que la norma dictada "choca con principios elementales del Derecho penal que la Constitución ampara"543.

De todos los documentos citados en ésta $\mathrm{Ley}^{544}$, interesa destacar, por la referencia directa que hace al tema objeto de estudio, la Decisión Marco 2004/68/JAI del Consejo, de 22 de diciembre de 2003, relativa a la lucha contra la explotación sexual de los niños y la pornografía infantil. Vale advertir, no obstante, que casi todo lo que establece éste instrumento fue incorporado en reforma anterior 15/2003 de 25 de noviembre ${ }^{545}$.

En relación al segundo elemento en el que se justifica la reforma al Código Penal nos preguntamos ¿que significa la realidad social cambiante?. A juzgar por las últimas reformas significan la necesidad de más control, mayor represión, penas más largas, criminalización de nuevas conductas. Lo extraño es que la transformación social siempre apunten al mismo lado y no sucede lo contrario; no hay cabida para que la transformación implique que se descriminalicen o despenalicen conductas. Desde la exposición de motivos del Anteproyecto de ésta Ley $^{546}$ se planteaba la necesidad de la reforma por el acaecimiento en los últimos tiempos de casos de especial gravedad que han provocado en la sociedad la reapertura del debate en torno a las respuestas jurídicas

${ }^{543}$ Ley Orgánica 5/2010, de 22 de junio, por la que se modifica la Ley Orgánica 10/1995, de 23 de noviembre, del Código Penal, Preámbulo IV.

${ }^{544}$ En la disposición final sexta de la Ley se hace referencia a la Incorporación de Derecho de la Unión Europea. Y se mencionan las siguientes normas: Decisión Marco 003/568/JAI del Consejo, de 22 de julio de 2003, relativa a la lucha contra la corrupción en el sector privado. Decisión Marco 2004/68/JAI del Consejo, de 22 de diciembre de 2003, relativa a la lucha contra la explotación sexual de los niños y la pornografía infantil. Decisión Marco 2004/757/JAI del Consejo, de 25 de octubre de 2004, relativa al establecimiento de disposiciones mínimas de los elementos constitutivos de delitos y las penas aplicables en el ámbito del tráfico ilícito de drogas. Decisión Marco 2005/212/JAI del Consejo, de 24 de febrero de 2005, relativa al decomiso de los productos, instrumentos y bienes relacionados con el delito. Decisión Marco 2005/222/JAI del Consejo, de 24 de febrero de 2005, relativa a los ataques contra los sistemas de información. Decisión Marco 2008/919/JAI del Consejo, de 28 de noviembre de 2008, por la que se modifica la Decisión Marco 2002/475/JAI, sobre la lucha contra el terrorismo. Decisión Marco 2002/629/JAI del Consejo, de 19 de julio de 2002, relativa a la lucha contra la trata de seres humanos. Directiva 2008/99/CE del Parlamento Europeo y del Consejo, de 19 de diciembre de 2008, relativa a la protección del medio ambiente mediante el derecho penal. Directiva 2003/6/CE del Parlamento Europeo y del Consejo, de 28 de enero de 2003, sobre las operaciones con información privilegiada y la manipulación del mercado (abuso del mercado).

${ }^{545}$ El tipo que faltaba por incorporar en la legislación española para recoger en su totalidad la Decisión Marco 2004/68/JAI era el denominado grooming previsto en el artículo 183 del CP a partir de la LO $5 / 2010$ de 25 de noviembre.

${ }^{546}$ Anteproyecto de Ley Orgánica por la que se modifica la Ley Orgánica 10/1995, de 23 de noviembre, del Código Penal Español. (Aprobada por el Consejo de Ministro en fecha 14 de noviembre de 2008). 
previstas para los delincuentes sexuales, en particular en aquellos supuestos en los que las víctimas son menores de edad, y se hacia referencia al caso de la niña Mariluz Cortes que durante los últimos años ha tenido gran repercusión mediática, sobre el que apuntamos amplias consideraciones en el capítulo primero.

A éste respecto, QUINTERO OLIVARES se pregunta que pudo suceder desde el proyecto de reforma de enero de $2007^{547}$ hasta el Anteproyecto de noviembre de $2008^{548}$, pues con apenas dos años de diferencia se decide retirar un buen número de artículos del primero y agregar un número casi análogo de nuevas reglas en el segundo. Aparte de algún hecho puntual en materia de crímenes pedófilos o de puesta en libertad de algún importante terrorista o delincuente sexual, insiste el autor, nada ha pasado que explique este cambio ${ }^{549}$.

En la misma línea de las reformas anteriores, se continúa apostando por la pena privativa de libertad como panacea para mantener alejado de la sociedad a los autores de los delitos considerados de extrema gravedad: delitos cometidos contra la libertad e indemnidad sexual de menores de trece años, delitos referentes a organizaciones y grupos terroristas y delitos de terrorismo, así como los delitos cometidos en el seno de una organización o grupo criminal. Para ello se modificó el artículo 36 de forma que los casos de penas privativas de libertad superiores a cinco años se exigirá el cumplimiento de al menos la mitad de la condena antes de poder obtener la clasificación en tercer grado. Dicho art. 36 no abarca a todos los delitos con penas superiores a cinco años de prisión, sólo se aplicará a los pederastas, terroristas y grupos organizados. El preámbulo de la reforma señala que el mecanismo que se está imponiendo es más flexible, se elimina el automatismo de darle a todos los que infringen la norma el mismo tratamiento, y la forma como se pretende adecuar este trato diferencial es dejar en manos de los jueces y los tribunales la decisión de acuerdo con los criterios de "la responsabilidad criminal a la gravedad del hecho y a la personalidad del delincuente."

\footnotetext{
${ }^{547}$ Proyecto de Ley de reforma del Código Penal de 15 de enero de 2007.

${ }^{548}$ Anteproyecto de Ley Orgánica por la que se modifica la Ley Orgánica 10/1995, de 23 de noviembre, del Código Penal Español. (Aprobada por el Consejo de Ministro en fecha 14 de noviembre de 2008).

${ }^{549}$ Véase, QUINTERO OLIVARES, G., Sobre el Anteproyecto de Ley ..., op. cit., pág. 1.
} 
No podemos dejar de asociar esta "flexibilización" con los postulados del Derecho penal de autor, retomados y retocados por el Derecho penal del enemigo que plantea un tratamiento diferente entre "ciudadanos" e "individuos" que violenten las normas básicas que rigen la sociedad y representan una amenaza para el orden social. En un sentido más amplio, podemos afirmar que este tipo de reforma responde al modelo de seguridad que interviene sobre determinados "grupos de riesgo" formados por individuos peligrosos que deben ser alejados de la sociedad.

En la justificación que se hace en el preámbulo III se expone que "la remodelación del llamado "periodo de seguridad" garantiza la primordial finalidad constitucional de la pena, la resocialización, sin que por otra parte ello comporte detrimento alguno en la persecución por el Estado de otros fines legítimos de la misma" 550 .

Ahora bien, ¿a qué otros fines se refiere la nueva legislación? QUINTERO OLIVARES plantea que este responde a una línea político criminal común en España y otros Estados de la UE dirigida al endurecimiento de la ley penal. Es así como "frente a la amplia solicitud doctrinal de que se supriman o flexibilicen los llamados períodos de seguridad, la decisión que se toma es justamente la contraria: ampliarlos a más delitos. Sabemos que la causa hay que buscarla en el impacto de los graves delitos asociados a la pederastia. En todo caso, la extensión del régimen excepcional de ejecución penitenciaria debiera propiciar una reforma de la Ley General Penitenciaria y del Reglamento" 551 . Siendo que la pornografía infantil objeto de nuestro trabajo está

\footnotetext{
${ }^{550}$ El punto 2 del artículo 36 quedó redactado como sigue: "Cuando la duración de la pena de prisión impuesta sea superior a cinco años, el Juez o Tribunal podrá ordenar que la clasificación del condenado en el tercer grado de tratamiento penitenciario no se efectúe hasta el cumplimiento de la mitad de la pena impuesta.

En cualquier caso, cuando la duración de la pena de prisión impuesta sea superior a cinco años y se trate de los delitos enumerados a continuación, la clasificación del condenado en el tercer grado de tratamiento penitenciario no podrá efectuarse hasta el cumplido de la mitad de la misma: a) Delitos referentes a organizaciones y grupos terroristas y delitos de terrorismo del Capítulo VII del Título XXII del Libro II de este Código; b) Delitos cometidos en el seno de una organización o grupo criminal; c) Delitos del artículo 183; d) Delitos del Capítulo V del Título VIII del Libro II de este Código, cuando la víctima sea menor de trece años.

El Juez de Vigilancia, previo pronóstico individualizado y favorable de reinserción social y valorando, en su caso, las circunstancias personales del reo y la evolución del tratamiento reeducador, podrá acordar razonadamente, oídos el Ministerio Fiscal, Instituciones Penitenciarias y las demás partes, la aplicación del régimen general de cumplimiento, salvo en los supuestos contenidos en el párrafo anterior."

${ }^{551}$ Véase, QUINTERO OLIVARES, G., Sobre el Anteproyecto de Ley..., op. cit., pág. 4
} 
contemplada dentro de los delitos expresamente previstos para la aplicación de medidas de seguridad posterior al cumplimiento de la pena privativa de libertad, consideramos oportuno apuntar las implicaciones y el fin de la pena perseguidos con la aplicación de la nueva medida de libertad vigilada en los delitos sexuales.

\subsection{LIBERTAD VIGILADA O INOCUIZACIÓN}

Posterior al "caso Mariluz" el Grupo Parlamentario Popular presentó una propuesta no de ley que, tras el tramite de presentación de enmiendas fue aprobado el 3 de junio de 2008 e incluía la introducción de medidas de seguridad post penitenciarias para delincuentes patológicos con pronósticos de reincidencia, como al final ha recogido la reforma.

El número IV del preámbulo se hace referencia a la inocuización y a la libertad vigilada como medida de seguridad necesaria para evitar el riesgo de reincidencia en supuestos de especial gravedad donde el efecto rehabilitador de la pena se ve obstaculizado $^{552}$. Se afirma que aún cuando la inocuización -prolongación ilimitada y/o indiscriminada de la privación de libertad- es contraria a principios elementales del Derecho penal amparados por la Constitución, se justifica cuando se trata de valores "no menos dignos de tutela, como son la seguridad y la libertad del resto de los ciudadanos, potenciales víctimas del delincuente no rehabilitado que el sistema penitenciario devuelve a la sociedad. Agotada, pues, la dimensión retributiva de la pena, la peligrosidad subsistente del sujeto halla su respuesta idónea en una medida de seguridad." 553

El término "inocuización" del delincuente se vincula al positivismo criminológico. En Von Liszt constituía uno de los tres fines de la "pena funcional" en términos preventivos especiales: la intimidación individual se dirigía al delincuente

\footnotetext{
552 En la nueva normativa se define la libertad vigilada como una medida de seguridad que el Tribunal impone, de manera facultativa o preceptiva, según la propia norma señala en cada caso, y cuyo contenido se concreta en una serie de limitaciones, obligaciones, prohibiciones o reglas de conducta, aplicables separada o conjuntamente, dentro de los márgenes de duración específicos que en su caso resulten de la parte especial del Código. Véase, Preámbulo de la LO 5/2010 de 22 de junio, por la que se modifica la LO 10/1995, de 23 de noviembre, del CPE.

553 Ley Orgánica 5/2010, de 22 de junio, por la que se modifica la Ley Orgánica 10/1995, de 23 de noviembre, del Código Penal.
} 
ocasional; la resocialización, al delincuente reiterado corregible; y la inocuización, al delincuente de estado incorregible ${ }^{554}$. De acuerdo a lo expuesto en el preámbulo IV el objetivo de la aplicación de estas penas -y que rige toda la reforma- estaría en función de "la protección a las víctimas, y a la rehabilitación y la reinserción social del delincuente", es decir, que se utilizarán penas neutralizadoras, posteriores a la penas de privación de libertad en personas que se consideren corregibles, rehabilitables. Llama la atención que en nuestros días se declare como fin de la pena medidas que en el positivismo criminológico eran consideradas sólo en casos extremos a delincuentes incorregibles. La intención es que los condenados no recuperen su "libertad total" de movimientos mientras no haya "confirmación y garantía total" de su rehabilitación 555 (cursivas añadidas). Se afinca también en el alegato de que la pena privativa de libertad no logra responder plenamente a sus objetivos de prevención especial, por lo que se le asigna a la "libertad vigilada" el fin principal de lograr la reinserción del sujeto a la sociedad $^{556}$.

La libertad vigilada en los términos fijados en la LO 5/2010, no es una medida alternativa a la pena de prisión sino accesoria-sucesiva, es decir, posterior al cumplimiento de la pena privativa de libertad. En los casos expresamente previstos en esta Ley el Tribunal dicta sentencia de la pena de prisión a cumplir y en el mismo dictamen se impone la medida de libertad vigilada para su ejecución posterior a la excarcelación ${ }^{557}$. En los delitos contra la libertad e indemnidad sexual y de terrorista, la libertad vigilada será de hasta diez años ${ }^{558}$. Como el pronóstico de peligrosidad se

\footnotetext{
${ }^{554}$ Véase, SILVA SÁNCHEZ, J., El retorno a la Inocuización..., op. cit., pág. 699. Véase, Von Liz, F. "La idea del fin en el Derecho penal, Programa de la Universidad de Marburgo de 1882 (Intervención y nota biográfica de José M Z. E...”, Comares, Granada, 1995.

555 Véase, Justicia quiere imponer medidas de control a los pederastas tras cumplir condena. El País, 04/08/2008.

556 Véase, Exposición de Motivos del Anteproyecto de Ley Orgánica por la que se modifica la Ley Orgánica 10/1995, de 23 de noviembre, del Código Penal Español. (Aprobada por el Consejo de Ministro en fecha 14 de noviembre de 2008), pág. 2.

${ }^{557}$ En el artículo 106.2 de la LO 5/2010 se establece que "sin perjuicio de lo dispuesto en el artículo 105, el Juez o Tribunal deberá imponer en la sentencia la medida de libertad vigilada para su cumplimiento posterior a la pena privativa de libertad impuesta siempre que así lo disponga de manera expresa este Código."

${ }^{558}$ En el Anteproyecto de Reforma siempre que se refiere a la "libertad vigilada" se le antecede del vocablo "pena", lo que evidencia cuanto menos un cambio conceptual de lo que antes era denominado como "medida,". Ahora es una pena sucesiva al cumplimento de la pena de prisión. ¿Es posible una pena
} 
relaciona no solo con estados patológicos ${ }^{559}$, sino que también se puede determinar por el pronóstico del sujeto imputable en relación con la naturaleza del hecho cometido, la medida se hará o no efectiva en función de ese pronostico, que se realizará cuando esté próximo a finalizar la pena de prisión y debiendo ser considerado como mínimo una vez al año (artículo 98.1) ${ }^{560}$. En la sustitución, modificación, suspensión o cesación, intervienen tanto el Juez de Vigilancia Penitenciaria, como el Juez o Tribunal sentenciador al que corresponde hacer ejecutar lo juzgado ${ }^{561}$. "Su duración, en fin, se mantiene en general en un máximo de cinco años, que es el que establecía hasta ahora el Código para las medidas de seguridad no privativas de libertad que se refunden bajo el concepto de libertad vigilada, pero a ello se añade, ciertamente pensando en esta nueva modalidad postpenitenciaria, la posibilidad de que el propio Código Penal la extienda hasta los diez años (artículo 105.2), como, de hecho, esta misma Ley dispone para los delitos contra la libertad e indemnidad sexual y de terrorismo." ${ }^{562} / 563$

La imposición de ésta medida de seguridad incluye la sujeción de los actos imputado a alguna o algunas de las medidas especiales como: estar siempre localizable

después del cumplimiento de la pena? Véase Anteproyecto, cit., pág. 2. Este error fue corregido en la Ley 5 /2010 y se denomina medida de seguridad postpenitenciaria.

${ }^{559}$ El pronóstico de peligrosidad del individuo tal como está entendido en esta medida de seguridad libertad vigilada- no sólo se asocia a estados patológicos que determinan su inimputabilidad o semiinimputabilidad, sino también cuando el propio legislador así lo haya previsto de manera expresa en el sujeto imputable en relación con la naturaleza del hecho cometido. Véase Preámbulo IV de la Ley Orgánica 5/2010, de 22 de junio, por la que se modifica la Ley Orgánica 10/1995, de 23 de noviembre, del Código Penal.

${ }^{560}$ El artículo 98.1 CP establece que: "cuando se trate de una medida de seguridad privativa de libertad o de una medida de libertad vigilada que deba ejecutarse después del cumplimiento de una pena privativa de libertad, el Juez de Vigilancia Penitenciaria estará obligado a elevar al menos anualmente, una propuesta de mantenimiento, cese, sustitución o suspensión de la misma. Para formular dicha propuesta el Juez de Vigilancia Penitenciaria deberá valorar los informes emitidos por los facultativos y profesionales que asistan al sometido a medida de seguridad o por las Administraciones Públicas competentes y, en su caso, el resultado de las demás actuaciones que a este fin ordene."

${ }^{561}$ La medida puede modificarse, ya en fase de ejecución, atendiendo a la evolución del sujeto y mediante un sencillo trámite que se caracteriza por un reforzamiento de la garantía de contradicción, que alcanza incluso a las víctimas que no sean parte en el proceso.

${ }^{562}$ Véase, Preámbulo IV y Artículo 192 de la Ley Orgánica 5/2010, de 22 de junio, por la que se modifica la Ley Orgánica 10/1995, de 23 de noviembre, del Código Penal.

${ }^{563}$ En la Exposición de Motivos del Anteproyecto de Reforma se argumenta que se trata de estos delitos por la especial peligrosidad de sus autores y la gran dificultad en su tratamiento. Véase, Anteproyecto de Ley Orgánica por la que se modifica la Ley Orgánica 10/1995, de 23 de noviembre, del Código Penal Español. (Aprobada por el Consejo de Ministro en fecha 14 de noviembre de 2008). 
mediante aparatos electrónicos que permita su seguimiento permanente; la presentación periódica en el lugar que se establezca; la de comunicación inmediatamente de cada cambio del lugar de residencia o del lugar o puesto de trabajo; la prohibición de ausentarse del lugar de residencia sin autorización del juez o tribunal; la prohibición de no aproximarse a la víctima, o a aquellos de sus familiares u otras personas que determine el Juez o Tribunal; la prohibición de comunicación con estas mismas personas; la prohibición de asistencia a determinados lugares o establecimientos; la prohibición de residencia en determinados lugares; la prohibición del ejercicio de determinadas actividades que pueda aprovechar para cometer hechos punibles de similar naturaleza; la obligación de participar en programas formativos, laborales, culturales, de educación sexual u otros similares; la de seguir tratamiento médico externo. En suma todas estas medidas están destinadas a la neutralización del delincuente. ${ }^{564}$

La tan polémica castración química a los delincuentes sexuales ha sido contemplada definitivamente en la LO 5/2010, en la letra K) del artículo 106.1 se establece "La obligación de seguir tratamiento médico externo, o de someterse a un control médico periódico".

Según SILVA SÁNCHEZ, a la pena tutelada por el principio de proporcionalidad, se suma una medida regida por el principio de inocuización. Se trata de un sistema dualista con ejecución de la medida indeterminada posterior al cumplimiento de la pena ${ }^{565}$. Esta pena inocuizadora es similar a la "Sexually Violent Predators Act" aplicada en EEUU en el Estado de Washington (1990) a delincuentes sexuales violentos, estimados peligrosos. En ese caso no se requiere que se constate una situación de habitualidad o, al menos una reincidencia de pasado. Los únicos requisitos eran un pronóstico de reincidencia futura, que haya afectado al menos a dos víctimas ${ }^{566}$.

Para Quintero Olivares, la libertad vigilada -ya contemplada en el sistema español en la legislación de menores- no puede tildarse si no de una decisión sin parangón en el

\footnotetext{
${ }^{564}$ Véase, artículo 106.1 de la LO 5/2010, en sus literales a) hasta el k) se establece todas las obligaciones -restricciones- que tendrán lugar con la medida de seguridad de libertad vigilada.

${ }^{565}$ Véase, SILVA SÁNCHEZ, J. M. El retorno a la Inocuización..., op. cit., pág. 703.

${ }^{566}$ SILVA SÁNCHEZ, J. M., El retorno a la Inocuización..., op. cit., pág. 702.
} 
Derecho comparado, puesto que son muchos los sistemas que establecen una vigilancia post/penitenciaria para algunos grupos de infractores, por un tiempo más o menos largo y con sistemas que a su vez difieren. "Ahora bien, como ya se ha dicho, y para evitar contradicciones, la libertad vigilada ha de cohonestarse con el régimen de ejecución "progresiva" de la pena de libertad, si no se quiere dar lugar a que la libertad vigilada equivalga a vaciar de contenido la fase de la libertad condicional. Mención separada es la crítica a las medidas que se pueden acordar dentro de la libertad vigilada a las consecuencias de su quebrantamiento"

Por otra parte, no es defendible que esta medida pueda impedir la reincidencia en terroristas y agresores sexuales ${ }^{568}$. En el caso de los terroristas no existe constancia histórica de su tendencia a reincidir; antes bien, las largas condenas penitenciarias los terminan alejando tanto de la ideología del grupo como de la militancia activa. En el caso de los pederastas y agresores sexuales, los niveles de reincidencia son bajos y no justifican, en todo caso, esta pena de libertad vigilada. Las advertencias de Instituciones Penitenciarias señalan que en España cumplen condena por agresión sexual unas 2.500 personas, de las cuales solo el $20 \%$ vuelve a cometer delito en los cuatro años siguientes a su salida de prisión, frente al $40 \%$ de promedio de reincidencia para el caso del resto de los delitos. ${ }^{569}$ Este porcentaje se reduce considerablemente en los casos que siguen programas especiales de tratamiento psicológico. Así lo demuestra un estudio realizado en el año 2002 en la cárcel de Brians: para un período de seguimiento promedio de cuatro años la tasa de reincidencia que sería esperable del $18 \%$ se redujo a una del $4 \%$. Con el tipo de medidas terapéuticas aplicadas para este caso, se notaron cambios personales en los sujetos en sus habilidades, actitudes, modos de pensamiento y controles emocionales que contribuyeron a la inhibición de la agresión sexual ${ }^{570}$.

\footnotetext{
${ }^{567}$ Véase, QUINTERO OLIVARES, G., Sobre el Anteproyecto de Ley ..., op. cit., pág. 5

568 Véase, la enmienda núm. 28 presentada por el grupo parlamentario de Esquerra Republicana, Izquierda Unida-Iniciativa per Catalunya-Els Verds, citando las conclusiones de un estudio del grupo de Política Criminal.

${ }^{569}$ Cuando la ley se hace a golpe de escándalo. Diario El País 21/11/2008.

${ }^{570}$ REDONDO ILLESCAS, S., “¿Sirve el tratamiento para rehabilitar a los delincuentes sexuales?”, en Revista Española de Investigaciones Criminológicas, artículo 6, número 4, año 2006, pág. 18, disponible en www.criminología.net.
} 
Ahora bien, la finalidad declarada de esta medida termina siendo una paradoja en la medida que pretende controlar y limitar la libertad de acción personal y su vida en sociedad posterior al cumplimiento de la condena. ¿Cumplida una pena se es libre o no?. ¿Vencido el lapso de privación de libertad se recuperan o no las libertades constitucionales? Antes que una estrategia de reinserción social, esta medida es propia del modelo de la seguridad que se consolida como tendencia político/criminal en España. Se interpreta como aspiración de la sociedad a mostrar su intolerancia a correr riesgos con la posible reincidencia de estos sujetos, razón por la cual se continúa segregando aún después de cumplida su pena de prisión, por lo que se traduce en una verdadera forma de aislamiento y exclusión social. Se trata de blindar las exigencias ciudadanas de seguridad, manteniendo controlada la posibilidad de riesgo de delito por una posible reincidencia. No obstante, las críticas justificadas a la medida de seguridad de libertad vigilada, vemos con buenos ojos que no se aplicara todo lo que estaba previsto en relación a ésta medida en el Anteproyecto de Ley, pues se suprimió el artículo 57 bis que en su apartado 2 establecía la aplicación de esta medida como agravante en los casos que concurran las circunstancias de reincidencia, habitualidad, pluralidad de delitos o extrema gravedad de los mismos ${ }^{571}$. Es posible que la decisión de no incluirla en la LO 5/2010 estuvo influida por las fuertes críticas que desde la doctrina se hicieron.

\subsection{Delitos Sexuales Contra Menores de Trece AÑos}

En el ámbito de los delitos sexuales en el Título VIII del Libro II del Código Penal, se introduce un nuevo Capítulo II bis denominado "De los abusos y agresiones sexuales a menores de trece años". Con el contenido de éste Capítulo, el legislador procura aumentar la protección de las víctimas en esta franja de edad, "Resulta indudable que en los casos de delitos sexuales cometidos sobre menores el bien jurídico a proteger adquiere una dimensión especial por el mayor contenido de injusto que presentan estas conductas". El bien jurídico que declara proteger mediante la

\footnotetext{
${ }^{571}$ Anteproyecto de Ley Orgánica por la que se modifica la Ley Orgánica 10/1995, de 23 de noviembre, del Código Penal Español. (Aprobada por el Consejo de Ministro en fecha 14 de noviembre de 2008).
} 
incorporación de los nuevos preceptos son la indemnidad sexual y la formación y desarrollo de la personalidad y sexualidad del menor. ${ }^{572}$

La otra gran novedad se encuentra en la tipificación del uso de Internet y las Tecnologías de Información y Comunicación (TIC) con fines sexuales contra menores. Así, se introduce el articulo 183 bis que regula el denominado "child grooming", que consiste en la utilización por parte de una persona adulta de las mencionadas tecnologías con intención de ganarse la confianza de menores con el fin de concertar encuentros para obtener concesiones de índole sexual, en el precepto las penas serán agravadas cuando el acercamiento al menor se obtenga mediante coacción, intimidación o engaño $573 / /^{574} / 575$.

En relación al delito de prostitución de menores de edad o incapaz, se incorpora la conducta del cliente, así queda establecido en el artículo 187.1 la pena de uno a cinco años y multa de doce a veinticuatro meses, "al que solicite, acepte u obtenga a cambio de una remuneración o promesa, una relación sexual con persona menor de edad o incapaz". El 187.2 agrava las penas cuando la víctima sea menor de trece años, estableciéndose la pena de prisión de cuatro a seis años.

En la pornografía infantil se tipifican nuevas conductas en el artículo 189.1 como el caso de la captación de niños para que participen en espectáculos pornográficos. De igual forma, se introduce en el apartado 1. a) del artículo 189 la figura de quien se lucra con la participación de los niños en esta clase de espectáculos. Y en el apartado 189.1b) se agrega la figura del que ofrezca este tipo de material para la producción o venta.

\footnotetext{
${ }^{572}$ Véase, Preámbulo XIII de la Ley.

${ }^{573}$ Preámbulo XIII de la Ley.

${ }^{574}$ El artículo 183 bis, establece que, "El que a través de Internet, del teléfono o de cualquier otra tecnología de la información y la comunicación contacte con un menor de trece años y proponga concertar un encuentro con el mismo a fin de cometer cualquiera de los delitos descritos en los artículos 178 a 183 y 189, siempre que tal propuesta se acompañe de actos materiales encaminados al acercamiento, será castigado con la pena de uno a tres años de prisión o multa de doce a veinticuatro meses, sin perjuicio de las penas correspondientes a los delitos en su caso cometidos. Las penas se impondrán en su mitad superior cuando el acercamiento se obtenga mediante coacción, intimidación o engaño"

575 Véase, PARDO ALBIACH, J., "Ciberacoso: Cyberbullying, Grooming, Redes Sociales y otros peligros” en GARCÍA GONZÁLEZ, J., (Coord.), Ciberacoso: la tutela penal de la intimidad, la integridad y la libertad sexual en Internet, Ed. Tirant lo Blanch, Valencia, 2010, págs. 51 - 83.
} 
Continuando con la protección de los menores, también se instaura la pena de privación de la patria potestad o instituciones análogas previstas en la legislación civil de las Comunidades Autónomas que se incluye en el catálogo de penas privativas de derechos previstas en el artículo 39, fijándose su contenido en el artículo 46. Esta nueva pena tendrá el carácter de principal en los supuestos previstos en el artículo 192 y el de pena accesoria de acuerdo a lo establecido en los artículos 55 y 56, cuando los derechos derivados de la patria potestad hubieren tenido una relación directa con el delito cometido $^{576}$. De acuerdo a la nueva redacción del apartado 3 del art. 192, el juez podrá imponer la pena de inhabilitación especial para el ejercicio de los derechos de la patria potestad, tutela, curatela, guarda, por el tiempo de seis meses a seis años, o bien la privación de la patria potestad.

Según QUINTERO OLIVARES, "En los delitos contra la libertad sexual se ubican buena parte de los problemas que han marcado la crónica negra de estos últimos años, concretamente, las agresiones a menores. La importancia de la materia está fuera de toda duda, y por eso sorprende el empecinamiento en mantener mezcladas la regulación de las infracciones penales contra adultos y contra menores. Es un hecho que se entiende sin esfuerzo que la violencia o la intimidación no pueden interpretarse de la misma manera al margen de que la víctima sea mayor o menor, y eso da lugar a incomprensibles decisiones, como la de no estimar constitutivos de violación el acceso carnal con un niño de dos años, por ejemplo, porque no hubo violencia. Para enmendar esa consecuencia se pasa al otro extremo: penar más gravemente el acceso carnal no violento con menores de trece años que lo mismo hecho con violencia a un adulto. Convendría una regulación autónoma para todos los menores de dieciocho años, como propone la Decisión Marco 2004/68/JAI, del Consejo de 22 de diciembre de 2003, relativa a la lucha contra la explotación sexual de los niños y la pornografía infantil, que la E. de M. del Anteproyecto parece acoger, pero no es así. La necesidad de un tratamiento unitario de las agresiones a menores requiere respuestas comunes para todo el grupo de posibles victimas."

\footnotetext{
${ }^{576}$ Véase, Preámbulo XIII de la Ley.

${ }^{577}$ Véase, QUINTERO OLIVARES, G., Sobre el Anteproyecto de Ley..., op. cit., pág. 10.
} 


\subsection{La reforma en el artículo 189 del Código Penal Español. PORNOGRAFÍA INFANTIL}

Esta reforma continua la línea del incrementó de las penas en el tipo básico adoptado por las reformas anteriores realizadas al texto de 1995. A partir de la LO 5/2010 de 22 de junio se castiga con penas de uno a cinco años. Otras novedades tienen que ver con que se modifican el primer párrafo y las letras a) y b) del apartado 1 y el primer párrafo del apartado 3; además se elimina el apartado 8 del artículo referido a la aplicación de las medidas previstas para la asociaciones u organizaciones criminales; por último se introduce un nuevo artículo 189 bis que regula la participación de las personas jurídicas en actividades relacionadas con la pornografía infantil.

En relación a los sujetos que participan en las figuras delictivas del art. 189 no hay cambios respecto a la reforma anterior, el sujeto activo es indiferenciado "el que", con excepción de delito omisivo del apartado (189.5). El sujeto pasivo sigue siendo "los menores edad o incapaces”. Se introduce el artículo 189 bis referido a la participación de las personas jurídicas en actividades relacionadas a la pornografía infantil.

\subsubsection{Modificaciones en el tipo básico del 189.1}

En este aparte, intentamos explicar y analizar los cambios que contempla la novísima reforma al Código Penal. Más que apuntar afirmaciones intentamos dar respuesta a todas las interrogantes que nos surgieron y que no pudieron ser alimentadas o contrastadas por la doctrina con lo reciente de la misma. Sin embargo, como punto de inicio a futuros debates y análisis apuntamos las siguientes observaciones, relaciones, notas e inquietudes.

El apartado 189.1 quedó redactado como sigue:

1. Será castigado con la pena de prisión de uno a cinco años:

a) El que captare o utilizare a menores de edad o a incapaces con fines o en espectáculos exhibicionistas o pornográficos, tanto públicos como privados, o para elaborar cualquier clase de material pornográfico, cualquiera que sea su soporte, ofinanciare cualquiera de estas actividades o se lucrare con ellas. 
b) El que produjere, vendiere, distribuyere, exhibiere, ofreciere o facilitare la producción, venta, difusión o exhibición por cualquier medio de material pornográfico en cuya elaboración hayan sido utilizados menores de edad o incapaces, o lo poseyere para estos fines, aunque el material tuviere su origen en el extranjero o fuere desconocido.

La primera y tal vez una de las más importante observación tiene que ver con el aumento de las penas de prisión. Con la intención de homologar la legislación española a los estándares europeos, se aumenta el límite máximo del tipo básico a cinco años, con esto se responde a la exigencia de la Decisión Marco 2004/68/JAI, (artículo 5). (Ver Tabla $\mathrm{N}^{\mathrm{o}}$ 1).

Además del aumento de la pena, se agregan en la redacción del 189.1 a) la conducta de el que captare $^{578}$ a menores de edad para que participen en espectáculos o en la elaboración de materiales pornográficos. La introducción de ésta nueva figura prevista en el artículo 2 b) de la Decisión Marco 2004/68/JAI- nos lleva a preguntarnos ¿Cuál es la intención del legislador? ¿Acaso no está comprendido en la utilización de menores el que previo al espectáculo o a la elaboración del material pornográfico, atrae, invita, o seduce al menor o incapaz en procura de su intervención en las actividades mencionadas? O, lo que es igual, ¿quedaba impune esta conducta antes de la reforma 5/2010? Obviamente no, sólo que el legislador al colocarlo expresamente busca castigar al que realiza la conducta como autor, lo que antes de la reforma podían conocerse como participe o cooperador necesario. Se eleva a la categoría de autoría contribuciones que claramente son favorecedoras de la acción delictiva pero no de autoria del propio delito.

\footnotetext{
578 Para la Real Academia de la Lengua Española captar es atraer, ganar la voluntad o el afecto. Conseguir, lograr la benevolencia, estimación, atención, antipatía, etc. de otro." Véase, Diccionario Real Academia Española, vigésima primera edición, Tomo I, Madrid, 1992, pág. 403.
} 
TABLA No 1

\begin{tabular}{|c|c|c|c|}
\hline \multicolumn{4}{|c|}{$\begin{array}{c}\text { Pena Privativa de Libertad Establecida en el Tipo Básico y } \\
\text { Agravado del Art. } 189 \\
\text { en el Código Penal Español }\end{array}$} \\
\hline LO 10/1995 DE 23 & LO 11/1999 DE 30 & LO 15/2003 DE 25 & LO 5/2010 DE 22 \\
\hline DE NOVIEMBRE & DE ABRIL & DE NOVIEMBRE & DE JUNIO \\
\hline $\begin{array}{l}1 \text { a } 3 \text { años de } \\
\text { prisión }\end{array}$ & $\begin{array}{l}1 \text { a } 3 \text { años de } \\
\text { prisión }\end{array}$ & $\begin{array}{l}1 \text { a } 4 \text { años de } \\
\text { prisión }\end{array}$ & $\begin{array}{l}1 \text { a } 5 \text { años de } \\
\text { prisión }\end{array}$ \\
\hline $\begin{array}{l}\text { No se contemplan } \\
\text { agravantes }\end{array}$ & $\begin{array}{l}\text { Agravante: pena } \\
\text { superior en grado. }\end{array}$ & $\begin{array}{l}\text { Agravantes: de } 4 \text { a } 8 \\
\text { años. }\end{array}$ & $\begin{array}{l}\text { Agravantes: de } 5 \text { a } 9 \\
\text { años. }\end{array}$ \\
\hline
\end{tabular}

Ahora bien, ¿Qué sucede si luego de que el sujeto pasivo sea captado no se produce la utilización con fines exhibicionistas o pornográficos?. Cuando el legislador coloca "el que captare" como tipo autónomo se le otorga la misma consecuencia jurídica que al que utilizare a los menores e incapaces con fines exhibicionista o pornográficos. Apreciamos esta homologación de conductas en cuanto a penas como un enorme error. Equiparar el castigo en conductas que no tienen el mismo nivel de gravedad, ni afectan el mismo bien jurídico, no se basa sobre fundamentaciones jurídicas.

La tendencia político criminal expresada en las reformas penales anteriores se mantiene, ampliándose y profundizándose. Cuando se ubica al que captare como tipo autónomo se esta castigando estadios anteriores de la conducta -ex antes- del tipo básico de la pornografía infantil del CP como es la utilización.

Compartimos la postura de CUGAT MAURI cuando afirma que es discutible " la bondad de la inclusión de la conducta consistente en "captar" al menor con fines exhibicionistas o pornográficos...puede considerarse suficientemente cubierta por el nuevo 177 bis que recoge la trata de personas para su explotación sexual, entendida ésta como la captación de un sujeto con el fin de su explotación sexual, incluida la pornografía (ap.1, b). La previsión simultanea de los dos tipos planteará enojosos problemas concursales, que deberán lidiar además con la distinta naturaleza de cada uno 
de los delitos, pues mientras que la trata tiene un sujeto colectivo, no sucede lo mismo con el delito de captación con fines exhibicionistas o pornográficos"

En el mismo precepto 189.1 a) se incluye la figura del que se lucrare ${ }^{580}$ - también recogido en la Decisión Marco 2004/68/JAI en su artículo 2 a)-. Al igual que con la conducta anterior nos preguntamos si es necesario incluirla de forma expresa, ¿el que se lucra con estas actividades no está utilizando a los menores e incapaces con fines o en espectáculos pornográficos?; ¿Agrega algo nuevo ésta conducta?. Nuevamente nos preguntamos ¿Cuál es la hipótesis especifica que quiere recoger?. Evidentemente, la intención del legislador es acabar con la industria de la pornografía infantil ${ }^{581}$, castigando el eslabón de la cadena criminal que está detrás del negocio de la explotación sexual de menores. Ahora bien, para alcanzar ésta finalidad -evitar que se sigan cometiendo abusos sexuales con el ánimo de lucro- ya existía en 189.1 b) y sigue existiendo la figura del que vendiere o facilitare la venta por cualquier medio de este tipo de material pornográfico de menores.

¿Cuál es la diferencia entre el que se lucrare y el que vendiere o facilitare la venta de pornografía infantil?. Lo primero es ubicar que el que se lucrare aparece en el 189.1 a) destinado a la conducta de forma particular y concreta tanto de la realización de espectáculos pornográficos con menores como a elaborar material con ese contenido, mientras que la venta esta contemplada en el apartado b) del articulo 189.1 que hace referencia a las conductas dirigidas a la difusión y tráfico de material pornográfico. ¿Quién se lucra sin vender el material pornográfico? La conducta del que se lucra pudiera ser por ejemplo el que alquila un local a sabiendas de que en el se realizaran espectáculos de pornografía infantil; o, el que alquila equipos como cámaras, videos grabadoras y otros equipos para el mismo fin. La diferencia sería entonces que el

\footnotetext{
${ }^{579}$ CUGAT MAURI, M., "Delitos contra la libertad e indemnidad sexuales", en ALVAREZ GARCÍA, Francisco J.; GONZÁLEZ CUSSAC, J. L., (DIR). Comentarios a la Reforma Penal de 2010, Ed. Tirant lo Blanch, Valencia, 2010, ciudad, pág. 241

${ }^{580}$ Según la Real Academia de la Lengua Española, lucrar significa ganar, sacar provecho de un negocio o encargo. Véase, Diccionario Real Academia Española, vigésima primera edición, Tomo II, Madrid, 1992, pág. 1273.

${ }^{581}$ El riesgo que supone tanto la producción como el comercio de pornografía infantil, y el hecho de ser una material ilegal en muchos ordenamientos jurídicos hace que los potenciales beneficios que pueden derivar de estas actividades sean muy superiores a los que puedan producir los de la pornografía legal. Véase, ROJO GARCÍA, J. C., "La realidad de la pornografía infantil en Internet" en revista de Derecho penal y Criminología, $2^{a}$ Etapa, No 9, 2009, pág. 213.
} 
primero -quién se lucra- saca provecho con una ganancia económica con la actividad más no se dedica a vender, producir con ánimo de lucro, que son las actividades propias del negocio o industria de la Pornografía infantil. Nuevamente la interrogante ¿agrega algo nuevo esta figura?

Ahora bien, la ampliación del tipo viene a cubrir algún vacío de punibilidad? Pareciera que estando ya tipificada la conducta de "financiación" de la utilización de menores a fines pornográficos, no sea necesaria la incriminación especifica de la obtención del lucro. Al respecto CUGAT MAURI plantea que “...quizás por un mimetismo literalista de la Decisión Marco, el legislador ha estimado necesaria la explicita mención a la obtención del lucro. Dentro de esta lógica, lo que sorprende, como acertadamente observaba el informe CGPJ al Anteproyecto aprobado el 27 de octubre de 2006, es que la mención al lucro no recoja en el segundo apartado del artículo en el que se reúnen las actividades más estrictamente vinculadas a la comercialización del producto pornográfico" 382,583 .

En el apartado 189.1b) se agregó la figura de el que ofreciere ${ }^{584}$ - contemplado en el artículo 3.1 c) de la Decesión Marco 2004/68/JAI. ¿Qué hipótesis busca incluir el legislador con ésta conducta? Las últimas manifestaciones de la pornografía por Internet tienen que ver con el intercambio entre pedófilos pero ¿cual es la diferencia entre ofrecer y la conducta de facilitar?, pareciera que en este caso se busca penalizar al que ofrece que es una conducta previa a facilitar. (ex-antes de facilitar). De igual forma que en los puntos anteriores cabe la pregunta ¿tiene el mismo nivel de afectación sobre el

\footnotetext{
${ }^{582}$ CUGAT MAURI, M., Delitos contra la libertad..., op. cit., pág. 242

583 “Ciertamente, esta modalidad se asemeja a la que se introdujo en la regulación de los delitos relativos a la prostitución por LO 11/2003 para el cumplimiento del convenio Internacional para la Represión de la trata de personas y de la explotación de la prostitución ajena, aunque con diferencias sustanciales respecto a la misma. En efecto, el art. 188CP exige que el lucro provenga de la propia explotación de la prostitución ("se lucre explotando"), mientras que el art. 189 CP no deja tan claro que el lucro provenga de la propia participación en las correspondientes actividades ("se lucrare con ellas"). De modo que, lo que parece que en efecto se ha incluido es una especifica modalidad de blanqueo no obstante la mayor benignidad de la pena prevista en el art. 189 respecto la del art. $301 \mathrm{CP}$, en lo que se desconoce si reparó el legislador, que más bien parecía apuntar al recrudecimiento penal en la materia". Véase, CUGAT MAURI, M., Delitos contra la libertad..., op. cit., pág. 243.

584 Según la Real Academia de la Lengua Española, ofrecer significa prometer, obligarse uno a dar; presentar y dar voluntariamente una cosa; manifestar y poner patente una cosa para que todos la vean; mostrar una cosa determinado aspecto. Véase, Diccionario Real Academia Española, vigésima primera edición, Tomo II, Madrid, 1992, pág. 1468.
} 
bien Jurídico la conducta del que produce, vende, distribuye con el que facilita la producción del material pornográfico, más aún con el que la ofrece?

Considerando que actualmente casi la totalidad de supuesto de pornografía infantil son a través de Internet y que el intercambio entre pedófilos se ha convertido en la principal forma de distribución, la figura del que ofreciere, pareciera dirigido a criminalizar el intercambio entre uno o un reducido número de sujetos. En este sentido, presenta diferencia con las modalidades de distribución o exhibición que exige que el destinatario sea un círculo más o menos extenso de sujetos. "Sin embargo, en especial consideración a la gravedad de la pena prevista, el principio de ultima ratio aconseja una interpretación en este sentido"

A juicio de CUGAT MAURI, "no queda claro si en la nueva modalidad cabe incluir la publicidad del producto pornográfico. Como ya advertía el informe al Anteproyecto del Consejo Fiscal de noviembre de 2008, hasta la reforma, esta conducta no estaba recogida con la necesaria claridad y singularidad en nuestra legislación. La tarea que ahora tiene por delante la jurisprudencia es la de delimitar el alcance de la conducta consistente en la "oferta" del material y su eventual extensión a la publicidad, en la que podrá tener en cuenta la interpretación que de ese mismo término se maneja en el delito publicitario del art. $282 \mathrm{CP}, 586$

En resumen, puede afirmarse que con la inclusión de estas tres figuras no se agrega nada a los tipos de pornografía infantil contemplada en el artículo 189 del CP. Por el contrario, puede afirmarse que las nuevas figuras son reiterativas e innecesarias, con establecer la punición de la utilización de menores con fines exhibicionistas o pornográficos se comprenderían todas las hipótesis especificadas el que captare, lucrare $\mathrm{u}$ ofreciere. Es un inventario innecesario con la avidez de acopiar de forma amplia toda posible actividad o conducta inadecuada. Es una forma de exponer las dudas que se tienen sobre el desempeño del juez, pues se determina expresamente un listado para evitar que el juez las deje impunes. En definitiva se trata de una mala técnica legislativa.

\footnotetext{
${ }^{585}$ CUGAT MAURI, M., Delitos contra la libertad..., op. cit., pág. 242.

${ }^{586}$ Ibídem, pág. 243.
} 


\subsubsection{Otras modificaciones del artículo 189}

En el apartado tres las circunstancias agravantes siguen siendo las mismas que estaban previstas en la reforma anterior. Lo que si se modificó fue las penas de prisión establecidas, que estaban estipuladas en el margen de cuatro (4) a ocho (8) años de prisión, y con la nueva legislación se aumentaron de cinco (5) a nueve (9) años. Es importante señalar que está decisión de aumentar el mínimo y el máximo de marco penal no respondía a las exigencias de los estándares europeos- no esta contemplado en la Decisión Marco-, sino que fue una decisión autónoma del legislador español siguiendo la línea de exasperación punitiva que ha caracterizado en los últimos años las reformas al Código Penal español.

El (189.7) referido a la pseudo/pornografía, es una figura fuertemente cuestionada desde la doctrina. Tanto la redacción como la estructura sistémica quedaron exactamente igual. Debe celebrarse que el legislador español no incluyo en la reforma el tipo referido a la pornografía de carácter simulado o virtual puro -contemplada en la Decisión Marco 2004/68/JAI que en su artículo 1 las define como imágenes de adultos con apariencias de niños e imágenes realista de niños inexistente- . El legislador resistió la presión que ejercieran partidos políticos y otras instituciones para criminalizar estas modalidades asignándole un supuesto efecto "provocador" de ulteriores delitos sexuales, del mismo se solicitaba la introducción de la apología de la pederastia ${ }^{587}$. Es un gran acierto que estas modalidades no fueran tipificadas pues suponían el adelantamiento de las barreras de punibilidad y afectación al principio de ultima ratio $^{588}$.

Resulta contradictorio que no se tipifique la asistencia al espectáculo exhibicionista o pornográfico y se continúe con la criminalización de la posesión simple. No es que estemos a favor de que se criminalice la primera como que nos pronunciamos por la destipificación de la mera tenencia para propio consumo que se sigue con el argumento de eliminar la demanda para acabar con la oferta. La

\footnotetext{
${ }^{587}$ Véase, Proposición no de ley de ERC-IU-ICV (162/000160, presentada al Pleno el 5/9/2008) y en la enmienda núm. 151 presentada por el grupo Parlamentario Popular en el Senado, BOCG-Senado, de 27 de mayo de 2010. También Contenida en el Informe del Consejo Fiscal acerca del Anteproyecto de Ley de 14 de noviembre de 2008 .

${ }^{588}$ CUGAT MAURI, M., Delitos contra la libertad..., op. cit., pág. 243.
} 
criminalización de esta conducta también fue solicitada en El Informe del Consejo Fiscal sobre el Anteproyecto de noviembre 2008.

Por otro lado, en la línea llevada a cabo por la reforma de homologar la legislación española a los estándares europeos, pareciera que debemos de estar agradecidos que no se tipificara la mera "adquisición" de material pornográfico que no haya llegado a la posesión del comprador. Esta figura está contemplada en la normativa comunitaria, específicamente en el Art. 3.1, d) de la Decisión marco 2004/68/JAI.

Por otra parte no se recogió en la reforma lo establecido en el art. 3.2, b) de la Decisión Marco sobre la posibilidad que tienen los Estados de declarar atípico los casos donde el protagonista de la imagen producida o poseída sea un menor de edad que hubiere alcanzado la edad de consentimiento sexual, que hubiere consentido y se destinara al exclusivo uso privado. En estos casos se comprometen el principio de ofensividad y mínima significación. Sin embargo, aunque no quedara establecida su atipicidad en la LO 5/2010 de 22 de junio, puede alcanzarse el mismo efecto por vía interpretativa en el sentido de excluir del tipo determinados supuestos de posesión de imágenes de desnudo del menor, de acuerdo con una interpretación material del precepto. $589 / 590$

No fueron modificados los apartados (189.4) referido a la corrupción de menores; en la infracción del deber de guarda y custodia previsto en el (189.5); en la actuación del ministerio fiscal (189.6). El apartado 8 que refería la posibilidad de aplicar a todos

\footnotetext{
${ }^{589}$ Ibídem, pág. 244.

590 En el 189.1 referido a la utilización de menores con fines pornográficos, se castiga cualquier utilización del menor de 18 años o incapaz, el eventual consentimiento tenga relevancia, aquí pueden citarse las siguientes Jurisprudencia del Tribunal Supremo: TS 1-10-07, RJ 6495, donde se convence a una menor para que exhiba sus pechos y pubis delante de la Webcams del ordenador y de que se masturbe; TS 16-2-98,RJ 1051, donde a cambio de gratificaciones varios menores acceden a ser grabados en poses de claro significado sexual. Se impone coactiva o abusivamente su intervención con fines exhibicionistas o pornográficos, el ataque adicional contra la libertad del menor se castigará junto aeste delito. En este sentido, conviene recordar que el CP establece la libertad de autodeterminación a los mayores de 13 años, en este sentido puede darse la paradoja de que la conducta sexual practicada con el menor no genere responsabilidad penal, pero la elaboración de material pornográfico a partir de ella si lo haga. No tiene validez si el menor conoce y acepta participar ya que la prohibición de la pornografía infantil incluye las imágenes de todos los menores de 18 años. Véase, MARTIN LORENZO, M., Libertad e indemnidad..., op. cit., pág. 122.
} 
los preceptos anteriores el artículo 129 del CP cuando el culpable perteneciere a una sociedad, organización o asociación que se dedicare a la realización de tales actividades criminales fue suprimido. Este aspecto es tratado ahora en un nuevo artículo 189 bis.

\subsubsection{La Responsabilidad de las personas jurídicas. El nuevo artículo 189 bis.}

El nuevo artículo 189 bis quedó redactado como sigue:

"Cuando de acuerdo con lo establecido en el artículo 31 bis una persona jurídica sea responsable de los delitos comprendidos en este Capítulo, se le impondrán las siguientes penas:

a) Multa del triple al quíntuple del beneficio obtenido, si el delito cometido por la persona física tiene prevista una pena de prisión de más de cinco años. b) Multa del doble al cuádruple del beneficio obtenido, si el delito cometido por la persona física tiene prevista una pena de prisión de más de dos años no incluida en el anterior inciso.

c) Multa del doble al triple del beneficio obtenido, en el resto de los casos. Atendidas las reglas establecidas en el artículo 66 bis, los jueces y tribunales podrán asimismo imponer las penas recogidas en las letras b) a g) del apartado 7 del artículo 33."

En el artículo se hace expresa mención a las penas que pueden ser aplicadas a las personas jurídicas que incurran en cualquiera de los delitos previstos en el capítulo V, referido a los delitos relativos a la prostitución y la corrupción de menores. Esta figura también era una exigencia de la decisión Marco 2004/68/JAI. Se determinan multas además de las penas de prisión correspondiente para la persona física que realice la conducta. En cualquier caso, la multa puede ser del doble y hasta del quíntuple de las ganancias obtenidas, dependiendo de la gravedad del delito delimitado por la pena privativa de libertad impuesta. Además, en los delitos considerados graves se podrán imponer las penas recogidas en el nuevo apartado 7 del artículo 33 establecidas en las letras b) a g) que consisten en: 
b) disolución de la persona jurídica. La disolución producirá la pérdida definitiva de su personalidad jurídica, así como la de su capacidad de actuar de cualquier modo en el tráfico jurídico, o llevar a cabo cualquier clase de actividad, aunque sea lícita;

c) suspensión de sus actividades por un plazo que no podrá exceder de cinco años;

d) clausura de sus locales y establecimientos por un plazo que no podrá exceder de cinco años;

e) prohibición de realizar en el futuro las actividades en cuyo ejercicio se haya cometido, favorecido o encubierto el delito. Esta prohibición podrá ser temporal o definitiva. Si fuere temporal, el plazo no podrá exceder de quince años;

f) Inhabilitación para obtener subvenciones y ayudas públicas, para contratar con el sector público y para gozar de beneficios e incentivos fiscales o de la Seguridad Social, por un plazo que no podrá exceder de quince años;

g) Intervención judicial para salvaguardar los derechos de los trabajadores o de los acreedores por el tiempo que se estime necesario, que no podrá exceder de cinco $\operatorname{años}^{591} \rho^{592}$.

\footnotetext{
${ }^{591}$ Véase, Ley Orgánica 5/2010, de 22 de junio, por la que se modifica la Ley Orgánica 10/1995, de 23 de noviembre, del Código Penal.
}

${ }^{592}$ El nuevo artículo 66 bis, de la LO 5/2010, establece que: en la aplicación de las penas impuestas a las personas jurídicas se estará a lo dispuesto en las reglas $1 .^{a}$ a $4 .^{a}$ y $6 .^{a}$ a $8 .^{a}$ del primer número del artículo 66, así como a las siguientes:

$1^{\text {a }}$ En los supuestos en los que vengan establecidas por las disposiciones del Libro II, para decidir sobre la imposición y la extensión de las penas previstas en las letras b) ag) del apartado 7 del artículo 33 habrá de tenerse en cuenta: a) Su necesidad para prevenir la continuidad de la actividad delictiva o de sus efectos; b) Sus consecuencias económicas y sociales, y especialmente los efectos para los trabajadores; c) El puesto que en la estructura de la persona jurídica ocupa la persona física u órgano que incumplió el deber de control.

$2^{\mathrm{a}}$ Cuando las penas previstas en las letras c) a g) del apartado 7 del artículo 33 se impongan con una duración limitada, ésta no podrá exceder la duración máxima de la pena privativa de libertad prevista para el caso de que el delito fuera cometido por persona física.

Para la imposición de las sanciones previstas en las letras c) a g) por un plazo superior a dos años será necesario que se dé alguna de las dos circunstancias siguientes: a) Que la persona jurídica sea reincidente; b) Que la persona jurídica se utilice instrumentalmente para la comisión de ilícitos penales. Se entenderá que se está ante este último supuesto siempre que la actividad legal de la persona jurídica sea menos relevante que su actividad ilegal. Para la imposición con carácter permanente de las sanciones previstas en las letras b) y e), y para la imposición por un plazo superior a cinco años de las previstas en las letras e) y f) del apartado 7 del artículo 33, será necesario que se dé alguna de las dos circunstancias siguientes: a) Que se esté ante el supuesto de hecho previsto en la regla 5. ${ }^{\mathrm{a}}$ del primer número del artículo 66; b) Que la persona jurídica se utilice instrumentalmente para la comisión de ilícitos penales. Se entenderá que se está ante este último supuesto siempre que la actividad legal de la persona jurídica sea menos relevante que su actividad ilegal. 
En la redacción del art. 189 bis, también se hace mención expresa al nuevo artículo 31 bis que contempla los supuestos previstos en el Código Penal sobre la responsabilidad penal de las personas jurídicas por los delitos cometidos en su nombre y en su provecho, por sus representantes legales y administradores de hecho o de Derecho. ${ }^{593}$ Así mismo, en el precepto 4 de este artículo se señalan las circunstancias atenuantes de la responsabilidad penal de las personas jurídicas cuando posterior a la comisión del delito y a través de sus representantes legales, se realicen las siguientes actividades: a) haber procedido, antes de conocer que el procedimiento judicial se dirige contra ella, a confesar la infracción a las autoridades; b) haber colaborado en la investigación del hecho aportando pruebas, en cualquier momento del proceso, que fueran nuevas y decisivas para esclarecer las responsabilidades penales dimanantes de los hechos; c) haber procedido en cualquier momento del procedimiento y con anterioridad al juicio oral a reparar o disminuir el daño causado por el delito; d) haber establecido, antes del comienzo del juicio oral, medidas eficaces para prevenir y descubrir los delitos que en el futuro pudieran cometerse con los medios o bajo la cobertura de la persona jurídica. ${ }^{594}$

Por último, en el apartado 5 del artículo 31, se contempla que las disposiciones relativas a la responsabilidad penal de las personas jurídicas no serán aplicables al

${ }^{593}$ En los apartados del uno al tres el nuevo artículo 31 bis de la LO 5/2010, se establece la responsabilidad de las personas jurídicas de la siguiente forma:

“1. En los supuestos previstos en este Código, las personas jurídicas serán penalmente responsables de los delitos cometidos en nombre o por cuenta de las mismas, y en su provecho, por sus representantes legales y administradores de hecho o de derecho.

En los mismos supuestos, las personas jurídicas serán también penalmente responsables de los delitos cometidos, en el ejercicio de actividades sociales y por cuenta y en provecho de las mismas, por quienes, estando sometidos a la autoridad de las personas físicas mencionadas en el párrafo anterior, han podido realizar los hechos por no haberse ejercido sobre ellos el debido control atendidas las concretas circunstancias del caso.

2. La responsabilidad penal de las personas jurídicas será exigible siempre que se constate la comisión de un delito que haya tenido que cometerse por quien ostente los cargos o funciones aludidas en el apartado anterior, aun cuando la concreta persona física responsable no haya sido individualizada o no haya sido posible dirigir el procedimiento contra ella. Cuando como consecuencia de los mismos hechos se impusiere a ambas la pena de multa, los jueces o tribunales modularán las respectivas cuantías, de modo que la suma resultante no sea desproporcionada en relación con la gravedad de aquéllos.

3. La concurrencia, en las personas que materialmente hayan realizado los hechos o en las que los hubiesen hecho posibles por no haber ejercido el debido control, de circunstancias que afecten a la culpabilidad del acusado o agraven su responsabilidad, o el hecho de que dichas personas hayan fallecido o se hubieren sustraído a la acción de la justicia, no excluirá ni modificará la responsabilidad penal de las personas jurídicas, sin perjuicio de lo que se dispone en el apartado siguiente.

${ }^{594}$ Véase, Ley Orgánica 5/2010, de 22 de junio, por la que se modifica la Ley Orgánica 10/1995, de 23 de noviembre, del Código Penal. 
Estado, a las Administraciones Públicas territoriales e institucionales, a los Organismos Reguladores, las Agencias y Entidades Públicas Empresariales, a los partidos políticos y sindicatos, a las organizaciones internacionales de Derecho público, ni a aquellas otras que ejerzan potestades públicas de soberanía, administrativas o cuando se trate de sociedades mercantiles estatales que ejecuten políticas públicas o presten servicios de interés económico general. Así mismo, establece que en estos supuestos, los órganos jurisdiccionales podrán efectuar declaración de responsabilidad penal en el caso de que aprecien que se trata de una forma jurídica creada por sus promotores, fundadores, administradores o representantes con el propósito de eludir una eventual responsabilidad penal. ${ }^{595}$

En lo que se refiere a la pornografía infantil, las últimas manifestaciones del fenómeno a través de la red, muestran el intercambio entre pedófilos como le medio mayormente utilizado en la difusión de éste material. Es un hecho innegable que existe una industria de explotación sexual de niños en la que participan grupos, asociaciones, y/o personas jurídicas a las que el Derecho penal debe dar una respuesta contundente, Sin embargo, no vemos la necesidad de introducir un nuevo artículo 189 bis para tratar en concreto o de forma especifica los delitos relativos a la prostitución y la corrupción de menores, pues siguiendo esta lógica sería necesario introducir un artículo bis en cada capítulo en el que sea posible la actuación de las personas jurídicas. Insistimos, está muy bien la figura que determine la responsabilidad de las personas jurídicas en cualquier hecho delictivo, lo que no parece necesario u oportuno es aumentar los preceptos, engordar el Código Penal agregando nuevos artículos bis, ter, quáter, colocarlo explícitamente para que no quede dudas de la aplicación en cada delito.

\subsection{TOMA DE POSTURA SOBRE LA LO 5/2010, DE 22 DE JUNIO.}

Como notas de cierre de este aparte, manifestamos lo ilusorio que resultaba esperar que la reforma al artículo 189 del CP pudiera atender a las numerosas críticas realizadas desde la doctrina para que se destipificara la posesión de pornografía infantil y la pornografía virtual por la falta de lesividad a bien jurídico alguno. Por el contrario,

\footnotetext{
${ }^{595}$ Véase, Ley Orgánica 5/2010, de 22 de junio, por la que se modifica la Ley Orgánica 10/1995, de 23 de noviembre, del Código Penal.
} 
parece que las voces que si ha escuchado el legislador es la de las crónicas negras de los últimos años. Es inaceptable que después de cada titular de prensa deba procederse a la reforma del Código Penal para tipificar nuevas conductas o aumentar las penas que exigen. Compartimos la opinión del Grupo de Estudios de Política Criminal cuando señala que, "una norma tan importante para el nivel de protección de derechos y libertades como el Código Penal no puede ser objeto de reformas constantes, sin reflexión y ausentes de cualquier debate técnico. Precisamente requiere un debate sosegado, alejado en todo lo que sea posible de la mediatización del caso concreto" ${ }^{„ 59}$.

Ya resulta redundante analizar las reformas y apuntar que se trata de una mala técnica legislativa, que abundan los delitos de peligro abstracto, y que todo el arsenal punitivo del Derecho penal va dirigido a los considerados enemigos de la sociedad (pedófilos, maltratadores y terroristas) que se tipifican conductas que en algunos casos resultan inocuas y adelantan cada vez más las barreras punitivas del Derecho penal.

\section{BIEN JURÍDICO PROTEGIDO EN LA PORNOGRAFÍA INFANTIL.}

En un Estado moderno de Derecho, los bienes jurídicos son realidades necesarias para una convivencia social pacífica y en libertad. Para la realización de bienes jurídicos se requiere en primer lugar, que en la función estatal de protección el Derecho penal debe dejar intactos los derechos fundamentales y humanos de sus ciudadanos: respetar la dignidad humana y la libertad de opinión. El irrespeto a los Derechos humanos conduce a una comunidad violenta, que impide una vida en común libre. En segundo lugar, es necesario preservar el carácter subsidiario del Derecho penal, es decir, que en aquellos casos en los que el fin de asegurar la libertad se pueda conseguir con medios menos gravosos que la pena se debe renunciar a la utilización de la violencia punitiva del Estado ${ }^{597}$. Hacemos nuestras las palabras de ROXIN cuando afirma que como bien jurídico "sólo puede ser reconocido lo que es relevante para la

\footnotetext{
${ }^{596}$ Grupo de Estudios de Política Criminal. "Comunicado que sobre el modelo de política criminal de nuestros poderes públicos" aprobado en la asamblea ordinaria de Barcelona celebrada los días 18 y 19 de septiembre de 2009. Disponible en http://www.gepc.es/

597 ROXIN C., El bien Jurídico, Conferencia dictada el 23 de febrero del 2007, en la Universidad Complutense de Madrid. Mimeografiado, págs. 2 y ss.
} 
existencia de la sociedad y asegura la vida de sus componentes, por lo que la ética social debe desaprobar toda lesión de un bien jurídico",598

En los últimos años se ha resquebrajado el consenso en la doctrina sobre la protección de bienes jurídicos como la finalidad del Derecho penal. En consecuencia en la teoría del bien jurídico han empezado a aparecer diversas grietas. Esto es así por lo siguiente: a) algunos autores como Jakobs han mantenido que la finalidad del Derecho penal consiste en la protección de la vigencia de la norma. b) quienes defienden la teoría del bien jurídico son los primeros en reconocer que el concepto de bien jurídico, en el que se subsumen las más diversas definiciones, carecen de contornos precisos. c) porque incluso estos últimos autores mantienen que, si bien excepcionalmente, con algunos tipos penales es difícil determinar que bien jurídico estarán tutelando. ${ }^{599}$

Teniendo presente las controversias sobre la teoría del bien jurídico señaladas anteriormente, pasamos a revisar el artículo 189 del Código Penal español.

Posterior a la última reforma con ocasión de la Ley Orgánica 5/2010 del 22 de junio, el artículo 189 ha quedado conformado por siete apartados que procuran dar cobertura legal a los supuestos relacionados con la pornografía y la corrupción de menores. Además, se agrega el art. 189 bis que recoge todo lo referido a las personas jurídicas responsables de alguno de los delitos comprendidos en el capítulo $\mathrm{V}$ denominado, "De los delitos relativos a la prostitución y la corrupción de menores". Ahora bien, no todos los tipos referidos en el 189 del Código Penal han de ser consideradas como modalidades de pornografía infantil, delito que resulta objeto central de este trabajo. De allí que una primera consideración a formular antes de disertar sobre el bien jurídico protegido es aclarar que no vamos a considerar el aparte que hace mención a la corrupción de menores ${ }^{600}$ contemplado en el 189.4. El análisis de

\footnotetext{
${ }^{598}$ ROXIN C., El bien Jurídico, op. cit., pág. 8.

${ }^{599}$ GIMBERNAT ORDEIG, E., Presentación del libro: La teoría..., op. cit., pág. 11.

${ }^{600}$ No compartimos la analogía que se ha venido desarrollando desde la jurisprudencia y la doctrina entre el delito del artículo 189.1 del Código Penal y la corrupción de menores. El delito corrupción de menores abarca una generalidad de supuestos eróticos y pornográficos, mientras que el delito de pornografía infantil refleja sólo una particularidad del mismo, ceñido a los supuestos pornográficos. La propia jurisprudencia ha equiparado en más de una ocasión el tipo del artículo 189.1 con la corrupción de
} 
las figuras delictivas alineadas a los objetivos de este trabajo ha de centrarse básicamente en los apartados primero: captación y utilización de menores de edad para la creación y tráfico de material pornográfico infantil; segundo: la posesión simple; y, séptimo: alusivo a la pseudo/pornografía.

La tipificación de la pornografía infantil la encontramos ubicada dentro del Título VIII del Código Penal, título que, como sabemos, tras la reforma efectuada por la Ley Orgánica 11/1999, aparece bajó la rúbrica "Delitos contra la libertad e indemnidad sexuales $" 601$. Al tratarse de menores de edad la determinación del objeto tutelable del artículo 189 del Código Penal tiene planteamientos diferentes en relación con el resto de los tipos integrantes del Título VIII del Libro II del vigente Texto Punitivo. Conforme a este planteamiento se ha presentado una abundante discusión doctrinal sin lograr un consenso sobre los bienes fundamentales protegidos en el mencionado precepto. Tarea que ha resultado complicada considerando que: a) se recoge varios tipos; b) se sancionan diversas conductas de personas que no han participado en la elaboración del material c) se condena el mero consumo; d) el objeto sobre el que

menores, obsérvese, entre otras, la Sentencia de la Audiencia Provincial de Alicante 501/2002, de 11 de noviembre [ARP 20021870] al indicar que "los hechos descritos en el apartado (...) del relato fáctico constituyen un delito continuado de corrupción de menores de los arts. 189.1 literal a) y 74 del Código Penal". De igual forma, la Sentencia de la Audiencia Provincial de Barcelona, de 16 de mayo de 2001 [JUR 20011262916] indica que "no puede negarse la analogía entre el delito del artículo 189,1 del Código Penal de 1995 con el delito de corrupción de menores del Código Penal de 1973, de modo que puede afirmarse que el legislador ha dejado subsistente la forma de corrupción consistente en la utilización de menores para fines o en espectáculos exhibicionistas o pornográfico".

${ }^{601}$ Desde 1848 hasta la reforma fundada en la Ley Orgánica 3/1989, de 21 de junio, del Código Penal de 1973 el bien jurídico protegido en el ámbito sexual era la honestidad. Como consecuencia de las demandas y presiones de la doctrina que planteaba la necesidad de dejar atrás concepciones propias de la moral sexual se logró la sustitución de la tradicional expresión "Delitos contra la honestidad" en la rubrica del Titulo IX del Libro 11 que regulaba los delitos sexuales, por la de "Delitos contra la libertad sexual". La reforma, no obstante ser bien acogida por la doctrina, dejaba sin resolver el objeto tutelable en los menores y deficientes mentales pues, si algo caracteriza a estos sujetos es precisamente su falta de autonomía para decidir en materia sexual. A partir de estos razonamientos se comienza a acuñar la terminología "indemnidad sexual" para los supuestos en que el sujeto pasivo sea un menor o incapaz fundamentando tal planteamiento en la negación del consentimiento que ostentan estos individuos. El Código Penal de 1995 no modificó el bien jurídico de los delitos sexuales, manteniéndose el nombre del titulo VIII en "delitos contra la libertad sexual". De tal suerte que no será sino hasta la Ley Orgánica 11/1999, de 30 de abril, que el legislador advierte que la libertad sexual no es el único bien jurídico protegido en todos los delitos regulados en este Titulo y amplia su contenido sustituyéndolo por la de "Delitos contra la libertad e indemnidad sexuales". Véase, MORILLAS FERNÁNDEZ, D. L., Análisis dogmáticos y criminologico..., op. cit., págs. 152 y ss. 
recae la conducta típica es el material pornográfico y no los menores de edad pornografía virtual- ${ }^{602}$.

La primera controversia en la doctrina surge en relación a si es uno o son varios los bienes jurídicos subyacentes en el precepto. Un sector minoritario y tradicional de la doctrina considera que la libertad sexual abarca a todos los tipos del 189 del $\mathrm{CP}^{603}$; sin embargo, otros niegan esta postura y argumentan la posibilidad de diversos bienes jurídicos de forma conjunta y simultáneos como ${ }^{604}$ : la indemnidad o intangibilidad sexual; la dignidad de la persona humana y los derechos derivados de ella; Derecho a un desarrollo y una formación adecuados; intimidad y propia imagen; la moral sexual colectiva; la dignidad de la infancia en general. Y por último, - aunque no menos importante- una tercera postura doctrinal cuestiona que con el lema de mayor protección a la infancia se justifiquen la creación de tipos que criminalizan comportamientos que, aunque estén alejados de las prácticas sexuales mayoritarias no lesionan los intereses sexuales de los menores en general, ni ningún bien jurídico de relevancia penal ${ }^{605} / 606$.

\footnotetext{
${ }^{602}$ FERNÁNDEZ TERUELO, J., Cibercrimen. Los delitos..., op. cit., pág. 63.

${ }^{603}$ Véase, DIEZ RIPOLLÉS, J. L., El objeto de protección,., op. cit., pág. 70.

${ }^{604}$ Véase entre otros, QUERAIT JIMÉNEZ, J. J., Derecho... op. cit., págs. 109-111; ORTS BERENGUER, E.; ROIG TORRES, M., Delitos... op. cit., pág. 129; MORALES PRATS, F. Y GARCÍA ALBERO, R., Artículo 189..., op. cit., pág. 983; MANTOVANI, F., Idelitti di prostituzione e di pornografía minorili, pág. 12 y 13 de la Parte Segunda.
}

${ }^{605}$ Para una revisión exhaustiva, Véase, BOLDOVA PASAMAR, M. A., "Artículo 189”, en DíEZ RIPOLlÉS; ROMEO CASABONA, Comentarios al Código Penal, Parte Especial, vol.II, Valencia, 2004 pág. 524; BUENO ARÚS, F., "Análisis general de las últimas tendencias político-criminales en materia de delitos sexuales. Justificación político-criminal de la reforma española de 1999", en Delitos contra la libertad sexual, Estudios de Derecho Judicial $\mathrm{N}^{\circ}$ 21, Madrid, 2000, pág. 271; CONDEPUMPIDO TOURÓN, C, "Delitos de prostitución. Especial referencia a la prostitución de menores", en Delitos contra la libertad sexual, Madrid, 2000 pág. 293; DIEZ RIPOLLÉS, J. L., "El objeto de protección del nuevo Derecho penal sexual", en Delitos contra la libertad sexual, Madrid, 2000, págs. 217 y ss.; GONZÁLEZ-CUÉLLAR GARCÍA, A., "Articulo 189”, MORALES PRATS, F.; GARCÍA ALBERO, R., "Delitos contra la libertad e indemnidad sexuales", Quintero Olivares, Comentarios al Nuevo Código Penal, Navarra, 2004, págs. 926 y 928; SÁNCHEZ TOMÁS, J. M., "Los abusos sexuales en el Código Penal de 1995: en especial sobre menor de doce años y abusando de trastorno mental", en Cuadernos de Política Criminal, № 61, Madrid, 1997, pág. 111; SERRANO GÓMEZ, A., Derecho Penal, Parte Especial, Madrid, 2004, pág. 210; TAMARIT SUMALLA, J. M., La ProtecciónPenal del menor frente al abuso y la explotación sexual. Análisis de las reformas penales en materia de abusos sexuales, prostitución y pornografía de menores, Navarra, 2002, pág. 60. De su parte la jurisprudencia del Tribunal Supremo en sentencia 654/1997, de 7 de mayo [RJ 199713800] indica que "el bien jurídico es la libertad sexual (en sentido amplio, incluida la protección de quienes no tienen plena capacidad de autodeterminación sexual es decir menores e incapaces)"; o la Sentencia de la Audiencia Provincial de 
La exposición de Motivos de la Ley Orgánica 11/1999, de 30 de abril es el punto de partida para acercarse y fundamentar un cuerpo doctrinario sobre el bien jurídico protegido en el delito de pornografía infantil, pues, señala tres bienes jurídicos además de la libertad sexual como son, los derechos inherentes a la dignidad de la persona humana, el derecho al libre desarrollo de la personalidad y la indemnidad o integridad sexuales de los menores. Esto es, que el legislador desde la reforma de 1999 expresa que la libertad sexual no es la única manifestación tutelada en el nuevo Título VIII del Código Penal ${ }^{607}$. En este sentido, QUERALT JIMÉNEZ, plantea que en situaciones parecidas a las que suceden con otros delitos afectos al área de la libertad, el bien jurídico protegido no suele ser único, sino que se dan protecciones conjuntas y simultáneas de otros. Estamos así en presencia de delitos pluri/ofensivos, por ejemplo con la integridad física y psíquica de la víctima. Con todo, precisa QUERALT JIMÉNEZ, el bien jurídico principal sobre el que pivota la punición de las conductas sancionadoras reside en la capacidad de la persona madura -o medianamente madurade decidir las prácticas sexuales que desea, fundado sobre el derecho al libre desarrollo de la personalidad ${ }^{608}$.

Compartimos la postura de MORILLAS FERNÁNDEZ, cuando afirma que "el artículo 189 del Código Penal engloba una serie de supuestos típicos que, unos casos por su confusa redacción y otros por la inclusión de tipos de dudosa legitimidad, no permiten tratar la figura de la pornografía infantil bajo una perspectiva de unidad de bienes jurídicos... Esta figura delictual representa un delito pluriofensivo no

Alicante 501/2002, de 11 de noviembre [ARP 20021870] en donde se habla de "un delito contra la libertad sexual de varios menores".

${ }^{606}$ MARTÍN LORENZO, M., "Libertad e Indemnidad sexuales", en Memento Experto, Reforma Penal 2010, Ley Orgánica 5/2010, ORTIZ DE URBINA, G. (Coord.), Ed. Francis Lefebvre, Madrid, 2010, pág. 120.

${ }^{607}$ Según MARTÍN LORENZO, la doctrina se ha planteado dos vías para la legitimación de estas figuras delictivas: “a) Por un lado, se asigna a estos ilícitos la naturaleza de delitos de peligro abstracto para la indemnidad y/o libertad sexual de los menores, por estimarse que todos los actos relacionados con la pornografía infantil pueden determinar a un aumento de la oferta y, con ello, introducen un riesgo de utilización de menores en prácticas sexuales lesivas de su indemnidad sexual. b) La otra vía sugerida es la de incidir en la lesión a la intimidad personal de los menores, pues se ponen a disposición de múltiples personas aspectos relativos a la imagen o intimidad sexual de los menores presentes en el material, sobre todo en las conductas de distribución, o incluso se ha apelado más genéricamente al ataque a la dignidad de los menores representados en los materiales". Véase, MARTÍN LORENZO, M., Libertad $e$ Indemnidad ..., op. cit., pág. 120.

${ }^{608}$ QUERALT JIMÉNEZ, J. J., Derecho penal español. Parte especial, Barcelona, 2002, págs. 109-111. 
circunscribiéndose su objeto tutelable a un único ámbito -la indemnidad sexual- sino que con él coexisten otros aplicables de forma subsidiaria o independiente" ${ }^{, 609}$.

En lo que sigue vamos a referimos a la libertad sexual, la indemnidad y la intimidad como bienes jurídicos en los delitos donde el sujeto pasivo son los menores e incapaces. Posteriormente centraremos el análisis en los tipos que han generado más discusión en el seno de la doctrina en la pornografía infantil básicamente en los apartados 189.1 creación y tráfico de material pornográfico infantil; 189.2 referido a la posesión simple; 189.7 alusivo a la pseudo/pornografía.

Cuándo se trata de menores de edad puede hablarse de libertad sexual? ¿Se tutela en la pornografía infantil la libertad sexual en su vertiente positiva o negativa? ¿Es la indemnidad sexual el bien jurídico que abarca todos los previstos en el artículo 189? ¿Es la intimidad del menor victima lo que se protege? Intentemos responder sistemáticamente a estas preguntas.

\subsection{LIBERTAD SEXUAL}

Dentro de la libertad ${ }^{610}$ en general la libertad sexual tiene efectivamente su propia autonomía, y aunque los ataques violentos intimidatorios a la misma son también ataques a la libertad que igualmente podrían ser castigados como tales, su referencia al ejercicio de la sexualidad le da a su protección penal connotaciones propias. MUÑOZ CONDE la define como aquella parte de la libertad referida al ejercicio de la propia sexualidad y, en cierto modo, a la disposición del propio cuerpo, añadiendo que se trata de un bien jurídico merecedor de una protección penal especifica, no siendo suficiente

\footnotetext{
${ }^{609}$ MORILLAS FERNÁNDEZ, D., Análisis dogmático y criminológico ... op. cit., pág. 187.

${ }^{610}$ La libertad es uno de los bienes jurídicos más importante después de la vida y la salud y, probablemente, el mas expuesto a ser atacado en la vida cotidiana. En el Código penal se dedica todo el Titulo VI a regular los delitos contra la libertad y en la Constitución se garantiza, junto con la seguridad, en el artículo 17. La libertad es, además un bien jurídico que frecuentemente es atacado como medio para atentar contra otros bienes jurídicos. La prueba de ello es que si, por las razones que sean, el ataque del otro bien jurídico (propiedad, dignidad funcionarial, intimidad de la morada) no llega a materializarse o, de algún modo, no es específicamente castigado, siempre cabe la posibilidad de castigar autónomamente el ataque a la libertad como delito contra la misma. Véase MUÑOZ CONDE, F. Derecho Penal ..., op. cit., pág. 199.
} 
para abarcar toda su dimensión con la protección genérica que se concede a la libertad $^{611}$.

En los delitos sexuales cuando se hace referencia a la libertad como objeto jurídico, se agrupan en dos grandes tesis delimitadoras de su contenido: la libertad positiva y la libertad negativa. Entendiendo la positiva como la libre disposición del propio cuerpo a efectos sexuales, y la libertad negativa como el derecho a no verse involucrado en un contexto de carácter sexual sin un consentimiento válidamente prestado $^{612}$. La reforma de 1989 incrusta dentro de ésta doble vertiente de la libertad sexual a saber: positivo / dinámica de una parte y negativo / pasiva por otra ${ }^{613}$.

La mayor parte de la doctrina, se inclina por sostener que en el caso de los delitos relativos al orden sexual el objeto de protección se centra en la libertad positiva. Sin embargo, autores como GONZÁLEZ RUS afirman que las esferas positiva y negativa son complementarias y que la dimensión negativa se manifiesta como consecuencia necesaria y tutelada por el Derecho cuando se vulnera la libre disponibilidad de elección, es decir, la libertad positiva ${ }^{614} /{ }^{615}$. MORALES PRATS y GARCÍA ALBERO se pronuncian por el aspecto negativo afirmando que "sosteniendo que sólo el aspecto

\footnotetext{
${ }^{611}$ MUÑOZ CONDE, F., Derecho Penal..., op. cit., pág. 200.

${ }^{612}$ Véase, CARUSO FONTÁN. M. V., Nuevas perspectivas sobre los Delitos contra la Libertad Sexual, Ed. Tirant lo Blach, Valencia, 2006, pág. 153.
}

${ }^{613}$ ARROYO ZAPATERO Y BERDUGO GOMÉZ DE LA TORRE hablan de estos dos aspectos de la libertad sexual, como bien jurídico protegido. "Por un lado, un aspecto dinámico-positivo que se concreta en el libre ejercicio de la sexualidad sin más limitaciones que las que derivan del respeto hacia la libertad ajena. Por otro, una vertiente negativa, concretada en el derecho a no verse involucrado, activa o pasivamente, en conductas de contenido sexual y, con mayor motivo, a repeler las agresiones sexuales de terceros".Véase, ARROYO ZAPATERO, L; BERDUGO GOMÉZ DE LA TORRE, I; FERRÉ OLIVÉ, J:C:, "Comentarios al Código Penal" Madrid, 2007, pág. 429. En el mismo sentido se expresa CARMONA SALGADO, C, "Delitos contra la libertad sexual (I)", en Cobo del Rosal, Curso de Derecho Penal Español. Parte Especial, Madrid, 1995, pág. 303. Más recientemente vid. CARMONA SALGADO, C, "Delitos contra la libertad e indemnidad sexuales (I)", en Cobo del Rosal, Derecho Penal Español, Parte General, Madrid, 2004, pág. 224.

${ }^{614}$ GONZÁLEZ RUS, J. J., La violación en el Código Penal español, Granada, 1982, pág. 244.

${ }^{615}$ Pueden ubicarse dentro de la concepción positiva a: SUÁREZ RODRÍGUEZ, C; El delito de agresiones sexuales..., op. cit., pág. 51; MORAS MOM, J. R.: Los delitos de violación..., op. cit., pág. 13; PECO, J.: "El delito de violación" en La Ley, 1937, pág. 42.; PRIETO RODRÍGUEZ, J. I.: "La nueva configuración de los delitos contra la libertad sexual: Violación y agresiones sexuales" en Actualidad Penal, Madrid, 1991, pág. 122.; CASA NOMBELA, J. J.: "Los delitos contra la libertad e indemnidad sexuales en la PANCP" en Revista de la Facultad de Derecho de la Universidad Complutense de Madrid, Madrid, 1983, pág. 213. 
estático pasivo de la libertad sexual es merecedor de protección penal específica. Estos autores entienden que lo contrario implicaría igualar supuestos muy dispares, ya que sería necesario entender que los casos en los que se impide realizar una conducta sexual también quedarían incluidos. Así, no tendría ningún sentido privilegiar, respecto del resto de manifestaciones, una pura concreción de la libertad de obrar que ya recibe adecuada protección vía delito de coacciones, por muy significativa que esta resulte para el desarrollo de la personalidad" ${ }^{\prime 616}$.

Hasta aquí cabría entender que se produce una afectación del bien jurídico cuando se desarrollen actos de naturaleza sexual sin la voluntad de alguna de las partes. Sin embargo, el principal inconveniente imputado a esta concepción gira en torno al comentado problema de los menores e incapaces pues difícilmente se puede proteger su libertad sexual si no la pueden ejercer efectivamente ${ }^{617}$ sea porque carecen de los atributos cognitivos o volitivos para ello, sea porque, aunque los poseen, todavía no los tienen jurídicamente reconocidos ${ }^{618}$.

Ahora bien, cuando se trata de menores de edad los límites y alcances de la libertad sexual resultan controvertidos. En relación al artículo 189.1 literal a), BOLDOVA PASAMAR afirma que aun con consentimiento no viciado o no condicionado, nunca existen condiciones de libertad para el ejercicio de la sexualidad de los menores de edad. El consentimiento de los menores es absolutamente irrelevante “...para tomar parte en acciones o en espectáculos exhibicionistas o pornográficos, el sujeto activo que obra dolosamente actúa con desprecio de una voluntad favorable que sabe inválida en las circunstancias típicas, comprometiendo el ejercicio de la sexualidad del menor o incapaz al involucrarle en la práctica del exhibicionismo o la

\footnotetext{
${ }^{616}$ MORALES PRATS, F.; GARCÍA ALBERO, R., Comentarios..., op. cit., pág.. 309.

${ }^{617}$ SÁNCHEZ TOMÁS considera que el consentimiento no sólo es posible sino también válido debiendo intervenir el Derecho Penal únicamente cuando dicho consentimiento aparece viciado por un tercero que abusa de esa capacidad cognoscitiva y volitiva disminuida. A su juicio, tal planteamiento encuentra respaldo constitucional en los artículos 49 - integración de los disminuidos físicos, sensoriales y psíquicos -; 17.1 - derecho a la libertad-; 18.1 - intimidad personal - y 10.1 - como fundamento del orden político, la dignidad de la persona, los derechos inviolables que le son inherentes y el libre desarrollo de su personalidad - de la Carta Magna Véase, SÁNCHEZ TOMÁS, J. M., Los abusos..., op. cit., pág. 111.

${ }^{618}$ Véase entre otros CARMONA SALGADO, C, "Delitos contra la libertad ...", op. cit., págs. 224 y ss.; DIEZ RIPOLLÉS, J. L., El objeto..., op. cit., pág. 52; GONZÁLEZ RUS, J. J., "Los delitos...” cit, pág. 324; MUÑOZ CONDE, F., Derecho..., op. cit., págs. 206 y ss.
} 
pornografía" $" 619 / 620$. En este sentido, MUÑOZ CONDE, apunta que los menores de forma provisional, o los incapaces de forma definitiva, carecen de autonomía para determinar su comportamiento en el ámbito sexual ${ }^{621}$.

Bien podemos advertir con base en lo dicho hasta aquí, asumiendo buena parte de la doctrina expuesta, que el menor o incapaz "carece de libertad sexual desde la perspectiva jurídica como imposición legal, por lo que no cabe concluir que sea la libertad sexual el bien jurídico protegido en el delito de pornografía infantil pues carece de ella por imperativo legal”,622

\subsection{INDEMNIDAD O INTANGIBILIDAD SEXUAL}

La intangibilidad sexual se fundamenta en "la especial protección que la Ley dispensa a individuos que, estando incapacitados para ejercer la libertad sexual por encontrarse en determinadas circunstancias especiales se hallan más desamparados que el resto de la comunidad"623. Es decir, deben permanecer completamente al margen de experiencias sexuales ${ }^{624}$. El término “indemnidad" se define como aquel "estado o situación del que está libre de daño o perjuicio"625. La Ley Orgánica 11/1999 de 30 de abril reconoce la existencia junto a la libertad sexual, de un segundo bien jurídico necesitado de protección penal, en concreto, la indemnidad o integridad sexual de los menores e incapaces. Para perfilar su sentido se afirma que éstos carecen de la necesaria formación para que su voluntad pueda ser considerada fruto del ejercicio de su libertad

\footnotetext{
${ }^{619}$ BOLDOVA PASAMAR, M. A., “Artículo 189”, op. cit., pág. 524.

${ }^{620}$ En relación a los menores de edad, MORALES PRATS Y GARCÍA ALBERO plantean que "la orientación teleológica de los tipos penales analizados se dirige a castigar conductas que obstaculicen la libre opción sexual; con respecto a los menores que todavía carecen de capacidad de análisis para decidir responsablemente en el ámbito sexual, los tipos penales se orientan a la preservación de las condiciones básicas para que en el futuro puedan alcanzar un libre desarrollo de la personalidad en la esfera sexual, preservándolos de lastres y traumas impuestos por terceros". Véase, MORALES PRATS, F.; GARCÍA
} ALBERO, R., "Delitos contra la libertad...”, op. cit. pág. 926.

${ }^{621}$ MUÑOZ CONDE, F., Derecho Penal...., op. cit., pág. 200.

${ }^{622}$ MORILLAS FERNÁNDEZ, D. L., Análisis dogmático y criminológico ..., op. cit., pág. 160.

${ }^{623}$ Véase la Sentencia del Tribunal Supremo de 26 de octubre 1987 [RJ 1987\7602].

${ }^{624}$ DIEZ RIPOLLÉS, J. L., “El objeto...”, op. cit., pág. 232.

${ }^{625}$ Diccionario de la Lengua Española, vigésimo primera edición, Tomo 2, Madrid, 2000, voz indemnidad, pág. 1157. 
y no puede ser siempre determinante de la licitud de unas conductas que, sin embargo, podrían ser lícitas entre adultos ${ }^{626}$.

Actualmente, en los medios culturales de opinión y académicos existe una especie de consenso no escrito sobre la "intangibilidad" o "indemnidad" que frente a la sexualidad de terceros debe otorgarse a estas personas. Mas que la libertad del menor o incapaz, se pretende proteger su libertad futura o mejor dicho la normal evolución y desarrollo de su personalidad, para que cuando sea adulto decida en libertad su comportamiento sexual; y, en el caso del incapaz o deficiente mental, evitar que sea utilizado como objeto sexual de terceras personas que abusen de su situación para satisfacer sus deseos sexuales. De allí la importancia y vigencia de su reconocimiento en el orden jurídico. Con el criterio de la "libertad sexual", a lo mas que podría llegarse es a prohibir el ejercicio de violencia o intimidación con estas personas con el fin de realizar actos sexuales: por lo que la situación de menores e incapaces no puede reducirse a delitos que vulneren la libertad sexual. Esto es, en definitiva, lo que ha venido a reconocer la nueva rubrica del Titulo VIII, al incluir la referencia a la "indemnidad sexual" en pie de igualdad con la "libertad sexual".

MUÑOZ CONDE comparte la vigencia y autonomía del tipo de indemnidad cuando afirma que los delitos sexuales que recaen sobre menores o incapaces (abusos sexuales, delitos de exhibicionismo "obsceno" y difusión de pornografía entre menores o incapaces, y los relativos a la prostitución y corrupción de menores o incapaces) no se pueden explicar como delitos contra la libertad sexual. El problema especial que presentan estos delitos es precisamente que no se puede hablar de la "libertad sexual" como bien jurídico específicamente protegido en ellos, dado que los sujetos pasivos sobre los que recaen son personas que carecen de esa libertad, bien de forma provisional (menores), bien de forma definitiva (incapaces). ${ }^{627} / 628$

\footnotetext{
${ }^{626}$ COBO DEL ROSAL y QUINTANAR DIEZ, se refieren a la indemnidad sexual como "el proceso de formación en el caso de los menores, en la educación, si se quiere, sexual como parte del más amplio proceso formativo y educativo ya no sólo del niño, sino del adolescente y en general del joven no se vea menoscabado, roto, por ataques especialmente graves, en muchos casos, irreversiblemente traumáticos, que dentro del mencionado proceso psicobiológico vienen a suponer intolerables atentados contra la dignidad y la integridad física y psíquica del menor". Véase, COBO DEL ROSAL, M.; QUINTANAR DIEZ, M., De los delitos..., op. cit. pág. 691.
}

${ }^{627}$ MUÑOZ CONDE, F, Derecho Penal..., op. cit., pág. 203. 
Buena parte de la jurisprudencia conviene en que el objeto tutelable no es tanto su libertad sexual como su derecho a un normal y libre desarrollo de la personalidad, bien constitucionalmente tutelado, especialmente en su vertiente psíquica que comprende el descubrimiento espontáneo de la sexualidad, sin intromisiones de adultos, ni experiencias traumáticas con potenciales efectos dañinos sobre su bienestar psíquico y que pueden condicionar negativamente su vida futura ${ }^{629}$. Es decir, el derecho de esas personas a estar exentas de cualquier daño de orden sexual para que su desarrollo no se vea perturbado por la iniciación en prácticas sexuales inadecuadas o impropias de su edad $^{630}$. Sin embargo, BOLDOVA PASAMAR, plantea que el termino de indemnidad sexual resulta demasiado genérico y vago como bien jurídico, con ella sólo se alude a la ausencia de todo daño sexual en relación con menores de edad e incapaces, lo cual está abierto a distintas posibilidades interpretativas, en particular las de corte estrictamente moralista $^{631}$.

Uno de los principales cuestionamientos que han realizado en torno a este bien jurídico es que el legislador no definió con precisión el término Indemnidad sexual. Algunos autores plantean que la intangibilidad es una forma de libertad sexual. En esta línea, CARUSO FONTÁN, toma partida por la libertad sexual en su vertiente negativa como el bien jurídico protegido en el Título VIII. Para la autora, sería acertado denominar a este bien protegido "indemnidad sexual", entendida esta última, como el derecho de todos los individuos a no ser obligados a soportar sobre su propio cuerpo o realizar sobre el cuerpo de terceras personas conductas de contenido sexual. ${ }^{632}$ Sin

\footnotetext{
${ }^{628}$ DÍEZ RIPOLLÉS rechaza el concepto de indemnidad sexual como específico objeto de tutela de menores e incapaces, al sostener que los autores que propugnan esta teoría olvidan que el Derecho penal protege intereses sociales y no meros derechos subjetivos, por lo que propugna la libertad sexual como objeto de protección. A pesar de pronunciarse por la genérica "libertad sexual" como bien jurídico protegido por los delitos sexuales, el autor acepta posteriormente que dicha libertad sexual se protege exclusivamente en la medida en que se involucra a una persona en un comportamiento sexual no deseado. De esta forma llega a la conclusión de que la introducción del término "indemnidad sexual" resulta innecesaria y superflua. Véase, DIEZ RIPOLLÉS, J. L., “El objeto de protección,.,”, , pág. 70.

${ }^{629}$ Véase las Sentencia del Tribunal Supremo 19.6.1990, 20.5.1991; STS 20.5.1993; STS 9.12.1999 (Ref Iustel: §215615); STS 21.12.1995 (Ref. Iustel: §215473); STS 18.6.1983 ; STS 22.9.1993 ; STS 8.2.1995; STS 14.12.1991.

${ }^{630}$ ARROLLO ZAPATERO, L., BERDUGO GÓMEZ DE LA TORRE, I., y otros en Comentarios al Código Penal, Madrid, 2004, pág. 457.

${ }^{631}$ BOLDOVA PASAMAR, M. Á., Artículo 189..., op. cit., pág. 526.

${ }^{632}$ CARUSO FONTÁN, M., Nuevas perspectivas..., op. cit., págs. 157 y ss.
} 
embargo, la Sentencia del Tribunal Supremo 144/1995, de 8 de febrero de [RJ 1995/712], expone las principales diferencia entre la libertad sexual e indemnidad sexual “... la libertad sexual exige voluntad consciente y responsable en el sujeto pasivo del agravio, y en los menores o los privados de razón o sentido tal condición es inevitable o deficiente, sin embargo, no puede negárseles el derecho a estar protegidos en su intangibilidad e indemnidad sexual y a exigir seguridad para su futura libertad sexual, derecho que reclama una exquisita salvaguarda porque estos sujetos están más expuestos a la captación y a la influencia por no ser capaces de generar inhibiciones para prevenir y defenderse frente a los ataques abiertos o insidiosos a su facultad de autodeterminación sexual”.

Un elemento común en la mayoría de los autores que se refieren a la indemnidad sexuales que lo asocian a los menores e incapaces, sin embargo CARUSO FONTÁN plantea que la indemnidad sexual no es un bien jurídico exclusivo para los menores e incapaces, puesto que “...el estar exento de daño no es un derecho que corresponde exclusivamente a menores e incapaces, sino a todos los individuos con independencia de las características volitivas personales. La protección del normal desenvolvimiento de la sexualidad en los menores, al que alude parte de la doctrina, no es más que una consecuencia de la prohibición de interferir en la esfera sexual de terceros sin un consentimiento válidamente prestado". ${ }^{633}$ En su opinión el concepto de indemnidad sexual se integra dentro del término "libertad sexual" como su aspecto negativo, frente al positivo, que queda configurado como la posibilidad de autodeterminarse sexualmente.

Un importante y numeroso sector de la doctrina y la jurisprudencia señala la indemnidad sexual como bien jurídico tutelado en los delitos sexuales relacionados con menores e incapaces, considerando que, efectivamente reúnen las condiciones que les inhabilitan o incapacitan para ejercer la libertad sexual ${ }^{634}$. A pesar del álgido debate

${ }^{633}$ CARUSO FONTÁN, M., Nuevas perspectivas..., op. cit., pág.175.

${ }^{634}$ la indemnidad sexual como bien jurídico protegido en los delitos de pornografía infantil es respaldada entre muchos otros autores por: GONZÁLEZ RUS, J. J., Los delitos..., cit. pág. 324 y 356; CARMONA SALGADO, Delitos contra la libertad sexual (II)..., op. cit., pág. 290; MUÑOZ CONDE, F., Derecho.., op. cit., págs. 207 y ss.; RODRÍGUEZ RAMOS, L., "Los delitos contra la libertad e indemnidad sexuales”, en RODRÍGUEZ RAMOS, L., COBOS GÓMEZ de LINARES, M. A., SÁNCHEZ TOMÁS, J. M., Derecho Penal. Parte Especial I, Madrid, 1998, pág. 160; VARGAS CABRERA, B., "Prostitución 
alrededor de todas las modalidades típicas del artículo 189, existe prácticamente un consenso en relación a que en la elaboración de pornografía infantil el bien jurídico tutelado es la indemnidad sexual del menor ${ }^{635}$.

Otra de las figuras legitimada desde la doctrina con el bien jurídico de la indemnidad sexual es la omisión prevista el Artículo 189.5. Al respecto MORILLAS FERNÁNDEZ plantea que en la "omisión del deber de impedir el estado de corrupción o prostitución del menor o incapaz el bien jurídico protegido es la indemnidad sexual (relativa) en tanto se trata de un tipo penal en donde se sanciona la conducta omisiva llevada a cabo por el titular de la relación legal el menor a quien, entre los distintos deberes legales asignados, corresponde velar por la correcta formación del infante en el ámbito sexual, justificándose a través de la incriminación penal la inobservancia de semejante directriz" ${ }^{636}$. En la misma línea, BOLDOVA PASAMAR plantea que en la conducta omisiva, “el bien jurídico protegido es también la indemnidad sexual de la personalidad, pues se trata de no impedir la continuación en el estado de prostitución o de corrupción de un menor de edad o incapaz" ${ }^{\text {,37. }}$.

En la Jurisprudencia puede citarse la Sentencia de la Audiencia Provincial de Valladolid 866/2002, de 30 de noviembre [ARP 2002 849] en la que “el bien jurídico protegido en el delito del artículo 189 núm. 1 letra a) viene referido por las necesidad de preservar la indemnidad sexual de los sujetos pasivos, que por su condición de menores o incapaces, deben ser objeto de una especial protección en el ordenamiento jurídico, en cuanto y esencialmente los menores que nos ocupan, dada su edad, no tiene capacidad para orientar el ejercicio de su propia sexualidad... la sociedad no puede consentir que se someta a unos niños de tan corta edad como son los fotografiados que nos ocupan a actos respecto de los cuales no tienen capacidad para consentir"638

\footnotetext{
y corrupción de menores", en Estudios sobre violencia familiar y agresiones sexuales, tomo III, Madrid, 2000 , pág. 321.

${ }^{635}$ MARTÍN LORENZO, M., Libertad e Indemnidad..., op. cit., pág. 120.

${ }^{636}$ MORILLAS FERNÁNDEZ, D. L., Analisis dogmático y criminológico..., op. cit., pág. 185.

${ }^{637}$ BOLDOVA PASAMAR, M. Á., Artículo 189..., op. cit., pág. 527.

${ }^{638}$ Una nutrida jurisprudencia del Tribunal Supremo señala expresamente la indemnidad sexual como bien jurídico protegido. Sentencias 1494/2002, de 20 de septiembre [RJ 2002/8162]; 496/2002, de 20 de
} 
En opinión de MORILLAS FERNÁNDEZ, la terminología indemnidad sexual no pretende proteger exclusivamente lo sexualmente correcto - en atención a la moral social - sino velar por unos derechos básicos de los menores o incapaces, como son su correcta formación personal o socialización en materia sexual libre de injerencias externas, otorgando una concreta regulación a lo que se ha denominado "víctimas especialmente vulnerables" de esta tipología delictiva. La comparación entre ambos bienes jurídicos no parece, en cualquier caso, acertada ${ }^{639}$.

Compartimos las apreciaciones de TORRES FERNÁNDEZ cuando afirma que "la protección penal de los menores frente a acciones de contenido sexual no persigue convertirlos en una suerte de sujetos intangibles o inaccesibles a cualquier manifestación de la sexualidad. La indemnidad sexual de los menores no se justifica como un fin en sí mismo, sino en cuanto medio para asegurar las condiciones básicas para el desarrollo de la personalidad, que permita en el futuro la libertad de elección en materia sexual ${ }^{640 "}$ "En términos muy parecidos se ha manifestado BOLDOVA PASAMAR al referir que no toda actividad o contacto sexual con menores o incapaces deriva en un perjuicio de índole sexual; es más, "la ley no prohíbe en el tipo de la corrupción cualquier contacto sexual con menores o incapaces, sino sólo los que tengan la capacidad de perjudicarles, y no física o moralmente, sino en el ámbito de su personalidad"641.

Antes de finalizar este aparte consideramos necesario hacer mención a la crítica realizada por parte de la doctrina a la reforma de 1999, por la influencia que tuvo la opinión pública movida por la alarma social en relación a la "supuesta" desprotección en la que se encontraban los menores e incapaces; dicho clamor popular estaba signado por sesgadas connotaciones morales. Es unánime la posición de la doctrina sobre que el llamado clamor popular está determinado por connotados sesgos morales. En criterio

marzo [RJ 200214018]; 432/2002, de 8 de marzo [200213975]; 2343/2001, de 11 de diciembre |RJ 2002/1525]; 1030/2000, de 13 de junio, [RJ 2000\6305]; 144/1995, de 8 de febrero [RJ I '*95\712]; 1468/1993, de 18 de junio [RJ 199315197]. Tácitamente en las Sentencias del Tribunal Supremo 1316/2002, de 10 de julio [200217450] y 492/2000, de 21 de marzo [RJ2000।2385].

${ }^{639}$ MORILLAS FERNÁNDEZ, D. L., Análisis dogmático y criminológico ..., op. cit., pág. 168.

${ }^{640}$ TORRES FERNÁNDEZ, E., "El nuevo delito de corrupción de menores", en Revista Electrónica de Ciencia Penal y Criminología (RECPC 01-12), 1999.

${ }^{641}$ BOLDOVA PASAMAR, M., Artículo 189, op. cit., pág. 526. 
nuestro el llamado clamor popular sobre el que funda la opinión pública las exigencias de seguridad penalizando más e incrementando las penas, es la cara más mediática de la moral sexual colectiva que pretende imponer su razón en el ámbito de la esfera íntima de las personas y en particular sobre la libertad sexual.

\subsection{INTIMIDAD}

La intimidad ${ }^{642}$ es entendida como "el reducto más privado de la vida del individuo, esto es, como aquellos extremos más personales de su propia vida y de su entorno familiar, cuyo conocimiento está restringido a los integrantes de la unidad familiar" ${ }^{243}$. En la doctrina la referencia a la intimidad siempre aparece conjuntamente con otros bienes jurídicos protegidos. En esta línea ORTS BERENGUER y ROIG TORRES señalan que cuando se trata de delitos donde el sujeto pasivo sean los menores e incapaces el legislador tiene la intención de proteger penalmente varios bienes jurídicos como son los adecuados procesos de formación y socialización de unos y otros, y su intimidad ${ }^{644}$. Para CABRERA MARTÍN, la pornografía infantil aunque no lesione bienes en el estricto terreno sexual, afecta a la dignidad y al derecho a la intimidad y a la propia imagen de ese menor ${ }^{645} /{ }^{646} /{ }^{647}$.

En la misma línea se pronuncia MARTÍN LORENZO. La intimidad ha sido reconocida como una de las vías para la legitimación de las figuras de la pornografía

\footnotetext{
${ }^{642}$ En al Constitución Española, la intimidad está contemplada en su artículo 18;en el se hace referencia especifica a la intimidad personal y familiar y la propia imagen (18.1), la inviolabilidad del domicilio (18.2), el secreto de las comunicaciones (18.3) y la limitación del uso de la informática (18.4).

${ }^{643}$ ESPÍN, E., "Los derechos de la esfera personal", en LÓPEZ GUERRA, Derecho Constitucional, vol. I, Valencia, 1994, págs. 208 y ss.

${ }^{644}$ ORTS BERENGUER, E.; ROIG TORRES, M., Delitos..., op. cit., pág. 129.

${ }^{645}$ CABRERA MARTÍN, M., La pornografía ..., op. cit.

${ }^{646}$ MUÑOZ CONDE circunscribe el concepto de intimidad como bien jurídico protegido bajo una doble perspectiva: a) negativo, como una especie de derecho a la exclusión de los demás de determinados aspectos de la vida privada, que pueden calificarse de secretos; b) un derecho de control sobre la información y los datos de la propia persona, incluso los ya conocidos, para que sólo puedan utilizarse conforme a la voluntad de su titular. Véase, MUÑOZ CONDE, F., Derecho Penal..., op. cit., pág. 210.

${ }^{647}$ Según ORTS BERENGUER y SUÁREZ-MIRA RODRÍGUEZ, "el bien jurídico lesionado en el art. 189.1 no es distinto de los demás delitos del título VIII, cuando el sujeto pasivo es un menor de edad o un incapaz, con el añadido de la intimidad, sobre la que dichos sujetos no tienen plena disponibilidad, según se señala en el art. 4 LO 1/1996"véase, ORTS BERENGUER; SUÁREZ-MIRA RODRÍGUEZ, op. cit., pág. 245.
} 
infantil, pues se pone a disposición de múltiples personas aspectos relativos a la imagen o intimidad sexual de los menores presentes en el material, sobre todo en las conductas de distribución, o incluso se ha apelado más genéricamente al ataque a la dignidad de los menores representados en los materiales ${ }^{648}$.

Consideramos que cuando circulan materiales con contenidos pornográficos en la red, siempre que la imagen o la voz puedan ser identificable (se excluye la pornografía técnica) sería un atentado a la intimidad personal a la esfera privada de la persona -los menores e incapaces en este caso- ${ }^{649}$.

\subsection{Bien Jurídico Protegido en el ART. 189.1}

El bien jurídico protegido en este precepto ha sido muy debatido, como señalamos anteriormente un importante sector de la doctrina insiste en que la libertad sexual del menor es extensibles a todo los preceptos de pornografía infantil, sin embargo, otros consideran que el bien jurídico va desde el derecho a la propia imagen, la intimidad, la indemnidad sexual relativa, o la moral sexual relativa como un bien jurídico supraindividual. Donde coinciden la mayoría es en establecer bienes jurídicos diferentes entre el apartado a) y b) del artículo 189.1 En lo que sigue intentamos recoger el fructífero debate de la doctrina.

MORALES PRAT Y GARCÍA ALBERO, se pronuncian sobre la dignidad del menor o su derecho a la propia imagen como bien jurídico protegido en este precepto, es decir, el derecho a no ser molestado en la tranquilidad de la esfera privada, en la que el sujeto organiza de modo originario su libre desarrollo de la personalidad. En este sentido, el objeto jurídico de tutela en este precepto no debe ser la libertad o la indemnidad del menor en la esfera sexual, es así como, "la referencia a la indemnidad

\footnotetext{
${ }^{648}$ MARTÍN LORENZO, M., Libertad e Indemnidad..., op. cit., pág. 120.

${ }^{649}$ La Ley Orgánica 1/1996, de 15 de enero, sobre Protección Jurídica del Menor, al establecer el artículo 4.3 que "se considera intromisión ilegítima en el derecho al honor, a la intimidad personal y familiar y a la propia imagen del menor, cualquier utilización de su imagen o su nombre en los medios de comunicación que pueda implicar menoscabo de su honra o reputación, o que sea contraria a sus intereses incluso si consta el consentimiento del menor o de sus representantes legales".
} 
sexual, no ha venido a ofrecer una referencia omnicomprensiva de los bienes jurídicos tutelados en la rúbrica del Titulo VIII del C P"650.

ORTS BERENGUER, también comparte el criterio sobre que los comportamientos recogidos en este tipo puedan considerarse en alguna medida nocivos para la libertad sexual o los procesos de formación y socialización de menores e incapaces, toda vez que tienen lugar en un momento cronológico posterior a la consumación de la lesión a tales valores. En efecto señala, “...para que fuera posible vincular el bien jurídico en estos casos a contenidos de carácter sexual habría de entenderse que estamos ante un delito de peligro abstracto, cuyo contenido de injusto se cifraría en un extremo, tan remoto e indirecto respecto del objeto de tutela indicado, cual es el riesgo que ofertar (produciendo, vendiendo, distribuyendo, etc.) semejante clase de material comporta respecto del mantenimiento o incremento de la demanda del mismo, que a la postre, puede entenderse que acabará repercutiendo en la continuación de la participación de menores o incapaces en su elaboración, con la consiguiente lesión (en este caso ya, efectiva) que se derivará de este hecho para los aludidos bienes de aquéllos",651.

Para BOLDOVA PASAMAR, en el 189.1 a) el punto de partida de interpretación es la libertad sexual ${ }^{652}$. Sin embargo, como en la pornografía la utilización sexual del menor supone la captación de su imagen en soportes mecánicos o técnicos (informáticos, digital) al atentado contra la libertad sexual se acompaña un menoscabo del derecho a la propia imagen. En el 189.1b) tanto en el tráfico como en la posesión con la intención de difundir el contenido de pornografía infantil, a través del medio de reproducción correspondiente, se perpetúa el atentado a la libertad sexual del menor o incapaz que tuvo lugar con su participación en la escena pornográfica o en la acción exhibicionista. Puesto que la pornografía implica el empleo de la imagen, el

\footnotetext{
${ }^{650}$ Véase, MORALES PRATS, F.; GARCÍA ALBERO, R., Artículo 189..., op. cit., pág. 352.

${ }^{651}$ ORTS BERENGUER, E.; ALONSO RIMO, A., "La reforma de los delitos contra la libertad sexual" en ZÚÑIGA RODRÍGUEZ, L.; MÉNDEZ RODRÍGUEZ, C.; DIEGO DÍAZ- SANTOS, R., Derecho penal sociedad y nuevas tecnologías, Ed. Colex, Madrid, 2001, pág. 51.

${ }^{652} \mathrm{El}$ bien jurídico es la libertad sexual "tanto si falta el consentimiento del sujeto pasivo, como si dicho consentimiento se encuentra viciado o se vincula a la obtención de una retribución económica, se distorsiona o está ausente un acto libre de la voluntad." Véase, BOLDOVA PASAMAR, M. Á., Artículo $189 . . .$, op. cit., pág. 524.
} 
ataque contra el derecho a la propia imagen del menor de edad o incapaz aparece también como un aspecto inherente a las mismas ${ }^{653}$.

MORILLAS FERNÁNDEZ específica que en el aparte 189.1 a) los dos principales bienes jurídicos que pudieran entrar en cohesión son la indemnidad sexual relativa y la intimidad. Y se puede llegar a dos conclusiones: “a) Cuando el sujeto pasivo sea consciente de que es objeto de la realización de la conducta típica el bien jurídico protegido es la indemnidad sexual relativa, y b) Cuando de manera oculta sin que el menor advierta su participación en la filmación, el bien jurídico protegido debe ser la intimidad del sujeto pasivo por cuanto al no ser consciente de semejante situación no existirá afección a la indemnidad sexual relativa"654. En relación al 189.1.b) MORILLAS FERNÁNDEZ plantea que “... es la cuestión que genera una mayor problemática a la hora de delimitar el objeto tutelable en esta modalidad delictual. En tanto se procede a comercializar con una iconografía obtenida de manera ilegítima, y se utiliza su imagen de forma contraria a sus intereses, independientemente de que medie el consentimiento del infante o de sus representantes legales, debiendo rechazar la dignidad en virtud de ese ámbito de actuación demasiado genérico, es la intimidad del menor el objeto tutelable en este apartado" ${ }^{\circ 55}$.

En definitiva, el criterio dominante en relación al bien jurídico que se protege en el 189.1 b) es la intimidad del menor, "dado que se trata de hechos que se producen con posterioridad a la consumación del ataque a la libertad sexual de menor y que en cualquier caso afectan a aspectos relativos a su intimidad cuya revelación es contraria a sus intereses" ${ }^{\prime 656 / 657}$. En este sentido se afirma que esta figura era innecesaria y se cae en

\footnotetext{
${ }^{653}$ Véase, BOLDOVA PASAMAR, M. Á., Artículo 189..., op. cit., pág. 525.

${ }^{654}$ MORILLAS FERNÁNDEZ, D. L., Análisis dogmático y criminológico... op. cit. págs. 177 y ss. ${ }^{655}$ MORILLAS FERNÁNDEZ, D. L., Análisis dogmático y criminológico..., op. cit. pág. 178.

${ }^{656}$ TAMARIT SUMALLA, J. M., La protección penal..., op. cit. pág. 157.

${ }^{657}$ Para ORTS BERENGER lo que se afecta en el 189.1 b) es la intimidad del menor y no la libertad sexual.
} 
solapamiento con el art. 197, párrafos primero y tercero que tipifica los delitos contra la intimidad $^{658}$.

Un dato importante de apuntar es la redacción literal del 189.1, que refiere el sujeto pasivo en plural "menores". Pareciera que remite a un bien jurídico supraindividual -como la moral sexual colectiva -, y no a un bien jurídico individual la libertad sexual. ${ }^{659}$ No puede entenderse un único delito cuando son múltiples las víctimas, esto "puede dar la impresión de que no protege personalmente al menor e incapaz, sino solo colectivamente. Pero además si se estima irrelevante a los efectos de apreciar una sola infracción que sean uno o varios los sujetos pasivos del delito, este criterio puede hacer pensar que no se investiga hasta el fondo la verdadera dimensión de los hechos. Aunque se pueda tropezar con dificultades procesales, lo cierto es que hay que demostrar e individualizar todos y cada uno de los atentados contra la libertad sexual de los sujetos involucrados, y no únicamente una parte para concluir con la aplicación de una sola infracción",660.

\subsection{Bien Jurídico Protegido en la Pornografía Virtual}

La mayor discusión doctrinal se ha centrado en la dificultad para determinar el concreto bien afectado en la pornografía virtual, pues el objeto de la acción son los materiales producidos y no los menores o incapaces. En este sentido, el pronunciamiento mayoritario apunta hacia un delito de peligro abstracto para la indemnidad y/o libertad sexual de los menores en su conjunto y no el menor en concreto objeto de la manipulación de su imagen o su voz ${ }^{661}$. El referido bien jurídico aún se hace más difuso considerando que se trata de una situación ficticia en la que no se

\footnotetext{
${ }^{658}$ El artículo 197 del Código Penal Español establece en sus apartados 1 y 3 lo siguiente: “1. El que, para descubrir los secretos o vulnerar la intimidad de otro, sin su consentimiento, se apodere de sus papeles, cartas, mensajes de correo electrónico o cualquiera otro documentos o efectos personales o intercepte sus telecomunicaciones o utilice artificios técnicos de escucha, trasmisión, grabación o reproducción del sonido o de la imagen, o de cualquier otra señal de comunicación, será castigado con las penas de prisión de uno a cuatro años y multa de doce a veinticuatro meses... 3. Se impondrá pena de prisión de uno a tres años y multa de doce a veinticuatro meses, el que, con conocimiento de su origen ilícito y sin haber tomado parte en su descubrimiento, realizare la conducta en el párrafo anterior".
}

\footnotetext{
${ }^{659}$ Véase, BOLDOVA PASAMAR, M. Á., Artículo 189..., op. cit., pág. 539.

${ }^{660}$ BOLDOVA PASAMAR, M. Á., Artículo 189..., op. cit., pág. 539.

${ }^{661}$ Véase, FERNÁNDEZ TERUELO, J., Cibercrimen. Los delitos ..., op. cit., pág. 63.
} 
involucró a menores reales en comportamiento sexual alguno para elaborar los materiales, FERNÁNDEZ TERUELO estima que "salvando las distancias, sería como castigar el consumo o tráfico de sustancias lícitas e inocuas para la salud por el hecho de que las mismas puedan parecer o simular droga"662. Sin embargo, este autor considera probable que exista una lesión de la intimidad personal que en la medida que se divulgan aspectos relacionados a la imagen o intimidad sexual de los menores ${ }^{663}$.

Por su parte, BOLDOVA PASAMAR plantea que este delito puede "llegar a constituir una intromisión ilegítima en el derecho al honor, la intimidad personal y la propia imagen, que es susceptible de protección civil, en la medida en que por tal se entiende, entre otras, la utilización del nombre, de la voz o de la imagen de una persona ( $\sin$ su consentimiento) para fines publicitarios, comerciales o de naturaleza análoga (art. 76 de la L.0.1/1982, de 5 de mayo, de protección civil del derecho al honor, a la intimidad personal y familiar y a la propia imagen). Por lo tanto, desde el punto de vista de la protección penal en el marco de los delitos del Título VIII sólo puede considerarse estamos ante un peligro abstracto para los bienes jurídicos de los delitos sexuales"664. Para GÓMEZ TOMILLO, en el delito prima el derecho a la propia imagen del menor frente a su indemnidad sexual ${ }^{665}$. Otros autores coinciden en que la determinación del bien jurídico se agrupa en la hipótesis de la lesión a la dignidad y a la intimidad de los menores e incapaces que aparecen en los materiales pornográficos, ${ }^{666}$ entre ellos, DÍEZ RIPOLLÉS $^{667}$ y GIMBERNAT ORDEIG, este último, adicionalmente, afirma que el

\footnotetext{
${ }^{662}$ Ibídem, pág. 64.

${ }^{663}$ Idem.

${ }^{664}$ BOLDOVA PASAMAR, M., A., Artículo 189..., op. cit., págs. 531 y ss.

${ }^{665}$ Véase, GÓMEZ TOMILLO, M., Derecho penal Sexual..., op. cit., pág. 2.

${ }^{666}$ Véase, MORILLAS FERNÁNDEZ, D. L., Análisis dogmático y crimionológico..., op. cit., pág. 185.

${ }^{667}$ DÍEZ RIPOLLÉS, considera que en este precepto puede vulnerarse la intimidad de las personas, estos casos pueden subsumir en el art. 197.3, párrafo 1 y 2 , referido a revelar o ceder a terceros los datos o hechos descubiertos o las imágenes captadas sin su consentimiento, "puede entran en relación con el art. 197.1, apreciando incluso las figuras agravadas de los números 5 (por afectar a la vida sexual) y 6 (si existen fines lucrativos) del art. 197. Prácticamente lo mismo puede decirse respecto a la dignidad dado que, como expresa manifestación de la integridad moral, aparece protegida a través del tipo contenido en el art. 173.1 del Código penal." Véase, DÍEZ RIPOLLES, J. L., "Trata de seres humanos y explotación sexual de menores. Exigencias de la Unión y legislación española", en Revista Penal, n 2, 1998, pág. 19. BOLDOVA PASAMAR coincide con esta apreciación cuando plantea que "esta nueva figura delictiva podría entrar en concurso medial con el delito del art. 197, si concurren sus requisitos objetivos y subjetivos”. Véase, BOLDOVA PASAMAR, M., Artículo 189..., op. cit., pág. 568.
} 
consumo de material pornográfico contribuye al mantenimiento y expansión de una nueva industria ${ }^{668}$.

Sin embargo, es criterio de MORILLAS FERNÁNDEZ el que aun cuando la dignidad de la persona se verá afectada de manera subsidiaria en la mayor parte de los ilícitos pornográficos, el 189.7 del Código Penal referente a la pseudopomografía, es la excepción, “... debido al extenso objeto conformante de este término, por ello no es de extrañar que suela optarse por contemplar otros bienes jurídicos que limitan o describen el ámbito de protección penal de manera más concisa"669. Por su parte, SUÁREZMIRA RODRÍGUEZ, considera atinado el precepto siempre que la imagen o sonido una vez alterada siga siendo reconocible, es decir, que si de lo que se trata es de proteger la intimidad, y la propia imagen del menor, el hecho de que se pueda identificar aún después de ser modificada se estaría causando un daño al menor (p.ej. “cortar" la cabeza de la imagen del menor o incapaz y "pegarla" sobre la imagen de otro cuerpo); pero si el montaje distorsiona de tal forma la voz o de la imagen que no permiten su reconocimiento, no sería necesaria la punición de tales conductas, pues resulta dudoso que bien jurídico pudiera resultar entonces vulnerado. ${ }^{670}$ Con una postura contraria se pronuncia GÓMEZ TOMILLO cuando plantea que "es irrelevante que el material obtenido sea o no de forma perceptible, se el resultado artificial de una manipulación informática sobre imágenes iniciales",671.

En nuestro criterio, el delito de tráfico de pornografía infantil virtual no puede asociarse ni con atentados a la libertad sexual ni a la indemnidad sexual, por el hecho de que no se ha involucrado en ningún caso a menores e incapaces en contexto de naturaleza sexual, se ha empleado su voz o imagen para implantarlos en un contexto sexual al que son totalmente ajenos. Compartimos la apreciación de BOLDOVA PASAMAR cuando advierte que la utilización de modo ficticio de los menores, "no lesiona el bien jurídico personal de la libertad sexual, ni siquiera el hipotético de la

\footnotetext{
${ }^{668}$ GIMBERNAT ORDEIG, Enrique, “Código Penal” Ed. Tecnos, 9ª edición, año, pág. 18.

${ }^{669}$ Véase, MORILLAS FERNÁNDEZ, D. L., Análisis dogmático y criminológico..., op. cit. pág. 162.

${ }^{670}$ Véase, SUÁREZ-MIRA RODRÍGUEZ, C., "Delitos relativos a la prostitución, corrupción de menores y pornografía infantil: una nueva revisión" en FARALDO CABANA, P., (Dir.), Política criminal y reformas penales, Ed. Tirant lo Blanch, Valencia, 2007, pág. 280.
}

${ }^{671}$ GÓMEZ TOMILLO, M., Derecho penal Sexual..., op. cit., pág. 2. 
indemnidad sexual. Como mucho se podría hablar de un peligro abstracto para estos bienes jurídicos individuales, aunque en gran medida la inclusión de la pseudopornografía infantil en el concepto de pornografía infantil implicaría más bien además de una analogía in malam partem- el retorno de la protección de la moral sexual colectiva" ${ }^{\prime 672}$.

Así, la expansión punitiva experimentada en las últimas reformas al Código Penal español, en las conductas relacionadas con la pornografía infantil pareciera orientada a castigar las prácticas que se apartan de las sexualmente mayoritarias. Dicho afán penal del legislador es una respuesta pragmática más que jurídica, que busca ante todo solucionar situaciones y problemas novedosos frente a los que la sociedad se ve desbordada. Se utiliza el Derecho penal, como se ha venido sosteniendo a lo largo del trabajo, como prima ratio y criminaliza todo lo que no se corresponda con las concepciones sexuales mayoritarias, aunque no lesionen ni pongan en peligro concreto un bien jurídico personal de contenido sexual.

\subsection{Bien JURídico Protegido en el Art. 189.2}

El art. 189.2 que alude a la posesión simple de pornografía infantil constituye el objeto central de análisis político-criminal de ésta tesis doctoral. Su revisión exhaustiva a la luz de la doctrina española y el alcance político-criminal de su vigencia se exponen ampliamente en el capítulo IV. Sin embargo, ello no impide que en razón de la coherencia y el orden normativo histórico expuesto en éste apartado, adelantemos algunos comentarios respecto del debate sobre el bien jurídico.

Para MORILLAS FERNÁNDEZ, el artículo 189.2 del Código Penal es uno de los supuestos más extraños y criticables a la hora de apreciar un bien jurídico protegido. Éste autor considera que el único objeto de aplicación "coherente" en este tipo penal es la moral sexual colectiva ${ }^{673}$, es decir, castigar comportamientos contrarios al común

\footnotetext{
${ }^{672}$ BOLDOVA PASAMAR, M. Á., Artículo 189..., op. cit., págs. 531 y ss. Este autor es categórico cuando señala que en el 189.7 “... no se produce la lesión o el peligro concreto de un bien jurídico de contenido sexual, a lo sumo cabe reconocer un peligro abstracto de no muy clara fundamentación". Véase, BOLDOVA PASAMAR, M. Á., Artículo 189..., op. cit., pág. 528.

${ }^{673}$ La protección de la moral sexual colectiva supone un retroceso temporal en la evolución del Derecho Penal. Véase, MORILLAS FERNÁNDEZ, D. L., Análisis dogmático y criminológico ..., op. cit. pág. 184.
} 
sexual de la población, “...lo cual resulta, en cierta medida, positivo si semejante acción lleva implícita la lesión de bienes jurídicos relevantes -indemnidad sexual, intimidad, etc.-; lo que no parece de recibo es tipificar comportamientos que lesionen aspectos intangibles o inmateriales fundados en cuestiones subjetivas o morales cuya única pretensión sea discriminar una manifestación sexual no causadora en sí misma de daño material" ${ }^{\prime 674}$. En este sentido, “...la sanción de la mera tenencia de la referida iconografía no parece que sea una solución muy útil para combatir esta tipología delictual" ${ }^{675}$.

Según ESQUINAS VALVERDE, la tenencia de material pornográfico para la difusión (189.1, letra b.), como para el consumo propio (189.2) puede considerarse atentatorios de los derechos a la intimidad y a la propia imagen del menor. "Así, podría afirmarse, una vez consumado sobre la persona del niño o joven el hecho del abuso sexual, acto destinado en la hipótesis concreta a la captación de imágenes y sonidos de carácter obsceno, el resto de los comportamientos consistentes en la grabación de dichos registros, la utilización a esos fines de medios tecnológicos sofisticados, la producción técnica del material y su difusión desautorizada a terceros, vienen a afectar exclusivamente a la dignidad, intimidad, etc., del menor, y no ya a su indemnidad sexual propiamente dicha. En consecuencia, algo semejante podría apreciarse en relación con la posesión de aquellas imágenes pornográficas, conducta que tampoco sería ya reconducible al apartado de los delitos contra la indemnidad sexual"676. Para GIMBERNAT ORDEIG, los bienes jurídicos en el artículo 189.2 son la dignidad y la intimidad. $^{677}$

Parte importante de la doctrina considera que se trata de un delito de peligro abstracto $^{678}$, es decir, el adelantamiento de la intervención penal a fases previas y

\footnotetext{
${ }^{674}$ Ibídem, pág. 185.

${ }^{675}$ Ibídem, pág. 181.

${ }^{676}$ ESQUINAS VALVERDE, P., El tipo de mera posesión..., op. cit. págs. 220 y ss.

${ }^{677}$ GIMBERNAT ORDEIG, E., Presentación del libro: La teoría..., op. cit., págs. 111 y ss.

${ }^{678}$ Se considera a los delitos de peligro concreto a los que la realización del tipo exige la creación de una situación de peligro efectivo, concreto y próximo para el bien jurídico. Delito de peligro concreto serían los relativos a la energía nuclear, por ejemplo. Estos delitos son siempre de resultado, pues se requiere la comprobación por parte del juez de la proximidad del peligro al bien jurídico y de la capacidad lesiva del riesgo. Por el contrario los delitos de peligro abstracto son de mera actividad, se consuman con la
} 
alejadas de la lesión del bien jurídico protegido en el tipo. La finalidad de introducir estos delitos a los códigos penales es la prevención en procura de evitar la realización de daños catastróficos e irreparables. En este sentido, "el legislador no espera para intervenir a que se produzca el daño o la lesión, sino que la adelanta al momento de la aparición concreta del peligro (delito de peligro concreto) o, incluso, a la simple realización de la conducta considerada normativamente peligrosa (delitos de peligro abstracto)" ${ }^{\prime 679}$.

Los delitos de peligro abstracto en cuanto que castigan una "peligrosidad presunta" que no admite prueba en contrario de la ausencia de ese peligro, plantean serios problemas de constitucionalidad. Estos delitos no reúnen los requisitos mínimos de daño material que debe reunir una conducta para dar lugar a la imposición de la pena $^{680}$. Compartimos la posición de JIMÉNEZ VILLAREJO cuando afirma que la tipificación del delito de posesión de pornografía infantil se acerca peligrosamente a los tipos de autor propios de un Derecho penal no democrático ya que una cosa es el reproche de la moral sexual y otro el jurídico ${ }^{681}$.

Este conflicto entre la autonomía del Derecho para sancionar conductas que afectan objetivamente bienes jurídicos y la invasión de una cierta idea del bien y del mal para regular comportamientos, viene tensionando la vigencia de ciertos delitos que hoy resultan representativos de una orientación político criminal.

realización de la conducta supuestamente peligrosa, no es necesario que el juez entre a valorar la proximidad del peligro para el bien jurídico ni la capacidad lesiva, pues constituyen un grado previo respecto de los delitos de peligro concreto. El legislador castiga aquí la peligrosidad de la conducta en sí misma. Véase, BERDUGO GÓMEZ DE LA TORRE, I.; ARROYO ZAPATERO, L.; y otros, Curso de Derecho Penal. ..., op. cit. pág.209.

${ }^{679}$ BERDUGO GÓMEZ DE LA TORRE, I., ARROYO ZAPATERO, L., y otros, Curso de Derecho Pena..., op. cit., pág. 210.

${ }^{680}$ Con la intención de reducir la aplicación de los delitos de peligro abstracto la doctrina propone "el reconocimiento de de una categoría intermedia denominada delitos de peligro hipotético o de peligro abstracto -concreto, en estos casos no es necesario demostrar la existencia de un peligro concreto para el bien jurídico, pero tampoco es suficiente conformarse sólo con establecer la peligrosidad en abstracto de la acción, sino que deberá además comprobarse la idoneidad objetiva de la acción para producir un perjuicio al bien jurídico, como sucede, por ejemplo, en el supuesto de la publicidad engañosa (art. 282 CP)." Véase, BERDUGO GÓMEZ DE LA TORRE, I.; ARROYO ZAPATERO, L., y otros, Curso de Derecho Penal.., op. cit., pág. 210.

${ }^{681}$ JIMÉNEZ VILLAREJO, J., “Artículo 189” en CONDE-PUMPIDO TOURÓN (Dir.), Comentarios al Código Penal, Ed. Bosch Barcelona, 2007, pág. 1488. 
En resumen, la revisión de la evolución del delito de pornografía infantil que hemos intentado a lo largo del capítulo da cuenta de dos momentos que marcan el hito normativo de distintas tendencias. Ambos momentos tienen como línea fronteriza la inclusión del precepto corrupción de menores en la reforma de 1999 de 30 de abril, quedó plasmado incluso en el nombre del Capítulo V "De los delitos relativos a la prostitución y la corrupción de menores".

A partir de entonces comienza una involución que rompe con una tendencia que se inició en los inicios del arribo de las instituciones democráticas en España. En efecto las reformas penales promovidas entre los años 1978 y 1995 están orientadas hacia la tutela de la libertad sexual y la disposición a dejar atrás juicios y prejuicios morales en la regulación de los delitos sexuales. Empujados por ese espíritu se suprimieron los delitos de adulterio y amancebamiento, se modificaron los delitos de rapto y estupro, se eliminó el delito de escándalo público y en su lugar se erigieron los de exhibicionismo y provocación sexual. En la década de los años noventa los que eran delitos contra la honestidad pasan a llamarse "de los delitos contra la libertad sexual", delimitándose claramente el bien jurídico tutelado en desmedro del juicio moral que subyacía en el adverbio honestidad. La reforma penal de 1995 cierra este ciclo eliminando el llamado delito de corrupción de menores, dando paso entonces a la conformación del delito de pornografía infantil que emerge por primera vez en el Código penal de 1995. En un período de aproximadamente veinte años los avances en la conformación, organización y redacción de los delitos que ocurren en la esfera del comportamiento sexual de las personas se vacían de contenido moral y adquieren cierta autonomía jurídica atendiendo a sus efectos sobre un bien jurídico identificado.

Con la Reforma de 1999 ocurre un giro que contraviene ésta tendencia. Los cambios en la norma penal vienen desde entonces empujados por otra tendencia en la que se juntan los intentos de restauración de la moral sexual como bien jurídico tutelado - la inclusión de nuevo del precepto corrupción de menores- y el cerrojo penal que se cierne sobre cualquier desviación traducido en la expansión de los límites del marco punitivo, incorporando nuevos delitos, incrementando las penas establecidas e introduciendo la inédita figura de medidas de seguridad como la libertad vigilada posterior al cumplimiento de pena de prisión. 
El delito de posesión de pornografía infantil expresado en el art. 189.2 resume íntegramente ésta tendencia, de allí el tratamiento especial del que es objeto en el capítulo siguiente. 
CAPITULOIV

POSESIÓN DE PORNOGRAFÍA INFANTIL 


\section{INTRODUCCIÓN}

Como veíamos en el capítulo anterior la criminalización de la pornografía infantil en el ordenamiento jurídico español ha sido progresiva y expansiva, esto es ha ido a más y expandiendo su alcance. Se comenzó por la tipificación de la creación de material pornográfico infantil (Código Penal de 1995) posteriormente se penalizó toda la cadena de comercialización y tráfico - producción, venta, distribución, exhibición y facilitación- incluyendo la posesión orientada a la venta (LO 11/1999) hasta llegar en la LO 15/2003 a castigar la posesión para uso propio, fundado en la premisa de que sin consumidores no hay mercado ${ }^{682}$. Más recientemente, en la LO 5/2010 se penalizan nuevas conductas tales como: el que captare, se lucrare u ofreciere pornografía infantil. Además, se añade un art. 189 bis, que establece la responsabilidad de las personas jurídicas que participen de cualquiera de los tipos descritos en el art. 189 CP. Ocurre, sin embargo, que ésta ampliación punitiva alrededor de la pornografía infantil se ha realizado al calor de la discusión y el rechazo de la mayor parte de la doctrina.

Estas nuevas reformas a los delitos de pornografía infantil hacen que el tema tenga mucha presencia en la actualidad en los ámbitos o debates de la opinión pública y académicos. No cesan las controversias a su alrededor, especialmente jalonados por eventos esporádicos relacionados con casos sobreexpuestos al despliegue mediático. Sin embargo, la dimensión más controvertida y rechazada por la doctrina sigue siendo la tipificación del delito de posesión de pornografía infantil para el propio consumo; en consecuencia, no existe dentro de la doctrina una posición unánime en relación con el bien jurídico protegido en el art. 189.2.

La mayoría de las voces se pronuncian por la nula necesidad de su tipificación. Buena parte de los referentes de la doctrina le califica como un tipo ineficaz, desafortunado ${ }^{683}$; que hace apología de la pedofilia ${ }^{684}$; como una intromisión en la vida

\footnotetext{
${ }^{682}$ Véase, MORILLAS FERNÁNDEZ, D. L., Análisis dogmático y criminológico..., op. cit., pág. 321.

${ }^{683}$ ORTS BERENGUER, E., "Delitos contra la indemnidad sexual" en VVAA, Derecho Penal. Parte Especial, Ed. Tirant lo Blanch, Valencia 2004, pág. 294.

${ }^{684}$ FERNÁNDEZ TERUELO, J., Cibercrimen. Los delitos... op cit., pág. 62.
} 
privada de los adultos ${ }^{685}$; que violenta los principios de mínima intervención y lesividad del Derecho penal ${ }^{686}$; y que, en definitiva hace un uso simbólico del Derecho penal. En cualquier caso y al margen de las razones diversas aludidas por las voces que se han alzado contra el artículo, si en algo confluyen todas las opiniones anteriores es en la idea de abogar por su destipificación por considerar que se trata de un delito de peligro abstracto $^{687}$, ausente de bien jurídico tutelable y que violenta las garantías constitucionales.

Sin embargo, un sector minoritario de la doctrina se ha esforzado en justificar la existencia de este precepto, estimando que el bien jurídico protegido va desde la intimidad del menor, su dignidad ${ }^{688}$, hasta el peligro de acciones de imitación ${ }^{689}$, por tanto, se han esforzado por fundamentar y blindar la validez jurídica de castigar al consumidor. Esta postura cuenta con un amplio respaldo de los documentos y convenios internacionales -sobre todo en el ámbito europeo- que en los últimos años han instado a los países que los suscriben a incorporar el tipo en sus legislaciones internas ${ }^{690}$. Estos argumentos a favor y en contra de que continúe tipificada la tenencia de pornografía infantil, nos permiten exponer la cuestión central del debate alrededor del delito y el bien jurídico tutelado; al mismo tiempo nos enlazan con el cuestionamiento de fondo que se hace sobre las reformas penales recientes. En lo que sigue, el capítulo trata de recoger el debate suscitado y formulamos nuestras consideraciones.

\footnotetext{
${ }^{685}$ PÉREZ CEPEDA, A. I., "Un ejemplo más del Derecho penal simbólico: el delito de corrupción de menores", en Revista Actualidad Penal No 22, 2001, pág. 478.

${ }^{686}$ FERNÁNDEZ TERUELO, J., Cibercrimen. Los delitos... op. cit., pág. 62.

${ }^{687}$ La definición de delito de peligro abstracto la revisamos ampliamente en el capítulo III pág.

${ }^{688}$ GIMBERNAT ORDEIG, E., Presentación del libro: La teoría del Bien..., op. cit., págs. 11 y ss.

${ }^{689}$ HÖRNLE, T., "La protección de Sentimientos en el STGB”, en HEFENDEHL, R., (edit.) La teoría del bien jurídico. ¿Fundamento de legitimación del Derecho Penal o juego de abalorios dogmáticos?, Ed., Marcial Pons, Ed. Jurídicas y Sociales, S. A, Madrid 2007, pág. 397.

${ }^{690}$ Para una revisión más completa sobre los instrumentos internacionales, congresos y reuniones que proponen sancionar penalmente a los consumidores de pornografía infantil, véase, DE LA CUESTA ARZAMENDI, J. L., "Las Nuevas Corrientes Internacionales En Materia De Persecución De Delitos Sexuales A La Luz De Los Documentos De Organismos Internacionales Y Europeos", en Estudios de Derecho Judicial, CGPJ, Madrid, 1999, págs. 325 y ss.; véase, MORILLAS FERNÁNDEZ, D. L., "Los Delitos de Pornografía Infantil en el Derecho Comparado" en Cuadernos de Política criminal, Ed. CESEJ, Nº4, 2004, págs. 31-80; Véase, Capítulo II.
} 
Para dar inicio a la cuestión vale la pena formularnos las siguientes preguntas: ¿Cuál son las razones últimas que subyacen detrás de la penalización de la posesión de pornografía infantil? $\mathrm{O}$, lo que es igual, ¿qué criterio utilizó el legislador para justificar la intervención penal en la vida privada de un adulto? ¿Dónde nace la necesidad de tipificar ésta conducta y cual es la eficacia alcanzada y/o esperada? ¿Dónde están los límites entre la necesaria protección a los menores como colectivo susceptible de amparo jurídico y la imposición de una determinada moral sexual mayoritaria? ¿Es la punición de la mera posesión el instrumento más adecuado para contrarrestar la aparente tendencia creciente a la pedofilia? En la posesión de la pornografía infantil, ¿a qué intimidad se alude cuando se advierte sobre su violación?, ¿la intimidad del menor víctima o la privacidad del adulto que consume pornografía infantil? Adicionalmente, y desde la perspectiva de la administración de su aplicación ¿existe una correspondencia entre el interés social que se pretende salvaguardar y los costes de penalizar esta conducta? Tales interrogantes procuran dejar planteado el marco para la exposición de la controversia.

\section{DELITOS DE POSESIÓN.}

Los delitos de posesión no están presentes en las clasificaciones tradicionales de hechos punibles y formas de conducta. No son percibidos como una categoría autónoma o incluso problemática y no han sido tratados sistemáticamente ${ }^{691}$. Sin embargo, en los últimos años han ido en aumento tanto en materia penal sustantiva como procesal, sobre todo en los EEUU que, de acuerdo con la aplicación práctica tanto policial como judicial, marcan la pauta del accionar punitivo de ese país, alejándose por cierto de la doctrina y jurisprudencia citada más arriba ${ }^{692}$.

Estos delitos pueden ser clasificados en: a) tipos penales que describen expresamente la conducta punible como tener una cosa incriminada, por ejemplo la tenencia de estupefacientes; b) tipos penales que enlazan materialmente la punibilidad a

\footnotetext{
${ }^{691}$ STRUENSSE, E., Los delitos de Tenencia, op. cit., pág. 107.

${ }^{692}$ Tanto en materia penal sustantiva como procesal el United States Code tiene más de doscientos tipos de tenencia entre ellos encontramos los relativos a: a) posesión de armas de distinta naturaleza y peligrosidad; b) de propiedad y herramientas robadas; c) de droga y sus relacionadas; d) de material obsceno; e) de tarjetas de beneficencia, grabaciones y otra serie de elementos no autorizados; f) aceleradores de taxímetros. Véase. COX LEIXELARD, J. P., Contexto Político-Criminal....op. cit., pág. 139 y ss.
} 
la mera tenencia de una cosa, por ejemplo la Ley de armas; c) tipos penales que enlazan la punibilidad a la posesión de determinadas cosas, cuando para esas cosas se ha planeado un uso determinado, por ejemplo "exponer para la venta", el "tener disponible" o el "tener en custodia" objetos descritos detalladamente ${ }^{693}$.

Cuándo puede considerarse la tenencia una conducta?

Existen dos premisas. En primer lugar: el Derecho penal sólo se refiere a conductas de personas naturales. Aunque personas jurídicas o determinadas asociaciones de personas pueden ser amenazadas con penas, sin embargo, en el Derecho positivo son numerosos los ejemplos que confirman que la punición de la conducta esta dirigida a las personas naturales. Las penas o consecuencias jurídicas también parecieran estar dirigidas a personas naturales: pena privativa de libertad, días multas, tratamiento curativo o desintoxicación, medidas de internación en un establecimiento de desintoxicación, entre otras ${ }^{694}$.

En segundo lugar: la conducta humana puede manifestarse sólo bajo dos formas: actuar u omitir, tertium non datur ${ }^{695}$. El significado gramatical del verbo "tener" parece expresar una actividad. Sin embargo, en el uso lingüístico pueden enumerarse múltiples significados que no remiten a una conducta en el sentido de la ejecución u omisión de un movimiento corporal voluntario ${ }^{696}$. Así lo expresa Manzini, razonando sobre el art. 708 del CP italiano vigente plantea que "la posesión no es ni una acción ni una omisión, sino un resultado; la acción es de quien descubre aquella posesión y no del poseedor; y

\footnotetext{
${ }^{693}$ STRUENSSE, señala que el verbo "tener" puede ser utilizado en la expresión "ejercicio del poder de hecho" como una forma de reproducir la definición usual de tenencia. Véase STRUENSSE, E. Los delitos de Tenencia, op. cit., pág. 108.

${ }^{694}$ STRUENSSE, E., Los delitos de Tenencia, op. cit., pág. 108 y ss.

${ }^{695}$ En relación al "tener como omitir", STRUENSSE señala que “...en la jurisprudencia como en la doctrina -Alemana- han aparecido referencias que dicen que "tener" no describe un actuar, sino un omitir, a saber, la omisión de interrumpir o acabar la tenencia. Pero en el "tener", tampoco se puede ver la forma de conducta de una omisión”. STRUENSSE, E., Los delitos de Tenencia ..., op. cit., págs. 109 y ss.

${ }^{696}$ STRUENSEE menciona los siguientes usos y significado de la palabra tener: 1. "tener" o "tenencia", como relaciones de determinada clase entre una persona y una cosa, (p. e. "A" tiene una casa, un auto); 2. para expresar que a una persona le corresponden determinadas propiedades o capacidades (p.e. "A" tiene humor, comprensión); 3. con la palabra "tener" se describen relaciones entre personas (p.e. "A" tiene una mujer, dos hijos); 4. con esta palabra también puede ser caracterizada la estima que se le profesa a una persona o a una cosa (p. e. "A". tiene el afecto de su familia y el apoyo del tutor). Véase, STRUENSSE, E., Los delitos de Tenencia ..., op. cit., pág.110.
} 
la causa que ha producido ese resultado no tiene importancia constitutiva, sino sólo eventualmente incriminante. Por otra parte, el poseedor no tiene deber jurídico alguno de despojarse de aquella posesión. Tampoco la omisión de justificar la posesión es elemento constitutivo del delito, sino condición de punibilidad, y tal justificación suele también ser imposible por causas independientes del origen de la posesión"697

Los mayores obstáculos que se presentan a los delitos de tenencia están referidos a la propia expresión "tener", pues en contra de su forma gramatical, no describe ninguna conducta especifica. No existe ningún término técnico generalizado que establezca tal categoría, por ello, buena parte de la doctrina señala que los delitos de tenencia son un traspiés legislativo ${ }^{698} /{ }^{699}$.

STRUENSSE, expone múltiples significados posibles que se desprenden del vocablo tener, por ello se hace la siguiente interrogante ¿Qué puede significar "tener" como conducta cuando el legislador utiliza este verbo para la descripción de la punibilidad, y qué consecuencias se derivan para la aplicación del tipo de un comportamiento semejante ${ }^{700}$ Interpreta el autor que aquí seguimos que se pueden clasificar varios significados con implicaciones jurídicas, entre ellas: el tener como hacer positivo (se tiene a disposición una cosa); tener como un hacer activo (adquirir la tenencia); tener como ejercicio de la tenencia; tener como acto de omisión; y, de acuerdo a las prescripciones de Derecho civil, el tener se expresa como una actividad, es

\footnotetext{
${ }^{697}$ MANZINI, V., citado por JIMÉNES DE ASUA, L. Tratado de Derecho Penal, Ed. Losada, Buenos Aires, 1950, pág. 455 y ss., nota al pie $\mathrm{N}^{\circ}$ 57,

${ }^{698}$ STRUENSSE, E., Los delitos de Tenencia ..., op. cit., pág. 107.

${ }^{699}$ En relación al uso discriminado al recurso de los delitos de posesión Cox Leixelard, plantea que tanto el enfoque europeo continental como el anglosajón, aportan herramientas cualificadas que permiten intentar contrarrestar los excesos. Afirma que "El fuerte desarrollo de la dogmática visible en el sistema europeo continental, con sus impresionantes engranajes teóricos, aminora la influencia de los actores políticos en las decisiones técnicas. Así, las reacciones sociales frente a determinados sucesos no se ven inmediata y totalmente reflejadas en el subsistema jurídico-penal, dado que los filtros dogmáticos atenúan sus efectos y añaden necesarias cuotas de racionalidad. Por otra parte, la histórica vinculación entre el derecho penal y la filosofía política en el mundo anglosajón permite abrigar ciertas esperanzas: si bien en este sistema sí existe una interconexión más fuerte entre opciones políticas y decisiones penales, a la vez es perceptible un mayor compromiso con ciertas instituciones ancladas en el liberalismo como corriente dominante. Luego, buena parte de la racionalidad de las respuestas penales en este sentido dependerán del mantenimiento de una filosofía política liberal como entorno del sistema penal. De lo contrario, filosofías políticas de otros tintes repercutirán directamente en la resolución de los problemas criminales" Véase, COX LEIXELARD, J. P., Contexto Político-Criminal..., op. cit., pág.142.
}

${ }^{700}$ STRUENSSE, E., Los delitos de Tenencia ..., op. cit., pág.111. 
decir, como una relación de dominio ${ }^{701}$. Finaliza este autor afirmando que "las constelaciones que podrían describir un tener mediante un hacer activo conciernen a sucesos a los que el legislador, precisamente, no quería limitar o extender la punibilidad" ${ }^{, 702}$.

En la doctrina se utilizaba indistintamente los términos de tenencia o posesión. Ya hemos visto, sin embargo, en la relación seguida hasta aquí que la utilización del verbo "tener" es más problemático al momento de precisar un concepto, por ello el legislador español apostó en la redacción por el verbo "poseer"703. Ahora bien, en el Art. 189.2 del CP español ¿cómo se aplica el “poseer” como acción u omisión? ¿Hasta donde llega la descripción del tipo?, cabe entender que se trata de tener a disposición, es decir, guardado en un dispositivo de almacenamiento de datos; o ¿basta la adquisición de la tenencia, que penaliza los actos previos a la tenencia?; o, peor aún, ¿se incluye en el tipo la omisión de interrumpir o acabar la tenencia? En las líneas que siguen abundamos en los esfuerzos interpretativos para limpiar un sendero desde el que se aprecie más claramente el asunto.

\footnotetext{
701 STRUENSE enumera los posibles significados que el legislador y la doctrina han tratado de darle al verbo "tener" cuando describe una punibilidad: "Tener como hacer positivo, el tener debería caracterizar un movimiento corporal que es realizado con determinadas intenciones o resultados. Dado que en los delitos de tenencia se trata de casos en los que alguien tiene a disposición una cosa (peligrosa, deseada), el "tener" como "hacer" puede presentarse en las siguientes formas: a) adquisición de la tenencia mediante acción, por ejemplo, compra, receptación, sustracción de una cosa; b) impedir mediante una acción la pérdida de la tenencia que está por producirse, por ejemplo, ocultando armas ante un registro inminente o deglutiendo un recipiente con drogas; c) emplear o utilizar la cosa, por ejemplo, viajar con el auto, disparar el arma, consumir droga. La preservación de la tenencia se refiere a -el salvamento frente a una pérdida que está por producirse- es, ciertamente, un acto que mantiene una tenencia ya existente, pero, por otra parte, tampoco describe material y lingǘsticamente una conducta que pueda ser caracterizada como mero tener; además, en la práctica, no desempeña un papel digno de mención (...) Pero en este lugar basta, por el momento, con mantenerse en la opinión de que "tener", como hacer activo, tampoco puede ser reducido de manera razonable al empleo de una cosa". Por lo demás, también desde la sensibilidad lingüística me parece dudoso concebir el empleo, el uso o la utilización de una cosa como sub/casos de un tener activo. El tener describe más bien la posibilidad presupuesta y concomitante de recurrir a la cosa, que se actualiza mediante su uso. De manera característica se habla también del "ejercicio de la tenencia", lo cual presupone la posibilidad de una "tenencia sin ejercicio". El Tener, como ejercicio del poder de hecho sobre una cosa, describe la relación de coordinación entre cosa y persona y presupone, evidentemente, que la persona no se haya deshecho de la cosa. Pero no puede ser concebido materialmente como la omisión de abandonar la tenencia. También en el lenguaje de la Ley naturalmente, prescindiendo de los delitos de tenencia a ser aún investigados con más detalle- la palabra "tener" menta sólo una relación de dominio y no una actividad; me remito sólo a las prescripciones sobre la tenencia en el Código Civil”. Véase, STRUENSSE, E., Los delitos de Tenencia ..., op. cit., págs. 111 y ss.

${ }^{702}$ STRUENSSE, E., Los delitos de Tenencia ..., op. cit., pág. 113.

703 "Posesión" es el acto de poseer o tener una cosa corporal con ánimo de conservarla para sí o para otro. Véase, Real Academia Española, Vigésima Primera edición. Madrid, 2001, pág. 1645.
} 


\section{ARGUMENTOS A FAVOR DE LA TIPIFICACIÓN DE LA POSESIÓN.}

El postulado de la doctrina que funda de razones al legislador y que prevalece detrás de la penalización de la posesión de pornografía infantil, está asociado a una medida político criminal que pretende actuar directamente contra lo que se considera el último eslabón de la cadena de tráfico de material pornográfico, es decir, el consumidor $^{704}$. Razona el legislador, en consecuencia, que la pornografía infantil se produce porque hay consumidores de esos materiales ${ }^{705}$.

En este sentido, son tres los principales argumentos esgrimidos para llegar hasta la penalización del consumidor de pornografía infantil, a saber:

a) Impedir la futura utilización de menores y evitar que se generen nuevas necesidades en el mercado que mantengan aceitada la mecánica del círculo vicioso de explotación sexual infantil. Con ello alude obviamente a un concepto central de la ciencia económica: el juego de la oferta y la demanda.

b) Evitar el supuesto estimulo que se genera en el consumidor. Peligro de acciones imitadoras por parte de los usuarios de estos materiales.

c) Un estado de empatía con las víctimas.

Demos cuenta detallada de estos fundamentos.

\subsection{Controlar la Demanda PARA AnUlar la OfERTA y ACABAR CON la EXPLOTACIÓN SEXUAL INFANTIL}

Para justificar trasladar hasta el consumidor la responsabilidad penal, el legislador ha esgrimido criterios económicos de acuerdo con la economía convencional. Alude a la norma fundamental de la economía de mercado: las relaciones entre la oferta y demanda. Partiendo del supuesto de que la demanda incide directamente en el aumento de la oferta, y de que la oferta sólo puede cubrirse utilizando a menores reales, se castiga de este modo a la persona que consume este tipo de materiales pretendiendo

\footnotetext{
${ }^{704}$ MORILLAS FERNÁNDEZ, D. L., Análisis dogmático y criminológico..., op. cit., pág. 321.

${ }^{705}$ ROJA GARCÍA, J. C., "La realidad de la pornografía infantil en Internet" en Revista de Derecho

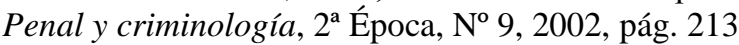


con ello intervenir en la lógica del negocio que está detrás de la explotación sexual de menores, de manera que se generen condiciones o reglas de juego que impidan su emergencia.

FERNÁNDEZ TERUELO, aunque sin mostrar su acuerdo con el mismo, explica que éste criterio se fundamenta en que "tanto los actos de difusión de pornografía infantil como los relacionados con la misma pueden determinar -con base en la experiencia general- un aumento de la oferta. De este modo, la puesta en el "mercado" de estos materiales generaría nuevas necesidades estimulando la demanda. Si aumenta la demanda aumentará también la oferta y la oferta sólo puede satisfacerse utilizando a menores "de carne y hueso" en prácticas de naturaleza sexual para tomar las imágenes o realizar grabaciones en otros soportes."706 Según este autor, “... es precisamente esa la razón que justifica una intervención penal en este ámbito, y en ningún caso el hecho de obtener satisfacción sexual con la contemplación de imágenes de menores, lo que en definitiva queda dentro de la moral sexual de cada uno",707.

Esta postura es defendida por DE LA ROSA CORTINA. El autor considera que la intervención penal está justificada puesto que la circulación del material pornográfico a gran escala en la red estimula la demanda, que tienen sus efectos sobre la oferta, que en última instancia y salvo casos residuales (pornografía virtual, técnica y pseudo/pornografía) habrá de utilizar a menores en prácticas de naturaleza sexual para tomar las imágenes ${ }^{708}$.

Con el criterio expuesto anteriormente el Considerando 4 de la Decisión Marco 2004/68/JAI del Consejo de 22 de diciembre de 2003, establece la ampliación punitiva como vía para frenar la actividad de pornografía infantil y su demanda-causa última de explotación sexual infantil- considerada como paso previo a la pederastia y en sí misma

\footnotetext{
${ }^{706}$ FERNÁNDEZ TERUELO, J., Cibercrimen. Los delitos... op cit. pág. 63

${ }^{707}$ FERNÁNDEZ TERUELO, J., La sanción penal de la distribución..., op. cit., págs. 253 y ss. 254.

${ }^{708}$ DE LA ROSA CORTINA, J. M., Los Delitos De Pornografía Infantil. Aspectos Penales, Procesales $Y$ Criminológicos, Ed. Tirant lo blanch, Valencia, 2011, págs. 261 a 294, www.tirantonline.com.
} 
atentatoria de los derechos de los niños a una educación y un desarrollo $\operatorname{armonioso}^{709} f^{710}$. (Cursivas añadidas).

El objetivo pragmático del legislador de criminalizar la mera posesión para debilitar el mercado de pornografía infantil es compartido por GIMBERNAT ORDEIG. Para este, es un motivo legítimo para una necesaria represión penal de la conducta, pues, se trata de “...un comportamiento estructuralmente semejante al clásico delito de la receptación -que se comete, por ejemplo cuando se compran objetos robados con conocimiento de su ilicitud de origen-, ya que la razón por la cual esa conducta se considera punible reside, por una parte, en que el receptador ataca el mismo bien jurídico (la propiedad) que el delincuente originario, pues al adquirir la cosa sustraída perpetúa y agudiza la situación patrimonial antijurídica creada por el ladrón; y, por otra, en consideraciones de prevención general, ya que el perista supone un estímulo para que se cometan delitos contra la propiedad, en cuanto que -por acudir a un ejemplo característico - muchos robos de joyas no se cometerían si el autor no contara con que, a posteriori, iba a encontrar una persona que diera salida a las alhajas sustraídas. De la misma manera, el adquiriente de pornografía infantil, por una parte y cada vez que pasa en video las imágenes reproducidas -a veces de menores de 5 o de 6 años, incluso, de bebes-, perpetúa el ataque a la libertad y a la dignidad de los niños que han sido grabados previamente"

Algunos autores diferencian entre la demanda y la posesión de pornografía infantil. La demanda serían las conductas o actuaciones dirigidas a procurarse o proporcionarse la posesión. Esta diferenciación es importante a los efectos de determinar hacia donde está dirigido el objetivo práctico de eliminar del mercado este tipo de material. En la legislación alemana, además del comportamiento de posesión se ha tipificado también el de procurarse la posesión para sí mismo o para otro. La hipótesis acerca del estimulo del mercado sólo tendría sentido cuando quien procura la

\footnotetext{
${ }^{709}$ RUIZ RODÍGUEZ, L. R.; GONZÁLEZ AGUDELO, G., El factor tecnológico en ..., op. cit., pág. 31.

${ }^{710}$ Pareciera que existe alguna contradicción entre la premisa de que se produce pornografía por el consumo y a la vez se afirma que el consumo e intercambio de material por la red ha afectado al lucro con el tráfico.

${ }^{711}$ GIMBERNAT ORDEIG, E., Estado de Derecho y Ley Penal, Ed. La Ley, Madrid, 2009, págs. 206 y ss.
} 
posesión lo hace con miras a su intermediación, de tal manera que su conducta tendría como objeto final facilitar el material a un tercero en el que despierte interés por consumir y procurarse más y nuevos materiales.

ESQUINAS VALVERDE, se interroga sobre ¿qué se pretende sancionar mediante esa segunda modalidad de posesión a secas? ¿Simplemente la posibilidad de que el consumidor pueda incitar a otra persona a que también utilice semejante material ${ }^{712}$. En este sentido, plantea que dado que en el artículo 189.2 no se exige ésta última acción o propósito de difusión para establecer la punibilidad de la tenencia, cabe suponer que el legislador -y esto es válido también para el legislador alemán- se haya conformado con que la posibilidad de que ello ocurra es suficiente para activar los mecanismos de sanción. Vale recordar que la producción y distribución ya están tipificadas, por lo que carece de sentido tratar de alcanzar también a estas conductas a través de la penalización de la simple posesión.

Partir del supuesto de que penalizando la simple tenencia de pornografía infantil se va a erradicar la explotación sexual de menores es, cuando menos, inocente. Así lo confirman ORTS BERENGUER y ROIG TORRES para quienes esta postura resulta tan ingenua como la que, desde la política antidrogas, pretende penalizar al consumidor de drogas para así acabar con el tráfico de las mismas, atribuyendo al Derecho penal una eficacia que ningún estudioso le reconoce y desviando la atención de los lentos, costosísimos y revolucionarios remedios que la explotación de los menores tiene $e^{713} / 714$. La criminalización de la tenencia de material pornográfico con menores significa "ceder

\footnotetext{
${ }^{712}$ ESQUINAS VALVERDE, P., El tipo de mera posesión..., op. cit., pág. 178.

${ }^{713}$ ORTS BERENGUER, E.; ROIG TORRES, M., Delitos informáticos y... op. cit, pág. 321.

${ }^{714}$ Esta postura es refutada por GIMBERNAT ORDEIG, que plantea que no puede establecerse una analogía entre la adquisición de droga para le propio consumo y la posesión de pornografía infantil , ya que estos supuestos no tienen nada que ver pues "....El bien jurídico protegido en los delitos de tráfico de drogas es el de la salud, y el titular de ese bien jurídico es el adquiriente, por lo que carecería de cualquier clase de lógica politicocriminal que se pretendiera castigar precisamente a aquel a quien la legislación penal trata de amparar; además: como la vida y la integridad física son bienes disponibles por su titular, de ahí que un CP que no castiga ni el suicidio frustrado ni la automutilación, tampoco puede castigar, inconsecuentemente, la adquisición de para el propio consumo de una sustancia que sólo potencialmente puede menoscabar la vida o la salud de quien legítima y libremente puede disponer de ellas. En cambio, el bien jurídico protegido en un eventual delito de adquisición de pornografía infantil no pertenece al comprador, sino a un tercero (por ejemplo, al bebe cuya libertad e indemnidad sexuales son brutalmente atropelladas por el productor pornográfico), por lo que, al contrario de lo que sucede con quien se procura droga, el adquiriente no tiene ninguna legitimación para disponer de los intereses de un tercero" Véase, ORTS BERENGUER, E.; ROIG TORRES, M., Estado de Derecho y..., op. cit., pág. 207.
} 
ante un pragmatismo de connotaciones mercantilistas que considera necesario intervenir indirectamente sobre la oferta a base de cortar la demanda" ${ }^{715}$.

Más allá de reconocer lo acertado y pertinente que resulta un campo de actuación jurídico-penal que proteja al menor, evento y situación que reúne absoluto consenso y en la que insisten los organismos internacionales -armonizar las legislaciones para evitar la impunidad en la lesión de los derechos de los niños por la simple situación geográfica-, también lo es suponer, erradamente, que este evento y situación se realiza en el Derecho penal. La protección de bienes jurídicos no puede ser el correlato del interés superior del menor; menos aun cuando se alude a una protección abstracta del mismo ${ }^{716}$. No hay dudas de que el marco de actuación para la protección del menor a que convocan los organismos internacionales tiene una dimensión jurídica, que por las condiciones de desarrollo de las altas tecnologías de información y comunicación debe propender a homogeneizar las legislaciones nacionales; pero de ello no se desprende que ésta dimensión jurídica se realiza en la expansión de su ratio penal, creando nuevos tipos y ampliando su alcance. Si alguna razón tiene recurrir a las lecciones que da la política antidrogas es que no es penalizando al consumidor que se reduce la demanda.

Ahora bien, ¿se puede impedir la futura utilización de menores y evitar la explotación sexual infantil penalizando la posesión para el propio consumo? Más aún, ¿se puede justificar una intervención penal en esta materia cuando el objeto de la acción son los materiales pornográficos y no los menores?

Excepto algunos autores, pocos en realidad, que se muestran a favor de su tipificación, existe cierto consenso en la doctrina sobre lo desacertado que resulta la decisión político criminal tendente a evitar la elaboración de material pornográfico infantil a través de la penalización de la posesión para uso propio. Es una difícil tarea la de “...justificar un contenido ofensivo mínimo en el acto de simple visualización de las imágenes pornográficas, que resulte suficiente para explicar por qué el legislador le ha adjudicado relevancia penal. A su vez, desde un punto de vista estrictamente práctico se

\footnotetext{
${ }^{715}$ TAMARIT SUMALLA, J. M., La protección penal del menor..., op. cit., pág. 156.

${ }^{716}$ RUIZ RODÍGUEZ, L. R., GONZÁLEZ AGUDELO, G., El factor tecnológico en la ..., op. cit., pág. 28.
} 
muestra difícil el objetivo de perseguir este comportamiento, pues por regla general se lleva a cabo en el espacio inabarcable de Internet" ${ }^{717} \mathrm{f}^{718}$.

Dicho de otro modo, debemos entender que con el artículo 189.2 del CP, que criminaliza la posesión de pornografía infantil, se pretende impedir la futura utilización de menores para la realización de dichos materiales. Compartimos la postura de MORILLAS FERNÁNDEZ cuando afirma que la tipificación de ésta conducta no representa ninguna solución. El problema y su tipificación se encuentran en el inicio de la cadena de tráfico y no en el consumidor final. Muy posiblemente en las motivaciones de este subyacen eventos ocurridos en el proceso de formación de la personalidad sexual que generan atracción hacia personas menores de edad como consecuencia de algún episodio particular. En consecuencia, la prohibición de la posesión de la iconografía relacionada no viene a representar alternativa alguna de solución, en tanto que la atracción física permanece sin afectar las tendencias del pedófilo a continuar consumiendo material pornográfico infantil ${ }^{719} /^{720}$.

Desde nuestra perspectiva, sin embargo, la atención y los esfuerzos de argumentación contra la penalización deben proveerse de otro tipo de razones. De partida, debe entenderse que la tenencia del material pornográfico no implica ni representa un abuso sexual. La raíz del problema de la explotación sexual de niños la ubicamos en el momento en el que se produce el acto de utilización del menor (abusos sexuales); y no ocurre cuando alguien ve una imagen alejado en el tiempo y el espacio del hecho como si el acto se reprodujera en el tiempo mimetizándose ${ }^{721}$.

En segundo lugar, el tráfico de contenidos ilegales es movido por la intención de lucro de organizaciones criminales. Para acabar con la industria lo lógico sería entonces

\footnotetext{
${ }^{717}$ ESQUINAS VALVERDE, P., El tipo de mera ..., op. cit., pág. 194.

${ }^{718}$ Véase en el Capítulo I, El antes y después de Internet en la pornografía por Internet.

${ }^{719}$ MORILLAS FERNÁNDEZ, D. L., Análisis dogmático y criminológico...op. cit., pág. 323.

${ }^{720}$ Esta postura, no obstante, es criticada por ESQUINAS VALVERDE alegando como contradictorio pedir la destipificación de la posesión de la pornografía infantil por considerarse que está alejada en el tiempo y la distancia del hecho de los abusos sexuales del menor y después estar de acuerdo con que se penalice todas las conductas de comercialización. Véase ESQUINAS VALVERDE, P., El tipo de mera posesión mera... op. cit.
}

${ }^{721}$ Véase ESQUINAS VALVERDE, P., El tipo de mera posesión mera... op. cit. 
castigar a los eslabones indispensables en la cadena de comercialización y distribución como la producción, venta y difusión, hipótesis que efectivamente tiene muy alto reproche social y jurídico previsto en el artículo 189.1. b) del Código Penal Español ${ }^{722}$. En este sentido, es importante destacar que en los últimos años la principal forma de adquisición de material pornográfico se realiza a través del intercambio de forma gratuita entre pedófilos en la Red, es decir, el hecho de que no exista transacción económica detrás del intercambio de ésta iconografía contradice la postura que reseñamos antes de GIMBERNAT ORDEIG quien considera que el consumo de pornografía infantil contribuye al mantenimiento y expansión de una nueva industria de explotación sexual de niños en la medida que el material filmado sólo se produce para generar beneficios, encontrando compradores ${ }^{723}$.

Finalmente, compartimos la opinión de COX LEIXELARD cuando afirma que en la punición indiscriminada de la posesión de material pornográfico infantil “...las insuficiencias político-criminales se conjugan con las debilidades dogmáticas. Sea que se opere dentro del enmarque de una lógica de fundamento del injusto post/consumativa, o dentro de una de adelantamiento o anticipación, no es posible apoyar sólidamente el castigo" ${ }^{724}$. Bien sea por la inexistencia de lesión material del bien jurídico o por la insuficiencia de argumentos sobre una imputación objetiva arraigada en una peligrosidad hipotética y difusa, que se justifica ligada a criterios de acumulación de material pornográfico, no es de buen recibo en la doctrina la tipificación indiscriminada sobre supuestos que no resisten la prueba material.

\subsection{Peligro de acciones imitadoras por Parte de los Usuarios de Pornografía Infantil. vs Efecto de Prevención o Catártico.}

Evitar un posible estimulo en el consumidor para ejercer una acción efectiva de abuso contra niños reales, es otro de los argumentos expuestos por el legislador para penalizar la posesión de material pornográfico infantil. En efecto, “... se ha aludido al

\footnotetext{
${ }^{722}$ Desde la LO 11/1999 de 30 de abril, está tipificado en el Código Penal español el tráfico de pornografía infantil

${ }^{723}$ GIMBERNAT ORDEIG, E., Estado de Derecho y..., op. cit., págs. 206 y ss.

${ }^{724}$ COX LEIXELARD, J. P., "Contexto Político-Criminal. De los Delitos de posesión. War on Crime y Expansión del derecho Penal", en Rodríguez Collao, Luis (Coord.) Delito, Pena y proceso. Homenaje a Tito Solari Peralta, Ed. Jurídica de Chile, 2008, pág. 142.
} 
potencial criminógeno que en sí mismo entrañaría dicho consumo de material pornográfico fabricado con menores, en la medida en que la persona que lo contemple, probablemente al efecto de excitarse sexualmente, podría sentirse empujada a cometer una acción efectiva de abuso o maltrato sobre niños" ${ }^{\text {725 }}$. Partiendo de ésta premisa, el legislador pretende actuar "contra los efectos de estímulo y de (posible) emulación que pueda tener una difusión pública, e incluso aquella que se realice en el marco de un grupo cerrado" ${ }^{, 726}$.

El hecho de que las personas que consumen este tipo de material puedan ser conducidas a realizar abusos a menores reales no se ha demostrado. El criterio expuesto sobre el peligro de imitación de la conducta de los consumidores de material pornográfico carece de fundamento científico. No existe investigación alguna que sustente una relación directa entre el consumo de los mencionados materiales y el tránsito hacia la comisión de abuso sexual a menores.

Por el contrario, diversas investigaciones criminológicas han sustentado que el consumo para la autosatisfacción puede tener un efecto preventivo pues actúa como un freno a los impulsos sexuales y en un porcentaje bastante elevado de supuestos, evita la comisión de ilícitos más graves ${ }^{727}$. Así lo señala ESQUINAS VALVERDE, cuando refiere acerca de opiniones científicas sobre la materia, la mayor parte de las cuales sustentan que quienes padecen la alteración no llegan a traspasar el terreno de la fantasía, conformándose con vivir esa expresión «enfermiza» de la sexualidad de modo individual y privado ${ }^{728} /{ }^{729}$. Un Informe de Anesvad apunta a que Internet puede, en ciertos casos, sustituir a los posibles abusos sexuales de menores, por cuanto suele facilitar un contacto fantaseado con esa situación. A diferencia de los hechos consumados, esto tiene consecuencias y riesgos mucho menores. Es más, justifican que para algunas personas, Internet simboliza y representa una vía segura de dar rienda

\footnotetext{
${ }^{725}$ ESQUINAS VALVERDE, P., El tipo de mera posesión mera... op. cit., pág. 180.

726 TRÖNDLE, H.; FISCHER, T., Strafgesetzbuch und Nebengesetze, 53. ${ }^{\text {a }}$, C. h. BECK Verlag, München, 2006, págs.1183 y 1184, marginal 2, citado por ESQUINAS VALVERDE, P., El tipo de mera posesión mera... op. cit., pág. 177.

${ }^{727}$ MORILLAS FERNÁNDEZ, D. L., Análisis dogmático y criminológico...op. cit., pág. 323.

${ }^{728}$ ESQUINAS VALVERDE, Patricia, El tipo de mera posesión... op. cit., págs. 181 y ss.

${ }^{729}$ Véase, TAMARIT SUMALLA, J. M., La protección penal del menor ..., op. cit., pág. 158.
} 
suelta a una fantasía de este tipo. Esta denominada hipótesis catártica, sin embargo, ha sido fuertemente contestada desde otros informes. ${ }^{730}$ / $^{731}$

La adquisición de material de pornografía infantil se corresponde con la segunda fase por la que pasa todo pedófilo ${ }^{732}$. En ésta fase, el material pornográfico infantil se utiliza para satisfacer mediante la masturbación las necesidades sexuales del individuo $^{733}$. En esta línea, diversos trabajos de investigación ${ }^{734}$ llevados a cabo con personas condenadas por posesión ilegal concluyen que el consumo de material pornográfico infantil puede representar un freno a los impulsos delictivos ${ }^{735}$. Las personas que utilizan o intercambian este tipo de material no llegan a desarrollar ningún tipo de agresiones a menores reales, puesto que se utiliza esta iconografía principalmente con fines masturbatorios con los que satisfacen necesidades y fantasías sexuales sin necesidad de incurrir en responsabilidad penal. Así visto, la posesión ejerce una función preventiva sobre la futura realización de conductas delictivas ${ }^{736}$, ya que la única finalidad de los consumidores es alcanzar un estado de excitación propia ${ }^{737}$

\footnotetext{
${ }^{730}$ Véase, DE LA ROSA CORTINA, J. M., Los Delitos De Pornografía..., op. cit., págs. 261 a 294 , www.tirantonline.com.

${ }^{731}$ Otros informes de organizaciones como los de Save the children, mantienen una posición contraria a la del efecto catártico del uso de pornografía infantil. Afirman que "por el contrario el consumo de este tipo de iconografía en algunos delincuentes opera como un mecanismo que les permite vencer sus inhibiciones". Véase, Position paper on child pornography and Internet-related sexual exploitation of Children”. Save the Children Europe Group, May 2004, pág. 12.
}

${ }^{732}$ Estas fases pueden resumirse en: a) presencia de fantasías sexuales confortantes de la parafilia; b) adquisición de material pornográfico infantil; c) establecimiento de contactos con otros pedófilos para intercambiar material pornográfico infantil; d) filmación de sus propias imágenes; y e) realización de actos sexuales con menores. Véase, MORILLAS FERNÁNDEZ, D. L., Análisis dogmático y criminológico.., op. cit., págs. 197-206.

${ }^{733}$ MORILLAS FERNÁNDEZ, D. L., Cuestiones conflictivas en la..., op. cit., pág. 210 y ss.

${ }^{734}$ Es importante señalar que la investigación llevada a cabo por QUAYLE, E.; TAYLOR, M., está respaldada por una muestra realizada mediante sendas entrevistas semi-estructuradas a trece sujetos condenados por posesión ilegal y obscena de imágenes de menores en sus ordenadores obtenidas tras la bajada de archivos a través de Internet, lo cual aporta una aproximación al pensamiento y a la forma de actuar de estos individuos muy en consonancia con la realidad. Véase, QUAYLE, E.; TAYLOR, M., "Child pornography and the Internet: Perpetuating a cycle of abuse", en Deviant Behaviour, 2002.

${ }^{735}$ CÁRTER, Daniel, PRENTKY, Robert, KNIGHT, Raymond, VANDERVEER, Penny y BOUCHER, Richard, "Use of Pornography in the Criminal and Developmental Histories of Sexual Offenders", en Journal of lnterpersonal Violence, 2, 1987, pág. 205.

${ }^{736}$ QUAYLE, E.; TAYLOR, M., “Child...” cit., págs. 333 y 334.

737 SETO, Michael C, MARIC, Alexandra y BARBAREE, Howard E., "The role of Pornography in the Etiology of Sexual Aggression”, en Agression and Violent Behaviour, 6, 2001, págs. 35 y ss. 
de la intimidad personal. Esto queda demostrado en el hecho de que una vez que logran su satisfacción sexual con la masturbación mediante la exposición visual de una iconografía virtual a través de Internet, inmediatamente se desconectan del ordenador o entran en otra página de contenido no sexual ${ }^{738}$. Ha ocurrido un acto que más allá del juicio moral que podamos tener sobre él no ha lesionado bien jurídico alguno y que se encaja dentro del estricto espacio de la intimidad de las personas; para el que además se ha utilizado cierta iconografía que motiva la incitación sexual del que visualiza, deslizando y agotando el comportamiento dentro de cauces que para nada vulneran tipo jurídico alguno.

La posesión y el consumo de esta iconografía a través de Internet es considerada por los propios consumidores como una terapia que les permite controlar su adicción por medio de la satisfacción de sus fantasías sexuales, convirtiéndose en un freno ante la posible comisión de actos ilícitos con menores ${ }^{739}$.

La controversia se extiende hasta la interpretación de los jueces en la aplicación del orden legal. La jurisprudencia del Tribunal Superior de la región o provincia de Columbia Británica, por ejemplo, también acoge la función preventiva de la posesión de material pornográfico: “...se puede hacer un uso inocuo de la pornografía: de esa forma podría pensarse en coleccionistas que recopilan ese material por simple curiosidad, o incluso por un interés obsceno o lascivo, pero sin que tal actitud responda a propósito perjudicial alguno, y quizá sin que la posesión de esa documentación consiga influenciarles de forma significativa. Más aun, señala el tribunal, la prohibición alcanzaría también a aquellos pederastas que, en lugar de tratar de explotar a menores o abusar de ellos, usen la pornografía para fines estrictamente personales, como aliviar su obsesión sexual por medio de la masturbación. A este respecto, está demostrado que la pornografía explicita se emplea para descargar la tensión de esta índole reprimida por aquellas personas que de otro modo podrían llegar a convertirse en agresores

\footnotetext{
${ }^{738}$ QUAYLE, E.; TAYLOR, M., Child..., op. cit., pág. 339.

${ }^{739}$ QUAYLE, E.; TAYLOR, M., "Child pornography and the Internet: Perpetuating a cycle of abuse”, en Deviant Behaviour, 2002, págs. 348-352.
} 
sexuales" ${ }^{, 740}$. Y, aunque ciertamente no pueda asegurarse con absoluta certeza que este efecto "catártico" logre compensar el supuesto daño causado por la propia conducta de posesión de pornografía infantil, en todo caso ha de ser un factor significativo que puede relajar la penalización de la posesión coadyuvando en el propósito de la inocuidad de la disposición de material a los fines íntimos.

Además del efecto catártico o preventivo debe considerarse otro elemento de suma importancia, apuntado por MORILLAS FERNÁNDEZ, como la elección racional que hace una persona sobre la realización de una determinada conducta considerando la relación coste/beneficio. “...si se tipifica semejante conducta ilícita, la función preventiva destinada a la posesión puede desaparecer a favor de la comisión de actos delictivos con menores e incapaces por esa relación coste/beneficios expuesta en la teoría del delito como elección racional". ${ }^{741}$ Es decir, razonando de acuerdo con ésta teoría, en el momento de plantearse el sujeto activo los posibles costes de la comisión del hecho delictivo y cotejar cómo, tanto la posesión como el abuso sexual o la elaboración de su propia iconografía de manera directa, representan una hipotética carga de prisión, en el supuesto de ser descubierto, muy posiblemente opten por la segunda de las conductas enunciadas puesto que es la que le proporcionará mayor gratificación sexual, afectando directamente al menor e incapaz en su esfera de la indemnidad sexual. $^{742} \mathrm{O}$ lo que es igual si los costes de asumir cualquiera de los actos tipificados suponen una sanción penal, la decisión racional sería realizar aquella que le proporcione mayor gratificación sexual, dejando sin efecto la contención del acto que en teoría deben ejercer los otros dos y siendo, además, que es la que directamente afecta la indemnidad del menor.

A pesar de lo reprochable y socialmente perniciosa que pueda parecer a gran parte de la población la condición sexual del pedófilo, así como el propio comportamiento de intercambio de fotografías, videos y otros recursos iconográficos en la red, nos parece inviable que se recurra al Derecho penal para pretender no sólo

\footnotetext{
${ }^{740}$ Véase, Jurisprudencia del Tribunal Superior de la región o provincia de Columbia Británica (British Columbiá), en la Sentencia de la causa Regina versus Sharpe, de 13 de enero de 1999, citada por ESQUINAS VALVERDE, P., El tipo de mera posesión..., op. cit., pág. 193.

${ }^{741}$ MORILLAS FERNÁNDEZ, D. L., Análisis dogmático y criminológico..., op. cit., pág. 324 y ss.

${ }^{742}$ Idem.
} 
reprimir la práctica sexual de una persona adulta de autosatisfacerse con la contemplación de iconografía obscena de menores, y además censurable que se espere que con un tipo penal (art. 189.2) se elimine el trastorno o desviación psico-sexual como se le quiera llamar a la satisfacción alcanzada con esa contemplación ${ }^{743}$.

\subsection{EMPATÍA CON LAS VÍCTIMAS DE LA PORNOGRAFÍA INFANTIL.}

Como ausencia total de empatía con lo niños y niñas víctimas de la pornografía infantil, califica GIMBERNAT ORDEIG a los que tienen una posición contraria a la tipificación de la simple tenencia -para la autocomplacencia- de este tipo de material. En especial señala que “...por si fuera poco el trauma sufrido por haber sido objeto de brutales agresiones sexuales filmadas o fotografiadas, que probablemente van a influir determinante y negativamente en el desarrollo adulto de su vida sexual y sentimental, encima se les quiere hacer soportar que los bienes jurídicos de su dignidad y de su intimidad puedan seguir siendo pisoteados continuamente y ad eternum, sin consecuencia jurídico penal alguna, cada vez que un paidófilo decide contemplar las imágenes del atropello del que aquellos fueron objeto en la infancia"744. Para GIMBERNAT ORDEIG antes que el respeto por la orientación sexual del paidófilo está en juego la dignidad y la intimidad del menor, por la que se decanta.

Revisemos, sin embargo, la argumentación aquí expuesta de quienes se advierten con empatía por la víctima forzando la subordinación de otros intereses y razones a ésta elección. Ya hemos advertido en el aparte final del primer capítulo que la prevalencia de los intereses de la víctima es una de las tendencias de la Política Criminal reciente ${ }^{745}$, enseñoreando el papel protagónico de la víctima en la retórica del debate penal y encontrando acomodo en el cuerpo legal. En los movimientos de exigencia de mayor represión y el reclamo del endurecimiento de las penas, sobre todo ante las infracciones de especial gravedad de delitos sexuales contra menores, los intereses de la víctima -incluso la víctima o sus familiares en directo- ha estado en un

\footnotetext{
${ }^{743}$ Véase, ESQUINAS VALVERDE, P., El tipo de mera posesión..., op. cit., pág. 180.

${ }^{744}$ GIMBERNAT ORDEIG E., Presentación del libro: La teoría del Bien..., op. cit., págs. 11 y ss.

745 LANDROVE DÍAZ, G., El nuevo derecho penal, Tirant lo Blanch, Valencia, 2009, págs. 60 y ss.; GARLAD, D., La cultura del control..., op. cit., págs. 46 y ss.
} 
primer $_{\text {plano }}{ }^{746}$. El retorno de la víctima aparece así integrado al discurso del populismo punitivo. De manera similar a como ocurre con la retórica de la tolerancia cero o la guerra contra el crimen, la retórica de la víctima pretende obtener un amplio apoyo del colectivo social en el endurecimiento de la represión que satisfaga las exigencias vindicativas. ${ }^{747}$

En criterio nuestro la discusión sobre si la tipificación de la tenencia de pornografía infantil es o no la mejor herramienta para evitar la futura explotación sexual infantil debe estar alejada del sentimiento o empatía que se pueda sentir por las víctimas. De igual forma, como bien advierte LANDROVE DÍAZ, desde un enfoque estrictamente de técnica jurídica queda ampliamente cuestionada la obsesión por la recurrencia al encaje penal de medidas preventivas para contrarrestar formas de satisfacción sexual que no albergan daño a bien jurídico alguno y que deben permanecer dentro del estricto ámbito de la intimidad de las personas. ${ }^{748} \mathrm{Si}$, en todo caso, se conviene en su intervención, hay todo un conjunto de medidas y políticas de corte social que mejor se corresponden con la naturaleza de un Estado Social de Derecho que todavía está contenido dentro de la norma constitucional, a pesar de las tendencias que orientan la Política Criminal de estos días y su adecuación en las reformas penales.

Queda claro, en consecuencia, que no compartimos la afirmación de GIMBERNAT ORDEIG sobre que "Un Derecho penal progresista sólo puede - pero en esos casos debe- intervenir para proteger de la imposición de comportamientos sexuales contra o sin el consentimiento de la víctima, o cuando ejecutan sobre niñas o niños. Por ello, y en la medida que se han cubierto lagunas legales en relación con la protección sexual de la infancia, la reciente reforma supone un avance frente a la regulación del Código Penal de $1995^{, 749}$. Y no la compartimos, porque con el argumento de la empatía y la necesaria conformación de un marco de protección jurídico/social sobre el desarrollo sexual del menor en tanto que débil jurídico, se pretende violentar la

\footnotetext{
${ }^{746}$ Los casos de la niña Mariluz Cortes y Marta del Castillo son emblemáticos por las campañas públicas y mediáticas realizadas a favor de la cadena perpetua para los agresores sexuales.

${ }^{747}$ LANDROVE DÍAZ, G., El nuevo derecho penal, op. cit., pág. 60.

${ }^{748}$ ESQUINAS VALVERDE, P., El tipo de mera posesión..., op. cit., págs. 181 y ss.

${ }^{749}$ GIMBERNAT ORDEIG, E., Estado de Derecho y Ley..., op. cit., pág. 208.
} 
intimidad de quienes tienen a bien procurarse la iconografía que les plazca para obtener gratificación sexual que dudosamente afecta, como se pretende hacer ver, la indemnidad sexual de menor alguno.

\section{ARGUMENTOS PARA LA DESTIPIFICACIÓN DE LA POSESIÓN SIMPLE.}

La discusión sobre la pornografía y la obscenidad ampliamente desarrollada en los últimos años en Estados Unidos se funda sobre determinadas premisas filosóficopolíticas y constitucionales. El eje central de la cuestión es determinar si existe un daño suficiente que amerite y legitime la intervención punitiva estatal, esto es, si en el proceso mediante el que se procura satisfacción sexual de alguien ocurre la afección de otro (menor en este caso) causando daño a un bien jurídico. Un importante sector del liberalismo anglosajón considera que no debe intervenirse penalmente en esta conducta, pues se afectarían los siguientes derechos y garantías: a) La libertad de expresión como libertad en sentido negativo constitucionalmente protegida; b) el derecho a la privacidad; c) la autonomía o independencia moral; d) y la ausencia de un daño significativo conforme a criterios de utilidad $^{750}$. Buena parte de la doctrina española ha asumido la cuestión central de ésta tesis en línea con la perspectiva liberal de salvaguardar los derechos y garantías del individuo.

A continuación se apuntan los señalamientos que hace la doctrina científica mayoritaria sobre la improcedencia de la tipificación de la tenencia de la pornografía infantil para el propio uso, sustentada en la ausencia de lesividad de la conducta, como en la violación de las garantías y principios del Derecho penal.

\subsection{VULNERACIÓN DE LOS PRINCIPIOS DE MÍNIMA INTERVENCIÓN, OFENSIVIDAd Y ULTIMa RATIO. AfÁn REPRESOR Y USO SIMBóliCO DEL DEREChO PENAL.}

El principio de mínima intervención plantea, que por la magnitud de las consecuencias que genera la aplicación del Derecho penal, en cuanto a las restricciones de las libertades y el ejercicio de los derechos fundamentales sólo sea utilizado en los casos de agresiones severas a los bienes jurídicos más importantes. El poder punitivo

\footnotetext{
${ }^{750}$ COX LEIXELARD, J. P., Contexto Político-Criminal. De los..., op. cit., pág.129, nota 83.
} 
del Estado -reservado al Derecho penal- sólo debe intervenir cuando para la protección de los bienes jurídicos se han puesto en práctica y resultan insuficientes medidas organizativas y de intervención propias de otras ramas del ordenamiento jurídico no represivas, como pueden ser las administrativas, sociales, mercantiles y otras. Dada su propia naturaleza y las restricciones que supone para la acción humana, resultaría desproporcionado e inadecuado para promover una protección eficaz de los bienes jurídicos del orden social comenzar con el Derecho penal y empujar la actuación del Estado en su dimensión punitiva ${ }^{751}$.

Es así como en la tradición doctrinal que ha configurado el marco político criminal forjado en el marco del Estado Social de Derecho, con la mínima intervención se hace referencia tanto al carácter subsidiario $^{752}$ del Derecho penal, como a la utilización de éste como ultima ratio, es decir, como último recurso al que se recurre cuando ya han sido agotadas todas los instancias e instrumentos de los que dispone el Estado para la protección de los bienes jurídicos ${ }^{753}$. Así, el carácter de ultima ratio es aplicable en los casos donde el ataque no sea muy grave, el bien jurídico no sea tan importante, y sobre todo el conflicto pueda ser solucionado a través de instancias menos radicales que las sanciones penales propiamente dichas ${ }^{754}$. En definitiva, ultima ratio significa la "graduación de la intervención sancionadora administrativa y penal"755.

\footnotetext{
${ }^{751}$ BERDUGO GÓMEZ DE LA TORRE, I., y Otros, Curso de Derecho Penal..., op. cit., pág.73.

752 El fundamento constitucional del carácter subsidiario del Derecho penal consiste en graduar la intervención penal tras la civil y la administrativa. Es subsidiario en relación a las demás ramas del ordenamiento jurídico "cuya eficacia pretende "subsidiariamente" garantizar. A su vez, configurado el Derecho penal con esos criterios, su intervención en la protección de los bienes jurídicos aparece como fragmentaria, es decir, no los tutela frente a todos los ataques, sino ante los más graves o más peligrosos, por lo que el Derecho penal define sólo una parte de los antijurídico o, dicho de otro modo, del conjunto de lo antijurídico el Derecho penal acota sólo un fragmento. Véase, BERDUGO GÓMEZ DE LA TORRE, I. y Otros, Curso de Derecho Penal..., op. cit., pág.73.

753 En la ultima ratio no solo debe considerarse el Derecho penal como el último recurso del ordenamiento jurídico al que acudir para la protección de los bienes jurídicos; sino que además su aplicación debe ser lo menos grave posible para los derechos individuales; y finalmente, que resulte adecuado para alcanzar los fines de protección que se persiguen. Véase, BERDUGO GÓMEZ DE LA TORRE, I. y Otros, Curso de Derecho Penal..., op. cit., pág.72.

${ }^{754}$ MUÑOZ CONDE, F., GARCIA ARAN, M., Derecho Penal. Parte General. Ed. Tirant lo Blanch, Valencia, 2004, pág. 74.

${ }^{755}$ BERDUGO GÓMEZ DE LA TORRE, I., y Otros, Curso de Derecho Penal..., op. cit, pág.73.
} 
Contrario a ésta tradición, la expansión del Derecho penal en los últimos años se ha expresado en la creación de nuevos delitos, la imposición de penas cada vez más severas y la búsqueda de la eficacia represiva, anteponiendo la seguridad por encima de las garantías y libertades de los ciudadanos. Toda una mecánica se ha puesto en marcha para justificar la excesiva intromisión del Estado en la esfera privada, pretendiéndose la regulación de los actos estrictamente individuales. Ésta invasión de la vida privada por parte del poder del Estado en el caso del Derecho penal ha entrado, además, en un círculo vicioso en el que el aumento de la criminalidad en los tiempos que corren viene aparejado con un aumento de la dureza en la represión punitiva, con lo que parecen volver “...los tiempos de una política penal autoritaria de donde parecía se había salido ya definitivamente" 756 .

La tipificación de la posesión para el propio consumo de la pornografía infantil es un ejemplo claro de la vulneración del principio de la mínima intervención. Elevar a la categoría de delito hechos como la simple tenencia de pornografía infantil para la autosatisfacción, sin intención de remitirla a terceros, supone castigar el sólo contacto con el objeto ${ }^{757}$. La criminalización de está conducta es particularmente expresiva de la cesión a la irracionalidad o a un Derecho penal simbólico, “...la mera posesión no supone necesariamente la previa comisión de un delito sexual grave contra menores, por lo que en todo caso tal criminalización sería contraria al principio de mínima intervención, que aconseja acometer la lucha contra esta clase de industria pornográfica con medios menos drásticos y dirigiendo la intervención hacia el que vende y no hacia el que compra"758. En el mismo sentido se pronuncia MUÑOZ CONDE, cuando plantea que "debe insistirse, una vez más, en el principio de intervención mínima del Derecho penal que, en ningún caso, debe intervenir para reprimir hechos que no lesionan derechos de terceros o que carecen de «nocividad social». El Derecho penal debe abstenerse de intervenir en esta materia cuando el acto sexual en cuestión no lesione o ponga en peligro gravemente la indemnidad sexual de los menores o incapaces"759.

\footnotetext{
${ }^{756}$ MUÑOZ CONDE, F., GARCIA ARAN, M., Derecho Penal..., op. cit., pág. 71.

${ }^{757}$ TAMARIT SUMALLA, J. M., La protección penal del menor...op. cit., pág. 156.

${ }^{758}$ Ibídem, pág. 111.

${ }^{759}$ MUÑOZ CONDE, F., Derecho Penal ...., op. cit., pág. 248.
} 
Al margen del reproche moral que la tenencia de pornografía infantil pueda generar o las censuras sobre la desviación de la orientación sexual de quien archiva ficheros iconográficos relacionados, la tipificación de este hecho resulta difícilmente compatible con principios como el de ofensividad y ultima ratio entre otros. Los tres requerimientos que caracterizan el principio de ultima ratio del Derecho Penal son vulnerados, a saber: a) es desproporcionado recurrir al Derecho penal antes que a cualquier otra rama del ordenamiento jurídico; b) la aplicación penal no cumple con la exigencia de ser lo menos grave posible para los derechos individuales de las personas a quienes se les aplica; y c) no resulta adecuado para alcanzar los fines de protección que se persiguen ${ }^{760}$.

En este sentido, puede afirmarse que el delito tipificado en el artículo $189.2 \mathrm{del}$ CP español es consecuencia de la presión de determinados sectores sociales que se abrogan la defensa de una pretendida moral sexual de validez universal, pues de otra forma no se justifica su punición ${ }^{761}$. Es aquí donde deben considerarse los altos costes que significan poner en marcha todo el sistema penal dispuesto para la sanción de la posesión (gastos, trabajos y complejos procesos jurídicos) que en nada contribuyen a la protección del menor y que en definitiva tiene una utilidad nula en el efecto preventivo de la conducta $^{762}$. De manera que no solo se violenta un principio del Derecho penal según hemos visto, adicionalmente se encarece enormemente el funcionamiento de la administración de justicia al arreglar su organización y dinámicas con sujeción al cumplimiento de la observancia de un tipo que no existiría en la tradición de un Derecho penal erigido sobre la base de un Estado Social.

\subsection{Adelantamiento de las Barreras del Derecho Penal. Delito de Peligro AbStracto.}

Algunos autores plantean la discusión en torno a los delitos de posesión partiendo de la distinción entre el concepto formal o material de delito. Ya advierte COX LEIXELARD, sin embargo, que “...si se parte de la concepción formal del delito,

\footnotetext{
${ }^{760}$ BERDUGO GÓMEZ DE LA TORRE, I., y Otros, Curso de Derecho Penal..., op. cit., pág.72.

761 FERNÁNDEZ TERUELO, J., Cibercrimen. Los delitos... op. cit., pág. 62.

${ }^{762}$ MORILLAS FERNÁNDEZ, D. L., Cuestiones conflictivas en la actual..., op. cit., pág. 210.
} 
la delimitación del contenido de injusto de los tipos de posesión carece de relevancia, pues éste vendrá dado por su existencia legal y constitucionalmente producida. Este enfoque es más bien pobre en criterios de corrección para enfrentar tipos delictivos con consecuencias insatisfactorias. Una visión material, por su parte, aunque por supuesto no garantiza mejores resultados, permite la inclusión de más elementos de ponderación. Dentro de las teorías materiales, las ancladas en la protección de bienes jurídicos cubren un espectro que va desde el rechazo a la existencia de los delitos de peligro abstracto hasta aquellas que, amparadas en la noción de bienes jurídicos supraindividuales, no sólo la toleran, sino que la ven con cierta satisfacción. A su vez, planteamientos materiales diversos, como el de Frisch -que intenta fundamentarse en criterios de racionalidad y justicia y llega a rechazar la viabilidad misma de cualquier delito de peligro abstracto-, aportan factores para intentar detener la verdadera marea de corte funcionalista. En general, las visiones materiales cuentan con más recursos interpretativos a la hora de intentar limitar los alcances de un delito de peligro abstracto" ${ }^{, 763}$. En efecto, compartiendo las advertencias del autor sobre los aportes del concepto material del delito, siempre será mejor ponderar un juicio a partir de evidencias materiales que hacerlo con sujeción a potenciales eventos sobrevenidos respecto de los actos humanos. El peligro abstracto restringe el radio de acción permitida y abre el horizonte a la sanción como único mecanismo contenedor de actos que se estiman como dañinos o potencialmente dañinos de un bien jurídico.

Entendemos que en el precepto 189.2 del CP no se contempla una hipotética participación del mero poseedor en los delitos perpetuados en el material pornográfico. De ser así entraría en concurso de delitos con cualquier otro de los contenidos en el Título VIII. Luego, la punibilidad prevista en el artículo citado, se centra en evitar o prevenir que en el futuro se sigan utilizando a los fines que aquí comentamos a menores o incapaces por la existencia de un mercado negro que lo demanda en forma de material pornográfico. Como se deduce se imputa la ocurrencia potencial de un delito, esto es, el peligro abstracto para los bienes jurídicos de contenido sexual de menores de edad e incapaces ${ }^{764}$. Ésta ausencia de lesividad a bien jurídico alguno en el presente a partir de la posesión de material pornográfico con menores en escena deja claramente al

\footnotetext{
${ }^{763}$ COX LEIXELARD, J. P., Contexto Político-Criminal. De los..., op. cit., págs. 130 y ss.

${ }^{764}$ BOLDOVA PASAMAR, M. Á., Artículo 189..., op. cit., pág. 540.
} 
descubierto un adelantamiento de las barreras del Derecho penal, tendencia que aquí denunciamos haciéndonos eco de buena parte de la doctrina que así lo cree.

ORTS BERENGUER, estima que la mera posesión de material con esta iconografía, "puede ser catalogado entre los de peligro abstracto remoto, pues a la postre, si se castiga la posesión de material pornográfico, en cuya elaboración han sido utilizados menores o incapaces, es porque se presume que si se disuade al usuario de adquirirlo, los que lo producen dejaran de hacerlo, con lo cual se conjugará el eventual riesgo que, para los procesos de formación y socialización de unos y otros, entraña su intervención en la realización de los repetidos productos"765. (Cursivas añadidas). GÓMEZ TOMILLO, en cambio, al tiempo que indica se trata de un delito de peligro abstracto puro, critica que con él se sigue el modelo penal de determinados países o regiones, sería el caso de los ordenamientos penales de algunos Estados norteamericanos $^{766}$. (Cursivas añadidas)

Por su parte, TAMARIZ SUMALLA considera que si se parte del supuesto de que la finalidad del castigo del consumo de este tipo de materiales es incidir o atacar la explotación sexual infantil, ello obligaría "a admitir un desmedido e insólito avance de la barrera de protección, pues de lo que se trataría no sería ya de castigar una incitación directa al abuso sexual de menores, pues el pedófilo puede limitarse a vivir su parafilia en el ámbito exclusivo de sus fantasías interiores, sino una incitación a una desviación sexual que puede llegar a provocar un atentado contra un bien jurídico (y ello sin entrar en la problemática de la eficacia de semejante incitación, pues ahí habría que plantearse si el usuario potencial de esta clase de pornografía es o no exclusivamente la persona que ya está afectada por esta patología sexual) ${ }^{\text {,767. }}$

Siguiendo ésta línea de argumentación compartimos, para concluir, la afirmación de MORILLAS FERNÁNDEZ, cuando señala que admitiendo la preocupación de fondo que subyace en el precepto, la única opción que posiblemente tendría acomodo sería entender que se trata de un delito de peligro que se cierne como una amenaza para

\footnotetext{
${ }^{765}$ ORTS BERENGUER, E., Delitos contra la indemnidad..., op. cit., pág. 294.

${ }^{766}$ GÓMEZ TOMILLO, M., Derecho Penal y reforma legal..., op. cit., pág. 34.

${ }^{767}$ TAMARIT SUMALLA, J. M., La protección penal del menor ..., op. cit., pág. 158.
} 
los procesos de formación y socialización de los menores e incapaces, sin requerir ningún tipo de lesión. Algo que podemos estimar lógico pero que se corresponde con una desfasada y errónea medida de Política Criminal, en virtud de la cual se criminaliza una conducta carente de lesividad que, en cualquier caso, nunca debería haberse incluido en el Código Penal ${ }^{768}$.

\subsection{INTROMISIÓN O INVASIÓN EN LA VIDA PRIVADA DE LOS ADULTOS.}

En la ponderación jurídica de la intimidad en el art. 189.2 nos planteamos las siguientes controversias: ¿qué se vulnera? ¿La intimidad del menor objeto de pornografía infantil o la privacidad del adulto? En nuestro juicio con la tenencia de pornografía infantil para consumo privado, antes que proteger un bien jurídico se violenta la intimidad del consumidor.

Más que atentar contra la intimidad del menor que es utilizado para elaborar material pornográfico, lo que se violenta con el artículo 189.2 del $\mathrm{CP}$ es el mandato constitucional a la intimidad del adulto que hace uso de esta iconografía para autosatisfacerse, puesto que supone una intromisión o invasión inaceptable de la esfera íntima de las personas, desnaturalizándose la vida privada, violentada cuando se pretende regular las condiciones de la gratificación sexual ${ }^{769}$. Una vez más, este precepto en palabras de MUÑOZ CONDE “...criminaliza una conducta que, por inmoral que parezca, no afecta directamente al bien jurídico protegido en este precepto, indemnidad o intangibilidad sexual del menor o incapaz. Ciertamente, de un modo indirecto el consumidor del material pornográfico (...) igual que el consumidor de drogas ilegales favorece el tráfico de las mismas, pero igual que en este caso las conductas de mero consumo no deben ser castigadas",770.

Castigar la adquisición de pornografía infantil para el propio consumo no sólo infringe el principio de mínima intervención, además transgrede la libertad de la personas para gobernar su vida privada y puede violentar fácilmente el derecho

\footnotetext{
${ }^{768}$ MORILLAS FERNÁNDEZ, D. L., Cuestiones conflictivas en la ..., op. cit., pág. 198.

${ }^{769}$ PÉREZ CEPEDA, A. I., "Un ejemplo más del Derecho penal simbólico: el delito de corrupción de menores", en Revista Actualidad Penal, $\mathrm{N}^{\circ}$ 22, 2001. pág. 478.

${ }^{770}$ MUÑOZ CONDE, F., Derecho Penal...., op. cit., pág. 258.
} 
fundamental a la intimidad domiciliaria una vez se autoriza su escrutinio para obtener la prueba procesal del supuesto de hecho. Como de manera irrefutable plantea MUÑOZ CONDE “... ¿bastará la sospecha de que alguien tiene este tipo de material en su casa para su uso privado para justificar una orden de allanamiento y registro?. ¿Qué cantidad se considerará que excede del simple uso y constituye ya posesión para el tráfico?”. ¿Basta intercambiar un archivo con contenidos pornográficos para ser considerado un distribuidor?. ${ }^{771}$

En definitiva, el riesgo o peligro que la tenencia de material pornográfico infantil pueda significar para la difusión o tráfico de dicho material por la red; las dificultades para determinar cuando es para el consumo propio y cuando se posee con la intención de distribuir, y los obstáculos en cuanto a la persecución de estos delitos, no pueden llevar a justificar una lesión del derecho de todo individuo a leer u observar lo que le plazca. Y porque todo cuanto ese derecho tan cardinal y fundacional representa para la civilización occidental imbricado a la idea de libertad individual, no se puede justificar su restricción con base en la necesidad de facilitar la aplicación de otras normas jurídico-criminales por válidas y legales que estas sean ${ }^{772}$.

ESQUINAS VALVERDE hace referencia a una jurisprudencia emitida por el Tribunal Superior (Corte Suprema) de la región o provincia de Columbia Británica (British Columbia) en Canadá para ilustrar la argumentación en este sentido. Cita que “...a través de la sentencia de la causa Regina versus Sharpe, de 13 de enero de 1999, se declaró la incompatibilidad entre la prohibición penal de la posesión de pornografía infantil real, contenida en la Sección 163.1 del Código Criminal, y la «Carta de Derechos y Libertades de Canadá», en particular por lo que concierne a la libertad de expresión y el derecho a la privacidad personal. En efecto, considera la Corte que las pertenencias personales de un sujeto constituyen expresión de su identidad esencial: los libros, diarios, dibujos, ropa y otros elementos son expresiones individuales y privadas de sus propias creencias, opiniones, pensamientos y conciencia. Por lo tanto, al castigarse la simple posesión del material pornográfico se está afectando a un aspecto

\footnotetext{
${ }^{771}$ MUÑOZ CONDE, F., Derecho Penal.... op. cit., pág. 258.

772 Ver Sentencia Stanley v. Georgia, citado por ESQUINAS VALVERDE, P., El tipo de mera posesión... op. cit., págs. 179 y ss.
} 
muy privado e íntimo de la vida de una persona y, a juicio de los magistrados, este hecho debe ser valorado con un peso considerable. De ese modo, la limitada efectividad práctica que eventualmente pueda desplegar dicho tipo penal es insuficiente para justificar su impacto sumamente profundo e invasivo en la esfera individual de libertad y privacidad, sobrepasando sustancialmente este efecto perjudicial las posibles consecuencias beneficiosas" ${ }^{, 773}$. (Cursivas añadidas)

Vale la pena transcribir las notas finales de la Jurisprudencia de Canadá aludida por ESQUINAS VALVERDE: "En definitiva, dada la protección que a dicha conducta personal de posesión de pornografía presta el Derecho Constitucional y fundamental a la privacidad, y habida cuenta de que hasta ahora no han sido demostradas las supuestas ventajas político-criminales que en la persecución de la criminalidad sexual habría de arrojar tal prohibición, declara esta Supreme Court la improcedencia jurídica de la misma"774.

\subsection{Moral Sexual Colectiva.}

La percepción generalizada de la población en los países desarrollados sobre los riesgos y peligros que representa la red como escenario o espacio que expande las posibilidades de acción y el impacto de los efectos de la delincuencia organizada, así como el estado de alarma social sobre el que se dibuja el nuevo Derecho penal ha alimentado la tendencia expansiva de su uso hasta invadir ámbitos de la vida privada de los individuos. Es el caso, según hemos tratado de demostrar, de la posesión para consumo propio de la pornografía infantil.

En el reproche social que se hace al consumidor o poseedor de pornografía infantil se suele asociar directamente la conducta de este con los abusos sexuales sufridos por los niños que aparecen en dicho material. Es decir, se utilizan y confunden indiscriminadamente términos relacionados pero nunca iguales como lo son la pedofilia y pederastia ${ }^{775} /^{776}$. Así lo afirma MORALES GARCÍA cuando le atribuye a esa

\footnotetext{
${ }^{773}$ ESQUINAS VALVERDE, P., El tipo de mera posesión... op. cit., págs. 192 y ss.

${ }^{774}$ ESQUINAS VALVERDE, P., El tipo de mera posesión... op. cit., pág. 194. Traducción de la autora.

${ }^{775}$ Conviene aquí recordar que el pedófilo es aquel que visualiza con fines de autosatisfacción este tipo de material, incapaz de llevar a la acción su fantasía con niños reales; mientras que el que abusa sexualmente de un menor es el pederasta.
} 
tendencia teñida de alarma social y con pretensiones morales la extensión de la relevancia penal de la pornografía infantil, hasta estadios previos completamente alejados de la libertad sexual y próximos a concepciones preñadas de carga moral sobre las tendencias sexuales, como ocurre con la tipificación de la posesión para el consumo personal $^{777}$.

Con el art. 189.2 el Derecho penal pasa a tutelar intereses relativos a una difusa moral colectiva, criminalizando conductas no lesivas en las que queda diluida la función de protección de bienes jurídicos ${ }^{778}$. ROXIN expone la influencia que tiene la moral social sobre el Derecho penal cuando dice que “...casi todas las prohibiciones o prescripciones jurídico-penales se refieren a formas de comportamiento ética $\mathrm{y}$ socialmente reprochable. La amplia coincidencia de las normas jurídico-penales con las representaciones ético-sociales de la mayoría puede inducir fácilmente a la conclusión de que de la desaprobación de la moral social de un comportamiento se desprende, sin más, la admisibilidad de su punición."779 Según el autor, es este un asunto de difícil reconocimiento, a partir del cual se pretende legislar fundado en razones de una moral socialmente legítima y auto/referente al punto que no necesita justificarse. Pero dicha aspiración de guiar los designios de un orden social para penalizar lo inmoral lleva consigo la amenaza de la pena en “...determinados supuestos de comportamientos especialmente reprochables por ética y según la convicción de la mayoría, aunque con

\footnotetext{
${ }^{776}$ Esta asociación directa que se hace del consumidor y el pederasta se recoge con el termino dual offenders, definido como los consumidores de pornografía infantil que además abusan de menores directamente, descubriéndose normalmente esta doble faceta en el curso de una misma investigación, a veces a partir de una investigación de pornografía, que lleva a descubrir un delito de agresión o de abusos sexuales y otras veces a la inversa. Véase, DE LA ROSA CORTINA, J.M., Los Delitos de Pornografía..., op. cit., pág. 261 a 294, www.tirantonline.com.

777 MORALES GARCÍA, O., "Criterios de atribución de responsabilidad penal a los prestadores de servicios e intermediarios de la sociedad de la información”, en AA.VV., Delincuencia informática, Problemas de responsabilidad, Cuadernos de Derecho Judicial, Ed. Consejo General del Poder Judicial, nº IX, Madrid, 2002, págs. 189 y 190.

778 MOÑOZ CONDE define la moral sexual como "aquella parte del orden moral social que encauza dentro de unos límites las manifestaciones del instinto sexual de las personas". Véase, MUNOZ CONDE, F., Derecho... op. cit, pág. 210; Para RODRÍGUEZ DEVESA, la moral sexual es a aquella parte del orden moral que limita por razones éticas, las manifestaciones del instinto sexual contrarias a una pacífica convivencia dentro de una colectividad. Véase, RODRÍGUEZ DEVESA, J. M., Derecho Penal Español, parte Especial, Madrid, 1983, pág. 156.
}

779 ROXIN C., El bien jurídico, Conferencia dictada el 23 de febrero del 2007, en la Universidad Complutense de Madrid. Mimeografiado, pág. 8. 
este hecho no se lesione directamente ningún bien jurídico determinado" ${ }^{, 780}$. Sin desconocer la influencia que un conjunto de ideas respecto del bien y del mal ejerce sobre el imaginario social y admitiendo su existencia como institución que regula los actos humanos, ROXIN entiende que una ética social sólo tendría significación para el Derecho penal en el ámbito de la protección subsidiaria de los bienes jurídicos pero ubicando su alcance e influencia- no puede fundamentar en sí misma y de forma independiente ninguna punibilidad. ${ }^{781}$

En la tipificación de la posesión para uso propio de la pornografía infantil la moral sexual ha adquirido protagonismo y aunque sabemos que los prejuicios culturales o morales influyen en el legislador a la hora de configurar los tipos penales, y que también pueden estar presentes en el intérprete y en el que tiene que aplicar la ley en los casos en los que el legislador no ha resuelto expresamente el problema ${ }^{782}$, en un Estado Social y Democrático de Derecho debe velarse por los derechos o facultades subjetivos de los ciudadanos y no por concepciones ideológicas prejuciadas sobre la realidad social. En este sentido, MUNOZ CONDE plantea que "cualquier intento de convertir la "moral sexual" como tal, sin identificar los concretos bienes jurídicos que pueden ser específicamente cuestionados en los respectivos tipos delictivos, en un bien jurídico protegido autónomo conlleva el peligro de convertir el Derecho penal en esta materia en un Instrumentó ideológico más propio de la Inquisición que de un moderno Estado pluralista y democrático" ${ }^{783}$ BEGUÉ LEZAÚN, comparte la premisa de que el único objeto posible a tutelar en el articulo 189.2 es la moral sexual resultando obvio que sólo de manera forzada y tangencial esa conducta lesionan la libertad sexual de los menores e incapaces ${ }^{784}$.

DÍEZ RIPOLLÉS refiere que cuando se tipifica la posesión de la pornografía infantil, en realidad se están protegiendo situaciones o relaciones sociales de la realidad

\footnotetext{
${ }^{780}$ Ibidem., págs. 8 y ss.

${ }^{781}$ Ibídem, pág. 9.

${ }^{782}$ MUÑOZ CONDE, F., Derecho Penal..., op. cit., pág. 204.

${ }^{783}$ Ibídem, pág. 210.

784 BEGUÉ LEZAÚN J. J., Delitos Penal..., op, cit., pág. 207.
} 
que encajan dentro de una cierta idea de lo bueno y lo malo, representaciones sociales de lo que debe ser; pero no simples derechos o facultades objetivos. Se legislan intereses sociales y no sobre voluntades subjetivas ${ }^{785}$. Para PÉREZ CEPEDA, el legislador lo que pretende es satisfacer el sentimiento de rechazo social a la pederastia que en general predomina en la sociedad, pues se "castiga ex post a sujetos que no han participado ex ante en la elaboración de material pornográfico" ${ }^{, 786}$. Se trata de un Derecho penal de autor que busca la personalidad enemiga para neutralizarla. Nos encontramos con un tipo de autor en la medida en que se castiga la tendencia pederasta. Si a la pederastia le antecede una etapa de pedofilia, razonan, hay que neutralizar ésta última sancionando su estado latente de pederastia. Identificada la personalidad enemiga solo resta la punibilidad de sus inclinaciones para neutralizarla. JIMÉNEZ VILLAREJO, alineado con este criterio denuncia que la tipificación del delito de posesión de pornografía infantil se acerca peligrosamente a los tipos de autor propios de un Derecho penal no democrático, ya que una cosa es el reproche de la moral sexual que eventualmente demandaría una sanción en el marco de las normas sociales y otra es su imputación jurídica como acto penalizado ${ }^{787}$.

Neointegrismo punitivo denomina MORALES PRATS ésta tendencia suscitada en buena medida por la angustia e incertidumbre que generan los riesgos inmanentes a la imparable evolución de las nuevas autopistas de la información. ${ }^{788}$. A su juicio la penalización de la sola tenencia de material pornográfico infantil es una opción irracionalmente incriminadora que debe ser descartada. Y, abundando en los peligros de ésta forma de penalizar conductas, repara en que por esta vía el Derecho penal pasa a tutelar intereses relativos a una difusa moral colectiva, pues se le atribuye la competencia de sancionar cualquier acto calificado de inmoral, conductas que

\footnotetext{
${ }^{785}$ DÍEZ RIPOLLÉS, J. L., "El bien jurídico protegido en un Derecho penal garantista2, en Jueces para la Democracia, No 30, 1997, págs. 17 y ss.

786 PÉREZ CEPEDA, A. I., La Seguridad como Fundamento de la deriva del Derecho Penal Postmoderno, Ed. Iustel, Madrid, 2008, págs. 413 y ss.

787 JIMÉNEZ VILlAREJO, J., Art. 189.., en CONDE-PUMPIDO TOURÓN (Dir.), Comentarios al Código Penal, Ed. Bosch, Barcelona, 2007, pág. 1488.

${ }^{788}$ MORALES PRATS, F., "El Derecho Penal ante la pornografía infantil en Internet" en Revista Aranzadi, No 8, 2002, págs. 112 y ss.
} 
difícilmente alcanzan el grado de incitación directa a la desviación sexual o pedofilia ${ }^{789}$ (Cursivas añadidas).

Igualmente crítica es la opinión de TAMARIT SUMALLA cuando sostiene que “...un Derecho Penal basado en la protección de la libertad sexual es incompatible con la pretensión de poner el aparato represivo del Estado al servicio de la protección de contenidos morales"790 $\mathrm{Y}$, dando un paso más allá de las justificaciones expuestas, apunta acertadamente que no cabe orientar la punibilidad de las acciones que pueden estimarse como desviadas, tanto si los contenidos morales que les enjuician son materialmente vigentes en la sociedad como si estos aluden a una ética que se muestra como ideal y que aspira su legitimación social.

En el mismo sentido, MORILLAS FERNÁNDEZ afirma que la criminalización de la posesión destinada al uso personal del sujeto retoma la moral pública como bien jurídico. Con ella se intenta imponer qué actitudes y comportamientos sexuales son correctas o censurables amparado en planteamientos contrarios a un Estado Democrático de Derecho ${ }^{791}$. (Cursivas añadidas). Defender una moral sexual colectiva como objeto tutelado remite a estadios históricos de la sociedad en los que una religión se abrogaba la representación de los intereses públicos y tutelaba la actuación del Estado. De ahí la validez de la designación de MORALES PRATS de la tendencia analizada como neointegrismo y de sus peligros como discurso y fuente de argumentación para el Derecho penal $^{792}$. De este mismo criterio es QUERALT JIMÉNEZ cuando afirma que “en este precepto, vulnerando la máxima de protección exclusiva de bienes jurídico penales, castiga una tendencia moral del sujeto. Por tanto, ha de entenderse esta punición como ilegítima por incasable con el Derecho penal propio de un Estado Social y Democrático de Derecho"793.

\footnotetext{
${ }^{789}$ Idem.

790 TAMARIT SUMALLA, J. M., La protección penal del menor..., op. cit., pág. 58.

${ }^{791}$ MORILlAS FERNÁNDEZ, D. L., Análisis dogmático y criminológico..., op. cit., pág. 141. nota al al pie.

${ }^{792}$ MORILLAS FERNÁNDEZ, D. L, Cuestiones conflictivas en la actual..., op. cit. pág. 198.

793 QUERALT JIMÉNEZ, J. J. “Derecho penal español. Parte especial” Quinta edición. Ed. Atelier, 2008, pág. 223.
} 
Ahora bien, ¿qué criterios orientan la ponderación entre el derecho a la intimidad del consumidor o la moral sexual colectiva?

ESQUINAS VALVERDE es categórica al afirmar que tienen supremacía los derechos personales, en este caso la intimidad del consumidor, sobre los intereses supraindividuales como la salvaguarda de una moral sexual pública. La autora considera que “... tomando conciencia de la inocuidad y la ausencia de ofensividad que objetivamente presenta la actitud de contemplación privada de pornografía, sería posible sostener que, en una ponderación entre los derechos fundamentales del consumidor, por un lado, y los intereses de la mayoría social, por el otro, aquéllos llegaran a merecer primacía sobre éstos, una vez descartado que sigan en juego bienes jurídicos individuales de los propios menores"794; así, continúa “... podría concederse prioridad al criterio de la libertad de conciencia y de expresión de los ciudadanos — materializada aquí en la actitud del pedófilo que busca su satisfacción sexual individual en la contemplación de las fotografías-, aun debiendo sacrificar para ello el bienestar que una mayoría de personas hallaría en la represión incondicional de tales tendencias"795. No cabe pues el sacrificio de la libertad sexual individual para honrar una moral sexual difusa que aspira el blindaje de sus orientaciones mediante la sanción sobre aquello que estima incorrecto. El ejercicio de la libertad humana, especialmente en la esfera privada y con extremo celo en el espacio íntimo de realización sexual y en cuya dinámica no se afecten bienes jurídicos esenciales, está en la base del Derecho penal que hasta ahora hemos conocido en las sociedades modernas ancladas en marcos constitucionales de un Estado Social y Democrático. Adicionalmente, su desarrollo alejado de integrismos y fundamentalismos morales o religiosos es condición fundamental para que permanezca abierto al debate y a la razón jurídicas fundadas solo en condiciones materiales de afectación de bienes jurídicos.

\footnotetext{
${ }^{794}$ ESQUINAS VALVERDE, P., El tipo de mera posesión... op. cit., pág. 186.

${ }^{795}$ ESQUINAS VALVERDE, P., El tipo de mera posesión... op. cit., págs. 187 y ss.
} 


\subsection{Protección de SEnTIMientos EN LA POSESión de Pornografía INFANTIL. ¿LEGÍTIMOS O ILEGÍTIMOS?}

El debate central del Derecho penal en el último siglo ha girado en torno a la teoría del bien jurídico. Las cuestiones discutidas van desde la perspectiva teórica sobre cual es la finalidad de está rama del ordenamiento jurídico, hasta aspectos prácticos de política legislativa de cuales son las conductas que legítimamente pueden prohibirse en un Código penal ${ }^{796}$.

La idea de que las normas penales deban proteger sentimientos es rechazada intensamente por la doctrina contemporánea. El fundamento o principio aceptado de forma generalizada por la ciencia penal es que el fin y el sentido del Derecho penal es la protección de los bienes jurídicos. En consecuencia, no se justifican las prohibiciones penales que apuntan a la protección de sentimientos. ${ }^{797}$

La protección de sentimientos entendida como "las prohibiciones que pretenden evitar exclusivamente estados sentimentales desagradables" ${ }^{\text {798 }}$, constituyen la materia sobre la que confluye la voluntad de influencia que una moral social quiere ejercer sobre el Derecho penal. ROXIN plantea que “...la protección de sentimientos desagradables como tal no supone ninguna lesión de bien jurídico alguno. Muchas personas se enojan por formas de comportamiento y aspectos que contradicen su sensibilidad o su representación de los que es una vida "correcta". Pero este enojo no debe evitarse con ayuda del Derecho penal porque una sociedad libre se basa en el presupuesto de que cada uno puede hacer y dejar hacer lo que el quiera en tanto no afecte a la esfera jurídica del otro. Esto no excluye totalmente, en la medida que la Constitución deje margen para ello y se halle una mayoría democrática que lo legitime, una regulación obligatoria de buenas costumbres, pero esto se puede llevar a cabo con sanciones más suaves que las del Derecho penal. Así, por ejemplo, en regiones de costumbres muy estrictas el bañarse desnudo puede estar prohibido, pero no se debe admitir su criminalización. Allí donde estén necesitados de protección jurídico-penal los

\footnotetext{
${ }^{796}$ GIMBERnAT ORDEIG, E., Presentación del libro: La teoría del Bien Jurídico..., op. cit., pág. 22.

${ }^{797}$ HÖRNLE, T., La protección de Sentimientos..., op. cit., pág. 383.

${ }^{798}$ HÖRNLE, T., La protección de Sentimientos..., op. cit., págs. 392 y ss.
} 
sentimientos, allí se generará miedo. Así pues, la coexistencia libre que asegura el Derecho penal implica una vida en común sin miedo."799

Sin reservas algunas compartimos esta postura de Roxin sobre que los sentimientos aún cuando estén legitimados por mayorías democráticas no puede otorgársele una protección jurídico-penal, pues el Derecho penal debe estar reservado para las conductas más graves que afecten bienes jurídicos. Obsérvese que no se está asumiendo como admisible y buena la posesión de pornografía infantil, si recurriéramos a enjuiciar tales actos desde la óptica moral. Lo que se cuestiona es su criminalización, es su inclusión dentro del campo de influencia de los actos punibles mediante el ordenamiento jurídico; menos aún en la medida que viene justificada por las razones que aquí se desnudan.

No es ésta la postura de GIMBERNAT ORDEIG quien considera que cuando los sentimientos de la mayoría son legítimos pueden constituir un interés digno de protección penal $^{800}$. Para el autor todo tipo penal procura la tutela de algún interés legítimo o ilegitimo. Para que este interés alcance la categoría de bien jurídico es necesario que sea valorado positivamente por el ordenamiento jurídico, y ello sólo es posible cuando se trata de un derecho subjetivo de la persona, o incluso por cualquier otra razón como la de un sentimiento social legítimo.

¿Cómo determinar o identificar cuándo los sentimientos sociales son merecedores de tutela penal?

Partimos del presupuesto de que la protección de un sentimiento -aunque esté extendido y arraigado en la sociedad- no es legítima cuando se afecta o entra en contradicción con los derechos a la intimidad y de libertad sexual que le asiste al autor de la conducta escandalosa o perturbadora. En este sentido, GIMBERNAT ORDEIG expone que “...la correcta fundamentación de que diversas conductas sexuales tradicionalmente castigadas en los Códigos Penales deberían ser despenalizadas porque el sentimiento de escándalo que podían originar en un sector más o menos amplio de la

\footnotetext{
${ }^{799}$ ROXIN C., El bien Juridico, op. cit., pág. 10.

${ }^{800}$ GIMBERNAT ORDEIG, E., Presentación del libro: La teoría del Bien...,op. cit., págs.15 y ss.
} 
sociedad no podía ser considerado un bien jurídico, ha originado la confusión de que, igualmente, había que negar esa cualidad de bien jurídico a cualquier otra clase de sentimiento. Pero esa conclusión es equivocada. Aquel sentimiento de escándalo no era un bien jurídico, no porque fuera un sentimiento, sino porque era un sentimiento ilegitimo ${ }^{801} /^{802}$. De manera que siguiendo la línea de argumentación del autor, el criterio se sujeta a la condición de legitimidad que asiste a un sentimiento social para alcanzar dimensión jurídica conteniendo efectos punibles su violación.

Así, por ejemplo, el sentimiento de escándalo que puede producir la homosexualidad u otras conductas sexuales, es ilegitima y no merece protección alguna porque, entra en colisión con los derechos de los actores de la relación sexual constitucionalmente reconocidos en los arts. 10.1, 14 y $16 \mathrm{CE}^{803}$. Por el contrario "el sentimiento de malestar que origina el «maltrato con ensañamiento e injustificadamente a animales domésticos causándoles la muerte o provocándoles lesiones que produzcan un grave menoscabo físico» (art. $337 \mathrm{CP}$ ) es un sentimiento legítimo sobre el que no puede prevalecer un inexistente derecho del maltratador a desarrollar libremente su personalidad haciendo sufrir a los animales" $" 804$.

La protección de sentimientos no implica la lesión a bien jurídico alguno pero si pueden estar fundamentados en la protección de grandes tabúes sociales como sugiere

\footnotetext{
${ }^{801}$ Ibídem, págs.18 y ss.

${ }^{802}$ Las mayores dificultades de justificación de un sentimiento social se expresan cuando la referencia a los bienes jurídicos individuales se establece a través de los delitos de peligro abstracto, allí no sólo se evidencian los problemas de legitimación sino, además, de imputación de tales tipos.
}

${ }^{803}$ Considera GIMBERNAT que “... detrás del «estado peligroso» de la homosexualidad o de la venta de productos anticonceptivos (castigada hasta 1978 en el art. 416 CP 1973) o de la comercialización de pornografía de adultos entre adultos (tipificada hasta 1988 por el art. 431 CP 1973) se encontraba $-\mathrm{y}$ todavía, en menor medida, se encuentra- el interés de los católicos «bienpensantes» en no verse heridos en los sentimientos que les ha inculcado su ortodoxia religiosa, no existe inconveniente en afirmar, descriptivamente, que tales comportamientos tipificados como delitos o como estados peligrosos lesionaban el interés de un amplio sector de la población en no tener que soportar una conducta que «alteraba», escandalizándola, el equilibrio de sus sentimientos morales. Lo que sucede en estos casos es que ese «interés» realmente lesionado por la conducta homosexual ajena o por la pornografía de adultos no es susceptible de ser elevado a la categoría, positivamente valorada, de bien jurídico, porque no puede prevalecer sobre otro interés preponderante constitucionalmente protegido: el de que cualquier persona tiene derecho a la libertad ideológica, al libre desarrollo de su personalidad y a no ser discriminada por su condición o circunstancias personales (arts. 10.1, 14 y $16 \mathrm{CE}$ ), y, en consecuencia, a practicar las conductas sexuales que le parezcan oportunas." Véase GIMBERNAT ORDEIG, E., Presentación del libro: La teoría del Bien Jurídico..., op. cit., pág.15.

804 Idem. 
HÖRNLE TATJANA. Hay “...prohibiciones penales que prohíben conductas que provocan en otras personas indignación u otros sentimientos negativos, pero que no pueden justificarse con el criterio de la «lesión de derechos». A menudo sobrevienen sentimientos con especial virulencia, porque se lesionan importantes tabúes sociales. Dado que la transgresión de tabúes conduce a reacciones emocionales fuertes, los tipos que protegen tabúes protegen también de forma necesaria sentimientos. Al revés esta conexión no es obligada: no todo tipo protector de sentimientos debe apoyarse en la infracción de un tabú. No obstante, los tipos de simple protección de sentimientos - que no lesionan derechos pero tampoco tabúes sociales — son realmente raros." ${ }^{\circledR 85}$

Existen una gran cantidad de tipos que pueden ser clasificados como delitos protectores de sentimientos en tanto que no dejen consecuencias concretas identificables como daños tras la comisión del hecho. Aquí pueden incluirse por ejemplo los delitos contra el honor o los delitos contra la libertad sexual. Sin embargo, la imputación de tipos de comportamientos en el ámbito de la sexualidad de las personas, nos da la oportunidad de evaluar críticamente hasta qué punto es válido que los sentimientos puedan considerarse bienes jurídicos.

La penalización de la tenencia de pornografía infantil puede catalogarse dentro de las normas protectoras de tabúes y sentimientos, “...la elección de niños como compañeros sexuales y la afirmación de tales formas de conducta a través del consumo de pornografía infantil lesionan las expectativas de conducta generalmente reconocidas que fundamentan un tabú" ${ }^{806}$. Haciendo alusión a la legislación alemana, la autora plantea que el tipo referido a la obtención de la posesión (§184, párrafo $5^{\circ}$, inciso $1^{\circ}$ ) está justificado en el criterio de mercado que atribuye responsabilidad a las personas que demandan tales productos, -pues facilitan el abuso futuro de niños para producir nuevo género-, por lo que no es necesario recurrir allí a la protección de un tabú. ${ }^{807}$ No obstante, aclara que “...para el puro delito de tenencia ( $\$ 184$, párrafo $5^{\circ}$, inciso $2^{\circ}$ ) cabría remitirse al peligro de acciones imitadoras por parte de los usuarios de

\footnotetext{
${ }^{805}$ HÖRNLE, T., La protección de sentimientos en ..., op. cit., págs. 395 y ss.

${ }^{806}$ HÖRNLE, T., La protección de Sentimientos en ..., op. cit., pág. 397.

${ }^{807} \mathrm{Idem}$.
} 
pornografía infantil, que, sin embargo, es difícil de probar dada la falta de conocimientos empíricos" ${ }^{\prime 08}$. (Cursivas añadidas).

\subsection{TOMA DE POSTURA.}

Como punto de partida es menester reconocer que en los tipos de protección de sentimientos aún cuando sean legítimos pueden entrar en contradicción con un autentico bien jurídico constitucionalmente reconocido para el autor de la conducta rechazada y considerada nefasta desde los tabúes sociales y la moral sexual colectiva. El tema aquí analizado de la posesión de pornografía infantil para consumo propio contemplada en el artículo 189.2 del Código Penal español llena todos los requisitos para ser considerada un tipo de protección de sentimientos, por lo siguiente:

a) no supone la lesión a ningún bien jurídico, la contemplación de las imágenes con esa iconografía esta alejada en el tiempo y en el espacio de abuso sexual sufrido por el menor;

b) la criminalización de la conducta afecta la esfera jurídica del otro. El derecho a la intimidad y privacidad de la persona que consume este tipo de materiales es violentado;

c) el consumo de estos materiales no deja consecuencias concretas identificables como daños tras la comisión del hecho;

d) sin dudas, con este tipo se procura únicamente evitar sentimientos desagradables, contrarios a la moral sexual dominante, que lesionan las expectativas de conducta generalmente reconocidas que fundamentan un tabú.

A la tipificación de ésta conducta sexual ha contribuido el manejo mediático exacerbado que se hace de los casos de los niños que han sido víctimas de abusos sexuales. El sentimiento de miedo y enfado de un sector más o menos amplio de la sociedad es utilizado para generar un escándalo y con ello la exigencia de más penas y castigos para cualquier conducta relacionada con la relación social entre adultos y

\footnotetext{
${ }^{808}$ Idem.
} 
menores. El legislador español ha respondido al estado de alarma social con la utilización del Derecho penal como única vía para calmar a las exigencias vindicativas sociales, creando nuevos tipos carentes de bienes jurídicos, que responden a sentimientos ilegítimos en la medida que entran en contradicción con los derechos del autor de las conductas penalizadas.

Partimos del supuesto de que el adulto que en un espacio íntimo tiene satisfacción sexual con la visualización de imágenes de pornografía infantil está haciendo uso de su derecho a la intimidad y privacidad. Es importante recordar el interés preponderante constitucionalmente protegido: el de que cualquier persona tiene derecho a la libertad ideológica, al libre desarrollo de su personalidad y a no ser discriminada por su condición o circunstancias personales (arts. 10.1, 14 y $16 \mathrm{CE}$ ), y, en consecuencia, a practicar las conductas sexuales que le parezcan oportunas.

Conviene concluir con las palabras de ORTS BERENGUER sobre el arsenal punitivo previsto por el legislador para la libertad y la indemnidad sexuales en menores e incapaces, arsenal sin dudas tosco en que se ha victimizado y victimiza a las personas a las que se quiere especialmente proteger. Hacemos nuestras las palabras del autor cuando afirma que "...la eficacia preventiva del Derecho penal es sólo relativa; que el Derecho penal por su carácter subsidiario y fragmentario, debe ocuparse únicamente de las conductas más intolerables que atentan de la forma más grave contra los bienes tenidos por más valiosos en un conjunto social, y seleccionar las conductas más rechazables, más inaceptables para la convivencia ordenada de sus miembros, reservando para ellas la conminación punitiva; en consecuencia, que ha de evitarse la criminalización de hechos tenidos, meramente, por inmorales; y que nunca debiera hacerse un uso simbólico del Derecho Penal”"809

En vista del afán punitivo manifiesto en las últimas reformas caracterizadas por nuevos tipos penales carentes de bien jurídico, con aumentos de penas en los ya existentes y con nuevas medidas complementarias a las penas, entre otros, nos asiste cierto pesimismo en relación con la posibilidad de eliminar los tipos penales clasificados como protectores de sentimientos o de tabúes y sentimientos. A pesar de

${ }^{809}$ ORTS BERENGUER, E.; ALONSO RIMO, A., La reforma de los delitos contra la..., op. cit., pág. 41. 
que son ampliamente cuestionados por la ciencia penal, sin embargo, consideramos, encontrará poco apoyo tanto en la doctrina penal que se está construyendo desde la ideología de la seguridad como en la sociedad en la medida en que se refiera a las normas protegidas por nuevos tabúes ${ }^{810}$. Posiblemente el contexto social colonizado por la ideología de la seguridad de ínfulas a ésta forma de legislar penalizando comportamientos movidos por una fe social integrista que se abroga el juicio moral sobre los actos de las personas. Y los razonamientos que aluden a bienes intangibles como la seguridad nacional o la paz social amparen la creación de tipos o alarguen la pena de los ya existentes o ensanchen la cuarentena social inocuizando peligrosos sociales. Seguramente será necesario no perder el norte del marco doctrinal en el que más temprano que tarde ha de dilucidarse su fundamentación, de manera que se vuelva sobre las condiciones materiales del delito y se recurra solo de forma accesoria a las tesis protectoras del sentimiento social o a la prevalencia de ciertos juicios morales para regular bienes secundarios que, en cualquier caso, eludan su criminalización

\section{ILEGITIMIDAD DE LA TIPIFICACIÓN DE LA POSESIÓN DE PORNOGRAFÍA INFANTIL.}

Existen tres asuntos fundamentales a partir de las cuales se puede determinar la licitud o ilicitud de la tipificación expresa de la mera posesión de pornografía infantil. Estos son: a) la protección de un bien jurídico que fundamente su aplicación; b) la utilidad práctica del precepto; y, c) la ampliación del tipo a otros supuestos ${ }^{811}$.

Siendo coherente con lo que hemos expuesto en las páginas anteriores, consideramos que no existe un bien jurídico que fundamente la tipificación de la posesión de pornografía infantil. La criminalización de la conducta es la respuesta punitiva del Estado a un sentimiento ilegítimo de un sector más o menos amplio de la sociedad que posee determinada moral sexual y procura su primacía sobre otras o sobre la libre elección de la inclinación sexual. Si, en efecto, la justificación de la punibilidad de la tenencia o posesión representa la asunción del Estado de una moral en virtud de la cual reprime y castiga ciertas prácticas sexuales, probablemente no se haya reparado en que con ello se discrimina a un colectivo de personas atendiendo a sus tendencias

\footnotetext{
${ }^{810}$ HÖRNLE, T., La protección de Sentimientos..., op. cit., pág. 399.

${ }^{811}$ MORILLAS FERNÁNDEZ, D. L., Análisis dogmático y criminológico..., op. cit., pág. 322.
} 
sexuales y se enseñorea jurídicamente a ésta figura de la moral sexual colectiva rechazada ampliamente por la doctrina penal española. Arreglar el ordenamiento jurídico para disponer de las formas de control social del Estado al servicio de la protección de contenidos morales es incompatible con un Estado Democrático de Derecho.

En relación con la utilidad del precepto, nos preguntamos: ¿qué cabe esperar una vez tipificada la conducta? ¿La eficacia de la incriminación se va a reflejar en la disminución de toda la cadena de tráfico? ¿Se puede corregir un trastorno de la personalidad como la pedofilia con un tipo penal? O estamos en presencia de lo que la doctrina denomina un Derecho penal de autor.

En términos generales, los delitos de posesión han mostrado que no resultan ser eficaces en lo que declaradamente dicen proteger. El razonamiento político criminal es que eliminando la demanda se acaba con la oferta, por tanto, la penalización de la posesión está dirigida al que se estima el último eslabón de la cadena de tráfico de material pornográfico, es decir, el consumidor. Hasta ahora se desconoce que a partir de la penalización de la pornografía infantil en España se haya producido la disminución en las tasa de criminalidad de distribución o producción de este tipo de iconografía, como esperaba el legislador; por supuesto, tampoco se han evidenciado efectos favorables en términos de una protección supraindividual a los menores en su indemnidad sexual. Peor aún, si lo que se plantea desde la tendencia político criminal de control del crimen es garantizar a los miembros de la sociedad la seguridad necesaria para desarrollar su vida adecuadamente, con el recurso exagerado de tipos cada vez más alejados de la lesión de bienes jurídicos individuales es imposible llevar a cabo esa finalidad.

Pese a su ineficacia los delitos de tenencia o posesión no son transitorios o fugaces en el sistema penal actual. Ante la tendencia político criminal de más control y seguridad se utiliza al Derecho penal como principal recurso y los delitos de posesión son la herramienta más idónea pues permiten el adelantamiento de las barreras a través de los delitos de peligro abstracto. Prevención, precaución, suspicacia, inocuización, prejuicio, parecieran ser los vocablos que alientan los cambios penales y que traducen los miedos sociales ante los riesgos potenciales. Toda una cultura preventiva que para 
garantizar las ansias de seguridad expande las fronteras de control social no mediante medidas y políticas propias del Estado Social y Democrático, sino castigando cuanta conducta sea vista como el germen del delito de acuerdo con una moral dominante. En la doctrina, sin embargo, se advierte con mucha fuerza de la ineficacia de este uso indiscriminado y poco distintivo de los tipos de posesión, imponiendo protecciones genéricas y descentrando el esfuerzo que ha de privilegiarse sobre el bien jurídico, dejando en evidencia la inutilidad de la actuación represiva ${ }^{812}$.

Por último, con la ampliación del tipo a otros supuestos, hay que tener en cuenta que si la penalización de la posesión obedece a una medida de Política Criminal tendiente a actuar sobre el consumidor como el último eslabón de la cadena del tráfico, “...no parece acertada la idea del legislador de tipificar como delito la simple posesión de material pornográfico infantil y mantener impune la mera asistencia a espectáculos pornográficos infantiles en tanto ambas conductas presentan similitudes de contenido e, incluso, una mayor reprochabilidad penal en atención a las razones a través de las cuales se vulnera el bien jurídico protegido en el art. 189.1.a)"813 Aclara MORILLAS que con ésta afirmación no se legitima el delito de posesión; solo da cuenta de la asimetría de criterios para enjuiciar actos similares. Por último, encuentra el autor elementos que dentro de la política legislativa restrictiva que en ésta materia es dominante en el Derecho y políticas comunitarias, que puede representar un criterio que si bien no permite la destipificación del supuesto, si aboga por una menor rigidez punitiva. Tal vez, de acuerdo con los postulados que se han venido exponiendo a lo largo de este capítulo, el recurso de estos criterios de flexibilidad punitiva puede fundar en la política real otra línea de actuación administrativa y legislativa más ajustada con las tesis de la doctrina española que demuestren la ineficacia jurídica y social de continuar por el sendero punitivo de actos vejatorios de la libertad sexual. ${ }^{814}$

En resumen, consideramos que es ilegítima la penalización de la pornografía infantil por que no reúne los tres requisitos indispensables a saber: no se salvaguarda ningún bien jurídico a menos que el legislador acepte que se protege la moral sexual

\footnotetext{
${ }^{812}$ COX LEIXELARD, J. P., Contexto Político-Criminal. De los..., op. cit., pág.141.

${ }^{813}$ MORILLAS FERNÁNDEZ, D. L., Análisis dogmáticoy criminológico..., op. cit., pág. 327.

${ }^{814}$ Ibídem, pág. 328.
} 
colectiva; el precepto no tiene ninguna utilidad o eficacia demostrada, y, el tipo no puede ser ampliado a otros supuestos.

\section{LA POSESIÓN COMO ACTOS ALEJADOS EN EL TIEMPO, EN EL ESPACIO Y EN LA LÍNEA DE ACCIÓN DEL EPISODIO DE ABUSO SEXUAL.}

Hemos intentado desde el inicio de este trabajo dejar clara la diferencia entre el abuso sexual a un menor y la posesión de una imagen o representación de un niño desnudo con fines de satisfacción sexual. De igual forma, hemos diferenciado los términos pedofilia y pederastia. La razón de la insistencia en establecer estas distinciones es esclarecer y contrarrestar la analogía que se quiere hacer desde los medios de opinión pública cuando tratan el tema de pornografía infantil metiendo todo en el mismo costal. Además de apuntar que no puede aceptarse que una regulación penal sancione por igual todos los supuestos sin considerar el -mayor o menorcontenido del injusto.

La simple conducta de posesión de material pornográfico para el propio consumo está alejado en la línea de acción del abuso sexual producido al menor, por lo que también estarían alejados los efectos perjudiciales sobre el bien jurídico, en este caso la indemnidad sexual. Así lo expresa ESQUINA VALVERDE, “...consumado el delito originario de abuso sexual, terminada la acción peligrosa desde el punto de vista estricto de la intangibilidad sexual del menor y, en definitiva, agotadas las distintas etapas del curso lesivo (abuso sexual, fabricación del material, distribución y comercialización del mismo), ya la mera conducta de posesión de la pornografía no implica per se más efectos perjudiciales para ese concreto bien. Y a partir de tal premisa, cabría la posibilidad de que fueran preferentemente otros valores sociales y supraindividuales, como quizás «la moral sexual colectiva», o la sensibilidad ética mayoritaria, los que resultaran ofendidos de forma directa por similar comportamiento, al ser éste objetivamente impúdico, indecente o desviado" ${ }^{\text {815. }}$.

\footnotetext{
${ }^{815}$ ESQUINAS VALVERDE, P., El tipo de mera posesión... op. cit., págs. 187 y ss.
} 
Ahora bien, ¿cómo justificar que se despenalice la posesión y no la distribución o el tráfico de material pornográfico infantil, cuando en estos últimos también se encuentran igualmente alejados del hecho principal de abuso sexual?

Siendo que el consumo esta destinado al disfrute individual y se produce en un ámbito privado inaccesible a otros, constituye el último eslabón de la cadena de antijuridicidad penal en este contexto típico y por lo tanto la conducta con menor contenido punible, si conviniéramos que lo tiene. La actividad de distribución cuando sobrepasa el espacio íntimo de emisor y receptor definido por un simple intercambio entre usuarios individuales, incorpora elementos de mayor peligrosidad pues lleva consigo la posibilidad de incentivar al consumo a otras personas hasta ese momento ajenas. Ésta razón abona en la justificación de que se le atribuya mayor contenido de injusto, pues se supone enlaza con la expansión del mercado.

Fundado en los argumentos anteriores, “... no puede aceptarse una regulación penal que sancione por igual todos los supuestos, tanto los de los consumidores que resulten inocuos, que carecen de efectiva peligrosidad en relación con los intereses tutelados, como los de quienes si puedan, en un momento dado, decidir materializar sus obsesiones sexuales en un acto de directa agresión...teniendo sobre todo en cuenta que dichos comportamientos de conducta violenta sexual ya se sancionan de modo autónomo por medio de los correspondientes tipos de abusos o agresiones sexuales, podría declararse como oportuna la destipificación de la simple posesión privada de dichos documentos". 816

La jurisprudencia americana, por su parte ha determinado que la posesión para el propio consumo de la pornografía virtual no representa ninguna afectación o ataque al bien jurídico indemnidad sexual, puesto que la lesividad de la acción originaria está muy alejada en el tiempo, en el espacio y en la línea de acción de la mera posesión para el consumo. Esta hipótesis también debería de manejarse en el supuesto de la posesión de material real. Así lo expresa ESQUINAS VALVERDE, “...habiéndose alegado en relación con la producción de pornografía virtual que ésta se encuentra excesivamente alejada de la acción originariamente lesiva para el bien jurídico «indemnidad sexual del

\footnotetext{
${ }^{816}$ ESQUINAS VALVERDE, P., El tipo de mera posesión...op. cit., pág. 218.
} 
menor» (es decir, la de abuso sexual), lo mismo podría decirse respecto de la simple posesión de pornografía real, pues también en este caso ha de negarse toda ofensividad del comportamiento en lo tocante a dicho interés concreto. Y por otro lado, si en favor de sancionar penalmente el comercio con aquellas imágenes ficticias se ha alegado la reiteración, la persistencia que las mismas suponen en cuanto al ataque contra la intimidad y la dignidad del menor que ya lleva implícito el acto del abuso sexual, un enfoque similar podría sostenerse en lo concerniente a la posesión de la pornografía «auténtica». De igual modo ocurrirá en cuanto al frecuentemente esgrimido punto de vista de que castigando esas conductas se desincentiva o dificulta la futura comisión de abusos sexuales a niños y se reprimen las tendencias pederastas. Por consiguiente, sensu contrario, también resultará criticable la idea de su respectiva tipificación penal apelando al principio de la libertad de expresión y de opinión como garantías constitucionales en beneficio de todo ciudadano, especialmente por lo que se refiere al marco de privacidad de éste y de sus derechos personales." ${ }^{817}$

Rechazamos la pretensión cada vez mayor de control del Estado sobre conductas que no afectan a ningún bien jurídico. Es el caso del consumidor de pornografía infantil que le es violentado un derecho constitucionalmente consagrado como la libertad de expresión cuando se adelantan las barreras de protección del Derecho penal invadiéndose la esfera íntima de la vida privada y pretendiendo penalizar tendencias o fantasías sexuales que forman parte de la libertad de pensamiento de la persona. En este sentido, vale citar una célebre y añeja sentencia de la Corte Suprema sobre la causa Stanley versus Georgia de 7 de abril de 1969 en Estados Unidos. Ésta defendía expresamente que “...la simple posesión de material obsceno nunca puede ser punible, ya que tal opción político-criminal implicaría un inadmisible control del pensamiento por parte del Estado, irreconciliable con el principio constitucional de la libertad de expresión (...) que resulte plausible el interés gubernamental en regular el uso de la pornografía, la afirmación de dicho valor colectivo no puede ser aislada, en cualquier contexto del que se trate, de todos los intereses constitucionalmente protegidos, ya que, se dice, también es fundamental el derecho a ser libre, excepto en circunstancias muy

\footnotetext{
${ }^{817}$ ESQUINAS VALVERDE, P., El tipo de mera posesión..., op. cit., pág. 192.
} 
restringidas, de intrusiones no deseadas por parte de las autoridades en la esfera de privacidad personal" ${ }^{\prime 818}$.

Resumamos los argumentos expuestos hasta aquí. Queda claro que en la penalización de la posesión simple de pornografía infantil existe un distanciamiento entre la conducta del sujeto y la lesión de un bien jurídico individual o personal. Esto es así, entre otras cosas, porque el tipo fue canalizado a través de un modelo de incriminación que paulatinamente va haciendo abstracción de condiciones de la conducta provocadora del resultado. Que continúe siendo criminalizada en el Código Penal español sólo puede significar que responde a la necesidad del Estado de dar cumplimiento a la función de neutralización de la fuente de peligro, como le exige la nueva orientación político criminal y la de satisfacer la creciente demanda social por seguridad. Luego, son desproporcionadas las consecuencias de castigar una conducta desprovista de todo efecto externo reconocible.

Por lo demás, no parece la solución más correcta intentar salvaguardar el interés del menor como potencial víctima de la pornografía infantil a través de la sanción penal de la conducta del simple consumo o visualización de la iconografía asociada por parte de personas adultas y con plena capacidad jurídica. ${ }^{819}$

\section{FINALIDAD DE LA PENA EN LA POSESIÓN DE PORNOGRAFÍA INFANTIL.}

La pena establecida en el artículo 189.2 del Código Penal español es de tres meses a un año de prisión o multa de tres meses a dos años. A partir de la definición de los límites de la pena nos preguntamos: ¿cuál es la finalidad de la pena en la posesión para el simple consumo? ¿Se cumple la finalidad resocializadora establecida en las penas de prisión? ¿Se cumple la prevención especial? ¿se trata de una norma de prevención general?

La pena privativa de libertad como institución destinada a cumplir el fin de resocialización está altamente cuestionada. La cárcel ha terminado siendo sinónimo de

\footnotetext{
${ }^{818}$ Citado por ESQUINAS VALVERDE, P., El tipo de mera posesión... op. cit., pág. 189.

${ }^{819}$ ESQUINAS VALVERDE, P., El tipo de mera posesión..., op. cit., pág. 218.
} 
depósitos de individuos considerados peligrosos para la sociedad. Ahora bien, tomando en consideración la particularidad del autor del delito -el pedófilo-, es una persona que siente atracción sexual por los menores de edad y en cuanto tal tiene una necesidad de satisfacción sexual innata que debe satisfacer como cualquier otra persona dependiente de alguna droga. La prisión para el caso de personas castigadas por tendencias pedófilas carece de utilidad a los efectos de que abandone tales inclinaciones, pues no existe ningún evento que lleve a considerar que una vez cumplida la condena hayan desaparecido las pulsiones que al parecer le llevan a la búsqueda de espacios de realización sexual con menores de edad. ${ }^{820}$ Esto es, la finalidad preventiva de la pena de prisión establecida en el precepto que revisamos únicamente tendrá valor sobre los postulados de lo que verdaderamente es: una norma de prevención general, en tanto que la atracción sexual por los menores seguirá presente en el individuo por motivos innatos a la personalidad sexual de la sujeto que en espacios de libertad tenderá a volver sobre los actos propios de quien procura su gratificación sexual ${ }^{821}$.

En definitiva, considerando que la conducta del consumidor es inocua, que además no tiene ninguna utilidad práctica su tipificación, y que la pena no tiene ninguna finalidad que no sea la de protección de la sociedad ante individuos calificados de peligrosos, no queda más que insistir en la destipificación.

\section{ELEMENTOS EMPÍRICOS DE LA EXISTENCIA DEL DELITO DE POSESIÓN. ¿EN QUÉ INSTANTE COMIENZA O SE CONSUMA LA POSESIÓN DE PORNOGRAFÍA INFANTIL A TRAVÉS DE INTERNET?}

Casi en su totalidad los supuestos de posesión en la actualidad son de material pornográfico de índole y origen informático, por ello se hace necesario buscar nuevos criterios jurídicos para un problema también muy actual. Tanto la jurisprudencia germana como la doctrina se han encargado de definir el concepto de difusión de

\footnotetext{
${ }^{820}$ Existen tratamientos psicosociales para delincuentes sexuales genéricos que han mostrado eficacia en la disminución de la tasa de reincidencia entre un 10 a $20 \%$ para los que se han sometido de manera voluntaria. Este dato no debe ser subestimado por quienes propugnan salidas más allá de la protección de los intereses de la sociedad mediante funciones preventivas generalizadas. Véase, REDONDO ILLESCA; S., ¿Sirven el tratamiento para reeducar ..., op. cit., pág. 17; LÖSELL, F., "¿Sirve el tratamiento para reducir la reincidencia de los delincuentes sexuales?", en REDONDO ILLESCAS, Delincuencia sexual y sociedad, Ed. Ariel, 2002, Barcelona, págs. 361-396.
}

${ }^{821}$ MORILLAS FERNÁNDEZ, D. L., Cuestiones conflictivas en la ..., op. cit., pág. 212. 
pornografía para determinar en qué momento y bajo qué acción ocurre efectivamente la simple trasmisión de contenidos y comienza el estado jurídico de la posesión ${ }^{822}$.

Existen tres posiciones en relación con este asunto. En primer lugar la aceptada y aplicada en gran parte de las legislaciones y jurisprudencia a nivel internacional, que consiste en que hay posesión cuando se guardan los archivos o imágenes en algún dispositivo de almacenamiento ${ }^{823}$. Una segunda postura considera que bastaría la exposición visual en la pantalla del ordenador de las imágenes para que se considerara la posesión, es decir, que sería suficiente que los datos se hayan descargado en la memoria de trabajo del ordenador del usuario, aunque aún no se hubieran guardado en ninguna memoria permanente. Y la tercera postura encuentra que cometerá la conducta típica de posesión quien siendo conciente de la existencia de datos ilícitos en la memoria caché no proceda a eliminarlos ${ }^{824}$.

En detalle, estas posturas pueden sintetizarse como sigue:

1. La posesión ocurre cuando se almacenan en dispositivos ficheros con imágenes u otro material iconográfico. El tipo no se realiza sólo con contemplar el material pornográfico en la pantalla del ordenador luego de acceder a él en la Red. Es necesaria la tenencia física y tangible, así como su almacenamiento en los archivos del ordenador u otro dispositivo o medio permanente de conservación de los datos. Ésta información debe estar, obviamente, en el ámbito o esfera de disposición del sujeto $^{825} /^{826}$.

La mayor parte de la doctrina española se pronuncia a favor de esta posición. Así

\footnotetext{
${ }^{822}$ ESQUINAS VALVERDE, P., El tipo de mera posesión... op. cit., pág. 209.

${ }^{823}$ Véase, ORTS BERENGUER, E., Derecho Penal part..., op. cit. pág. 294y ss.

${ }^{824}$ En la llamada ante/memoria de reserva o "caché" del ordenador situada en el disco duro del mismo por regla general y de forma automática se graban las direcciones y contenidos de la Red consultados por el usuario, a fin de garantizar en el futuro un acceso más rápido a esas páginas. En el "caché" o "almacén secreto" permanecen registrados los datos aún después de terminada la conexión a Internet y aun después de apagado el ordenador, los datos permanecen disponibles hasta que dependiendo de la intensidad y frecuencia con la que el usuario se introduzca en la Red, será sustituido por las nuevas referencias. Véase, ESQUINAS VALVERDE, P., El tipo de mera posesión... op. cit., págs. 213 y ss.

${ }^{825}$ ORTS BERENGUER, E., Delitos contra la libertad e..., op. cit., págs. 294 y ss.

${ }^{826}$ Véase, ESQUINAS VALVERDE, Patricia, El tipo de mera posesión... op. cit. pág. 209.
} 
podemos mencionar a URIARTE VALIENTE, para quien el concepto de posesión debe delimitarse restrictivamente, y en “...ningún caso podrá abarcar el simple visionado de la pornografía sin que éste vaya acompañado de un acto expreso de "ocupación" de la misma, como podría ser el grabado a través de cualquier medio, la impresión de la imagen, o cualquier otro acto de adquisición que permita de algún modo al sujeto volver a acceder al disfrute de ese material sin depender de la colaboración o actuación de un tercero (...) En este sentido, no sería posesión el almacenamiento en el ordenador de una dirección URL que ofreciera pornografía infantil, pues la efectiva conservación de la pornografía en ese sitio no dependería de la voluntad del usuario, sino del titular de la página $w^{8} b^{827}$. En la misma línea pronuncia ÚBEDA DE LOS COBOS, para quien es impune la conducta de quien acceda a las páginas con pornografía en la red sin descargarla ${ }^{828 / 829}$.

Al respecto, MUÑOZ CONDE afirma que del concepto de posesión “...deben excluirse los casos en los que el material pornográfico se ha obtenido de forma fortuita navegando por Internet, o por simple descarga de la imagen para visualizarla, borrándola después. Tampoco debe incluirse en este delito la posesión, por ejemplo, de un vídeo de unas relaciones sexuales con un menor de edad, cuando las relaciones en sí mismas no son constitutivas de delito y la grabación ha sido realizada por el mismo sujeto que ha intervenido en la misma y después la guarda como recuerdo."830

Queda claro que el tipo de posesión incluye tanto la tenencia física de material pornográfico, como su almacenamiento en los archivos de un ordenador. El solo hecho de contemplarlo en el monitor tras haberlo buscado en la red no constituiría este delito $^{831}$. La jurisprudencia española también la recogen las sentencias que expresamente señalan que fueron incautados archivos con la referida iconografía en los

\footnotetext{
${ }^{827}$ URIARTE VALIENTE, L. M., Delitos relativos..., op. cit., pág. 6.

${ }^{828}$ ÚBEDA DE LOS COBOS, J. J., "La persecución de la pornografía infantil. Problemas relacionados con su distribución por Internet" La Ley Penal, № 37, Sección Estudios, Ed. LA LEY, abril 2007, págs. 67-80.

${ }^{829}$ En ésta misma línea, véase MARTÍN-CASALLO LÓPEZ, J. "Internet y pornografía infantil”, Actualidad informática Aranzadi, $\mathbf{N}^{\circ}$ 40, julio de 2001, págs. 1-9.

${ }^{830}$ Véase, MUÑOZ CONDE, F., Derecho Penal. ..., op. cit., pág. 259.

${ }^{831}$ Véase, en el capítulo III, La posesión simple de pornografía infantil.
} 
discos duros de los ordenadores personales o en otros dispositivos de almacenamiento de datos.

2. Una segunda postura más polémica entiende que la misma se realiza cuando los contenidos, imágenes etc. son transferidos de forma electrónica y se accede a la llamada memoria de trabajo del computador, es decir, cuando simplemente se descarguen en la pantalla o monitor del mismo ${ }^{832}$. En este sentido, la posesión quedará consumada sencillamente cuando los datos se hayan descargado en la memoria de trabajo del usuario, aunque todavía no se hubieran almacenado o grabado de hecho en la memoria permanente o disco duro del ordenador, pues existió la posibilidad de que en cualquier momento se guardaran o almacenaran dichos contenidos. ${ }^{833}$

Esta tesis es recogida por la jurisprudencia alemana. ${ }^{834}$ Sin embrago, parte de la doctrina de ese país argumenta que la decisión tomada por el Tribunal Superior se había pronunciado en relación al concepto de difusión de imágenes pornográficas, para lo que es suficiente con poner en camino los datos. Pero, tanto el término típico posesión, la expresión procurarse la posesión y la adquisición de la posesión, se habían dejado abierto a interpretación. En este sentido, reafirman que para la tenencia de pornografía

\footnotetext{
${ }^{832}$ Conviene en este punto aclarar que: "Adquirir la tenencia, es un acto que precede el tener o bien que coincide temporalmente con el tener. Por eso, la jurisprudencia ve ya en el acto de adquisición el comienzo de la tenencia. Esto no puede ser objetado. Sólo que no se puede reducir la acción de tener al acto de adquirir la tenencia. Pues el legislador, apoyándose en el mero tener, quiso lograr, precisamente, que la persecución penal fuese aliviada, en la medida en que ya no es necesario probarle, al tenedor, la adquisición ilegal del estupefaciente. Pero aquí justamente se busca una determinación de la tenencia que se base solamente en un hacer activo". Véase, STRUENSSE, Eberhard, "Los delitos de Tenencia", en GÜNTHER JAKOBS Y STRUENSSE, Problemas capitales del Derecho Penal Moderno. Libro Homenaje a Hans Welzel, Ed. Hammurabi, 1998, Buenos Aires, págs. 111 y ss.

${ }^{833}$ ESQUINAS VALVERDE, P., El tipo de mera posesión... op. cit., pág. 210 y ss.

${ }^{834}$ Véase la reseña de la Sentencia del BGH de 27 de junio de 2001, “...la difusión de pornografía infantil a través de Internet se consuma, en efecto, en cuanto que los datos llegan al ordenador de uno de los usuarios, con independencia de que una vez allí accedan sólo a la citada memoria de trabajo, o bien incluso ya a un soporte o medio de archivo permanente. El BGH hizo descansar su decisión, como señala HARMS, S., "SÍ das blofie Anschauen...", op. cit., pág. 647, en la nueva definición otorgada por la Ley de servicios de información y comunicación de 22 de julio de 1997 \{Informations- und Kommunikationsdienstegesetz, luKDG) al concepto jurídico de "material" ("Schriften"). De acuerdo con dicha reforma, pues, dentro de la noción de material pornográfico se incluirían, además de las fotografías, películas, publicaciones, etc., asimismo todo "soporte de datos" y, por lo tanto, también la propia "memoria de trabajo» del ordenador. (La mención específica a esta última apareció recogida en la Exposición" Véase, Esquinas Valverde, P., El tipo de mera posesión ..., op. cit., pág. 210, (nota al pie).
} 
infantil será necesario "que la información se encuentre ya grabada en un soporte de datos permanente a disposición del destinatario" $" 835$

Ahora bien, la función de la memoria de trabajo del ordenador es como la pantalla de un televisor que proyecta contenidos que desaparecen sin posibilidades de recuperación una vez que se abre otra dirección de Internet o se desconecta el ordenador. Como lógicamente se sigue no cabe sostener que la memoria de trabajo tenga por objeto o contenido dato alguno, ya que para ello sería preciso que la información luciera una cierta permanencia o estabilidad, siendo que la fijación de las imágenes en este caso no pasa de ser una proyección "volátil". Por tanto, esa memoria no puede ser considerada homóloga a los dispositivos expresos de almacenamiento como verdadero "soporte de datos" o material sobre el que se fijan a efectos de guardado de ficheros en los términos que contempla la normativa. Que esté al alcance no traduce si no que tales características forman parte del funcionamiento del mismo computador, al igual que los datos que se asientan provisionalmente en ella. En consecuencia no puede apreciarse como posesión punible ni equipararse con una relación de dominio durante un cierto tiempo, condiciones que actúan como fundamento del tipo previsto en el art. 189.2 $\mathrm{CP}^{836}$

Una postura similar ha tenido el Tribunal Superior Español respeto del delito de tenencia de drogas, según el cual resulta suficiente para considerarlo con una posesión mediata de ésta. Por posesión mediata se entiende aquella situación en la que el individuo, aunque sin detentar físicamente la sustancia, puede procurarse la misma, puede disponer de ella sin restricciones y ésta queda a merced de su voluntad ${ }^{837}$.

Sin embargo, no es posible encajar ésta noción de posesión mediata para el caso del delito de posesión de pornografía infantil. No es posible, insistimos, porque como bien apunta ESQUINAS VALVERDE, “...la naturaleza, en sí ya desproporcionada, de éste, aconseja apreciar su consumación sólo en aquellos supuestos más indiscutibles: es

\footnotetext{
${ }^{835}$ ESQUINAS VALVERDE, P., El tipo de mera posesión..., op. cit., pág. 211.

${ }^{836}$ ESQUINAS VALVERDE, P., El tipo de mera posesión..., op. cit., pág. 211.

${ }^{837}$ Ídem.
} 
decir, a partir de que se adquiera la disposición material sobre la cosa y las facultades características del propietario" ${ }^{\circ 38}$.

3. La tercera de las posturas que revisamos aduce que cometerá la conducta típica de posesión quien siendo consciente de la existencia de datos ilícitos en la memoria caché no proceda a eliminarlos. No sería imputable, por defecto, la responsabilidad penal a aquel usuario que no haya llegado a percatarse del asiento de este tipo de materiales en la llamada memoria caché.

Demos cabida en éste aparte al giro dado en la doctrina germana, señalado por ESQUINAS VALVERDE. Para conseguir incriminar tales hipótesis, se ha planteado una nueva redacción del tipo de procurarse la posesión (\$184.b.IV StGB), argumentando que si la intención verdadera del legislador es la erradicación definitiva del mercado relativo a la pornografía infantil, también debería reprimirse el acto de simple contemplación aunque no ocurra un registro de las imágenes en la memoria caché, en el disco duro del ordenador o en cualquier otro dispositivo de almacenamiento $^{839}$.

Esta postura se enfrenta a la complicación de la prueba del dolo en la conducta. ¿Qué sucede con el internauta medio que por lo general desconoce la función de la memoria caché? ¿Podrá atribuírsele una posesión consciente? ¿Cómo determinar las circunstancias particulares mediante las cuales la posesión es fortuita, accidental o consciente?

La doctrina germana para dilucidar respecto de lo planteado arriba, y convenir que ha existido un consumo deliberado movido por un deseo de naturaleza sexual y no una aproximación fortuita u ocasional, ha tomado como indicadores tanto la frecuencia de acceso a las imágenes como la extensión temporal de cada momento. De esa forma traza la línea de demarcación que separa el acto fortuito del acceso intencionado que si revela un interés penalmente relevante en dicha información ${ }^{840}$.

\footnotetext{
${ }^{838}$ Ibídem, pág. 213.

${ }^{839}$ Ibídem, págs. . 214 y ss.

${ }^{840}$ Ibídem, págs. 215 y ss.
} 
En definitiva, como ya se habrá podido apreciar este tercer considerando va dirigido a castigar la simple tentativa de procurarse la posesión. La legislación germana ha rebajado, como da cuenta ESQUINAS VALVERDE, aún más que la española, la frontera mínima de punibilidad a estadios muy anteriores a la consolidación de la tenencia en sí. Ésta comienza ya con la simple tentativa de procurarse la posesión ${ }^{841}$. Queda claro entonces que con la simple visualización de algún contenido con iconografía pornográfica con menores captado por la memoria de trabajo del ordenador o en el archivo caché, ya se habría traspasado el umbral de la relevancia penal y existe la posibilidad de abrirse una investigación judicial $\mathrm{y}$, eventualmente, autorizar un registro del ordenador personal del usuario. Luego, para que se observe el tipo subjetivo (dolo), se determinan las circunstancias en la que se produjo el acceso a la red para concluir sobre si el acceso ha sido fortuito o ha habido voluntad de búsqueda, exposición y archivo.

Para ESQUINAS VALVERDE, “....sostener esa opción interpretativa proclive a castigar el mero comportamiento de consumo implicaría realmente aproximarse «de forma inquietante» a una política penal de represión del puro y simple pensamiento, lo cual no puede de ningún modo tolerarse en el marco del Estado de Derecho. Y aún más criticable se antoja la mencionada posibilidad, prevista en la normativa germana, de sancionar con la pena de la consumación incluso la tentativa de hacerse con el material pornográfico, de modo que ya la búsqueda (también la que resulte infructuosa) de las correspondientes páginas en Internet podría ser vista como un inmediato comienzo de la ejecución" ${ }^{, 842}$. (Cursivas añadidas)

Ajustado a lo que hemos expuesto es criterio nuestro que la posesión de pornografía infantil obtenida a través de Internet no se consuma hasta que se guarda de forma deliberada las imágenes en algún dispositivo de almacenamiento. Por tanto, no compartimos las posturas defendidas por el legislador y jurisprudencia germana que adelantan las barreras punitivas a estadios anteriores a la obtención de la posesión. Bastaría, según ésta interpretación con la elemental contemplación de las imágenes para estar en presencia de una tentativa de procurarse la posesión de pornografía infantil, es

\footnotetext{
${ }^{841}$ Ibídem, págs. 216 y ss.

${ }^{842}$ Ibídem, pág. 217.
} 
decir, el paso previo muy anterior a la tenencia. Más aún, la simple búsqueda de determinadas páginas o información en Internet aunque resultare infructuosa podría considerarse como un inmediato comienzo de la ejecución.

Aunque buena parte de la referencia expuesta se correspondan con la jurisprudencia y la legislación germana; sin embargo, no están muy lejos de ser asumidas por otras legislaciones como la española, una vez han sido recogidas en la nueva Propuesta de Directiva del Parlamento Europeo y del Consejo relativa a la lucha contra los abusos sexuales, la explotación sexual de los niños y la pornografía infantil $^{843}$. Ésta sustituiría a la Decisión Marco 2004/68/JAI. En dicha propuesta está contemplada la tentativa para: la posesión, el acceso, el ofrecimiento y la producción de pornografía infantil continuando y ampliando el alcance de la orientación político criminal aquí denunciada.

Recordemos de manera sustantiva el sumario de razones que hemos venido desplegando. En resumen, abogamos por la eliminación del precepto contemplado en el artículo 189.2 del Código Penal Español,

a) Porque invade un ámbito de la vida privada de un adulto que el Estado no puede y no debe controlar.

b) No es efectivo para salvaguardar los intereses que pretende: la protección del menor. A efectos prácticos no se ha producido una disminución del consumo ni de los materiales disponibles en la red.

c) Su tipificación no tiene ninguna utilidad práctica.

d) Es ilícita en cuanto no protege ningún bien jurídico.

e) Es inconstitucional pues violenta varios derechos.

f) El costo de poner en marcha el sistema judicial es muy alto y la eficacia de la norma nula.

g) La posesión puede actuar como un efecto preventivo, catártico.

${ }^{843}$ Véase, artículo 5 de La Propuesta de Directiva del Parlamento Europeo y del Consejo relativa a la lucha contra los abusos sexuales, la explotación sexual de los niños y la pornografía infantil, por la que deroga la Decisión Marco 2004/68/JAI. 
h) No se cumple la finalidad de la pena: no se resocializa. La pena es de multa hasta 3 meses o prisión de un año con lo que en ninguno de los caso alcanza para aplicar tratamiento psicológico.

i) La estancia en prisión solo tendría valor a efectos de prevención general. 
CAPÍTULO $V$

ORIENTACIÓN POLÍTICO CRIMINAL EN LAS REFORMAS

A LA PORNOGRAFÍA INFANTIL 


\section{INTRODUCCIÓN}

En el capítulo anterior se realizó un análisis de la posesión de pornografía infantil para el simple consumo, se revisaron tanto los argumentos utilizados por el legislador para justificar la tipificación como los fundamentos jurídicos y de Política Criminal aportados por la doctrina y la jurisprudencia para la destipificación de esta conducta.

Es criterio nuestro que castigar al consumidor de esta iconografía supone la violación de principios constitucionales - privacidad del adulto-; principios del Derecho penal -proporcionalidad, subsidiaridad y de ultima ratio- y lo más significativo por lo que debe desaparecer este precepto, es que no lesiona ningún bien jurídico. Desde 1995 el artículo 189 del Código Penal ha sido sometido a tres reformas ${ }^{844}$. Las modificaciones se han expresado en una expansión del artículo con la creación de nuevos tipos, aumento de las penas, más circunstancias agravantes, adelantamiento de las barreras del Derecho penal con el delito de posesión y de pseudo/pornografía. Estas reformas no son aisladas o gratuitas sino que obedecen a una tendencia u orientación político criminal instaurada en Europa y Norteamérica y que llegan a las fronteras nacionales implantadas a través de los instrumentos internacionales. No puede explicarse que el Derecho penal recurra al delito de posesión de pornografía infantil si no se enmarca su tipificación dentro de la tendencia político criminal dictadas por la UE que privilegia la seguridad por encima de las garantías.

Este Capítulo cierra el desarrollo expositivo desplegado a lo largo del trabajo. Habiendo expuesto el lienzo social general en el que se inserta el delito de pornografía infantil, su evolución normativa internacional y su encaje dentro de la legislación nacional y centrado su discernimiento alrededor del bien jurídico afectado y la controversia sobre la tipificación de la posesión, el capítulo sintetiza los rasgos fundamentales de la Política Criminal cuya especificidad asociada al delito de pornografía infantil hemos expuesto. Concluye pues presentando de una forma más acabada las orientaciones generales de dicha Política Criminal como dictamen que se vierte gradualmente justificada en una ideología de la seguridad.

\footnotetext{
${ }^{844}$ El artículo 189 del Código Penal español ha sido modificado en tres oportunidades desde su inclusión en 1995: LO 11/1999 de 30 de abril; LO 15/2003 de 25 de noviembre; LO 5/2010 de 22 de julio.
} 
De manera que el capítulo vuelve sobre las grandes cuestiones que se plantean alrededor de la nueva orientación de la Política Criminal para ya presentarla no como su adecuación alrededor del delito que hemos estudiado, si no como un cuerpo de tesis que trazan las grandes líneas de las reformas penales que vendrán y la correspondiente adecuación de las instituciones de control social alrededor e ese ideal. Se expone como el desarrollo de las nuevas tecnologías de información y comunicación, la modernidad y la globalización son el marco cultural de la sociedad del riesgo, y el modelo penal de seguridad como aquel por el que se ha optado para responder al miedo posmoderno trasmutado en miedo a la violencia callejera. En el modelo penal de seguridad el Estado se limita a la gestión y distribución del riesgo ante individuos peligrosos. Además se explica cómo los medios de comunicación han incidido directamente en la tendencia represiva del Derecho otorgando un papel protagónico a las víctimas en su exigencia de retribución. La LO 5/2010 de 22 de junio fue impregnada con casi todas las peticiones que se hicieron en la cruzada de la familia del célebre "caso Mariluz", con excepción de la cadena perpetua. El Estado abandona el ideal resocializador para asumir una ideología de la seguridad que reduce la dimensión social de la Política Criminal a su esfera penal. Esto abre el espacio a los rasgos característicos del Derecho penal del enemigo como corriente teórica en el que se enmarcan las transformaciones que se suceden en el ámbito penal y su adecuación en la doctrina española mediante el llamado Derecho penal de la tercera velocidad.

Siendo que la Pornografía infantil ya fue analizada desde la perspectiva fenomenológica, criminológica (Cap. I) y; desde la perspectiva jurídica (Cap. II y III); no estaría completo el análisis si no se enmarca dentro de la tendencia actual de Política Criminal que influye y determina las sucesivas reformas penales y el arreglo de las instituciones de control social a su ideario.

\section{PLANTEAMIENTO: RADIOGRAFÍA DE LA TRAMA SOCIO/JURÍDICA CONTEMPORÁNEA.}

Bastaría un dato referencial - tasa de criminalidad y tasa de encarcelamiento para intuir cual ha sido la orientación político criminal de España en los últimos años. En efecto, mientras España tiene una de las tasas de criminalidad más bajas de la Unión Europea inferiores a las existentes en Alemania, Dinamarca, Francia, Holanda y Bélgica; presenta, sin embargo, una de las tasas de encarcelamiento más altas del 
continente. La tasa de criminalidad de España - delitos por mil habitantes- desde el año 2003 ha seguido una tendencia descendente a pesar del crecimiento demográfico experimentado (7,8\%). Durante el año $2010^{845}$, la tasa de criminalidad se ubicó en 45,1 delitos por cada 1.000 habitantes, una de las más bajas de Europa. Si se considera que la media es de 67,6 infracciones por cada mil habitantes, la criminalidad de España se ubica por debajo de Suecia $(121,0)$, Bélgica $(95,1)$, Dinamarca $(88,4)$, Reino Unido $(84,7)$, Holanda $(74,5)$, Alemania $(73,9)$, Luxemburgo $(71,2)$, Finlandia $(67,8)$, Irlanda $(67,5)$, Austria $(64,4)$, Italia $(57,0)$ y Francia $(56,4)^{846}$.

Si puntualizamos sólo en los delitos más violentos -aquellos que implican violencia física o psíquica sobre la víctima, es decir, los que más escandalizan a la opinión pública- la tasa fue de 2,5 crímenes por cada 1.000 habitantes en 2007, inferior a la de Alemania $(2,6)$, Dinamarca $(3,5 \%)$, Francia $(5,1)$, Holanda $(6,8)$, Bélgica $(9,6)$ o Suecia $(10,8)^{847}$. Y sin embargo, el número de personas en régimen de privación de libertad ha crecido más de un $60 \%$ del año 2000 a $2008^{848}$. ¿Que significan estos datos y cómo interpretar tales tendencias? ¿Por qué a la apuesta clara por la disminución de la criminalidad en los últimos años, se corresponde una población carcelaria aún mayor? La respuesta a estas inquietudes están asociadas como veremos más adelante a la tendencia de la utilización de la cárcel como prima ratio; a la mayor represión -las falta se convierten en delitos-, y a la creación de nuevos tipos penales dando paso a la denominada expansión del Derecho penal.

Lo paradójico, no obstante, es que a pesar de la contundencia de estos datos objetivos sobre la dinámica decreciente de la tasa delictiva, las sensaciones de miedo e

\footnotetext{
${ }^{845}$ Ministerio del Interior de España. Balance 2010. Evolución de la criminalidad.

${ }^{846}$ Las tasas de cada país corresponden a los años de 2008 y 2009. En el caso de España (Territorio MIR) y Francia corresponden a diciembre 2010. Ministerio del Interior de España. Balance 2010. Evolución de la criminalidad.

847 Según datos aportados por la directora general de Instituciones Penitenciarias en la Comisión de Interior del Congreso el 30 de septiembre de 2008, hasta la primera semana de noviembre de ese mismo año la cifra total de presos en cárceles españolas era de 73.138. Esta cifra representa 156 reclusos por cada 100.000 habitantes, lo que ubica a España con 54 puntos por encima de la media de la UE, situada en 102, según fuentes de interior. Diario El País, "Cuando la Ley se hace a base de escándalo" 21/11/2008. ww.elpais.com

${ }^{848}$ Diario El País, “cuando la Ley se hace a base de escándalo” 21/11/2008. www.elpais.com
} 
inseguridad siguen estando presentes en la sociedad española ${ }^{849}$. Según los datos aportados por el Ministerio del Interior la preocupación por la seguridad ha disminuido de 13,6\% (en el periodo de septiembre 2007 a septiembre de 2008) a 11,0\% en febrero de 2009, llegando en febrero de 2011 a 9,4\% la percepción de inseguridad ciudadana ${ }^{850}$. Sin embargo, la palabra que encierra y/o caracteriza el tono emocional de la sociedad de nuestros días es el miedo. Existe una sensación de inseguridad venida de los riesgos inmanentes de la sociedad posmoderna y las nuevas tecnologías, trasmutada en miedo a la delincuencia callejera, vertida, alimentada y construida desde los medios de comunicación y la amplificación de la resonancia social que facilitan. El temor y la alarma social recreados alrededor de casos emblemáticos explotados desde los medios de comunicación contribuyen enormemente a que la población se sienta vulnerable y se aprecie víctima potencial.

Las demandas de seguridad y protección a su vez están lideradas por las victimas - reales, potenciales o simbólicas - arropadas con el discurso fundado en el axioma de que "cualquiera de nosotros puede ser la próxima víctima”. Quienes ejercen la vocería de las víctimas han tomado el protagonismo en las exigencias de retribución del castigo, asumiendo para si los intereses de la sociedad que quedan subsumidos dentro de sus propios intereses: son sus sentimientos, sus experiencias traumáticas, sus exigencias particulares los que asumen la representación de los intereses públicos. ${ }^{851}$ A esto se suma el debilitamiento de la confianza en la capacidad de las instituciones de control social formal - la policía y del gobierno en general - para hacer algo al respecto. ${ }^{852}$ Pero sobre todo reclaman un sistema de justicia penal más duro, con penas de prisión más elevadas y cumplidas íntegramente. ${ }^{853}$ No hay magnanimidad alguna con el victimario; tampoco atenuantes ni beneficios. Se trata de que caiga sobre él todo el peso de la ley y, en lo posible, que no se levante.

\footnotetext{
${ }^{849}$ Véase, SOTO NAVARRO, S., La influencia de los medios en..., op. cit., págs. 25 y ss.

${ }^{850}$ Ministerio del Interior de España. Balance 2010. Evolución de la criminalidad.

${ }^{851}$ DIÉZ RIPOLLÉS, J. L., La política criminal en la encrucijada, Editorial B de la F, MontevideoBuenos Aires, 2007, págs. 77 y ss.

${ }^{852}$ GARLAND, D., La cultura del control..., op. cit., pág. 45.

${ }^{853}$ GARCÍA ARÁN, M., "Delincuencia, inseguridad y pena en el discurso mediático." En Muñoz Conde (coord.), Problemas actuales del derecho penal y de la criminología: estudios penales en memoria de la Profesora Dra. María del Mar Díaz Pita, Ed. Tiran lo Blanch, Valencia, 2008, pág. 106.
} 
La imagen y el estereotipo del delincuente también ha cambiado. Ya no son identificados individualmente como indeseados, sin el cual la sociedad estaría a salvo; ya no hay imputación alguna respecto de su procedencia social o a su historia de vida para comprender las circunstancias sociales del comportamiento desviado. Ahora son señalados como grupos peligrosos de riesgo ante los que hay que protegerse: la delincuencia violenta sexual -en especial los pederastas-, los terroristas, los delincuentes reincidentes o habituales y los inmigrantes.

Las instituciones políticas - particularmente el legislador - y de administración, por su parte, han respondido a estas demandas con lo que se ha venido a denominar populismo punitivo: idas y venidas de sucesivas reformas penales y aprobación de nuevas leyes, cuyas iniciativas se forman al calor de los dramas personales de las víctimas a los que se pretende atender y complacer. En la complacencia de las expectativas y exigencias de estas, en tanto que portavoces del interés general, se atiende a las exigencias de la sociedad.

Advierte GARLAND que el delito se ha redramatizado. Esa sensación de un público temeroso y resentido ha tenido fuerte impacto en el estilo y el contenido de las políticas públicas en los últimos años ${ }^{854}$. Así, la Política Criminal está ahora destinada a cumplir la función simbólica de calmar el miedo de la gente, suerte de bálsamo que tranquiliza en la medida que neutralice las fuentes del miedo, a saber, los grupos peligrosos de riesgo.

Se utiliza la pena como respuesta de la temida inseguridad. ${ }^{855}$ Siguiendo a Garland, "el nuevo discurso de la Política Criminal invoca sistemáticamente un público lleno de ira, cansado de vivir con temor, que exige medidas fuertes de castigo y protección. El sentimiento que atraviesa la Política Criminal es ahora con más frecuencia un enojo colectivo y una exigencia moral de retribución en lugar del

\footnotetext{
${ }^{854}$ GARLAND, D., La cultura del control... op. cit., pág. 45.

${ }^{855}$ MAQUEDA ABREU, M. L., "Crítica a la reforma penal anunciada", Jueces para la democracia, $\mathbf{N}^{\circ}$ 47, 2003, pág. 8 .
} 
compromiso por buscar una solución justa, de carácter social. La temperatura emocional de las políticas públicas se ha elevado". 856

Los estudiosos de las ciencias penales han dedicado gran esfuerzo y tiempo en explicar los modelos de intervención penal - Garantista, Resocializador y de la seguridad- ${ }^{857}$. Han abundado los debates que mueven los límites de la discusión entre las garantías de un Estado de Derecho y la eficacia de la Política Criminal, entre el llamado Derecho penal del enemigo frente a una Política Criminal integradora; la sectorización, modernización y la expansión del Derecho penal; la sociedad del riesgo y los factores objetivos y sujetivos del miedo. En los hechos, no obstante, se ha venido imponiendo y legitimando social, política y jurídicamente en los últimos años el incremento de la represión y el endurecimiento de las penas. De allí que algunos estudiosos han convenido en que el modelo penal garantista que conocimos inherente al Estado de Bienestar ha sido sustituido por un "modelo penal de la seguridad ciudadana", pauta que parece seguir el Anteproyecto de Reforma al Código Penal 2008.

\section{EL MODELO DE SEGURIDAD COMO RESPUESTA A LA SOCIEDAD DEL RIESGO. (MÁS SEGURIDAD, MENOS LIBERTAD)}

Los aspectos mencionados hasta aquí dando cuenta de una dirección trazada en los ámbitos penal y criminológico, no son aislados ni están ajenos al proceso de transformaciones sociales, económicas y culturales de las sociedades tardomodernas.

\footnotetext{
${ }^{856}$ GARLAND, D., La cultura del control... op. cit., pág. 45.

${ }^{857}$ Véase, Ente otros: DÍEZ RIPOLLÉS, J. L., La política criminal...op. cit.; SILVA SÁNCHEZ, J. M., La expansión del Derecho penal. Aspectos de la política criminal en las sociedades postindustriales, Ed. B de F, Montevideo-Buenos Aires, reimpresión de la segunda edición, 2006; GOMEZ MARTIN, V., "Libertad, seguridad y "sociedad del riesgo", en CORCOY BIDASOLO, M.; GÓMEZ MARTÍN, V. y MIR PUIG, S., La política criminal en Europa, Ed. Atelier, Barcelona, 2004 pags. 59-90. HASSEMER, W., "Sobre el ejercicio abusivo de los derechos," en GUZMÁN DALBORA, J. L. (Coord), El penalista liberal. Controversias nacionales e internacionales en derecho penal, procesal penal y criminología. Homenaje a Manuel de Rivacoba y Rivacoba, Ed. Hammurabi, Buenos Aires, 2004, pags. 111-127; MAQUEDA ABREU, M. L. "Políticas de seguridad y Estado de Derecho." en PÉREZ ALVAREZ, F., (ED.), Serta: in memoriam Alexandro Baratta, Ed. Universidad de Salamanca, 2004, pags. 1287-1298.; ACALE SÁNCHEZ, "Del Código Penal de la democracia al Código Penal de la seguridad", PÉREZ ALVAREZ, F., (ED.), Serta: in memoriam Alexandro Baratta, Ed. Universidad de Salamanca, 2004, pág. 1204; MENDOZA BUERGO, "Gestión del riesgo y política criminal de seguridad en la sociedad del riesgo", en DA AGRA, DOMÍNGUEZ, GARCÍA AMARO, HEBBEERECHT, RECASENS, (edits.), La seguridad en la sociedad del riesgo. Un debate abierto. Ed. Atelier, Barcelona, 2003, págs. 46 y ss. ZUÑIGA RODRÍGUEZ, L. "Viejas y nuevas tendencias políticocriminales en las legislaciones penales", en BERDUGO GÓMEZ DE LA TORRE, I.; SANZ MULAS, N., (coords.), Derecho penal de la democracia “vs" seguridad pública, Ed. Comares, Granada, 2005, pág. 99-130.
} 
Con la irrupción del neoliberalismo anglosajón en la década de 1980 se generaron cambios significativos en todos los órdenes sociales, de los cuales el más significativo ocurre en la dimensión cultural -o del mundo de la vida, para algunos- donde se construyen las estructuras de control social, se ordena su uso y se les otorga significado $^{858}$.

La tendencia de Política Criminal asentada en Estados Unidos y Europa en las dos últimas décadas abandona la concepción terapéutica del Estado de Bienestar y asume una neoliberal que, entre otros cambios, reduce el gasto en la rehabilitación y resocialización ${ }^{859}$. No quiere decir esto que el sistema penal correccionalista del Estado de Bienestar haya desaparecido. Formalmente sigue existiendo, pero sus instituciones se han redefinido. El principal cambio se ha producido en el tejido cultural, allí donde se forjan las sensibilidades y se asientan los valores. La resocialización y el correccionalismo como ideales de un modelo penal se sacrifican ante el ideal de protección, aseguramiento y el control. ${ }^{860}$ Las instituciones del Estado benefactor sin ser desmontadas pasan ahora a cumplir una función asegurativa y no correccionalista. La prisión deja de ser un instrumento de resocialización para convertirse en una institución puesta al servicio de la exclusión y la neutralización. La rehabilitación del delincuente antes un fin en si mismo, es ahora un medio o instrumento para conseguir fortalecer el control social y reducir los costes. Las garantías legales, los beneficios procesales y las prestaciones administrativas de los que gozaba el delincuente, se sacrifican por el ideal de la seguridad del gran público. En última instancia este desplazamiento del foco de la Política Criminal se traduce en una pretendida racionalización económica del gasto público, puesto que ya no existe soporte social al gasto destinado antes al tratamiento y rehabilitación del delincuente ${ }^{861}$.

\footnotetext{
${ }^{858}$ GARLAND, D., La cultura del control... op. cit., pág. 286.

${ }^{859}$ En América Latina la reinserción social contenida en la ideología de la resocialización ha sido algo quimérico, asumido en sus aspectos formales. En los hechos, sin embargo, las prisiones continúan siendo depósito de personas sin derechos y sin las garantías mínimas; una vez dentro no se garantiza la vida a los reclusos.

${ }^{860}$ GARLAND, D., La cultura del control... op. cit., págs. 286 y ss.

${ }^{861}$ GÓMEZ MARTÍN, V., Cultura del control, sociedad..., op. cit., págs. 70 y ss.
} 
Este proceso de grandes transformaciones se sucede en el marco de un nuevo tipo de sociedad que va emergiendo y que ha sido resumida por algunos como la sociedad del riesgo ${ }^{862}$.

\subsection{Modernidad Y Globalización: El Marco Cultural de la SOCIEDAD DEL RIESGO.}

La característica de la conditio humana a comienzos del siglo XXI son los riesgos impronosticables e inseguridades fabricadas fruto de la victoria de la modernidad $^{863}$. Esta cita tomada de uno de los últimos libros del ya célebre Beck, se ciñe tal vez como ninguna a la idea expuesta hace ya una década de la sociedad del riesgo esbozada por el autor. Obsérvese que se asocia tal idea con la condición humana del siglo en curso, cuyos riesgos (impronosticables) e inseguridades (fabricadas) resultan inmanentes a la entronización de la modernidad. De forma que estas vienen asociadas intrínsecamente a ella y no resultan lastres o desviaciones del proyecto ilustrado. Están en su núcleo, son inmanentes a su naturaleza como la propiedad de la tierra lo era al régimen feudal. Vienen aparejadas a las bondades que nos llegan, asociadas especialmente al confort susceptible de alcanzar mediante el consumo y uso de las novedades tecnológicas, cuyos atributos y aprovechamientos sobrepasan con creces nuestras posibilidades de experiencia. Lo que sigue, en la línea de BECK, procura situar el marco cultural en el que se ubica el tratamiento del miedo como hecho social y sociológico que desarrollaremos más adelante. Por lo pronto, quedémonos con la idea de que los riesgos y miedos a los que aquí aludimos son inherentes a la idea de modernidad que ha triunfado.

Habitar el mundo moderno, hacerse de un espacio, organizarse en el, demanda una comprensión de la confrontación con estos riesgos de alcance catastróficos - lo que define la cualidad novísima de la sociedad del riesgo mundial en BECK -, confrontación que es en realidad una auto/confrontación con los dispositivos institucionales de los que

\footnotetext{
${ }^{862}$ BECK, U., La sociedad del riesgo. Hacia una nueva modernidad, Ed. Paidós, 1998., Barcelona; del mismo autor, La sociedad del riesgo global, Ed. Siglo XXI, Madrid, 2002; BECK, U., ¿Qué es la globalización? Falacias del globalismo, respuestas a la globalización, Estado y sociedad, Ed. Paidós, 2001.

${ }^{863}$ BECK, U., La sociedad del riesgo mundial, en busca de la seguridad perdida. Ed. Paidós, Barcelona, 2007, pág. 260 y ss.
} 
nacen los peligros y con la particular lógica distributiva de los conflictos entre quienes disfrutan de las ventajas y oportunidades de los riesgos y quienes tienen que cargar con sus inconvenientes, lo que Beck denomina “antagonismo del riesgo". 864

La singularidad histórica que diferencia a la sociedad del riesgo mundial de la sociedad industrial nacional que encarnaba a la primera modernidad - y de todas las civilizaciones precedentes - es la posibilidad de decidir sobre la suerte del planeta. Esto incluye tanto la posibilidad de auto/aniquilación - el Apocalipsis está en nuestras manos- como la posibilidad de la auto/transformación antropológica abierta con el descubrimiento del mapa del genoma humano (julio/2000) que ensanchaba enormemente el horizonte humano en las puertas del siglo que apenas se iniciaba. El propio Beck presagia este hecho en el horizonte retrospectivo como "el acto fundador, el motor de, ahora ya, la sociedad del bio/riesgo mundial" ${ }^{\prime 865}$.

Los riesgos sobrevenidos del uso extendido de las nuevas tecnologías a cualquier espacio de la acción humana, por un lado, y de las consecuencias socio/ecológicas de la industrialización, por otro, son el resultado de decisiones humanas conscientes y con arreglo a ciertos fines, materializadas a través de organizaciones en un marco institucional que las posibilita y legitima. Decisiones que han estado fundadas en el cálculo de la racionalidad instrumental en todas sus dimensiones, desde la pecuniaria hasta la prospectiva. Estos riesgos alcanzan su dimensión política no como consecuencia de su magnitud sino en virtud de su especificidad social: no son fatalidades ineludibles del destino; antes bien, son el resultado social de acciones humanas, fruto de la simbiosis del saber técnico y el cálculo económico. La madera particular de esta clase de riesgos es diferente de la de aquellos causados por las guerras sobre el imaginario de los pueblos, causas de la mayor destrucción derivada de la interacción humana conocida en la historia. Los riesgos posmodernos se presentan por vías pacíficas, son fruto del árbol de la racionalidad que nos gobierna, de los centros de

\footnotetext{
${ }^{864}$ Véase, BECK, U., La sociedad del riesgo mundia, ..., op. cit., págs. 265 y ss.

${ }^{865}$ Idem, págs. 261y ss.
} 
pensamiento y tecnología a su servicio y de las estructuras de bienestar que les bordan socialmente y blindan de la protección de quienes velan por la ley y orden ${ }^{866}$.

Cuando se acuña el concepto de sociedad del riesgo, se hace mención a las inseguridades derivadas del desarrollo tecnológico, de la globalización de la economía y el temor e inseguridad que produce la sensación de inexistencia de control sobre las consecuencias de dinámicas sociales desplegadas bajo el impulso de dichas tecnologías. A ello se suman las fuentes socioeconómicas del miedo ante los riesgos individuales o sociales del régimen productivo, y el declive de los rasgos identitarios asociados al desplome de las certezas de los referentes socioculturales que marcaban la vida de las sociedades modernas, a saber, la familia, la clase social, la religión o las identidades de género.

\subsection{DEL RIESGO EXTERNO Y EL RIESGO FABRICADO.}

Pero, ¿qué son los riesgos? ¿Puede identificarse un riesgo sin determinar para quién? ¿Puede una misma situación riesgosa representar oportunidades para algunos y marco de amenazas para otros? ¿Quién los crea y quienes los sufren?

Desde el punto de vista objetivo el riesgo es la posibilidad de ocurrencia de un daño futuro, susceptible de medición por medio de la constatación estadística de las probabilidades de materialización de perjuicios, al margen de cualquier valoración subjetiva. Desde la perspectiva sociológica es algo construido por y desde la percepción que los individuos tienen de él. Los riesgos no existen en sí mismo como las cosas o el mundo natural. Constituyen estados sociales de percepción respecto del futuro inmediato. El riesgo es una categoría psicológica y socialmente construida, más allá de una escala de probabilidad de que un daño ocurra ${ }^{867}$.

Pero, y nuevamente hacemos énfasis en su especificidad en tanto que Estado Social y no cúmulo de eventos que traducen peligros, la imprecisión de los riesgos, su ubicuidad y su deriva en un agregado de percepciones expanden su potencial. La

\footnotetext{
${ }^{866}$ Idem, pág. 49.

${ }^{867}$ PRIETO NAVARRO, E., "Sobre los límites y posibilidades de la respuesta jurídica al riesgo", en AA.VV., La seguridad en la sociedad del riesgo. Un debate abierto. Ed. Atelier, Barcelona, 2003, págs. 31 ys.
} 
percepción del riesgo se hace más profunda y extendida en la medida que los riesgos globales se sustraen a los métodos científicos de su medición y valoración. La diferencia entre los riesgos reales y la percepción del riesgo se desvanece y el imaginario social sobre el riesgo llega a ser más importante que los sofisticados escenarios de probabilidad de su ocurrencia a los que arriban los expertos ${ }^{868}$.

GIDDENS ha diferenciado entre el riesgo externo y el riesgo fabricado agregando precisión a la entidad particular de ambos ${ }^{869}$. Sobre el primero refiere que alude a la posibilidad de que se produzcan eventos que pueden afectar a los individuos de forma inesperada, pero debido a que tal cosa ocurre con cierta frecuencia se trataría de un fenómeno predecible, estocástico, y por lo tanto asegurable, incluso mercantilmente asegurable. El riesgo fabricado, en abierto antagonismo con el anterior, es una situación que presenta problemas nuevos, en muchos casos imprevisibles y cuyas consecuencias son muy difíciles de calcular. La causa general de esta nueva situación es, como se ha dicho antes, la intervención humana. El riesgo fabricado es una consecuencia de la dinámica civilizatoria del desarrollo humano, especialmente en sus dimensiones científico/tecnológica y socio/ecológica, y se refiere a un aspecto que los fundadores de la sociología no lograron apreciar en su disección de la sociedad industrial que amanecía. Tal vez la idea del riesgo fabricado se comprende mejor asociado sobre todo a los nuevos riesgos del medioambiente (contaminación, alteración climática, agotamiento de recursos, etc.) respecto de los cuales la historia proporciona muy pocos precedentes, al menos en el alcance global que hoy día poseen, y que ha expuesto ante la evidencia a la ilusión progresista del ideal moderno.

Una de las paradojas de la ilustración se reduce a que del mayor conocimiento no vienen mayores seguridades. Las fuentes de peligro ya no están en la ignorancia sino en el saber ${ }^{870}$. Los riesgos en las sociedades más avanzadas tienen la cualidad de tratarse de amenazas que suelen permanecer invisibles o por lo menos no evidentes, por ejemplo, el boquete de la capa de ozono o el deshielo del Ártico. Estos riesgos deben

\footnotetext{
${ }^{868}$ BECK, U., La sociedad. del riesgo mundial... op. cit., pág. 266.

${ }^{869}$ GIDDENS, A., "Vivir en una sociedad postradicional", en BECK, U., GIDDENS, A., y LASH, S. Modernización reflexiva. Política, tradición y estética en el orden social moderno, Ed. Alianza, Madrid, 1997, págs. 75 y ss.

${ }^{870}$ BECK, U., La sociedad del riesgo. Hacia una ..., op. cit., pág. 237.
} 
necesariamente basarse en interpretaciones causales y por ello quedan insertos en los espacios de dominio de los sistemas/expertos, porque quedan abiertos a procesos sociales de definición ${ }^{871}$.

Claro que el riesgo ya existía en la primera modernidad, pero era radicalmente diferente a la que se destaca en el modelo de la sociedad post/industrial. Ubicados en la esfera que nos interesa, mientras que en la primera, la admisión del concepto del riesgo permitido favorece la delimitación de las fronteras de la incriminación y el alcance de las conductas penalmente relevantes; en la sociedad del riesgo, la asunción del principio de precaución lleva a la restricción de los ámbitos de riesgo tolerados y a una exacerbación de la seguridad como ideología ${ }^{872}$.

\subsection{Del Riesgo Postmoderno al Miedo a la Inseguridad. La RECONSTRUCCIÓN DEL CONTROL SOCIAL.}

La criminología de la sociedad del riesgo está obligada a re/construir con estos mimbres su discurso sobre el control social. Está constreñida a develar cómo ocurre el encaje del miedo cotidiano que anida en las ciudades en este escenario de riesgos entendido como Estado social de percepción de fuentes de amenazas difusas. El modelo de control social de la política administrativa clásica ya no es idóneo para enfrentarse a este nuevo marco socio/cultural. Entre otras cosas porque está desbordada como consecuencia de la irrupción de la complejidad que la amenaza del riesgo trae consigo.

Los cambios en la lucha contra el crimen en realidad son esfuerzos por adecuar las instituciones penales a los valores políticos y culturales de la sociedad del riesgo. Pero estas transformaciones, a su vez, también desempeñan un papel en la producción de esta sociedad, ayudando a constituir el significado de la modernidad tardía. Las políticas policiales y judiciales de hoy no se diseñan solo con sujeción a los problemas del crimen y la inseguridad. También institucionalizan un conjunto de respuestas a estos conflictos que provocan efectos secundarios en su impacto social. Como advierte

\footnotetext{
${ }^{871}$ CAMPIONE, R., "El que algo quiere algo le cuesta: notas sobre la Kollateralschádengesellschaft", en AA.VV., La seguridad en la sociedad del..., op. cit., págs. 14 y ss.

${ }^{872}$ MENDOZA BUERGO, B., "Gestión y política criminal de seguridad en la sociedad del riesgo", en AA.VV., La seguridad en la sociedad del..., op. cit., págs. 76 y ss.
} 
Garland $^{873}$, especialmente en las sociedades avanzadas, “...la modernidad tardía es vivida - no sólo por los delincuentes, sino por todos nosotros - de una forma más que nunca definida por instituciones policiales, penales y preventivas".

El riesgo de procedencia humana como hemos visto se alimenta en primer lugar de la desconfianza hacia los expertos que controlan y toman las decisiones en el manejo de los avances técnicos a las que el resto de ciudadanos está expuesto; y, en segundo lugar, de los residuos humanos ${ }^{874}$ que la sociedad tecnológica, crecientemente competitiva, desplaza hacia la marginalidad y cuyos individuos inmediatamente son percibidos como fuente de riesgos personales y patrimoniales ${ }^{875}$. Lo significativo en cualquier caso es que el miedo ante esos múltiples riesgos tecnológicos, económicos y sociales ha sido transformado colectivamente, drenado institucionalmente, en temor hacia la delincuencia. La criminalidad de los marginados o de los grupos socialmente excluidos pasa a ser "la dimensión no tecnológica de la sociedad del riesgo" ${ }^{876}$.

Como bien señala $\mathrm{HASSEMER}^{877}$, también “...la violencia, el riesgo y la amenaza son hoy fenómenos centrales de la percepción social. Cada vez con mayor intensidad aparece la seguridad ciudadana como bien jurídico, alimentando a una creciente industria al respecto”. Antes que a graves amenazas o grandes peligros, la sociedad se confronta con «inseguridades fabricadas» como consecuencia de las crisis económicas y el deslave de las instituciones del Estado de Bienestar, de la legitimidad del sistema político y del Estado de Derecho ${ }^{878}$.

\footnotetext{
${ }^{873}$ GARLAND, D., "Lucha contra el crimen y modernidad tardía en Estados Unidos y Gran Bretaña", en Revista Archipiélago. Prisiones de la Miseria. Estado Penal y Seguridad Ciudadana, № 55, 2003, págs. 102 y ss.

${ }^{874}$ Vidas desperdiciadas les llama Bauman. BAUMAN, Z., Vidas desperdiciadas, Ed. Siglo XXI, Madrid, 2006.

${ }^{875}$ SILVA SÁNCHEZ, J. M., La Expansión del derecho penal..., op. cit., pág. 14.

${ }^{876}$ DÍEZ RIPOLLÉS, J. L., "De la sociedad del riesgo a la seguridad ciudadana: Un debate desenfocado", en AA.VV., Libro Homenaje al Profesor Dr. Gonzalo Rodríguez Mourullo, Ed. Civitas, 2005, pág. 278 y ss.

${ }^{877}$ HASSEMER, W., Persona, mundo y responsabilidad. Bases para una teoría de la imputación en Derecho Penal. (T rad. MUÑOZ CONDE/ DÍAZ PITA), Ed. Tirant lo Blanch, Valencia, 1999, pág. 81.

${ }^{878}$ PÉREZ CEPED, A. I., La seguridad como fundamento..., op. cit., pág. 340.
} 
El carácter arriesgado e inseguro de las actuales relaciones socioeconómicas es el pasto donde florece la preocupación en los voceros del orden por el control, así como la urgencia con la que se segrega, fortifica y se excluye. Este marco de riesgos ubicuos y de circunstancias que potencian el miedo impulsa los esfuerzos obsesivos por mantener bajo vigilancia la vida diaria de los individuos peligrosos, aislar a los grupos de riesgo e imponer controles sobre entornos abiertos y no regulados. Este marco, reafirma Garland $^{879}$, es la fuente de profundas formas de ansiedad que se expresan en la actual conciencia del delito, en la mercantilización de la seguridad y en un medio ambiente cuya cartografía se ha diseñado para desmembrar los espacios urbanos y separar a la gente.

La extendida sensación de inseguridad no guarda correspondencia con las posibilidades reales de sufrir tales riesgos. La inseguridad proviene no solo de la sobre/exposición mediática de delitos a la que haremos referencia posteriormente; también de la incapacidad del ciudadano para asimilar el acelerado cambio tecnológico $\mathrm{y}$, por último, de la convicción de que se suceden estos con tanta rapidez que se lleva por delante las certezas ancladas en un tipo de relaciones sociales y en los valores y normas asociados a la primera modernidad.

En la sociedad del riesgo, la criminalidad es vista como el "efecto colateral", el fallo indeseado de una actividad útil, concretamente, del proceso de producción, intercambio y consumo de los valores de cambio. La "desviación” respecto a la ley se contempla ahora como algo "normal" y, en gran medida, inevitable. Ambas conceptos desviación y normal - de amplio contenido social en la criminología crítica se reducen ahora a sus connotaciones estadísticas. Se trata de reducir ese riesgo a niveles aceptables, lo cual, en definitiva, es lo único que puede lograr la tecnología del aseguramiento a través de la redistribución de la probabilidad del riesgo o del siniestro en el lenguaje actuarial. La decisión individual de transgredir la ley se considera el resultado de un cálculo realizado por el propio sujeto delincuente entre las ganancias y costes virtuales de su actuación. Desde esta explicación de la conducta humana, el control social pasa a preocuparse sólo del comportamiento de los individuos en sentido externo, físico, cuasi somático y no en relación a los condicionantes subjetivos de orden

$\overline{879}$ GARLAND, D., Lucha contra el crimen y modernidad... op. cit., pág. 102. 
cognitivos, institucionales y normativos de la persona. El control social busca ahora el doble objetivo de identificar y neutralizar los comportamientos de riesgo. La pena, en consecuencia, tiene exclusivamente como función la gestión de los riesgos. Ya no anida en su aliento la erradicación de la delincuencia, menos el ánimo resocializador que inspiraba la Política Criminal reciente. La delincuencia se da por preexistente y normal. Simplemente, se trata de mantener separados a aquellos que son considerados productores de riesgos y aquellos otros que son potencialmente víctimas de esos riesgos y pagan la nueva tecnología aseguradora ${ }^{880}$.

El riesgo significa en las políticas penales de nuevo cuño, paradigma del cual son emblema los programas de "tolerancia cero", la cuantificación, según parámetros hipotéticamente objetivos, del grado de peligrosidad presente en un determinado sujeto que, según su frecuencia y rango estadísticos, se enmarca dentro de un determinado "grupo de riesgo". ${ }^{881}$ Tristemente, esta Política Criminal basada en los "cálculos" de los peligros y la redistribución de los mismos termina siempre sesgando su fuerza real y simbólica contra los más débiles.

Según DÍEZ RIPOLLÉS ${ }^{882}$, las principales manifestaciones de la sociedad del riesgo en el campo del Derecho penal tienen que ver con:

a) las dificultades para determinar el riesgo con anterioridad;

b) las confusiones que resultan de establecer la imputación de la responsabilidad individual o colectiva, dado que el control del riesgo no solo escapa a la gobernabilidad individual sino que aparece difuminado diluyendo las responsabilidades;

c) La amplia sensación de inseguridad que no guarda correspondencia con las posibilidades reales de sufrir tales riesgos.

\footnotetext{
${ }^{880}$ PÉREZ CEPEDA, A. I., La seguridad como fundamento ..., op. cit., págs. 343 y ss.

${ }^{881}$ Idem, pág. 387.

${ }^{882}$ DÍEZ RIPOLLÉS, J. L., La política criminal ..., op. cit. págs. 132 y ss.
} 


\subsection{Gestión y Distribución del Riesgo ante Individuos Peligrosos.}

Ante el poder público los delincuentes ya no son clientes que necesitan ayuda sino riesgos que deben ser gestionados. Los tratamientos de rehabilitación en procura de la reinserción social del delincuente son sustituidos por los controles efectivos y de bajo coste para el Estado. ${ }^{883}$ La racionalidad en Política Criminal de la gestión del riesgo se entiende como minimizar los costes y maximizar la seguridad. La finalidad ya no es acabar con la delincuencia, sino procurar su gestión atenuando o minimizando sus consecuencias. La criminalidad ha dejado de ser concebida como una desviación social de acuerdo con las teorías funcionalistas de antes, susceptible de ser tratada con fines resocializadores. Se sustenta en que la sociedad ya no debe asumir los riesgos que significa la reincidencia, por lo tanto dichos riesgos deben recaer sobre el autor que debe ser sometido a extremas medidas asegurativas ${ }^{884}$

Con este discurso de la maximización de la seguridad ante el riesgo representado por grupos de delincuencia señalados socialmente, se entroniza también un conjunto de prácticas de base actuarial ${ }^{885}$-técnicas cuantitativas probabilísticas y de estadística propias de la industria aseguradora- para determinar la peligrosidad del delincuente y la posibilidad de reincidencia, desplazando a las técnicas predictivas basadas en el análisis individual de responsabilidad y reincidencia.

El modelo político-criminal que se orienta por la ideología de la seguridad reconoce como punto de partida la incapacidad fáctica del Estado para derrotar a la criminalidad y, consecuentemente, garantizar la seguridad absoluta de la ciudadanía. Ante semejante reconocimiento se atribuye a la Política Criminal la gestión y distribución de unos riesgos que no pueden ser absolutamente controlados, en un escenario de gasto público restringido en el que el principio del coste/beneficio determina los límites en el diseño de las orientaciones político- criminales. ${ }^{886}$

\footnotetext{
${ }^{883}$ Ibídem, pág. 287.

${ }^{884}$ BRANDARIZ GARCÍA, J., Política criminal de la exclusión, Ed. Granada, 2007, pág. 82.

${ }^{885}$ SILVA SÁNCHEZ, J. M., El retorno a la Inocuización..., op. cit. pág. 701.

${ }^{886}$ BRANDARIZ GARCÍA, J., Política criminal de la ... op. cit., pág. 82.
} 


\section{MEDIOS, CRIMINALIDAD Y ORDEN POLÍTICO. LA VÍCTIMA COMO ELEMENTO CENTRAL DEL DISCURSO MEDIÁTICO.}

\subsection{EXCURSO INTRODUCTORIO.}

Que la construcción social de la realidad sea hoy mediada desde los despachos de los medios de comunicación, especialmente los audiovisuales, es un hecho sobre el que existe unanimidad en los ámbitos académicos, sociales o políticos. El tratamiento de la noticia ya ha dejado de ser estrictamente un asunto de "comunicación social" para ser abiertamente correspondido con una línea editorial o alineado a ciertos intereses ${ }^{887}$. Ello por supuesto no es inocuo a la percepción social que se genera respecto de un tema o un evento, erigiéndose en el imaginario colectivo unas formas cognitivas y conductuales sobre el mismo, generando unos efectos o resultados. Estos en el ámbito del hecho criminal puede resumirse en un discurso mediático sobre los temas de inseguridad personal en los que:

(a) se tiende a exagerar el volumen de la realidad criminal;

(b) se recurre al sensacionalismo y a la dramatización de la información;

(c) se crea alarma social alrededor de algunos casos emblemáticos; y, finalmente,

(d) se construye socialmente la realidad influyendo directamente en la percepción de inseguridad de los ciudadanos.

En la medida que es mayor la presencia de noticias relacionadas con la inseguridad, también es mayor la sensación de inseguridad y el temor, el miedo de ser víctima de algún delito, aunque no se corresponda con las posibilidades reales de serlo. O lo que es igual, existe una correspondencia entre el tratamiento mediático del hecho criminal y el estado de ánimo de la población, especialmente urbana, expectante ante la probabilidad de ser víctima potencial de un delito.

Ahora bien, ¿cuál es el mensaje que exitosamente elaboran y trasmiten los medios a través del discurso construido? Sin pretender una caracterización válida para todas las latitudes, seguidamente se presenta un perfil que encaja para la realidad

\footnotetext{
${ }^{887}$ Nota: citar la diferencia entre opinión pública y opinión publicada
} 
española y eventualmente puede orientar un trazado igual para el caso de algunos países latinoamericanos.

En los programas de sucesos los medios recurren a dos tipos discursivos de la noticia penal. El primero, tendiente a la expansión del miedo y la alarma social, se presenta en sucesos inéditos donde se destaca el relato de la víctima y su exigencia de retribución. Regularmente se exponen en las conexiones "en directo", el espacio de teleinformativo o en avances de estos. En el segundo, proclive a la expansión del Derecho penal, se presentan sucesos conocidos ya tratados en programas anteriores, se resalta la peligrosidad del autor y se crítica el sistema de garantías penales. La construcción de estas noticias, se basa en la aproximación de la peligrosidad de determinados individuos o grupos sociales con el cuestionamiento de las garantías penales y procesales. Esto suele ocurrir, en los programas de opinión o de debate ordinario o especialmente dedicado al asunto ${ }^{888}$.

Estos dos procesos podemos encontrarlo combinados entre sí, en mayor o menor grado en los programas de sucesos, en informativos de televisión y en los periódicos de tirada nacional. En todos de forma recurrente se destaca: a) la nacionalidad de los presuntos autores del delito, en caso de ser extranjeros; b) el déficit policial y la alternativa a la seguridad privada; c) la debilidad de las leyes y la necesidad de emprender una reforma del Código Penal para dar una respuesta punitiva adecuada a este tipo de delincuencia [el endurecimiento de las penas]; y, d) el protagonismo de las víctimas, enfatizando en su discurso y la reivindicación de su derecho a exigir el castigo. $^{889}$

La pornografía infantil y los abusos sexuales de menores, ${ }^{890}$ junto con los homicidio/asesinato, lesiones, delitos contra la libertad sexual, robo y desórdenes públicos son los delitos que tienen mayor cobertura informativa. El periodismo

\footnotetext{
${ }^{888}$ BAUCELLS LLADÓS, J.; PERES-NETO, L., "Discurso televisivo sobre el crimen: los programas especializados en sucesos", en GARCÍA ARÁN, M..; BOTELLA CORRAL, J. (Dir.), Malas noticias. Medios de comunicación, política criminal y garantías penales en España. Ed. Tirant Lo Blanch, Valencia, págs. 139 y ss.

${ }^{889}$ REBOLLO VARGAS, R., "Oleadas informativas y respuesta político criminal”, en GARCÍA ARÁN, M.; BOTELLA CORRAL J., (Dir.), Malas noticias...op. cit., pág. 77 y ss.

${ }^{890}$ SOTO NAVARRO, S., La influencia..., op. cit., pág. 12.
} 
sensacionalista se distingue por la presentación de relatos sobre persona, conductas o sucesos que suponen transgresiones de la ley, de la moral aceptada y de las normas sociales que se presumen conforman las virtudes públicas. Este tipo de prensa se nutre de asuntos próximos a la colectividad, utiliza una serie de recursos lingüísticos y discursivos que contribuyen a falsear los hechos y a hiperbolizar la realidad, y busca convertir al lector en un testigo imaginario de los sucesos narrados. ${ }^{891}$

En el discurso de los medios se juega con el arquetipo mediático del antagonismo socio/moral simple y primario, que contraponen la figura de la víctima exigiendo retribución a la del delincuente como fuente de peligro. Ocurre que en los programas de sucesos cuanto más se novela un acontecimiento para construir la noticia, más se elabora una historia social en la que los actores se convierten en personajes que asumirán los roles típicos de los relatos. Con el recurso a los binomios de víctima/bueno y delincuente/malo, se procura la empatía del receptor. El narrador, a su vez, encarna parte de la historia, implicándose personal y emocionalmente en las reivindicaciones de la víctima y en la estigmatización del delincuente ${ }^{892}$.

\subsection{De la Víctima Real a las Víctimas Potenciales. Las ExigenCias de ENDURECIMIENTO DEL CONTROL SOCIAL.}

En el discurso mediático reciente, la víctima será siempre protagonista de la crónica. Se le otorga el monopolio de la descripción del caso, descargando sobre el autor el papel de verdugo, villano o mero contrapunto discursivo ${ }^{893}$. "En los programas dedicados a la crónica criminal a cada noticia los presentadores comentan las singularidades de cada caso, opinan sobre la situación de las víctimas o familiares de las víctimas, conjeturan sobre las penas teóricas o impuestas, analizan el sistema de administración de la justicia y en repetidas ocasiones teorizan sobre las leyes penales españolas" $" 894$.

\footnotetext{
${ }^{891}$ PARRA GONZÁLEZ, A.; DOMÍNGUEZ, M., Los Medios de comunicación ..., op. cit., pág. 33.

${ }^{892}$ BAUCELLS LLADÓS, J., y PEREZ-NETO, L., Discurso televisivo...op. cit., págs. 150 y ss.

${ }^{893}$ Ibídem, págs. 127 y ss.

${ }^{894}$ Ibídem, pág. 125.
} 
La otra cara de este discurso es la imagen del delincuente. Se trata de otro elemento común en estos programas de crónica criminal la construcción de una determinada imagen del delincuente. El discurso moral, implícito o explicito, imputa valores sobre el autor. Se hace común el uso indiscriminado de adjetivos descalificadores como "monstruos", "loco", "pervertido", "criminal", "bestia", entre otros tantos. El recurso al "alias" -como mecanismo perlocutivo- refuerza la lógica moral que se ha impuesto sobre el autor del delito lo que, además de deshumanizarlo procura evitar la empatía del telespectador. Para reforzar esa imagen de peligrosidad o bien se recurre sistemáticamente a la reincidencia del acusado o, en ausencia de estos, se dan por hecho sus cualidades para reincidir al menor descuido ${ }^{895}$.

Claro que ésta relación de la crónica criminal sobre las víctimas tiene sus excepciones sobre las que no nos vamos a extender, ya que no es el objeto de estas notas, pero que no podemos dejar de mencionar. Como no podía ser de otro modo, el enfoque, el tratamiento, la intensidad, los estereotipos, se difuminan cuando se trata de la relación de un delito económico. El protagonismo de la víctima se diluye en la prevalencia que se otorga al debido proceso; el estigma del delincuente como ser peligroso se desdibuja; el acusado, hasta ayer hombre de virtudes públicas, genera empatía con el periodista en cuya entrevista se asoma su lado más humano; su versión de los hechos es escuchada; y el sistema penal se perfila como el garante de sus derechos y garantías, luego, es su refugio y no su calvario.

Asumido como dinámica de ajuste de las normas penales, este discurso encarna una forma de adecuación del sistema penal que ya antes hemos denominado populismo punitivo. Tal acepción debemos entenderla como las respuestas de las instituciones políticas y administrativas a las demandas de reformas o iniciativas de sanción penal que se forman al calor de los dramas personales de las víctimas, de amplia resonancia en los medios, y que se circunscriben a aspectos puntuales que aspiran saciar las exigencias vindicativas de la víctima o de sus voceros. El proceso termina dominado por ésta lógica cíclica de sucesivas reformas penales y aprobación de nuevas leyes para atender casos revestidos del interés general.

\footnotetext{
${ }^{895}$ Ibídem, págs. 132-134.
} 
Por lo demás, la unilateralidad de los pactos de acción política y el consenso de las propuestas en materia penal, entre los grupos parlamentarios de derecha e izquierda que culminan con la aprobación de proyectos de ley en gran medida comunes, que buscan prioritariamente encontrar un eco legitimador en la acción de los medios de comunicación, desprovistos de racionalidad, nos lleva a creer que, como afirmó Habermas ${ }^{896}$, vivimos un momento de "agotamiento" de las energías utópicas.

\subsubsection{Juicios Paralelos en los Medios de Comunicación.}

El tratamiento que le otorgan los medios de comunicación a los supuestos victimarios de delitos que involucran a menores de edad violenta el principio de inocencia, hacen juicios paralelos que inculpan y sentencian al margen de la justicia. Un ejemplo es el caso de la niña Aitana, de tres años, donde un increíble error en el diagnostico médico y la infiltración de dicho informe a un medio de comunicación fue el inicio para el linchamiento mediático ${ }^{897}$, el juicio paralelo y la lapidación popular de que fue víctima Diego P. acusado de malos tratos y abusos sexuales a la niña. Con una fotografía a toda página, en portada y con el titular: "La mirada del asesino de una niña de tres años" ${ }^{898}$, se estimulaba la histeria colectiva. Para los medios que se hicieron eco de éstas informaciones no había lugar a dudas de que se trataba de un asesino y violador. Pero especialmente tenía el perfil de la noticia que reportaría muchos titulares durante mucho tiempo, sí se exponía con el dramatismo de la víctima en el primer plano (los familiares solicitando justicia y endurecimiento de penas para el culpable) el estigma del hombre maltratador y pederasta, la atmósfera de consternación de la población y las movilizaciones públicas y de calle en apoyo a la familia de la víctima.

El desenlace de la historia ya es conocida por todos. La autopsia de la niña confirmó, y la justicia ha ratificado, que no sufrió ninguna agresión física y sexual y que su muerte se debió a una hemorragia interna, no diagnosticada médicamente en su

\footnotetext{
${ }^{896}$ HABERMAS, Jürgen, The new obscurity and the exhaustion of utopian energies, citado en HabermaS, J. (comp.) Observations on the spiritual situation of the age. Cambridge, MIT Press, 1984.

${ }^{897}$ Véase, "Muere niña de tres años con signos de maltrato", Edición digital del diario El País, 28/11/2009 en www.elpais.es; "Una brutal paliza mató a Aitana" en Edición digital del diario canarias7, 27/11/2009, www.canarias7.es; "Libertad sin cargos para el detenido tras la muerte de una niña en Tenerife" Edición digital del diario El País 29/11/2009, www.elpaís.com

${ }^{898}$ Véase, "La mirada del asesino de una niña de tres años" Diario ABC, 28/11/2009. En la edición digital del ABC; "Novio, canguro y asesino", Diario ABC, 28/11/2009.
} 
momento, producida cinco días antes al caerse de un columpio mientras jugaba en el parque, como había declarado el supuesto verdugo de acuerdo con el juicio mediático que se le hizo a Diego P. A partir de un diagnóstico ligero y errado se produjo la vulneración del derecho al honor, a la intimidad y la imagen, y a la presunción de inocencia. Los medios juzgaron antes incluso de que declarase ante el juez y sin darle oportunidad de explicarse ante las infundadas sospechas de su culpabilidad.

Contrasta este tratamiento con el recibido apenas unas semanas antes por dirigentes políticos en cargos de administración y empresarios relacionados en la comunidad de Cataluña. A nivel académico se ha estudiado desde hace mucho tiempo el tratamiento diferencial que los medios de comunicación hacen en las noticias cuando se trata de los delitos convencionales y cuando se trata de delitos de cuello blanco. ${ }^{899}$

En efecto, el hecho último a que hacemos mención ha producido una polémica en la opinión pública española por la difusión de las imágenes de los detenidos en una investigación de corrupción urbanística en Cataluña ${ }^{900}$. Las imágenes en las que los detenidos llegan esposados a la Audiencia Nacional han generado una discusión sobre la vulneración del derecho a la intimidad de esos sospechosos de delito de cuello blanco. Desde diversos sectores judiciales y políticos se han calificado los hechos de "escarnio", "paseíllo", "exhibición” e incluso "pena de telediario", contribuyendo a crear una suerte de cortina de humo sobre unos graves hechos de corrupción política a costa de unos segundos de televisión y de unas fotografías en los diarios ${ }^{901}$. A juzgar por la polémica generada pareciera que escandalizaron más las imágenes de los detenidos que las acusaciones que pesan sobre ellos. Desde la Audiencia Nacional se ha abierto una investigación para esclarecer lo ocurrido y se ha solicitado un informe del comisario de policía para conocer por qué fueron "expuestos" ante los medios de comunicación los detenidos. Contrasta esta forma diligente de actuar de la Audiencia Nacional para exigir

${ }^{899}$ Fue Edwin h. Sutherland el primero que acuño el término de cuello blanco. En su teoría de la Asociación Diferencial desarrollo el delito de cuello blanco como aquel cometido por una persona de respetabilidad y alto status social en el curso de su ocupación. En 1949 publicó su libro "Delincuencia de cuello blanco" de Nueva York: Holt Rinehart y Winston.

900 Investigación realizada en el Ayuntamiento de Santa Coloma de Gramenet, relacionada con la presunta adjudicación de obras y servicios vinculada a la construcción, se le conoce con el nombre de "Operación Pretoria".

901 Véase, "Unos más iguales que otros en los telediarios", Edición digital del Diario El País, 09/11/2009, en www.elpais.com. 
responsabilidades en la vulneración del derecho a la intimidad, al honor y al principio de inocencia de sospechosos de delitos de cuello blanco, cuando guarda silencio por las imágenes que diariamente llenan los periódicos y telediarios sobre todo de presuntos maltratadores o pederastas que aún no han sido juzgados por un tribunal. Pareciera que ante el linchamiento mediático que ocurre ante imputados que reúnen el perfil del estereotipo socio/mediático, la inacción de la fiscalía la hace cómplice de la vulneración de los derechos de cualquier ciudadano; o, lo que es igual, su diligencia en defender el principio de inocencia, los derechos al honor, a la intimidad y a la imagen, sólo cuenta para las personas "socialmente reconocidas", aunque sean sospechosos de delitos de cuello blanco.

Estos casos vienen a confirmar el tratamiento sesgado que los medios de comunicación tienen con los delitos, de acuerdo con la extracción social o representación de quien lo comete; entre ellas, tal vez la más importante, la invisibilidad de las personas acusadas cuando se trata de delitos de cuello blanco o de corrupción contra el patrimonio público, lo que facilita la impunidad, y la deliberada manipulación de la exposición abierta y descarnada del delincuente común sometido al juicio mediático.

\subsection{INTERESES Y MEDIACIÓN DISCURSIVA.}

El manejo que hacen los medios de comunicación sobre la criminalidad se ha explicado básicamente a través de dos hipótesis que involucran por un lado los intereses económicos de los medios y por el otro los intereses políticos del Estado y sus estrategias de control social.

La primera hipótesis soportada sobre las teorías conspirativas considera que el Estado en sus estrategias de control estaría manipulando a los medios influyendo en el contenido de las informaciones para generar preocupación social con la intención de legitimar la represión. Así, los intereses políticos que predominan e intervienen en la acción de los medios, acabarían influyendo sobre los ciudadanos. La segunda hipótesis es justamente inversa, es decir, la preeminencia de los intereses particulares y económicos de los medios de comunicación sobre los intereses políticos de Estado. En este sentido, los medios en su manejo interesado de la criminalidad actuarían sobre la 
opinión pública creando alarma social y esto determinaría las acciones y decisiones de la esfera política ${ }^{902}$. En el campo académico son más las investigaciones que se inclinan por la tesis del impacto de los medios de comunicación sobre la acción política en materia de criminalidad. Concretamente, se plantea que existe una correspondencia entre los discursos de los medios de comunicación y las decisiones legislativas que, si bien no determina de forma causal, mecánica y absolutamente la producción legislativa, al menos la alimenta y le proporciona una legitimación social ${ }^{903}$

En los últimos años es común que los diversos Proyectos y Anteproyectos de leyes de reforma del Código Penal Español" ${ }^{904}$ hagan referencia a la "alarma social" generada por las informaciones publicadas sobre determinados hechos criminales. De manera que la acción de los medios de comunicación constituye, por lo menos, una importante fuente de legitimación de las reformas penales. Y, claro, en este contexto, no cabe esperar análisis matizados, atención a los detalles no expuestos o razonamientos complejos, sino mensajes simplistas, de trazos gruesos y apelaciones de corte más o menos populista, perdiéndose sustancialmente la esencia del debate democrático y rebajando la calidad de la democracia a la adecuación del derecho a los dramas televisados de las víctimas. ${ }^{905}$

Salvo excepciones, los medios y su discurso legitiman el orden social; luego, son funcionales a los intereses políticos del Estado. O, lo que es igual, actúan en el marco de un arreglo a partir del cual construyen su discurso desde su naturaleza mediática, para legitimar un orden, incluso cuando se enarbolan reformas no se hacen pensando en un nuevo orden sino en blindar más aún el pacto existente. Aún así, es tal su naturaleza que

\footnotetext{
${ }^{902}$ BOTELLA CORRAL, J.; PEREZ-NETO, L., La formación de la opinión..., op. cit., pág. 21.

903 GARCÍA ARÁN, M.; PEREZ-NETO, L., "Discursos mediáticos y reformas penales de 2003", en GARCÍA ARÁN, M.; BOTELLA CORRAL, J. (Dir.), Malas noticias..., op. cit., pág. 156.

${ }^{904}$ En la exposición de motivos del Anteproyecto de Ley Orgánica por la que se modifica la Ley Orgánica 10/1995, de 23 de noviembre, del Código Penal Español. (Aprobada por el Consejo de Ministro en fecha 14 de noviembre de 2008), plantea la necesidad de la reforma en el acaecimiento en los últimos tiempos de casos de especial gravedad que han provocado en la sociedad la reapertura del debate en torno a las respuestas jurídicas previstas para los delincuentes sexuales, en particular en aquellos supuestos en los que las víctimas son menores de edad y hace referencia al caso de la niña Mariluz Cortes que durante los años 2008 y 2009 ha tenido gran repercusión mediática.
}

${ }^{905}$ BOTELLA CORRAL, J., Y PEREZ-NETO, L., La formación de la ... op. cit., pág. 22. 
se desdoblan en hacer valer también su talante económico/comercial encontrando acomodo a sus intereses dentro del orden social que legitiman.

\section{LA ACTUACIÓN DEL ESTADO. DEL IDEAL RESOCIALIZADOR A LA IDEOLOGÍA DE LA SEGURIDAD Y EL ANCLAJE PENAL DE LA POLÍTICA CRIMINAL.}

\subsection{Respuestas InSTITUCiONALES ANTE LOS Miedos Y RiESgos DE LA

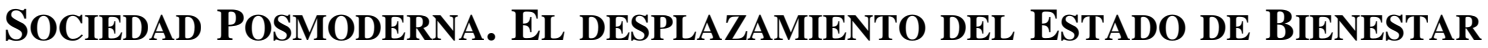 HACIA LA ESFERA PENAL.}

No se trata de que las funciones de seguridad, orden y control del Estado sean una novedad. Son asuntos inherentes al orden social que subyace en toda cultura. Pero, nos recuerda Garland, ésta tríada - seguridad, orden y control - que resume la Política Criminal de nuestros días, ha impuesto su agenda delimitando los grupos peligrosos sobre quienes recaen las demandas represivas, pero, al mismo tiempo, afectando de manera difusa la convivencia cívica del resto de la sociedad y corroyendo el tejido social que construye ciudadanía. "Controles espaciales, situacionales, de gestión, de sistema, controles sociales, autocontroles: en un entorno social tras otro encontramos ahora la imposición de regímenes más intensivos de regulación, inspección y vigilancia, y de esta forma nuestra cultura cívica se hace cada vez menos tolerante y receptiva, cada vez menos dispuesta a confiar. Después de un largo proceso de expansión de la libertad individual y descenso de las limitaciones socioculturales, el control se reafirma en cualquier área de la vida social, con la excepción singular y espantosa de la economía, de cuyo entorno desregulado surge día a día la mayoría de los actuales riesgos"906.

La temperatura emocional de la Política Criminal se ha elevado en correspondencia con la irritación social. Se invoca sin reparo el hastío ciudadano, colmado ante la complejidad social y la atmósfera de temor -explotado hasta la ira colectiva- que reivindica como exigencia moral el endurecimiento del sistema de castigos y penas contra quienes encarnan la peligrosidad ${ }^{907}$. La vindicta social así sustituye el ideal resocializador, abandonando la dimensión social de la desviación y

\footnotetext{
${ }^{906}$ GARLAND, D., Lucha contra el crimen..., op cit., pág. 103.

${ }^{907}$ MAQUEDA ABREU, M. L., Crítica a la reforma penal..., op. cit., pág. 8.
} 
reduciéndola a la responsabilidad individual del acto delictivo. De allí que asistimos a un anclaje penal de la Política Criminal.

El destinatario de todas las demandas de seguridad es ahora el Derecho penal, no solo en su momento de castigos y sanciones sino también en su dinámica procesal. Las demandas de seguridad ya no son atribución de lo que era su "lugar natural": el Derecho administrativo. Ahora se drenan hacia el Derecho penal provocando una evidente tendencia a la ampliación de su esfera de actuación y desempeñando un papel que no le pertenece ni en exclusiva ni de modo prioritario. El resultado es la configuración de un modelo preventivo exasperado, orientado hacia la seguridad, vaciando de contenido al Estado garantista y erigiendo lo que algunos han dado en denominar el Estado de seguridad $^{908}$ ante el que se rinde o sacrifica el sistema de garantías y derechos individuales si es necesario.

A las funciones del Derecho penal como dispositivo institucional intimidatorio, como altavoz de los valores del Derecho o como medio de resocialización, se unen las intensas demandas sociales de seguridad. La sociedad, cautiva de su temor a ser víctima, no está dispuesta a asumir el riesgo de que se repitan determinados delitos, por eso se recibe de buen agrado la "tolerancia cero" con la reincidencia cuando se trata de cierto tipo de delincuencia. Por ello, demanda la "neutralización de la fuente de peligro" 909 y se opone al sistema de garantías y beneficios procesales del delincuente. Este ya no es merecedor de una nueva oportunidad, ni digno de confianza a que el ejercicio de su recobrada libertad se haga con arreglo a Derecho; hay que dejarlo fuera de juego en un ejercicio de asepsia social.

\subsubsection{Del fin Resocializador de la Pena a los Planteamientos Inocuizadores.}

Cabe señalar aquí que el poder político saca buenas partidas de medidas como la libertad vigilada que calman el clamor popular ante el miedo generalizado a los terroristas y pederastas, grupos considerados ahora como los nuevos enemigos. Estas

\footnotetext{
${ }^{908}$ MENDOZA BUERGO B., Gestión y política criminal... op. cit., págs. 82 y ss.

${ }^{909}$ SILVA SÁNCHEZ, J.; FELIP I, S.; ROBLES PLANA, R.; MUÑOZ, P.; "La ideología de la seguridad en la legislación penal española presente y futura", en DA AGRA; DOMÍNGUEZ; GARCÍA AMADO y otros, La seguridad en la sociedad del riesgo. Un debate abierto, Ed. Atelier, Barcelona, 2003, pág. 122.
} 
medidas de libertad vigilada posterior a la pena de prisión no tienen otro fin que el de la inocuización - incapacitación - del delincuente para eliminar el riesgo que corre la sociedad ante una posible reincidencia, manteniéndolo al margen, controlado y vigilado, a los fines de garantizar a la sociedad que puede sentirse a salvo. Ya no se confía en la reinserción del delincuente. El desencanto por la resocialización es generalizado en las instituciones de control social. A su vez, en la opinión pública ha cambiado la representación del delincuente prevaleciente en los años setenta y ochenta cuando era considerado un ser socialmente desfavorecido y marginado económicamente, susceptible de reintegración, para lo que existía un orden de garantías, beneficios y prestaciones que recogían el mandato de ayuda a que la sociedad estaba obligada ${ }^{910}$. Ahora se los representa como culpables, indignos y peligrosos, que deben ser cuidadosamente controlados para la protección del público y la prevención de delitos futuros. ${ }^{911} \mathrm{La}$ exclusión tiende a consolidarse. Calificaciones como las de "predador sexual", "criminal incorregible", "asesino en serie", "jóvenes desalmados", entre otros que conforman el lugar común de la ciudadanía, reflejan acertadamente el nuevo estatus social del delincuente, deshumanizado e indigno de derechos. ${ }^{912}$ Sin que procedan distinciones ajustado a la gravedad o frecuencia de su comportamiento delictivo, señala Garland, los delincuentes son vistos como seres que persiguen sin escrúpulos y en pleno uso de su libre arbitrio intereses egoístas e inmorales, a costa de los legítimos intereses de todos nosotros. ${ }^{913}$

Refiere GARLAND que discursivamente coexisten en la ideología oficial políticas y prácticas contradictorias que se corresponden con unos marcos criminológicos que son diametralmente opuestos en aspectos cruciales. Existe una criminología del sí mismo que caracteriza a los delincuentes como consumidores racionales y normales, tal como nosotros; y existe una criminología del otro, del desafiliado atemorizante, el extraño peligroso, el resentido y excluido. La primera es invocada para hacer del delito algo cotidiano, reducir los temores desproporcionados y promover acciones preventivas. A la otra se recurre para demonizar y estigmatizar al

\footnotetext{
${ }^{910}$ DÍEZ RIPOLLÉS, J., La política criminal ... op. cit., pág. 75.

${ }^{911}$ GARLAND, D., La cultura del control... op. cit., pág. 287.

${ }^{912}$ DÍEZ RIPOLLÉS, J., La política criminal ... op. cit., pág. 75.

${ }^{913}$ Idem.
} 
delincuente, encauzar los miedos e indignaciones populares y legitimar socialmente el endurecimiento del castigo estatal. ${ }^{914}$

En resumen, que la base ideológica de los planteamientos de inocuización incapacitar para no causar daño a la sociedad mientras dure la estancia en prisión además de neutralizarlo durante 20 años más con libertad vigilada, se fundamenta por un lado por la híper/sensibilidad ante el riesgo inherente a la sociedad moderna y, por otro lado, la obsesión por la seguridad que ha venido desplazando otros valores sociales sobre los cuales se funda la convivencia. A esto hay que añadir también la intención del Estado de minimizar los costes, inspirado en la ideología de la eficiencia de corte neoliberal, que significaban el tratamiento y la rehabilitación del delincuente en procura de su resocialización tal como inspiraba el Estado de Bienestar.

\subsubsection{Los Delitos Sexuales: entre el Populismo Punitivo y el Protagonismo de la Víctima.}

La Ley Orgánica 5/2010 de 22 de junio, justificó la reformas al Código Penal español en materia de delitos sexuales en la necesidad de ajustar la legislación interna a la legislación europea ${ }^{915}$. Desde la exposición de motivos del Anteproyecto sin ningún disimulo, el legislador reconoce que ésta también se debe al acaecimiento en los últimos tiempos de casos de especial gravedad que han provocado en la sociedad la reapertura del debate en torno a las respuestas jurídicas previstas para los delincuentes sexuales, en particular en aquellos supuestos en los que las víctimas son menores de edad ${ }^{916}$.

Numerosos estudios ${ }^{917}$ han señalado la influencia de los medios de comunicación en la legislación penal. Otros han puesto de manifiesto específicamente

\footnotetext{
${ }^{914}$ GARLAND, D., La cultura del control... op. cit., págs. 231 y ss.

915 Se refieren a la Decisión Marco 2004/68/JAI del Consejo, de 22 de diciembre de 2003, relativa a la lucha contra la explotación sexual de los niños y la pornografía infantil. También se hace alusión a la Proposición no de Ley aprobada por el Congreso de los Diputados el día 3 de junio de 2008, por la cual se insta al Gobierno a realizar determinadas modificaciones legales en materia de los delitos contra la libertad e indemnidad sexuales contenidos en el Título VIII del Libro II del Código Penal.

${ }^{916}$ Anteproyecto de Ley Orgánica por la que se modifica la Ley... cit., pág. 1.

${ }^{917}$ Véase, BARATA, F., "Las nuevas fabricas del miedo. Los mass media y la inseguridad ciudadana", en MUÑAGORRI LAGUÍA, I., (edit.), La protección de la seguridad ciudadana, Inst. Internacional de Sociología Jurídica, Oñati, 1995, págs.83 y ss.; LA MISMA Autora, "Los más media y el pensamiento criminológico" en BERGALLI, R. (Coord.), Sistema penal y problemas sociales, Ed. Tirant lo Blanch,
} 
como las reformas al Código penal de 1995 han venido respondiendo a una demanda social equivocada alimentadas por la alarma social creada a partir de casos concretos, respondiendo a un simbolismo de la intervención penal ${ }^{918}$.

Los medios de comunicación social han explotado al máximo las innegables potencialidades mediáticas de la criminalidad, a la que mantienen, una y otra vez, en sus portadas o noticieros como la noticia del día. El caso de la niña Mariluz ${ }^{919}$ ha sido tomado como el expediente público y mediático para la cruzada contra los pederastas durante todo el año $2008^{920}$. Ha impregnado toda la reforma del capitulo de los delitos sexuales y ha endurecido prácticamente todos los delitos donde la víctima son menores, a veces casi duplicando las penas, todo ha sido plasmado en la LO 5 /2010 de 22 de junio.

El discurso de la víctima tiene especial reflejo en los medios de comunicación ${ }^{921}$, como ya hemos referido antes, sobre todo lo que se refiere a la movilización de las

Valencia, 2003; CUERDA RIEZU, A., "Los medios de comunicación y el Derecho Penal" en ARROYO ZAPATERO, L.; BERDUGO GÓMEZ DE LA TORRE, I., (Dirs.), Homenaje al Dr. Mariano Barbero Santos. In Memoriam, Vol. II, Univ. Castilla-La Mancha/Univ. Salamanca, Cuenca, 2001; SOTO NAVARRO, S., "La influencia de los medios en la percepción social de la delincuencia", en Revista electrónica de Ciencia Penal y Criminología, No 7, 2005. pág 23 y ss.; FUENTES OSORIO, J.L., "Los medios de comunicación y el Derecho penal”, en Revista Electrónica de Ciencia Penal y Criminología, $\mathrm{N}^{\mathrm{o}} 7,2005$, Pág. 25 y ss.

${ }^{918}$ NUÑEZ PAZ, M. Á., "Dogmática penal y Política Criminal frente a la Reforma Penal." en AAVV, La reforma penal a Debate. XVI Congreso de alumnos de derecho penal Universidad de Salamanca,. Ed. Ausejp, Salamanca, 2004. págs. 11-34.

${ }^{919}$ Este caso que ha conmocionado a la opinión pública del país se refiere a la niña Mariluz Cortes, gitana de 5 años que el 13 de enero de 2008 desapareció, siendo encontrado su cuerpo el día 7 de marzo de ese mismo año en las rías de Huelva. Fue asesinada presuntamente por Santiago Del Valle pederasta reincidente quién estaba en libertad a pesar que sobre él recaía una condena desde noviembre de 2002 por el Juzgado de lo Penal número uno de Sevilla, a dos años y nueve meses de prisión por un delito continuado de abusos sexuales a su hija menor. Una sentencia que la Audiencia de Sevilla confirmó en diciembre de 2005 -aunque la ejecutoria de la misma estuvo paralizada durante más de dos años y dos meses-. Además cuenta con otra condena de dos años de cárcel que dictó el Juzgado penal cuarto de Sevilla en diciembre de 2004 por agredir sexualmente a otra menor.

${ }^{920}$ También ha servido este caso para llevar a la palestra la discusión sobre la eficacia de la administración de Justicia, ya que el supuesto asesino debía estar en prisión por condenas anteriores no ejecutadas. La responsabilidad del Juez Tirado se estableció en falta leve y tres mil euros de multas y la sanción de la secretaria judicial en falta grave y 2 años de suspensión de sueldo y actividad laboral. La diferencia en las sanciones ha generado peleas gremiales conllevando a paralizaciones y protestas por parte de los secretarios judiciales alegando desproporción en las mismas, al juez tirado lo sanciono su gremio y a la secretaria el Ministerio de Justicia.

${ }^{921}$ Véase, Miles de personas se manifiestan por la niña de Huelva (17/01/2008). El padre de Mariluz proseguirá su campaña en Arrigorriaga (03/0772008). La familia de Mariluz se siente "estafada, utilizada e indignada" (25/06/2008). La manifestación más triste (22/0672008). Fuente: Diario El País. 
agrupaciones de víctimas de pederastas y terroristas, que presionan sobre los poderes públicos en demanda del endurecimiento penal. En este "caso Mariluz" la familia padres de la victima - desde que la niña desapareció se ha movilizado activamente siendo atendida por el Consejo General del Poder Judicial, por el Presidente del Gobierno, por el líder de la oposición; organizó una campaña de recolección de firmas en apoyo a una iniciativa popular de legislación para demandar el endurecimiento de las penas para los pederastas, la publicación de una lista con sus identidades y la imposición de la cadena perpetúa en ciertos casos de delitos sexuales.

En los momentos actuales el papel protagónico que está desempeñando la víctima plantea un conflicto triangular conformado por las demandas en procura de compensación aflictiva del mal causado a la víctima y la tradicional relación penal jurídico-pública, entre el Estado y el infractor. ${ }^{922}$ En este conflicto de intereses el simbolismo de la intervención penal es el mecanismo comunicativo entre el poder político y la ciudadanía, cuando la respuesta punitiva es demandada y bien recibida por la sociedad y al poder político le es rentable la imagen de que reacciona y atiende a las preocupaciones de la población -populismo punitivo-, se forma una espiral de demandas y respuestas punitivas en la que sale perjudicado obviamente el delincuente, quedando excluido del sistema de derechos y garantías propios de un Estado Social y Democrático de Derecho. Se trata de un juego suma cero tan puesto de moda por la teoría de juegos en la que la victoria de uno es la derrota del otro. Cualquier demostración de compasión hacia los delincuentes, cualquier mención hacia el ejercicio de sus derechos y garantías, cualquier esfuerzo por humanizar su castigo, es considerado un insulto a las víctimas y sus familias. Mediado por el caudal de emociones y drama que embarga el relato del suceso típico expuesto, se pasa por alto que en la estigmatización del delincuente no solo este sale perjudicado sino el ciudadano común y corriente que pierde derechos, libertades y garantías con la ampliación del control. Incluso, en ocasiones se olvida que no solo se puede ser víctima potencial; es que cabe también la posibilidad de ser imputado potencialmente como delincuente, para el que no caben ya - o en todo caso se cuestionan - las garantías de Derecho establecidas en el debido proceso.

${ }^{922}$ GARCÍA ARÁN, M., Delincuencia, ..., op. cit. pág. 89. 
En el modelo penal del Estado de bienestar el foco estaba dirigido hacia el delincuente y sus necesidades -resocialización-; para el modelo de seguridad que aceleradamente se impone, el centro del discurso penal es la proyección política de la víctima individual y sus sentimientos. ${ }^{923}$ Se ha construido una ideología de la víctima en la que, al decir de GARLAND:

a) más que por sus intereses y opiniones se construye una imagen proyectada y politizada de la víctima;

b) se invocan los sentimientos de las víctimas como fuente de legitimidad social;

c) la eliminación o reducción del sufrimiento actual o futuro de las víctimas justifica cualquier endurecimiento penal;

d) la sensibilidad ante los sentimientos de las víctimas refuerza una matriz de sentimientos retributivos que influyen cada vez más en la legislación penal;

e) la experiencia de la víctima es explotada y exhibida públicamente por políticos y medios masivos de comunicación;

f) la figura de la víctima se catapulta hasta ser convertida en celebridades mediáticas o reconocidos activistas de movimientos de víctimas;

g) el nuevo imperativo político y mediático es que las víctimas deben ser protegidas; sus voces deben ser escuchadas, su memoria respetada, su ira expresada y sus miedos atendidos;

h) La víctima es ahora un personaje representativo cuya experiencia se supone común y colectiva - la próxima puede ser uno de nosotros - en lugar de individual y atípica. El sufrimiento de la víctima mediatizado y (re)dramatizado con honda repercusión en la sensibilidad del espectador, produce efectos de identificación y reforzamiento utilizados luego políticamente por las instituciones de control social y comercialmente por los medios. Y con esto el debate se aleja del razonamiento instrumental del análisis del control del delito y pasa a ser dominado por las emociones viscerales de la identificación y la indignación.

\footnotetext{
${ }^{923}$ GARLAND, D., La cultura del control..., op. cit., pág. 242.
} 
Así, el "derecho de las víctimas" se equipara a un derecho al castigo, que en ningún caso, tiene base constitucional o legal, pues la acción penal ${ }^{924}$ no puede ser confundida por el "derecho a la pena", pasando por encima de las orientaciones superiores del Derecho penal como la reinserción. ${ }^{925}$

En definitiva, la figura simbólica de la víctima se ha enseñoreado, adquiriendo entidad y peso específico propios en el debate político y en la argumentación del discurso que fundamenta la nueva Política Criminal. ${ }^{926}$

Pero ¿es admisible ésta redimensión de la víctima como actor social privilegiado en los procesos de reforma penal y de construcción de una Política Criminal? Es obvio que no, porque la naturaleza de las víctimas o sus voceros presenta motivaciones subjetivas muy particulares, que sesgan su interés y orientan un tipo de comportamiento marcado por la experiencia personal. La posición de la víctima del delito es parcial - no puede ser de otra forma - y poco favorable a la racionalidad ${ }^{927}$. Por lo tanto, las víctimas, sus familiares, allegados o simpatizantes, no tienen las cualidades o atributos para hacerse del interés general y abogar por ella. Luego, el poder punitivo ha de seguir siendo atribuible al Estado, potestad inalienable de sus instituciones político / jurídicas que fundamenta el monopolio de la violencia, de la sanción y el castigo. Por último, la institución de la pena no puede ser entendida, a riesgo de desnaturalizarla, como mecanismo de ayuda a la superación por parte de la víctima del trauma generado por el delito $^{928}$.

La posición del Estado debe ser mediadora y racional y no orientar sus acciones por la avidez de las víctimas, afectando el principio de proporcionalidad, el principio de

\footnotetext{
${ }^{924}$ El Derecho procesal español reconoce a las víctimas mediante el ejercicio de la acusación particular, es lo que se denomina la pretensión punitiva.

${ }^{925}$ GARCÍA ARÁN M.; PEREZ-NETO, L., Perspectiva de análisis y..., op. cit., págs. 41 y ss.

${ }^{926}$ GARLAND, D., La culturadle control..., op. cit., pág. 241.

${ }^{927}$ GARCÍA ARÁN, M., Delincuencia, inseguridad..., op. cit., pág. 89.

928 "El fenómeno de la identificación con la víctima -postura de algunos autores- conduce a entender la propia institución de la pena como mecanismo de ayuda a la superación por parte de la víctima del trauma generado por el delito. Con el razonamiento de que la sociedad tiene una deuda con la víctima por no haberle evitado el sufrimiento causado, consideran que la única forma de saldar esa deuda es con el castigo del autor... La pena deja fuera al autor y, con ello, reintegra a la víctima." Véase, SILVA SÁNCHEZ, J. M., La expansión del Derecho..., op. cit., pág.51.
} 
reinserción que debe evitar las sanciones penales segregadoras, además de las garantías procesales de derecho a la defensa y la presunción de inocencia. ${ }^{929}$

\subsection{El Derecho Penal del Enemigo en la posesión de PORNOGRAFía INFANTIL.}

Para hacer frente a delitos peligrosos y a fenómenos "excepcionales" como el terrorismo, el narcotráfico, los delincuentes sexuales, la inmigración ilegal, ha surgido una postura teórica en la doctrina penal denominada Derecho penal del enemigo, cuyo principal exponente ha sido JAKOBS en Alemania y en España, con algunos matices, SILVA SÁNCHEZ. Esta nueva postura teórica en la doctrina penal descansa sobre un núcleo central alrededor del cual vertebra todo su discurso: un Derecho penal y/o procesal penal en los que las garantías son relativizadas e incluso suprimidas. ${ }^{930}$ Seguidamente tratamos de describir sus rasgos característicos y ubicarlo como marco conceptual teórico/penal en el que se inscriben las reformas penales recientes en España. ${ }^{931}$

El Derecho penal del enemigo tiene sus raíces en momentos históricos anteriores al actual. No se trata de un fenómeno coyuntural, ni se debe a factores exógenos. El actual Derecho penal del enemigo no es un simple retorno de una Política Criminal autoritaria, sino una fase evolutiva nueva. "La noción de Derecho penal del enemigo propuesta por JAKOBS en la primera aproximación (1985) es considerablemente más

\footnotetext{
${ }^{929}$ GARCÍA ARÁN M.; PEREZ-NETO, L., Perspectiva de análisis y..., op. cit., pág. 40 y ss.

${ }^{930}$ CANCIO MELIÁ, M., Derecho penal del Enemigo, en JAKOBS, G.; CANCIO MELIÁ, M., Derecho penal del enemigo, Ed. Civitas, segunda edición, Navarra, 2006, pág. 112.

${ }^{931}$ Para una revisión amplia, profunda y debatida, Véase, CANCIO MELIÁ, M., “¿Derecho penal del enemigo?", en ALCÁCER GUIRAO, R.; CUERDA RIEZU, A. R., La respuesta del derecho penal ante los nuevos retos: IX jornadas de profesores y estudiantes de derecho penal de las Universidades de Madrid, Universidad Rey Juan Carlos, 8, 9 y 10 de marzo de 2005, pags. 77-96. Ed. Dykinson. Universidad Rey Juan Carlos I, Servicio de Publicaciones, D.L, Madrid, 2006; DEMETRIO CRESPO, E., "Del Derecho penal liberal al Derecho penal del enemigo", en PÉREZ ALVAREZ, F., (Edit.), Serta : in memoriam Alexandri Baratta,. Ed. Universidad de Salamanca, Salamnca, 2004, pags. 1027-1054; PORTILlA CONTRERA, G., "El Derecho penal del enemigo", en Jueces para la Democrecia, № 49, 2004; GRACIA MARTÍN, L., "Consideraciones críticas sobre el actualmente denominado Derecho penal del enemigo", en Revista Electrónica de Ciencia Penal y Criminología, No 7, 2005; PORTILLA CONTRERAS, G., "La configuración del "Homo Sacer" como expresión de los nuevos modelos del Derecho Penal Imperial", en PÉREZ ALVAREZ (Ed.), Serta: in memoriam Alexandri Baratta, Ed. Ediciones Universidad de Salamanca, Salamanca, 2004, pags. 1401-1423; PRITTWITZ, C., "Sociedad del riesgo y Derecho penal." en ARROYO ZAPATERO, L. A.; NIETO MARTÍN, A.; ULFRIED N., "Crítica y justificación del derecho penal en el cambio de siglo: el análisis crítico de la Escuela de Frankfurt", Ed. Universidad de Castilla-La Mancha, Cuenca, 2003, pags. 259-288.
} 
amplia (incluyendo sectores de regulación más próximos al «Derecho penal de la puesta en riesgo» o delitos de nueva introducción dentro del sector de la actividad económica) que la de la segunda y tercera fase (a partir de 1999), más orientadas con base en delitos graves contra bienes jurídicos individuales (de modo paradigmático: terrorismo)." ${ }^{932}$

La propuesta de JAKOBS, parte de la coexistencia de dos modelos diferentes de Derecho penal: el primero dirigidos a los "ciudadanos" con una función de "seguridad normativa" entendida como restablecimiento de la vigencia de la norma transgredida por el delincuente y la confianza de los ciudadanos en el Derecho; y otro Derecho penal dirigido a los "individuos" cuya función es la "seguridad cognitiva" dirigida a dar una respuesta más contundente frente a individuos que de forma grave y reiterada se comportan en contra de las normas básicas que rigen la sociedad y constituyen una amenaza para el orden social. ${ }^{933}$ Para garantizar la seguridad cognitiva el "Derecho penal del enemigo" niega la condición de ciudadano a cierto tipo de delincuentes considerados enemigos sociales.

La primera observación que se puede hacer a JAKOBS es que su "Derecho penal del enemigo" recuerda mucho al "Derecho penal de autor" que propugnaron los penalistas nazis, donde lo relevante no era el hecho delictivo cometido, sino la "perversión", "inclinación o tendencia al delito" o "peligrosidad criminal" que pudiera tener su autor. ${ }^{934}$

A su vez y sobre la base de la idea de peligrosidad de tales delincuentes y el "daño potencial" que representan para la sociedad, se anticipa la intervención penal a fases previas a la ejecución e, incluso, a la preparación del delito. Es decir, se penalizan conductas inocuas muy alejadas de ser una amenaza o peligro para un bien jurídico. Según CANCIO MELIÁ, "se constata un amplio adelantamiento de la punibilidad, es decir, que en este ámbito, la perspectiva del ordenamiento jurídico-penal es prospectiva

\footnotetext{
${ }^{932}$ Véase, CANCIO MELIÁ, M., Derecho penal del enemigo..., op. cit. pág. 17.

${ }^{933}$ Véase, MUÑOZ CONDE, F., De nuevo sobre el "Derecho penal del enemigo", Ed. Hiammumi, $1^{\circ}$ edición, Buenos Aires, 2005, pág. 16 y ss.

${ }^{934}$ Véase, MUÑOZ CONDE, F., De nuevo sobre el..., op. cit., pág. 17.
} 
(punto de referencia: el hecho futuro), en lugar de -como es lo habitual- retrospectivo (punto de referencia: el hecho cometido)". 935

Un buen ejemplo es la posesión de pornografía infantil contemplada en el artículo 189.2 de CP español dirigida a castigar al consumidor de estos materiales. La conducta del que posee para su consumo está muy aleja del bien jurídico de la indemnidad o intangibilidad sexual del menor.

Otra característica de este Derecho penal del enemigo es que se imponen penas desproporcionadamente altas, especialmente, no se toma en cuenta la barrera de punición para reducir en correspondencia con la pena amenazada. ${ }^{936}$ Se recurre a los efectos inocuizadores con continuas reformas del Código Penal y/o a leyes penales especiales que, ante coyunturas particulares, establecen el incremento de las penas de prisión y se potencian medidas sancionadoras específicamente destinadas a combatir la peligrosidad de ciertos grupos delincuenciales: como los delincuentes sexuales.

Las características antes mencionadas del Derecho penal del enemigo pueden visualizarse en el artículo 189 del CP español que en sucesivas reformas se han aumentado las penas de prisión tanto del tipo básico como de las circunstancias agravantes.

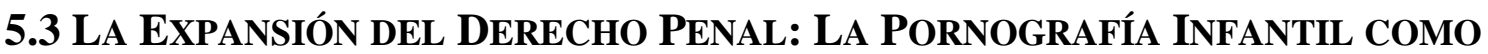 EL MEJOR EXPONENTE}

El concepto de "expansión” del Derecho penal es el denominador mínimo común que ha caracterizado la Política Criminal de los últimos años ${ }^{937}$. SILVA SÁNCHEZ en su obra la Expansión del Derecho penal hace referencia a la ampliación que experimenta en la actualidad el Derecho penal, como consecuencia, especialmente, del incremento de conductas tipificadas como delito en las diferentes legislaciones penales, así como a una agravación de los ya existentes, que cabe enclavar en el marco

\footnotetext{
${ }^{935}$ CANCIO MELIA, M., Derecho penal..., op. cit., pág. 112.

${ }^{936}$ Idem.

937 Desde mediados de los años 70, cuando se introdujo la tutela de los intereses difusos o colectivos hasta el momento actual el Derecho penal ha tenido una enorme expansión. Próximamente se tendrá que agregar la ampliación que significará la creación del Derecho penal Europeo.
} 
general de la restricción, o la "reinterpretación" de las garantías clásicas del Derecho penal sustantivo y del Derecho procesal penal. Es decir, la creación de nuevos "bienes jurídico-penales", la ampliación de los espacios de riesgos jurídico-penalmente relevantes, la flexibilización de las reglas de imputación y relativización de los principios político-criminales de garantía ${ }^{938}$.

Con el símil de las velocidades SILVA SÁNCHEZ, plantea la coexistencia de varios subsistemas penales determinados por los niveles de garantías que dependerán de la gravedad de la pena ${ }^{939}$, es así, como propone tres velocidades con un marco garantista diferente: las consecuencias jurídicas más graves demandarán de mayores garantías penales y procesales y; las consecuencias jurídicas menos relevantes las garantías podrían ser menores.

Así, los delitos con penas privativas de libertad se ubicarían en la primera velocidad, manteniéndose las máximas garantías; la segunda velocidad, para los casos en los que por tratarse de penas de privación de derechos o pecuniarias se daría una flexibilización de los principios, es decir, garantías parciales; y, la tercera velocidad ${ }^{940}$ que se aplicaría a las pena privativa de libertad pero con mínimas garantías, es decir, supone la combinación de un Derecho penal de la cárcel con una amplia relativización de las garantías. Esta velocidad puede utilizarse en los casos que amenazan con socavar los fundamentos últimos de la sociedad constituida en Estado - delincuencia patrimonial profesional, la delincuencia sexual violenta y reiterada, criminalidad organizada o terrorismo- Se excluye a la delincuencia socioeconómica que pertenecería a la primera o segunda velocidad. Amparado en el daño que producen los delitos ubicados en la tercera velocidad justifica la relativización de garantías político-criminales de las reglas de imputación y criterios procesales. ${ }^{941}$

\footnotetext{
${ }^{938}$ SILVA SÁNCHEZ, J. M., La Expansión del..., op. cit., págs. 4 y ss.

${ }^{939}$ Ibidem, págs. 178 y ss.

${ }^{940}$ La tercera velocidad propuesta por SILVA SÁNCHEZ ha sido calificada por la doctrina Española como una versión del Derecho penal del enemigo de JAKOBS Gúnther con algunas matizaciones. Véase, FERRÉ OLIVÉ, J., “Hacia un nuevo Derecho penal sectorizado?”, en PÉREZ ÁLVAREZ, F., Homenaje a Ruperto Núñez Barbero, Ed. Universidad de Salamanca, 2007, Salamanca, pág. 234.

${ }^{941}$ SILVA SÁNCHEZ, J. M., La Expansión del..., op. cit., pág. 183.
} 
SILVA SÁNCHEZ insiste en el carácter excepcional, tanto en lo referente a los periodos de vigencia como a los sectores sociales abarcados, del Derecho penal de tercera velocidad. "Tratándose de reacciones ceñidas a lo estrictamente necesario para hacer frente a fenómenos excepcionalmente graves, que puedan justificarse en términos de proporcionalidad y que no ofrezcan peligro de contaminación del Derecho penal de la normalidad", ${ }^{942}$ por este Derecho penal de guerra que cercan derechos y garantías.

La critica fundamental que se realiza a está sectorización del Derecho penal de tres velocidades es que sirve al mantenimiento del status quo: "un sistema de garantías que evoluciona a partir del Derecho penal liberal y las previsiones de los textos constitucionales más recientes. Pero estrictamente limitado a los delitos para los que se prevén penas de prisión" 943 . Pareciera que la sectorización del Derecho penal tiende a disminuir garantías para ganar en eficacia. La eficacia pretendida del sistema no puede ser utilizada como argumento para justificar cambios legislativos que permitan un sometimiento sin límites del ciudadano frente al Estado. ${ }^{944}$

El Si un artículo 189 del Código Penal español es el mejor ejemplo de la expansión del Derecho penal en los últimos años. Desde el año 1995 el artículo 189 referido a la pornografía infantil ha sido sometido a tres reformas (LO 11/1999 de 30 de abril; LO 15/2003 de 25 de noviembre; LO 5/2010 de 22 de junio) lo que ha significado la inclusión de nuevas figuras delictivas, aumento de las penas, más circunstancias agravantes. De tres preceptos en 1995 ha pasado a tener ocho más un artículo 189 bis. Se castiga la posesión para llegar hasta le consumidor de estos materiales, con el argumento que de que sin demanda no hay oferta y se erradica la explotación sexual comercial de niños.

\subsection{La Función Simbólica de LA Norma EN LA Posesión DE PORNOGRAFÍA INFANTIL.}

Hemos dicho anteriormente que la Política Criminal pasa ahora a cumplir una función simbólica: Tiene la ingrata tarea de asumir y gestionar los mecanismos de

\footnotetext{
${ }^{942}$ Ibídem, pág. 187.

${ }^{943}$ Véase, FERRÉ OLIVÉ, J., ¿Hacia un nuevo Derecho..., op. cit., pág. 234.

${ }^{944}$ Idem. 234.
} 
intervención que utiliza el Estado para controlar los riesgos y aplacar los temores, atender a las demandas de seguridad venidos de los miedos generados por todos los factores mencionados y procurarles, especialmente, su encaje penal.

Para GARCÍA ARAN, la norma simbólica tiene poca eficacia material pues, predominan los efectos simbólicos. "La norma simbólica tiene considerable aptitud para desvalorar y estigmatizar el comportamiento que sanciona, pero poca capacidad para evitarlo"945. El valor instrumental del mensaje desvalorizador es un Derecho penal orientado a las consecuencias. Dicho mensaje se convierte en su fin principal y deja de ser un mero instrumento para la producción de efectos materiales.

La irrupción de la ideología de la seguridad en el discurso político-criminal y su manifestación inmediata en la legislación penal ha significado un cambio de paradigma del llamado Derecho penal de la culpabilidad al Derecho penal de orientación preventiva y policial. Las características de este último pueden resumirse en ${ }^{946}$ :

a) un intento por adelantarse a los riesgos. La pena y las medidas de seguridad están dirigidas a la efectiva y eficaz protección de las potenciales víctimas.

b) la intervención del Derecho está mediada por la seguridad: a mayor percepción de inseguridad mayor intervención del Derecho Penal.

c) sólo la garantía de no peligrosidad impide la intervención represiva.

d) la seguridad se entiende como garantía de no reincidencia del autor, requisito necesario para la puesta en libertad del mismo.

e) lo que antes se entendía como manifestaciones del ius puniendi empiezan a concebirse como lagunas de seguridad de la legislación penal.

Las nociones de "riesgo" y "prevención” pasan a conformar el núcleo del nuevo programa de control social. Este, además de identificar y reprimir a los "grupos de riesgo" prioritarios o con mayor predisposición al delito producto de sus condiciones de vida precaria - migrantes, minorías étnicas, toxicómanos y jóvenes de periferia - se

\footnotetext{
${ }^{945}$ GARCÍA ARÁN, M., "El Derecho Penal Simbólico. A propósito del nuevo Delito de Dopaje en el Deporte y su tratamiento Mediático", en GARCÍA ARÁN, M.; BOTELLA CORRAL, J. (Dir.), Malas noticias...op. cit., Pág. 196.

${ }^{946}$ ROBLES PLANAS, R. “Sexual Predators. Estrategias..., op. cit., pág. 15.
} 
interesa también en la producción de nuevos "grupos de riesgo"947. Sobre estos grupos de riesgo se detraen los recursos públicos que alguna vez existieron, ya que se estiman fondos perdidos cualquier esfuerzo de reeducación o reinserción social. Como ya señalamos, la desviación como conducta socialmente condicionada se desencaja de su entorno y se internaliza en el grupo como sujeto peligroso, reconfigurando el cuadro de responsabilidad del hecho delictivo.

La peligrosidad del delincuente y su talante incapaz de regeneración son explotados en el tratamiento sesgado de los medios. Aquí se recurre al Derecho penal con fines exclusivamente publicitarios o de difusión de mensajes para moralizar a los ciudadanos. Poco se repara en la demanda que se le endosa, ajena a su rutina, cuando se confía a un instrumento coercitivo una misión pedagógica que contradice su naturaleza situándolo más alineado con una lógica autoritaria que en una cultura tolerante y democrática $^{948}$. A los efectos simbólicos señalados hay que añadir también estos efectos propagandísticos: mediante la nueva norma, el legislador demuestra que está atento a las demandas sociales y demuestra que la capacidad coercitiva del Estado está intacta, reafirmando su existencia y autoridad ante los ciudadanos y dando paso al rito ceremonial mediante el cual procura su legitimación.

Entre las razones por las que el legislador recurre al Derecho penal simbólico, algunos autores destacan que no sólo le reporta una buena imagen frente a la sociedad, también porque resulta más económico ${ }^{949}$. Las medidas o programas sociales que eran sustantivas en el Estado resocializador siempre suelen ser más costosas. Y en un ejercicio simplista del coste/beneficio siempre se concluye que no compensan los ingentes recursos destinados a lentos procesos de reinserción social con escasos resultados.

En esta línea la tipificación de la posesión de pornografía infantil tiene un efecto simbólico importante, pues el mensaje que se trasmite desde las instancias de control es

\footnotetext{
${ }^{947}$ RODRÍGUEZ, E., "España: zero tollerance”, en Revista Archipiélago. Prisiones de la Miseria. Estado Penal y Seguridad Ciudadana, No 55, 2003, pág. 112.

${ }^{948}$ PÉREZ CEPEDA, A. I., La seguridad como fundamento ..., op. cit., pág. 335.

${ }^{949}$ Ibídem, págs. 336 y ss.
} 
que imputando a los consumidores de estos materiales se esta protegiendo a la sociedad de grupos de riesgos como los agresores sexuales, enfermos mentales y pederastas. A través de la moral sexual se pretende controlar la conducta sexual de los miembros de la sociedad, una de las formas de establecer ese control es a través de la definición de los comportamientos repudiados como patógenos, causa de trastornos mentales ${ }^{950}$. Esto explica la asociación que se hace de entre la enfermedad mental y los intereses sexuales poco habituales $951 / 952$. En este sentido, se dirige todo el arsenal punitivo a usuarios de las TIC que en su espacio privado consume pornografía infantil, y se trasmite el mensaje a la sociedad de que el peligro u amenaza está neutralizado.

\subsection{LA INEFICACIA DE LA NORMA. ¿INEFICAZ PARA QUIÉN?}

Y, sin embargo, aún se cuestiona la ineficacia de la norma fundado en los escasos resultados materiales. Se olvida que las políticas no apuntan tanto a reducir el número de delitos como a rebajar los niveles de temor ${ }^{953}$. De ordinario si en las normas penales simbólicas predomina la transmisión de mensaje valorativo sobre sus atributos para producir efectos materiales, ello conduce a calificar a la norma simbólica como ineficaz. Pero ¿ineficaz para que? lógicamente, resultará ineficaz para la producción de efectos tangibles en la mejora de la protección del bien jurídico. No obstante, la norma

\footnotetext{
950 "Histórica e interculturalmente, la sola denuncia del interés por prácticas sexuales específicas podía acarrear la muerte, la cárcel, la pérdida de los derechos civiles y otras sanciones sociales. De la misma forma, ser clasificado como mentalmente enfermo podía tener los mismos resultados" Véase, MOSER, CH.; KLEINPLATZ, P. J., El DSM-IV y las parafilias: Un argumento para su retirada, Revista de Terapia Sexual y de Pareja, $\mathrm{n}^{\circ}$ 19, Agosto 2.004, pág. 31-56, disponible en http://www2.huberlin.de/sexology/BIB/DSM.htm,
}

${ }^{951}$ MOSER, Charles; KLEINPLATZ, Peggy J., El DSM-IV y las parafilias: Un argumento para su retirada, Revista de Terapia Sexual y de Pareja, $\mathrm{n}^{\circ}$ 19, Agosto 2.004, pág. 31-56, disponible en http://www2.hu-berlin.de/sexology/BIB/DSM.htm,

\footnotetext{
${ }^{952}$ En este sentido, El DSM IV contempla la pedofilia dentro de la clasificación de las parafilias como un trastorno de la identidad sexual. Para el diagnostico de una pedofilia se requiere que la persona durante un período de 6 meses tenga fantasías sexuales recurrentes y altamente excitantes, impulsos sexuales con niños menores de 13 años. La persona debe tener al menos 16 años y ser por lo menos 5 años mayor que el niño o los niños con los que tenga esas fantasías, quedan excluidas las personas en las últimas etapas de la adolescencia que se relacionan con personas de 12 o 13 años. Véase, VALDÉS MIYAR, M., (coord. de la edición española), DSM IV. Manual Diagnóstico y Estadistico de los Trastornos Mentales, Ed. Masson, S. A., Barcelona, 1995, págs. 540 y ss. [F65.4 Pedofilia (302.2)].
}

${ }^{953}$ GARLAND, D., La cultura del control... op. cit., pág. 45. 
simbólica sigue siendo apta, precisamente, para producir efectos de su naturaleza, esto es, efectos simbólicos ${ }^{954}$.

Este grado de ineficacia material que se le imputa a la norma, puede provenir de varios factores: su incorrección técnica, la inexistencia de instrumentos para aplicarla etc., pero también de la falta de aptitud de la norma penal para abordar el conflicto ${ }^{955}$. La producción o pretensión de efectos simbólicos, no deja de tener una cierta eficacia para las pretensiones del legislador y de las instituciones políticas, aunque sea efímera, ceremonial y no se traduzca en una protección real de bienes jurídicos en cuestión ${ }^{956}$. Calmar el miedo y dar la sensación de que se ocupa de los problemas de los ciudadanos es su misión y a ella se van reduciendo las iniciativas legislativas que atienden a las exigencias sociales de endurecimiento penal.

Tal ineficacia se concreta, en ocasiones, en normas que no añaden nada a la protección previamente existente, es decir, no aportan eficacia añadida a la que proporcionaban las normas anteriores. Son reformas destinadas a satisfacer los efectos propagandísticos antes aludidos e incidir en la necesidad de protección. Su utilidad se reduce a reforzar los valores que dicen proteger, pero buena parte de ella no es necesaria porque la Ley penal ya disponía de instrumentos reguladores. En este tipo de normas la función simbólica, como hemos dicho antes, deja de ser un instrumento para la protección de intereses y se convierte en un fin en sí mismo.

En la línea de lo que venimos exponiendo, la tipificación de la posesión de pornografía infantil no ha sido eficaz por cuanto no se ha producido una reducción de su consumo ni de los materiales disponibles en la Red.

La Política Criminal de la tríada seguridad, orden y control, tiende a reducirse a una política de orden público basada esencialmente en la acción de los aparatos policial y judicial ${ }^{957}$. Como no puede ser de otra forma, su dinámica va camino a perder de vista

\footnotetext{
${ }^{954}$ GARCÍA ARÁN, M., El Derecho Penal Simbólico..., op. cit., pág. 198.

${ }^{955} \mathrm{Idem}$.

${ }^{956}$ Ibídem, pág. 199.

957 PHIFIPPE R., "Prologo" en Recasens I Brunet, A., La seguridad y sus políticas, Ed. Atelier, Barcelona, 2007, pág. 8.
} 
la combinación de medidas represivas, preventivas y de acompañamiento social, sin cuyo recurso difícilmente se recuperen estados de confianza social y de ciudadanía fortalecida en su madurez para asumir los riesgos sin ceder al chantaje de la ideología de la seguridad.

Las iniciativas de reforma que emergen con frecuencia sorprendente expanden cada vez más las fronteras del Derecho penal, menguando la importancia y el alcance que antes tenía la Política Criminal. La Política Criminal que conocimos en el Estado de Bienestar no solo se suscribía a la sanción de normas y leyes, suponía además un espectro más amplio de investigaciones e intervenciones sociales dirigidas a la prevención y al tratamiento de la criminalidad. La Política Criminal, en su acepción más amplia, debería incluir también medidas de política social que no necesariamente se reflejan en normas con rango de ley ${ }^{958}$. Pero ésta ha dejado de ser sustantiva para alimentar las funciones del Derecho penal. Al tiempo que se ensanchan las fronteras del Derecho penal se contraen los límites del Derecho Administrativo sancionador, lanzándose el mensaje de que sólo el Derecho Penal - inocuización del delincuente, coerción y represión - está en condiciones de resolver los conflictos sociales. Se anulan así los principios claves de la Política Criminal como la intervención penal mínima, la subsidiariedad del Derecho penal respecto de otros instrumentos de control social y su carácter de ultima ratio $^{959}$.

\subsection{Delitos de POSESIÓN COMO la PANACEA DEL DERECHO PENAL ACTUAL. EL RECURSO A LA FIGURA DE POSESIÓN DE PORNOGRAFÍA INFANTIL EN LA LUCHA CONTRA LOS INDIVIDUOS "PELIGROSOS".}

¿Por qué han venido abriéndose paso en el Derecho penal los delitos de posesión? Si su justificación es muy cuestionada a la luz de la doctrina, ¿que justifica su existencia? Si son de compleja interpretación, ¿cómo es que han terminado por consolidarse dentro de la legislación y ampliado paulatinamente su radio de cobertura?

\footnotetext{
${ }^{958}$ GARCÍA ARÁN M.; PEREZ-NETO Luiz. “Discursos mediáticos y..., op. cit., pág. 154.

${ }^{959}$ Ibidem, pág. 193.
} 
A continuación exponemos las razones que asumimos como aquellas que dan respuesta a las controversias planteadas. ${ }^{960}$

1. Por lo relativamente fácil que resulta su identificación e imputación, frente a otros tipos de delitos.

A diferencia de los tipos de lesión o resultado, los delitos de posesión son fácilmente detectables, basta simplemente que se ajuste la conducta a la relación de posesión con una cosa para la comprobación de su encuadre objetivamente típico. También resulta sencillo obtener la prueba. En Estados Unidos existen varias regulaciones de posesiones típicas donde la responsabilidad objetiva se caracteriza por la ausencia de comprobación de la conducta, es decir que puede llegarse a certificar la conducta aun cuando el sujeto ignora la posesión.

2. Los delitos de tenencia o posesión resultan la principal arma de un Derecho Penal en expansión y se corresponde con la ideología de una Política Criminal en cruzada contra el crimen.

Su carácter flexible y funcional brinda respuestas rápidas a los requerimientos estatales en la lucha contra el crimen. El hecho de que no se imponen mayores exigencias para la realización del tipo y su comprobación, lo convierte en un sistema eficaz para la incriminación de conductas de sujetos calificados de peligrosos. Se castiga el autor de la posesión por las razones intrínsecas al acto de posesión. "Justamente ahí estriba la singularidad de la posesión: en tanto institución destinada a luchar contra la peligrosidad, el juicio sobre la misma tiende a construirse con prescindencia de factores ajenos al sujeto y la cosa"961.

Se suman otras ventajas significativas por las que el Estado recurre a la tipificación de estos delitos tales como que permiten la imposición de penas severas; no recibe críticas contundentes de inconstitucionalidad; y parte de la población que se

\footnotetext{
${ }^{960}$ Para la realización de este aparte ha sido fundamental la revisión de COX LEIXELARD, J. P., "Contexto Político-Criminal. De los Delitos de posesión. War on Crime y Expansión del derecho Penal", en RODRÍGUEZ COllaO, L. (Coord.) Delito, Pena y proceso. Homenaje a Tito Solari Peralta, Ed. Jurídica de Chile, 2008. págs. 111-143.

${ }^{961}$ COX LEIXELARD, J. P., Contexto Político-Criminal... op. cit., pág. 135, nota al pie, 119.
} 
siente a salvo, segura y protegida con la creación de estos tipos dirigidos a los peligrosos y enemigos de la sociedad las toleran y asumen como un mal menor. De esta forma, los delitos de posesión han desplazado a las figuras de vagancia como punta de lanza en la lucha contra los "indeseables" y "peligrosos"962.

\section{Las presunciones operan tanto retrospectiva como prospectivamente.}

El sistema de las presunciones en los delitos de posesión se utiliza de forma retrospectiva cuando en determinadas circunstancias se asume como la comisión previa de un injusto, y opera de forma prospectiva, cuando supone que a posteriori se ejecutará un ilícito. En este segundo caso se trataría de tentativa de posesión. Gradualmente se han venido estableciendo estas figuras sin consideraciones a factores ajenos a la relación entre el sujeto y la cosa. En esta línea, en los Estados Unidos se ha fallado que existen tentativas de posesión y conspiraciones para poseer. ${ }^{963} /^{964}$

En este sentido, estas figuras cada vez ganan más autonomía e independencia conceptual. En el proceso penal el modelo del poder policial ${ }^{965}$ le asigna a los tipos de posesión la tarea de control de las amenazas. Recordemos que este modelo se caracteriza por una orientación político criminal que busca la reafirmación estatal a través de la maximización de la eficiencia en desmedro de las garantías de los ciudadanos. Es por ello que estas figuras se han convertido en el engranaje perfecto para el desarrollo del poder policial, traducido en unas cada vez mayores prerrogativas del fiscal, que tiene en sus manos el montaje y decisión. Aquí el motivo de negociación y el debilitamiento del principio de la presunción de inocencia juegan un papel

\footnotetext{
${ }^{962}$ Véase, COX LEIXELARD, J. P., Contexto Político-Criminal... op. cit., pág. 136.

${ }^{963}$ Ibídem, pág. 137.

964 "En efecto, una respuesta ágil por parte de los agentes policiales supone dotarlos de un margen de autonomía y deliberación tal que les permita decidir con rapidez sobre la peligrosidad de los sujetos. Esta suerte de discrecionalidad operativa se logra primordialmente si no se hace depender dicho juicio de la eventual vinculación con una conducta pretérita (...) el recurso a las presunciones, desde esta perspectiva, no está tanto referido al castigo del poseedor, en tanto posible autor no acreditado de otro ilícito, sino a la peligrosidad del mismo" Véase, COX LEIXELARD, J. P., Contexto Político-Criminal... op. cit., pág. 137.

${ }^{965}$ El proceso penal ha transitado en los últimos años por el modelo del debido proceso, pasando por el modelo de control del crimen, hasta llegar hoy día al modelo del poder policial con los delitos de posesión como instrumento principal.
} 
esencial $^{966} / 967$. En una petición de negociación carente de estrictos controles, los incentivos están dispuestos de manera tal que fomenten las declaraciones de culpabilidad de los sujetos, con esto la erosión de la idea de inocencia como sustrato del enjuiciamiento no tarda en producirse.

Lo explicado anteriormente resume el patrón seguido en la tipificación de la posesión de pornografía infantil. Éste delito es sencillo de detectar e imputar, basta con seguir la huella informática de los usuarios que entran en alguna página Web que albergue contenidos de pornografía con menores para que salte la alarma de sospecha y se proceda a investigar todo lo relacionado con ese usuario (sus correos electrónicos, sus contactos, los archivos con fotografías, y todos los documentos personales que pueda tener en la Red). De este modo se invade la privacidad de las personas sin ninguna consideración al Derecho a la intimidad. A todas estas el usuario sospechoso puede que no haya cometido ningún delito, es decir que no haya descargado y guardado ningún archivo de pornografía infantil.

La de posesión de pornografía infantil es un fiel exponente de la expansión del Derecho penal en los últimos años, se recurre a este tipo para adelantarse las barreras de protección castigando conductas que no lesionan bien jurídico y que permiten el control de conductas que podrían representar una amenaza o peligro abstracto. Así, se penaliza al consumidor de esta iconografía para erradicar la explotación sexual comercial infantil cuyas causas están asociadas a factores sociales, económicos y culturales. En este sentido, para incidir realmente en la explotación sexual de los niños se necesita mucho más que penalizar a los consumidores de materiales pornografía con menores.

\footnotetext{
966 COX LEIXELARD, Juan Pablo, "Contexto Político-Criminal. De los Delitos de posesión. War on Crime y Expansión del derecho Penal", en Rodríguez Collao, Luis (Coord.) Delito, Pena y proceso. Homenaje a Tito Solari Peralta, Ed. Jurídica de Chile, 2008, pág.137.

${ }^{967}$ En una petición de negociación carente de estrictos controles los incentivos están dispuestos de manera tal que fomenten las declaraciones de culpabilidad de los sujetos, con esto la erosión de la idea de inocencia como sustrato del enjuiciamiento no tarda en producirse.
} 


\section{CONCLUSIONES}

1. La explotación sexual comercial infantil es un problema real que afecta a millones de niños en todo el mundo. Su reconocimiento y categorización por los gobiernos y organismos internacionales, aunque todavía indeterminada por la imprecisión empírica de su alcance y magnitud, ha permitido aflorar su naturaleza, especificidades y evolución como hecho criminológico en los últimos años.

2. La globalización, a su vez, ha trastocado los límites físico/territoriales de los Estados nación que aún rigen el combate contra la criminalidad organizada. Las altas Tecnologías de Información y Comunicación, a la cabeza de la globalización, han tenido efectos impresionantes en la construcción de la sociedad de nuestros días; pero al mismo tiempo han potenciado la distribución, el consumo e intercambio de pornografía infantil haciendo que adquiera unas características, dimensión y magnitud insospechadas hasta hacen algunos años.

3. El discurso de los medios de comunicación respecto del hecho criminal y del problema social de la inseguridad personal, se ha desplazado de la defensa del orden social que predominaba hace algunos años hacia otro lado centrado en la víctima, su historia personal y sus exigencias vindicativas. Esto ha tenido eco en las sucesivas reformas penales realizadas a los delitos cometidos contra menores de 13 años, en especial el caso que nos ocupa de pornografía infantil en el que se han endurecido las penas y se han expandido las conductas delictivas. En las exposiciones de motivos de los Proyectos de Reformas y de las propias Leyes Orgánicas que han reformado el Código penal se citan expresamente casos concretos de menores objetos de delitos de gran impacto mediático para justificar la necesidad de endurecer las penas en esos delitos.

4. Recientemente, los documentos y convenios internacionales han desarrollado un conjunto de medidas tales como: el bloqueo de contenidos o la restricción de acceso a Internet de materiales con pornografía de menores; el asesoramiento jurídico gratuito a los niños víctimas; el diseño e implementación de programas de capacitación y protección de los menores frente a las Tecnologías de Información y Comunicación. Este conjunto de medidas que atienden el problema desde una esfera de prevención, 
atención y apoyo a las víctimas resulta más efectivo que su defección ante la expansión de las barreras del Derecho Penal que, empujado por el modelo de seguridad, lastra la dimensión social del hecho fijando conductas delictivas de las que hay que proteger a la sociedad.

5. Los documentos, convenios internacionales y directivas europeas tienen una vocación punitiva, pretendiendo la regulación de la pornografía infantil a partir de la clasificación de conductas tipificadas, desdeñando la tradición de políticas de bienestar europeas que reconociendo la dimensión social del problema disponían actuaciones administrativas alineadas con un ideal político criminal: el de la resocialización del delincuente. El acento de los documentos analizados esta puesto en la dimensión penal, instando o sugiriendo su acomodo en las legislaciones nacionales influenciadas por el ideal de la seguridad. Se ha erigido así un marco normativo cuyo cerrojo penal se ha impuesto sobre toda la cadena, incluida la posesión para el autoconsumo.

6. La armonización de la legislación en la esfera internacional es un aspecto positivo que impide el desarrollo de los paraísos legislativos. Si además, ésta unificación en el ámbito jurídico promueve la cooperación judicial y policial entre los países miembros sus objetivos resultan inobjetables y no se puede si no apoyar su realización y reconocer sus avances. Sin embargo, en la última década nos encontramos con documentos en el ámbito de la Comunidad de Europa cuyas formulaciones legales son reprochables por la dudosa lesividad de la conducta que se exige. El mejor ejemplo lo encontramos en la pornografía infantil en el que el afán punitivo se ha expresado en la penalización de la posesión de este tipo de material. Y se pretende ir más lejos aún con ésta tendencia al castigar el simple visionado por Internet de algún material con esa clase de contenidos, según se recoge en la Propuesta de Directiva del Parlamento Europeo y del Consejo, Relativa a la lucha contra los abusos sexuales, la explotación sexual de los niños y la pornografía infantil, por la que se derogaría la Decisión Marco 2004/68/JAI.

7. La tendencia político criminal que anima la Propuesta de Directiva del Parlamento Europeo y del Consejo, Relativa a la lucha contra los abusos sexuales, la explotación sexual de los niños y la pornografía infantil, por la que se deroga la Decisión Marco 2004/68/JAI, arremete contra el consumidor de estos contenidos y no contra los proveedores de servicio que permiten que los materiales circulen por la Red. La nueva 
Propuesta de Directiva, es desproporcionada cuando contempla sanción penal para el que acceda o visione contenidos de pornografía infantil, y por el contrario cuando se refiere a los proveedores de servicio sólo los insta a desarrollar con carácter voluntario códigos de conducta y directrices para bloquear el acceso a esas páginas de Internet.

8. En los últimos años, en la legislación española existe una tendencia clara de expansión del Derecho penal en el ámbito del delito de pornografía infantil manifestado en el incremento de las penas, la agravación de las conductas y el aumento desmesurado de criminalización de conductas que, en algunos casos, penaliza conductas inocuas que no representan ni amenaza ni peligro para bien jurídico alguno. La tipificación de la posesión para uso propio de la pornografía infantil contemplada en el artículo 189.2 del Código Penal español desde el año 2003 es el ejemplo que con mayor claridad expone el afán punitivo sobre conductas que se alejan de las prácticas mayoritarias, pero que no afectan a ningún bien jurídico.

9. Ciertamente el abrumador impacto y dominio del Internet sobre la circulación, tráfico y distribución de material pornográfico forzaba aceleradamente a regular su tipificación. Es así como LO 11/1999 de 30 de abril, estuvo motivada o impulsada por la necesidad de sancionar penalmente estos supuestos. En esta emergencia se penalizó la posesión para el tráfico o producción de este material, lo que generó un amplio debate en la doctrina por la indeterminación de la posesión de material pornográfico para el consumo propio o para la difusión, venta o exhibición.

10. En la misma línea de las reformas anteriores la orientación de la LO 15/2003 de 25 de noviembre, modifica el artículo 189 respondiendo a la lógica de la expansión del modelo político criminal de emergencia caracterizado por más penas y más agravantes; interviniendo en ámbitos en los que no resulta sencillo determinar bien jurídico afectado y apelando a la creación de delitos de peligro abstracto para castigar conductas previas, muy anteriores a las que producen un daño real. Así se incorpora como tipo privilegiado la posesión para uso propio de material pornográfico, en cuya elaboración se hubieran utilizado menores de edad o incapaces, invadiendo el terreno más íntimo de la privacidad de los ciudadanos. Se incrimina asimismo la denominada pseudopornografía, situación ésta en la que no han sido utilizados directamente menores o incapaces, pero se emplea, su voz o imagen alterada o modificada. 
11. En los supuestos típicos contenidos en los apartados a) y b) del art. 189.1, existe una equiparación punitiva entre las figuras típicas del que "utilizare" a un menor de edad con fines o espectáculos pornográficos con el que no ha participado en la elaboración del material, pero que distribuye, vende, exhibe, facilita o lo posee con esos fines. Esta equiparación no es proporcional puesto que tiene mayor lesividad y proximidad al bien jurídico el que elabora el material en la medida en que se utiliza de forma directa a los menores en actividades de carácter pornográfico y no simplemente su imagen o la voz. De igual forma tampoco es proporcionado castigar con la misma pena las figuras delictivas dentro del propio artículo 189.1 literal b), pues merece mayor reproche penal la producción u exhibición que el ofrecimiento y la facilitación de este tipo de material. Equiparar el castigo en conductas que no tienen el mismo nivel de gravedad, ni afectan el mismo bien jurídico, no está basada en fundamentaciones jurídicas.

12. La inclusión de tres nuevas figuras (“captare, se lucrare, ofreciere") recogidas en la Reforma LO 5/2010, de 22 de junio no agregan nada a los tipos de pornografía infantil contemplada en el artículo 189 del CP. Por el contrario, puede afirmarse que las nuevas figuras son reiterativas e innecesarias, al establecer la punición de la utilización de menores con fines exhibicionistas o pornográficos se comprenderían todas las hipótesis especificadas el que "captare", "lucrare" u "ofreciere". Es un inventario innecesario con la avidez de acopiar de forma amplia toda posible actividad o conducta inadecuada. Es una forma de exponer las dudas que se tienen sobre el desempeño del juez, pues se determina expresamente un listado para evitar que el juez las deje impunes. En definitiva se trata de una mala técnica legislativa. Además, las nuevas modalidades delictivas del art. 189 a) "el que captare" y "el que se lucrare", no eran necesarias, puesto que el que captare lo homologa con el que utilizare y el que se lucrare está cubierto en el artículo 177 bis sobre trata de personas.

13. Cuando el legislador coloca "el que captare" como tipo autónomo se le otorga la misma consecuencia jurídica que al que utilizare a los menores e incapaces con fines exhibicionista o pornográficos. Apreciamos esta homologación de conductas en cuanto a penas como un enorme error. Cuando se ubica al que captare como tipo autónomo se está castigando estadios anteriores de la conducta -ex antes- del tipo básico de la pornografía infantil del CP como es la utilización. Esta misma situación se reproduce en 
la figura del que ofreciere el material pornográfico contemplada en el 189.1b). Se busca penalizar una conducta previa a facilitar, (ex-antes de facilitar). Ratificamos lo sostenido anteriormente sobre lo desproporcionado que resulta establecer la misma pena para conductas que no tienen el mismo nivel de afectación sobre el bien Jurídico. La conducta del que produce, vende, distribuye no se puede equiparar con el que facilita la producción del material pornográfico, más aún con el que la ofrece.

14. Resulta contradictorio que no se tipifique la asistencia al espectáculo exhibicionista o pornográfico y se continúe con la criminalización de la posesión simple. No es que estemos a favor de que se criminalice la primera como que nos pronunciamos por la destipificación de la mera tenencia para consumo propio que se sigue con el argumento de eliminar la demanda para acabar con la oferta. Por otro lado, en la línea llevada a cabo por la reforma de homologar la legislación española a los estándares europeos, ha sido un acierto que no se tipificara la mera "adquisición" de material pornográfico que no haya llegado a la posesión del comprador. Esta figura está contemplada en la normativa comunitaria, específicamente en el Art. 3.1, d) de la Decisión Marco 2004/68/JAI.

15. En la LO 5/2010 de 22 de junio el aumento del mínimo y el máximo de marco penal establecido en el artículo 189 del CP no respondía a las exigencias de los estándares europeos, de hecho no está contemplado en la Decisión Marco 2004/68/JAI. Fue una decisión autónoma del legislador español siguiendo la línea de exasperación punitiva que ha caracterizado en los últimos años las reformas al Código Penal español. La no proporcionalidad de las penas es un hecho en casi todos los delitos sexuales donde las víctimas son menores; el endurecimiento de las penas es tal que casi se duplican, a lo que añade la aplicación sucesiva de la pena de libertad vigilada con sus correspondientes medidas especiales.

16. Existe una equiparación punitiva de algunas de las figuras delictivas como por ejemplo: el que produce y el que intercambia para consumo propio material pornográfico, el pedófilo es tratado como distribuidor, una figura de tráfico. Al distribuidor no se le exige el ánimo de lucro para incluir el intercambio pedófilo por Internet, principal manifestación de la pornografía en los últimos años. Ello ha generado que los jueces hayan encontrado como salida para aquellos casos en los que parece un 
exceso castigar por distribución meras situaciones de intercambio de sólo uno o dos archivos con materiales con pornografía infantil, la aplicación del artículo 189.2 de posesión de pornografía infantil. En la jurisprudencia se observa que se ha condenado por posesión los intercambios de pocos archivos por Internet por considerar que es excesiva la pena destinada al tráfico hasta nueve años de cárcel. En este sentido, la figura de posesión de pornografía infantil puede estar llevando el mensaje a la población de que será castigado cualquier contacto con la pornografía infantil, es decir que descartadas todas las hipótesis de tráfico todavía se puede castigar por posesión.

17. La reforma al artículo 189 del CP en la LO 5/2010 de 22 de junio desoyó las numerosas críticas realizadas desde la doctrina para que se destipificara la posesión de pornografía infantil y la pornografía virtual por la falta de lesividad a bien jurídico alguno. Antes bien, parece que en su lugar ha dado cabida a la alarma social fundada en las llamadas crónicas negras de los últimos años. Asumimos como nuestra la opinión del Grupo de Estudios de Política Criminal cuando señala que, "una norma tan importante para el nivel de protección de derechos y libertades como el Código Penal no puede ser objeto de reformas constantes, sin reflexión y ausentes de cualquier debate técnico. Precisamente requiere un debate sosegado, alejado en todo lo que sea posible de la mediatización del caso concreto"

18. El análisis de las últimas reformas desvelan que se han tratado con una mala técnica legislativa, que abundan los delitos de peligro abstracto, y que todo el arsenal punitivo del Derecho penal va dirigido a los considerados peligrosos para la sociedad -como los pedófilos- que se tipifican conductas que en algunos casos resultan inocuas y que se adelantan cada vez más las barreras punitivas del Derecho Penal.

19. Es un hecho innegable que existe una industria de explotación sexual de niños en la que participan grupos, asociaciones, y/o personas jurídicas a las que el Derecho Penal debe dar una respuesta contundente; sin embargo, no vemos la necesidad de introducir un nuevo artículo 189 bis para tratar en concreto o de forma específica los delitos relativos a la prostitución y la corrupción de menores, pues siguiendo esta lógica sería necesario introducir un artículo bis en cada capítulo en el que sea posible la actuación de las personas jurídicas. Insistimos, está muy bien la figura que determine la responsabilidad de las personas jurídicas en cualquier hecho delictivo, lo que no parece 
necesario u oportuno es aumentar los preceptos, engordar el Código Penal agregando nuevos artículos bis, ter, quáter, colocarlo explícitamente para que no quede dudas de la aplicación en cada delito.

20. La expansión del control por parte del Estado consolidando el modelo de seguridad en desmedro de las garantías y libertades de los ciudadanos, parece contar con el consenso de amplias capas de la población, que asume como prioritaria la necesidad de protección ante un sentimiento colectivo de inseguridad propiciada por la alarma social a partir del manejo al que recurren frecuentemente los medios de comunicación sobre los delitos sexuales contra menores de edad, orientando la dirección de un debate que se reduce a las medidas punitivas como respuesta a la demanda social de seguridad. El recurso del miedo - socialmente construido - mediatiza la relación del ciudadano con el Estado; la reduce a la exigencia del endurecimiento del control social vía elevación de penas, sanciones y restricciones al sistema de garantías. De esta forma se influye en determinada respuesta legislativa en materia de Política Criminal dando paso a lo que se ha denominado populismo punitivo.

21. La cultura del control cada vez reduce más su dimensión social y expande su ratio penal encajando mejor dentro de un estado policial que de un estado de bienestar. A pasos agigantados se va imponiendo con medidas fundadas en teorías peligrosistas de la criminalidad y legitimándose sobre la base de la renovación de viejas y primarias ideas respecto de las predisposiciones subjetivas del delincuente, abandonando la concepción garantista del Estado Democrático de Derecho. El control social que emerge en las sociedades del riesgo y del miedo se orienta por la ideología de la seguridad, que prescinde de la dimensión social de la desviación del comportamiento delictivo para imputar toda la responsabilidad del delito sobre los grupos de riesgo. En el imaginario social, construido y alimentado desde los medios de comunicación, el consumidor de pornografía infantil se ha convertido en el nuevo peligro para la sociedad.

22. Los delitos sexuales especialmente los relacionados a la pornografía infantil son ejemplos claros e ilustrativos que permiten apreciar la orientación político criminal de las sucesivas reformas al Código Penal, alineados con el marco conceptual construido por JAKOBS de un "Derecho penal del enemigo". Los consumidores de pornografía infantil, nuevos enemigos imputados como "individuos" al carecer de la condición de 
"ciudadanos" han de ser tratados con sujeción a otro Derecho penal, diferente y abiertamente opuesto al que nos otorga garantías, beneficios y derechos a todos los demás. Para salvar las libertades nuestras con las exigencias de seguridad que aspiramos ante los riesgos de la sociedad moderna, han de cercenarse los derechos y garantías del que violente la norma.

23. Al estado de alarma social que gobierna una sociedad de miedos ante los riesgos modernos, no pocas veces manipulados desde los medios de comunicación, se ha impuesto una orientación de Política Criminal punitiva que adelanta las barreras del Derecho penal pretendiendo la neutralización del delincuente mediante medidas de tipo preventivas, seriamente cuestionadas por lo que traducen para el orden de libertades y garantías hasta ahora conocidas.

24. El ideal resocializador se ha abandonado, trasladando todas las demandas de un mayor control social hacia la esfera del Derecho penal. Ocurre una expansión de la intervención penal, supeditando a la Política Criminal al cumplimiento de las funciones simbólica y efectiva del Derecho penal. De ultima ratio en la orientación política del Estado de Bienestar, el Derecho penal se aplica ahora como primera y única ratio.

25. Ante eventos como la indeterminación en la tipificación de las conductas, la indefinición de los bienes jurídicos protegidos, el adelantamiento de la punibilidad guiado por el criterio de peligrosidad o la relajación de las garantías en procura de la eficacia, orientados por la ideología de la seguridad, cabe afirmar que en realidad la seguridad que está en riesgo es la seguridad jurídica de los ciudadanos ante la extralimitación del ámbito penal del Estado.

26. No puede aceptarse la exigencia de renunciar al orden de garantías y derechos, individuales y colectivos para acceder a un estadio de seguridad que más que un ideal se ha convertido en una obsesión. Los augurios, sin embargo, no son promisorios a la luz del consenso sociopolítico que se construye alrededor de los anhelos vindicativos de la víctima, de acuerdo con la orientación de la Política Criminal en España plasmada en las sucesivas reformas del Código Penal. 
27. El Estado recurre a la tipificación del delito de posesión de pornografía infantil porque permite la aplicación de pena privativa de libertad: son pocos los cuestionamientos contundentes que se hacen a su inconstitucionalidad $\mathrm{y}$, sobre todo, cuentan con el respaldo de amplios sectores de la población que se sienten a salvo, seguros y protegidos, con la creación de este tipo dirigido a los consumidores considerados una amenaza y un peligro para la sociedad. De esta forma, los delitos de posesión han desplazado a las figuras de vagancia como punta de lanza en la lucha contra los "indeseables" y "peligrosos".

28. Una de las razones jurídicas para la destipificación de la posesión para el propio consumo de pornografía infantil es la ausencia de lesividad contra el bien jurídico de la indemnidad sexual de los niños. El acto de contemplación de las imágenes esta alejada material y temporalmente de la acción originaria de abuso y de las conductas propias del tráfico como la elaboración, difusión o comercialización del material con esa iconografía. La mera conducta de posesión no involucra más efectos perjudiciales para ese bien concreto, pues, esta destinado al uso individual, íntimo, propio de la esfera privada inaccesible a terceros. En este sentido, la mera posesión es una conducta inocua que carece de efectiva peligrosidad en relación con los intereses tutelados. La satisfacción sexual con la contemplación de imágenes de menores, queda dentro de la moral sexual de cada persona y ello no justifica la intervención penal en este ámbito.

29. La criminalización de la mera posesión de pornografía es contrario al Derecho a la intimidad del adulto que en un ámbito íntimo, privado, contempla una imagen para su satisfacción sexual. En el control y represión de la posesión se afecta la esfera jurídica del consumidor. Y aunque eventualmente presumamos como cierta su efectividad práctica, ésta sería insuficiente para justificar la profunda afectación de la esfera individual de libertad y privacidad, seriamente agravadas para atender dudosos beneficios.

30. La represión penal de la posesión resulta ineficaz desde el punto de vista preventivo. Con un tipo penal no se puede corregir una desviación psicológica como puede considerarse a la pedofilia; por el contrario, investigaciones psicológicas apuntan a que el material pornográfico puede tener un efecto catártico que funciona como vía de escape para las personas con este tipo de deseos de carácter sexual. Tampoco tiene eficacia práctica, bien porque su tipificación no ha producido una disminución del 
consumo de la iconografía relacionada disponible en la Red, o bien por los altos costes económicos que implican activar los mecanismos dentro del sistema de justicia penal para perseguir y reprimir el comportamiento del simple usuario que visita una página de pornografía infantil.

31. La posesión simple es contraria al principio de mínima intervención, resultando excesivo el castigo de la simple tenencia del material pornográfico con fines de autocomplacencia. La represión penal ha de preservar el carácter subsidiario.

32. Todos los puntos anteriores nos llevan a ratificar que no existen razones válidas de Política Criminal, ni de orden jurídico, ni prácticas, para que continúe tipificada la posesión de pornografía infantil en el Código Penal español. Contrario a ello, su tipificación afecta principios constitucionales, derechos y garantías de los ciudadanos. De allí que cerremos proponiendo de lege ferenda su futura derogación. 


\section{BIBLIOGRAFÍA}

ACALE SÁNCHEZ, "Del Código Penal de la democracia al Código Penal de la seguridad", en Serta in Memorian Alexandri Baratta, Universidad de Salamanca, 2004.

ANARTE BORRALLO, Enrique., "Conjeturas sobre la criminalidad organizada", en FERRÉ OLIVÉ, J. C. y ANARTE BORRALLO, E., Delincuencia organizada: Aspectos penales, procesales y criminológicos, Huelva, 1999.

ARIÈS Phillipe, El niño y la vida familiar en el Antiguo Régimen. Taurus, Madrid, 1988.

ARROYO ZAPATERO, L; BERDUGO GOMÉZ DE LA TORRE, I; FERRÉ OLIVÉ, J:C:, "Comentarios al Código Penal” Madrid, 2007.

AZAOLA, Elena; ESTES, Richard J. La infancia como mercancía sexual. México Canadá, Estados Unidos. Siglo XXI, México 2003.

BAJO FERnANDEZ, Miguel, Compendio de Derecho Penal, Parte Especial, Vol. II, Ed. Centro de estudios Ramón Areces, S. A. Madrid, 1998.

BARATA, Francesc, "Las nuevas fabricas del miedo. Los mass media y la inseguridad ciudadana", en Muñagorri Laguía, I., (ed.), La protección de la seguridad ciudadana, Inst. Internacional de Sociología Jurídica, Oñati, 1995.

BARATA, Francesc, "Los más media y el pensamiento criminológico" en Bergalli, R. (Coord.), Sistema penal y problemas sociales, Tirant lo Blanch, Valencia, 2003.

BARNES VÁZQUEZ, José, “La Internet y el Derecho", en Cuadernos y Estudios de Derecho judicial, 1997.

BAUCELLS LLADÓS, Joan., y PERES-NETO, Luiz., "Discurso televisivo sobre el crimen: los programas especializados en sucesos", en GARCÍA ARÁN, Mercedes; BOTELlA CORRAL, Joan. (Dir.), Malas noticias. Medios de comunicación, Política Criminal y garantías penales en España. Tirant Lo Blanch, monografías 609. 2008.

BAUMAN, Zygmunt, Vida líquida, Paidós, Barcelona, 2005.

BAUMAN, Zygmunt, Vidas desperdiciadas, Siglo XXI, Madrid, 2006.

BECK, Ulrich, ¿Qué es la globalización? Falacias del globalismo, respuestas a la globalización, Estado y sociedad, Paidós, 2001.

BECK, Ulrich, La sociedad del riesgo. Hacia una nueva modernidad. Paidós, 1998., Barcelona; del mismo autor, LA sociedad del riesgo global, Ed. Siglo XXI, Madrid, 2002.

BECK, U., La sociedad del riesgo global, Ed. Siglo XXI, Madrid, 2002.

BECK, Ulrich., La sociedad del riesgo mundial, En busca de la seguridad perdida. Ed. Paidós, Barcelona, 2007. 
BECK, Ulrich., La sociedad del riesgo, Paidós, 1998.

BECK, Ulrich., GIDDENS, A., y LASH, S. Modernización reflexiva. Política, tradición y estética en el orden social moderno, Ed. Alianza, Madrid, 1997.

BEGUÉ LEZAÚN J. J., Delitos contra la libertad e indemnidad sexuales, Barcelona 1999.

BERDUGO GÓMEZ DE LA TORRE, I.; ARROYO ZAPATERO, L.; y otros, Curso de Derecho Penal. Parte General, Ed. Experiencia, S. L., Barcelona, 2004

BISBAL, Marcelino, "Medios, ciudadanía y esfera pública en la Venezuela de hoy", Revista SIC / Centro Gumilla, Caracas, nº 622, 2004.

BLANCO CORDERO, Isidoro, "Principales instrumentos internacionales (de Naciones Unidas y la Unión Europea) relativos al crimen organizado: la definición de la participación en una organización criminal y los problemas de aplicación de la Ley Penal en el espacio", en Criminalidad organizada, Reunión Preparatoria de la sección nacional Española preparatoria del XVI Congreso de la AIDP en Budapest, (1999) Universidad de Castilla-La Mancha, 1999.

BLANCO LOZANO, Carlos "Delitos relativos a la prostitución: conceptos de prostitución y corrupción de menores. Perspectivas jurídico-incriminadoras ante el nuevo código penal de 1995", en $C P C, \mathrm{n}^{\circ} 61,1997$.

BOLDOVA PASAMAR, M. “Art. 189...” en DÍEZ RIPOLLÉS y otros Comentarios al Código Penal, Parte Especial, tomo II. Ed. Tirant lo Blanch, Valencia, 2002.

BOLDOVA PASAMAR, Miguel Ángel, “Artículo 189” en Díez Ripollés y otros, Comentarios al Código Penal, Parte Especial, tomo II, Ed. Tirant lo Blanch, valencia, 2004.

BOLDOVA PASAMAR, Miguel Ángel, “Artículo 189” en Díez Ripollés y otros, Comentarios al Código Penal, Parte Especial, tomo II, Ed. Tirant lo Blanch, valencia, 2004.

BOLTANSKI, L. y CHIAPELLO, E., El nuevo espíritu del capitalismo. Ediciones Akal, Barcelona, 2002.

BOTELLA CORRAL, Joan, y PEREZ-NETO, Luiz., "La formación de la opinión pública”, en GARCÍA ARÁN, Mercedes.; BOTELLA CORRAL Joan. (Dir.) Malas noticias. Medios de comunicación, Política Criminal y garantías penales en España. Tirant lo Blanch, monografías 609. 2008.

BOTELlA CORRAL, Joan. (Dir.), Malas noticias. Medios de comunicación, Política Criminal y garantías penales en España. Tirant Lo Blanch, Valencia, 2008.

BRANDARIZ GARCÍA, José, Política Criminal de la exclusión, Editorial Comares, Granada, 2007. 
BUENO ARÚS, Francisco, “Análisis general de las últimas tendencias políticocriminales en materia de delitos sexuales. Justificación político-criminal de la reforma española de 1999", en Delitos contra la libertad sexual, Estudios de Derecho Judicial $\mathrm{N}^{\circ} 21$, Madrid, 2000.

CABRERA MARTÍN, M., "La pornografía infantil: Nuevos retos para el Derecho penal”, en LAZARO GONZÁLEZ, I.; MAYORAL NARROS I., (Coord.), Jornadas sobre Derecho de los menores, Ed. Comillas, Madrid, 2003.

CALMONA SALGADO, Carmen, "Delitos contra la libertad sexual II", en COBO Del ROSAL, Derecho Penal Español, Madrid, 2004.

CAMPIONE, Roger, "El que algo quiere algo le cuesta: notas sobre la Kollateralschádengesellschaft", en Da Agra; Domínguez; García Amado; y otros La seguridad en la sociedad del Riesgo. Un debate abierto. Ed. Atelier, Barcelona, 2003.

CANCIO MELIA, Manuel Derecho penal del enemigo y delitos de terrorismo. Algunas consideraciones sobre la regulación de las infracciones en materia de terrorismo en el Código Penal español después de la LO 7/2000, Jueces para la democracia, $\mathrm{N}^{\circ} 44$, 2002.

CANCIO MELIÁ, Manuel, Derecho penal del Enemigo, en JAKOBS, G. /CANCIO MELIÁ, Manuel., Derecho penal del enemigo, Civitas, segunda edición, Navarra, 2006.

CANCIO MELIÁ, Manuel. “¿"Derecho penal" del enemigo?” En La respuesta del Derecho penal ante los nuevos retos : IX jornadas de profesores y estudiantes de Derecho penal de las Universidades de Madrid, celebradas en la Universidad Rey Juan Carlos los días 8, 9 y 10 de marzo de 2005, en ALCÁCER GUIRAO, R., y CUERDA RIEZU, A. R., Ed. Dykinson, Madrid,Universidad Rey Juan Carlos I, Servicio de Publicaciones, D.L, 2006, pags. 77-96

CANCIO MELIÁ, Manuel., Derecho penal del enemigo, en Jokobs, Gúnther / CANCIO MELIÁ, Manuel, Derecho penal del enemigo, Civitas, segunda edición, Navarra, 2006.

CARMONA SALGADO, C., "Delitos contra la libertad e indemnidad sexuales (I)", en COBO DEL ROSAL, Derecho Penal Español, Parte General, Madrid, 2004.

CARMONA SALGADO, C., "Delitos contra la libertad sexual (I)", en Cobo del Rosal, Curso de Derecho Penal Español. Parte Especial, Madrid, 1995.

CARRASCOSA LÓPEZ, Valentín: “¿Es necesaria una legislación mundial para Internet? Informática y Derecho". Revista Iberoamericana de Derecho Informático, UNED, Extremadura, España, 1998.

CÁRTER, Daniel, PRENTKY, Robert, KNIGHT, Raymond, VANDERVEER, Penny y BOUCHER, Richard, "Use of Pornography in the Criminal and Developmental Histories of Sexual Offenders", en Journal of Interpersonal Violence, 2, 1987.

CARUSO FONTÁN. María Viviana, “Nuevas perspectivas sobre los Delitos contra la Libertad Sexual”, Ed. Tirant lo Blach, Valencia, 2006. 
CASA NOMBELA, J. J.: «Los delitos contra la libertad e indemnidad sexuales en la PANCP» en Revista de la Facultad de Derecho de la Universidad Complutense de Madrid, Madrid, 1983.

CASTELLS, M., La era de la información. Volumen I, La sociedad red. Alianza, Madrid, 1996.

CASTELLS, Manuel, La era de la información, Siglo XXI, Barcelona, España, 2000.

CASTELLS, Manuel, "La dimensión cultural de Internet", disponible [on line] http://www.uoc.edu/culturaxxi/esp/articles/castells0502/castells0502.html, consultado por última vez el 7 de junio de 2006.

CHODOROW N., El ejercicio de la maternidad. Gedisa, Barcelona, 1988; SEGALENE M., Antropología histórica de la Familia, Taurus, Madrid, 2000.

COBO DEL ROSAL, Derecho Penal Español, Parte General, Madrid, 2004.

CONDE-PUMPIDO TOURÓN, C, «Delitos de prostitución. Especial referencia a la prostitución de menores", en Delitos contra la libertad sexual, Madrid, 2000 p,293; DIEZ RIPOLLÉS, J. L., "El objeto de protección del nuevo Derecho penal sexual", en Delitos contra la libertad sexual, Madrid, 2000.

CONSENTIDO, GARCÍA, Guillermo, TEJERO, José y TEJERO Néstor, “Tras los pasos de la seguridad perdida. Delitos informáticos" Informática y Derecho. Revista Iberoamericana de Derecho Informático, UNED, Extremadura, España, No 23-26, Vol. II, 1998.

COX LEIXELARD, Juan Pablo, "Contexto Político-Criminal. De los Delitos de posesión. War on Crime y Expansión del Derecho Penal”, en Rodríguez Collao, Luis (Coord.) Delito, Pena y proceso. Homenaje a Tito Solari Peralta, Ed. Jurídica de Chile, 2008.

CUERDA RIEZU, A., Los medios de comunicación y el Derecho Penal” en ARROYO ZAPATERO, L.; BERDUGO GÓMEZ DE LA TORRE, I., (Dirs.), Homenaje al Dr. Mariano Barbero Santos. In Memoriam, Vol. II, Univ. Castilla-La Mancha/Univ. Salamanca, Cuenca, 2001.

CUGAT MAURI, MIRIAM, "Delitos contra la libertad e indemnidad sexuales", en ALVAREZ GARCÍA, Francisco Javier y GONZÁLEZ CUSSAC, José Luis, (DIR). Comentarios a la Reforma Penal de 2010, Ed. Tirant lo Blanch, Valencia, 2010.

DA AGRA, DOMÍNGUEZ, GARCÍA AMARO, HEBBEERECHT, RECASENS, (edits.), La seguridad en la sociedad del riesgo. Un debate abierto. Ed. Atelier, Barcelona, 2003

DÁVARA RODRÍGUEZ, M. A. Manual de Derecho Informático, Thomson Aranzadi, , Madrid, 1997.

DE LA ROSA CORTINA, José Miguel, Los Delitos De Pornografía Infantil. Aspectos Penales, Procesales Y Criminológicos, Ed. Tirant lo blanch, Valencia, 2011. www.tirantonline.com. 
DEMETRIO CRESPO, Eduardo. «Del "Derecho penal liberal" al "Derecho penal del enemigo".», en Serta: in memoriam Alexandri Baratta, de Fernando PÉREZ ALVAREZ (ED.), pags. 1027-1054. Salamanca: Ediciones Universidad de Salamanca, 2004.

DIEZ RIPOLLES, José Luis, El nuevo modelo penal de la seguridad ciudadana, Jueces para la democracia, No 49, 2004.

DÍEZ RIPOLLÉS, José Luis., "El bien jurídico protegido en un Derecho penal garantista2, en Jueces para la Democracia, nº 30, 1997.

DÍEZ RIPOLLÉS, José, La protección de la libertad sexual, Barcelona, 1985.

DÍEZ RIPOLLÉS, José. Luis., La Politica Criminal en la encrucijada, editorial B de la F, Montevideo- Buenos Aires, 2007.

DIÉZ RIPOLLÉZ, José L., “Corrupción de Menores”, el país 28/11/1996.

ESPÍN, E., "Los derechos de la esfera personal", en López Guerra, Derecho Constitucional, vol. I, Valencia, 1994.

ESQUINAS VALVERDE, Patricia, "El tipo de posesión de Pornografía infantil en el Código Penal español (art. 189.2): Razones para su destipificación". Revista de Derecho Penal y Criminología, $2^{\circ}$ Época, nº 18, 2006.

ESTES Richard J., y AZAOLA Elena (Coord.), La infancia como mercancía sexual. Ed. Siglo veintiuno, México D.F., 2003.

ESTES, R. Y WEINER, N. "Explotación sexual comercial de niños en Estados Unidos" en AZAOLA Elena, ESTES Richard, La infancia como mercancía sexual: México, Canadá y Estados Unidos, México, Siglo XXI. 2003.

FERÁNDEZ TERUELO, Javier. "La sanción penal en la llamada distribución de pornografía infantil a través de Internet y otras modalidades afines tras la reforma de 15/ 2003”, en GUZMÁN DÁlBORA, J. L.; SERRANO, MAÍlLLO,A. (edits), Derecho Penal y Criminología como fundamento de la Política Criminal. Estudios homenaje al profesor Alonso Serrano Gómez., Ed. Dykinson, Madrid, 2006, págs. 703-725.

FERNÁNDEZ TERUELO, Javier, "La sanción penal de la distribución de pornografía infantil a través de Internet: cuestiones claves", Boletín de la Facultad de Derecho, Universidad Nacional de Educación a Distancia, segunda época, nº 20, año 2002.

FERNÁNDEZ TERUELO, J., Cibercrimen. Los delitos cometidos a través de Internet. Ed., Constitutio Criminalis Carolina (CCC), 2007.

FRADE, Carlos, "Estructura, dimensiones, facetas y dinámicas fundamentales de la sociedad global de la información”, mimeografiado, Universidad Abierta de Catalunya, 2002.

FUENTES OSORIO, Juan Luis, Los medios de comunicación y el Derecho penal, en Revista Electrónica de Ciencia Penal y Criminología, no 7, 2005. 
FUKUYAMA, Francis, El fin de la historia y el último hombre, Planeta, Barcelona, 1992.

GALCÍA VALDÉS, Carlos, "Acerca del delito de pornografía infantil" en OCTAVIO DE TOLEDO Y UBIETO, E; GGURDIEL SIERA, M. CORTES BECHIARELLI, E., Estudios penales en recuerdo del profesor Ruiz Antón, Tirant lo Blanch, Valencia 2004.

GARCÍA ARÁN Mercedes; PEREZ-NETO, Luiz. Perspectiva de análisis y principios constitucionales en GARCÍA ARÁN, Mercedez.; BOTELLA CORRAL, Joan. (Dir.), Malas noticias. Medios de comunicación, Política Criminal y garantías penales en España. Tirant Lo Blanch, monografías 609. 2008.

GARCÍA ARAN, Mercedes, "Delincuencia seguridad y pena en el discurso mediático" en MUÑOZ CONDE (Dir.), Problemas Actuales de Derecho Penal y Criminología. Estudios penales en memoria de la profesora María del Mar Díaz Pita. Tiran lo Blanch, Valencia, 2008.

GARCÍA ARÁN, Mercedes. "El Derecho Penal Simbólico. A propósito del nuevo Delito de Dopaje en el Deporte y su tratamiento Mediático" en GARCÍA ARÁN, Mercedes; BOTELLA CORRAL, Joan. (Dir.), Malas noticias. Medios de comunicación, Política Criminal y garantías penales en España. Tirant Lo Blanch, monografías 609. 2008.

GARCÍA ARÁN, Mercedes., y PEREZ-NETO, Luiz., "Discursos mediáticos y reformas penales de 2003". en GARCÍA ARÁN, Mercedes. BOTELLA CORRAL, Joan. (Dir.), Malas noticias. Medios de comunicación, Política Criminal y garantías penales en España. Tirant Lo Blanch, monografías 609. 2008.

GARLAND, David, "Lucha contra el crimen y modernidad tardía en Estados Unidos y Gran Bretaña", en Revista Archipiélago. Prisiones de la Miseria. Estado Penal y Seguridad Ciudadana, N 55, 2003.

GARLAND, David, La cultura del control. Crimen y orden social en la sociedad contemporánea. Trad. M. SOZZO, Editorial Gedisa, Barcelona, 2005.

GARRIDO, V., STANGELAND, P. y REDONDO, S., Principios de Criminología, Valencia, 2001

GIDDENS, Anthony "Vivir en una sociedad postradicional", en Beck, Ulrich., Giddens, A., y Lash, S. Modernización reflexiva. Política, tradición y estética en el orden social moderno, Alianza, Madrid, 1997.

GIDDENS, Anthony, Las consecuencias de la modernidad. Alianza, Madrid, 1994.

GIMBERNAT ORDEIG Enrique en Roland Hefendehl (Ed), la presentación del libro: La teoría del Bien Jurídico ¿Fundamento de legitimación del Derecho Penal o juego de abalorios dogmáticos?, Marcial Pons, Ediciones Jurídicas y Sociales, S.A, Madrid, 2007.

GIMBERNAT ORDEIG, Enrique, “Código Penal” Ed. Tecnos, 9ª edición. 
GIMBERNAT ORDEIG, Enrique, "Presentación del libro" en Roland HEFENDEHL (edit.) "La teoría del Bien Jurídico ¿Fundamento de legitimación del Derecho Penal o juego de abalorios dogmáticos?", Marcial Pons, Ed. Jurídicas y Sociales, S. A, Madrid, 2007.

GIMBERNAT ORDEIG, Enrique, Estado de Derecho y Ley Penal, Ed. La Ley, Madrid, 2009.

GÓMEZ TOMILLO, Manuel "Derecho penal Sexual y reforma legal. Análisis desde una perspectiva político criminal", en Revista Electrónica de Ciencia Penal y Criminología, RECPC 07-04-2005. http://criminet.ugr.es/recpc.

GÓMEZ MARTÍN, Víctor, "Cultura del control, sociedad del riesgo y Política Criminal". En Política Criminal y reforma penal., MIR PUIG, S.; CORCOY BIDASOLO; M., Editorial B de F Montevideo-Buenos Aires. 2007.

GOMEZ MARTIN, Víctor. "Libertad, seguridad y "sociedad del riesgo". En La Política Criminal en Europa, de CORCOY BIDASOLO, Mirentxu, Víctor GÓMEZ MARTÍN y Santiago MIR PUIG....[et. al], Barcelona, Atelier, 2004.

GÓMEZ NAVAJAS, Justa, Lista de delincuentes: ¿pena de "escarnio público”?, en Estudios Penales sobre violencia doméstica. MORILLAS CUEVA, Lorenzo (Coord.) Ed. de Derecho Reunidas, S. A. Madrid, 2002.

GÓMEZ PERAL, Miguel "Los Delitos Informáticos en el Derecho Español”, en Actas del III Congreso Iberoamericano de Informática y Derecho, Mérida.

GOMEZ TOMILLO, Manuel, "Derecho penal sexual y reforma legal" en Revista Electrónica de Ciencia Penal y Criminología RECPC Nº 07, 2005.

GONZÁLEZ RUS, J. J., La violación en el Código Penal español, Granada, 1982.

GONZÁLEZ RUS, Juan José, "Protección penal de sistemas, elementos, datos, documentos y programas informáticos", en Revista Electrónica de Ciencia Penal y Criminología, $N^{o} 1,1999$.

GONZÁlEZ RUS, J. J., Aproximación al tratamiento penal de los ilícitos patrimoniales relacionados con medios o procedimientos informáticos, en RFDUCM, Monográfico $\mathrm{n}^{\circ} 12.1982$.

GONZÁLEZ-CUÉLLAR GARCÍA, Antonio, “Articulo 189”, en Código penal, doctrina y jurisprudencia, varios autores, Trivium, Madrid, 1997.

GRACIA MARTÍN, L., "Consideraciones críticas sobre el actualmente denominado Derecho penal del enemigo" En Revista Electrónica de Ciencia Penal y Criminología, $n^{\circ} 2005$.

GUDÍN RODRÍGUEZ-MAGARIÑOS, Faustino, "La Castración química para pedófilos: un problema ético y penológico", Actualidad Jurídica, ARANZADI, 8 de noviembre de 2007. Actualidad jurídica en la Red. www.aranzadi.es 
GUTIÉRREZ FRANCES, María Luz, "Delincuencia Económica en el nuevo Código Penal", en ARROYO ZAPATERO, Luis y TIEDEMANN, Klaus, Estudios de Derecho Penal Económico, Ed. Ediciones de la Universidad de castilla la Mancha, Cuenca, 1994.

GUTIÉRREZ FRANCÉS, María Luz, “Fraude Informático y Estafa”, Ministerio de Justicia, Madrid, 1991.

GUTIRERREZ FRANCÉS María LUZ "Problemas de aplicación de la Ley penal en el espacio virtual", en ROMEO CASABONA, Carlos María, Cibercrimen. Nuevos retos jurídico - penales, nuevas respuestas político criminales, Ed. Comares, Granada, 2006, pp. 43- 68.

GUTIRERREZ FRANCÉS María LUZ, "Notas sobre la delincuencia Informática: Atentados contra la "Información" como valor Económico de la empresa", en Ámbito Jurídico de las tecnologías de la Información en Revista Cuadernos de Derecho Judicial, 1996. pág. 183- 209.

GUTIRERREZ FRANCÉS María LUZ, "Reflexiones sobre la Ciberdelincuencia hoy (En torno a la Ley Penal en el espacio virtual)" en Revista electrónica de la Facultad de Derecho de Universidad de La Rioja (REDUR) no 3, 2005, pp. 69- 92.

HABERMAS, Jürgen, The new obscurity and the exhaustion of utopian energies, citado en HabermaS, J. (comp.) Observations on the spiritual situation of the age. Cambridge, MIT Press, 1984.

HASSEMER, Winfried, "Sobre el ejercicio abusivo de los derechos," en José Luis GUZMÁN DALBORA (Coord), El penalista liberal. Controversias nacionales $e$ internacionales en Derecho penal, procesal penal y criminología. Homenaje a Manuel de Rivacoba y Rivacoba, Buenos Aires: Hammurabi, 2004.

HASSEMER, Winfried, Persona, mundo y responsabilidad. Bases para una teoría de la imputación en Derecho Penal. (Trad. MUÑOZ CONDE/ DÍAZ PITA), Ed. Tirant lo Blanch, Valencia, 1999.

HERRERA BRAVO, Rodolfo, "Reflexiones sobre la delincuencia vinculada con la tecnología digital”, 2001. en http://rodolfoherrera.galeon.com/refxdel.pdf

HERRERA MORENO, Myriam, "El fraude informático en el Derecho penal español”, Revista Actualidad Penal, n 3, Madrid, 2001.

HERRERO HERRERO, C, Criminología. Edit. Dykinson, Madrid, 2001.

HÖRNLE, Tatjana, "La protección de Sentimientos en el STGB” en Roland Hefendehl (edit.), "La teoría del bien jurídico. ¿Fundamento de legitimación del Derecho Penal o juego de abalorios dogmáticos?", Ed. Marcial Pons, Ed. Jurídicas y Sociales, S. A, Madrid, 2007.

HUNTINGTON, Samuel, El choque de civilizaciones, Paidós, Madrid, 1997.

JIJENA LEIVA, Renato, Chile, la protección penal de la intimidad y el delito informático, Santiago de Chile, 1992. 
JIMÉNEZ VILLAREJO, José, “Art. 189” en CONDE-PUMPIDO TOURÓN (Dir.), Comentarios al Código Penal, Ed. Bosch, Barcelona, 2007.

LANDROVE DÍAZ, Gerardo, El nuevo Derecho penal, Tirant lo Blanch, Valencia, 2009.

LANNING, Kevin., Child Molesters: A Behavioural Analysis. Washington D.C., 1992.

LYOTARD, J-F., La condición posmoderna. Cátedra, Madrid, 1984.

MANTOVANi, F., Idelitti di prostituzione e di pornografía minorili, en prensa, pp. 12 y 13 de la Parte Segunda.

MANZINI, Vicenzo citado por JIMÉNES DE ASUA, Luís Tratado de Derecho Penal, Ed. Losada, Buenos Aires, 1950.

MAQUEDA ABREU, M. L. "Políticas de seguridad y Estado de Derecho." En Serta: in memoriam Alexandro Baratta, PÉREZ ALVAREZ, F., (Ed.), pags. 1287-1298. Salamanca: Ediciones Universidad de Salamanca, 2004.

MAQUEDA ABREU, Ma Luisa, "Crítica a la reforma penal anunciada." Revista Jueces para la democracia, $\mathrm{n}^{\circ}$ 47, 2003.

MARCOS MARTÍN, Teresa, "Pornografía infantil en Internet: Los Derechos del niño y su protección internacional" en VILLAGRASA ALCAIDE, Carlos, y RAVETLLAT BALLESTÉ (Coords.), Ed. Ariel S.A, Barcelona, 2006.

MARTÍN LORENZO, María, "Libertad e Indemnidad sexuales", en ORTIZ DE URBINA, Gimeno (Coord.), Memento Experto, Reforma Penal 2010, Ley Orgánica 5/2010, Ed. Francis Lefebvre, Madrid, 2010.

MARTÍN-CASALLO LÓPEZ, Juan “Internet y pornografía infantil” Actualidad informática Aranzadi no 40 julio de 2001.

MATA Y MARTÍN, Ricardo, Delincuencia informática y Derecho penal, Edisofer S.L., Madrid, 2001

MATELLANES RODRÍGUEZ, Nuria, “Algunas notas sobre las formas de delincuencia informática en el Código penal” en DIEGO DÍAZ-SANTOS y SÁNCHEZ LÓPEZ, Virginia, Hacia un Derecho Penal sin fronteras, Ed. Colex, 2000.

MATELLANES RRODRÍGUEZ, Nuria, "Penas, Rehabilitación y Delincuentes sexuales" en SANZ MULAS, Nieves, Dos décadas de reformas penales, Ed. Comares, Granada, 2008.

MEDINA ARIZA, J. J. "Una introducción al estudio criminológico del crimen organizado", en ANARTE BORRALlO, E., FERRÉ OLIVÉ, J. C., Delincuencia organizada: Aspectos penales, procesales y criminológicos, Huelva, 1999.

MENDOZA BUERGO Blanca, "Gestión y Política Criminal de seguridad en la sociedad del riesgo", en Da Agra; Domínguez; García Amado y otros, La seguridad en la sociedad del Riesgo. Un Debate abierto. Editorial Atelier, Barcelona, 2003. 
MENDOZA BUERGO, Gestión del riesgo y Política Criminal de seguridad en la sociedad del riesgo", en DA AGRA, DOMÍNGUEZ, GARCÍA AMARO, HEBBEERECHT, Recasens, (edit), la seguridad en la sociedad del riesgo. Un debate abierto. Barcelona, atelier, 2003.

MILITELLO Vincenzo. "Iniciativas supranacionales en la lucha contra la criminalidad organizada y el blanqueo en el ámbito de las nuevas tecnologías" en ZÚÑIGA RODRÍGUEZ; MÉNDEZ RODRÍGUEZ; DIEGO DÍAZ- SANTOS (Coord.), Derecho penal sociedad y nuevas tecnologías, Ed. Colex, Madrid, 2001.

MOLINÉ José Cid y LARRAURI Elena, Teorías Criminológicas, Ed. BOSCH, 2001

MORALES PRATS, F. y GARCÍA ALBERO, R., "Delitos contra la libertad e indemnidad sexuales", Quintero Olivares, Comentarios al Nuevo Código Penal, Navarra, 2004.

MORALES PRATS, Fermín, "La intervención penal en la red. La represión penal del tráfico de pornografía infantil estudio particular" en ZÚÑIGA RODRÍGUEZ; MÉNDEZ RODRÍGUEZ; DIEGO DÍAZ- SANTOS (Coords.), Derecho penal sociedad y nuevas tecnologías, Ed. Colex, Madrid, 2001.

MORALES PRATS, Fermín, "Los ilícitos en la Red (II): Pornografía infantil y cibercriminalidad" en ROMEO CASABONA, Carlos María (Coord.), El cibercrimen. Nuevos retos jurídicos- penales, nuevas respuestas político-criminales, Ed. Comares, Granada 2006.

MORALES PRATS, Fermín, "Pornografía Infantil e Internet: La respuesta en el Código Penal español", en Problemática Jurídica en torno a fenómenos de Internet, Cuadernos de Derecho Judicial, Madrid, 2000, págs. 177-205.

MORALES PRATS, Fermín, y GARCÍA ALBERO, Ramón, "Delitos contra la libertad sexual" en QUINTERO OLIVARES, Gonzalo, Comentarios a la Parte Especial del Derecho Penal, Navarra, 2002.

MORALES PRATS, Fermín. "El Derecho Penal ante la pornografía infantil en Internet", en MORALES PRATS, F.; MORALES GARCÍA, O., (Coords.), Contenidos ilícitos y responsabilidad de los prestadores de servicio de Internet. Revista Aranzadi de Proceso Penal, No 8 Madrid, 2002, págs. 95- 118.

MORALES PRATS, Fermín. Pornografía infantil $e$ Internet: Jornadas de Responsabilidad Civil y Penal de los Prestadores de servicios en Internet, Barcelona, 22-23 de noviembre de 2001.

MORALES PRATS, Fermín; GARCÍA ALBERO, Ramón, "Artículo 189", en Quintero Olivares, Comentarios a la Parte Especial del Derecho Penal, Ed. Thomson, Aranzadi, Navarra, 2007.

MORAS MOM, J. R., Los delitos de violación y corrupción de menores, Buenos Aires, 1971. 
MORILLAS FERNÁNDEZ, David Lorenzo, "Cuestiones Conflictivas en la actual regulación de los delitos de pornografía infantil”, en GARCÍA GONZÁLEZ, Javier (Coord.), Ciberacoso: la tutela penal de la intimidad, la integridad y la libertad sexual en Internet, Tirant lo Blanch, Valencia, 2010.

MORILLAS FERNÁNDEZ, David Lorenzo, "los delitos de pornografía infantil en el Derecho comparado", Cuadernos de Política Criminal, segunda época, nº 84, 2004.

MORILLAS FERNÁNDEZ, David Lorenzo, Análisis dogmático y criminológico de los delitos de pornografía infantil. Editorial Dykinson SL, Madrid, 2005.

MORÓN LERMA, Esther, Internet y Derecho Penal: Hacking y otras conductas ilícitas en la Red. Ed. Aranzadi, Pamplona, 1999.

MUNOZ CONDE, Francisco, Derecho Penal, Parte Especial, Ed., Valencia, 2002.

MUÑOZ CONDE, Francisco, Derecho Penal. Parte Especial, Ed. Tiran Lo Blanch, décima octava edición, Valencia, 2010.

MUÑOZ CONDE, Francisco, De nuevo sobre el "Derecho penal del enemigo", Editorial Hiammumi, $1^{\text {o }}$ edición, Buenos Aires, 2005.

MUÑOZ CONDE, Francisco, Derecho Penal, Parte Especial, Tirant lo Blanch, Valencia, 2002

MUÑOZ CONDE, Francisco, El nuevo Derecho penal autoritario, en Estudios penales recuerdo del Profesor Ruiz Antón, Valencia, 2004.

NUÑEZ PAZ, Miguel Ángel. "Dogmática penal y Política Criminal frente a la Reforma Penal." En La reforma penal a Debate. XVI Congreso de alumnos de Derecho penal Universidad de Salamanca. , de AAVV, Salamanca, Ausejp, 2004.

ORTS BERENGUER, E.; ALONSO RIMO, Alberto, "La reforma de los delitos contra la libertad sexual" en ZÚÑIGA RODRÍGUEZ; MÉNDEZ RODRÍGUEZ; DIEGO DÍAZ- SANTOS (Coord.), Derecho penal sociedad y nuevas tecnologías, Ed. Colex, Madrid, 2001.

ORTS BERENGUER, Enrique y ROIG TORRES, Margarita, Delitos informáticos y delitos comunes, cometidos a través de la informática Ed. Tirant Lo Blanch, Valencia, 2001.

ORTS BERENGUER, Enrique, "Delitos contra la indemnidad sexual" en VVAA Derecho Penal. Parte Especial, Ed. Tirant lo Blanch, Valencia2004.

ORTS BERENGUER, Enrique, ALONSO RIMO, Alberto, Delitos contra la libertad sexual. Valencia, 1995.

ORTS BERENGUER, Enrique. y ROIG TORRES, Margarita, Delitos informáticos y delitos comunes cometidos a través de la informática, Ed. Tirant lo Blanch, Valencia, 2001. 
ORTS BERENGUER, Enrique; ALONSO RIMO, Alberto, "La reforma de los delitos contra la libertad sexual" en ZÚÑIGA RODRÍGUEZ; MÉNDEZ RODRÍGUEZ; DIEGO DÍAZ- SANTOS, Derecho penal sociedad y nuevas tecnologías, Ed. Colex, Madrid, 2001.

PALAZZI, Pablo, Delitos informáticos, Ed. Ad- Hoc, Buenos Aires, 2000.

PARDO ALBIACH, Juan, "Ciberacoso: Cyberbullying, Grooming, Redes Sociales y otros peligros" en GARCÍA GONZÁLEZ, Javier (Coord.), Ciberacoso: la tutela penal de la intimidad, la integridad y la libertad sexual en Internet, Tirant lo Blanch, Valencia, 2010.

PARRA GONZÁLEZ Ana Victoria; DOMÍNGUEZ, Mariluz, "Los Medios de comunicación desde la perspectiva del delincuente", en revista OPCIÓN, Maracaibo, 2004.

PECO, José, "El delito de violación” en La Ley, 1937.

PÉREZ CEPEDA, Ana Isabel, “Un ejemplo más del Derecho penal simbólico: el delito de corrupción de menores", en Revista Actualidad Penal nº 22, 2001.

PÉREZ CEPEDA, Ana Isabel, La Seguridad como Fundamento de la deriva del Derecho Penal Postmoderno, Ed. Iustel, Madrid, 2008.

PÉREZ CEPEDA, Ana Isabel., La seguridad como fundamento de la deriva del Derecho penal postmoderno, IUSTEL, $1^{\circ}$ edición, Madrid, 2007.

PÉREZ LUÑO, Antonio. "Internet y el Derecho". Informática y Derecho. Revista Iberoamericana de Derecho Informático, UNED, Extremadura, España, 1998, Vol. I, $\mathrm{N}^{\circ} 19-22$.

PHIFIPPE Robert Prologo de Recasens I Brunet, A., La seguridad y sus políticas, Editorial Atelier, Barcelona, 2007.

PICARDO, OSCAR, El escenario actual de las Ciencias Sociales: La Sociedad del Conocimiento", UOC, mimeografiado, 2003.

PORTILlA CONTRERA, G., "El Derecho penal del enemigo", en Jueces para la Democrecia, $\mathrm{n}^{\circ}$ 49, 2004.

PORTILLA CONTRERAS, G., "La configuración del "Homo Sacer" como expresión de los nuevos modelos del Derecho Penal Imperial." en Serta : in memoriam Alexandri Baratta, PÉREZ ALVAREZ, Fernando (Ed.), pags. 1401-1423. Ediciones Universidad de Salamanca, Salamanca, 2004.

PRIETO NAVARRO, Evaristo., "Sobre los límites y posibilidades de la respuesta jurídica al riesgo", en Da Agra, C.; Domínguez, J. L.; GARCÍA AMADO, J.A.; HEBBERECHT, P.; RECASENS, A., La seguridad en la sociedad del riesgo. Un debate abierto. Editorial Atelier, Barcelona, 2003. 
PRIETO RODRÍGUEZ, J. I., "La nueva configuración de los delitos contra la libertad sexual: Violación y agresiones sexuales” en Actualidad Penal, Madrid, 1991.

PRITTWITZ, Cornelius. "Sociedad del riesgo y Derecho penal." En Crítica y justificación del Derecho penal en el cambio de siglo : el análisis crítico de la Escuela de Frankfurt, de ARROYO ZAPATERO, Luis Alberto, NIETO MARTÍN Adan y ULFRIED Neumann...[et. al], pags. 259-288. Cuenca: Universidad de Castilla-La Mancha, 2003.

QUAYLE, Ethel. y TAYLOR, Max, "Child pornography and the Internet: Perpetuating a cycle of abuse", en Deviant Behaviour, 2002.

QUERAlt JIMÉnEZ, Joan Josep, Derecho penal español. Parte especial, Ed. Bosch, Barcelona, 2002.

QUERALT JIMÉNEZ, Joan Josep, Derecho penal español. Parte especial, Quinta edición. Ed. Atelier, 2008.

QUINTERO OLIVARES, Gonzalo, sobre el Anteproyecto de Ley de Reforma del Código Penal de 2009. "Examen crítico de las líneas maestras de la reforma propuesta", en trabajo presentado en el XXI Congreso de Alumnos Universitarios de Derecho Penal. Universidad de Salamanca, Salamanca, 2009.

REBOLLO VARGAS, Rafael. "Oleadas informativas y respuesta político criminal”, en GARCÍA ARÁN, Mercedes.; BOTELLA CORRAL Joan. (Dir.), Malas noticias. Medios de comunicación, Política Criminal y garantías penales en España. Tirant Lo Blanch, monografías 609. 2008.

REDONDO ILLESCAS, Santiago, "¿Sirve el tratamiento para rehabilitar a los delincuentes sexuales?", en Revista Española de Investigaciones Criminológicas, artículo 6, número 4, año 2006. disponible en www.criminología.net.

ROBLES PLANAS, Ricardo, "Sexual Predatour estrategias y límites del Derecho Penal de la Peligrosidad", En Revista para el análisis del Derecho. INDRET 4/2007, Barcelona, octubre, 2007.

RODRÍGUEZ DEVESA, J. M., Derecho Penal Español, parte Especial, Madrid, 1983.

RODRÍGUEZ MARTÍN, Enrique, "Pornografía infantil en Internet”, en marco del Foro internacional Infancia y Violencia, en el X aniversario del Centro Reina Sofía para el Estudio de la Violencia, marzo de 2007, Madrid, Memoria de Comunicaciones.

RODRÍGUEZ GÓMEZ, Carmen, "Tráfico, explotación y venta de menores", en SANZ MULAS, El desafío de la criminalidad organizada, Ed. Comares, Granada 2006.

RODRÍGUEZ RAMOS, Luis, "Los delitos contra la libertad e indemnidad sexuales", en RODRÍGUEZ RAMOS, L., COBOS GÓMEZ de Linares, M. A., SÁNCHEZ TOMÁS, J. M., Derecho Penal. Parte Especial I, Madrid, 1998.

RODRÍGUEZ, Enrique, "España: zero tollerance”, en Revista Archipiélago. Prisiones de la Miseria. Estado Penal y Seguridad Ciudadana, No 55, 2003. 
ROJA GARCÍA, Juan Carlos, "La realidad de la pornografía infantil en Internet" en

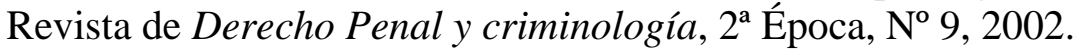

ROXIN Claus, El bien Jurídico, Conferencia dictada el 23 de febrero del 2007, en la Universidad Complutense de Madrid. Mimeografiado.

RUIZ RODÍGUEZ, Luís R., GONZÁLEZ AGUDELO, Gloria, "El factor tecnológico en la expansión del crimen organizado. ¿Menores en riesgo?, en PUENTE ALBA Luz María (Dir.) Criminalidad organizada, terrorismo e inmigración. Retos contemporáneos de la Política Criminal, Ed. Comares, nº 98, 2008.

SÁEZ VALCÁRCEL, Ramón, La inseguridad, lema de campaña electoral. Jueces para la democracia, $\mathrm{N}^{\circ}$ 45, 2002.

SÁNCHEZ MELGAR, Julián, (Coord.) Código Penal. Comentarios y Jurisprudencia, Ed. SEPIN, 2a edición, Madrid, 2006.

SÁNCHEZ TOMÁS, José María, "Los abusos sexuales en el Código Penal de 1995: en especial sobre menor de doce años y abusando de trastorno mental", en Cuadernos de Política Criminal, n ${ }^{\circ}$ 61, Madrid, 1997.

SERRANO GÓMEZ, Antonio, Derecho Penal, Parte Especial, Madrid, 2004.

SETO, Michael C, MARIC, Alexandra y BARBAREE, Howard E., "The role of Pornography in the Etiology of Sexual Aggression", en Agression and Violent Behaviour, 6, 2001.

SIEBER, U., (1990) La delinquance informatique. Centre de Recherches Informatique et Droit des Facultés Universitaires de Namur. E. Story Scientia, Bruselas.

SILVA SÁNCHEZ, José María, "El retorno de la inocuización. El caso de las reacciones jurídico-penales frente a los delincuentes sexuales violentos", en ARROYO ZAPATERO, Luís. y BERDUGO GÓMEZ DE LA TORRE, Ignacio (Dir.), Homenaje al Dr. Mariano Barbero Santos in memoriam, Ed., de la universidad de Castilla -La Mancha, Ed., Universidad de Salamanca, Cuenca 2001.

SILVA SÁNCHEZ, José María, La expansión del Derecho penal. Aspectos de la Política Criminal en las sociedades postindustriales, Editorial B de F, MontevideoBuenos Aires, reimpresión de la segunda edición, 2006.

SOTO NAVARRO, Susana, La influencia de los medios en la percepción social de la delincuencia, en Revista electrónica de Ciencia Penal y Criminología, $\mathrm{n}^{\circ}$ 7, RECPC 0709,2005 .

STRUENSSE, Eberhard, "Los delitos de Tenencia", en GÜNTHER JAKOBS Y STRUENSSE, Problemas capitales del Derecho Penal Moderno. Libro Homenaje a Hans Welzel, Ed. Hammurabi, Buenos Aires, 1998.

SUÁREZ-MIRA RODRÍGUEZ, Carlos, "Delitos relativos a la prostitución, corrupción de menores y pornografía infantil: una nueva revisión" en FARALDO CABANA, 
Patricia (Dir.), Política Criminal y reformas penales, Ed. Tirant lo Blanch, Valencia, 2007.

TAMARIT SUMALLA, José María, La ProtecciónPenal del menor frente al abuso y la explotación sexual. Análisis de las reformas penales en materia de abusos sexuales, prostitución y pornografía de menores, Ed. Aranzadi a Thomson Company, Navarra $2^{\circ}$ 2002.

TAYLOR, Max., HOLLAND, Gary and QUAYLE Ethel., "Typology of Paedophile Picture Collections", COPINE Project, The Pólice Journal, 74, 2001.

TÉLLEZ VALDÉS, Derecho Informático, Ed. McGraw Hill, México, 1996.

TORRES FERNÁNDEZ, E., El nuevo delito de corrupción de menores, en Revista Electrónica de Ciencia Penal y Criminología (RECPC 01-12), 1999.

TREMBLAY, Pierre, "Interacciones Sociales entre Pedófilos Canadienses", en La infancia como mercancía sexual, en AZAOLA, Elena; ESTES, Richard J. (Coord.) Ed. Siglo XXI, México, 2003.

TRÖNDLE, Hebert; FISCHER, Thomas, Strafgesetzbuch und Nebengesetze, 53. a C. h. BECK Verlag, München, 2006.

ÚBEDA DE LOS COBOS, Julio José "La persecución de la pornografía infantil. Problemas relacionados con su distribución por Internet" La Ley Penal, No 37, Sección Estudios, Ed. LA LEY, abril 2007.

URIARTE VALIENTE, Luis María, "delitos relativos a la pornografía infantil y corrupción de menores", Centro de estudios Jurídicos.

VALDÉS MIYAR, M., (coord. de la edición española), DSM IV. Manual Diagnóstico y Estadistico de los Trastornos Mentales, Ed. Masson, S. A., Barcelona, 1995

VARGAS CABRERA, B., "Prostitución y corrupción de menores", en Estudios sobre violencia familiar y agresiones sexuales, tomo III, Madrid, 2000.

WALLERSTEIN, Inmanuel, El futuro de la civilización capitalista, Icaria / Antrazyt, 1997.

ZUÑIGA RODRÍGUEZ, Laura. "Viejas y nuevas tendencias políticocriminales en las legislaciones penales." en Derecho penal de la democracia "vs" seguridad pública, de Ignacio BERDUGO GÓMEZ DE LA TORRE y Nieves SANZ MULAS (coords.), pp. 99-130. Granada: Comares, 2005.

\section{DOCUMENTOS INTERNACIONALES}

Conferencia Internacional del Trabajo, Convenio nº 182, Ginebra, junio de 1999.

Convenio del Consejo de Europa para la protección de los niños contra la explotación y el abuso sexual, hecho en Lanzarote el 25 de octubre de 2007. Ratificado por el BOE 274, del 12 de noviembre de 2010. 
Convenio sobre Cibercriminalidad de 23 de noviembre de 2001, Budapest.

Decisión Marco 2004/68/JAI del Consejo, de 22 de diciembre de 2003, relativa a la lucha contra la explotación sexual de los niños y la pornografía infantil (DO L 13 de 20/01/2004)

Dictamen del Comité Económico y Social sobre la "Comunicación de la Comisión al Consejo, al Parlamento Europeo, al Comité Económico y Social y al Comité de las Regiones, eEurope 2002" (DO C 311 de 07/11/2001).

Exposición de motivos de la Propuesta de Decisión Marco sobre explotación sexual infantil e Informe explicativo de la Convención sobre Cibercrimen, adoptado el 8 de noviembre de 2001.

Informe ANESVAD, de Parry Aftab, www.anesvad.org/nymphasex, consultado por última vez el 21 de septiembre de 2008.

Informe explicativo de la Convención sobre Cibercrimen y Exposición de Motivos de la Propuesta de Decisión Marco sobre explotación sexual infantil.

Ley Especial contra los Delitos Informáticos. República Bolivariana de Venezuela, Asamblea Nacional, 2001.

Ministerio de Trabajo y Asuntos Sociales y Observatorio de Infancia (2006). II Plan Nacional contra la explotación sexual de la infancia y la Adolescencia 2006-2009. Madrid.

Ministerio de Trabajo y Asuntos Sociales. UNICEF-Comité Español, 2005. ECPAT España.

Ministerio del Interior del Gobierno de España, Balance 2010. Evolución de la Criminalidad.

Proposición no de ley de ERC-IU-ICV (162/000160, presentada al Pleno el 5/9/2008) y en la enmienda núm. 151 presentada por el grupo Parlamentario Popular en el Senado, BOCG-Senado, de 27 de mayo de 2010. También Contenida en el Informe del Consejo Fiscal acerca del Anteproyecto de Ley de 14 de noviembre de 2008.

Propuesta de Directiva del Parlamento Europeo y del Consejo. Relativa a la lucha contra los abusos sexuales, la explotación sexual de los niños y la pornografía infantil, por la que se deroga la Decisión Marco 2004/68/JAI.

Recomendación (2001) 16 del Comité de Ministros del Consejo de Europa, adoptada el 31 de octubre de 2001.

Resolución 1386 (XIV) de la Asamblea General de Naciones Unidas de 20 de noviembre de 1959.

Resolución 44/25 de la Asamblea General de Naciones Unidas, 20 de noviembre de 1989.

Resolución de la Comisión de Derechos Humanos 2002/51. Naciones Unidas. 
Resolución Legislativa del Parlamento Europeo aprobada en su Acta del 12/06/ 2001 (A5-0206/2001).

UNICEF (2005). Hoja de datos: explotación sexual.

UNICEF (2001). Aprovecharse del abuso. Una investigación sobre la explotación sexual de nuestros niños y niñas.

UNICEF, Nueva York. UNICEF (2000). Children on the Edge: Protecting Children from Sexual Exploitation and Trafficking in East Asia and the Pacific. UNICEF East Asia and Pacific Regional Office, Thailand.

\section{CONGRESOS MUNDIALES}

I Congreso Mundial contra la explotación sexual comercial de los niños, Estocolmo 24 de agosto de 1996.

II Congreso Mundial Global de Yokohama 2001.

III Congreso Mundial sobre la explotación de niños, niñas y adolescentes. Declaración de Río de Janeiro y Plan de Acción para prevenir y detener la explotación sexual de niños y adolescentes (2008). 